\title{
SIMULAÇÃO FISICA E CARACTERIZAÇÃO DE ZONAS AFETADAS PELO CALOR DE AÇOS API 5L GRAU X80.
}

Dissertação apresentada à Escola Politécnica da Universidade de São Paulo para obtenção do titulo de Mestre em Engenharia

São Paulo 


\section{SIMULAÇÃO FISICA E CARACTERIZAÇÃO DE ZONAS AFETADAS PELO CALOR DE AÇOS API 5L GRAU X80.}

Dissertação apresentada à Escola Politécnica da Universidade de São Paulo para obtenção do titulo de Mestre em Engenharia

Área de concentração:

Engenharia Metalúrgica e de Materiais

Orientador:

Professor Dr. Sérgio Duarte Brandi

São Paulo 
Este exemplar foi revisado e alterado em relação a versão original, sob responsabilidade única do autor e a anuência de seu orientador.

São Paulo, 07 de dezembro de 2011.

Giancarlo Franko Sanchez Chavez

Prof. Dr. Sérgio Duarte Brandi

FICHA CATALOGRÁFICA

\section{Sanchez Chavez, Giancarlo Franko}

Simulação física e caracterização de zonas afetadas pelo calor de aços API 5L grau X80 / G.F. Sanchez Chavez. --São Paulo, 2011.

$247 \mathrm{p}$.

Dissertação (Mestrado) - Escola Politécnica da Universidade de São Paulo. Departamento de Engenharia Metalúrgica e de Materiais.

1. Soldagem 2. Aços API 5L X80 3. Constituinte MA 4. Óleodutos I. Universidade de São Paulo. Escola Politécnica. Departamento de Engenharia Metalúrgica e de Materiais II. t. 
"La practica debe ser siempre edificada sobre la buena teoria" Leonardo Da Vinci 


\section{DEDICATÓRIA}

Dedico este trabalho a Deus, a meus pais Arnaldo Sanchez Tejada, Raquel Chavez Paredes e a minha filha Luciana Sanchez Zegarra. 


\section{AGRADECIMENTOS}

Deus em primeiro lugar;

Ao professor Sérgio Duarte Brandi, por ter me orientado nesta odisséia que é a elaboração de uma dissertação de mestrado;

A meus pais pela sua confiança e carinho que tiveram desde o começo e que continua até hoje;

A meus amigos Raul, Luis, Marcos e Marvin pela sua amizade dia a dia;

Aos meus amigos da Poli - Metalurgia: Edgar, Dani, Erick, Mario, Vinicius, Alexander, Anderson, Davidson, Rafael, entre muitos outros;

Aos professores Andre, Helio, entre outros.

À CAPES pela bolsa de Mestrado concedida;

Aos Profs. Dr. John C. Lippold e Boian Alexandrov da OSU pela utilização do equipamento Gleeble e ao técnico Joshua McCarty, da OSU, pela ajuda na execução dos experimentos;

A Proaqt pela realização dos ensaios mecânicos em especial aos Srs. Mario, Corradini e Julio;

Finalmente a todos que, direta ou indiretamente, ajudaram na execução do presente trabalho. 


\section{RESUMO}

Os aços para tubos API $5 \mathrm{~L}$ X80 são aços de alta resistência e baixa liga (ARBL) usados na fabricação de tubos para o transporte de gás e petróleo conduzidos através de dutos. Os tubos API 5L X80 se caracterizam por terem excelentes propriedades mecânicas como resistência à tração, tenacidade, ductilidade e resistência à corrosão, além de boa soldabilidade. Estes tubos trazem muitos benefícios como, por exemplo, o fator econômico já que ao ter boa resistência mecânica estes tubos podem ser fabricados com espessuras de parede menores. Estas reduções nas espessuras diminuem os custos de transporte, construção, soldagem e instalação. Além disso, estes tubos podem ser fabricados com grandes diâmetros, permitindo o transporte de grandes quantidades de fluidos a elevadas pressões e vazões. A tenacidade confere ao material a propriedade de ser resistente à fratura frágil, uma vez que estes tubos em sua maioria trabalham em condições ambientais severas. O objetivo deste trabalho é simular fisicamente e estudar as propriedades mecânicas de regiões da zona afetada pelo calor (ZAC) produzidas por diferentes ciclos térmicos, que ocorrem quando o tubo é fabricado e o duto montado. A idéia foi estudar a ZAC produzida no tubo fabricado pelo processo UOE (solda longitudinal) e a solda feita no campo quando o tubo é montado (solda circunferêncial) além da ZAC na intersecção entre a soldagem longitudinal e circunferêncial. Foram usinados corpos-de-prova nas orientações L-T e T-L e com o cordão de solda longitudinal do tubo no centro. Estes corpos-de-prova foram submetidos a quatro ciclos térmicos únicos com temperaturas máximas de 650, 800, 950 e $1300{ }^{\circ} \mathrm{C}$ e ciclos térmicos multipasse 950-800 e 950-800$650{ }^{0} \mathrm{C}$. Estes corpos-de-prova foram submetidos a diferentes ensaios e caracterizações. Foram feitos ensaios de impacto a $0{ }^{0} \mathrm{C}$, as superfícies fraturadas foram analisadas no MEV e mediu-se a expansão lateral produzida pelo ensaio de impacto. Mediu-se a dureza da microestrutura por meio do ensaio Vickers com $300 \mathrm{~g}$ de carga. A microestrutura da ZAC foi caracterizada por microscopia óptica, com ataque convencional e ataque colorido Klemm, e microscopia eletrônica de varredura. Metalografia quantitativa foi usada para obter a quantidade de perlita na matriz dos corpos-de-prova. A trajetória da 
fratura na microestrutura dos corpos-de-prova simulados, provocada pelo ensaio Charpy, foi analisada com microscopia óptica e eletrônica de varredura. Os resultados mostraram que as energias absorvidas no ensaio de impacto pelos corpos-de-prova simulados cumprem com os requisitos exigidos pela norma API 5L para o metal base sem simulação e que as microestruturas observadas variam segundo o tipo de ciclo térmico aplicado a cada posição do tubo. 


\section{ABSTRACT}

API 5L Grade X80 steel are high strength low alloy steels (HSLA) used in the manufacture of pipes for transporting oil and gas by pipelines. API 5L X80 pipes are characterized by having excellent mechanical properties such as tensile strength, toughness, ductility, corrosion resistance, and good weldability. These pipes bring many benefits, for example, the economic factor related to the good mechanical strength of these tubes which can be produced with smaller wall thicknesses. This reduction in thickness lowers costs for transportation, construction, welding and installation. In addition, these tubes can be fabricated with large diameters, allowing the transport of large amounts of fluids at high pressures and flow rates. The toughness gives, to this material, the characteristic of being resistant to brittle fracture, since these tubes mostly work in agressive environmental conditions. The objective of this work is to physically simulate and study the mechanical properties of regions of the heat affected zone (HAZ) produced by different thermal cycles, which occur when the duct pipe is manufactured and assembled. The idea was to study the HAZ produced in the pipe manufactured by the UOE process (longitudinal weld) and the welding done in the field when the tube is mounted (HAZ beyond the intersection between the longitudinal and circumferential welding). Charpy $\mathrm{V}$ samples were machined in the L-T and T-L orientations and in the longitudinal weld in the center of the tube. These samples were subjected to single thermal cycles with maximum temperatures of $650,800,950$ and $1300^{\circ} \mathrm{C}$ and multipass thermal cycling with maximum temperatures of $950-800$ and $950-800-650^{\circ} \mathrm{C}$. The samples were subjected to different tests and characterizations. Impact tests were made at $0^{\circ} \mathrm{C}$, measured the lateral expansion produced and the surface fracture were examined under SEM. Vickers $300 \mathrm{~g}$ microhardness was also measured in the simulated $H A Z$ region. The microstructure of the HAZ was characterized by optical microscopy with conventional etching and Klemm colorful etching, and scanning electron microscopy. Quantitative metallography was used to obtain the amount of pearlite in the matrix of samples. The Charpy $\mathrm{V}$ fracture propagation path trajectory in the simulated microstructure was analyzed with optical microscopy and scanning electron microscopy. The results showed that the Charpy $\mathrm{V}$ absorbed energy by the simulated samples 
complies with the requirements of the API $5 \mathrm{~L}$ standard for the base metal without simulation and the HAZ observed microstructures vary according to the thermal cycle type applied to each tube position. 


\section{Lista de Figuras}

Figura 01. Comparação geral das tenacidades de aços ao carbono (ASTM A7, atualmente ASTM A283, grau D), aços ARBL, e aço estrutural tratado termicamente [1]

Figura 02. Requisitos dos aços para tubulações desenvolvidos em projetos recentes [4] .........................6

Figura 03. Mecanismos de endurecimento usados no desenvolvimento de aços ARBL para tubulações [4]

Figura 04. Evolução da soldabilidade dos aços API com relação à otimização da composição química

Figura 05. Evolução dos aços para a fabricação de tubos de grandes diâmetros [3]................................. 17

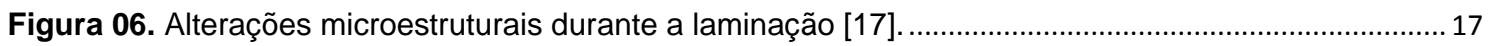

Figura 07. Diagrama do processo de laminação controlado [22 ................................................................ 19

Figura 08. Efeito da temperatura de laminação e da adição de $0,026 \% \mathrm{Nb}(2 \mathrm{~N})$ nas propriedades mecânicas e no tamanho do grão austenítico de aço $0,2 \%$ C[17] .......................................................... 21

Figura 09. Fração de $\mathrm{Nb}$ em solução na austenita para aços com $0,2 \% \mathrm{C}$ aquecidos em diferentes temperaturas [17].

Figura 10. Micrografias próximas à superfície da chapa obtidas por MO. (a) A seta indica colônias de ferrita poligonal de cor branco 200X, (b) Colônias de agregado eutetoíde (elipse) e grão maior de ferrita assinalado por a seta 500X. Nital 3\% [23].

Figura 11. Microestrutura da superfície da chapa do aço microligado para tubos API X80 obtidas por MEV. a) Grãos alongados de ferrita, agregados eutetóides. b) Grão antigo de austenita deformada que se transformou em agregados de eutetóides (setas amarelas) e grão de ferrita em forma de 'panqueca' (seta vermelha). Reagente Nital 3\% [23].

Figura 12. Processo de fabricação SAW longitudinal (U-O-E) [26] . ............................................................... 24

Figura 13. Temperatura de preaquecimento para a resistência ao trincamento de soldas em relação ao carbono equivalente, para dois tipos de revestimento, celulósico (CE) e básico [4].................................22

Figura 14. a) Representação da distribuição da temperatura máxima atingida na soldagem em função da distância ao eixo de solda b) Diagrama de fases Fe-C com a indicação das temperaturas máximas de soldagem e seu efeito sobre a microestrutura [adaptado da ref. 21].

Figura 15. a) Detalhe da linha de fusão e região termicamente afetada da solda com arame tubular autoprotegido em aço 20MnMoNi55. Estão indicadas, junto à linha de fusão, no material base, duas regiões: (s) região sem segregação no material base (c) com segregação. b) Esquema indicando as zonas de grãos grosseiros (GG) de um passe que são refinadas para granulação austenítica fina (GF) pelos passes subseqüentes. Ataque: Nital 2\% [21] . .......................................................................... 32

Figura 16. Ciclo térmico de soldagem em um ponto da junta soldada [30] .............................................. 33

Figura 17. Repartição térmica representando a ZAC de uma junta soldada [30]..................................... 34

Figura 18. Ciclos térmicos para distâncias perpendiculares à linha de centro do cordão de solda [30].....35

Figura 19. Ciclos térmicos de uma solda multipasse feitos em um ponto da ZAC perto da raiz e sem pré-

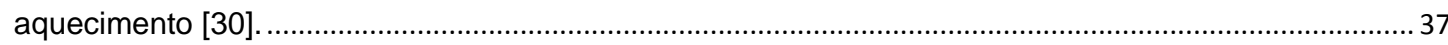

Figura 20. Fluxograma para a classificação de microconstituintes no metal de solda, adaptado para fins didáticos para classificação similar à do IIW [21].

Figura 21. Efeito do tamanho de grão austenítico no desenvolvimento da microestrutura de aços contendo inclusões no metal de solda [33].....

Figura 22. Microestrutura do metal de solda depositado mostrando a Ferrita Acicular, réplica de uma micrografia electrônica de transmissão. Nital $2 \%$ [33].

Figura 23. Microestrutura do metal depositado por arco submerso, submetido a alívio de tensões. (1) Ferrita acicular, (2) Ferrita de contorno de grão, (3) Ferrita com segunda fase alinhada, (4) Agregado ferrita-carboneto, (5) Ferrita com segunda fase não alinhada e (6) Ferrita poligonal intragranular. Nital $2 \%[21]$.

Figura 24. Microestrutura de um aço baixa liga revenido mostrando os limites dos grãos austeniticos iniciais. As ripas individuais de bainita/martensita também são delineadas. Reagente de Winsteard. Aumento de $500 \times$ [35].

Figura 25. Agregado MA num aço TRIP ( $C=0,27 \%, S i=1,4 \%, M n=1,4 \%)$. F=ferrita, (verde azulado no original, tom intermediário na foto) $B=$ bainita (marrom, tom mais escuro) $M A=$ martensita-austenita, (branco). Reagente LePera. [33]..... 
Figura 26. Representação esquemática da formação da bainita superior e inferior [33]. ............................47

Figura 27. Alinhamento de agulhas de bainita num grão de austenita. Nital 3\%.[33]................................ 48

Figura 28. Mudanças na microestrutura na ZAC de soldas em função das inclusões: a) Aço contendo inclusões de $\mathrm{TiO}, \mathrm{b})$ Aço sem inclusões de TiO [33]....

Figura 29. Influência do conteúdo de Titânio na microestrutura de metal de solda contendo 1,4\% Mn (FC,

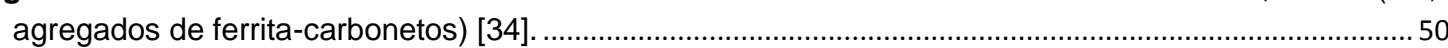

Figura 30. Efeito do Titânio na temperatura de transição do metal de solda com 1,4\% Mn [34] ................50

Figura 31. Influência do Nióbio na microestrutura da solda com 40ppm de Titânio e a) 0,6\%Mn, b) $1,4 \% \mathrm{Mn}[34]$

Figura 32. Efeito do Nióbio na tenacidade do metal de solda a $100 \mathrm{~J}$ após soldagem (S) e após alivio de tensão (AT) [38]

Figura 33. Influência do conteúdo de Vanádio na solda na microestrutura de soldas com a)0,6\%Mn e 40ppm Ti; b) 1,4\%Mn e 40ppm de Ti [34].

Figura 34. Efeito do Vanádio na tenacidade do metal de solda a 100J, após soldagem (S) e após alivio de tensão (AT) [38].

Figura 35. Influência do conteúdo de Alumínio na microestrutura da solda com: a) Sem adição de Ti b) 35ppm Ti [34]. 54

Figura 36. Influência na temperatura de transição em soldas de Aluminio a $100 \mathrm{~J}$ em soldas com 1,4\% Mn.

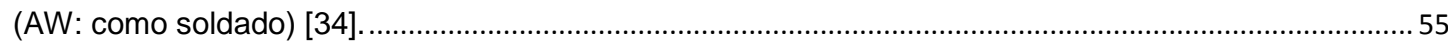

Figura 37. Influência do conteúdo de Boro na microestrutura de soldas com 1,4\%Mn e: a) <5ppm Ti; b) $35 p p m$ Ti [34]...

Figura 38. Efeito do Boro na tenacidade do metal de solda a 100J, após soldagem (S) e após alivio de tensão (AT) (37) [34] 56

Figura 39. Processo de soldagem por arco submerso [40]

Figura 40. Procedimentos de soldagem multipasse em arco-submerso[41] ...............................................64

Figura 41. Procedimento de soldagem multipasse com raiz através do processo MIG [41]. ......................65

Figura 42. Características da faixa de temperatura de transição para teste Charpy V-notch de chapa de

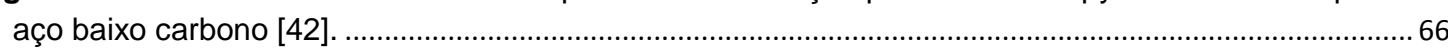

Figura 43. Efeito da orientação da amostra nos resultados do teste de impacto [42] .................................67

Figura 44. Porcentagem de área de fratura superficial de uma amostra de ensaio de impacto Charpy-V [42]......

Figura 45. Localização da medição de expansão lateral de um espécime Charpy $\mathrm{V}$ [42] ...........................69

Figura 46. Posições dos corpos-de-prova extraídos do tubo de aço API $5 \mathrm{~L}$ grau X80. ................................74

Figura 47. Temperaturas máximas dos ciclos térmicos realizados pelo equipamento Gleeble ${ }^{\circledR}$ de um passe único a) $650{ }^{\circ} \mathrm{C}$, b) $800{ }^{\circ} \mathrm{C}$ c) $950{ }^{\circ} \mathrm{C}$ e d) $1300{ }^{\circ} \mathrm{C}$.

Figura 48. Temperaturas máximas dos ciclos térmicos realizados pelo equipamento Gleeble $\AA^{\text {. a) }}$

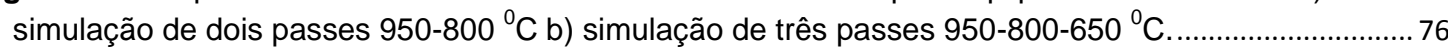

Figura 49. Dimensões dos corpos-de-prova de $650,800,900{ }^{\circ} \mathrm{C}$ e sem simulação, para o ensaio de impacto Charpy-V. Dimensões em (mm).

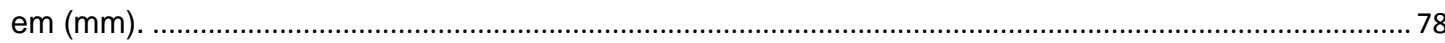

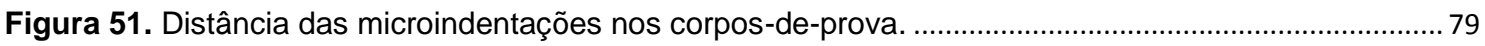

Figura 52. Microestrutura da posição 1 sem simulação; (1) ferrita de contorno de grão (GF), (2) ferrita acicular (AF), (3) ferrita poligonal intragranular (PF), (4) ferrita com segunda fase não alinhada SF(NA) e (5) perlita (P). a) 200X, b)500X c) 1000X. Ataque Nital 3\%...

Figura 53. Microestrutura da posição $1 \mathrm{com}$ ciclo térmico de $650{ }^{\circ} \mathrm{C}$; (1) ferrita de contorno de grão (GF), (2) ferrita acicular (AF), (3) ferrita poligonal intragranular (PF), (5) perlita (P) e (6) ferrita com segunda fase alinhada (AC). a) 200X, b) 500X e c) 1000X. Ataque Nital 3\%..................................................... 84

Figura 54. Microestrutura da posição 1 com ciclo térmico de $800{ }^{\circ} \mathrm{C}$; (1) ferrita de contorno de grão (GF), (2) ferrita acicular (AF), (3) ferrita poligonal intragranular (PF), e (6) ferrita com segunda fase alinhada (AC). a) $200 \mathrm{X}$, b) $500 \mathrm{X} \mathrm{e} \mathrm{c)} 1000 \mathrm{X}$. Ataque Nital $3 \%$.

Figura 55. Microestrutura da posição $1 \mathrm{com}$ ciclo térmico de $950{ }^{\circ} \mathrm{C}$; (1) ferrita de contorno de grão (GF). a) $200 \mathrm{X}$, b) $500 \mathrm{X}$ e c) 1000X. Ataque Nital 3\%.

Figura 56. Microestrutura da posição $1 \mathrm{com}$ ciclo térmico de $1300{ }^{\circ} \mathrm{C}$; (2) ferrita acicular (AF), (4) ferrita com segunda fase não alinhada SF(NA), (5) perlita (P), (6) ferrita com segunda fase alinhada (AC). a) $200 \mathrm{X}$, b) $500 \mathrm{X}$ e c) $1000 \mathrm{X}$. Ataque Nital $3 \%$. 
Figura 57. Microestrutura da posição 2 do material de base sem simulação; a)200X, b)500X e c)1000X.

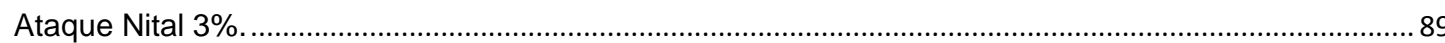

Figura 58. Microestrutura da posição 2 com ciclo térmico de $650{ }^{\circ} \mathrm{C}$; a)200X, b) $500 \mathrm{X}$ e c) $1000 \mathrm{X}$. Ataque Nital 3\%

Figura 59. Microestrutura da posição 2 com ciclo térmico de $800{ }^{\circ} \mathrm{C}$; a)200X, b)500X e c)1000X. Ataque Nital $3 \%$.

Figura 60. Microestrutura da posição 2 com ciclo térmico de $950{ }^{\circ} \mathrm{C}$; a)200X, b)500X e c) $1000 \mathrm{X}$. Ataque

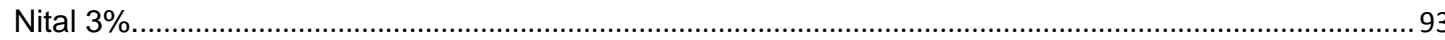

Figura 61. Microestrutura da posição 2 com ciclo térmico de $1300{ }^{\circ} \mathrm{C}$; a)200X, b)500X e c)1000X. Ataque

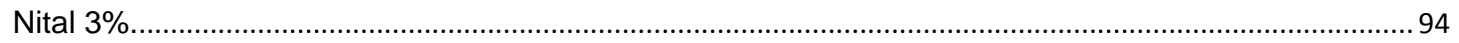

Figura 62. Microestrutura da posição 3 sem simulação; a)200X, b)500X e c)1000X. Ataque Nital 3\%...... 96

Figura 63. Microestrutura da posição 3 com ciclo térmico de $650{ }^{\circ} \mathrm{C}$; a)200X, b) $500 \mathrm{X}$ e c) $1000 \mathrm{X}$. Ataque Nital $3 \%$.

(1)

Figura 64. Microestrutura da posição 3 com ciclo térmico de $800{ }^{\circ} \mathrm{C}$; a)200X, b) $500 \mathrm{X}$ e c)1000X. Ataque

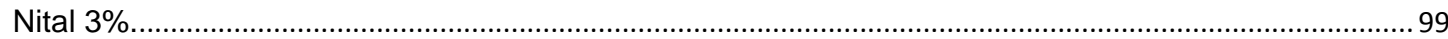

Figura 65. Microestrutura da posição 3 com ciclo térmico de $950{ }^{\circ} \mathrm{C}$; a)200X, b)500X e c)1000X. Ataque

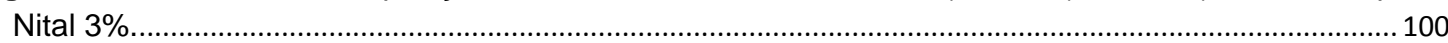

Figura 66. Microestrutura da posição 3 com ciclo térmico de $1300{ }^{\circ} \mathrm{C}$; a)200X, b) $500 \mathrm{X}$ e c) $1000 \mathrm{X}$. Ataque

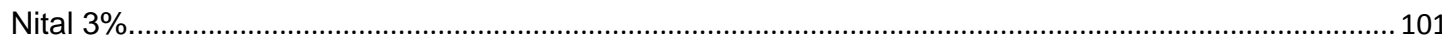

Figura 67. Microestrutura da posição $1 \mathrm{com}$ ciclo térmico multipasse de $950-800{ }^{\circ} \mathrm{C}$; (1) ferrita de contorno de grão (GF) (2) ferrita acicular (AF), (4) ferrita com segunda fase não alinhada SF(NA) e (6) ferrita com segunda fase alinhada (AC). a)200X, b)500X e c)1000X. Ataque Nital 3\%........................ 103

Figura 68. Microestrutura da posição $1 \mathrm{com}$ ciclo térmico multipasse de $950-800-650{ }^{\circ} \mathrm{C}$; (1) ferrita de contorno de grão (GF), (2) ferrita acicular (AF), ferrita poligonal intragranular (PF) e perlita (P). a)200X, b) $500 X$ e c) $1000 X$. Ataque Nital 3\%.............................................................................................. 104

Figura 69. Microestrutura da posição 2 com ciclo térmico multipasse de $950-800{ }^{\circ} \mathrm{C}$; a)200X, b) $500 \mathrm{X}$ e

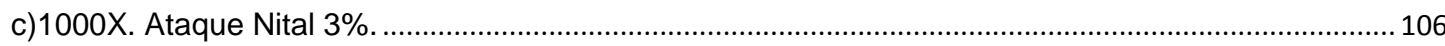

Figura 70. Microestrutura da posição 2 com ciclo térmico multipasse de $950-800-650{ }^{\circ} \mathrm{C}$; a)200X, b) $500 \mathrm{X}$ e c) 1000X. Ataque Nital 3\%......................................................................................................... 107

Figura 71. Microestrutura da posição 3 com ciclo térmico multipasse de $950-800{ }^{\circ} \mathrm{C}$; a)200X, b)500X e

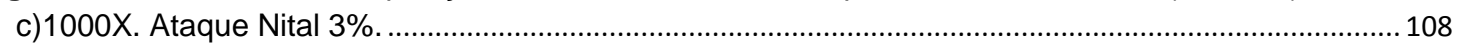

Figura 72. Microestrutura da posição 3 com ciclo térmico multipasse de $950-800-650{ }^{\circ} \mathrm{C}$; a)200X, b) $500 \mathrm{X}$

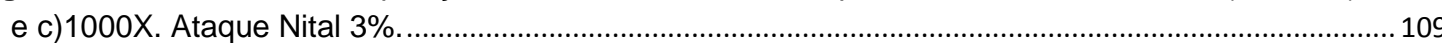

Figura 73. Microestrutura da posição 1 do material sem simulação em a)2000X e b) 5000X. Ataque Nital $3 \%$.

Figura 74. Microestrutura da posição 1 do material com ciclo térmico de $650^{\circ} \mathrm{C}$ em a) $2000 \mathrm{X}$ e b) $5000 \mathrm{X}$.

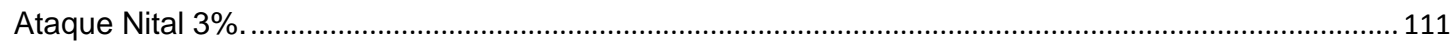

Figura 75. Microestrutura da posição 1 do material com ciclo térmico de $800^{\circ} \mathrm{C}$ em a) $2000 \mathrm{X}$ e b) $5000 \mathrm{X}$.

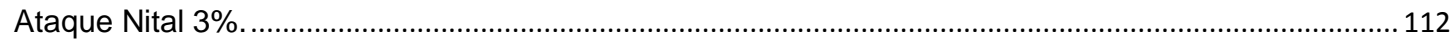

Figura 76. Microestrutura da posição 1 do material com ciclo térmico de $950^{\circ} \mathrm{C}$ em a) $2000 \mathrm{X}$ e b) $5000 \mathrm{X}$. Ataque Nital 3\%.

Figura 77. Microestrutura da posição 1 do material com ciclo térmico de $1300^{\circ} \mathrm{C}$ em a) $2000 \mathrm{X}$ e b) 5000X. Ataque Nital 3\%.

Figura 78. Microestrutura da posição 2 do material sem simulação em a) 2000X e b) 5000X. Ataque Nital 3\%

Figura 79. Microestrutura da posição 2 do material com ciclo térmico de $650{ }^{\circ} \mathrm{C}$ em a) $2000 \mathrm{X}$ e b) $5000 \mathrm{X}$.

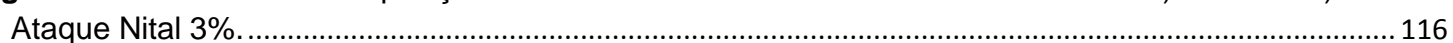

Figura 80. Microestrutura da posição 2 do material com ciclo térmico de $800{ }^{\circ} \mathrm{C}$ em a) $2000 \mathrm{X}$ e b) $5000 \mathrm{X}$.

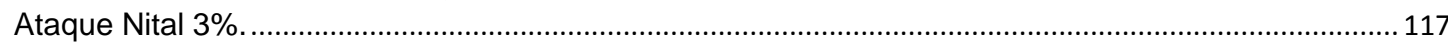

Figura 81. Microestrutura da posição 2 do material com ciclo térmico de $950{ }^{\circ} \mathrm{C}$ em a) $2000 \mathrm{X}$ e b) $5000 \mathrm{X}$. Ataque Nital 3\%......................................................................................................................... 118

Figura 82. Microestrutura da posição 2 do material com ciclo térmico de $1300{ }^{\circ} \mathrm{C}$ em a) $2000 \mathrm{X}$ e b)

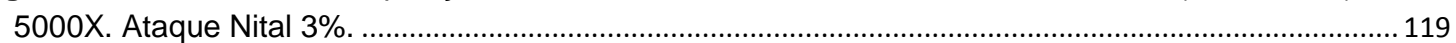

Figura 83. Microestrutura da posição 3 do material base sem ciclo térmico em a) 2000X e b) 5000X.

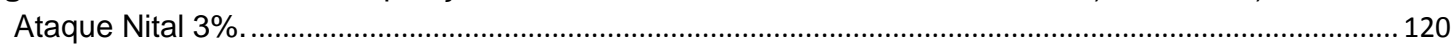

Figura 84. Microestrutura da posição 3 do material com ciclo térmico de $650{ }^{\circ} \mathrm{C}$ em a) $2000 \mathrm{X}$ e b) $5000 \mathrm{X}$.

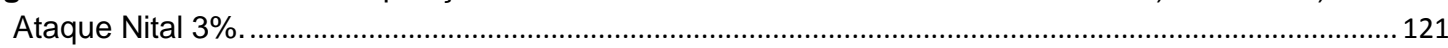


Figura 85. Microestrutura da posição 3 do material com ciclo térmico de $800{ }^{0} \mathrm{C}$ em a) $2000 \mathrm{X}$ e b) $5000 \mathrm{X}$.

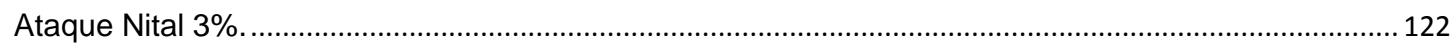

Figura 86. Microestrutura da posição 3 do material com ciclo térmico de $950{ }^{\circ} \mathrm{C}$ em a) $2000 \mathrm{X}$ e b) $5000 \mathrm{X}$. Ataque Nital 3\%.

Figura 87. Microestrutura da posição 3 do material com ciclo térmico de $1300^{\circ} \mathrm{C} \mathrm{em} \mathrm{a)} 2000 \mathrm{X}$ e b) 5000X. Ataque Nital 3\%.

Figura 88. Microestrutura da posição 1 do material com ciclo térmico multipasse de $950-800{ }^{0} \mathrm{C}$ em a)

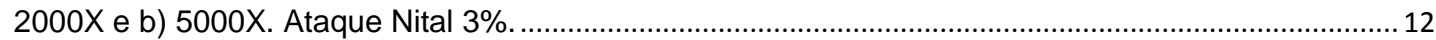

Figura 89. Microestrutura da posição 1 do material com ciclo térmico multipasse de $950-800-650{ }^{\circ} \mathrm{C}$ em

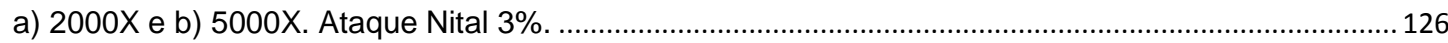

Figura 90. Microestrutura da posição 2 do material com ciclo térmico multipasse de $950-800{ }^{\circ} \mathrm{C}$ em a) 2000X e b) 5000X. Ataque Nital 3\%.

Figura 91. Microestrutura da posição 2 do material com ciclo térmico multipasse de $950-800-650{ }^{0} \mathrm{C}$ em

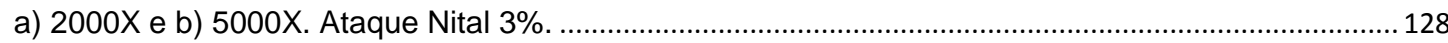

Figura 92. Microestrutura da posição 3 do material com ciclo térmico multipasse de $950-800{ }^{0} \mathrm{C}$ em a) 2000X e b) 5000X. Ataque Nital 3\%

Figura 93. Microestrutura da posição 3 do material com ciclo térmico multipasse de $950-800-650{ }^{\circ} \mathrm{C}$ em

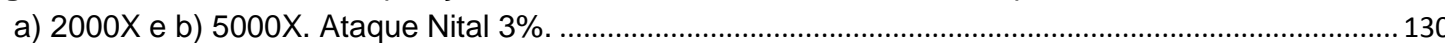

Figura 94. Microestrutura da posição 1 do material sem simulação, mostrando o agregado MA (branco) e os agregados eutetóides (azul escuro). Em a) 500X e b) 1000X. Ataque Klemm 1............................ 131

Figura 95. Microestrutura da posição 1 do material com ciclo térmico de $650^{\circ} \mathrm{C}$ em a) $500 \mathrm{X}$ e b) $1000 \mathrm{X}$.

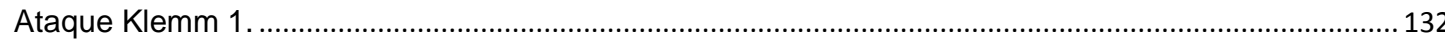

Figura 96. Microestrutura da posição 1 do material com ciclo térmico de $800^{\circ} \mathrm{C}$ em a) $500 \mathrm{X}$ e b) $1000 \mathrm{X}$.

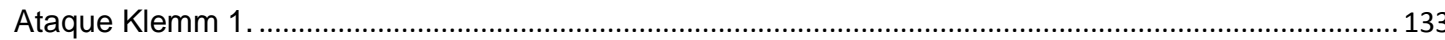

Figura 97. Microestrutura da posição 1 do material com ciclo térmico de $950^{\circ} \mathrm{C}$ em a) $500 \mathrm{X}$ e b) $1000 \mathrm{X}$. Ataque Klemm 1

Figura 98. Microestrutura da posição 1 do material com ciclo térmico de $1300^{\circ} \mathrm{C}$ em a) $500 \mathrm{X}$ e b) $1000 \mathrm{X}$. Ataque Klemm 1.

Figura 99. Microestrutura da posição 2 do material sem simulação em a) 500X e b) 1000X. Ataque Klemm 1

Figura 100. Microestrutura da posição 2 do material com ciclo térmico de $650^{\circ} \mathrm{C}$ em a) $500 \mathrm{X}$ e b) $1000 \mathrm{X}$.

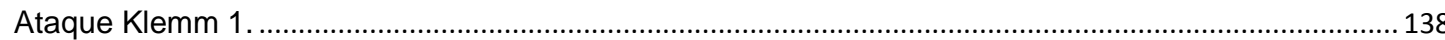

Figura 101. Microestrutura da posição 2 do material com ciclo térmico de $800^{\circ} \mathrm{C}$ em a) $500 \mathrm{X}$ e b) $1000 \mathrm{X}$. Ataque Klemm 1

Figura 102. Microestrutura da posição 2 do material com ciclo térmico de $950^{\circ} \mathrm{C}$ em a) $500 \mathrm{X}$ e b) $1000 \mathrm{X}$. Ataque Klemm 1.

Figura 103. Microestrutura da posição 2 do material com ciclo térmico de $1300^{\circ} \mathrm{C}$ em a) $500 \mathrm{X}$ e b) $1000 \mathrm{X}$.

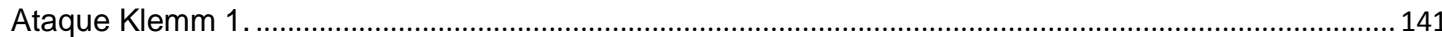

Figura 104. Microestrutura da posição 3 do material sem simulação em a) 500X e b) 1000X. Ataque

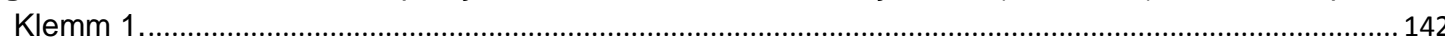

Figura 105. Microestrutura da posição 3 do material com ciclo térmico de $650^{\circ} \mathrm{C}$ em a) $500 \mathrm{X}$ e b) $1000 \mathrm{X}$. Ataque Klemm 1

Figura 106. Microestrutura da posição 3 do material com ciclo térmico de $800^{\circ} \mathrm{C}$ em a) $500 \mathrm{X}$ e b) $1000 \mathrm{X}$.

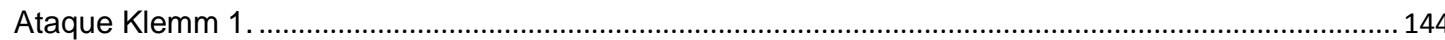

Figura 107. Microestrutura da posição 3 do material com ciclo térmico de $950^{\circ} \mathrm{C}$ em a) $500 \mathrm{X}$ e b) $1000 \mathrm{X}$.

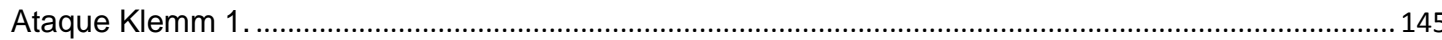

Figura 108. Microestrutura da posição 3 do material com ciclo térmico de $1300^{\circ} \mathrm{C}$ em a) $500 \mathrm{X}$ e b)

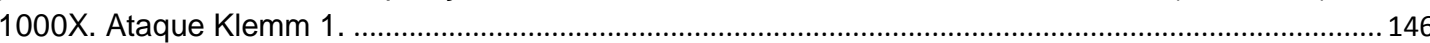

Figura 109. Microestrutura da posição 1 do material com ciclo térmico multipasse de $950-800{ }^{\circ} \mathrm{C}$ em a)

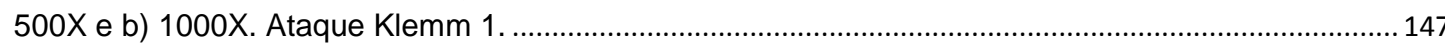

Figura 110. Microestrutura da posição 1 do material com ciclo térmico multipasse de $950-800-650{ }^{0} \mathrm{C}$ em

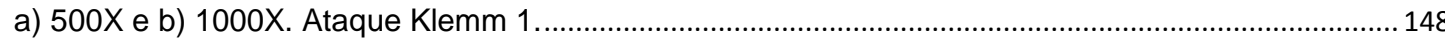

Figura 111. Microestrutura da posição 2 do material com ciclo térmico multipasse de $950-800{ }^{\circ} \mathrm{C}$ em a)

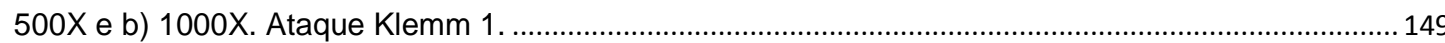

Figura 112. Microestrutura da posição 2 do material com ciclo térmico multipasse de $950-800-650{ }^{\circ} \mathrm{C}$ em

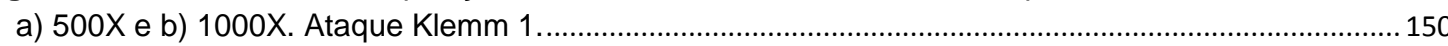


Figura 113. Microestrutura da posição 3 do material com ciclo térmico multipasse de $950-800{ }^{0} \mathrm{C}$ em a) 500X e b) 1000X. Ataque Klemm 1.......................................................................................... 151

Figura 114. Microestrutura da posição 3 do material com ciclo térmico multipasse de $950-800-650{ }^{\circ} \mathrm{C}$ em

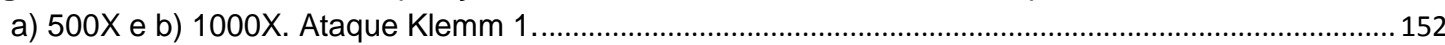

Figura 115. Conteúdo de agregados eutetóides em função dos ciclos térmicos de uma passe.................153

Figura 116. Fração volumétrica dos agregados eutetoides em relação as temperaturas máximas multipasse.

Figura 117. Energias absorvidas em relação a os ciclos térmicos.

Figura 118. Energias absorvidas para os ciclos térmicos multipasse.

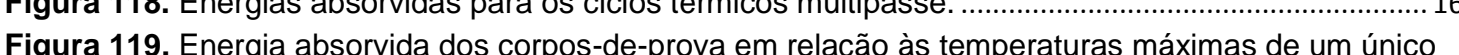
passe.

Figura 120. Expansão lateral dos corpos-de-prova em relação aos ciclos térmicos de um único passe. 166

Figura 121. Expansão lateral em relação a os ciclos térmicos multipasse...................................................168

Figura 122. Dureza Vickers em relação aos ciclos térmicos de um único passe. ........................................169

Figura 123. Durezas Vickers em função dos ciclos térmicos multipasse. ...................................................171

Figura 124. Fraturas superficiais observadas no MEV para a posição 1 sem simulação. ...........................173

Figura 125. Fraturas superficiais observadas no MEV para a posição $1 \mathrm{com}$ ciclo térmico de $650{ }^{\circ} \mathrm{C}$. Foto inferior comportamento dúctil, foto superior comportamento dúctil-frágil.............................................. 174

Figura 126. Fraturas superficiais observadas no MEV para a posição $1 \mathrm{com}$ ciclo térmico de $800{ }^{\circ} \mathrm{C}$. Foto inferior comportamento dúctil-frágil, foto superior comportamento principalmente frágil. ....................... 175

Figura 127. Fraturas superficiais observadas no MEV para a posição $1 \mathrm{com}$ ciclo térmico de $950{ }^{\circ} \mathrm{C}$. Foto inferior comportamento dúctil, foto superior comportamento frágil. .......................................................... 176

Figura 128. Fraturas superficiais observadas no MEV para a posição $1 \mathrm{com}$ ciclo térmico de $1300{ }^{\circ} \mathrm{C}$. Comportamento puramente dúctil na foto inferior e superior.

Figura 129. Fraturas superficiais observadas no MEV para a posição 2 sem simulação. Foto inferior comportamento dúctil formado por dimples originados pelas inclusões, foto superior comportamento frágil.

Figura 130. Fraturas superficiais observadas no MEV para a posição $2 \mathrm{com}$ ciclo térmico de $650{ }^{\circ} \mathrm{C}$. Comportamento puramente dúctil na foto inferior e superior com inclusões no interior dos dimples.... 179

Figura 131. Fraturas superficiais observadas no MEV para a posição 2 com ciclo térmico de $800{ }^{\circ} \mathrm{C}$. Comportamento dúctil na foto inferior, comportamento dúctil na foto superior...................................... 180

Figura 132. Fraturas superficiais observadas no MEV para a posição 2 com ciclo térmico de $950{ }^{0} \mathrm{C}$. Comportamento puramente dúctil na foto inferior e superior.

Figura 133. Fraturas superficiais observadas no MEV para a posição 2 com ciclo térmico de $1300{ }^{\circ} \mathrm{C}$. Comportamento dúctil na foto inferior, comportamento frágil na foto superior.....

Figura 134. Fraturas superficiais observadas no MEV para a posição 3 sem simulação. Comportamento dúctil na foto inferior, comportamento frágil na foto superior.

Figura 135. Fraturas superficiais observadas no MEV para a posição $3 \mathrm{com}$ ciclo térmico de $650{ }^{\circ} \mathrm{C}$. Comportamento puramente dúctil na foto inferior e superior............................................................... 186

Figura 136. Fraturas superficiais observadas no MEV para a posição $3 \mathrm{com}$ ciclo térmico de $800{ }^{\circ} \mathrm{C}$. Comportamento dúctil na foto inferior e comportamento frágil na foto superior.

Figura 137. Fraturas superficiais observadas no MEV para a posição 3 com ciclo térmico de $950{ }^{\circ} \mathrm{C}$. Comportamento puramente dúctil na foto inferior e superior.

Figura 138. Fraturas superficiais observadas no MEV para a posição $3 \mathrm{com}$ ciclo térmico de $1300{ }^{\circ} \mathrm{C}$. Comportamento dúctil na foto inferior e comportamento frágil na foto superior.

Figura 139. Fraturas superficiais observadas no MEV para a posição $1 \mathrm{com}$ ciclo térmico multipasse de 950-800 ${ }^{\circ} \mathrm{C}$. Comportamento ductil na foto inferior e comportamento frágil na foto superior. ................ 191

Figura 140. Fraturas superficiais observadas no MEV para a posição $1 \mathrm{com}$ ciclo térmico multipasse de 950-800-650 ${ }^{\circ} \mathrm{C}$. Comportamento dúctil-frágil na foto inferior e comportamento frágil na foto superior.

Figura 141. Fraturas superficiais observadas no MEV para a posição 2 com ciclo térmico multipasse de 950-800 ${ }^{\circ} \mathrm{C}$. Comportamento puramente dúctil na foto inferior e superior...

Figura 142. Fraturas superficiais observadas no MEV para a posição 2 com ciclo térmico multipasse de 950-800-650 ${ }^{\circ} \mathrm{C}$. Comportamento puramente dúctil na foto inferior e superior......................................... 194

Figura 143. Fraturas superficiais observadas no MEV para a posição $3 \mathrm{com}$ ciclo térmico multipasse de 950-800 ${ }^{\circ} \mathrm{C}$. Comportamento puramente dúctil na foto inferior e superior... 
Figura 144. Fraturas superficiais observadas no MEV para a posição 3 com ciclo térmico multipasse de 950-800-650 ${ }^{\circ} \mathrm{C}$. Comportamento puramente dúctil na foto inferior e superior.

Figura 145. Detalhes do caminho da trinca empregando microscopia óptica e eletrônica de varredura da posição 1 , sem simulação.

Figura 146. Detalhes do caminho da trinca empregando microscopia óptica e eletrônica de varredura da posição 2, sem simulação.

Figura 148. Detalhes do caminho da trinca empregando microscopia óptica e eletrônica de varredura da posição 1 , simulado a $1300{ }^{\circ} \mathrm{C}$

Figura 149. Detalhes do caminho da trinca empregando microscopia óptica e eletrônica de varredura da posição 2 , simulado a $1300{ }^{\circ} \mathrm{C}$.

Figura 150. Detalhes do caminho da trinca empregando microscopia óptica e eletrônica de varredura da posição 3 , simulado a $1300{ }^{\circ} \mathrm{C}$.

Figura 151. Detalhes do caminho da trinca empregando microscopia óptica e eletrônica de varredura da posição 1 , simulado a $800{ }^{\circ} \mathrm{C}$

Figura 152. Detalhes do caminho da trinca empregando microscopia óptica e eletrônica de varredura da posição 2 , simulado a $800{ }^{\circ} \mathrm{C}$.

Figura 153. Detalhes do caminho da trinca empregando microscopia óptica e eletrônica de varredura da posição 3 , simulado a $800{ }^{\circ} \mathrm{C}$.

Figura 154. Detalhes do caminho da trinca empregando microscopia óptica e eletrônica de varredura da posição 1 , simulado a $950{ }^{\circ} \mathrm{C}$.

Figura 155. Detalhes do caminho da trinca empregando microscopia óptica e eletrônica de varredura da posição 2 , simulado a $950{ }^{\circ} \mathrm{C}$.

Figura 156. Detalhes do caminho da trinca empregando microscopia óptica e eletrônica de varredura da posição 3 , simulado a $950{ }^{\circ} \mathrm{C}$.

Figura 157. Detalhes do caminho da trinca empregando microscopia óptica e eletrônica de varredura da posição 1 , simulado a $950-800{ }^{\circ} \mathrm{C}$

Figura 158. Detalhes do caminho da trinca empregando microscopia óptica e eletrônica de varredura da posição 2 , simulado a $950-800{ }^{\circ} \mathrm{C}$.

Figura 159. Detalhes do caminho da trinca empregando microscopia óptica e eletrônica de varredura da posição 3 , simulado a $950-800{ }^{\circ} \mathrm{C}$.

Figura 160. Detalhes do caminho da trinca empregando microscopia óptica e eletrônica de varredura da posição 1 , simulado a $950-800-650{ }^{\circ} \mathrm{C}$

Figura 161. Detalhes do caminho da trinca empregando microscopia óptica e eletrônica de varredura da posição 2 , simulado a $950-800-650{ }^{\circ} \mathrm{C}$.

Figura 162. Detalhes do caminho da trinca empregando microscopia óptica e eletrônica de varredura da posição 3 , simulado a $950-800-650{ }^{\circ} \mathrm{C}$. 


\section{Lista de Tabelas}

Tabela 01. Composição química típica e as propriedades mecânicas dos aços ARBL [1] ............................ 5

Tabela 02. Propriedades mecânicas dos aços segundo a norma API 5L [8] ................................................ 9

Tabela 03. Composição química para aços API $5 \mathrm{~L}$ em porcentagem em peso (8) [8].................................. 9

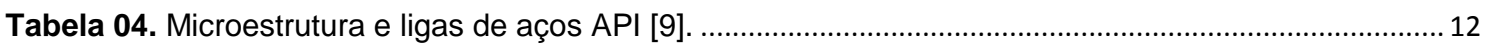

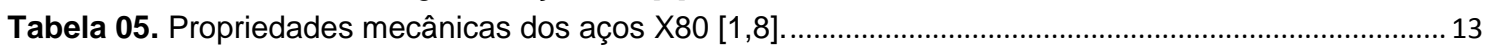

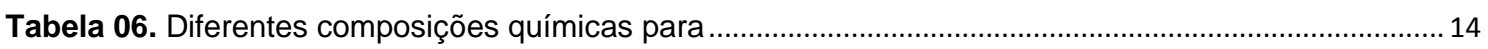

Tabela 07. Composição química de aços API 5L grau X80 produzidos no Brasil [10]................................ 19

Tabela 08. Constituintes no esquema de classificação de microestrutura de metal de solda de aços

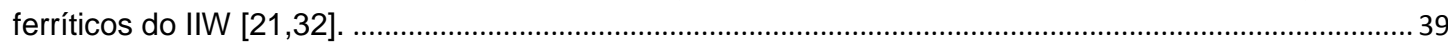

Tabela 09. Composição química do aço API 5L grau X80 como recebido..................................................... 72

Tabela 10. Composição química do arame e do metal de solda para soldagem longitudinal do tubo API

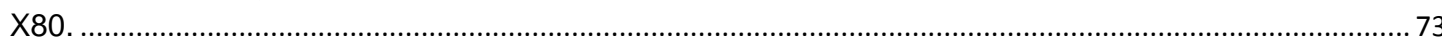

Tabela 11. Fração volumétrica dos agregados eutetóides na microestrutura do aço nos diferentes ciclos térmicos.

Tabela 12. Fração volumétrica dos agregados eutetóides versus temperaturas máximas dos ciclos

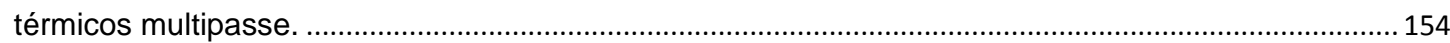

Tabela 13. Comparação das microestruturas dos corpos-de-prova estudados.......................................... 156

Tabela 14. Valores das energias absorvidas do ensaio de impacto Charpy- $V$ dos corpos-de-prova do metal base e com simulação do ciclo térmico de um passe. ........................................................................ 157

Tabela 15. Valores das energias absorvidas do ensaio de impacto Charpy- $V$ dos corpos-de-prova com

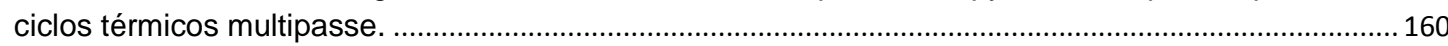

Tabela 16. Energia absorvida/área em relação às temperaturas dos ciclos térmicos. .................................163

Tabela 17. Expansão lateral dos corpos-de-prova submetidos ao ensaio de impacto Charpy-V para um

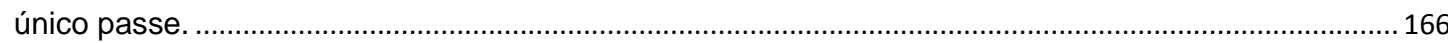

Tabela 18. Expansões laterais dos corpos-de-prova em relação a os ciclos térmicos multipasse.............167

Tabela 19. Dureza Vickers em relação aos ciclos térmicos de um único passe........................................169

Tabela 20. Durezas Vickers em função dos ciclos térmicos multipasse. ....................................................... 171 


\section{Listas de Abreviaturas e Siglas}

AC: Ferrita com Segunda Fase Alinhada.

AF: Ferrita Acicular.

API: Instituto Americano do Petróleo.

ARBL: Alta Resistência e Baixa Liga

ASTM: Sociedade Americana para Ensaios de Materiais.

ASM: Sociedade Americana de Metais.

AWS: Sociedade Americana de Soldagem.

B: Bainita

CCPD: Corrente Contínua com Polaridade Direta.

CCPR: Corrente Contínua com Polaridade Reversa.

CE: Carbono Equivalente.

FC: Agregado Ferrita Carboneto.

FCAW: Arco de Soldagem com Arame Tubular.

GF: Ferrita de Contorno de Grão.

GMAW: Arco de Soldagem com Gás de Proteção.

HIC: Trinca Induzida por Hidrogênio.

HTP: Processamento a Elevada Temperatura.

IIW: Instituto Internacional de Soldagem.

M: Martensita.

MA: Agregado Martensita/Austenita.

MAC: Martensita Austenita Carboneto

MAG: Metal de Solda Protegido com Gás Ativo.

MEV: Microscópio Eletrônico de Varredura.

MIG: Metal de Solda Protegido com Gás Inerte.

MO: Microscópio Óptico.

P: Perlita

PF: Ferrita Poligonal Intragranular.

Pcm: Parâmetro de Carbono Equivalente.

SF(NA):Ferrita Secundaria Não Alinhada.

SAW: Arco de Soldagem Submerso.

SMYS: Resistência ao Escoamento Mínimo Especificado. 
TL: Temperatura de Laminação.

TMCP: Processo Controlado Termomecanicamente.

TMCR: Laminação Controlada Termomecanicamente.

UOE: Conformação em U, O e expansão E. 


\section{Sumário}

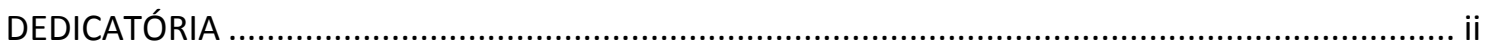

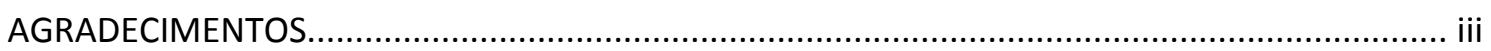

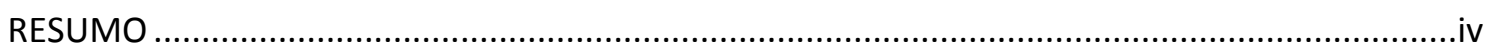

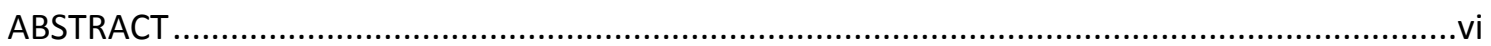

Lista de Figuras ......................................................................................................................

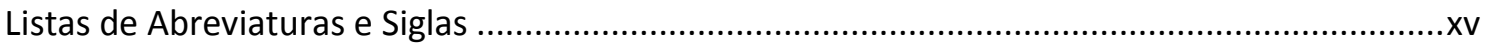

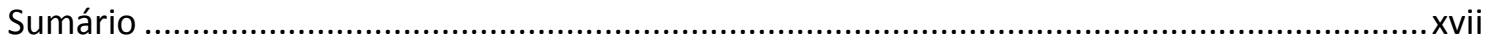

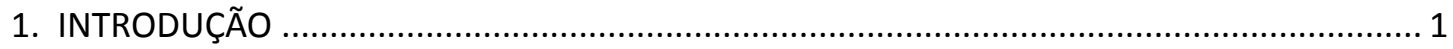

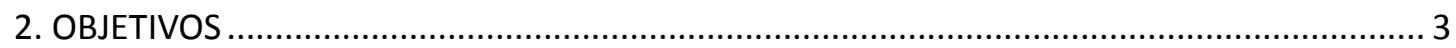

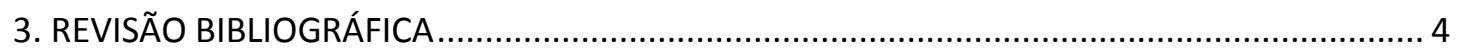

3.1. Aços de Alta Resistência e Baixa Liga (ARBL) …........................................................... 5

3.1.1. Aços Para Dutos ou Tubulações ........................................................................... 8

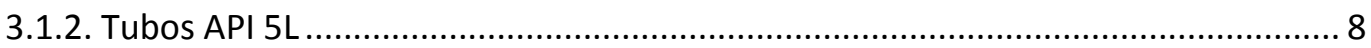

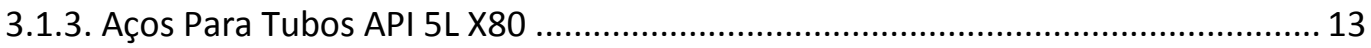

3.2. Processo de Fabricação de Aço API 5L grau X80 e Superior .......................................... 15

3.2.1 Processo de Fabricação do Aço API 5L Grau X80 Nacional ...................................... 18

3.2.2. Efeito dos Carbonitretos na Laminação de Aços com Baixo Teor de Carbono. .... 20

3.2.3. Microestrutura do Aço Microligado para Tubos de Aço API 5L Grau X80 ............ 22

3.3. Processo de Fabricação dos Tubos Com Costura (U-O-E) ........................................... 23

3.4. Soldabilidade dos Aços de Alta Resistência e Baixa Liga (ARBL) ................................... 25

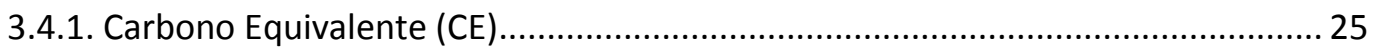

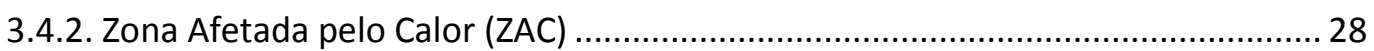

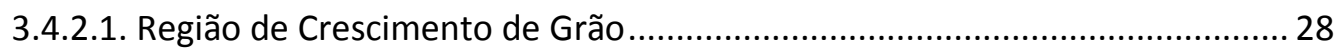

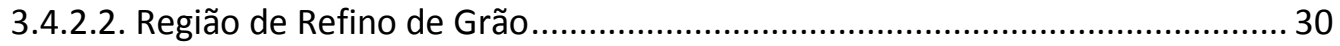

3.4.2.3. Região Intercrítica ou Parcialmente Transformada ....................................... 30

3.4.2.4. Região de Esferoidização de Carbonetos ...................................................... 31

3.4.3. Efeitos de Vários Passes de Solda na ZAC ......................................................... 31

3.4.4. Transferência de Calor na Soldagem................................................................... 32

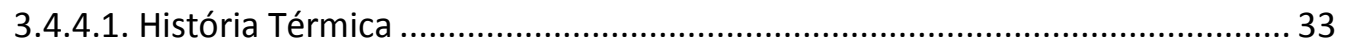

3.4.4.2 Ciclos Térmicos de Uma Solda Multipasse ...................................................... 36

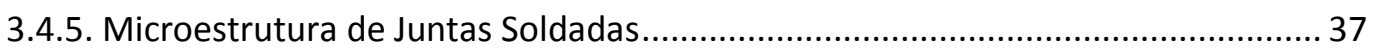

3.4.6 Classificação dos Microconstituintes do Metal de Solda de Aços Ferríticos .......... 38 
3.4.6.1. Ferrita Acicular no Metal de Solda (FA)

3.4.6.2. Ferrita Primária de Contorno de Grão (GF) ......................................... 43

3.4.6.3. Ferrita Poligonal Intragranular (PF) ............................................. 43

3.4.6.4. Ferrita com Segunda Fase Alinhada SF(AC) ....................................... 43

3.4.6.5. Ferrita com Segunda Fase Não Alinhada SF(NA) .................................... 43

3.4.6.6. Agregado Ferrita-Carboneto (FC) ...................................................... 45

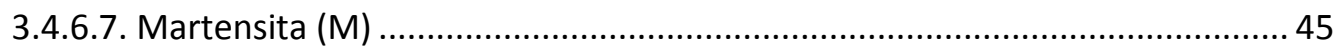

3.4.6.8. Microconstituinte Martensita/Austenita (MA) ...................................... 46

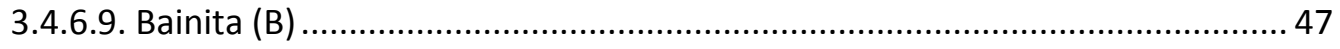

3.4.6.10. Inclusões.................................................................................. 48

3.4.7. Efeito dos Elementos de Liga no Metal de Solda ........................................ 49

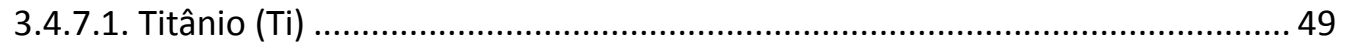

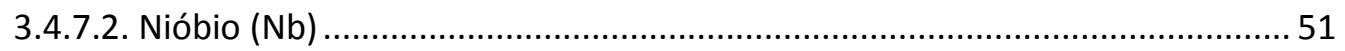

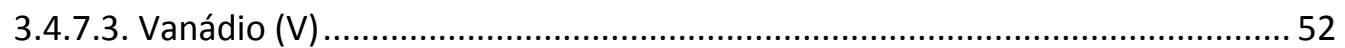

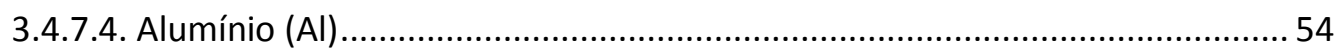

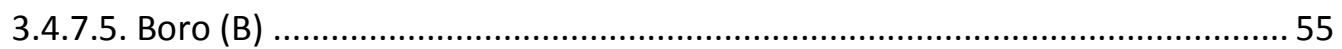

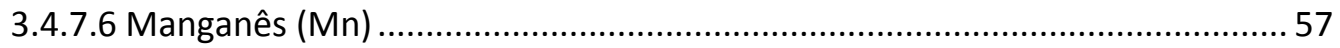

3.4.8. Soldagem com Arco Submerso (SAW) …................................................ 57

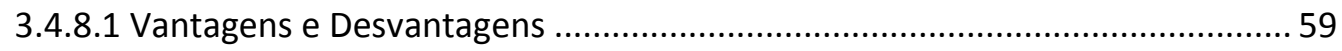

3.4.8.2. Efeito das Variáveis do Processo ............................................................ 60

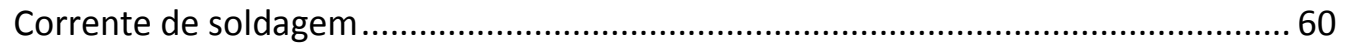

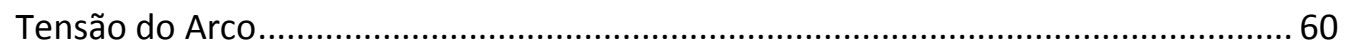

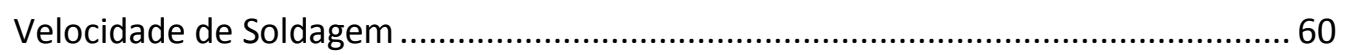

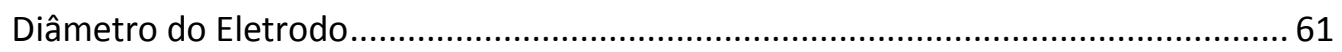

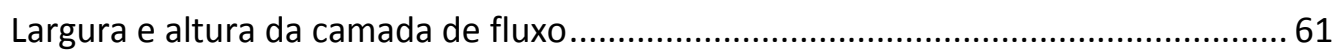

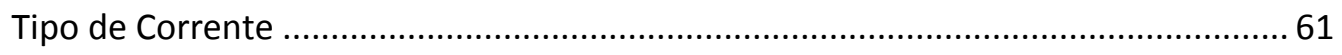

3.4.8.3. Consumíveis Usados no Processo para Arco Submerso............................. 62

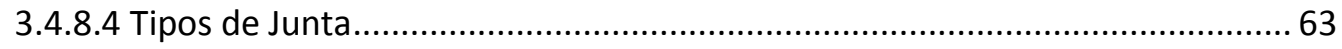

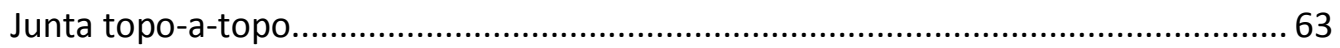

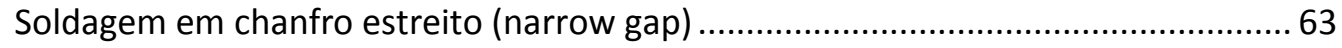

Soldagem em junta em ângulo..................................................................... 63

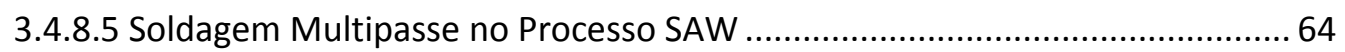

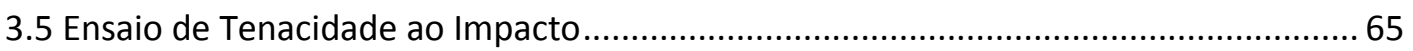

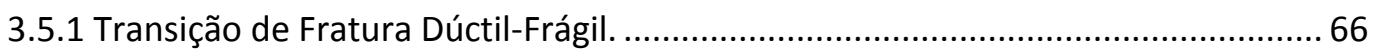


3.5.2 Ensaio de Impacto Charpy.

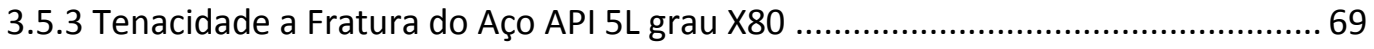

3.5.3.1 Tenacidade em Relação à Microestrutura ....................................................... 69

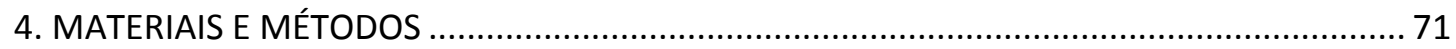

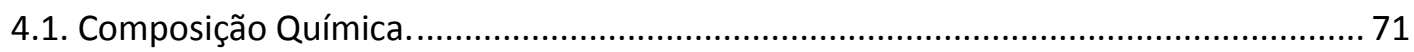

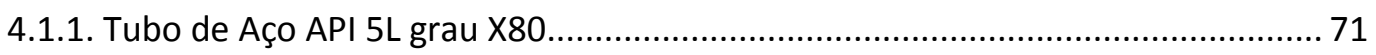

4.1.2. Composição Química do Arame e do Cordão de Solda Longitudinal..................... 73

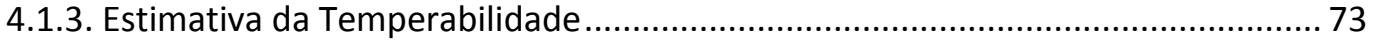

4.2. Simulações no Equipamento Gleeble ${ }^{\circledR}$........................................................................... 74

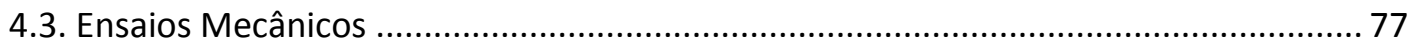

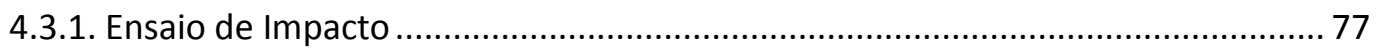

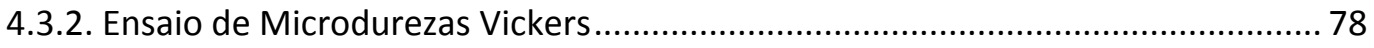

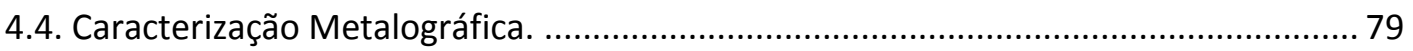

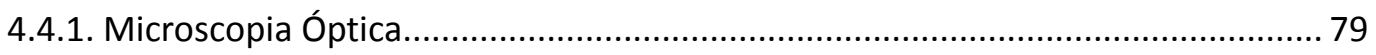

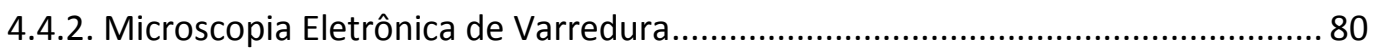

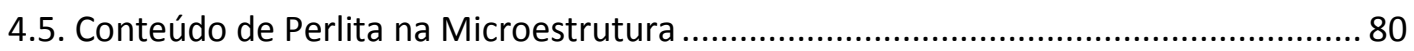

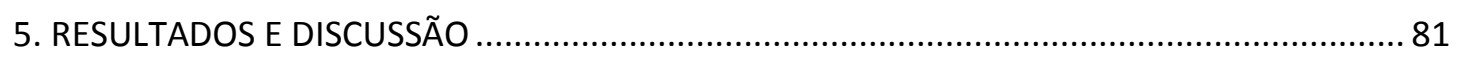

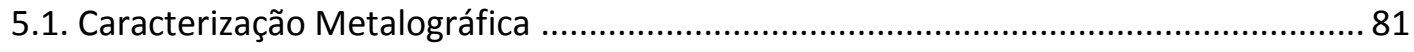

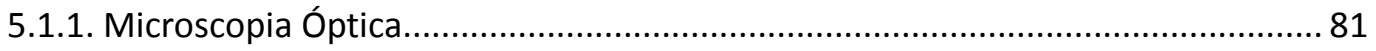

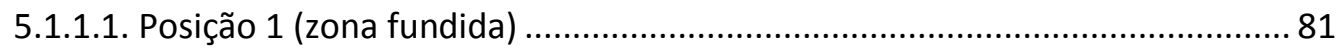

5.1.1.2. Posição 1 simulação de um único passe ......................................................... 83

5.1.1.3. Posição 2 (orientação L-T) no metal de base ............................................... 88

5.1.1.4. Posição 2 (orientação L-T) simulação de um único passe............................... 90

5.1.1.5. Posição 3 (orientação T-L) no metal de base .................................................. 95

5.1.1.6. Posição 3 (orientação T-L) simulação de um único passe ............................... 97

5.1.1.7. Posição 1 (zona fundida) simulação multipasse........................................... 102

5.1.1.8. Posição 2 (orientação L-T) e Posição 3 (orientação T-L) simulação multipasse

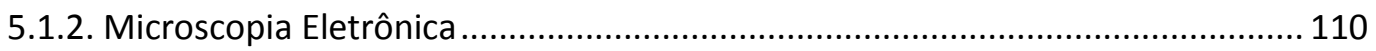

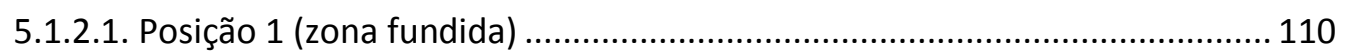

5.1.2.2. Posição 1 simulação de um único passe ...................................................... 111

5.1.2.3. Posição 2 (orientação L-T) no metal de base .............................................. 115

5.1.2.4. Posição 2 (orientação L-T) simulação de um único passe ............................. 116

5.1.2.5. Posição 3 (orientação T-L) no metal de base ................................................ 120 
5.1.2.6. Posição 3 (orientação T-L) simulação de um único passe 121

5.1.2.7. Posição 1 (zona fundida) simulação multipasse........................................... 125

5.1.2.8. Posição 2 (orientação L-T) simulação multipasse ........................................ 127

5.1.2.9. Posição 3 (orientação T-L) simulação multipasse ......................................... 129

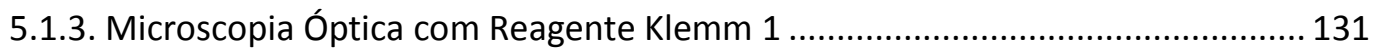

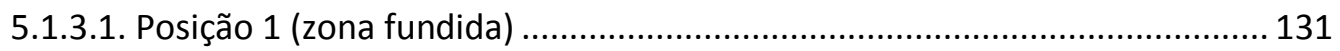

5.1.3.2. Posição 1 simulação de um único passe .................................................... 132

5.1.3.3. Posição 2 (orientação L-T) no metal de base …………………………...... 136

5.1.3.4. Posição 2 (orientação L-T) simulação de um único passe ............................... 138

5.1.3.5. Posição 3 (orientação T-L) no metal de base .............................................. 142

5.1.3.6. Posição 3 (orientação T-L) simulação de um único passe ............................. 143

5.1.3.7. Posição 1 (zona fundida) simulação multipasse............................................ 147

5.1.3.8 Posição 2 (orientação L-T) simulação multipasse ......................................... 149

5.1.3.9 Posição 3 (orientação T-L) simulação multipasse .......................................... 151

5.1.4. Conteúdo de Agregados Eutetóides na Microestrutura do Aço nos Diferentes

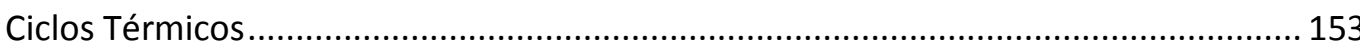

5.1.5. Resumo Comparativo dos Microconstituintes e Características da Microestrutura das Amostras Simuladas e na Condição Como-Recebida e Como-Soldada.................. 155

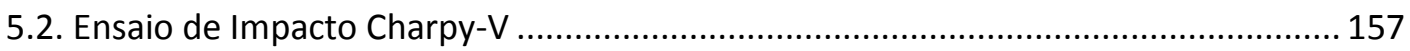

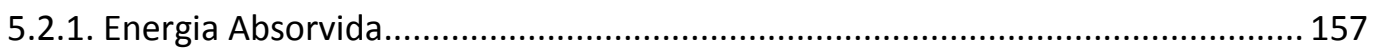

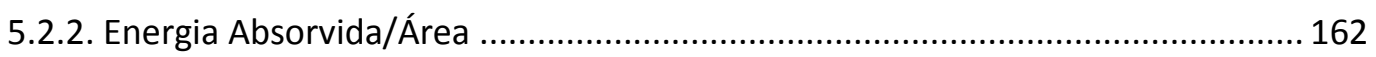

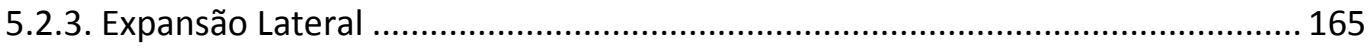

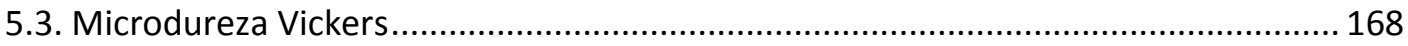

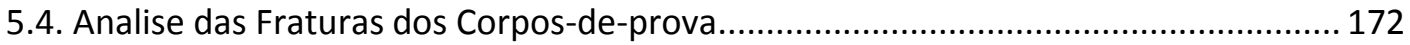

5.4.1. Caracterização das Superfícies de Fratura no Microscópio Eletrônico de Varredura

5.4.2. Caracterização dos caminhos de propagação das trincas por microscopia óptica e eletrônica de varredura.......................................................................................... 197

5.4.2.1 Caminhos de trinca dos corpos-de-prova sem simulação .............................. 197

5.4.2.2 Caminhos de trinca dos corpos-de-prova com simulação a $1300{ }^{\circ} \mathrm{C}$............. 201

5.4.2.3 Caminhos de trinca dos corpos-de-prova com simulação a $800{ }^{\circ} \mathrm{C}$............... 204

5.4.2.4 Caminhos de trinca dos corpos-de-prova com simulação a $950{ }^{\circ} \mathrm{C}$............... 207

5.4.2.5 Caminhos de trinca dos corpos-de-prova com simulação multipasse 950-800 ${ }^{0} \mathrm{C}$

5.4.2.6 Caminhos de trinca dos corpos-de-prova com simulação multipasse 950-800$650{ }^{\circ} \mathrm{C}$ 


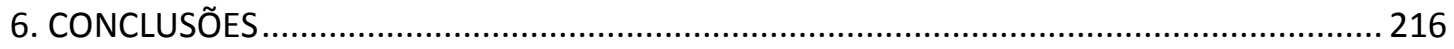

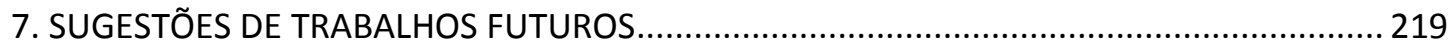

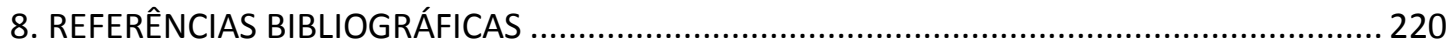




\section{INTRODUÇÃO}

O aço API 5L grau X80 é um aço de alta resistência e baixa liga (ARBL) e é usado na construção de redes dutoviárias. Este tipo de aço é usado por ter boas propriedades mecânicas como elevada resistência mecânica e boa tenacidade.

No transporte de óleo e gás, uma resistência mecânica elevada pode ser requerida para transportar a matéria prima a elevadas pressões. Esta resistência também propicia que o tubo possa ser feito com diâmetros maiores, o que garante maior transporte de óleo e gás. Além disso, estes tubos podem ser fabricados com espessuras de parede menores, gerando um benefício econômico não só na produção do aço, mais também no transporte, manuseio, soldagem e instalação dos dutos. A redução da espessura pode causar um problema no reparo de dutos em operação. As paredes dos tubos com espessuras menores podem ser um problema, principalmente se forem menores que $6,4 \mathrm{~mm}$. Pode ocorrer, durante o reparo do duto em operação, a perfuração da parede, que poderá causar prejuízos e acidentes sérios.

Este tipo de aço contém na sua composição química uma pequena quantidade de carbono, que proporciona ao material uma boa soldabilidade e tenacidade, mas prejudica a resistência mecânica do material. Esta diminuição na resistência, devido à diminuição de carbono, é compensada com a adição de elementos de liga, que proporcionam ao material maior resistência e propriedades adicionais. Além disso, os processos de conformação termomecânica também podem melhorar estas propriedades através da redução do tamanho de grão e da geração de microestrutura adequada.

As chapas dos aços para tubulações API X80 são produzidos em distintos países por um processo termomecânico controlado com resfriamento acelerado. No Brasil, o resfriamento acelerado foi inicialmente suprido com o manuseio da composição química do material e a otimização do processo termomecânico, que proporciona ao aço propriedades semelhantes aos produzidos com resfriamento acelerado, como o aço que foi estudado neste trabalho. Atualmente o Brasil está iniciando a laminação controlada com resfriamento acelerado. O tubo é produzido com a chapa que passa por um 
processo de conformação UOE. Este processo de formação do tubo trata-se de um dobramento em $U$, compressão em $\mathrm{O}$ e, após da soldagem longitudinal, é feito a expansão do tubo soldado (etapa E).

$\mathrm{Na}$ construção de dutos o processo de soldagem circunferêncial é requerido para a união dos tubos. A qualidade do processo é controlada pela norma API 1104 "Welding of Pipelines and Related Facilities". Este processo, se não for bem controlado, pode afetar as propriedades mecânicas do material soldado, 0 que significa perda de tempo e perdas financeiras para as empresas. $O$ processo de soldagem está diretamente ligado aos ciclos térmicos que se produzem durante a soldagem multipasse, que modifica a microestrutura do material e, assim, suas propriedades mecânicas.

Neste trabalho foram simulados distintos ciclos térmicos a diferentes temperaturas máximas. Foram feitos ciclos térmicos únicos com temperaturas máximas de $650,800,950$ e $1300^{\circ} \mathrm{C}$ e ciclos térmicos multipasse com temperaturas máximas de $900-800$ e $950-800-650^{\circ} \mathrm{C}$. Os ciclos térmicos foram feitos em corpos-de-prova extraídos de três posições distintas de um tubo API

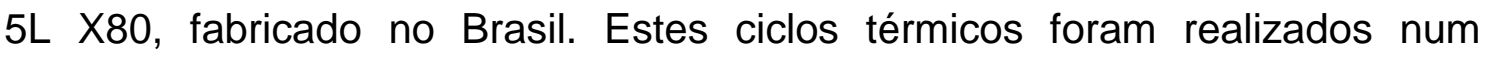
equipamento Gleeble®. A ZAC do cordão de solda e/ou zona fundida (ZF) e o material de base foram submetidas ao ensaio de impacto a $0^{\circ} \mathrm{C}$. As superfícies fraturadas foram analisadas no MEV e mediu-se a expansão lateral produzida pelo ensaio Charpy- $\mathrm{V}$. Além desse ensaio mecânico, mediram-se as microdurezas por meio do ensaio Vickers com $300 \mathrm{~g}$. A microestrutura da ZAC foi caracterizada por microscopia óptica, com ataque convencional, ataque colorido Klemm, e microscopia eletrônica de varredura. Análise quantitativa de fases foi usada para obter a quantidade de perlita na microestrutura. A macrografia e micrografia da trajetória da fratura na microestrutura do material provocada pelo ensaio Charpy foi analisada por microscopia óptica e eletrônica de varredura. Os ensaios de impacto foram feitos segundo a norma ASTM A370 e as microdurezas segundo a norma ASTM 384-08a.

Os resultados mostraram que os ciclos térmicos mudam a microestrutura do material afetando as propriedades mecânicas do material nas distintas posições do tubo. 


\section{OBJETIVOS}

Este trabalho tem por objetivos:

- caracterizar as propriedades mecânicas que se produz nas zonas afetadas pelo calor (ZAC), em soldagem de um único passe e multipasse, quando um tubo API $5 \mathrm{~L}$ X80 é submetido a distintos ciclos térmicos com diferentes temperaturas máximas e diferentes orientações relativas ao eixo longitudinal do tubo.

- relacionar as propriedades mecânicas com a mudança microestrutural na ZAC. 


\section{REVISÃO BIBLIOGRÁFICA}

Aços de alta resistência e aços de baixa liga têm limites de escoamento mais elevados que $275 \mathrm{MPa}$ (40 ksi), e podem ser divididos em quatro classificações[1]:

- Aços carbono - manganês, laminados;

- Aços de alta resistência e baixa liga (ARBL), que são também conhecidos como aços micro-ligados, laminados;

- Aços ao carbono tratados termicamente (normalizados ou revenidos e temperados);

- Aços de baixa liga tratados termicamente.

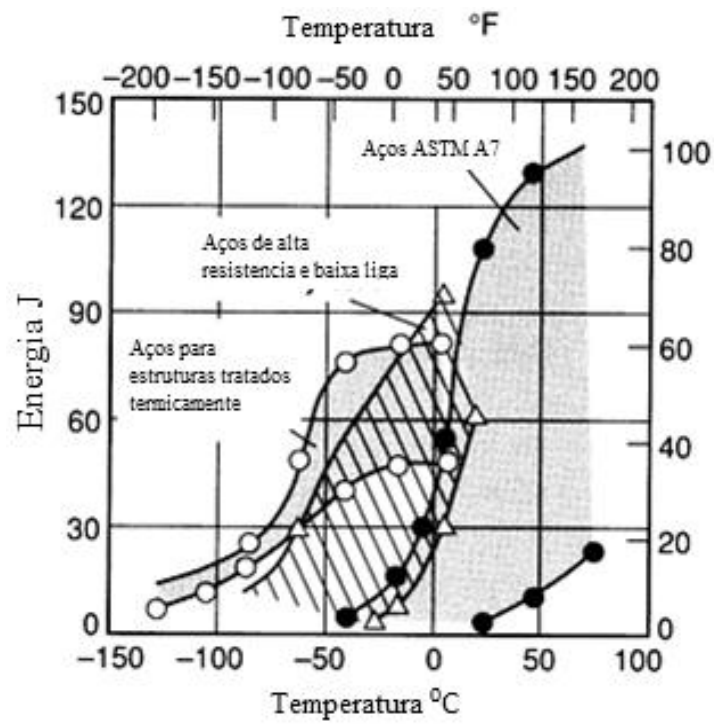

Figura 01. Comparação geral das tenacidades de aços ao carbono (ASTM A7, atualmente ASTM A283, grau D), aços ARBL, e aço estrutural tratado termicamente [1].

Neste trabalho se estudará os aços de alta resistência e baixa liga (ARBL), que são utilizados na construção de malhas dutoviárias, responsáveis pelo transporte de petróleo, gás e derivados. 


\subsection{Aços de Alta Resistência e Baixa Liga (ARBL)}

Os aços ARBL são aços de baixo carbono que utilizam pequenas quantidades de elementos de liga para atingir níveis de limite de escoamento elevados, seja na condição laminados ou tratados termicamente. Estes aços têm melhores propriedades mecânicas e melhor resistência à corrosão que os aços ao carbono. Além disso, devido a suas altas resistências, eles podem conter baixos conteúdos de carbono, o que melhora a soldabilidade de muitos aços ARBL [1]. A Tab. 1 apresenta a composição química típica e as propriedades mecânicas dos aços ARBL.

Tabela 01. Composição química típica e as propriedades mecânicas dos aços ARBL [1].

\begin{tabular}{|c|c|c|c|c|c|c|c|c|}
\hline \multicolumn{3}{|c|}{ Composição Química } & \multicolumn{2}{c|}{$\begin{array}{c}\text { Limite de } \\
\text { Escoamento } \\
\text { (mín.) }\end{array}$} & \multicolumn{2}{c|}{$\begin{array}{c}\text { Limite de } \\
\text { Resistência } \\
\text { (mín.) }\end{array}$} & $\begin{array}{c}\text { Ductilidade } \\
\text { (alongamento } \\
\text { em 50mm) }\end{array}$ \\
\hline C (max) & $\mathbf{S i}$ (max) & Mn & Outros & MPa & ksi & MPa & ksi & $\%$ \\
\hline 0,08 & 1,3 & $0,15-0,40$ & $\begin{array}{c}0,02 \mathrm{Nb} \text { ou } \\
0,05 \mathrm{~V}\end{array}$ & $275-450$ & $40-65$ & $415-550$ & $60-80$ & $18-24$ \\
\hline
\end{tabular}

Os aços ARBL são aços que apresentam boa resistência e tenacidade a baixas temperaturas. Apresentam microestrutura ferrítica-perlítica, com adições em pequenos teores de elementos de liga (microligantes) $\mathrm{Nb}, \mathrm{V}$ ou Ti para garantir propriedades mecânicas superiores [2].

Os aços ARBL representam diminuição nos custos de construção e transporte devido à menor massa que se têm, relacionada com menores espessuras de parede do tubo. Os custos de soldagem também são reduzidos uma vez que se requere menor quantidade de metal de adição durante a soldagem, produzindo soldagens mais rápidas. Além disso, estes aços viabilizam as operações do duto já que podem transportar maiores volumes de gás e petróleo a elevadas pressões [3].

A exploração de gás e óleo em áreas com condições adversas, onshore (terrestres) e offshore (plataforma), criaram um forte interesse para a economia e a segurança na construção e a operação de tubulações de grande diâmetro, 
freqüentemente operando a altas pressões em longas distâncias [4]. Essa influência nos requisitos do material para tubulações são resumidas na Fig. 2.

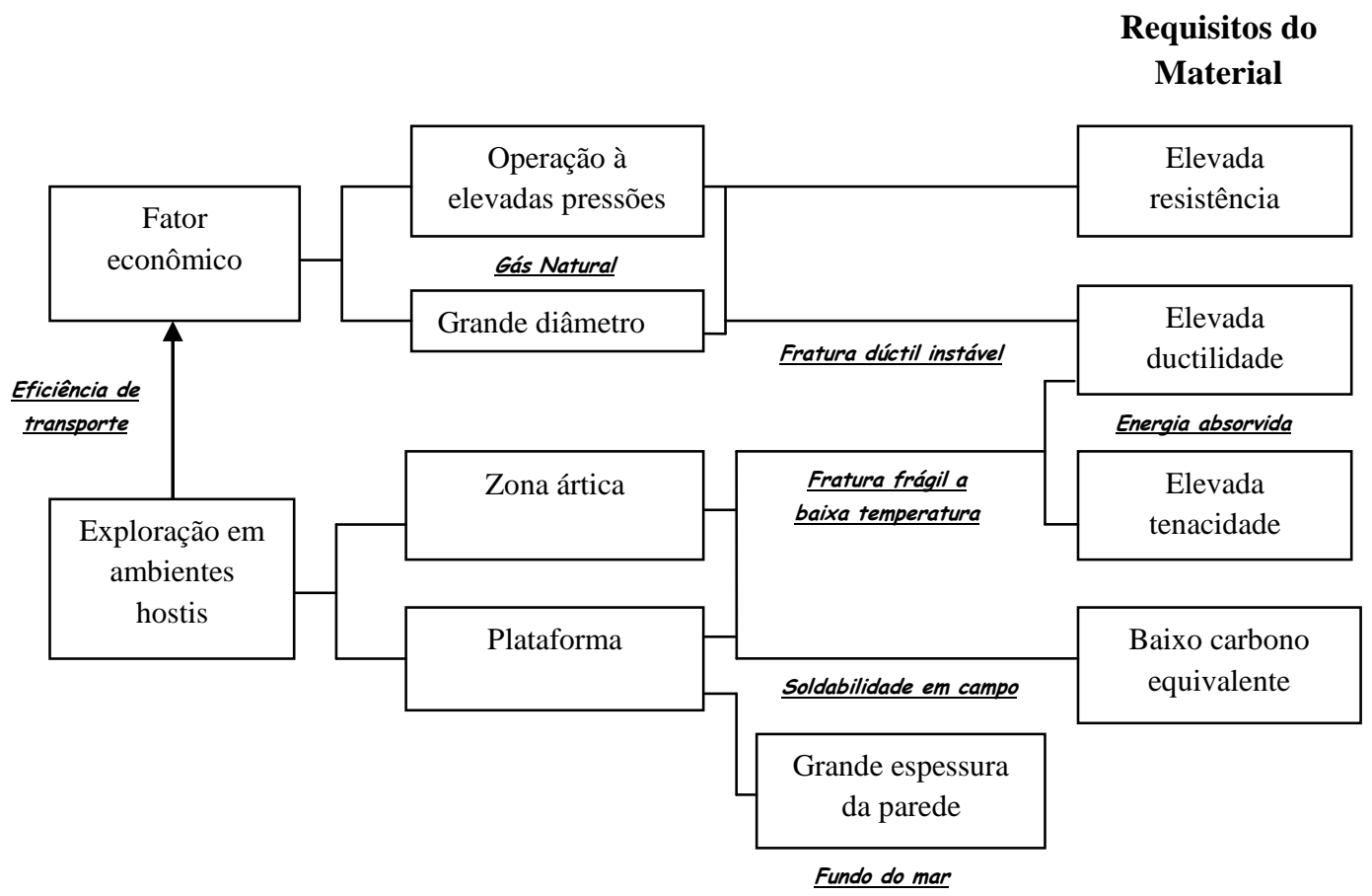

Figura 02. Requisitos dos aços para tubulações desenvolvidos em projetos recentes [4].

O comportamento à fratura, a soldabilidade e a resistência a fluidos e gases agressivos são propriedades de tubulações modernas que são desenvolvidas em resposta a problemas de construção e de serviço do uso final [4].

O aumento da resistência mecânica traz consigo uma diminuição na tenacidade e, para aumentar a resistência sem afetar a tenacidade, é realizada mudança na composição química e nos mecanismos de endurecimento [2]. A Fig. 3 mostra a relação entre o limite de o escoamento e a tenacidade, em função da soma vetorial dos diferentes mecanismos de endurecimento, para os principais tipos de aços para tubulações, com a resultante representando 0 ganho em resistência mecânica e tenacidade.

O aumento do conteúdo de carbono e manganês foi limitado para garantir os requisitos de boa soldabilidade e resistência à fratura frágil. Os elementos que formam carbonetos, nitretos e carbonitretos, como o V, Ti, Nb e Mo, dão 
elevada resistência através do endurecimento por precipitação e refino de grão sem prejudicar a tenacidade dos aços laminados ou normalizados [4].

Com a introdução do processo de laminação termomecânica controlada (TMCR), os efeitos favoráveis do mecanismo de endurecimento devido ao refino de grão sobre a resistência mecânica e a tenacidade puderam ser melhorados. Graças a isto foi possível baixar o conteúdo de carbono, que favorece tanto a tenacidade como a soldabilidade [4]. A tecnologia para produzir aços ARBL por esta rota vem-se desenvolvendo rapidamente. Esta tecnologia permite um aumento no limite de escoamento devido a uma diminuição no tamanho de grão e no conteúdo de carbono. A diminuição de carbono melhora a tenacidade e a soldabilidade e diminui a resistência, esta diminuição da resistência é compensada com a adição de $\mathrm{Nb}$ e $\mathrm{V}$, que endurecem o aço por precipitação e refino de grão [2].

\section{$\mathrm{A}=$ Endurecimento por precipitação $\mathrm{K}=$ Refino de grão \\ $\mathrm{P}=$ Redução do conteúdo de perlita \\ $\mathrm{D}=$ Endurecimento por encruamento}

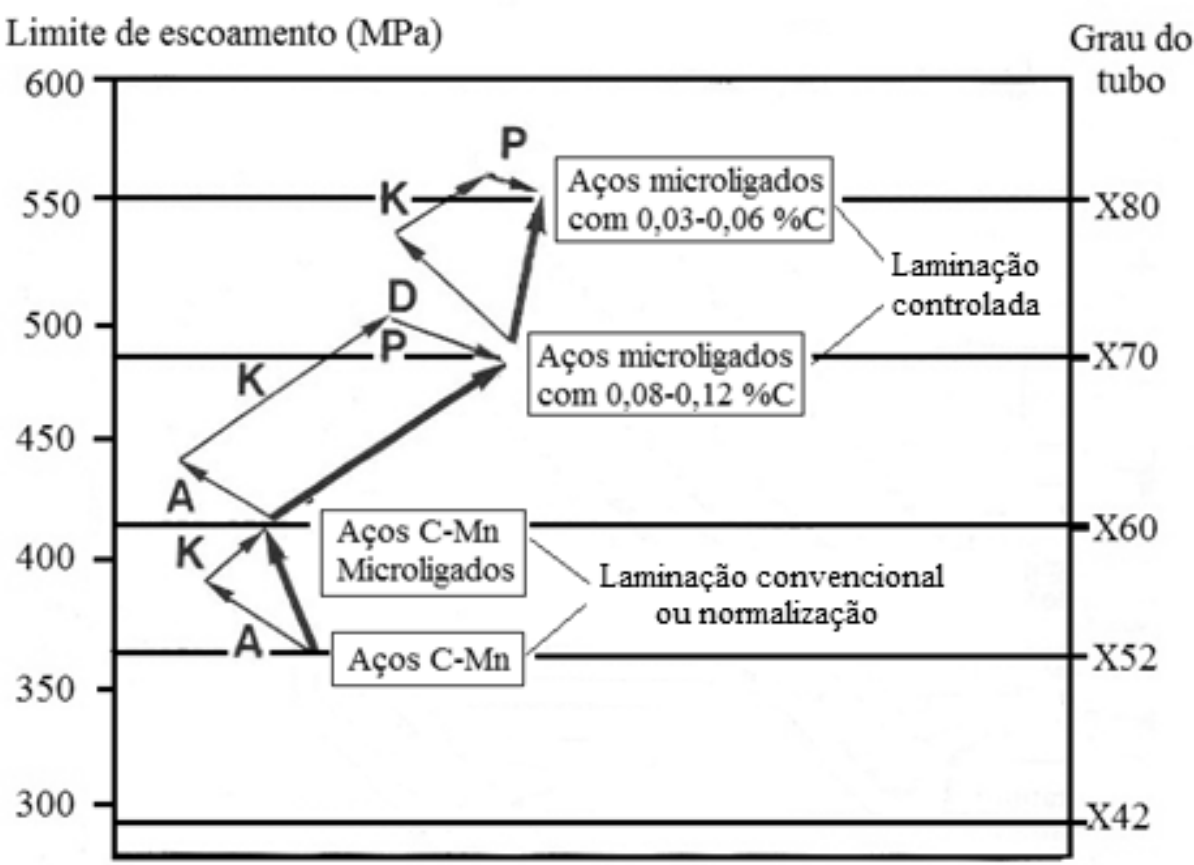

Tenacidade $\longrightarrow$

Figura 03. Mecanismos de endurecimento usados no desenvolvimento de aços ARBL para tubulações [4]. 


\subsubsection{Aços Para Dutos ou Tubulações}

As tubulações desempenham um papel muito importante no mundo como um meio de transporte de gases e líquidos a longas distâncias, desde sua origem até seu último consumidor [5].

A demanda mundial pela energia tem solicitado a construção de linhas de transmissão de gás ou óleo com elevadas pressões e eficiência no transporte a grandes distâncias. Estes fatores envolvem custos de construção e transporte, por isso que a tendência atual é desenvolver tubos de grande diâmetro e/ou tubos que resistam elevadas pressões de transporte de gás e/ou óleo. Esta tendência, por sua vez, precisa do desenvolvimento de tubos de grande resistência mecânica para evitar que os tubos sejam feitos com grandes espessuras de parede [6]. Além disso, estão sendo desenvolvidos aços microligados produzidos por um processamento termomecânico denominado Processo de Laminação Controlada com Resfriamento Acelerado (TCMP)[4].

As linhas de transmissão de fluidos geralmente operam a pressões elevadas de $6895 \mathrm{kPa}$ (1000 psi) e são feitas por tubos unidos por soldagem [5].

Propriedades desejadas para tubos como tenacidade, resistência mecânica, resistência à corrosão, ductilidade, resistência a trinca induzida pelo hidrogênio $(\mathrm{HIC})$, resistência à fragilização produzida por $\circ \mathrm{H}_{2} \mathrm{~S}$ contido no petróleo vem sendo desenvolvidas para os aços API 5L. Estas propriedades são controladas por meio da composição química e os parâmetros do processo de fabricação [7].

\subsubsection{Tubos API $5 \mathrm{~L}$}

O Instituto Americano de Petróleo (API) foi criado em 1919 com a finalidade de normalizar os processo de engenharia referentes a perfuração e produção de petróleo. Esta instituição abrange todos os segmentos da indústria petrolífera como: exploração, produção, transporte, etc...[8].

Os tubos utilizados na indústria do petróleo são geralmente classificados segundo a norma API em função de sua aplicação e resistência mecânica. A norma API para tubulação é a API $5 \mathrm{~L}$, que é a "Especificação de Aços para Tubulações". A especificação desta norma foi criada com a finalidade de 
fornecer critérios para o desenvolvimento de uma tubulação adequada, que é utilizada no transporte de gás, água e óleo e em indústrias de óleo e gás. Esta especificação também cobre a fabricação de tubos com e sem costura [8].

Os tubos para serem considerados como tubos API $5 \mathrm{~L}$ têm que cumprir com exigências descritas na especificação quanto a propriedades mecânicas, composição química, dimensão, peso, etc. A propriedade que determina o grau do tubo é o limite de escoamento especificado em ksi (SMYS). Os graus considerados na especificação são X42, X46, X52, X60, X70 e X80, a letra X representa aos aços de alta resistência [8]. A Tab. 2 e a Tab. 3 apresentam as propriedades mecânicas e a composição química para aços API $5 \mathrm{~L}$ segundo a norma API.

Tabela 02. Propriedades mecânicas dos aços segundo a norma API 5L [8].

\begin{tabular}{|c|c|c|c|c|c|c|c|c|}
\hline \multirow{2}{*}{ Grau } & \multicolumn{2}{|c|}{$\begin{array}{c}\text { Limite de } \\
\text { escoamento } \\
\text { (mín.) }\end{array}$} & \multicolumn{2}{c|}{$\begin{array}{c}\text { Limite de } \\
\text { escoamento } \\
\text { (máx.) }\end{array}$} & \multicolumn{2}{c|}{$\begin{array}{c}\text { Limite de } \\
\text { resistência } \\
\text { (mín.) }\end{array}$} & \multicolumn{2}{c|}{$\begin{array}{c}\text { Limite de } \\
\text { resistência } \\
\text { (máx.) }\end{array}$} \\
\cline { 2 - 9 } & ksi & MPa & ksi & MPa & ksi & MPa & ksi & MPa \\
\hline X42 & 42 & 290 & 72 & 496 & 60 & 414 & 110 & 758 \\
\hline X46 & 46 & 317 & 76 & 524 & 63 & 434 & 110 & 758 \\
\hline X52 & 52 & 359 & 77 & 531 & 66 & 455 & 110 & 758 \\
\hline X56 & 56 & 386 & 79 & 544 & 71 & 490 & 110 & 758 \\
\hline X60 & 60 & 414 & 82 & 565 & 75 & 517 & 110 & 758 \\
\hline X65 & 65 & 448 & 87 & 600 & 77 & 531 & 110 & 758 \\
\hline X70 & 70 & 483 & 90 & 621 & 82 & 565 & 110 & 758 \\
\hline X80 & 80 & 552 & 100 & 690 & 90 & 621 & 120 & 827 \\
\hline
\end{tabular}

Tabela 03. Composição química para aços API $5 \mathrm{~L}$ em porcentagem em peso (8) [8].

\begin{tabular}{|c|c|c|c|c|c|}
\hline Grau & C (máx.) & Mn (máx.) & $\mathbf{P}$ (máx.) & $\mathbf{S}$ (máx.) & Outros \\
\hline $\mathrm{X} 42$ & 0,22 & 1,30 & 0,025 & 0,15 & $(\mathrm{a}, \mathrm{b})$ \\
\hline $\mathrm{X} 46, \mathrm{X} 52, \mathrm{X} 56$ & 0,22 & 1,40 & 0,025 & 0,15 & $(\mathrm{a}, \mathrm{b})$ \\
\hline $\mathrm{X} 60^{(\mathrm{c})}$ & 0,22 & 1,40 & 0,025 & 0,15 & $(\mathrm{a}, \mathrm{b})$ \\
\hline $\mathrm{X} 65^{(\mathrm{c})}$ & 0,22 & 1,45 & 0,025 & 0,15 & $(\mathrm{a}, \mathrm{b})$ \\
\hline $\mathrm{X} 70^{(\mathrm{c})}$ & 0,22 & 1,65 & 0,025 & 0,15 & $(\mathrm{a}, \mathrm{b})$ \\
\hline $\mathrm{X} 80^{(\mathrm{c})}$ & 0,22 & 1,85 & 0,025 & 0,15 & $(\mathrm{a}, \mathrm{b})$ \\
\hline
\end{tabular}

Notas:

${ }^{a} \mathrm{O}$ nióbio, titânio, vanádio, ou combinações dos mesmos podem ser utilizados mediante acordo entre o comprador e o fabricante

${ }^{\mathrm{b}} \mathrm{A}$ soma do nióbio, vanádio, titânio e conteúdo não deve ultrapassar $0,15 \%$.

${ }^{\circ}$ Outras composições químicas podem ser feitas por acordo entre o comprador e o fabricante, sempre que os limites da nota b, e os limites de fósforo e enxofre sejam cumpridos. 
Freqüentemente o desenvolvimento da tecnologia de aços para tubulações tem sido dirigido para serviços em ambientes "sour" (relativo ao teor de $\mathrm{H}_{2} \mathrm{~S}$ gasoso), aços produzidos com teor de baixo carbono e enxofre. A tenacidade elevada é obtida quando se tem baixo carbono, enxofre e fósforo e redução no tamanho de grão. O aumento na resistência mecânica envolve a utilização de elementos microligantes, outros elementos de liga e processo de laminação a temperatura baixa e esfriamento acelerado (TMCP). O resultado final da evolução do processamento termomecânico e a composição química do aço alcançaram dois tipos de microestruturas, que agora são a base para a produção de tubulações API para transportar óleo e gás no mundo, ou seja, a microestrutura ferrítica/perlítica (F/P) e a ferrítica/ferrita acicular (F/FA). A ferrita acicular é definida como uma bainita de baixo carbono formada por nucleação intragranular [9].

O desenvolvimento dos aços para tubulações API começou com uma liga base de C-Mn-Si, que é usada nos aços API grau X42 de resistência mecânica mais baixa. Adições de elementos microligantes, junto com quantidades adequadas de outros elementos de liga como ( $\mathrm{Cu}, \mathrm{Ni}$ e $\mathrm{Cr}$ ), são usados para produzir os aços API graus X52 a X70. Os principais elementos microligantes para os aços API são o $\mathrm{Nb}$ e $\circ \mathrm{V}$, tendo um papel importante quando resistências mecânicas mais elevadas são requeridas. A liga base $\mathrm{C}-\mathrm{Mn}-\mathrm{Si}$ junto com adições de elementos microligantes tem como resultado uma microestrutura F/P sem considerar os efeitos das práticas de laminação [9].

$O$ projeto de ligas de aços API com elevadas resistências, $X 70$ e graus superiores, começou com um aumento na quantidade de elementos microligantes no sistema C-Mn-Si e a adição de pequenas quantidades de elementos de liga, tais como $\mathrm{Cu}, \mathrm{Ni}, \mathrm{Cr}$, ou uma combinação deles com adição de Mo. Adições de Mo junto com um processamento termomecânico adequado resultam em uma microestrutura F/FA. Adições de $\mathrm{Nb}$, sem Mo, podem também serem usadas para produzir uma microestrutura F/FA desejada. Esta ultima rota de processamento é denominada de processamento a elevadas temperaturas (HTP), já que o aço pode ter a etapa de laminação final a elevadas temperaturas [9].

Aumentos nas adições de elementos de liga como $\mathrm{Mn}, \mathrm{Cu}, \mathrm{Ni}, \mathrm{Cr}$ e $\mathrm{Mo}$, junto com o B, são usados para produzir os aços API X100 e X120. Essas adições 
produzem outras formas de bainita e pequenas quantidades de martensita, reduzindo a soldabilidade do aço e aumentando o custo do material com base microestrutural F/FA. A Tab. 4 resume os graus API segundo sua microestrutura e o conteúdo de liga [9]. 
Tabela 04. Microestrutura e ligas de aços API [9].

\begin{tabular}{|c|c|c|}
\hline Grau API & Microestrutura & Elementos de liga \\
\hline $\mathrm{X} 120$ & $\begin{array}{l}\text { FA/Bainita/ } \\
\text { Martensita }\end{array}$ & $\mathrm{C}<0,10, \mathrm{Mn}<2,0, \mathrm{Si}<0,40, \mathrm{Nb}<0,06, \mathrm{Cu}, \mathrm{Ni}, \mathrm{Cr}, \mathrm{Mo}, \mathrm{V}, \mathrm{B}, \mathrm{Pcm} \leq 0,25$ \\
\hline $\mathrm{X} 100$ & FA/Bainita & $\mathrm{C}<0,06, \mathrm{Mn}<2,0, \mathrm{Si}<0,40, \mathrm{Nb}<0,06, \mathrm{Cu}, \mathrm{Ni}, \mathrm{Cr}, \mathrm{Mo}, \mathrm{V}, \mathrm{Pcm} \leq 0,23$ \\
\hline \multirow[t]{2}{*}{$\mathrm{X} 80$} & $\mathrm{~F} / \mathrm{FA}$ & $\mathrm{C} \leq 0,06, \mathrm{Mn}<1,70, \mathrm{Si}<0,40, \mathrm{Nb}<0,10, \mathrm{Cu}, \mathrm{Ni}, \mathrm{Cr}, \mathrm{Pcm} \leq 0,18$ \\
\hline & F/FA & $\mathrm{C} \leq 0,06, \mathrm{Mn}<1,70, \mathrm{Si}<0,40, \mathrm{Nb}<0,10, \mathrm{Cu}, \mathrm{Ni}, \mathrm{Mo}, \mathrm{Pcm} \leq 0,21$ \\
\hline \multirow[t]{2}{*}{ X70 } & $\mathrm{F} / \mathrm{FA}$ & $\mathrm{C} \leq 0,06, \mathrm{Mn} \leq 1,65, \mathrm{Si}<0,40, \mathrm{Nb} \leq 0,10$ ou $\mathrm{Nb}+\mathrm{Mo}, \mathrm{Pcm} \leq 0,18$ ou 0,21 \\
\hline & $\mathrm{F} / \mathrm{P}$ & $\mathrm{C} \leq 0,10, \mathrm{Mn} \leq 1,65, \mathrm{Si}<0,40, \mathrm{Nb} \leq 0,065$ ou $\mathrm{Nb}+\mathrm{V} \leq 0,15, \mathrm{Pcm} \leq 0,20$ \\
\hline \multirow[t]{2}{*}{ X65 } & $\mathrm{F} / \mathrm{P}$ & $\mathrm{C} \leq 0,10, \mathrm{Mn} \leq 1,65, \mathrm{Si}<0,40, \mathrm{Nb} \leq 0,065$ ou $\mathrm{Nb}+\mathrm{V} \leq 0,15, \mathrm{Pcm} \leq 0,23$ \\
\hline & $\mathrm{F} / \mathrm{P}$ & $\begin{array}{l}C \leq 0,05, M n \leq 1,35, S \leq 0,003, S i<0,30, C u+N i+C r \leq 0,70, N b \leq 0,065 \text { ou } \\
N b+V \leq 0,15, P c m \leq 0,15\end{array}$ \\
\hline \multirow[t]{2}{*}{$\mathrm{X} 60$} & $\mathrm{~F} / \mathrm{P}$ & $\mathrm{C} \leq 0,10, \mathrm{Mn} \leq 1,50, \mathrm{Si}<0,40, \mathrm{Nb} \leq 0,065$ ou $\mathrm{Nb}+\mathrm{V} \leq 0,12, \mathrm{Pcm} \leq 0,23$ \\
\hline & $\mathrm{F} / \mathrm{P}$ & $\begin{array}{l}\mathrm{C} \leq 0,05, \mathrm{Mn} \leq 1,20, \mathrm{~S} \leq 0,003, \mathrm{Si}<0,30, \mathrm{Cu}+\mathrm{Ni}+\mathrm{Cr} \leq 0,70, \mathrm{Nb} \leq 0,065 \text { só, } \\
\text { ou } \mathrm{Nb}+\mathrm{V} \leq 0,12, \mathrm{Pcm} \leq 0,15\end{array}$ \\
\hline \multirow[t]{2}{*}{ X52 } & $\mathrm{F} / \mathrm{P}$ & $C \leq 0,10, M n \leq 1,20, S i<0,40, N b \leq 0,050, P c m \leq 0,17$ \\
\hline & $\mathrm{F} / \mathrm{P}$ & $\begin{array}{l}C \leq 0,05, M n \leq 1,10, S \leq 0,003, S i<0,30, C u+N i+C r \leq 0,60, N b \leq 0,050 \text { ou } \\
N b+V \leq 0,10, P c m \leq 0,13\end{array}$ \\
\hline $\mathrm{X} 42$ & $\mathrm{~F} / \mathrm{P}$ & $C \leq 0,10, M n \leq 1,00, S i<0,40, N b \leq 0,050, P c m \leq 0,16$ \\
\hline
\end{tabular}




\subsubsection{Aços Para Tubos API 5L X80}

Os aços API X80 tem sido amplamente utilizados em projetos distintos de operação durante as ultimas décadas com tenacidade e soldabilidade melhorados, quando os ambientes de transportes são cada vez mais agressivos [10].

O custo dos tubos representa aproximadamente $50 \%$ do custo total da construção da tubulação. O uso de novos graus com limites de escoamento elevados, como os aços grau X80, diminuem de 10 a $15 \%$ o custo da construção dos tubos, incluindo redução de custos relacionados ao transporte dos tubos, pelo tubo ser menos pesado, bem como a redução no custo relativo à soldagem em termos de quantidade de metal depositado menor e redução das horas de soldagem [10].

Os aços para tubos com grau X80 foram usados pela primeira vez em 1985. O Processo de Laminação Controlada com Resfriamento Acelerado (TMCP) permitiu a produção de materiais com grau X80 microligado com $\mathrm{Nb}$ e $\mathrm{V}$ com quantidade de carbono menor e boa soldabilidade $[3,6]$. O processo TMCP é escolhido quando tração, resistência e/ou características de tenacidade são requeridas [9]. Como exemplo, os aços X80 desenvolvidos na China têm elevada resistência e tenacidade, boa soldabilidade, excelente resistência a trinca por hidrogênio (HIC) e a corrosão [11]. Também, o laboratório de investigações técnicas POSCO da Coréia [12] tem desenvolvido aços de grau X80 para projetos no norte da América e o nordeste da Ásia, com o intuito de responder à necessidade de aços para tubulações de alta resistência, melhorando a tenacidade a baixas temperaturas e sua soldabilidade. A Tab. 5 mostra as propriedades mecânicas dos aços X80.

Tabela 05. Propriedades mecânicas dos aços X80 [1,8].

\begin{tabular}{|c|c|c|c|c|}
\hline \multirow{2}{*}{$\begin{array}{c}\text { Aço API 5L } \\
\text { grau X80 }\end{array}$} & \multicolumn{2}{|c|}{$\begin{array}{c}\text { Limite de } \\
\text { escoamento (min.) }\end{array}$} & \multicolumn{2}{c|}{$\begin{array}{c}\text { Limite de } \\
\text { resistência (min.) }\end{array}$} \\
\cline { 2 - 5 } & $\mathbf{M P a}$ & $\mathbf{k s i}$ & $\mathbf{M P a}$ & $\mathbf{k s i}$ \\
\hline a & 552 & 80 & 621 & 120 \\
\hline b & 552 & 80 & 620 & 90 \\
\hline
\end{tabular}

Notas:

${ }^{\mathrm{a}}$ Referência segundo a norma API $5 \mathrm{~L}$ [8].

${ }^{\mathrm{b}}$ Referência segundo ASM International Handbook [1]. 
Segundo Roza (13) [13], o limite de escoamento longitudinal e transversal do aço para tubo API 5L grau X80 produzido no Brasil é de $648 \mathrm{MPa}$ (94 ksi) e de $607 \mathrm{MPa}$ (88 ksi) respectivamente sem a utilização da técnica TCMP.

A norma API não faz restrição em relação aos elementos de liga, é por isso que pode haver diversas opções para a fabricação deste grau [8].

Pode-se notar que as características dos aços API $5 \mathrm{~L}$ estabelecem requisitos para a composição química, especificando níveis máximos permitidos para o carbono, manganês, enxofre e o fósforo, como mostra a Tab. 3. Por outro lado, as especificações dos consumidores são muito mais restritas na composição assim como para obter níveis elevados de tenacidade e soldabilidade e um nível específico de resistência ao escoamento [5]. As diferentes composições químicas usada para satisfazer os requisitos do aço API $5 \mathrm{~L}$ grau X80 é mostrada na Tab. 6 [5].

Tabela 06. Diferentes composições químicas para o processamento termomecânico de aços API 5L grau X80 [5].

\begin{tabular}{|c|c|c|c|c|c|c|c|c|c|c|c|c|c|}
\hline $\mathbf{C}$ & $\mathbf{S i}$ & $\mathbf{M n}$ & $\mathbf{P}$ & $\mathbf{S}$ & $\mathbf{C u}$ & $\mathbf{N i}$ & $\mathbf{M o}$ & $\mathbf{N b}$ & $\mathbf{V}$ & $\mathbf{T i}$ & $\mathbf{B}$ & $\mathbf{N}$ & $\mathbf{A l}$ \\
\hline 0,07 & - & 1,65 & - & 0,002 & - & - & 0,22 & 0,05 & 0,075 & - & - & - & - \\
\hline 0,02 & 0,26 & 1,95 & 0,022 & 0,003 & - & 0,38 & 0,31 & 0,04 & - & 0,019 & 0,001 & - & - \\
\hline 0,08 & 0,1 & 1,5 & - & - & - & - & - & 0,052 & 0,076 & - & - & - & - \\
\hline 0,036 & 0,1 & 1,6 & - & - & - & 0,35 & 0,29 & 0,064 & - & - & - & - & - \\
\hline 0,02 & 0,13 & 1,88 & 0,021 & 0,003 & 0,29 & 0,47 & - & 0,042 & - & 0,014 & 0,001 & 0,003 & 0,021 \\
\hline 0,06 & 0,16 & 1,85 & 0,020 & 0,001 & - & 0,20 & 0,20 & 0,044 & - & 0,007 & - & 0,005 & 0,017 \\
\hline 0,05 & 0,26 & 1,74 & 0,014 & 0,001 & 0,27 & 0,45 & - & 0,038 & 0,047 & 0,017 & - & 0,003 & 0,040 \\
\hline
\end{tabular}

Uma preocupação dos usuários de tubos de aços API 5L grau X80 está relacionada à soldabilidade, a qual aumenta com a diminuição do teor de carbono e do valor do carbono equivalente conforme a Fig. 4 [14]. Nota-se que os primeiros aços eram praticamente impossíveis de serem soldados comparados com o aço API 5L grau X80. Atualmente, este material apresenta teores de carbono menores que $0,12 \%$ e o parâmetro utilizado para medir a soldabilidade é o parâmetro do carbono equivalente $\left(P_{\mathrm{cm}}\right)$, fórmula proposta por Ito e Bessyo [4], citado pela norma API 5L [8] conforme Eq. (1): 


$$
P_{c m}=C+\frac{M n}{20}+\frac{M o}{15}+\frac{N i}{60}+\frac{C r}{20}+\frac{V}{10}+\frac{C u}{20}+\frac{S i}{30}+5 B
$$

O parâmetro do carbono equivalente $\left(\mathrm{P}_{\mathrm{cm}}\right)$ foi desenvolvida especialmente para aços ARBL, com conteúdo de carbono menor de $0,12 \%$.

O conteúdo de carbono equivalente máximo para um aço API $5 \mathrm{~L}$ grau X80 segundo a norma API $5 \mathrm{~L}$ é de $0,25 \%$ [8].

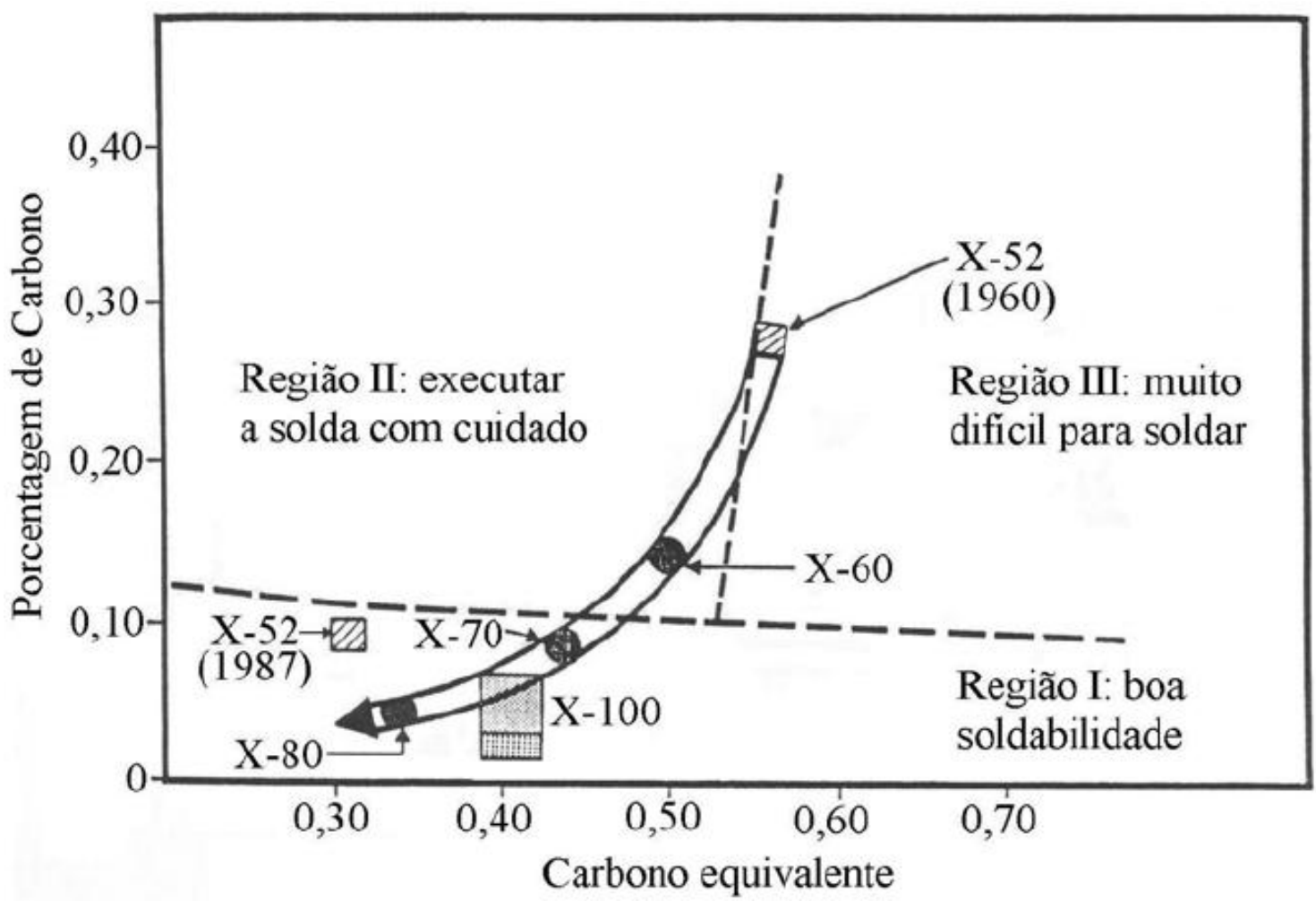

Figura 04. Evolução da soldabilidade dos aços API com relação à otimização da composição química [14].

\subsection{Processo de Fabricação de Aço API 5L grau X80 e Superior}

A produção de aços API usando a rota tradicional de laminação controlada, ao invés do resfriamento acelerado como usado em muitos outros países, precisa de um ajuste de composição combinado com a otimização do processo de laminação, para a deformação e características de transformação de fases dessas ligas modificadas [10]. 
Os aços API 5L grau X80, embora até agora relativamente pouco usado no Brasil, tem sido satisfatoriamente muito usado no mundo na construção de tubulações. Esses aços são fabricados utilizando uma rota de produção que inclui resfriamento acelerado, a taxas de resfriamento de 15 a $20{ }^{\circ} \mathrm{C} / \mathrm{s}$, até atingir uma temperatura próxima dos $550{ }^{\circ} \mathrm{C}$, e depois deixada resfriar até a temperatura ambiente $[10,15]$.

Os aços grau X80 são produzidos com teores de carbono reduzidos, melhorando sua soldabilidade e a sua microestrutura apresenta-se mais refinada, com microconstituintes do tipo ferrítica-bainítica. A Fig. 5 mostra esta evolução dos graus dos aços em função da composição química e do processamento termomecânico.

Segundo Hillenbrand [16], o resfriamento acelerado da placa desde a temperatura de laminação final tem um notável efeito na microestrutura e, conseqüentemente, sobre as propriedades mecânicas do aço. Para obter uma microestrutura quase totalmente bainítica é necessário que o resfriamento acelerado deva ser iniciado antes que a austenita comece a transformar-se em ferrita.

A Fig. 6 apresenta as alterações microestruturais que causam a formação de grãos ferríticos finos nos aços submetidos à laminação controlada. Neste gráfico pode-se ver, que quando o grão austenítico não recristaliza se tem grãos austeníticos menores e alongados o que favorece a formação de grãos ferríticos finos. Este tamanho de grão ferrítico pode ser obtido graças ao processo de laminação controlada que, com o resfriamento acelerado após a laminação, ajuda à formação de grão ferrítico fino [17]. 


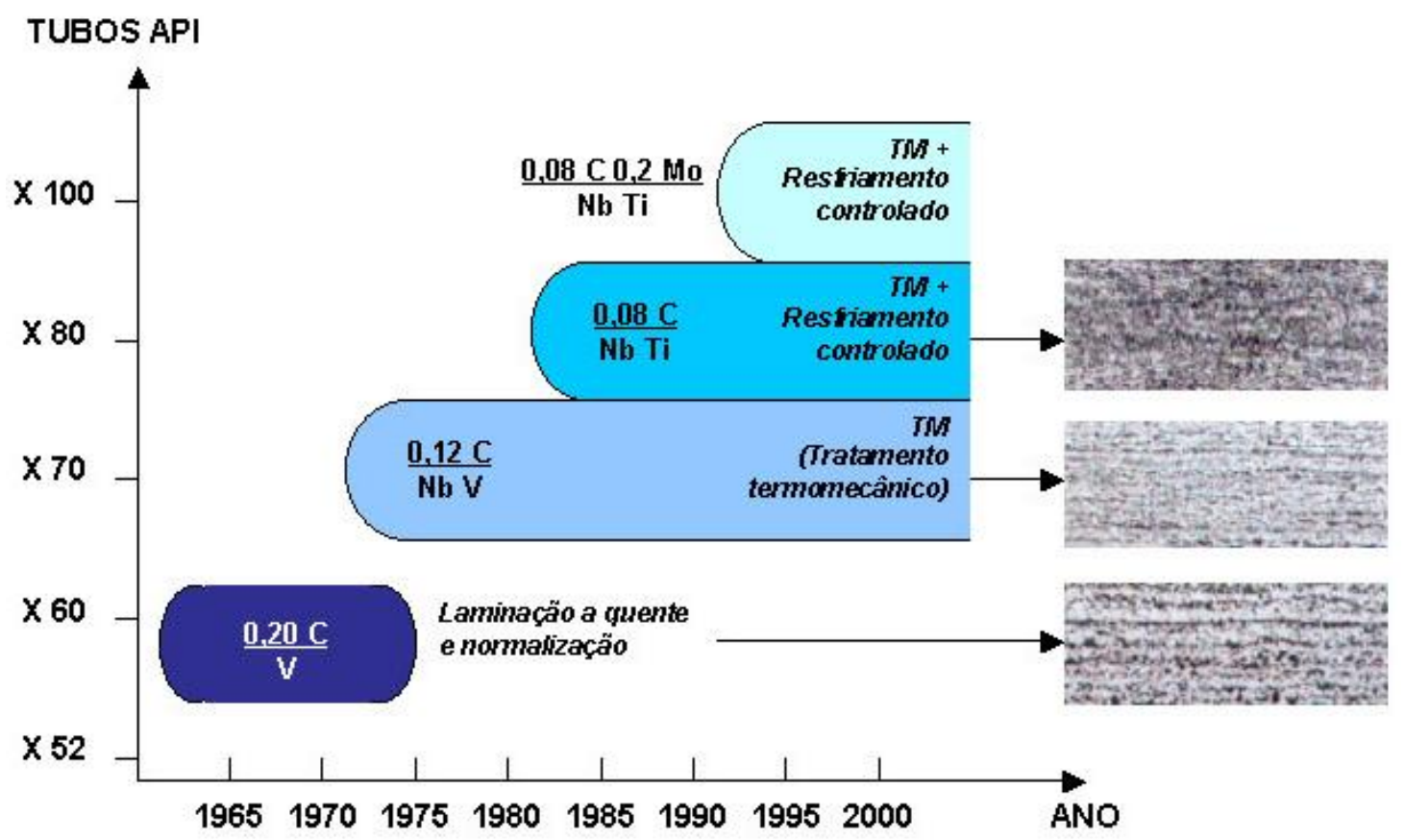

Figura 05. Evolução dos aços para a fabricação de tubos de grandes diâmetros [3].

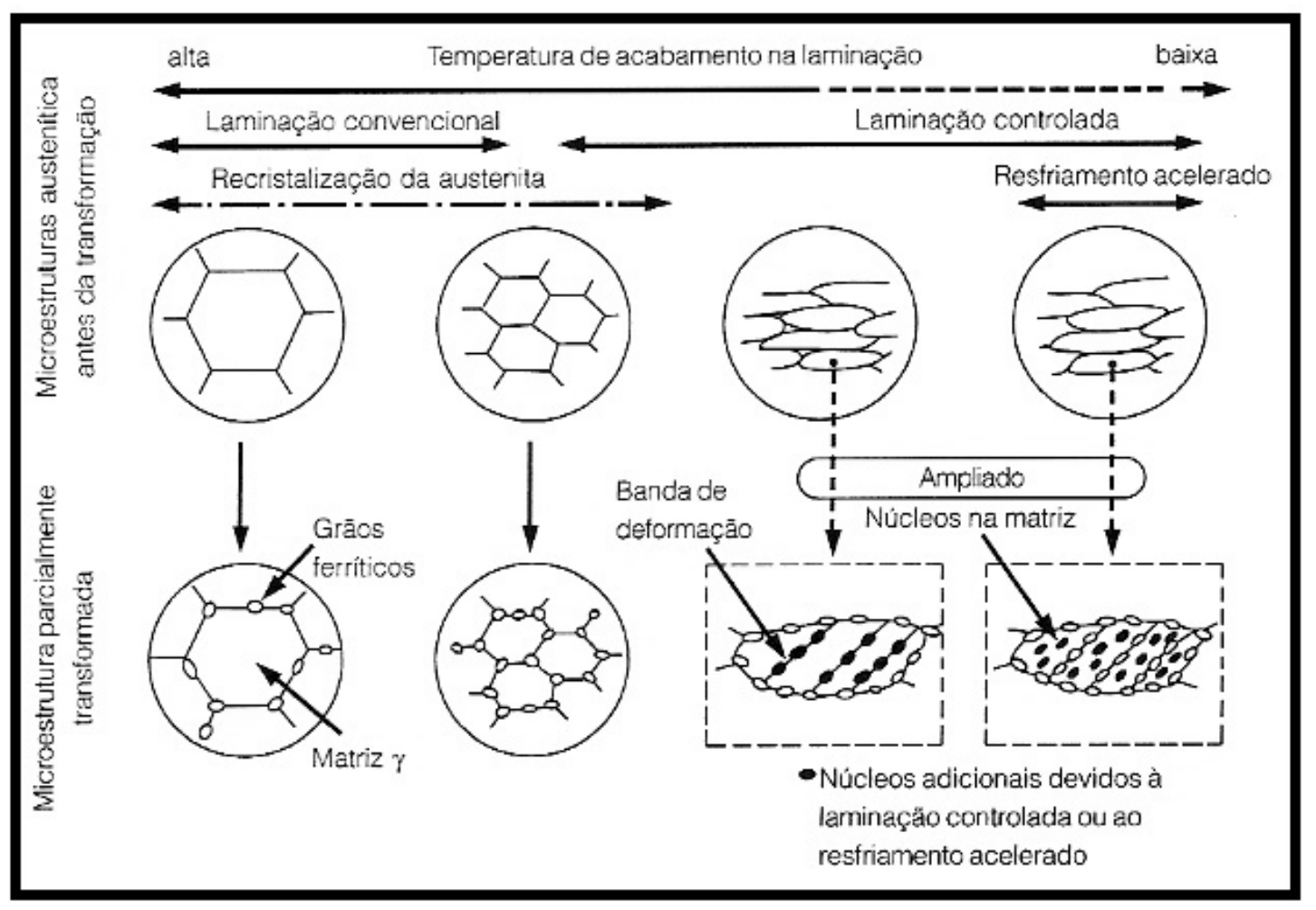

Figura 06. Alterações microestruturais durante a laminação [17]. 


\subsubsection{Processo de Fabricação do Aço API 5L Grau X80 Nacional}

De acordo com o boletim informativo "Tubos Para Condução (LinePipe)" da empresa TenarisConfab [18], no Brasil os aços API 5L grau X80 vêm sendo utilizados em obra desde alguns anos atrás, porém ainda necessita de mais pesquisas tecnológicas para aperfeiçoar as propriedades deste aço. Além disso, a composição química do aço API $5 \mathrm{~L}$ grau X80 é inerente a cada fornecedor do aço, composição esta que visa produzir o aço com as propriedades mecânicas requeridas pelo comprador.

No Brasil a produção do processo de aços API $5 \mathrm{~L}$ grau X80, é feita com 0 processo de laminação tradicional (TMCR), ou seja, sem o processo de resfriamento acelerado, que é usado em outros países [10], embora esteja sendo implantado atualmente no país, pela Usiminas. Para fabricar os aços API $5 \mathrm{~L}$ grau X80 se adicionam elementos de liga como V, Nb, $\mathrm{Cr}$ e Mo já que no Brasil ainda se tem limitações nos equipamentos para o processo TMCP, processo pelo qual os aços alcançam uma granulação fina [19]. Os elementos de micro-liga inibem 0 crescimento do grão austenítico durante 0 reaquecimento das chapas, retardando a recuperação e recristalização do grão austenítico deformado, gerando uma granulação fina no aço. O Al algumas vezes é empregado, em combinação com os elementos de micro-liga, para melhorar a resistência mecânica e a tenacidade destes aços [20].

As composições químicas, bem como os processos de fabricação aplicados, são características próprias de cada fornecedor e, normalmente, não são divulgadas [21].

$\mathrm{Na}$ Tab. 7 são mostradas as composições químicas de três grupos de aços micro-ligados, produzidos no Brasil. Cabe salientar que estes aços foram feitos sem resfriamento acelerado [10].

Uma composição química com baixo teor de carbono e uma combinação adequada de elementos de liga como $\mathrm{Mn}, \mathrm{Si}, \mathrm{Mo}, \mathrm{Cr}, \mathrm{Nb}, \mathrm{V}$ e Ti são aspectos importantes no projeto e desenvolvimento de um aço ligado para ter resistência e tenacidade elevadas. $O$ processo termomecânico (conhecido também por laminação controlada) é o outro componente. Como se mostra na Fig. 7 um complexo processo termomecânico é requerido para atingir uma microestrutura fina que apresente alta resistência e tenacidade [22]. 
Tabela 07. Composição química de aços API $5 \mathrm{~L}$ grau X80 produzidos no Brasil [10].

\begin{tabular}{|c|c|c|c|c|c|c|c|c|c|}
\hline \multirow{2}{*}{ Aço } & \multicolumn{10}{|c|}{ Composição química (\% peso) } \\
\cline { 2 - 11 } & $\mathbf{C}$ & $\mathbf{M n}$ & $\mathbf{S i}$ & $\mathbf{N b}$ & $\mathbf{V}$ & $\mathbf{T i}$ & $\mathbf{C r}$ & Mo & $\mathbf{~ N}$ \\
\hline \multirow{2}{*}{ NbCrMo } & 0,07 & 1,76 & 0,18 & 0,071 & - & 0,014 & 0,2 & 0,16 & 0,006 \\
\cline { 2 - 10 } & 0,04 & 1,75 & 0,17 & 0,073 & - & 0,013 & 0,21 & 0,16 & 0,004 \\
\hline \multirow{2}{*}{ NbCr } & 0,04 & 1,85 & 0,18 & 0,073 & - & 0,016 & 0,32 & 0,03 & 0,004 \\
\cline { 2 - 10 } & 0,04 & 1,86 & 0,19 & 0,075 & - & 0,017 & 0,33 & 0,03 & 0,005 \\
\hline NbCrMoV & 0,05 & 1,76 & 0,17 & 0,066 & 0,025 & 0,016 & 0,15 & 0,2 & 0,0057 \\
\hline
\end{tabular}

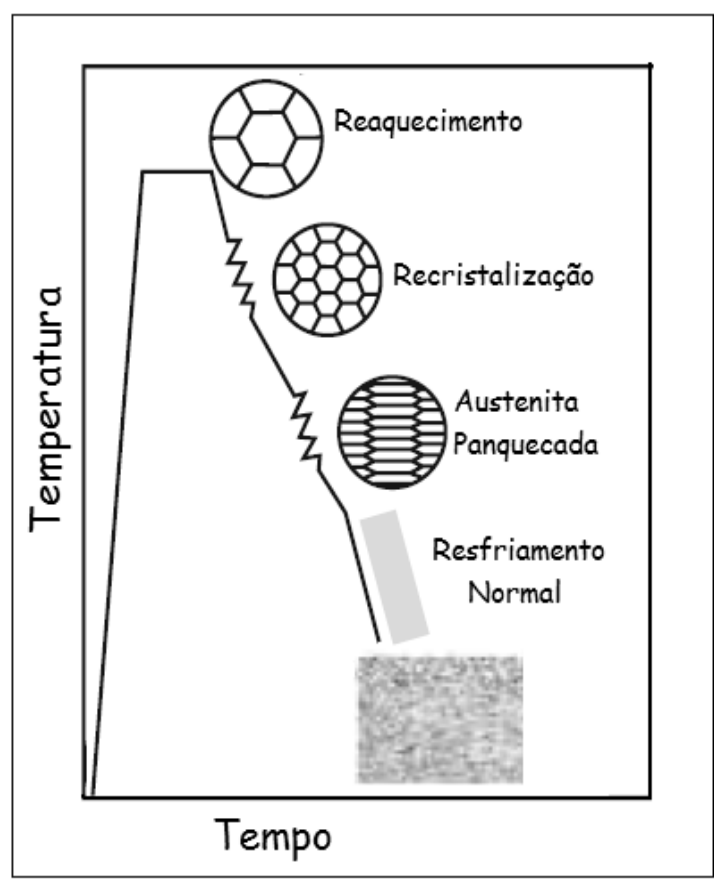

Figura 07. Diagrama do processo de laminação controlado [22

Durante o reaquecimento, uma fina dispersão de partículas de TiN é requerido para inibir o crescimento do grão austenítico, e as temperaturas devem ser 0 suficientemente elevadas para assegurar a dissolução de outros elementos micro-ligantes ( $\mathrm{Nb}$ e $\mathrm{V}$ ). Uma temperatura inicial elevada de laminação recristaliza e refina a estrutura do grão austenítico. A uma temperatura de laminação mais baixa, o começo da precipitação de $\mathrm{Nb}(\mathrm{C}, \mathrm{N})$ inibem ainda mais a recristalização da austenita, produzindo uma forte deformação, dando uma austenita na forma de 'panqueca' que, no final da laminação, que irá proporcionar grande resistência e tenacidade. $O$ controle da espessura é feito de forma automática, a fim de garantir pequena variação durante a laminação 
em toda a extensão da chapa. Depois da laminação, o aço é resfriado a uma temperatura adequada. Esta temperatura é selecionada para promover a nucleação de uma microestrutura de ferrita bem fina, bem como, para promover a precipitação carbonitretos de $\mathrm{Nb}$ e/ou $\mathrm{V}$ finos na microestrutura final [22].

Como no Brasil não se tinha até 2010 a tecnologia para o processo de resfriamento acelerado final ao término da laminação, a chapa é resfriada com jatos de água regulados automaticamente até atingir temperaturas abaixo de $600{ }^{\circ} \mathrm{C}$, para obter uma quantidade significante de bainita [13].

$\mathrm{Na}$ opinião de Costa da Silva [17], um processo que permita a obtenção de austenita de grão fino que, depois de encruada, favorecerá a nucleação de ferrita no resfriamento, com refinamento também do tamanho de grão da ferrita. Isso propiciará a formação de microestruturas de grãos extremamente finos, desde que os tratamentos termomecânicos com deformações significativas sejam realizados a temperaturas inferiores à temperatura de recristalização do material.

\subsubsection{Efeito dos Carbonitretos na Laminação de Aços com Baixo Teor de Carbono.}

Segundo Costa e Silva [17], a adição de $\mathrm{Nb}$ reduz o tamanho de grão austenítico em um aço com $0,2 \% \mathrm{C}$. Esta adição de $\mathrm{Nb}$ eleva o limite de resistência $\left(\sigma_{L R}\right)$ e o limite de escoamento $\left(\sigma_{L E}\right)$, embora com ligeira redução da ductilidade, expressa pela redução de área $(R A)$ e pelo alongamento, como mostra a Fig. 8.

Esses efeitos foram mais pronunciados à medida que a temperatura de laminação (TL) foi elevada, já que com o aumento da $T L$, houve uma maior fração de $\mathrm{Nb}$ dissolvida na ferrita, que precipitou como finas partículas de $\mathrm{NbC}$, impedindo crescimento de grão austenítico, e por conseqüência, o de grão ferrítico [17]. A Fig. 8 apresenta o efeito do $\mathrm{Nb}$ nas propriedades do aço em função da temperatura de laminação. 

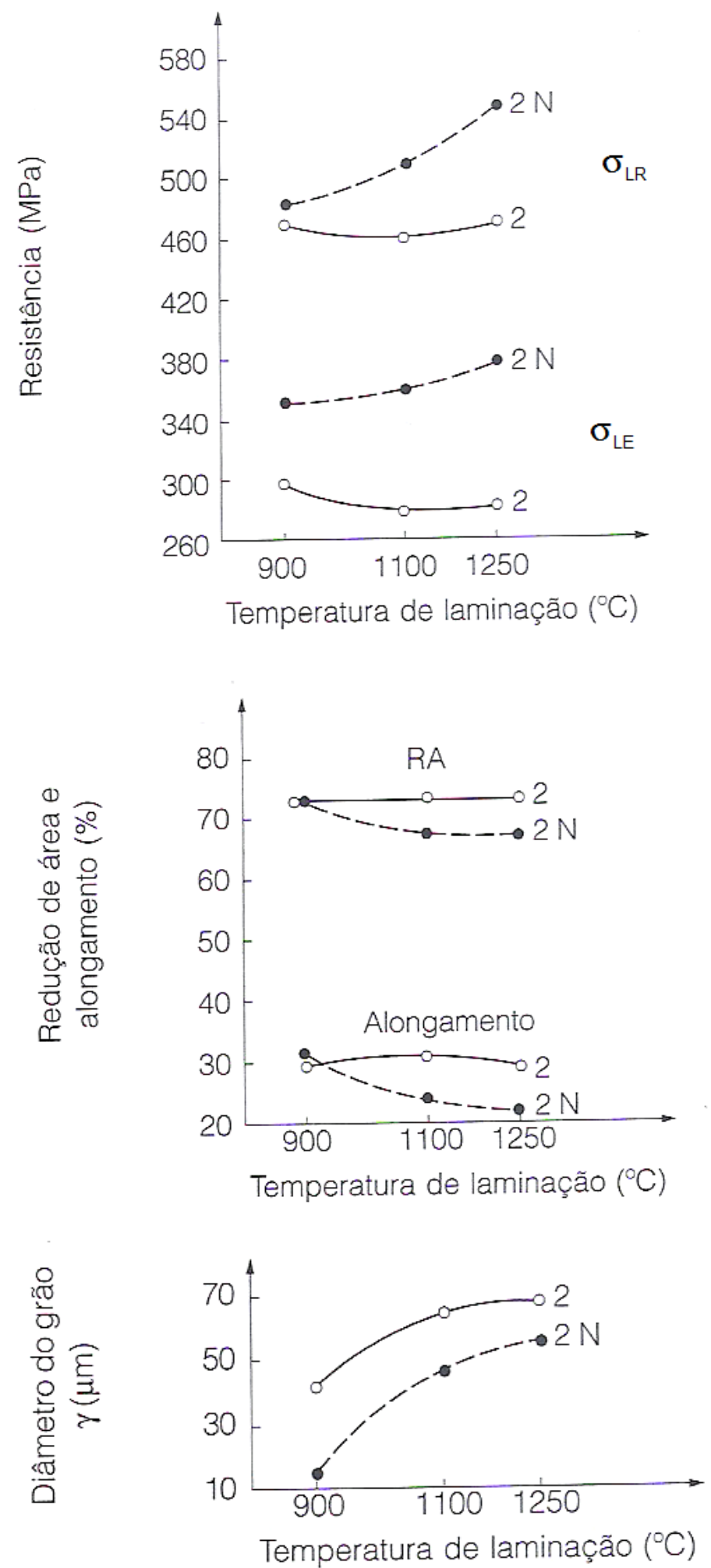

Figura 08. Efeito da temperatura de laminação e da adição de $0,026 \% \mathrm{Nb}(2 \mathrm{~N})$ nas propriedades mecânicas e no tamanho do grão austenítico de aço $0,2 \%$ C[17]. 
A elevação da $T L$ aumenta o $\mathrm{Nb}$ em solução na austenita, e sua posterior precipitação como $\mathrm{NbC}$, finamente disperso, aumentando a dureza da ferrita. $\mathrm{O}$ $\mathrm{Nb}$ em solução sólida na austenita favorece a formação de estruturas aciculares de maior dureza. Quanto maior a temperatura de laminação maior é sua fração dissolvida e maior o efeito de acicularização da estrutura [17], como apresenta a Fig. 9.

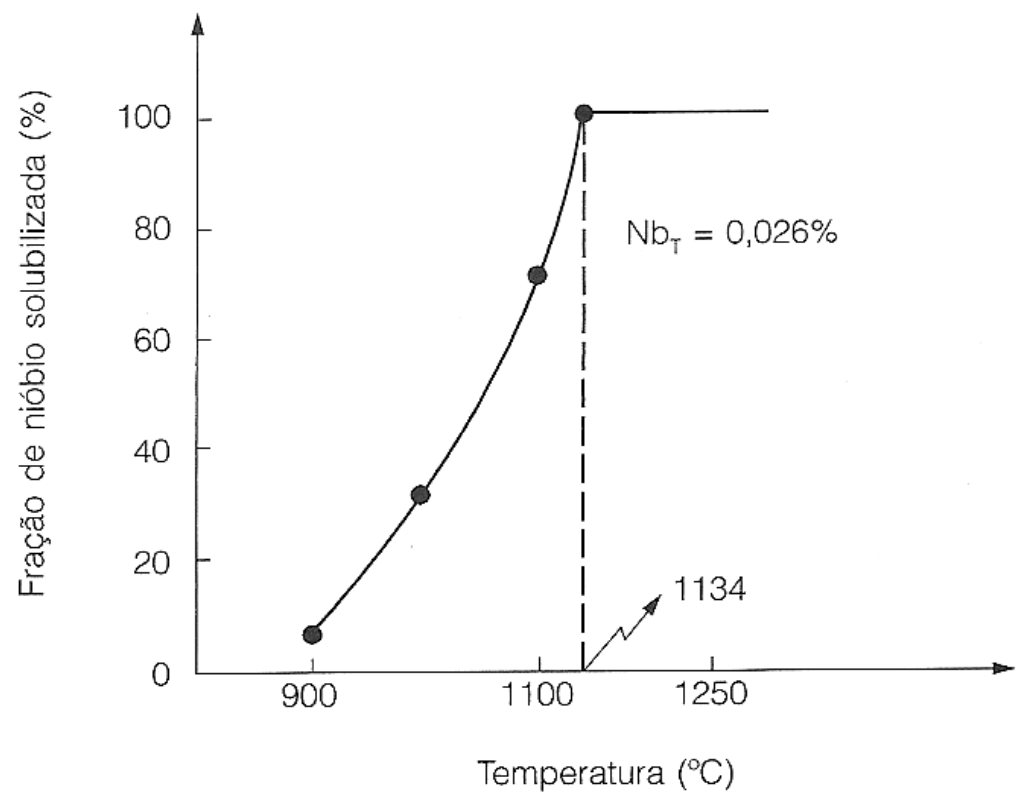

Figura 09. Fração de $\mathrm{Nb}$ em solução na austenita para aços com $0,2 \% \mathrm{C}$ aquecidos em diferentes temperaturas [17].

\subsubsection{Microestrutura do Aço Microligado para Tubos de Aço API 5L Grau $\mathrm{X} 80$}

Este aço apresenta uma microestrutura constituída de ferrita poligonal $\left(\alpha_{p}\right)$, ferrita quase-poligonal $\left(\alpha_{q}\right)$, ferrita granular refinada com tamanho heterogêneo e ferrita alongada na forma de grãos "panqueca". Além da ferrita formar colônias de bainita alotromórfica em forma de banda acompanhadas de ilhas de MA, originada de grãos de austenita deformada na direção da laminação [23-25], e apresentadas nas Fig. 10 e 11.

Os agregados MA localizam-se preferencialmente nos contornos de grão e distribuídos na matriz ferrítica, normalmente junto à bainita. Os agregados MA 
precipitam a partir da austenita enriquecida em carbono, rejeitado pela ferrita formada inicialmente [23,24].

Segundo Ramirez [24] a resistência do material esta relacionada com o refino de grão, endurecimento por solução sólida e precipitados de carbonetos.
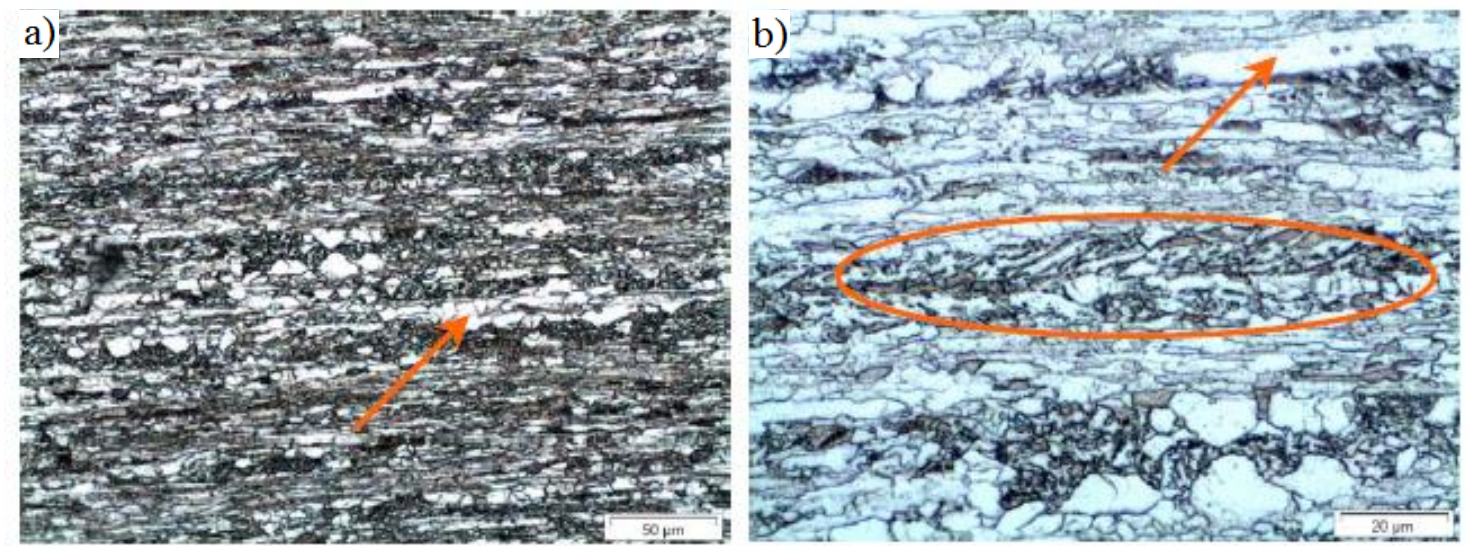

Figura 10. Micrografias próximas à superfície da chapa obtidas por MO. (a) A seta indica colônias de ferrita poligonal de cor branco 200X, (b) Colônias de agregado eutetoíde (elipse) e grão maior de ferrita assinalado por a seta 500X. Nital 3\% [23].
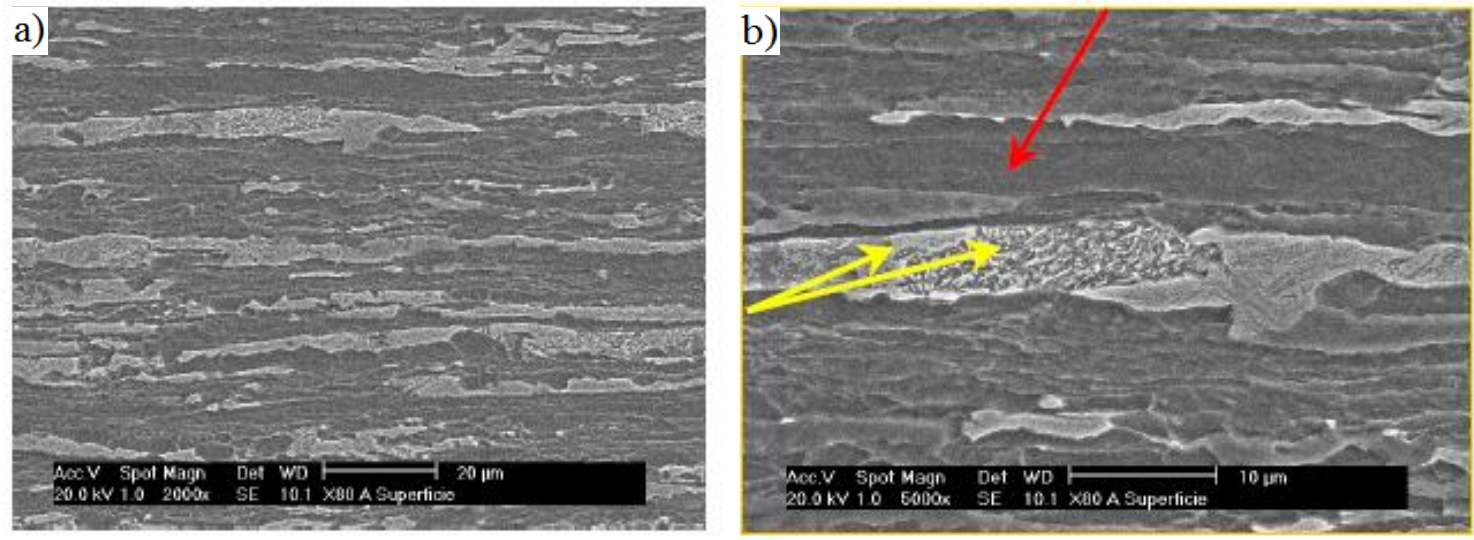

Figura 11. Microestrutura da superfície da chapa do aço microligado para tubos API X80 obtidas por MEV. a) Grãos alongados de ferrita, agregados eutetóides. b) Grão antigo de austenita deformada que se transformou em agregados de eutetóides (setas amarelas) e grão de ferrita em forma de 'panqueca' (seta vermelha). Reagente Nital 3\% [23].

\subsection{Processo de Fabricação dos Tubos Com Costura (U-O-E)}

Primeiramente se faz uma inspeção das chapas com a finalidade de detectar possíveis macrodefeitos e prevenir a formação de trincas longitudinais para, em 
seguida, as bordas da chapa são usinadas, chanfradas na direção longitudinal e prensadas.

Posteriormente a chapa é prensada no formato $U$ e O. Depois é feito um trabalho mecânico de selamento e faceamento no tubo. A etapa seguinte é o ponteamento da junta longitudinal a fim de evitar a distorção decorrente de contrações e dilatações térmicas, para que não ocorram mudanças no diâmetro durante a soldagem final, que é uma soldagem automática feita, externa e internamente, com o processo de soldagem a arco submerso (SAW). Para garantir a ausência de defeitos na junta soldada é realizado um ensaio de ultrasom após a soldagem. Em seguida o tubo é submetido a uma expansão interna a frio $(E)$, que tem a finalidade de ajustar o seu diâmetro às tolerâncias da norma API 5L, para que o tubo passe por inspeção e teste hidrostático. Novos ensaios de inspeção por ultra-som e inspeção radiográfica são realizados na junta soldada. Caso a solda longitudinal seja aprovada, é feito o biselamento nas faces do tubo. Finalmente uma inspeção dimensional e ensaios de laboratório são feitos. Este processo também é chamado de processo de fabricação longitudinal (U-O-E) com arco submerso [26]. A figura 12 mostra o processo de fabricação do tubo.

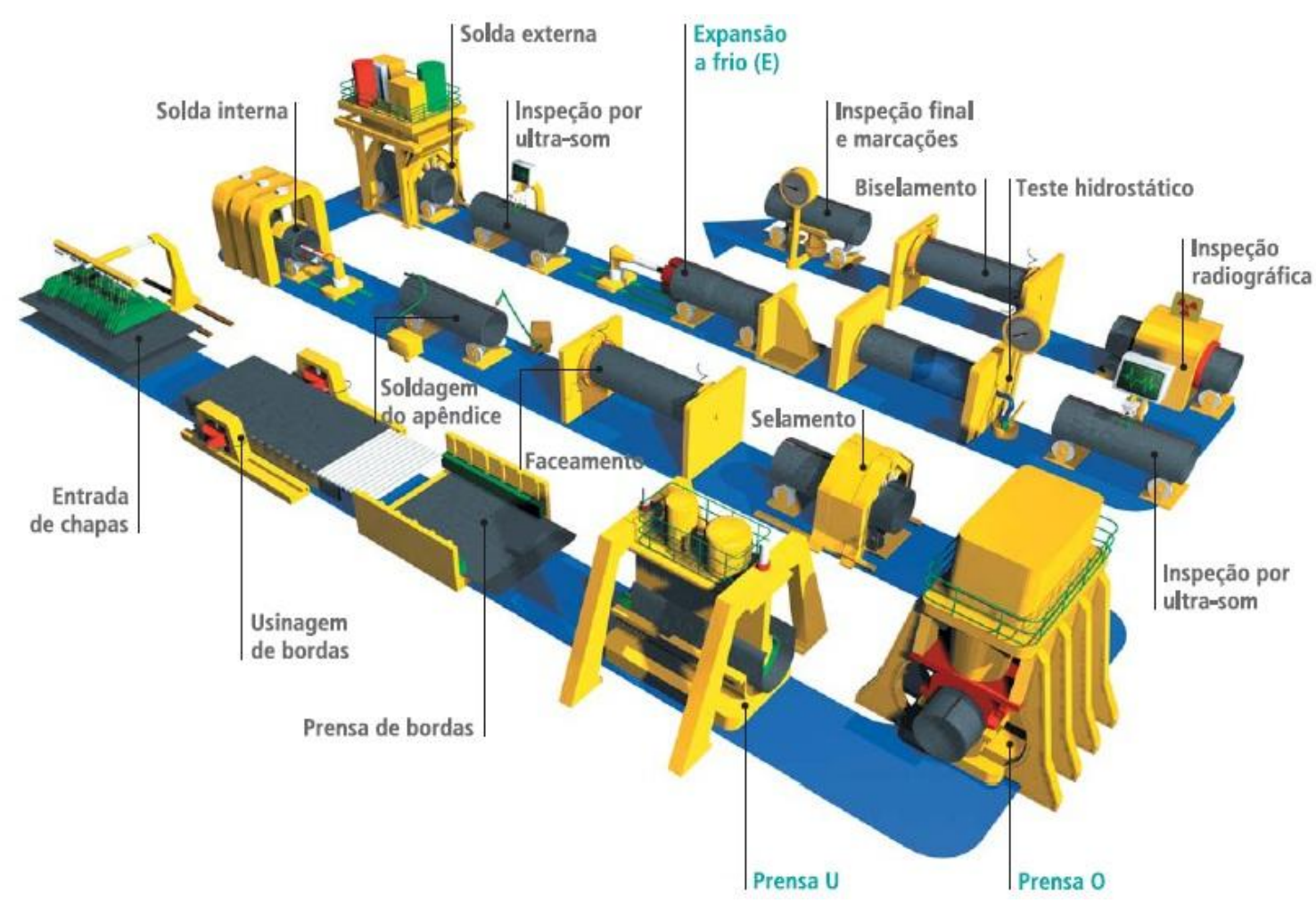

Figura 12. Processo de fabricação SAW longitudinal (U-O-E) [26]. 


\subsection{Soldabilidade dos Aços de Alta Resistência e Baixa Liga (ARBL)}

O conceito de uma boa soldabilidade, com aplicação de calor e metal de adição, de aços exige a necessidade que a junta soldada (metal de solda e ZAC) tenha propriedades mecânicas compatíveis com o metal de base.

No processo de fabricação da chapa de aço API $5 \mathrm{~L}$ grau X80 se tem uma laminação controlada e a adição de elementos de liga para obter o refino de grão, o qual melhora algumas propriedades mecânicas do aço. O resultado deste processamento pode ser parcialmente neutralizado durante o processo de soldagem. A solda longitudinal realizada durante a fabricação do tubo pelo processo U-O-E, geralmente tem as propriedades mecânicas garantidas pelo ajuste adequado dos parâmetros de soldagem, por ser uma soldagem de fabricação mecanizada. No entanto, durante a construção e montagem do duto é necessário determinar cuidadosamente os parâmetros de soldagem que venham a afetar o desempenho do duto em operação [19].

Em geral, um metal de base é soldável se, depois do processo de soldagem, este material apresenta boa tenacidade, e a composição química da zona fundida não se torne frágil por diluição com o metal de base [27] para a aplicação de tubos na indústria de óleo e gás.

Os fatores mais importantes que influem na soldabilidade dos metais são os seguintes [27]:

- As transformações que se produzem na zona afetada pelo calor (ZAC).

- A composição química dos materiais a unir (metal de base e metal de adição).

- As tensões residuais geradas durante a soldagem.

- O processo de soldagem.

- O procedimento de soldagem empregado.

\subsubsection{Carbono Equivalente (CE)}

Nas soldas, valores elevados de dureza podem representar problemas como trinca a frio por hidrogênio, corrosão-sob-tensão, comportamento frágil das zonas soldadas, etc. A dureza máxima no cordão de solda não depende 
somente do conteúdo de carbono e elementos de liga, depende também da temperabilidade e dos ciclos térmicos de soldagem [27].

Nas tubulações modernas uma boa tenacidade na zona afetada pelo calor (ZAC) e uma adequada resistência ao impacto no metal de solda são requisitos necessários e esperados. Na junta soldada, a ausência de trincas por hidrogênio, com velocidades altas de soldagem, e uma penetração total são requisitos básicos na ZAC da solda circunferêncial. A difusão de hidrogênio na ZAC é extremamente prejudicial, especialmente quando a microestrutura da ZAC no passe raiz é susceptível, e o nível de tensão residual local é elevado[4].

Uma das formas de prever a soldabilidade dos aços é através da dureza das soldas na zona afetada pelo calor (ZAC), já que a dureza máxima da ZAC é o parâmetro característico para o trincamento a frio de uma solda $[4,27]$.

Uma ferramenta simples para predizer a susceptibilidade ao trincamento a frio é por meio de fórmulas empíricas, como as Eq. 1 (Pcm) e Eq. 2 (CEIIW), que calculam o carbono equivalente, um parâmetro que representa a temperabilidade do aço em função de sua composição química [4]. O CEIIW é uma fórmula proposta pelo Instituto Internacional de Soldagem (IIW), que é valido para aços com conteúdo de $C$ maior que $0,12 \%$. Esta equação é usualmente requerida em especificações para tubulações com teores de carbono mais elevados [27].

$$
C E_{I I W}=C+\frac{M n}{6}+\frac{C r+M o+V}{5}+\frac{C u+N i}{15}
$$

Com o desenvolvimento de tubulações de aços de alta resistência e baixo carbono equivalente e o projeto adequado de consumíveis para soldagem, as propriedades na zona fundida podem ser bem controladas. Algumas medidas adotadas para minimizar o dano do trincamento por hidrogênio na solda circunferêncial são: o uso de aços com baixo carbono e reduzido conteúdo de elementos micro-ligantes para induzir uma baixa susceptibilidade microestrutural na ZAC. Esta é a forma mais eficiente para resolver o problema do trincamento, levando-se em conta os recentes desenvolvimentos de aços para tubulações produzidas por laminação termomecânica com ou sem 
resfriamento acelerado [4]. Colpaert também acredita que, as soldas para que tenham propriedades satisfatórias, é necessário controlar as propriedades de material a soldar, principalmente o carbono equivalente e o ciclo térmico de soldagem (21) [21].

$O$ preaquecimento também minimiza o trincamento por hidrogênio quando baixas temperaturas de operação são envolvidas, para aumentar o tempo de operação próximo a $100{ }^{\circ} \mathrm{C}$ e promover a difusão de hidrogênio para longe da junta soldada. A relação entre o hidrogênio, a composição química e a temperatura de preaquecimento são dadas na figura 13 , os aços termomecanicamente laminados se comportam melhor que os aços normalizados [4]. Na figura a legenda 'eletrodo-Ce' significa eletrodo com revestimento celulósico (E6010, por exemplo), com o teor típico de hidrogênio do cordão de solda feito por este consumível. A legenda 'eletrodo-básico' significa eletrodo com revestimento básico (E7018, por exemplo), com o teor típico de hidrogênio do cordão de solda feito por este consumível muito mais baixo que o teor do eletrodo celulósico.

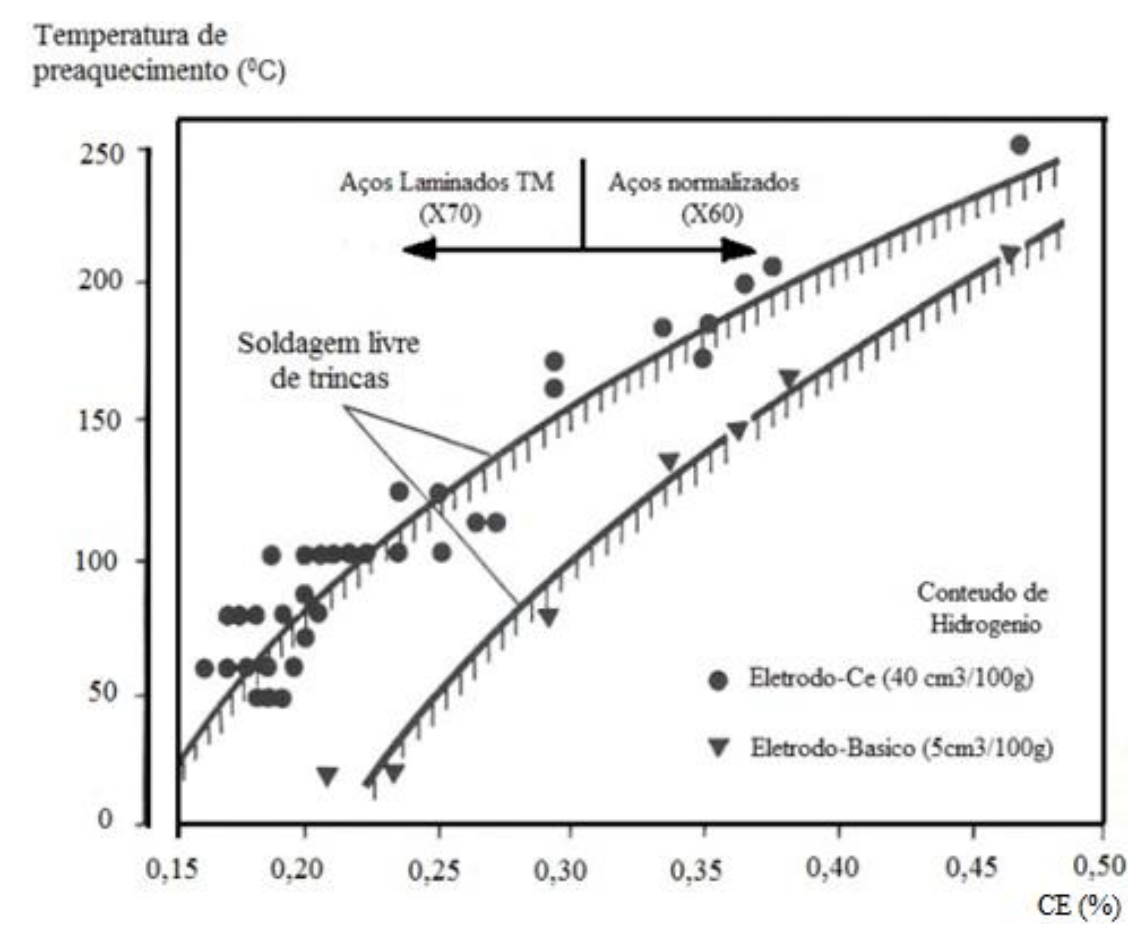

Figura 13. Temperatura de preaquecimento para a resistência ao trincamento de soldas em relação ao carbono equivalente, para dois tipos de revestimento, celulósico (CE) e básico [4]. 


\subsubsection{Zona Afetada pelo Calor (ZAC)}

As características da ZAC dependem fundamentalmente do tipo de metal de base, do processo e do procedimento de soldagem, isto é, da temperabilidade do aço e dos ciclos térmicos e da repartição térmica [28].

Outro critério para avaliar os riscos potenciais de trinca ou fragilidade de junta soldada de um aço é a medida da dureza da ZAC. Para prever com precisão as durezas na ZAC de um aço determinado, é necessário não só conhecer sua composição química completa, mas também ter em conta sua microestrutura inicial (que é o resultado da historia térmica associada a sua fabricação) e compreender como vai evoluindo sua microestrutura sobre a influência dos ciclos térmicos durante a soldagem. Todo este conjunto de informações determina a microestrutura final e as propriedades mecânicas da junta soldada [27]. A máxima dureza na ZAC do cordão é observada na proximidade imediata à zona de ligação; já que, nessa zona, é onde se atinge a máxima velocidade de resfriamento e a máxima temperatura. Esses fatores provocam um aumento do tamanho de grão devido à difusão e a dissolução completa dos carbonetos e outras partículas, o que aumenta a temperabilidade da matriz [27]. As regiões da ZAC no caso dos aços carbono e aços de baixa liga, são ilustradas na fig. 14 , e descritas a seguir.

\subsubsection{Região de Crescimento de Grão}

O crescimento de grão compreende a região do metal de base mais próxima da zona de ligação e que foi submetida a temperaturas máximas entre $1100{ }^{\circ} \mathrm{C}$ e a temperatura solidus, como mostra a Fig. 14. Nesta região a microestrutura austenítica sofre um grande crescimento de grão. Este crescimento depende do tipo de aço e da energia de soldagem. Os processos de maior energia resultarão em granulação mais grosseira [28]. O crescimento de grão depende da distribuição de partículas ou precipitados que evitam que o grão austenítico cresça. $O$ tamanho de grão dependera se essas partículas são ou não diluídas durante o ciclo térmico de soldagem [29]. 


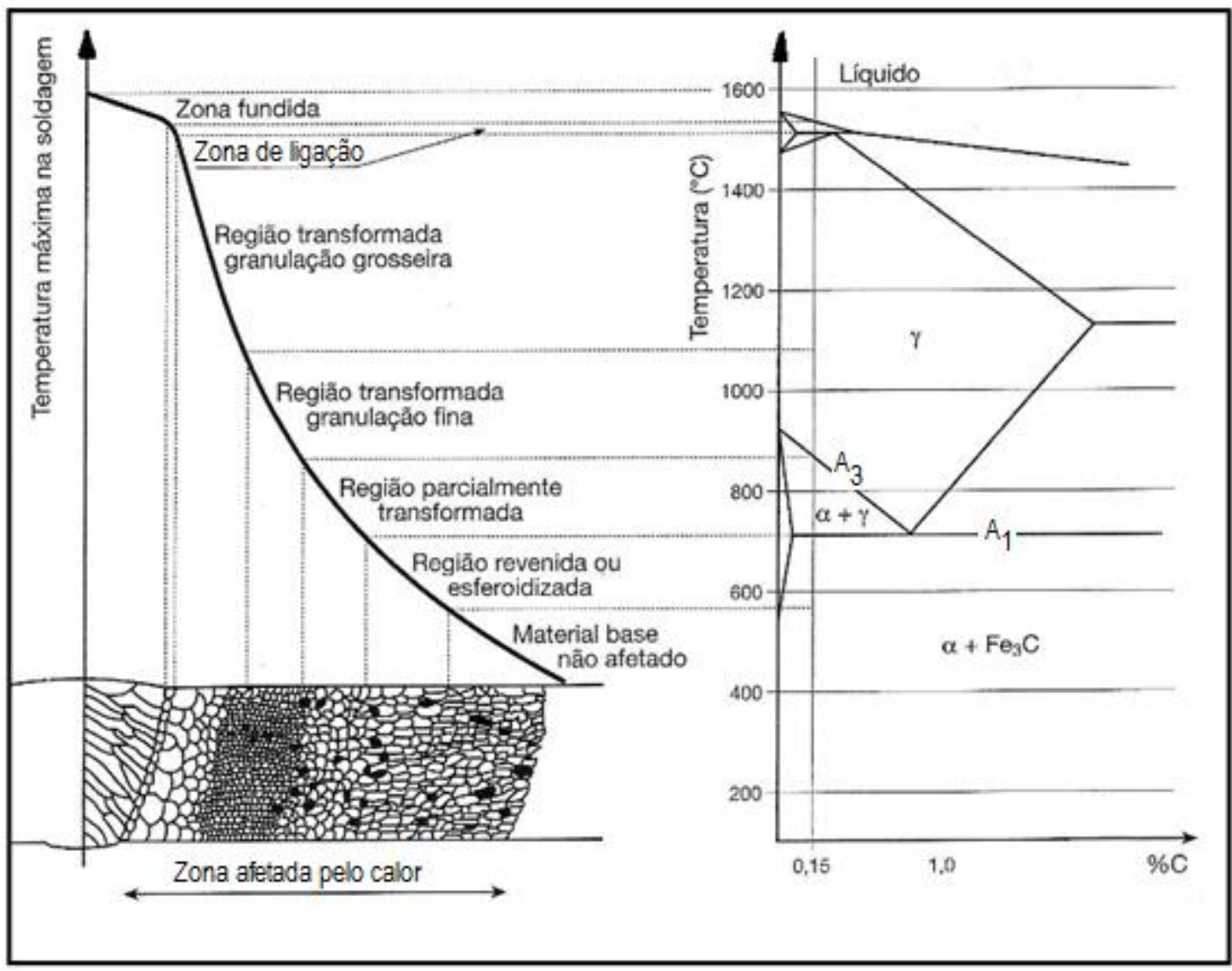

Figura 14. a) Representação da distribuição da temperatura máxima atingida na soldagem em função da distância ao eixo de solda b) Diagrama de fases Fe-C com a indicação das temperaturas máximas de soldagem e seu efeito sobre a microestrutura [adaptado da ref. 21].

A estrutura final de uma junta dependerá do tamanho de grão austenítico anterior, da quantidade de carbono e de elementos de liga e da velocidade de resfriamento. A granulação grosseira da austenita dificulta sua transformação durante o resfriamento, isto é, aumenta a temperabilidade do aço além dos efeitos do carbono e dos elementos de liga na temperabilidade. Esta região pode apresentar, além de tamanho de grão grande da austenita anterior, microestrutura martensítica, ferrítica e bainítica, dependendo de sua composição química e velocidade de resfriamento. Velocidades de resfriamento elevadas dão como resultado, dependendo se o aço tem elevado conteúdo de carbono e elementos de liga, uma microestrutura completamente martensítica nesta região da ZAC. Por estes motivos e pela segregação de impurezas e elementos fragilizantes para o contorno de grão da austenita anterior, esta região é a mais problemática da ZAC, porque pode apresentar problemas de tenacidade e é um lugar preferencial para a formação de trincas. 
Para um dado material, espessura e tipo de junta, as condições de resfriamento e, em conseqüência, a microestrutura desta região, poderão ser controladas pela seleção adequada das condições de soldagem, particularmente a energia de soldagem e a temperatura de preaquecimento da junta [28].

\subsubsection{Região de Refino de Grão}

Compreende a porção da junta aquecida a temperaturas máximas de 900 até próximo de $1100{ }^{\circ} \mathrm{C}$, como apresenta a Fig.14. Após o processo de soldagem, esta região se caracteriza por ter uma estrutura fina de ferrita e perlita e não apresenta problemas na maioria dos casos [28]. Esta região apresenta resistência e ductilidade elevada, sendo uma característica nos aços microligados [29].

\subsubsection{Região Intercrítica ou Parcialmente Transformada}

Nesta região a temperatura máxima varia entre a linha $A_{1}$ (temperatura eutetóide - $723{ }^{\circ} \mathrm{C}$ ) e a linha $A_{3}$ na Fig. 14, sendo caracterizada pela transformação da microestrutura original do metal de base. Nesta faixa de temperatura, uma parte da microestrutura do metal de base é austenizada e, portanto, alterada pelo ciclo térmico [28]. Nesta região, devido à diferença de solubilidade do carbono na ferrita e na austenita, a austenita fica enriquecida em carbono, aumentando ainda mais sua temperabilidade. Dependendo da velocidade de resfriamento, a austenita pode se decompor em perlita, bainita, austenita retida e martensita maclada, isto é, em martensita de alto carbono. Esta região pode apresentar as piores propriedades em comparação às propriedades do aço [29], mesmo com o refino de grão que ocorre também nesta região. Nesta região, particularmente na soldagem multipasse, podem se formar constituintes de elevada dureza e baixa tenacidade [28]. A temperatura mínima desta região $\left(A_{1}\right)$ geralmente define a fronteira entre a ZAC e o metal base. 


\subsubsection{Região de Esferoidização de Carbonetos}

Esta região apresenta temperaturas máximas menores que a linha $A 1$ (temperatura eutetóide $-723^{\circ} \mathrm{C}$ ), com uma mudança microestrutural quase que imperceptível, dependendo da composição química, dos parâmetros de soldagem e da velocidade de resfriamento, além dos eventuais reaquecimentos. Nesta região as lamelas de cementita da perlita podem esferoidizar. A resistência mecânica pode diminuir ainda que não seja comprovável, já que ocorre numa faixa estreita da ZAC [29].

\subsubsection{Efeitos de Vários Passes de Solda na ZAC}

Na soldagem multipasse a situação é mais complexa que a soldagem de um único passe, devido à transformação parcial da microestrutura na ZAC inicial causada pelo passe subseqüente, de forma que cada cordão de solda é 'tratado termicamente' pelo cordão subseqüente, tendo como resultado uma ampla gama de microestruturas, as quais dependem da distância na que se encontra aquela região até a zona fundida [26]. Esta distância determina a temperatura máxima e a velocidade de resfriamento da região.

A seqüência de deposição dos passes é importante, uma vez que o ciclo térmico do um passe subseqüente pode ajudar a refinar o grão grosseiro de um passe anterior. Quando um passe é aplicado ao metal de base há uma região ao lado da zona de fusão onde se alcança a temperatura suficiente para propiciar o crescimento de grão austenítico. A deposição ideal dos passes posteriores é aquela em que se atinge a re-austenização da região de grão grosseiro à temperaturas máximas inferiores às temperatura dos passes anteriores. A Fig. 15 mostra este efeito na soldagem multipasse [21] realizada pela soldagem com arame tubular auto-protegido (SAT-NG) em aço 20MnMoNi55, com composição nominal de 0,2 \% de carbono; 1,25\% de Mn; 0,5\% Mo e 0,6\% de $\mathrm{Ni}$, com pequenas adições de cromo e silício e enxofre residual. A figura 15(a) mostra duas regiões na zona de ligação: uma marcada com a letra (s), indicando uma região sem microssegregação e outra marcada com (s) indicando microssegregação no metal de base. Na figura 15(b) é apresentado um esquema das regiões da ZAC de uma soldagem multipasse, 
com grãos grosseiros (GG) e com grãos refinados (GF), transformadas diversas vezes conforme a posição relativa entre os cordões.

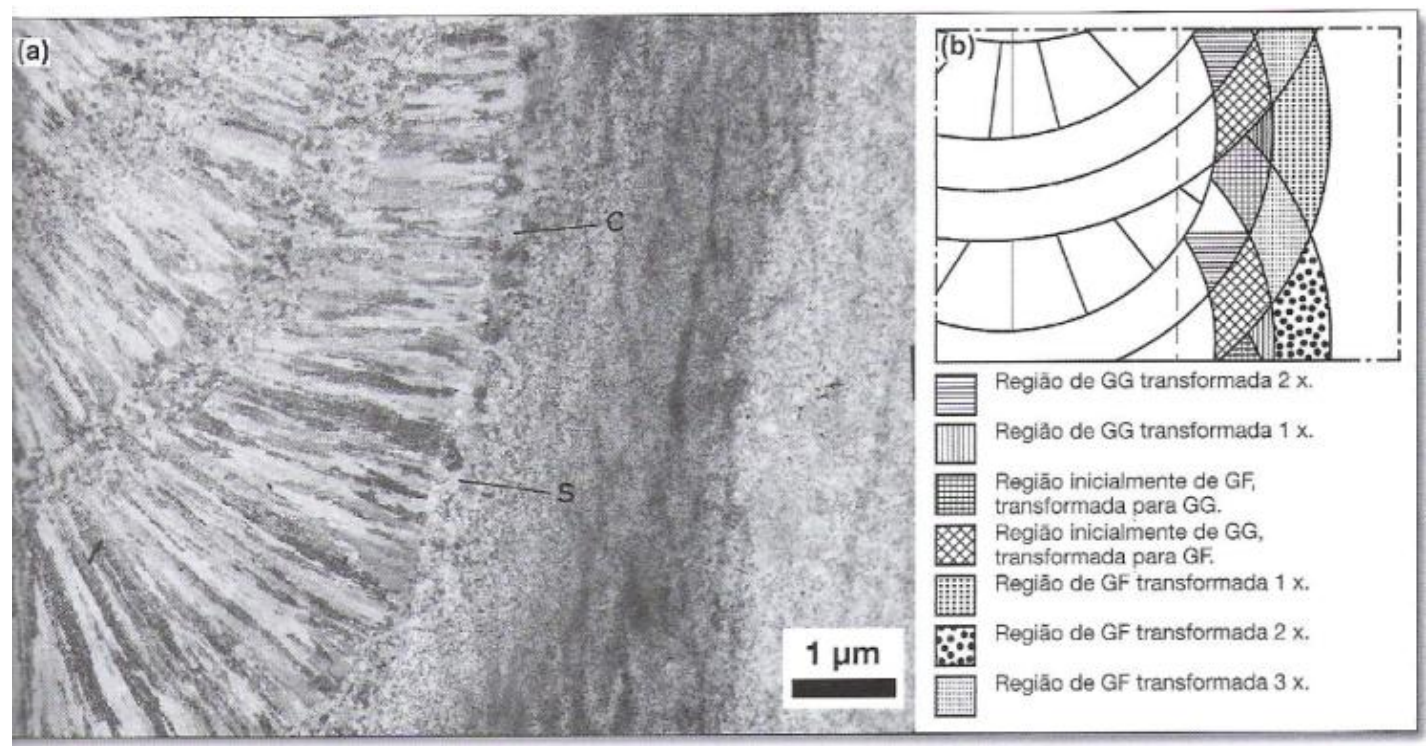

Figura 15. a) Detalhe da linha de fusão e região termicamente afetada da solda com arame tubular auto-protegido em aço 20MnMoNi55. Estão indicadas, junto à linha de fusão, no material base, duas regiões: (s) região sem segregação no material base (c) com segregação. b) Esquema indicando as zonas de grãos grosseiros (GG) de um passe que são refinadas para granulação austenítica fina (GF) pelos passes subseqüentes. Ataque: Nital 2\% [21].

\subsubsection{Transferência de Calor na Soldagem}

O calor é a principal fonte de energia nos processos de soldagem, sendo necessário supri-lo à poça de fusão em intensidade suficiente, de modo a garantir a execução de uma junta soldada de boa qualidade, nos processos de soldagem por fusão. Por outro lado, pode representar fonte potencial de problemas devido à sua influência direta nas transformações de fase e fenômenos mecânicos (tensões residuais e distorções) que ocorrem na junta soldada. Esses efeitos são conseqüências dos ciclos térmicos e das temperaturas a que a junta soldada é submetida. 


\subsubsection{História Térmica}

A história térmica representa as mudanças de microestrutura que ocorrem em um processo de soldagem. Para estabelecer essas alterações é preciso conhecer os ciclos térmicos de soldagem, em cada ponto próximo à solda, e a repartição térmica [30].

$O$ ciclo térmico de soldagem é definido pela variação da temperatura $(\theta)$ que ocorre em função do tempo (t) em uma dada posição no metal de base [30]. A temperatura máxima e a velocidade de resfriamento estão relacionadas com a microestrutura nos pontos de interesse e, portanto, nas propriedades finais do material soldado [29].

A curva $\theta=f(t)$, desenhada para um ponto $(A)$ perto do cordão de solda, como mostra a Fig. 16, mostra todas as informações necessárias do ciclo térmico. $\mathrm{Na}$ figura $\theta_{\mathrm{m}}$ representa a máxima temperatura alcançada; $\theta_{\mathrm{S}}$ é a temperatura critica (como as temperaturas mostradas na fig. 14) em um tempo ts e $V_{R}$ é a velocidade de resfriamento a uma temperatura $\theta_{R}$ em um tempo $t_{R\left(\theta 1 \text { a } \theta_{2}\right)}$ [30]. Geralmente, para os aços carbono e aços baixa e média liga, estas temperaturas $\theta_{1}$ e $\theta_{2}$ são 800 e $500^{\circ} \mathrm{C}$, definindo o $t_{R}$ como $\Delta t_{8-5}$.

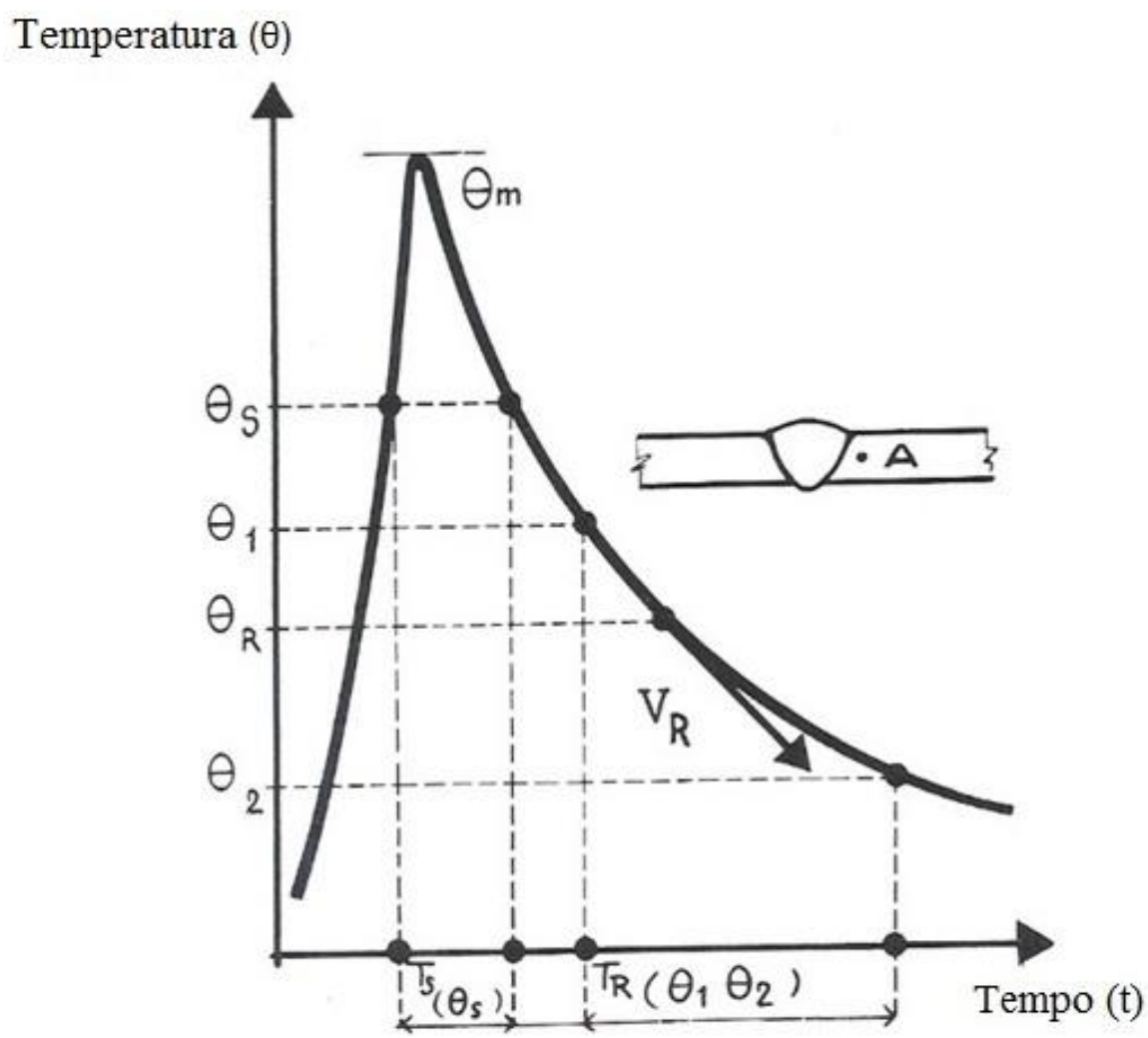

Figura 16. Ciclo térmico de soldagem em um ponto da junta soldada [30]. 
A repartição térmica mostra a extensão da região do metal base que teve sua microestrutura modificada pelo(s) cordão(ões) de solda. A curva que representa a repartição térmica $\theta_{m}=f(x)$, apresentada na figura 17 , mostra a variação da temperatura máxima $\left(\theta_{\mathrm{m}}\right)$ alcançada em cada ponto em função da distância a partir da zona de ligação (x). Para definir a extensão da zona afetada pelo calor para os aços carbono basta encontrar a distância entre a região que atingiu uma temperatura máxima igual a temperatura solidus e a temperatura $A_{1}$ na $Z A C[30]$.

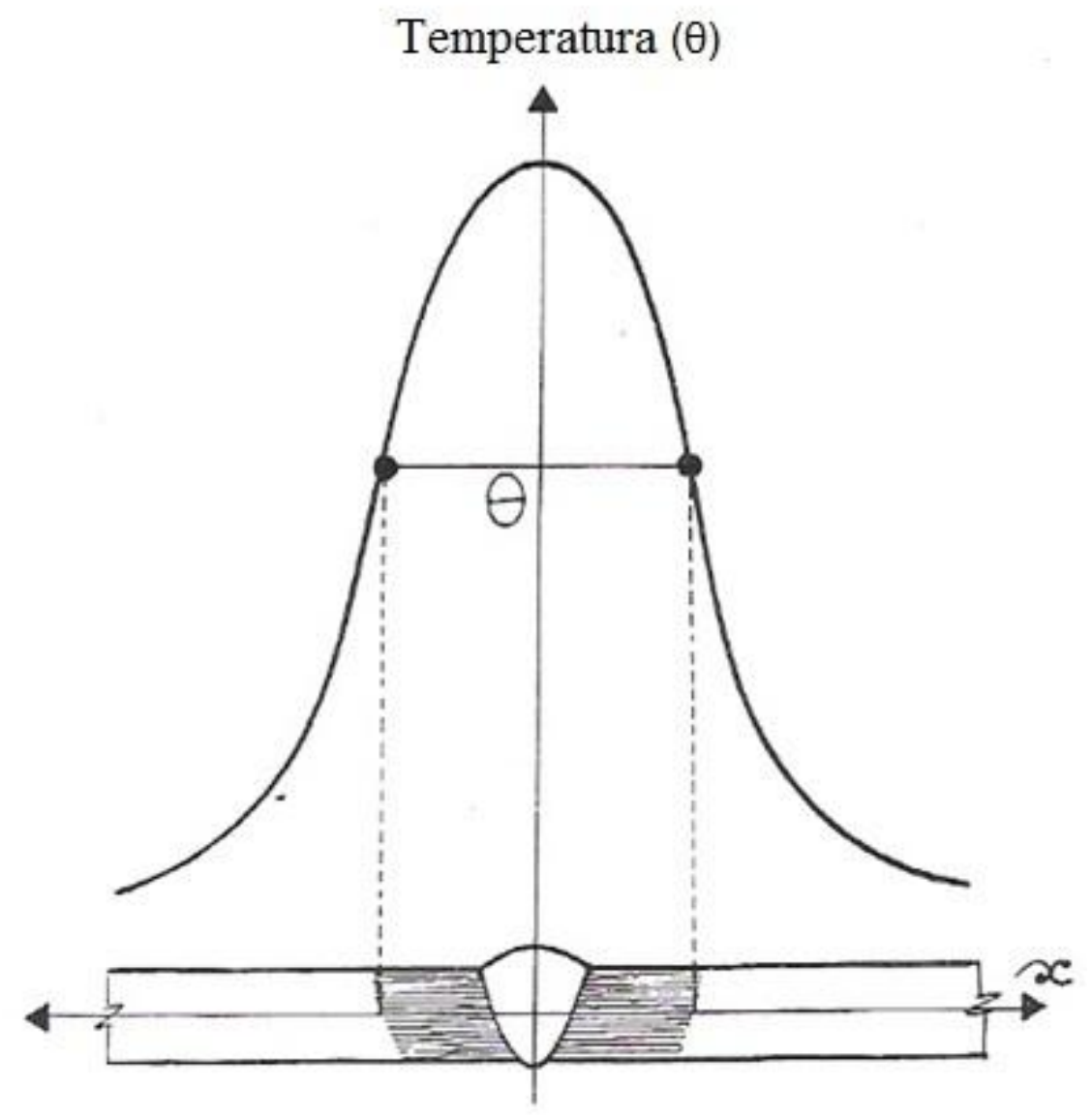

Figura 17. Repartição térmica representando a ZAC de uma junta soldada [30].

Na Fig. 18 podem-se observar os ciclos térmicos para diferentes distâncias perpendiculares à linha de centro do cordão de solda. As temperaturas máximas alcançadas $\theta_{\mathrm{mA}}, \theta_{\mathrm{mB}}, \theta_{\mathrm{mc}}$ de cada ciclo térmico diminuem com $o$ aumento da distância, enquanto os tempos $t_{\mathrm{mA}}, t_{\mathrm{mB}}, t_{\mathrm{mc}}$ aumentam. Estes valores são funções do material, geometria de junta, do processo e do 
procedimento de soldagem que é usado. O conjunto de temperaturas máximas resulta na curva $\theta_{\mathrm{m}}=\varphi(\mathrm{t})$, representada pela linha tracejada que une as temperaturas máximas alcançadas na fig. 18. Isto significa que, dependendo da distância, existem regiões que estão resfriando (próximas à zona de ligação) e outras que ainda estão no aquecimento (pontos mais afastados da zona de ligação). Para a distribuição de ciclos térmicos, a velocidade de resfriamento é menor para distâncias maiores da zona de ligação [30].

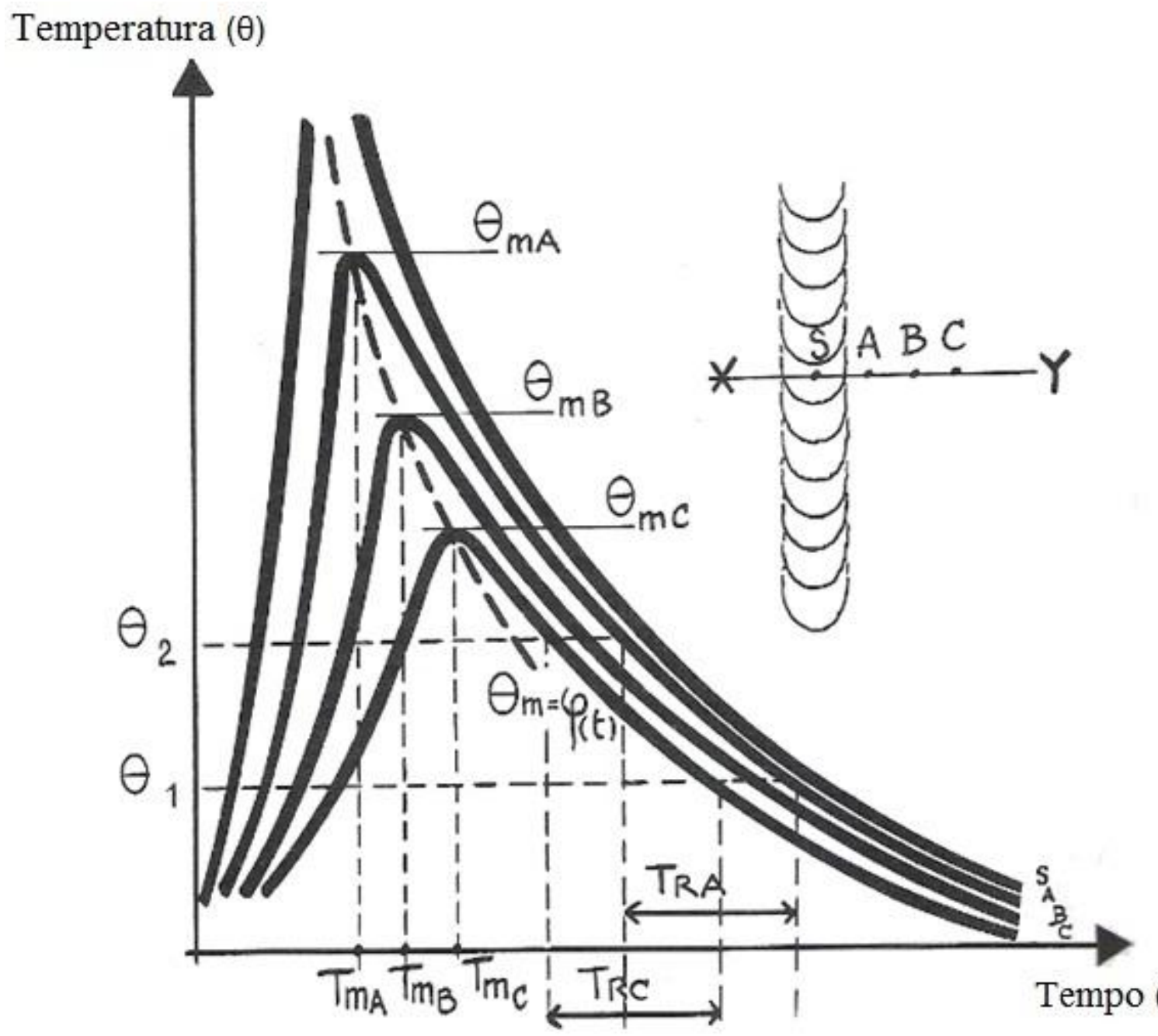

Figura 18. Ciclos térmicos para distâncias perpendiculares à linha de centro do cordão de solda [30].

Teoricamente, caso não haja alteração de nenhuma das condições durante a soldagem, pode-se dizer que existe uma única repartição térmica e infinitos ciclos térmicos durante a soldagem em regime pseudo-estacionário. 


\subsubsection{Ciclos Térmicos de Uma Solda Multipasse}

Em condições reais a maioria dos cordões de solda não é feita com um único passe, mas com vários passes. A Fig. 19 mostra, esquematicamente, para uma soldagem multipasse de uma junta em V, feita em três passes e sem preaquecimento, os ciclos térmicos no ponto $A$, que teve sua microestrutura afetada pelos três passes [30], isto é, a temperatura máxima dos três passes foi maior que a temperatura $A_{1}$.

O primeiro passe tem como resultado uma temperatura máxima $\theta_{\mathrm{ml}}$, seguido de um resfriamento, caracterizado por uma velocidade $V_{1}$ na temperatura $\theta_{V}$. $O$ resfriamento continuará até a temperatura inicial se o segundo passe é feito depois de um tempo adequado. Isso geralmente não ocorre, e o segundo passe é aplicado antes que a temperatura no ponto $A$ tenha retornado à temperatura inicial $\theta_{0}$; isto é, $\theta_{1}>\theta_{0}$. Quando o ciclo térmico produzido pelo segundo passe começa, ele é caracterizado por uma máxima temperatura $\theta_{\mathrm{mll}}$ e velocidade de resfriamento $V_{\|}$à temperatura $\theta_{V}$. Este ciclo térmico difere do primeiro $\left(\theta_{\mathrm{mll}}<\theta_{\mathrm{ml}}\right)$ devido a maior distância do ponto $A$ em relação ao segundo passe. $A$ velocidade de resfriamento $V_{\|}$é menor que $V_{\text {I }}$ pela mesma razão e especialmente a causa de que o ciclo térmico do segundo passe é influenciado por um efeito similar ao de pré-aquecimento, já que o ciclo térmico começa a uma temperatura inicial $\theta_{1}>\theta_{0}$. $O$ mesmo se aplica ao terceiro passe, já que, pela mesma razão e arranjo descrito, a temperatura máxima $\theta_{\text {mIII }}$ e velocidade de resfriamento $V_{\text {III }}$ são respectivamente menores que $\theta_{m \text { II }}$ e $V_{\text {II }}$ [30].

Aqui também pode se observar que as velocidades de resfriamento diminuem do primeiro para o último passe, visto que os passes subseqüentes ao primeiro são feitos a temperaturas iniciais mais elevadas, produzindo um efeito similar ao aumento da temperatura de pré-aquecimento [30]. A redução da velocidade de resfriamento também está associada ao tempo de resfriamento, que é maior para temperaturas máximas menores.

Os ciclos térmicos multipasse dependem de certos fatores como: temperatura inicial, número de passes, condição em que eles são aplicados, tempo entre passes e a relação entre a posição da solda e o ponto no qual a variação de temperatura será analisada [30]. 


\section{Temperatura $(\theta)$}

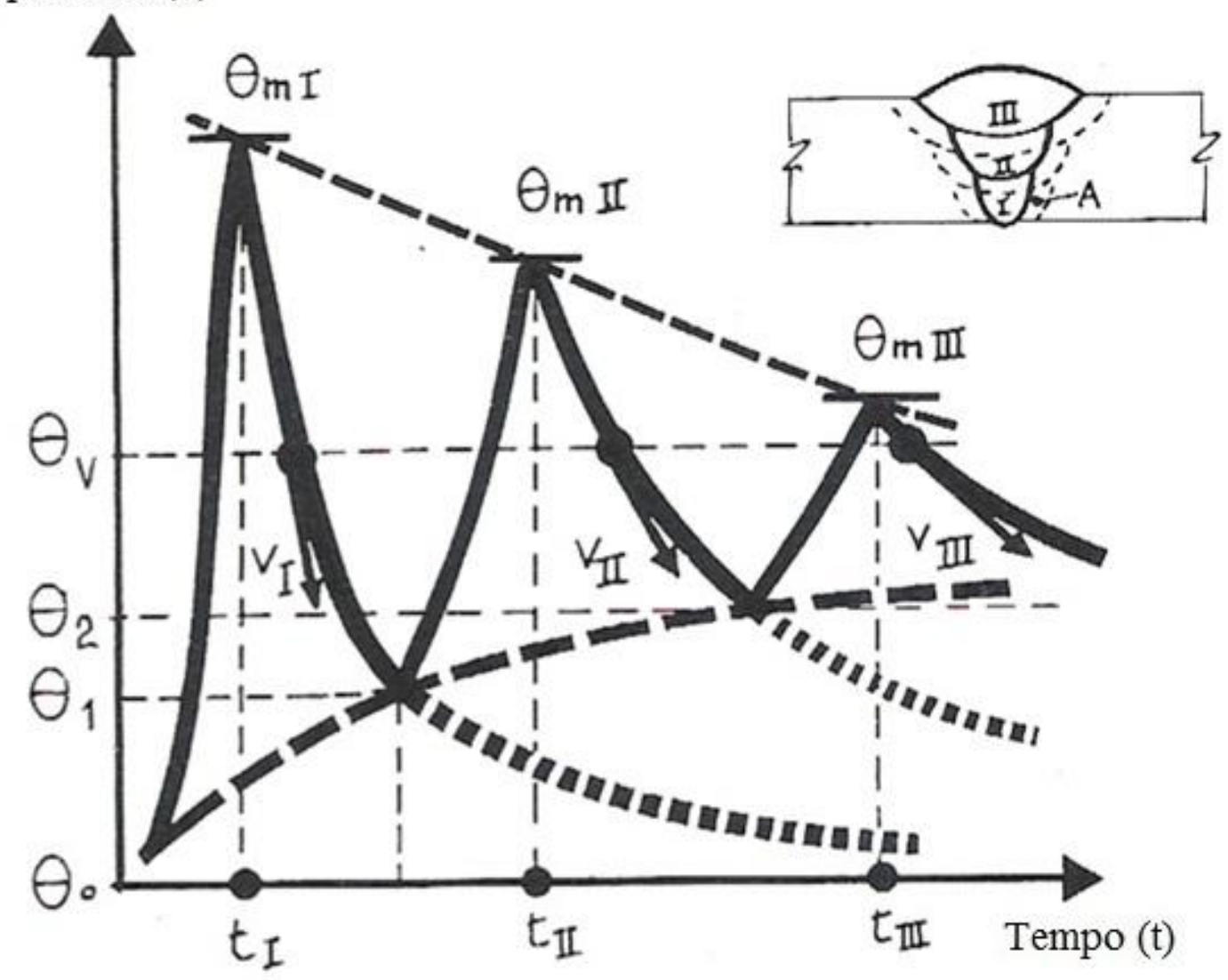

Figura 19. Ciclos térmicos de uma solda multipasse feitos em um ponto da ZAC perto da raiz e sem pré-aquecimento [30].

\subsubsection{Microestrutura de Juntas Soldadas}

A microestrutura de uma junta soldada de um aço API $5 \mathrm{~L}$ grau $\mathrm{X} 80$ para tubos deve ser tal que apresente propriedades mecânicas similares à chapa base. Isso significa que a ZAC e o metal fundido devem apresentar propriedades similares ao do metal base, o qual passou por um processo termomecânico especifico para adquirir propriedades especificas. Assim, tem que conhecer a relação entre as variáveis de soldagem e microestrutura final que será formada[29].

A microestrutura final do metal de solda depende dos ciclos térmicos de soldagem, tamanho de grão austenítico anterior, composição química, distribuição de inclusões, da história térmica e o procedimento de soldagem[29]. 
As transformações do metal de solda durante o resfriamento ocorrem em condições fora de equilíbrio e a velocidades altas. Nestas condições ocorre o fenômeno de nucleação heterogênea. E os locais preferenciais para esta nucleação são as superfícies livres, ponto triplo de encontro de contornos de grão, contornos de grão, inclusões e discordâncias [29]. A microestrutura da zona fundida esta relacionada com a microssegregação e, em conseqüência com, a variação localizada dos elementos de liga, além da presença de microinclusões, dependendo do processo de soldagem [29].

\subsubsection{Classificação dos Microconstituintes do Metal de Solda de Aços Ferríticos}

Durante a decomposição da austenita pode-se formar várias microestruturas nos metais de solda ferríticos dos aços $A R B L$, já que elas se formam em função das diferentes taxas de resfriamento e teores de elementos de liga no metal de solda [31].

O Instituto Internacional de Soldagem (IIW) desenvolveu um sistema de classificação para os constituintes do metal depositado na zona fundida, baseado na sua observação com o microscópio ótico, que se tornou o mais aceito mundialmente [21]. A subcomissão IXJ do Instituto Internacional de Soldagem apresenta uma classificação para os constituintes obtidos na soldagem por arco submerso de aços ferríticos [32]. Segundo estas classificações [21,31] foi feita uma classificação dos microconstituintes, apresentados na Tab. 8. O esquema de classificação proposto pelo IIW visa evitar dúvidas quando se emprega apenas a microscopia ótica [21]. Segundo Brandi [29] essa classificação tem limitações, uma vez que a microscopia ótica nem sempre consegue distinguir com clareza certos microconstituintes, principalmente os formados a baixa temperatura, abaixo da temperatura eutetóide.

No método do IIW um reticulado é aplicado sobre a metalografia ótica e o constituinte, em cada ponto do reticulado, é identificado segundo um fluxograma que praticamente elimina as duplas interpretações. A Fig. 20 mostra o fluxograma para identificação dos microconstituintes formados no metal de solda [21]. 
Tabela 08. Constituintes no esquema de classificação de microestrutura de metal de solda de aços ferríticos do IIW [21,32].

\begin{tabular}{|c|c|c|}
\hline $\begin{array}{c}\text { Categoria } \\
\text { principal do } \\
\text { constituinte }\end{array}$ & $\begin{array}{l}\text { Subcategoria do } \\
\text { constituinte }\end{array}$ & Abreviatura \\
\hline \multicolumn{2}{|c|}{ Ferrita primária } & $\mathrm{F}$ \\
\hline & $\begin{array}{l}\text { Ferrita de contorno de } \\
\text { grão }\end{array}$ & GF \\
\hline & $\begin{array}{c}\text { Ferrita intragranular } \\
\text { poligonal }\end{array}$ & PF \\
\hline \multicolumn{2}{|c|}{ Ferrita com segunda fase } & SF \\
\hline & $\begin{array}{l}\text { Ferrita com segunda } \\
\text { fase não-alinhada }\end{array}$ & SF(NA) \\
\hline & $\begin{array}{l}\text { Ferrita com segunda } \\
\text { fase alinhada }\end{array}$ & $A C$ \\
\hline & $\begin{array}{l}\text { Placas laterais de } \\
\text { ferrita (side plates) }\end{array}$ & $\mathrm{SF}(\mathrm{SP})$ \\
\hline & Bainita & $S F(B)$ \\
\hline & Bainita superior & SF(UB) \\
\hline & Bainita inferior & $\mathrm{SF}(\mathrm{LB})$ \\
\hline \multicolumn{2}{|c|}{ Ferrita acicular } & $\mathrm{AF}$ \\
\hline \multicolumn{2}{|c|}{ Agregado ferrita carboneto ou Perlita } & FC ou P \\
\hline \multicolumn{2}{|c|}{ Martensita } & M \\
\hline & Martensita em ripas & $M(L)$ \\
\hline & Martensita maclada & $M(T)$ \\
\hline & $\begin{array}{l}\text { Constituinte martensita- } \\
\text { austenita }\end{array}$ & MA \\
\hline
\end{tabular}




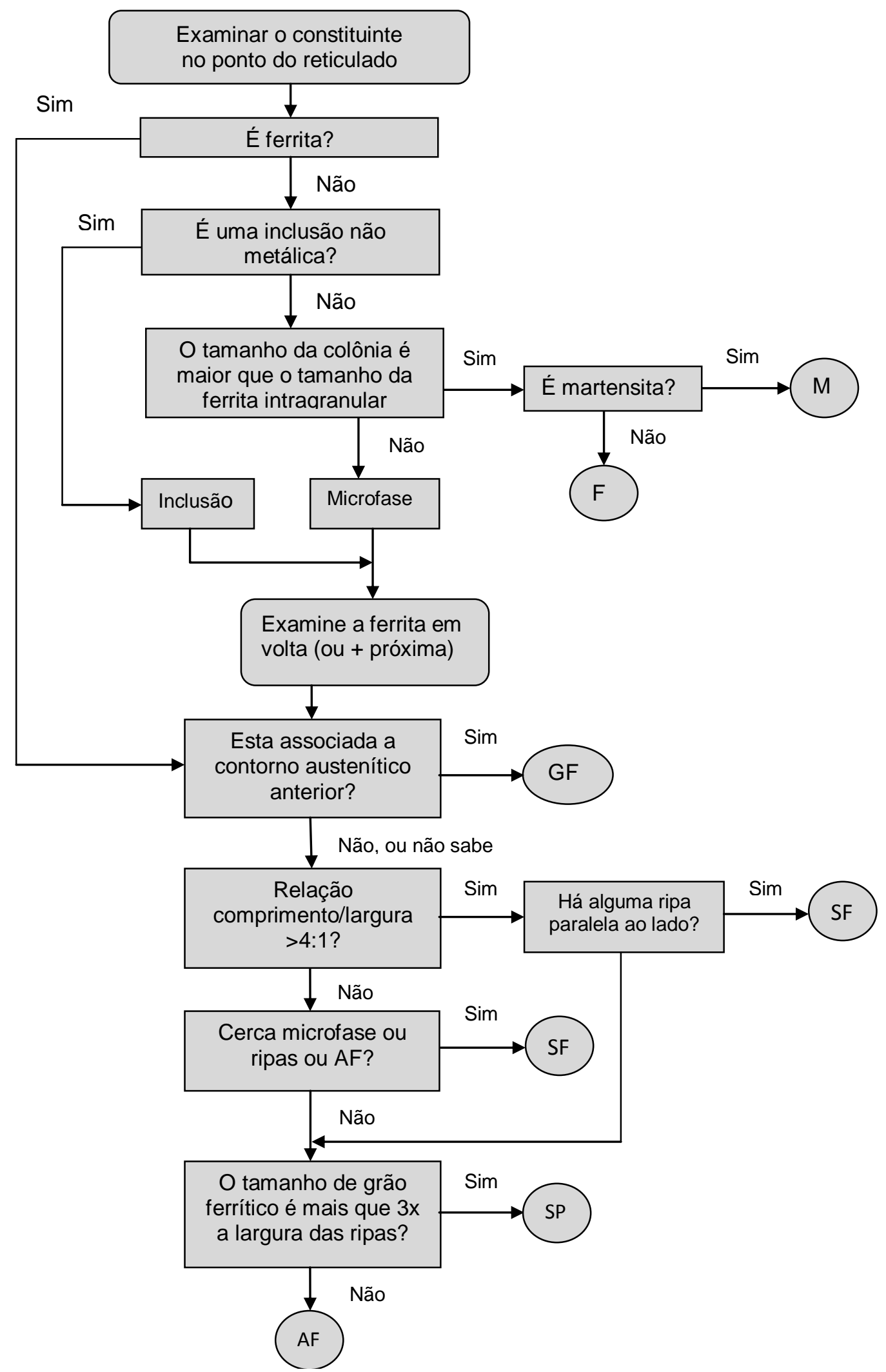

Figura 20. Fluxograma para a classificação de microconstituintes no metal de solda, adaptado para fins didáticos para classificação similar à do IIW [21]. 


\subsubsection{Ferrita Acicular no Metal de Solda (FA)}

A ferrita acicular é um microconstituinte que se forma durante o resfriamento do metal de solda, a temperaturas inferiores, na faixa de 650 a $500{ }^{0} \mathrm{C}$ [29]. As placas de ferrita acicular nucleiam heterogeneamente em inclusões não metálicas e crescem em distintas direções desde os pontos de nucleação como mostra a Fig. 21 [33].

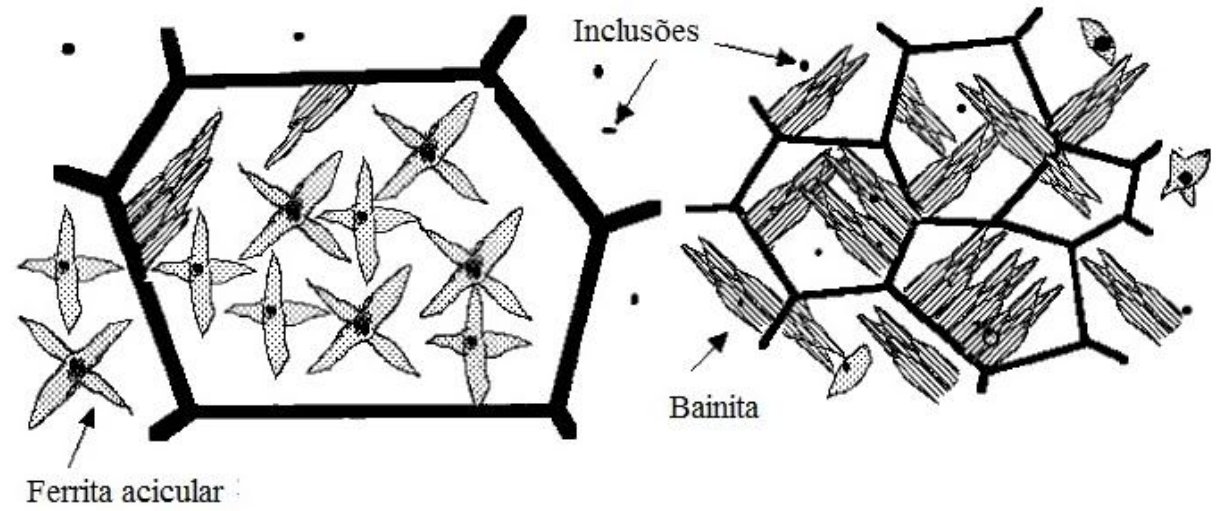

Figura 21. Efeito do tamanho de grão austenítico no desenvolvimento da microestrutura de aços contendo inclusões no metal de solda [33].

Dados cristalográficos mostram que as placas nucleadas na mesma inclusão apresentam elevada desorientação com relação à matriz, produzindo contornos de alto ângulo. A propagação de trincas é então interrompida quando esta se encontra com uma placa de ferrita acicular, proporcionando elevadas propriedades mecânicas, especialmente a tenacidade. As inclusões promovem a nucleação intragranular de ferrita acicular e melhoram a tenacidade sem comprometer a resistência mecânica. Mas também elas são responsáveis pela nucleação de vazios durante a fratura dúctil, ou a nucleação de trincas por clivagem durante a fratura frágil [33]. Segundo Evans [34] estudos têm mostrado que a introdução de ferrita acicular intragranular no metal de solda nos aços API 5L, a partir do controle da nucleação de ferrita de contorno de grão, reduz a dureza da microestrutura, e aumenta tenacidade a níveis aceitáveis.

A ferrita acicular tem boa resistência à fratura por clivagem, mas deve ter baixo teor de carbono e não seja circundada por ilhas de martensita (M) ou ferrita de 
segunda fase. Para melhorar as propriedades mecânicas, a quantidade ideal de ferrita acicular no metal de solda deve estar na faixa de 65 a 80\% [34].

A ferrita acicular é reconhecida como uma nucleação intragranular da bainita superior, sendo que a diferença em morfologia é devido à nucleação no interior do grão a partir de inclusões e da grande nucleação que ocorre a partir destas bainitas [34]. Badeshia [33] assinala que a ferrita acicular presente em muitas microestruturas de soldas é uma bainita nucleada intragranularmente, e que o termo ferrita acicular é devido a sua microestrutura fina e ao seu fator de forma. Quando o tamanho de grão da austenita é grande, a densidade de inclusões torna-se relativamente grande, como sítios de nucleação intragranular, promovendo a formação de ferrita acicular à custa da bainita [33].

A bainita forma-se quando o tamanho de grão da austenita é pequeno predominando nos contornos de grão. Assim, um crescimento subseqüente, completa o interior dos grãos de austenita, evitando o desenvolvimento da ferrita acicular [33]. A Fig. 21 ilustra estes mecanismos.

Os fatores que influem na formação da ferrita acicular entre outros são, a composição química do metal de solda, o tamanho de grão da austenita anterior, a velocidade de resfriamento, o tipo e o efeito de inclusões e outros sítios para nucleação [29]. A Fig. 22 mostra a ferrita acicular. É importante notar a nucleação em inclusões bem como o seu fator de forma.

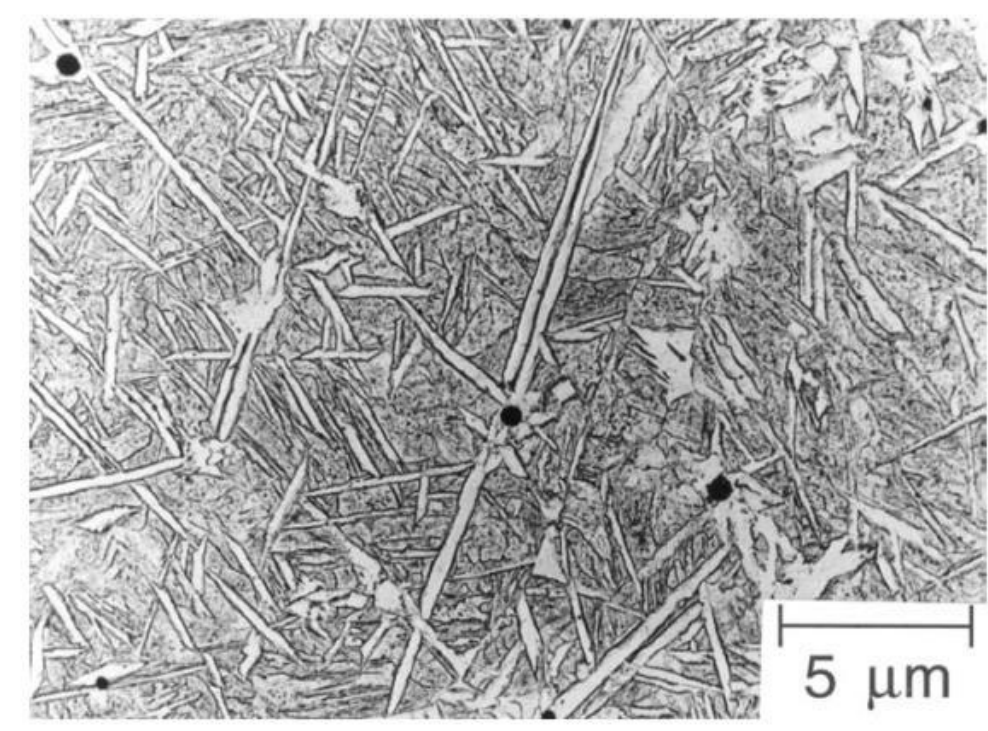

Figura 22. Microestrutura do metal de solda depositado mostrando a Ferrita Acicular, réplica de uma micrografia electrônica de transmissão. Nital 2\% [33]. 


\subsubsection{Ferrita Primária de Contorno de Grão (GF)}

A ferrita primária de contorno de grão (GF) é o primeiro microconstituinte a formar-se na decomposição da austenita e apresenta uma forma lisa e clara. Forma-se em taxas de resfriamento baixa e, geralmente, não é encontrada em metais de solda de aços de alta resistência, pois o elevado teor de elementos de liga desses aços retarda tanto a nucleação quanto as reações de crescimento por difusão que ocorrem no contorno de grão da austenita. A (GF) tem forma de veios, delineando o contorno de grão colunar da austenita, o que Ihe da uma forma alongada [31]. Fig. 23.

\subsubsection{Ferrita Poligonal Intragranular (PF)}

A ferrita poligonal intragranular (PF) aparece em forma de grãos poligonais e nucleia no interior do grão austenítico, possivelmente em inclusões ou outros sítios de nucleação heterogênea, ocorrendo em taxas de resfriamento muito lenta [31]. A Fig. 23 mostra a ferrita poligonal intragranular em um metal de solda.

\subsubsection{Ferrita com Segunda Fase Alinhada SF(AC)}

A ferrita com segunda fase alinhada $[S F(A C)]$ é formada por grãos grosseiros e paralelos alinhados, que crescem num plano bem definido formando ripas paralelas de ferrita. Sua nucleação se da no contorno de grão austenítico e seu crescimento no contorno de grão ou dentro do grão austenítico [31]. A Fig. 23 apresenta este tipo de microconstituinte.

\subsubsection{Ferrita com Segunda Fase Não Alinhada SF(NA)}

A ferrita com segunda fase não alinhada $F S(N A)$ é formada por ferrita circundando completamente microconstituintes ou ripas de ferrita acicular. Não se apresenta em forma paralela como a SF(AC), mas o mecanismo de formação e as características mecânicas são as mesmas [31]. A Fig. 23 mostra este tipo de constituinte. 

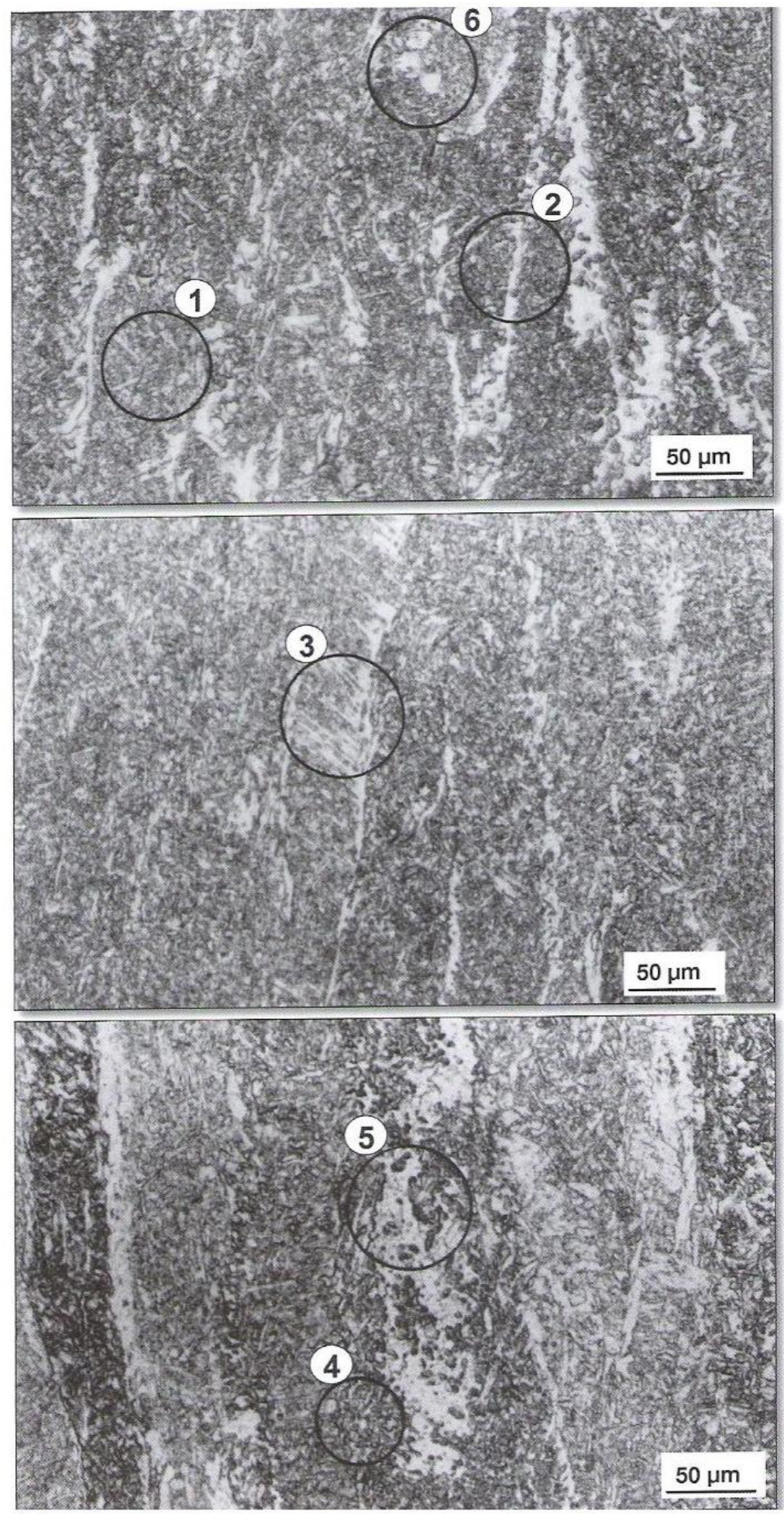

Figura 23. Microestrutura do metal depositado por arco submerso, submetido a alívio de tensões. (1) Ferrita acicular, (2) Ferrita de contorno de grão, (3) Ferrita com segunda fase alinhada, (4) Agregado ferrita-carboneto, (5) Ferrita com segunda fase não alinhada e (6) Ferrita poligonal intragranular. Nital 2\% [21]. 


\subsubsection{Agregado Ferrita-Carboneto (FC)}

Os agregados de ferrita-carboneto (FC) se formam fora dos contornos do grão austenítico e são compostos de ferrita e carbonetos, que incluem ferrita e perlita. Estes agregados têm aparência escura, uma vez que não consegue ser resolvida por microscopia óptica [31]. Na Fig. 23 pode-se ver o agregado.

\subsubsection{Martensita (M)}

A martensita é o ultimo constituinte que se forma na transformação da austenita e se forma a altas taxas de resfriamento e, com um elevado teor de $\mathrm{C}$ e/ou de elementos de liga. Dependendo do teor de $\mathrm{C}$ se pode ter a "martensita em ripas" ou a "martensita maclada". A martensita em ripas se forma por um mecanismo de deslizamento, sendo encontrada em aços com teor de carbono menor do que $0,5 \%$ em peso. A martensita maclada é encontrada em aços com teor de carbono acima de 0,8\% em peso [31]. A Fig. 24 mostra a martensita escorregada que geralmente é encontrada em metais de solda com alguma temperabilidade.

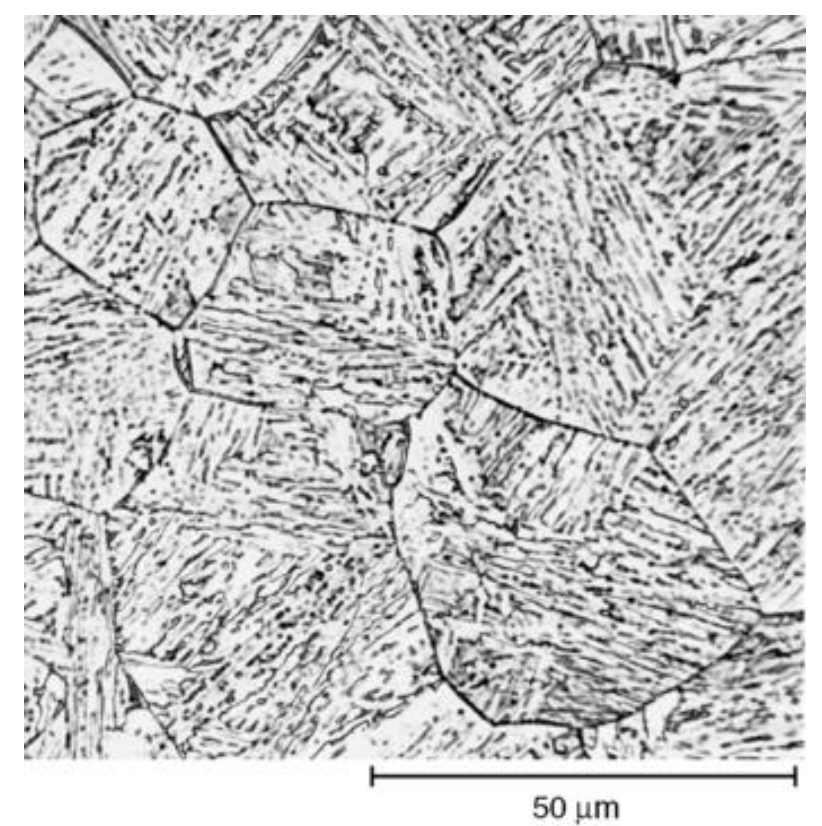

Figura 24. Microestrutura de um aço baixa liga revenido mostrando os limites dos grãos austeniticos iniciais. As ripas individuais de bainita/martensita também são delineadas. Reagente de Winsteard. Aumento de 500 X [35]. 


\subsubsection{Microconstituinte Martensita/Austenita (MA)}

O microconstituinte MA é formado de martensita de alto carbono e austenita retida que é encontrado em aços de $A R B L$ soldados, sendo quase impossível de ser eliminado. Sua presença também é influenciada pelos elementos de liga como o C, Ni, Mo, Si com altas taxas de resfriamento após a soldagem [36].

Em soldas multipasse o constituinte MA se forma preferencialmente nos contornos de grãos da austenita transformada a partir de uma região rica em carbono a qual é reaustenizada pelos passes subseqüentes [36].

Habraken e Economopulus [op. cit. ref. 33] observaram que, algumas vezes regiões podem ser enriquecidas com suficiente carbono para gerar martensita com austenita retida como mostra a Fig. 25. Estas regiões, em geral, respondem de forma uniforme à maior parte dos reagentes usados para ataque, de modo que é difícil diferenciar a martensita da austenita retida. Estas regiões passaram a ser chamadas de áreas MA. Este constituinte é importante para a tenacidade do aço, e anteriormente este foi associado a uma perda na tenacidade do aço devido a seu aumento na sua fração volumétrica.

Além disso, Colpaert [21] opina que a medida que se aumenta o teor de carbono dos aços, as temperaturas Mi (temperatura de inicio da transformação martensítica) e Mf (temperatura de fim da transformação martensítica) diminuem, aumentando então a tendência à retenção da austenita na têmpera.

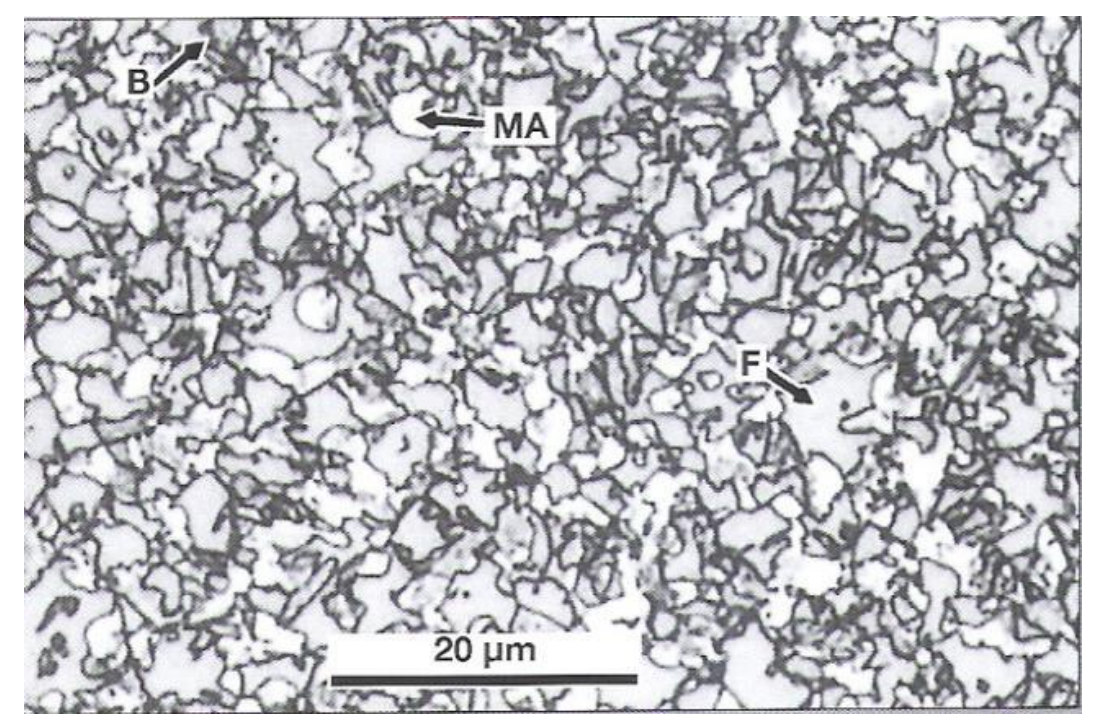

Figura 25. Agregado $M A$ num aço TRIP ( $C=0,27 \%, S i=1,4 \%, M n=1,4 \%)$. $\mathrm{F}=$ ferrita, (verde azulado no original, tom intermediário na foto) $\mathrm{B}=$ bainita (marrom, tom mais escuro) $\mathrm{MA}=$ martensita-austenita, (branco). Reagente LePera. [33]. 


\subsubsection{Bainita (B)}

A bainita é classificada como bainita superior ou bainita inferior de acordo com a temperatura na qual é formada [33] (Fig. 26). A bainita superior é formada por finas agulhas de ferrita, que crescem em blocos chamados de feixes. Dentro de cada feixe as agulhas, são separadas por partículas de cementita [33]. A formação da bainita superior envolve duas etapas. Na primeira, com a formação de agulhas da ferrita o carbono remanescente é rejeitado para a austenita. Na segunda etapa ocorre a precipitação da cementita entre as agulhas de ferrita, como se vê na Fig. 27 [33].

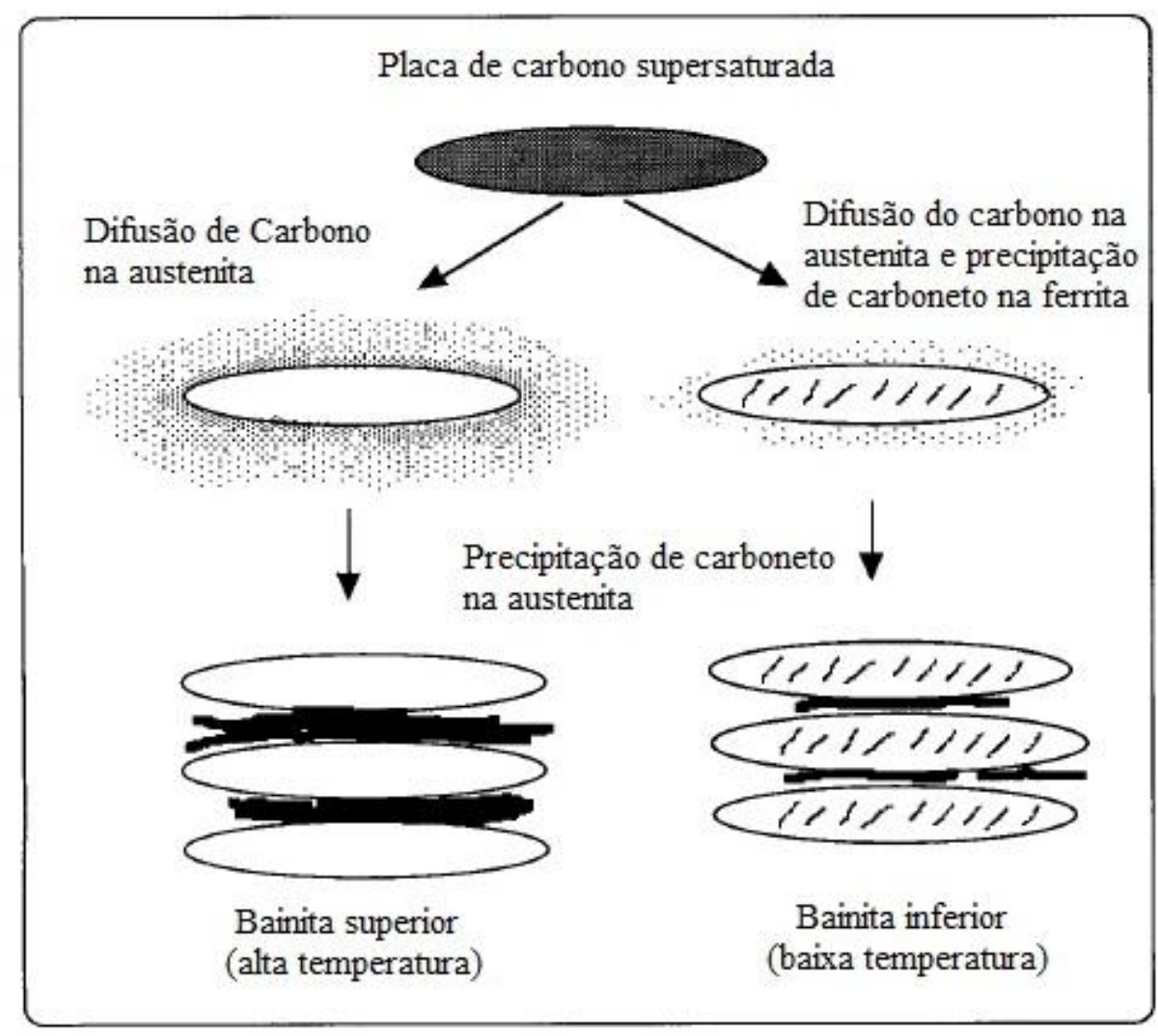

Figura 26. Representação esquemática da formação da bainita superior e inferior [33].

A bainita inferior apresenta microestrutura e características cristalográficas semelhantes às da bainita superior. A principal diferença é que o carboneto precipita entre as agulhas de ferrita e dentro das agulhas de ferrita. Isto porque, em temperaturas menores, a difusão do carbono é reduzida e este não consegue segregar totalmente para a austenita adjacente, ocorrendo a 
precipitação dentro da ferrita. Os carbonetos na bainita inferior são mais finos do que na bainita superior já que a difusão do carbono a baixas temperaturas é mais lento o que dificulta seu crescimento e colescimento. Tal fato confere à bainita inferior maior tenacidade, visto que as partículas dos carbonetos são mais grosseiras na bainita superior o que facilita a nucleação e a propagação de trincas [17].

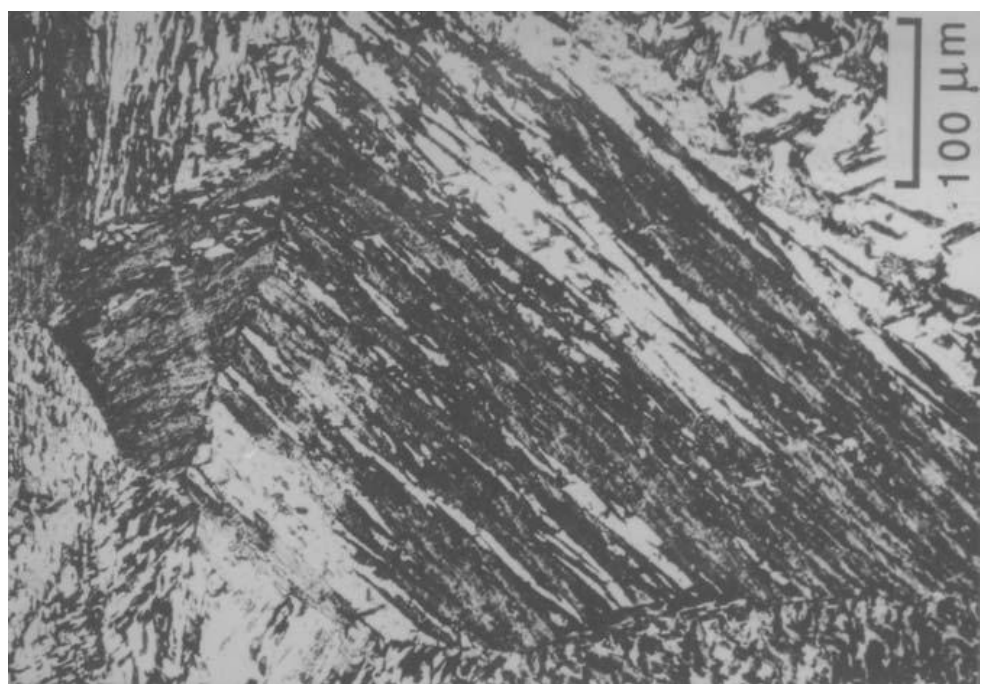

Figura 27. Alinhamento de agulhas de bainita num grão de austenita. Nital $3 \%$.[33].

\subsubsection{Inclusões}

As inclusões observadas no trabalho de Bose Filho et al. [37] são resultados de reações de desoxidação e/ou desulfuração que acontecem na poça da solda. As inclusões, como o TiO, são importantes na formação microestrutural dos metais de solda já que as inclusões são locais de nucleação de ferrita acicular. Pode ser também que estas inclusões possam causar um refinamento do grão austenítico. Dependendo da sua quantidade e distribuição elas também podem determinar a resistência à fratura de soldas de aços ARBL.

Badeshia [33] assinala que, quando um aço que contém quantidade adequada de inclusões é soldado, a taxa de ferrita acicular em relação à bainita é mais elevada na ZAC próxima à zona de fusão onde o tamanho de grão da austenita é maior, como mostra a Fig. 28(a). Na ausência de inclusões, o conteúdo de ferrita acicular é sempre menor como se observa na Fig. 28(b). 

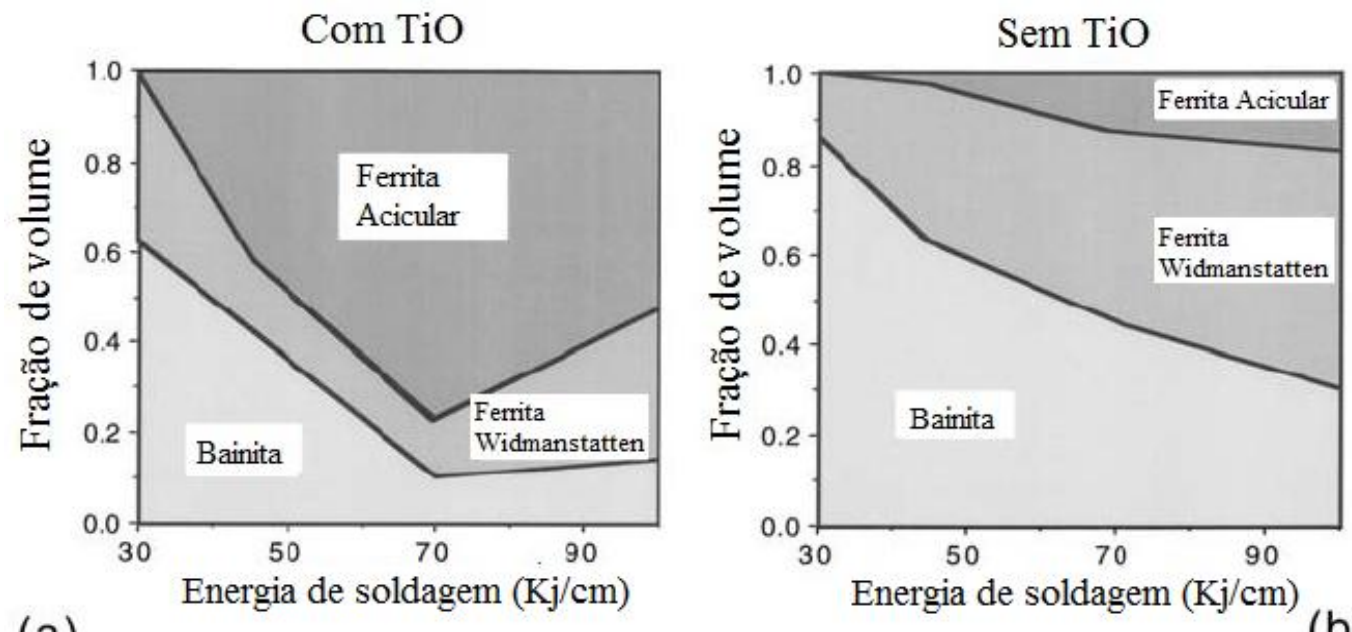

(a)

Figura 28. Mudanças na microestrutura na ZAC de soldas em função das inclusões: a) Aço contendo inclusões de TiO, b) Aço sem inclusões de TiO [33].

\subsubsection{Efeito dos Elementos de Liga no Metal de Solda}

Os elementos micro-ligantes no metal de solda em sua maioria provém do consumível utilizado, embora também possam ser introduzidos pela diluição com o metal base. Os elementos presentes, em até partes por milhão, apresentam um efeito complexo na microestrutura e propriedades do metal de solda dos aços ARBL. A seguir se apresenta os mecanismos de atuação dos elementos de liga [38].

\subsubsection{Titânio (Ti)}

O Ti, por ser um forte desoxidante, diminui o conteúdo de oxigênio no metal de solda, formando o TiO, que age como local para a nucleação da ferrita acicular [34].

Como se pode observar na Fig. 29, a 16 ppm de Ti tem-se uma microestrutura de ferrita acicular predominante sem agregados de carbonetos na ferrita. A máxima porcentagem de ferrita acicular, aproximadamente um $70 \%$, ocorreu perto de $30 \mathrm{ppm}$ de Ti. Teores maiores fizeram com que a Ferrita Acicular caísse até uma porcentagem em torno de $80 \mathrm{ppm}$ de $\mathrm{Ti}$ e subiu de novo próximo de $80 \%$ nos mais altos níveis de Ti de 255 ppm. A Ferrita primária aumentou quando a Ferrita Acicular alcançou $70 \%$ e a partir desse ponto permaneceu mais ou menos constante. Assim, subseqüentes modificações 
foram acompanhados por alterações na proporção de Ferrita com Segunda Fase [34].

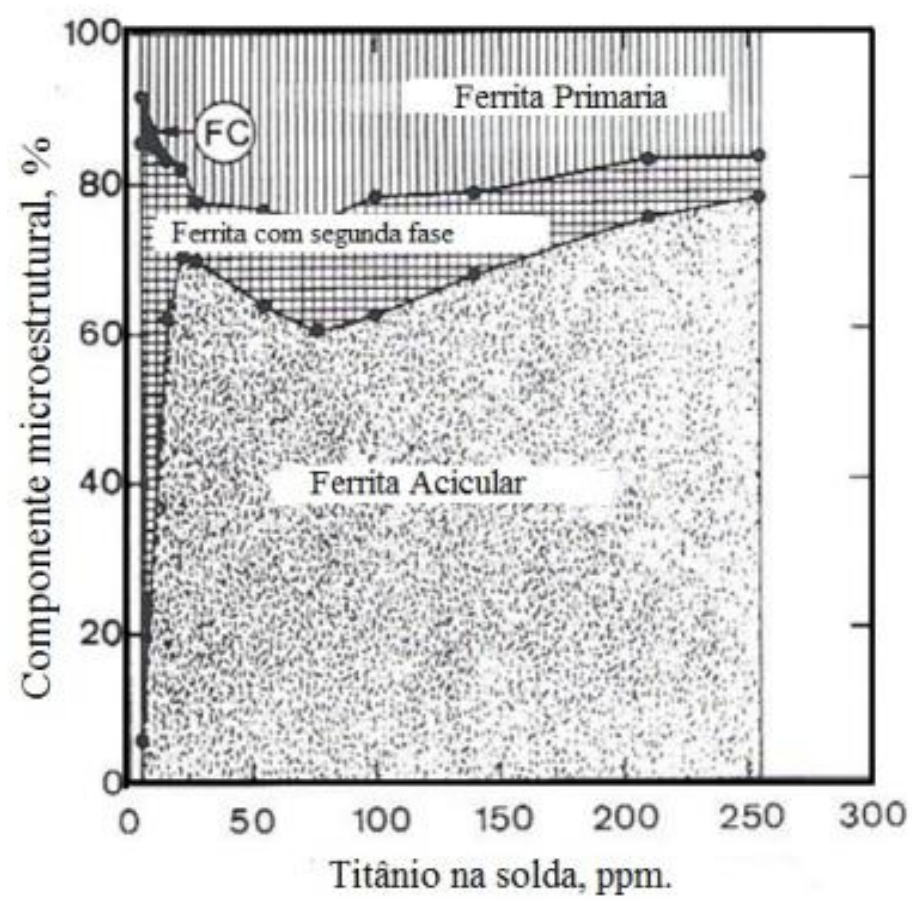

Figura 29. Influência do conteúdo de Titânio na microestrutura de metal de solda contendo 1,4\% Mn (FC, agregados de ferrita-carbonetos) [34].

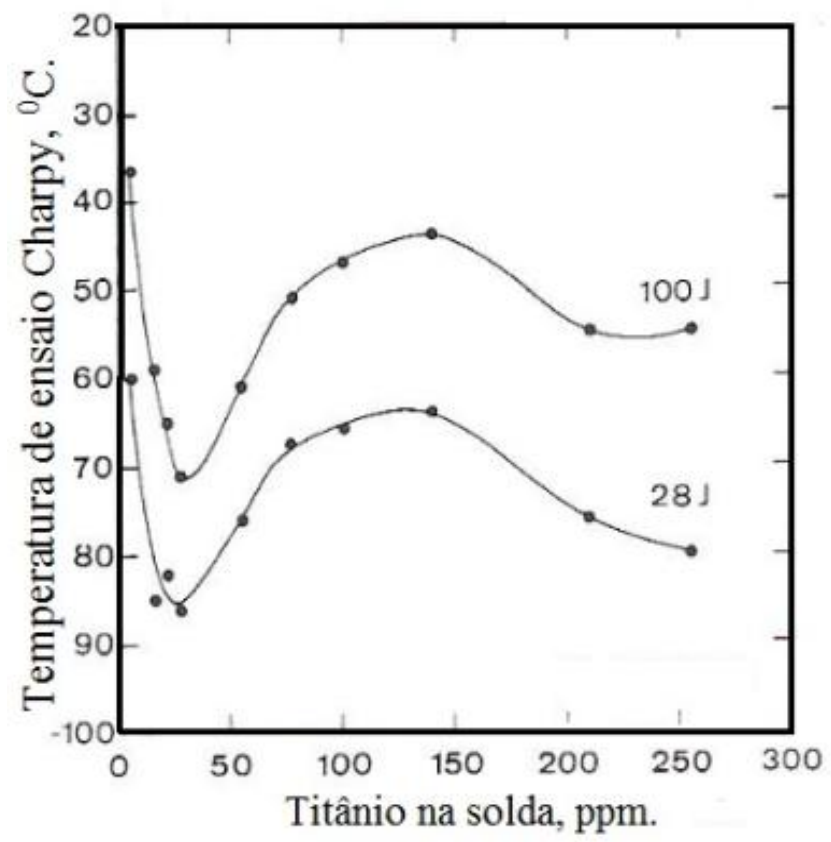

Figura 30. Efeito do Titânio na temperatura de transição do metal de solda com $1,4 \% \mathrm{Mn}[34]$.

Devido às variações involuntárias na composição química as variações na dureza e nas propriedades mecânicas de tração foram irregulares. Os 
resultados do ensaio de impacto, resumido na Fig. 30, mostraram um progressivo melhoramento na tenacidade a $100 \mathrm{~J}$ desde temperaturas de transição de $-35^{\circ} \mathrm{C}$ até $-70^{\circ} \mathrm{C}$. Este resultado foi devido ao conteúdo de Ti no metal de solda que, aumentou de 6 até $28 \mathrm{ppm}$; e foi seguido de uma pequena redução na tenacidade até cerca de $140 \mathrm{ppm}$, e de novo se teve um melhoramento na tenacidade [34].

\subsubsection{Nióbio (Nb)}

As micro-adições de $\mathrm{Nb}$ proporcionam ao aço altos níveis de resistência mecânica e tenacidade. Isso se pode conseguir com a redução do tamanho de grão ferrítico. Se por um lado a presença de $\mathrm{Nb}$ é benéfica às propriedades do aço, o mesmo não pode ser afirmado com respeito à junta soldada [38].

Evans[34] mostrou que o $\mathrm{Nb}$ diminuiu a ferrita acicular e aumentou a ferrita com segunda fase na microestrutura do metal de solda, como se vê na Fig. 31. Com porcentagens de 0,6 e 1,4\% Mn, a primeira adição de $\mathrm{Nb}$ diminuiu pronunciadamente o conteúdo de ferrita acicular em aproximadamente uns $10 \%$. Para uma porcentagem de $1,4 \%$ de Manganês uma redução da ferrita acicular aconteceu com adições mais elevadas de $\mathrm{Nb}$.
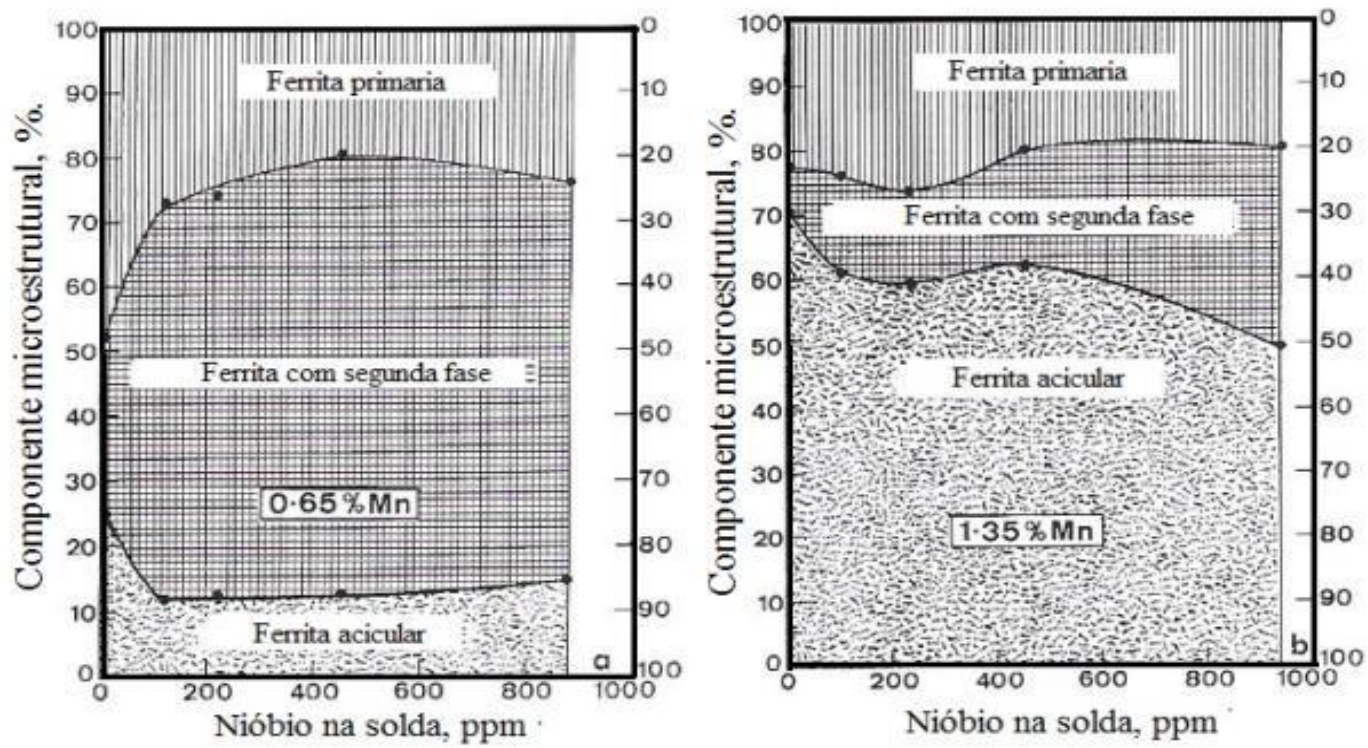

Figura 31. Influência do Nióbio na microestrutura da solda com 40ppm de Titânio e a) 0,6\%Mn, b) 1,4\%Mn [34]. 
Em relação à tenacidade o $\mathrm{Nb}$ teve um efeito prejudicial, conforme mostrado na Fig. 32. O teor de $\mathrm{Nb}$ deve ser mantido o mais baixo possível [38].

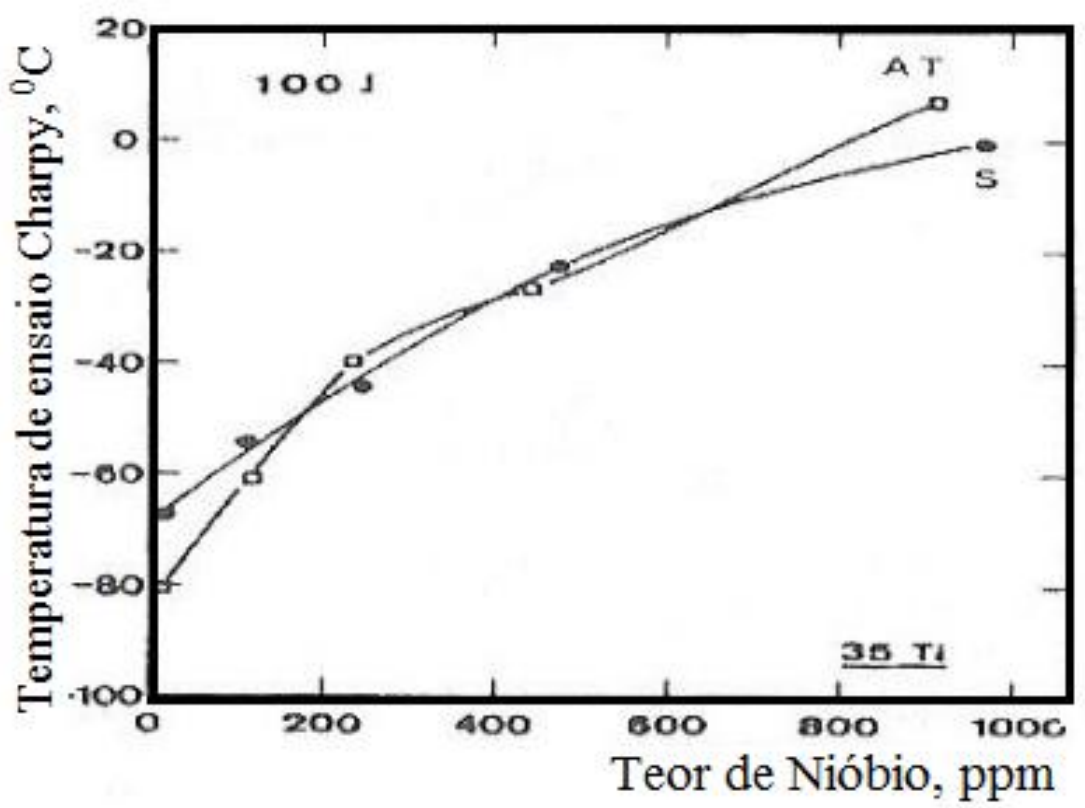

Figura 32. Efeito do Nióbio na tenacidade do metal de solda a $100 \mathrm{~J}$, após soldagem (S) e após alivio de tensão (AT) [38].

\subsubsection{Vanádio (V)}

Evans estudou o possível papel do Vanádio em pequenas quantidades como um refinador de grão, já que o $V$ é capaz de nuclear a ferrita acicular em alguns aços que contém o elemento. As soldas com conteúdo de $\mathrm{V}$ aumentaram a proporção de ferrita acicular à custa dos outros dois constituintes mostrados na Fig. 33, particularmente em soldas com baixo conteúdo de Manganês. $O$ aumento da ferrita acicular continuou para níveis mais elevados de $\mathrm{V}$, ainda que o conteúdo de Ti fosse mais baixo nesses depósitos. Além de alterar as proporções dos constituintes, o $\mathrm{V}$ também refinou a ferrita acicular da microestrutura [34]. 

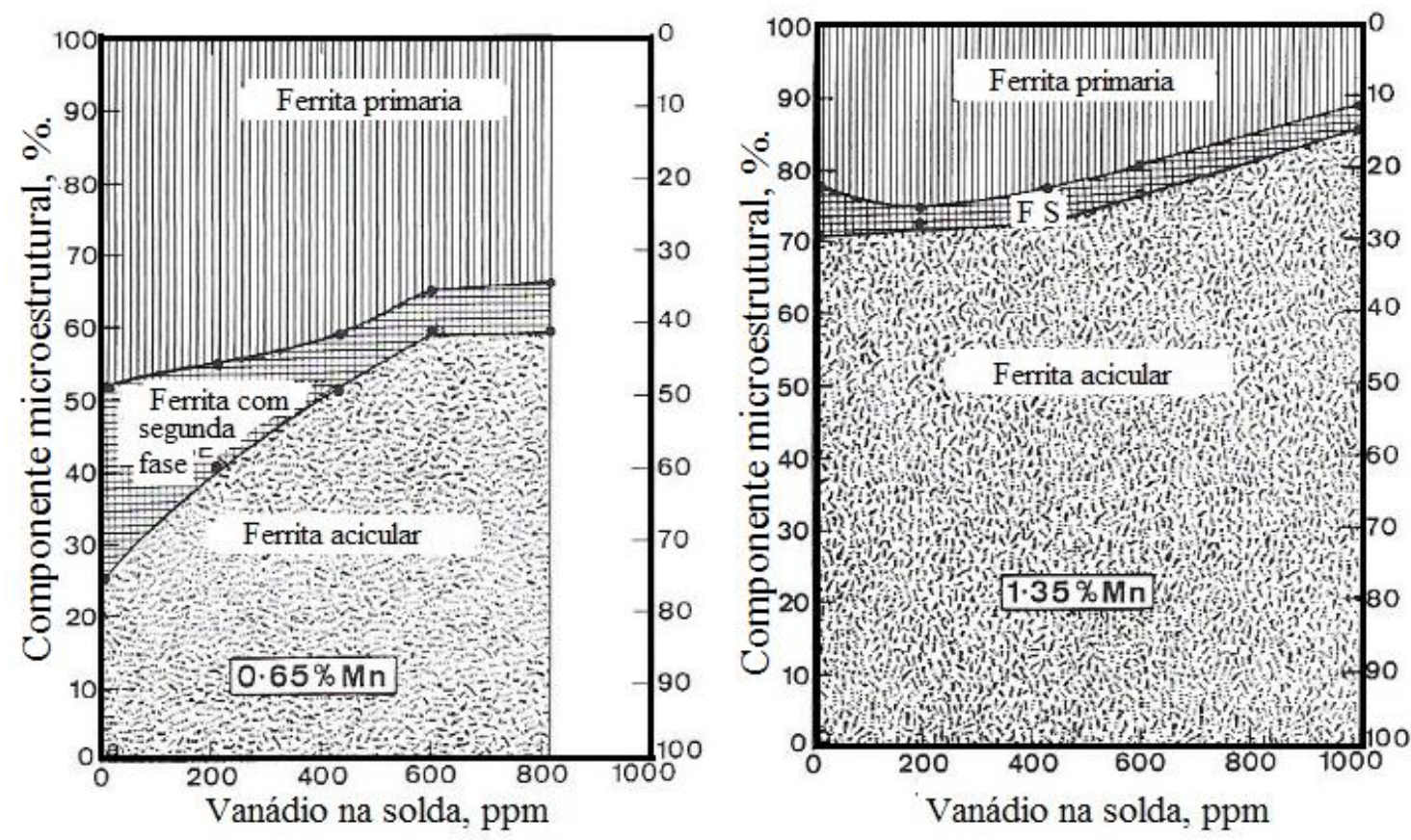

Figura 33. Influência do conteúdo de Vanádio na solda na microestrutura de soldas com a)0,6\%Mn e 40ppm Ti; b)1,4\%Mn e 40ppm de Ti [34].

Também se estudou a introdução de V no metal de solda, na faixa de 5 a 1000 ppm. Os resultados obtidos através de ensaios Charpy- $V$, na condição após da soldagem (S), mostraram um efeito benéfico do $\mathrm{V}$, obtendo se uma condição ótima pro volta de 60 ppm de V, conforme pode-se observar na Fig. 34 [38].

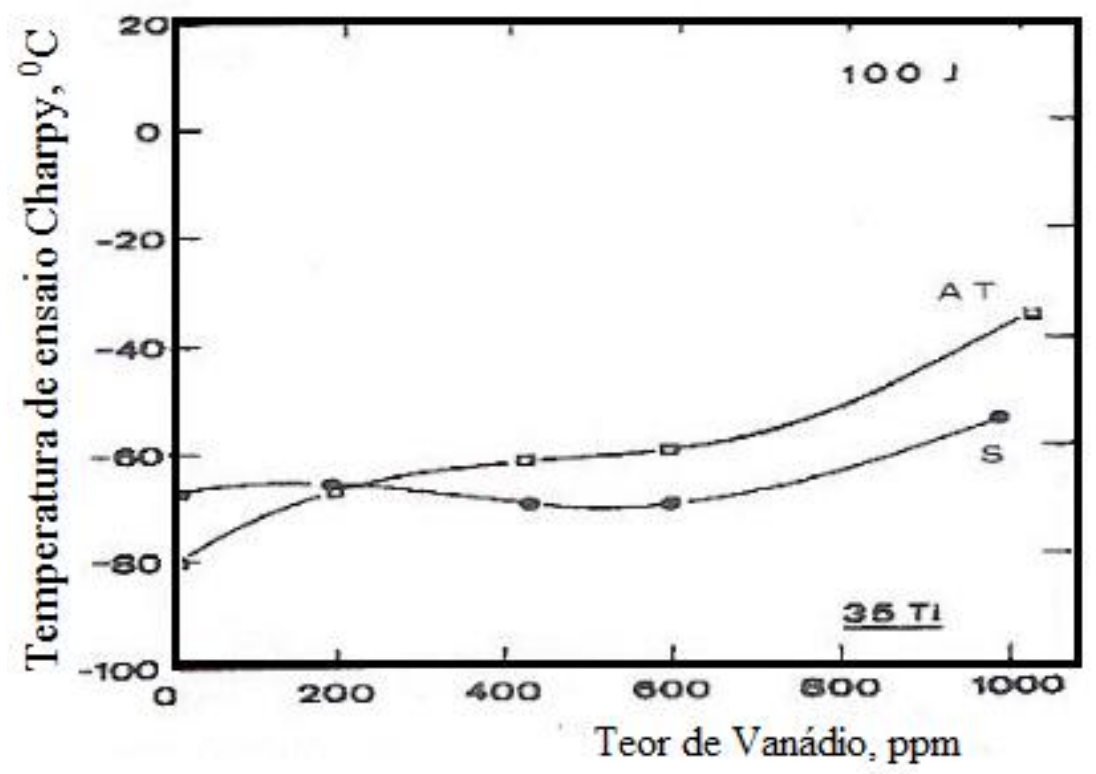

Figura 34. Efeito do Vanádio na tenacidade do metal de solda a 100J, após soldagem (S) e após alivio de tensão (AT) [38]. 


\subsubsection{Alumínio (Al)}

Como o $\mathrm{Al}$ é um desoxidante, pode-se dizer que as inclusões ricas em $\mathrm{Al}$ se formam primeiro do que aquelas compostas por outros elementos desoxidantes. Conseqüentemente, as primeiras terão mais tempo de residência em altas temperaturas, o que favorece o seu crescimento competitivo [38].

No metal de solda sem conteúdo de $\mathrm{Ti}$, o $\mathrm{Al}$ aumentou a ferrita acicular à custa da ferrita com segunda fase (Fig. 35 (a)), mais com conteúdo de Ti a ferrita acicular diminuiu (Fig. 35(b)). Embora o conteúdo de ferrita acicular aumente quando é adicionado o $\mathrm{Al}$, esse aumento é mínimo conforme mostrado na Fig. 35 (a) [34].

O Al dissolvido na austenita promove a formação da ferrita de Widmanstatten as custas da ferrita acicular, fração que diminui rapidamente para concentrações mais elevadas que 70 ppm [33].
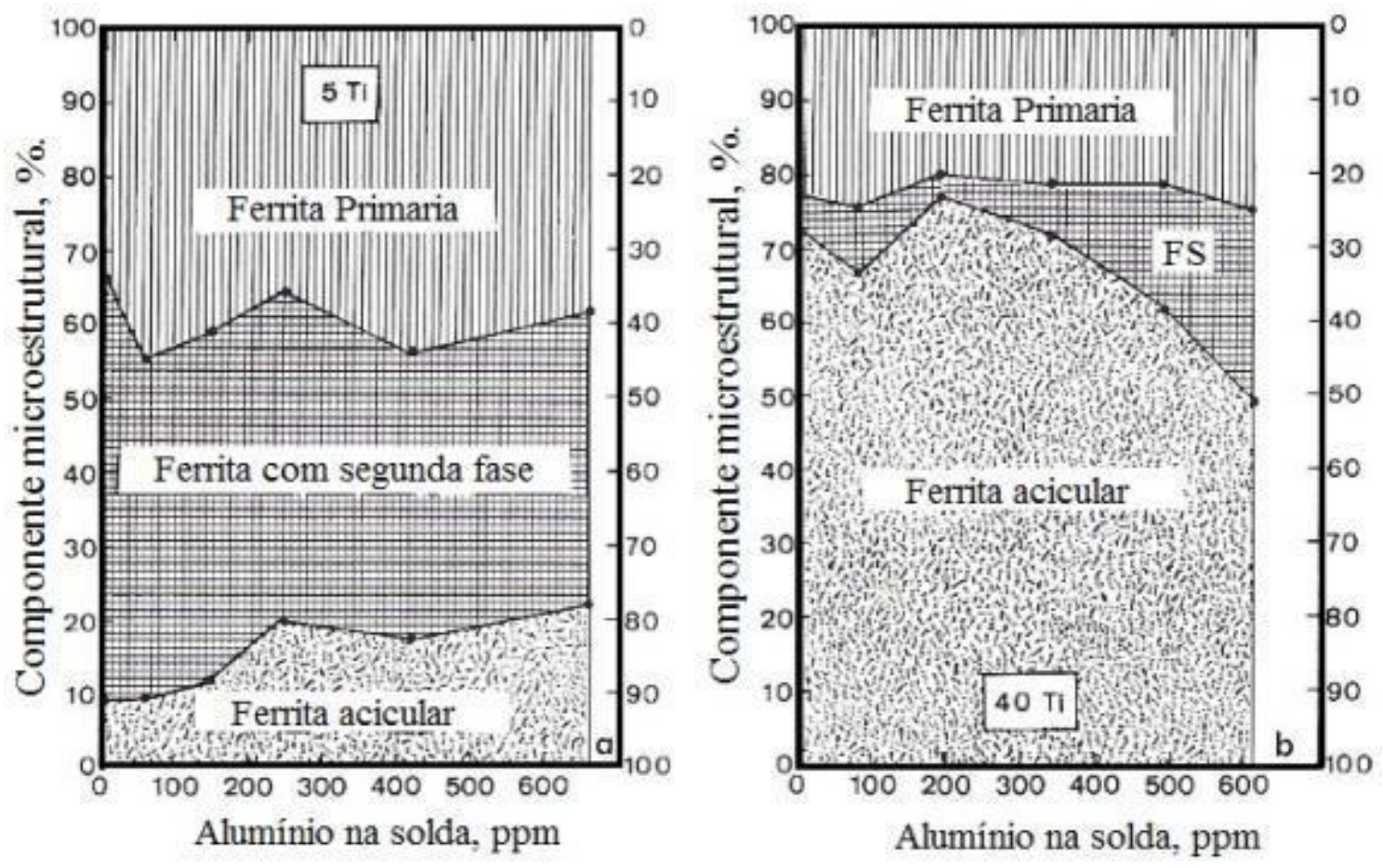

Figura 35. Influência do conteúdo de Alumínio na microestrutura da solda com: a) Sem adição de Ti b) 35ppm Ti [34].

Segundo Evans [34] o Al tem poucos efeitos sobre a dureza da solda, com 35 ppm de Ti, mantendo um valor médio de $210 \mathrm{HV}$. Sem adição de Ti, a tenacidade foi reduzida na solda com $1,4 \%$ de $\mathrm{Mn}$, mas depois de uma 
pequena adição de Al de $60 \mathrm{ppm}$, a tenacidade melhorou ligeiramente e progressivamente, com a adição de Al como mostra a Fig. 36.

A tenacidade foi boa em soldas livres de Al e com presença de Ti. Um aumento na temperatura de transição a 100J foi aparente (fig. 36) com adição acima de 100 ppm de Al. Assim esta solda foi apenas mais dura que a solda com o mesmo conteúdo de Al sem adição de Ti [34].

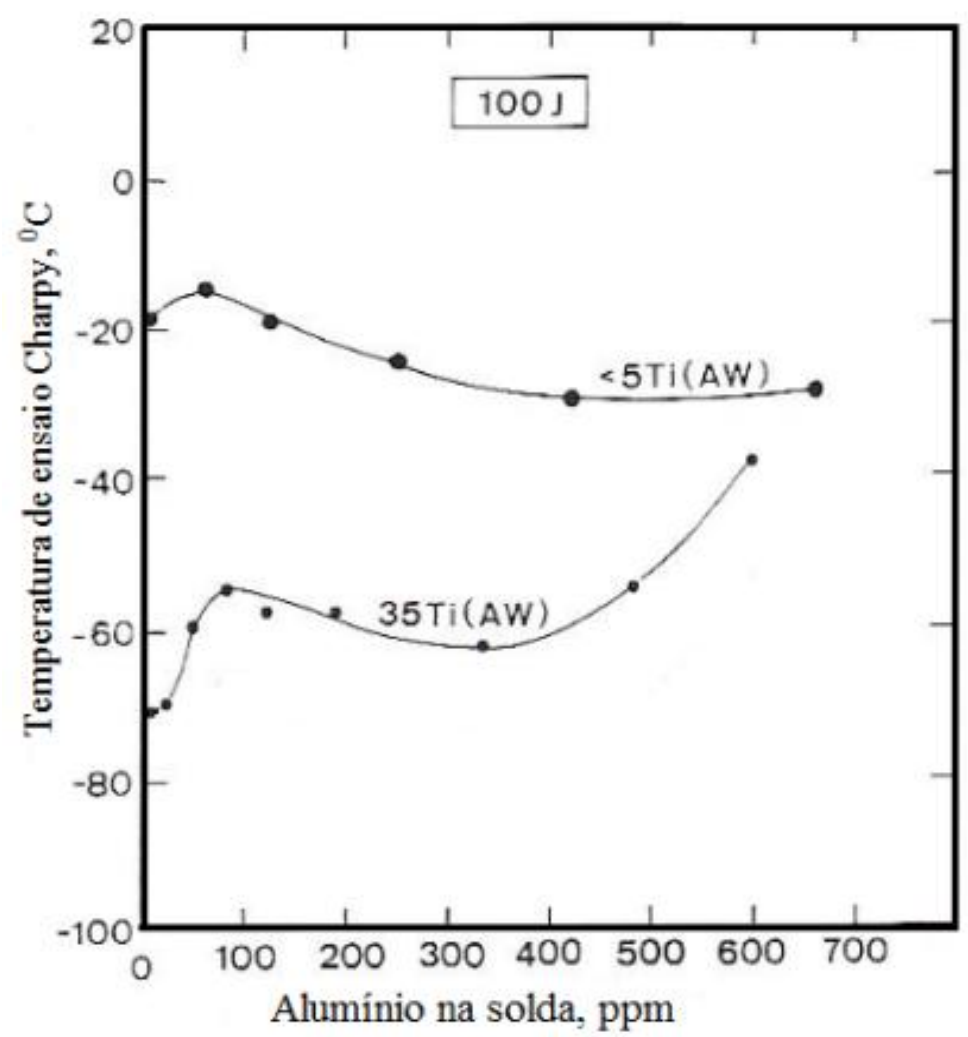

Figura 36. Influência na temperatura de transição em soldas de Aluminio a $100 \mathrm{~J}$ em soldas com $1,4 \% \mathrm{Mn}$. (AW: como soldado) [34].

\subsubsection{Boro (B)}

O boro é usado para aumentar a temperabilidade de aços para engenharia, enquanto que no metal de solda o Ti se junta com o B para aplicações críticas. Por outro lado, os metais de solda normais contém não mais de 1 ou 2 ppm de $B$ [34].

O B é um importante redutor da ferrita de contorno de grão já que esta microestrutura é prejudicial para as propriedades do metal de solda. A melhor combinação de resistência e tenacidade do metal de solda é obtida quando se 
tem uma microestrutura com ferrita acicular bem fina. Por isso qualquer fator que venha a aumentar a fração volumétrica deste constituinte conduzirá a uma melhoria das propriedades de tenacidade do metal de solda [34].

Importante é que juntamente com o B estejam presentes elementos desoxidantes como o $\mathrm{Ti}, \mathrm{Al}$ e $\mathrm{Zr}$, pois a função de estes elementos é reagir com o oxigênio e o nitrogênio presentes na poça de fusão, e evitar que estes elementos reagem com os átomos de $\mathrm{B}$ no metal líquido e nos contornos de grão. $\mathrm{Na}$ atualidade, se utiliza bastante $\mathrm{o} \mathrm{Ti}$, pois este além de ser um forte desoxidante, também atua, através do oxido de titânio, como locais para a nucleação da ferrita acicular [34].

Vê-se na Fig. 37 (a), com conteúdo na solda de 1,4\% de Mn e sem Ti, que o B aumentou o conteúdo de ferrita com segunda fase alinhada, à custa dos outros microconstituintes. O metal de solda com conteúdo de Ti (Fig. 37 (b)), que na ausência de B promove a ferrita acicular, mostrou comportamento similar. Assim grandes adições de B (200 ppm) reduziram a quantidade da ferrita acicular, tendo um conteúdo de ferrita com segunda fase de $50 \%$. Neste caso, uma adição de 33 ppm de B não tem efeitos na proporção dos constituintes. Pelo dito anteriormente recomenda-se não utilizar grandes quantidade de $\mathrm{B}[34]$.
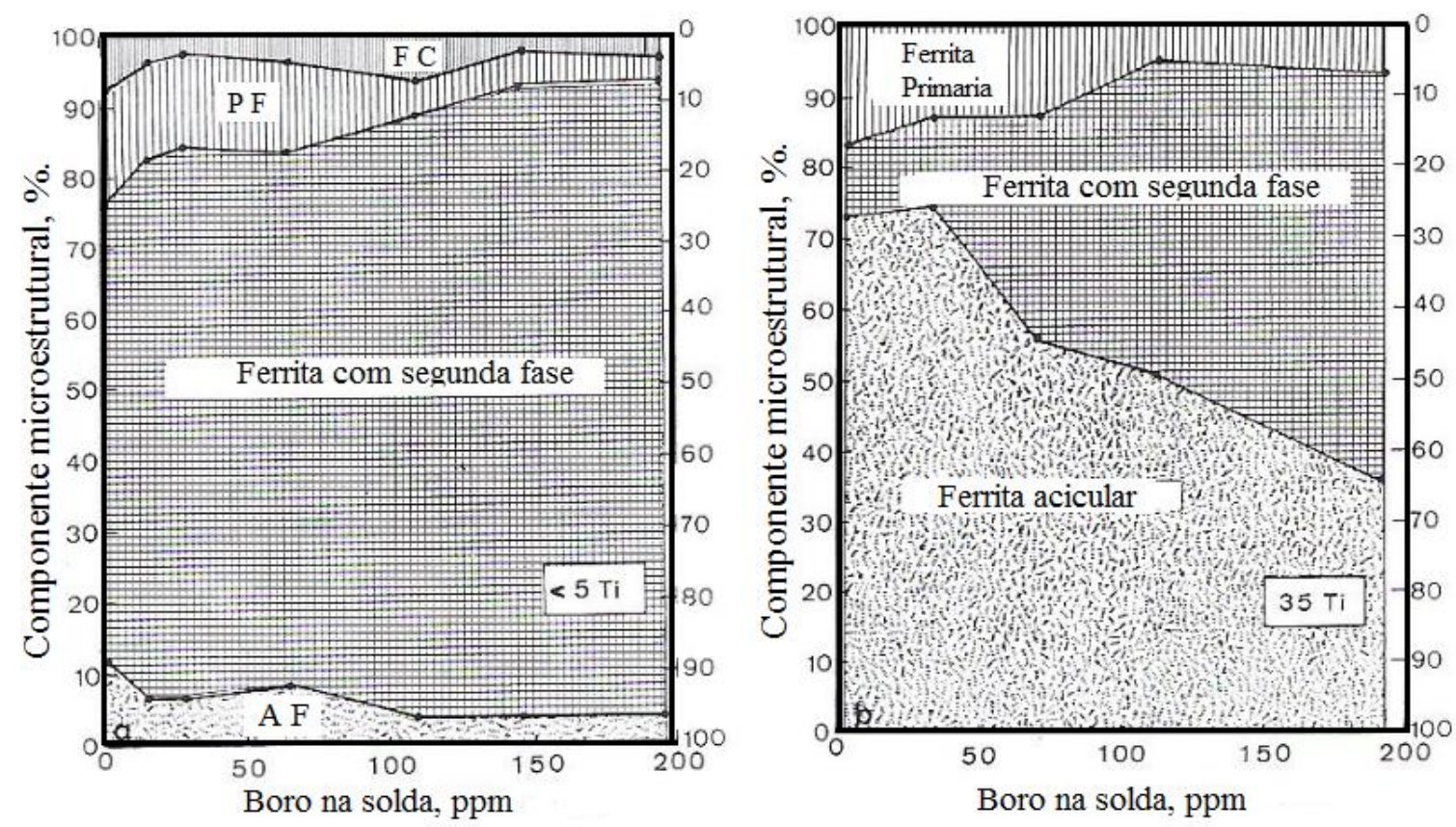

Figura 37. Influência do conteúdo de Boro na microestrutura de soldas com 1,4\%Mn e: a) <5ppm Ti; b)35ppm Ti [34]. 
Com relação à tenacidade, o ponto ótimo foi por volta de 140 ppm de $\mathrm{B}$, conforme mostra a Fig. 38.

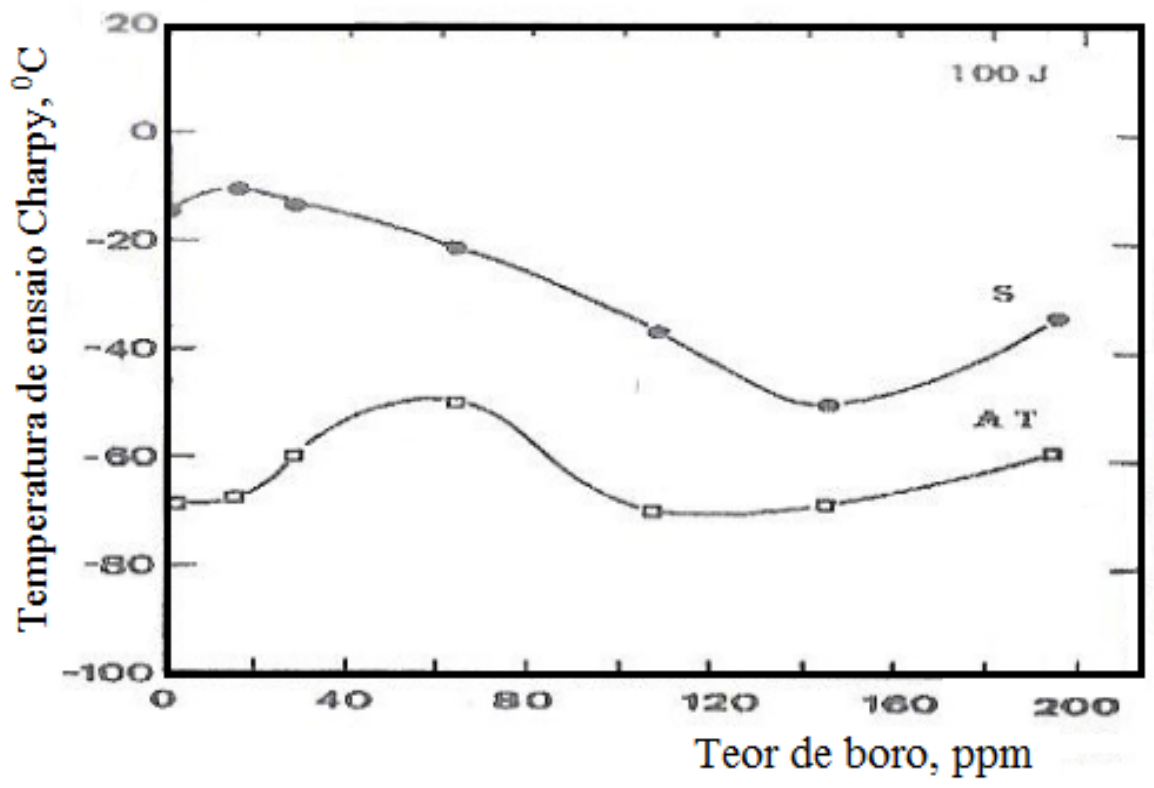

Figura 38. Efeito do Boro na tenacidade do metal de solda a 100J, após soldagem (S) e após alivio de tensão (AT) (37) [34].

\subsubsection{Manganês (Mn)}

Crawford [39] em suas investigações encontrou que quando se adiciona $\mathrm{Mn}$ a proporção de ferrita acicular aumenta a custa de ferrita de contorno de grão e ferrita com segunda fase alinhada. Os conteúdos de carbonetos foram gradualmente eliminados e a proporção de MA incrementou estacionariamente quando os conteúdos de Mn aumentaram.

\subsubsection{Soldagem com Arco Submerso (SAW)}

A soldagem com arco submerso é um processo pelo qual um, ou diversos, eletrodos nus e o metal de base são coalescidos por meio de um arco elétrico estabelecido, que aquece e funde os dois metais [29]. Este arco é coberto totalmente por uma camada de fluxo fundido e, dessa forma, a soldagem se desenvolve sem faíscas, respingos e luminosidades, que é uma característica 
de outros processos de soldagem a arco aberto como se mostra na Fig. 39 [29].

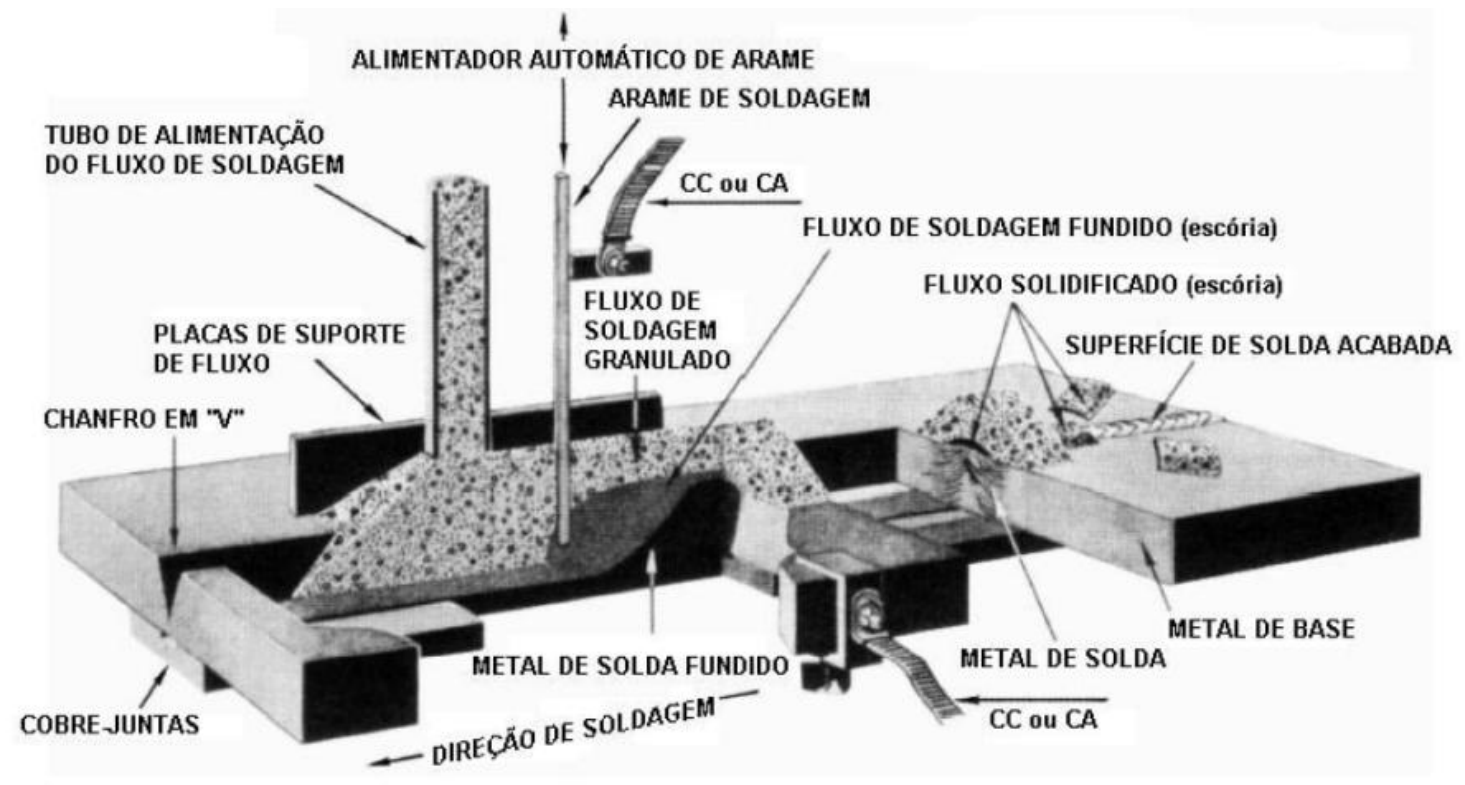

Figura 39. Processo de soldagem por arco submerso [40].

O metal fundido quando solidifica forma o cordão de solda, enquanto que o fluxo fundido solidifica a medida que o arco se afasta formando a escoria a qual atua como uma camada que evita que o cordão de solda se contamine e esfrie rapidamente [28].

Segundo Kou [41], a ação de proteção e refino da escória ajuda a produzir soldas limpas no processo com arco submerso. Uma vez que o arco é submerso, respingos e perda de calor para o ambiente são eliminados, ainda que as correntes de soldagem sejam elevadas. Um aumento na energia de soldagem pode reduzir a qualidade da solda e aumentar a distorção.

No processo de soldagem, a ponta do eletrodo funde continuamente junto com uma parte do fluxo protetor e a zona de soldagem fica sempre protegida pelo fluxo não fundido. Com o deslocamento do eletrodo ao longo da junta o fluxo fundido sobrenada a poça de fusão e se separa do metal de solda em forma de escória. Como o metal de solda tem maior ponto de fusão que o fluxo escorificante, este solidifica primeiro e a escória permanece fundida protegendo assim o cordão de solda do oxigênio e o nitrogênio do meio ambiente. Com o 
resfriamento posterior, remove-se o fluxo não fundido, e a escória solidificada rapidamente se separa do metal de solda [29].

O processo de soldagem pode ser semi ou totalmente automático, e o eletrodo é alimentado mecanicamente a partir de uma bobina para a pistola ou cabeçote de soldagem, à medida que é fundido e depositado. O fluxo é alimentado independentemente, caindo por gravidade em frente do eletrodo ou de forma concêntrica em relação a ele. Assim, tanto o fluxo como o eletrodo podem ser alterados a qualquer momento [40].

Este processo também pode ser usado em amplas faixas de intensidades de correntes, tensão e velocidades de avanço. Cada uma dessas variáveis pode ser controlada separadamente, porem todas elas devem operar em conjunto, produzindo soldas que estejam de acordo com as propriedades desejáveis. Todos esses fatores influenciam no cordão de solda, suas propriedades e sua aparência [40].

Este processo permite um alto grau de automatização comparado com outros processos de soldagem devido ao eletrodo ser alimentado continuamente no cabeçote de soldagem, que confere ao processo rapidez e economia. No Brasil, a soldagem por arco submerso é utilizada amplamente na indústria de equipamentos metálicos como tubos, navios e plataformas marítimas [40].

\subsubsection{Vantagens e Desvantagens}

As vantagens deste processo são as elevadas velocidades de soldagem com grandes taxas de deposição e boa integridade do metal de solda, é um processo de fácil uso, com ambiente de trabalho seguro para o operador [41]. Este processo tem elevado rendimento já que não há perdas do metal por projeção e as soldas feitas com este processo apresentam boa tenacidade ao impacto e ductilidade. Além disso, as soldas feitas tem boa compatibilidade com as propriedades mecânicas do metal de base [40].

A maior limitação que este processo apresenta é que não pode ser feito em todas as posições de soldagem devido a que a camada de fluxo pela força de gravidade pode cair e impedir a soldagem fora da posição horizontal. O uso de posicionadores de soldagem, às vezes torna-se necessário, como no caso de soldas circunferências [40]. 


\subsubsection{Efeito das Variáveis do Processo}

\section{Corrente de soldagem}

A corrente de soldagem controla a taxa de fusão do arame de solda, a profundidade de fusão e a quantidade de metal de base fundido. Se a corrente for excessivamente alta haverá uma elevada fusão no material (excesso de penetração). Devido a correntes altas se produz muito calor o qual pode alargar a ZAC do metal de base. Corrente altas provocam desperdício de energia e arame de soldagem no que se refere a reforços excessivos. Por outro lado corrente muito baixa provocam falta de penetração e reforço insuficiente [41].

\section{Tensão do Arco}

A tensão do arco é a diferença de potencial elétrico entre a ponta do arame de solda e a superfície do metal de solda fundido. A tensão de soldagem varia com a distância entre o arame de solda e a poça de fusão (comprimento do arco). No caso em que o comprimento do arco aumenta então a tensão aumenta, inversamente no caso em que o comprimento do arco diminui a tensão diminui. A tensão do arco determina principalmente a geometria da zona de fusão e o reforço (perfil do cordão de solda). Altas tensões do arco produzem cordões mais largos, mais planos e menos profundos [41].

\section{Velocidade de Soldagem}

A velocidade de soldagem controla a penetração e tamanho do cordão de solda. Em soldas de um único passe se deve controlar a corrente e a velocidade de soldagem para se obter uma profundidade do cordão adequada da mesma maneira e em soldas multipasse para se obter o tamanho do cordão adequado [40]. 


\section{Diâmetro do Eletrodo}

Mantendo as outras variáveis constantes, com um eletrodo de maior diâmetro se tem uma maior largura de cordão e menor densidade de corrente menor penetração e taxa de deposição. Com eletrodos de maior diâmetro se tem a capacidade de suportar maiores intensidades de corrente e assim se pode aumentar a taxa de deposição [40].

\section{Largura e altura da camada de fluxo}

Estas dimensões da camada de fluxo granulado influenciam na aparência e a integridade do cordão de acabamento assim como na soldagem propriamente dita [41].

Quando a camada de fluxo granulado for muito alta, o cordão de solda se torna áspero e rugoso. Os gases gerados na soldagem não conseguem escapar prontamente e a superfície do metal de solda fundido fica distorcida [41].

Por outro lado, se a camada de fluxo granulado for muito pequena, a zona de soldagem não estará inteiramente submersa e ocorrerão centelhamento e respingos; o cordão de solda terá uma aparência ruim e poderá apresentar porosidade [41].

O recomendável é aplicar uma camada com largura três vezes superior à largura da poça de fusão. Em cordões largos pode ser necessário aplicar uma camada mais larga [41].

\section{Tipo de Corrente}

A corrente continua de polaridade reversa $\operatorname{CCPR}(+)$, é a mais recomendada neste tipo de processo quando se requer uma rápida seqüência de deposição de passes e uma boa penetração. Este tipo de corrente tem boa resistência á porosidade e da um bom formato de cordão de solda [40].

A corrente continua de polaridade direta CCPD(-) oferece $30 \%$ mais de taxa de deposição de material que a CCPR, porem com menor penetração.

A corrente alternada proporciona penetração e taxas de penetração intermediarias entre $\operatorname{CCPR}(+)$ e $\operatorname{CCPD(-).~Este~tipo~de~corrente~e~usada~para~os~}$ 
eletrodos auxiliares em soldagem 'tandem', para velocidades lentas de soldagem e quando se tem sopro magnético e apagamento do arco com CC[40].

\subsubsection{Consumíveis Usados no Processo para Arco Submerso}

Os fluxos para soldagem têm a função de proteger a poça de solda contra a atmosfera, atuar como desoxidantes, limpando o metal de solda e ainda podem modificar a composição química do metal de solda. Segundo sua fabricação, os fluxos podem ser: aglomerados ou fundidos [40].

Dois fatores influenciam a escolha do fluxo [41]:

- $\quad$ Características de desempenho;

- $\quad$ Propriedades mecânicas.

As características de desempenho indicam que fluxos podem ser empregados e incluem facilidade de remoção da escória, capacidade de remoção de óxidos, capacidade de condução de corrente elétrica, possibilidade de uso de vários arames e possibilidade de aplicação de corrente alternada.

As propriedades mecânicas são de importância para muitas aplicações críticas tais como vasos de pressão e serviços a baixas temperaturas. Para essas soldas, as características de desempenho devem satisfazer às propriedades mecânicas requeridas [41].

Os eletrodos são fabricados em faixas de composição química especificada e trefilados ate diâmetros requeridos. Estes são cobreados, para evitar oxidações superficiais durante seu armazenamento [40].

Os principais fatores que governam a escolha do arame de soldagem são sua influência na composição química e nas propriedades mecânicas da solda.

As propriedades mecânicas e químicas de uma solda por arco submerso são determinadas principalmente por quatro fatores [41]:

- $\quad$ a composição do metal de base;

- $\quad$ a composição do arame empregado; 
- o fluxo empregado

- $\quad$ as condições de soldagem.

\subsubsection{Tipos de Junta}

\section{Junta topo-a-topo}

Este tipo é usado na soldagem com arco submerso, normalmente em chapas com espessura de 5 até $25 \mathrm{~mm}$.

Em soldas de topo em chapa fina se deve ter cuidado do controle da distorção e a possibilidade da chapa a ser perfurada. Para evitar a distorção da chapa esta deve ser adequadamente fixada e se coloca um cobre junta, de aço ou de cobre, que evita também que a peça seja perfurada [40].

Nas soldas de topo em chapa grossa se tem uma soldagem com uma completa penetração sem furo, usando chapas com espessuras superiores a 10mm [40].

\section{Soldagem em chanfro estreito (narrow gap)}

Para chapas com espessuras acima de $19 \mathrm{~mm}$, emprega-se qualquer tipo de configuração de juntas os mais comuns são em V, em X e em U. Normalmente usam-se técnicas de passes múltiplos, que proporcionam melhores valores de tenacidade ao impacto para o metal de solda [40].

\section{Soldagem em junta em ângulo}

Nestas juntas se tem normalmente cordões com grande largura com um passe só e os cordões feitos com grandes larguras provocam mordeduras. Estas são normalmente sensíveis à trinca a quente, devido à elevada restrição imposta pelo cordão. A largura do cordão deve ser ao menos $25 \%$ maior que a profundidade, pois cordões estreitos são sujeitos a trincas [40]. 


\subsubsection{Soldagem Multipasse no Processo SAW}

A soldagem multipasse é freqüentemente empregada com o processo de arco submerso. Quando a espessura da peça exceder a limitação das técnicas de dois passes ou quando não for possível fazer uma boa montagem da junta, de modo que não se possam aplicar altas correntes, a soldagem multipasse por arco submerso deve ser empregada [40].

Quando for possível, deve ser aplicado um procedimento de soldagem conforme mostrado na Fig. 40 para facilitar a remoção do fluxo e evitar a trinca dos cordões. Cada passe de solda deve ser ligeiramente côncavo conforme mostrado para auxiliar na remoção da escória e evitar fissurações [41].

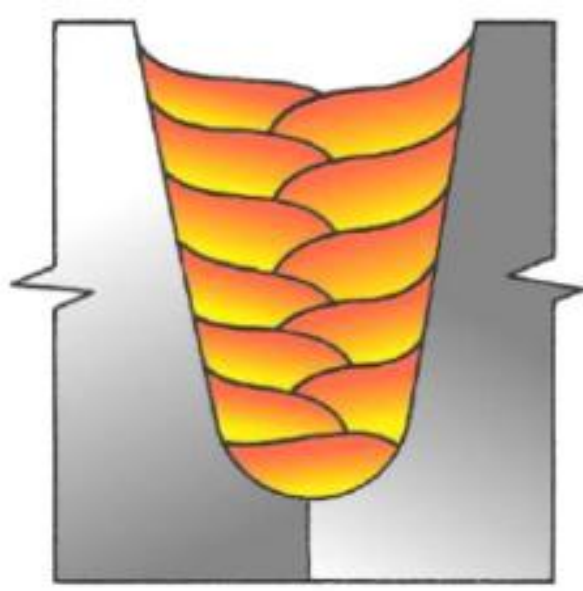

(a)

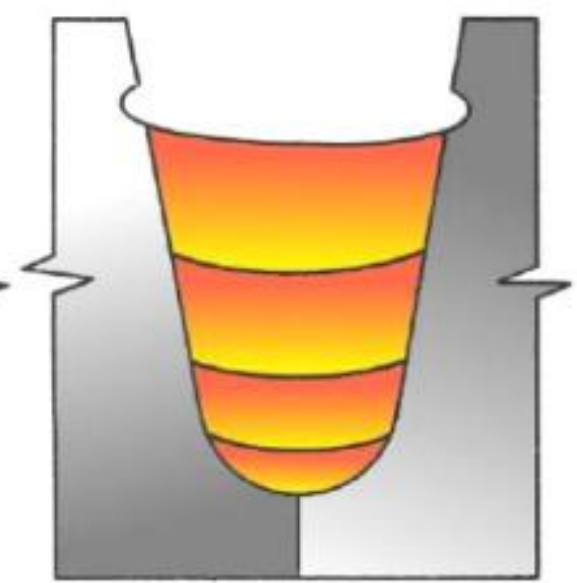

(b)

Figura 40. Procedimentos de soldagem multipasse em arco-submerso[41].

Os procedimentos de soldagem multipasse também permitem que uma gama de juntas e espessuras de peças seja soldada com os mesmos procedimentos e materiais. Em certos materiais de base, a técnica de soldagem multipasse deve ser empregada para manter propriedades adequadas na zona afetada pelo calor do metal de base [41].

Para juntas circunferênciais de vasos de pressão tais como anel-calota e anelanel, essa preparação de duplo bisel empregando MIG automático ou semiautomático para contornar a variação de abertura da raiz é uma excelente combinação. Os passes de enchimento podem então ser soldados com arco submerso, resultando em soldas de qualidade consistente a custos baixos. $\mathrm{O}$ processo de soldagem com gás de proteção é a melhor escolha para uma raiz 
manual ou automática ou para o primeiro passe. O metal de solda resultante é livre de inclusões de escória e a escória externa é mínima, tornando os passes subseqüentes por arco submerso livres de defeitos [41], como mostra a Fig. 41.

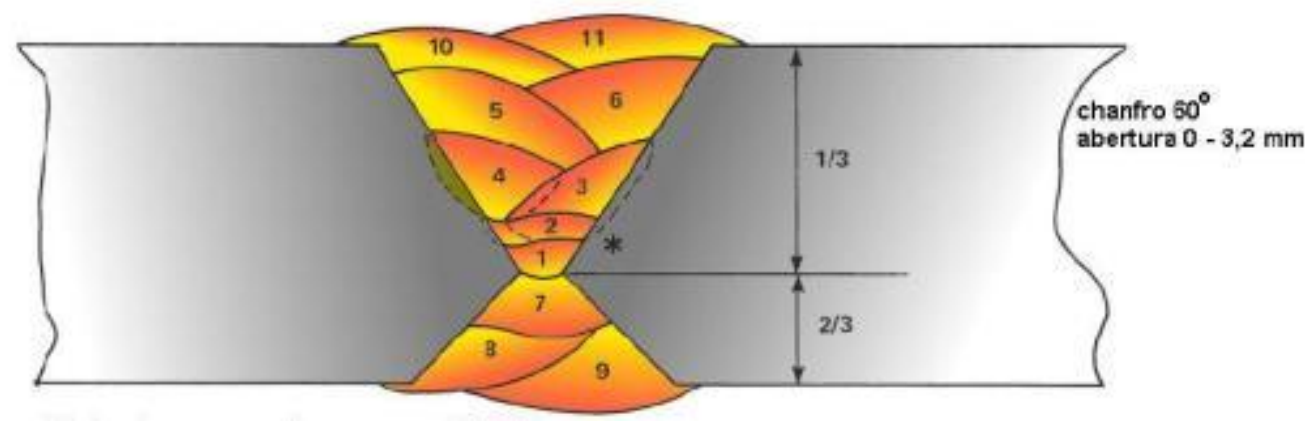

Figura 41. Procedimento de soldagem multipasse com raiz através do processo MIG [41].

O fluxo e o arame de solda devem ser escolhidos tendo em mente procedimentos multipasse. O controle da composição química do metal de solda depositado é particularmente importante para garantir depósitos livres de trincas. Normalmente, empregam-se fluxos neutros para tais aplicações [41].

\subsection{Ensaio de Tenacidade ao Impacto}

Este tipo de ensaio ocorre sob fratura dinâmica de uma carga aplicada, produzida por impacto ou explosão. A fratura dinâmica inclui o caso de uma trinca estacionária sujeita a aplicação de uma carga rápida, tal como o caso da rápida propagação de uma trinca sob uma carga quase estacionária [42]. Nos materiais existem condições externas que contribuem para uma fratura prematura como: entalhes superficiais, temperaturas reduzidas e taxas de deformação elevadas [43]. A presença de entalhe superficial, além de concentrar tensões, provoca estado triaxial de tensões. Nas ligas CCC, tais como os aços ferríticos, a tensão aumenta com a diminuição da temperatura, causando nesses materiais aumento no limite de escoamento a baixas temperaturas. Isto pode produzir fraturas prematuras em estruturas fabricadas com estes materiais $[43,44]$.

Em geral, a tenacidade é medida em termos da energia absorvida devido ao impacto necessário para causar a fratura do material. Outros parâmetros 
quantitativos, tais como a fratura aparente (porcentagem de fratura fibrosa) e grau de ductilidade/deformação (expansão lateral ou contração da raiz do entalhe), também são muitas vezes medidos, além da energia de fratura $[42,43]$.

\subsubsection{Transição de Fratura Dúctil-Frágil.}

Tradicionalmente as características de tenacidade com entalhe de aços com alta e baixa resistência têm sido descritos em termos de comportamento com transição dúctil/frágil com o aumento da temperatura. Porém, os aços estruturais podem falhar de uma forma dúctil ou frágil dependendo das condições como: temperatura, taxa de carregamento e restrição [42]. Os efeitos da temperatura sobre a energia de fratura têm sido relacionados com aços ferríticos de baixa resistência, apresentando clivagem a baixas temperaturas e coalescência de vazios a altas temperaturas [43]. A taxa de mudança de comportamento dúctil para frágil depende de vários parâmetros, incluindo resistência e composição do material [42]. A Fig. 42 apresenta um exemplo de fratura dúctil-frágil para diferentes temperaturas.

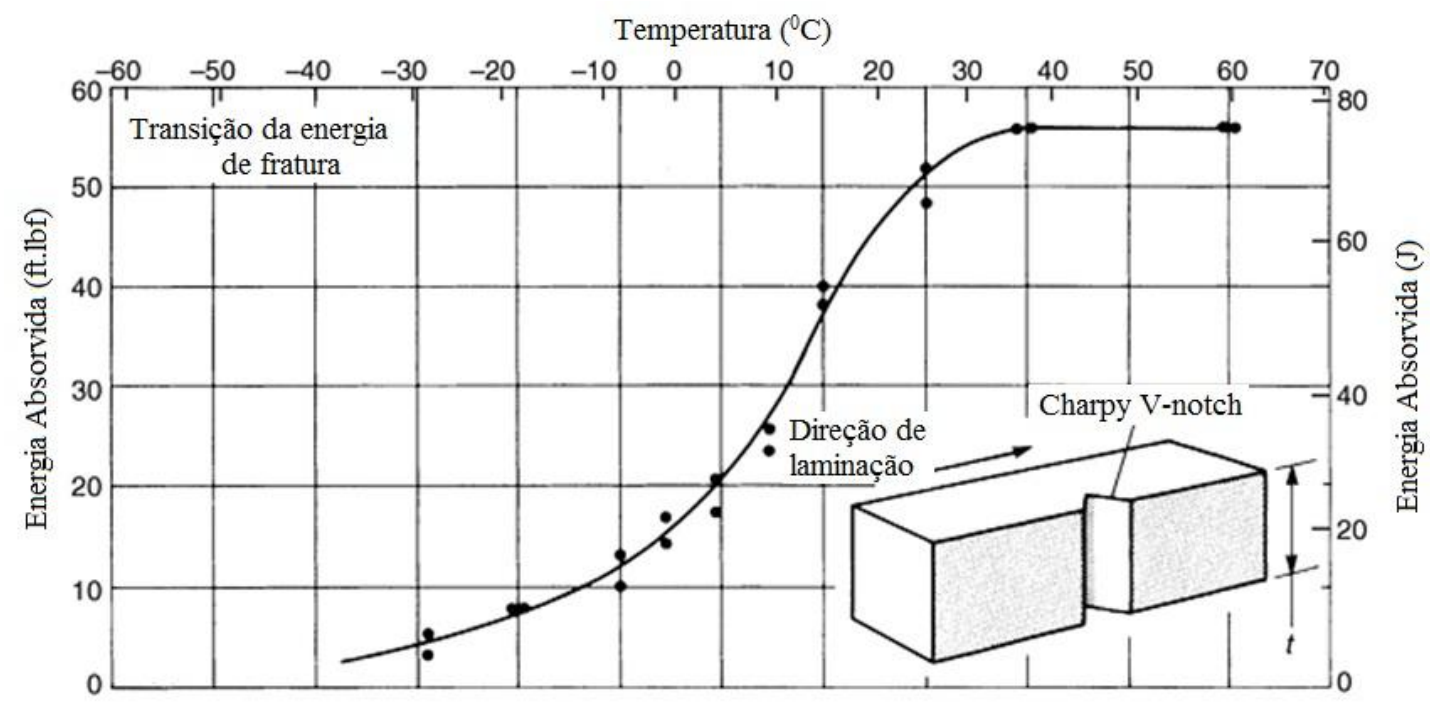

Figura 42. Características da faixa de temperatura de transição para teste Charpy V-notch de chapa de aço baixo carbono [42]. 


\subsubsection{Ensaio de Impacto Charpy}

É importante que as amostras sejam usinadas com cuidado e que todas as tolerâncias dimensionais sejam seguidas. Cuidados devem ser tomados para assegurar que as amostras estejam quadradas. É fácil esmerilhar lados opostos paralelos, mas isso não garante a perpendicularidade. A usinagem do entalhe é o fator mais crítico. A forma designada e tamanho do entalhe devem ser rigorosamente seguidas, e o entalhe deve ter um acabamento (não polido) liso, podendo ser chanfrado o entalhe com uma brochadora especial [42].

As amostras devem ser geralmente fornecidas com marcas de identificação. Isto é feito melhor nas extremidades da amostra. Na preparação de amostras, onde a orientação é um fator essencial, tal orientação deve ser levada em consideração, porque a orientação pode causar grandes variações nos resultados dos testes. Se não for indicado o contrário, a amostra deve ser orientado na direção de laminação da chapa e o entalhe deve ser perpendicular à superfície [42]. A resistência à fratura de uma chapa laminada pode ser aumentada consideravelmente quando as linhas de fluxo de laminaçao são orientadas normais à trajetoria de uma trinca, o qual produz valores de máxima energia absorvida no ensaio de impacto [42,43], orientação (A) na Fig. 43. Todos os entalhes devem ser feitos após qualquer tratamento térmico, que possa ser realizado [42].
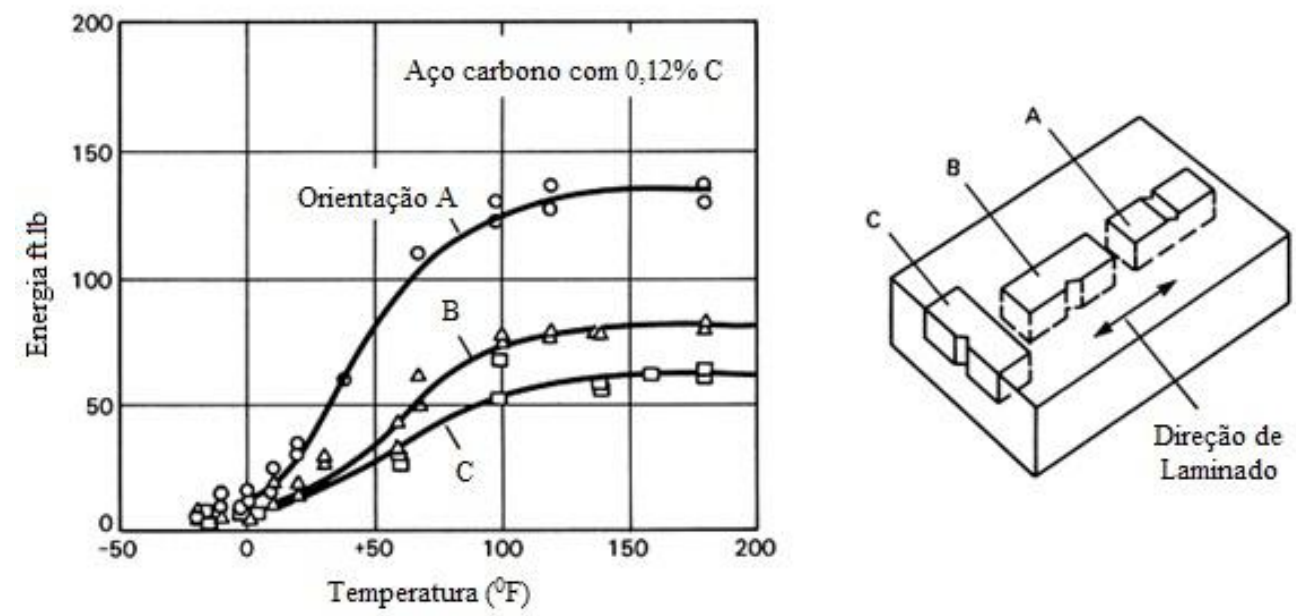

Figura 43. Efeito da orientação da amostra nos resultados do teste de impacto [42]. 
Ao contrário da energia absorvida no ensaio Charpy, a aparência da fratura é um indicativo de como uma amostra falhou. Portanto, é útil quando se tenta correlacionar os resultados dos testes Charpy- $\mathrm{V}$ com outros métodos de ensaio de tenacidade que usam amostras de diferentes geometrias e taxas de carregamento. No entanto, o método para observar a fratura também pode ser subjetivo [42].

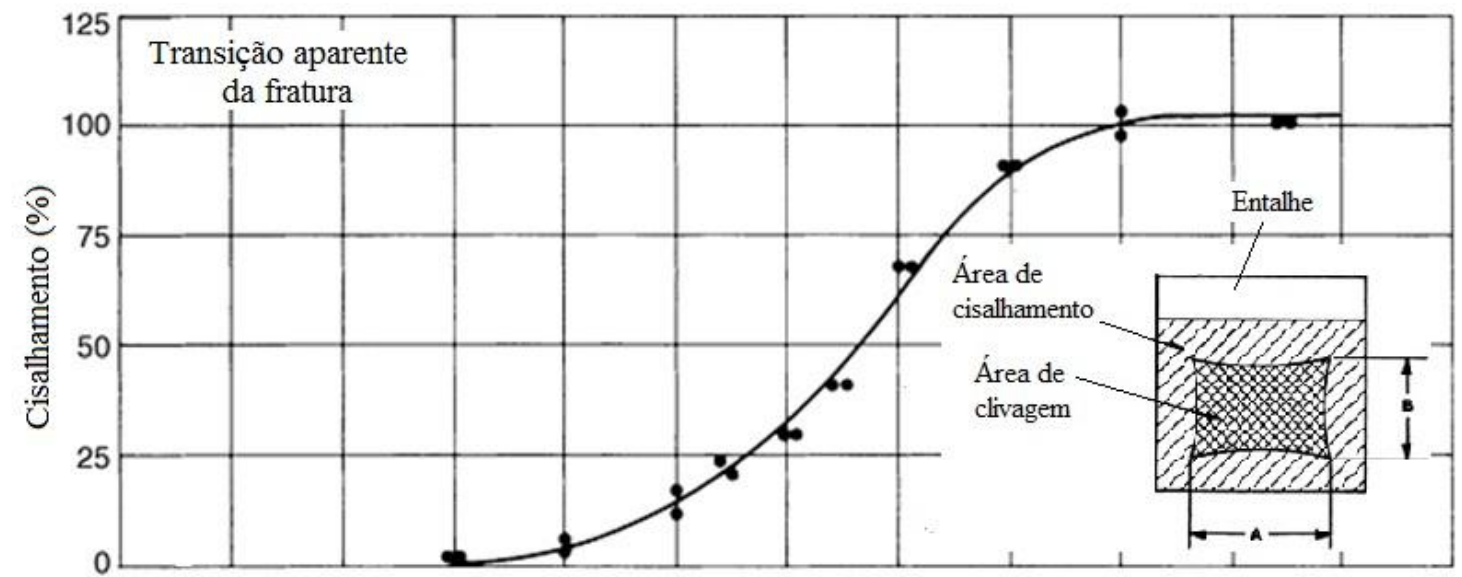

Figura 44. Porcentagem de área de superfície de fratura de uma amostra de ensaio de impacto Charpy-V [42].

O método da expansão lateral é baseado no fato de que as regiões salientes, devido ao cisalhamento (perpendicular ao entalhe), são produzidos em ambos os lados de cada amostra quebrada. Quanto maior for a ductilidade, maiores serão as saliências. Esta expansão lateral pode ser expressa como uma medida da ductilidade aceitável a uma temperatura de teste específico. As extremidades de cada amostra quebrada serão medidas. Os valores mais altos de cada lado são somados, e esse total é o valor da expansão lateral. Um valor mínimo de expansão lateral deve ser especificado como um valor de transição. Estes resultados são plotados contra a temperatura de ensaio e uma curva interpolada [42]. 


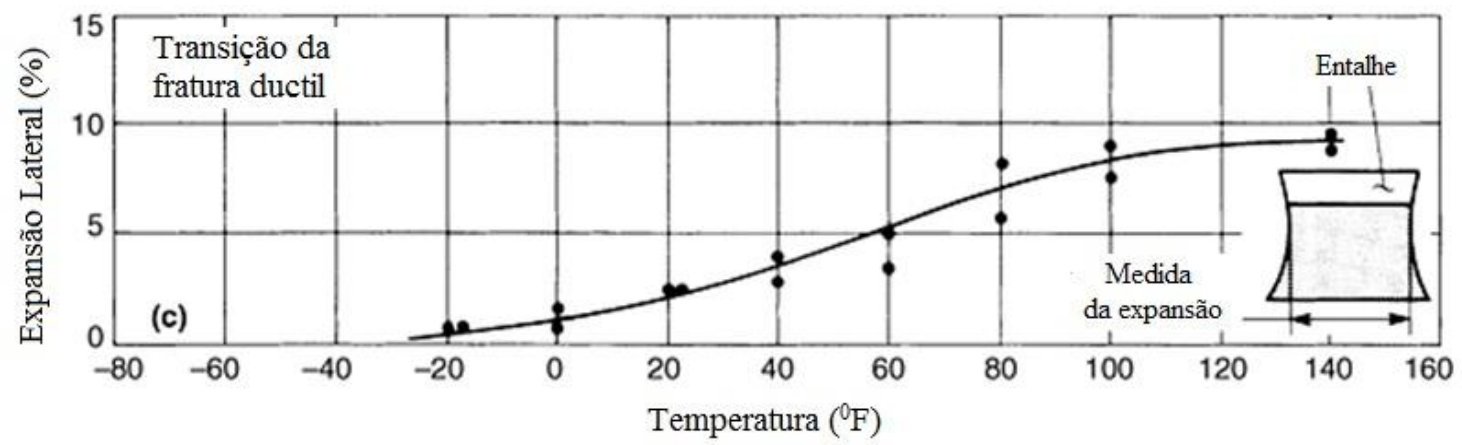

Figura 45. Localização da medição de expansão lateral de um espécime Charpy V [42].

\subsubsection{Tenacidade a Fratura do Aço API 5L grau X80}

Com relação à resistência a fratura nas tubulações de transmissão de gás a elevadas pressões, a origem de trincas a partir de defeitos superficiais, tais como defeitos de soldagem, corrosão ou dano por fadiga, que podem avançar através da espessura de parede, na direção longitudinal, para propagar eventualmente numa forma instável, quando seus valores excedem um valor crítico, que podem causar um completo colapso da tubulação em condições severas de serviço. Para minimizar o risco de ruptura de forma instável, a tenacidade do material deve ser suficientemente elevada para permitir trincas com tamanhos grandes e não mostrar comportamento frágil [4, 45]. O controle das trincas é uma importante propriedade das tubulações de alta qualidade. Além disso uma boa tenacidade na ZAC é uma das mais importantes propriedades do aço para ter segurança numa estrutura soldada [25].

\subsubsection{Tenacidade em Relação à Microestrutura}

O melhoramento da tenacidade se da quando as trincas são desviadas de seu plano e direção de crescimento devido a que estas encontram em seu caminho contornos de grao, linhas de fluxo e inclusoes que estao alinhadas paralelas a uma direçao de processamento particular [43].

Aços com microestrutura refinada apresentam boa tenacidade e resitência como no caso dos aços API X80. Tenacidades e resistencias superiores de materiais com grão fino são obtidos por medio de temperado e revenido ao 
inves de um processo de normalizado. Aços temperados e revenidos contem productos de transformaçao fina como a bainita inferior e a martensita. $O$ efeito benefico do refinamento do grão é uma reducao da temperatura transiçao ductil fragil [43]. Para obter altas tenacidades, o conteudo de carbono deve de ser cerca de $0,07 \%$ ou menos [25].

A explicação do aumento da tenacidade em uma estrutura refinada é devido a que as microtrincas são restringidas devido ao tamanho fino dos contornos de grao. Ja que a trínca é forçada a reiniciar sua trajetoria rapidamente e consideravel energia é consumida para alterar sua direção em busca de um plano de mais facil propagacão nos graos contiguos [43].

A segregação de elementos como o fosforo, exofre e nitrogenio junto aos contornos de grao causam fragilização. A segregacao do $P$ e $S$ é aumentada na presença do Mn ou Si [43]. 


\section{MATERIAIS E MÉTODOS}

\subsection{Composição Química.}

\subsubsection{Tubo de Aço API 5 L grau $X 80$}

O metal base utilizado neste trabalho experimental foi uma chapa de aço API $5 \mathrm{~L}$ grau X80 produzida pelo processo de laminação controlada sem resfriamento acelerado. O material foi recebido na forma de tubo fabricado pelo processo UOE a partir da chapa com as seguintes dimensões: diâmetro externo de 20 pol. (510 mm) e espessura de parede de $3 / 4$ pol. (19 mm). A composição química, do aço API $5 \mathrm{~L}$ grau X80 como recebido foi obtida por meio de espectrofotometria de emissão óptica (EEO), com o carbono medido por equipamento LECO ${ }^{\circledR}$. Esta composição química está apresentada na Tab. 9. 
Tabela 09. Composição química do aço API 5L grau X80 como recebido.

\begin{tabular}{|c|c|}
\hline $\begin{array}{c}\text { Elementos de } \\
\text { liga }\end{array}$ & $\begin{array}{c}\text { Analise química do aço } \\
\text { API 5L grau X80 }\end{array}$ \\
\hline C & 0,051 \\
\hline $\mathrm{Mn}$ & 1,805 \\
\hline $\mathrm{Si}$ & 0,183 \\
\hline$P$ & 0,019 \\
\hline$S$ & 0,004 \\
\hline $\mathrm{Cr}$ & 0,161 \\
\hline $\mathrm{Ni}$ & 0,013 \\
\hline Mo & 0,207 \\
\hline $\mathrm{Al}$ & 0,029 \\
\hline $\mathrm{Cu}$ & 0,012 \\
\hline $\mathrm{Ti}$ & 0,014 \\
\hline $\mathrm{V}$ & 0,021 \\
\hline $\mathrm{Nb}$ & 0,0658 \\
\hline$B$ & 0,0003 \\
\hline $\mathrm{Ca}$ & 0,0031 \\
\hline Co & 0,002 \\
\hline $\mathrm{Pb}$ & 0,0007 \\
\hline $\mathrm{Sb}$ & 0,0031 \\
\hline Sn & 0,001 \\
\hline $\mathrm{Ta}$ & 0,0095 \\
\hline W & 0,0013 \\
\hline $\mathrm{Zn}$ & 0,003 \\
\hline $\mathrm{Zr}$ & 0,0018 \\
\hline $\mathrm{Fe}$ & 97,39 \\
\hline $\mathrm{Ce}_{\| I W}$ & 0,43 \\
\hline $\mathrm{Ce}_{\mathrm{Pcm}}$ & 0,17 \\
\hline
\end{tabular}

$\mathrm{Ce}_{\text {IIw }}$ : Carbono equivalente segundo o instituto internacional de soldagem.

Ce $\mathrm{Pcm}_{\mathrm{Pm}}$ : Carbono equivalente segundo a norma API 5L. 


\subsubsection{Composição Química do Arame e do Cordão de Solda Longitudinal}

A composição química do metal de solda e do arame empregado na soldagem com arco submerso está apresentada na Tab. 10.

Tabela 10. Composição química do arame e do metal de solda para soldagem longitudinal do tubo API X80.

\begin{tabular}{|c|c|c|c|c|c|c|c|c|c|}
\hline & $\mathrm{C}$ & $\mathrm{Mn}$ & $\mathrm{Si}$ & $\mathrm{Cr}$ & $\mathrm{Mo}$ & $\mathrm{Ni}$ & $\mathrm{Cu}$ & $\mathrm{CEIIW}(2)$ & $\mathrm{Pcm}(3)$ \\
\hline $\mathrm{EA2}$ & 0,059 & 1,952 & 0,191 & 0,050 & 0,545 & 0,011 & 0,298 & 0,52 & 0,22 \\
\hline $\begin{array}{c}\text { Segundo } \\
\text { Norma AWS }\end{array}$ & $0,05-$ & $1,65-$ & $\leq$ & $\mathrm{NE}(1)$ & $0,45-$ & $\mathrm{NE}(1)$ & $\leq$ & $\mathrm{NE}(1)$ & $\mathrm{NE}(1)$ \\
A5.23 & 0,17 & 2,20 & 0,20 & & 0,65 & & 0,35 & & \\
\hline WM & 0,053 & 1,849 & 0,185 & 0,128 & 0,308 & 0,012 & 0,089 & 0,46 & 0,19 \\
\hline Notas: 1) NE = não especificado \\
2) Carbono equivalente segundo fórmula do IIW \\
3) Parâmetro do carbono equivalente (Pcm).
\end{tabular}

\subsubsection{Estimativa da Temperabilidade}

Uma das maneiras empíricas de estimar a temperabilidade é através do cálculo do diâmetro ideal (DI). A definição de diâmetro ideal é o maior diâmetro da barra que pode ser temperado para produzir $50 \%$ de martensita no seu centro para um meio perfeito de têmpera. Segundo a ASTM A255 "Standard method for determining hardenability of steels". A equação para calcular o DI, para um aço com $0,05 \% \mathrm{C}$, segundo $\mathrm{O}$ site 'www.heat-treatdoctor.com/documents/IdealDiameter.pdf' é dada por:

DI (em pol. $)=1,167^{*} \% \mathrm{Mn}+1,035 \% \mathrm{Si}+1,018^{*} \% \mathrm{Ni}+$ Eq. (3) $1,108 \% \mathrm{Cr}+1,150 \% \mathrm{Mo}$

Calculando-se os DI para o metal de solda da solda longitudinal e do metal base obtém-se 2,72 pol. e 2,86 pol. Por este método, a temperabilidade do metal de solda é aproximadamente $5 \%$ maior que o metal base. 


\subsection{Simulações no Equipamento Gleeble ${ }^{\circledR}$}

Para a execução dos experimentos foram usinados corpos-de-prova de

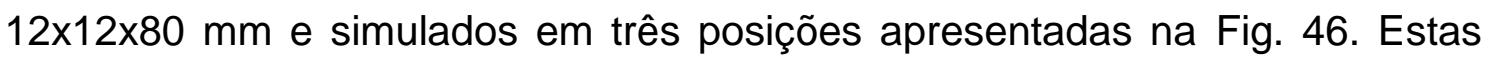
posições foram designadas: Posição 1 (solda longitudinal do tubo); Posição 2 ( $\mathrm{L}-\mathrm{T}=$ material base na seção paralela ao eixo do tubo) e Posição $3(\mathrm{~T}-\mathrm{L}=$ material base na seção perpendicular ao eixo do tubo). Em outras palavras, a posição 1 simulará a ZAC produzida pela soldagem circunferencial no cordão de solda de costura do tubo longitudinal; a posição 2 está relacionada com a ZAC produzida pela soldagem circunferencial do tubo (paralela à direção de laminação do tubo) e a posição 3 relacionada com a ZAC produzida pela soldagem longitudinal do tubo (perpendicular à direção de laminação da chapa).

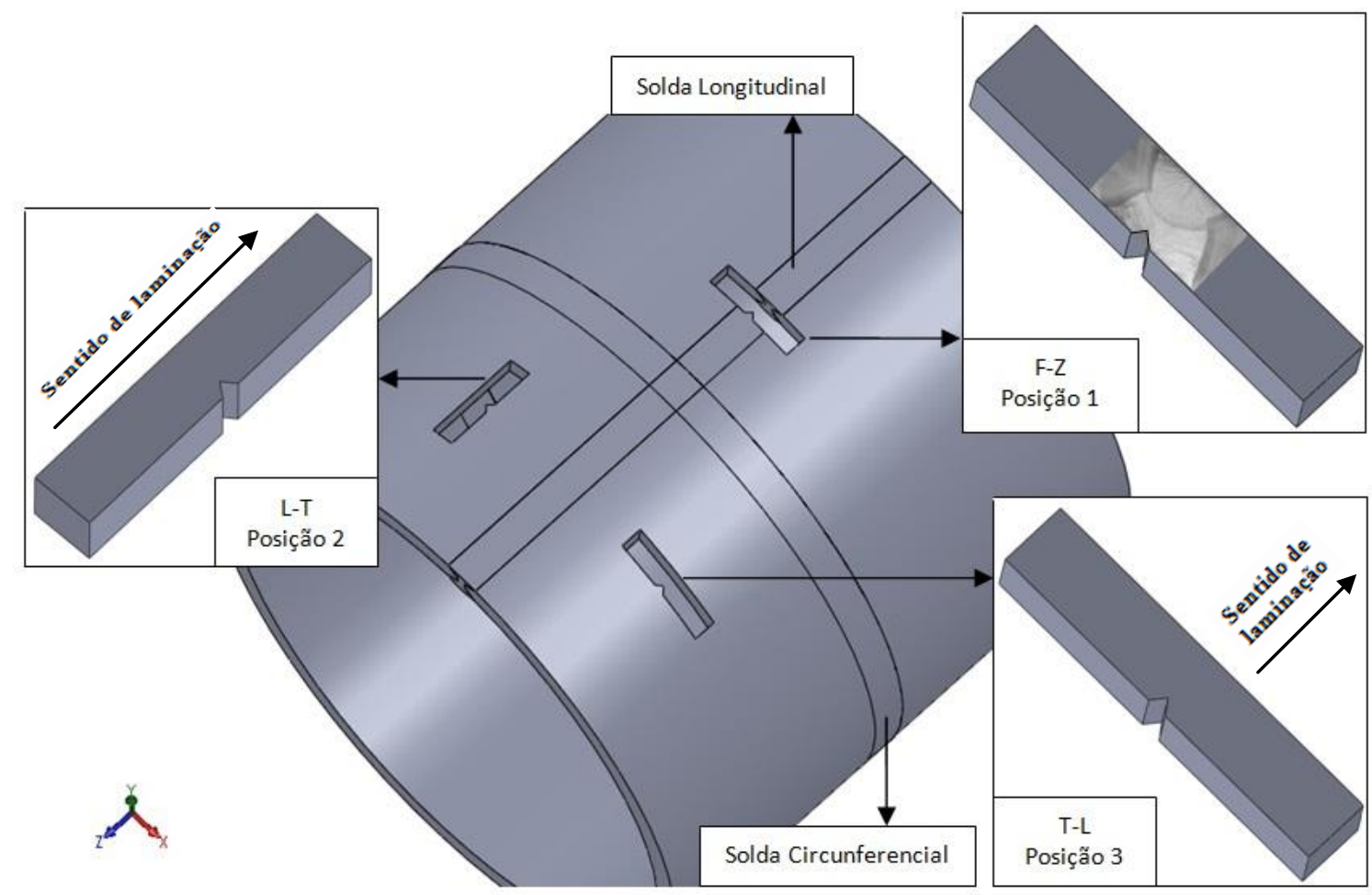

Figura 46. Posições dos corpos-de-prova extraídos do tubo de aço API $5 \mathrm{~L}$ grau X80.

Estes corpos-de-prova foram simulados em diferentes ciclos térmicos máximos nas chapas do aço API $5 \mathrm{~L}$ grau X80. Os corpos-de-prova foram aquecidos até as temperaturas máximas de um único passe de 650, 800, 950 e $1300{ }^{\circ} \mathrm{C}$ 
apresentados na Fig. 47. Os ciclos térmicos ensaiados foram escolhidos de 4 regiões características da evolução térmica dos aços na ZAC. A primeira zona escolhida é a zona subcrítica a uma temperatura de $650{ }^{\circ} \mathrm{C}$ onde não se alcança a transformação austenítica devido a que esta por embaixo da A1; a segunda região é a zona critica onde se alcança a transformação parcial da austenita a $800{ }^{\circ} \mathrm{C}$ por embaixo da $\mathrm{A}_{3}$; a terceira região é a zona de refino de grão devido a que esta ligeiramente acima da $A_{3}$ a $950{ }^{\circ} \mathrm{C}$ onde se alcança a transformação total austenítica e uma quarta região a $1300{ }^{\circ} \mathrm{C}$ onde se tem o aumento do tamanho do grão devido a temperatura desta região encontra-se muito acima da $A_{3}$, onde também se tem a presença de transformação austenítica [46].
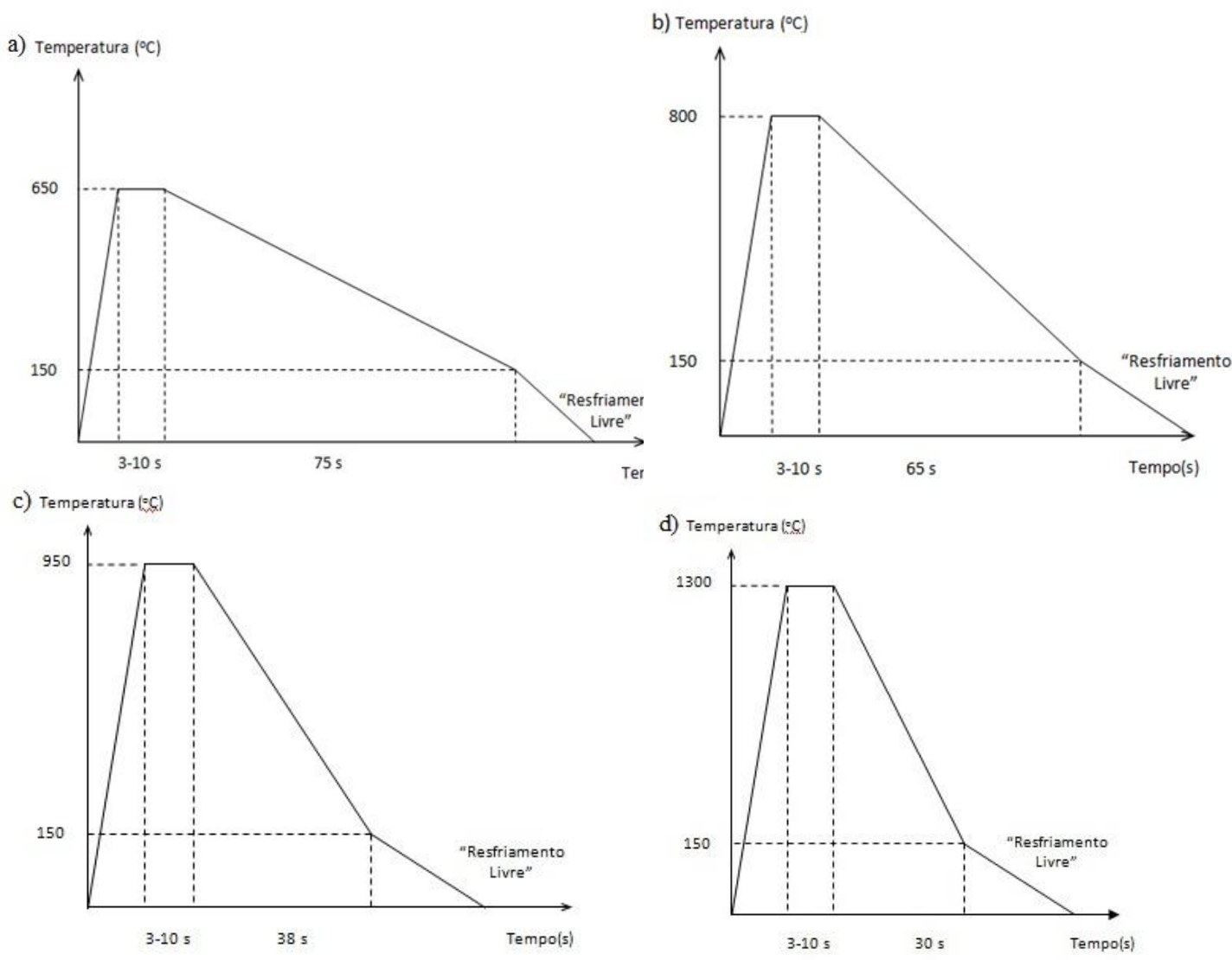

Figura 47. Temperaturas máximas dos ciclos térmicos realizados pelo equipamento Gleeble ${ }^{\circledR}$ de um passe único a) $650{ }^{\circ} \mathrm{C}$, b) $800{ }^{\circ} \mathrm{C}$ c) $950{ }^{\circ} \mathrm{C} \mathrm{e}$ d) $1300{ }^{\circ} \mathrm{C}$. 
Além disso, os corpos-de-prova simularam a soldagem multipasse com dois e com três passes, respectivamente com temperaturas máximas de $950-800{ }^{\circ} \mathrm{C}$ e 950-800-650 ${ }^{\circ} \mathrm{C}$, apresentados na Fig. 48.
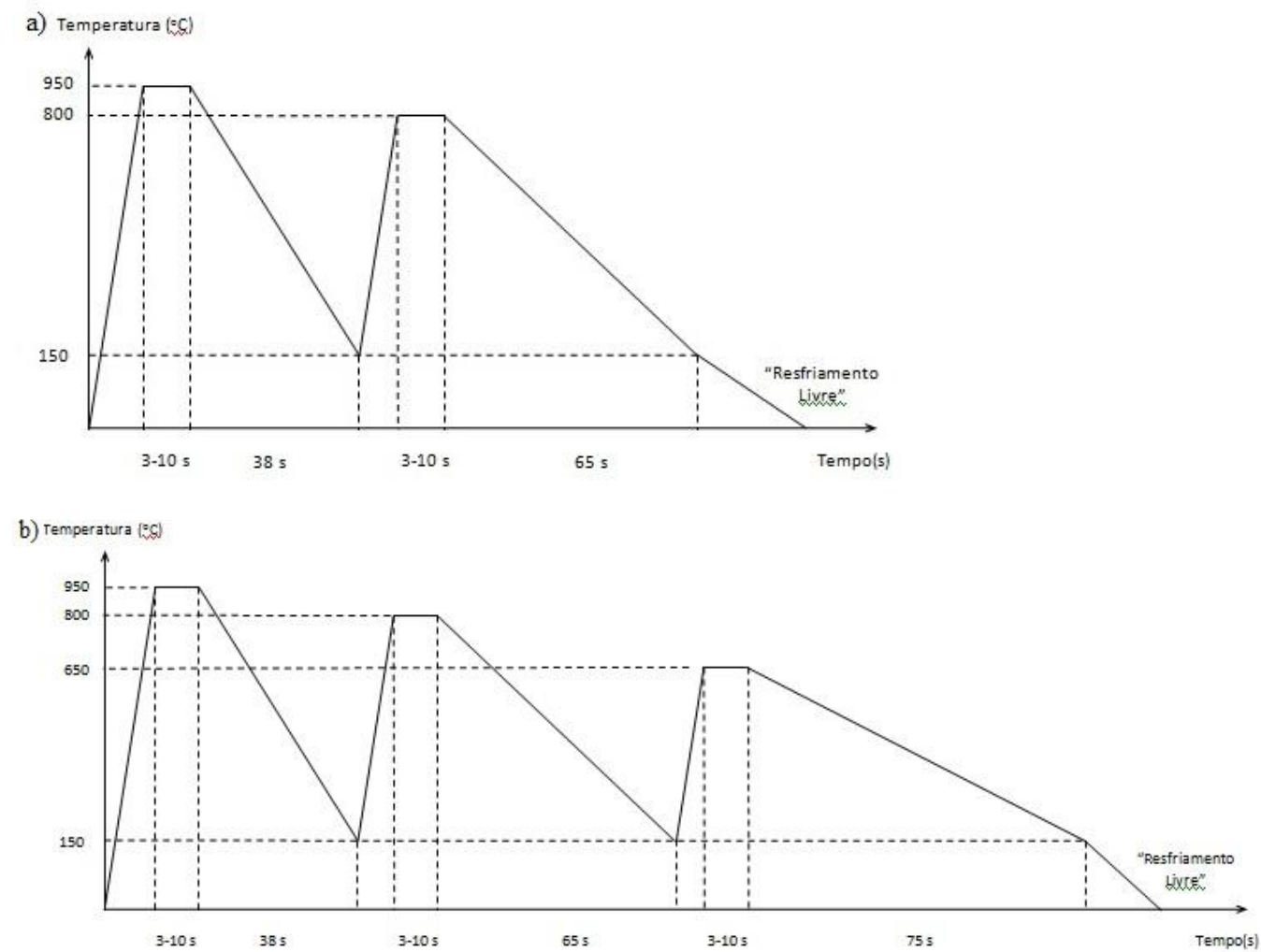

Figura 48. Temperaturas máximas dos ciclos térmicos realizados pelo equipamento Gleeble®. a) simulação de dois passes $950-800{ }^{\circ} \mathrm{C}$ b) simulação de três passes $950-800-650{ }^{\circ} \mathrm{C}$.

O monitoramento e aquisição dos ciclos térmicos foram realizados e simulados em um equipamento Gleeble ${ }^{\circledR}$ 3180, na The Ohio State University. Foi empregado um termopar tipo $\mathrm{K}$ com um diâmetro de 0,2 mm, soldado na região central do corpo-de-prova, para controlar o ciclo térmico desejado no corpo-deprova. 


\subsection{Ensaios Mecânicos}

\subsubsection{Ensaio de Impacto}

Três corpos-de-prova, segundo o número de corpos-de-prova mínimo da norma API 5L [8], para cada uma das posições 1,2 e 3 , sem simulação e simulados em cada ciclo térmico de um único passe e multipasse, com as temperaturas e tempos descritos no item 4.2 foram usinados com dimensões de $10 \times 10 \times 55 \mathrm{~mm}$ e feito um entalhe em $V$ como apresenta a Fig. 49. Também foi usinado um corpo-de-prova para cada posição a $1300{ }^{\circ} \mathrm{C}$ com dimensões de 10x5x55mm e entalhe em $V$ apresentado na Fig. 50. O entalhe em $V$ foi feito com uma brochadeira para evitar dispersões nos valores das energias absorvidas causadas pelo processo de fabricação do entalhe. Estes corpos-deprova foram usinados, dimensionados e ensaiados segundo a norma ASTM A 370 [47].
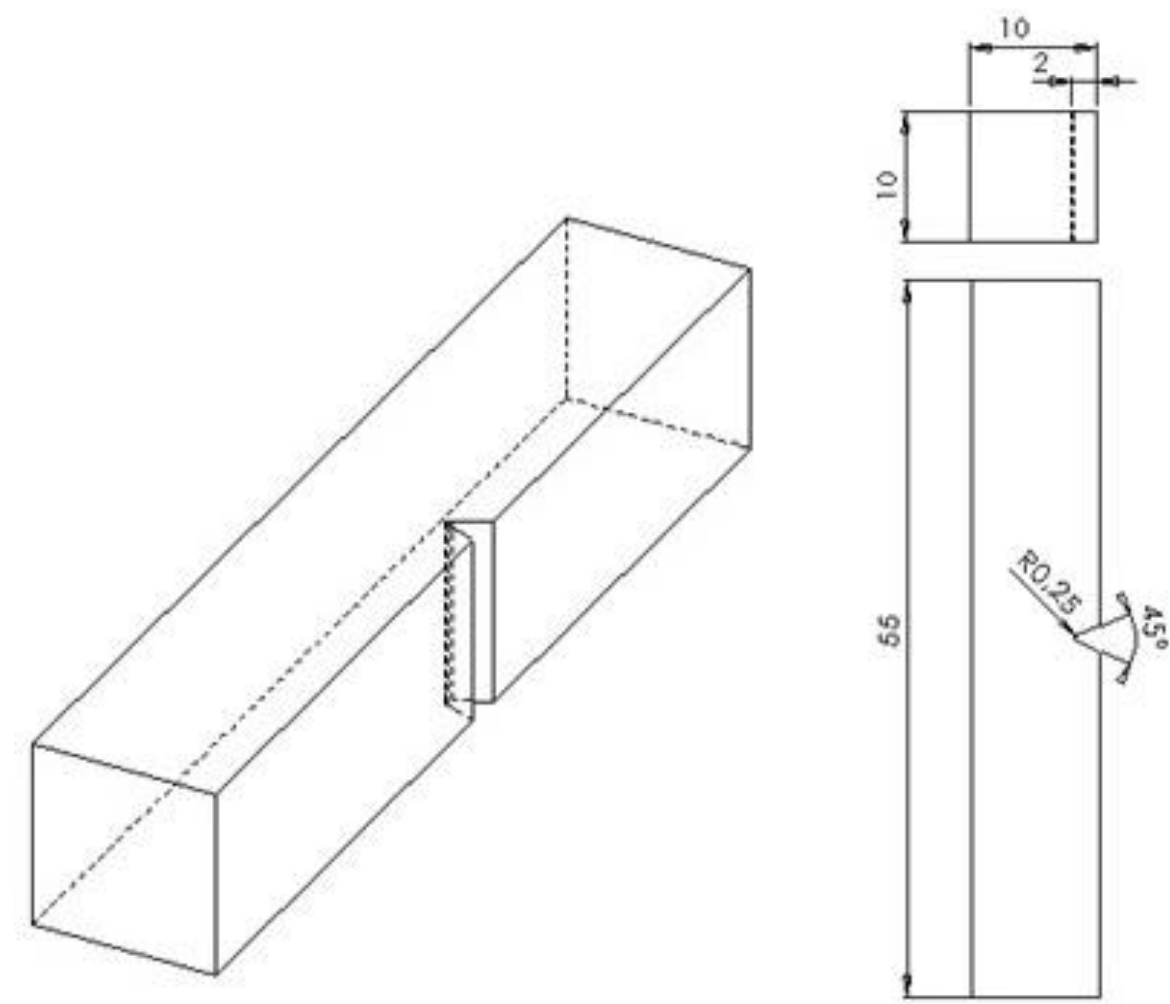

Figura 49. Dimensões dos corpos-de-prova de $650,800,900{ }^{\circ} \mathrm{C}$ e sem simulação, para o ensaio de impacto Charpy-V. Dimensões em (mm). 
Os ensaios de impacto (Charpy-V) foram feitos a uma temperatura de $0{ }^{\circ} \mathrm{C}$ em um equipamento com uma capacidade de $300 \mathrm{~J}$ e realizados na empresa Proaqt. O objetivo foi avaliar o efeito do ciclo térmico nas propriedades do aço nas distintas posições simuladas. Segundo a norma API $5 \mathrm{~L}$ a energia absorvida para tubos de aço API $5 \mathrm{~L}$ grau $\mathrm{X} 80$, para este tipo de ensaio a $0{ }^{\circ} \mathrm{C}$, deve de ser de 80J no mínimo [8]. Também foi medida a expansão lateral obtida depois do ensaio Charpy-V. A macrografia das superfícies das fraturas foi feita numa lupa Stemi 2000-C marca Zeiss e no microscópio eletrônico de varredura (MEV) Philips XL30.
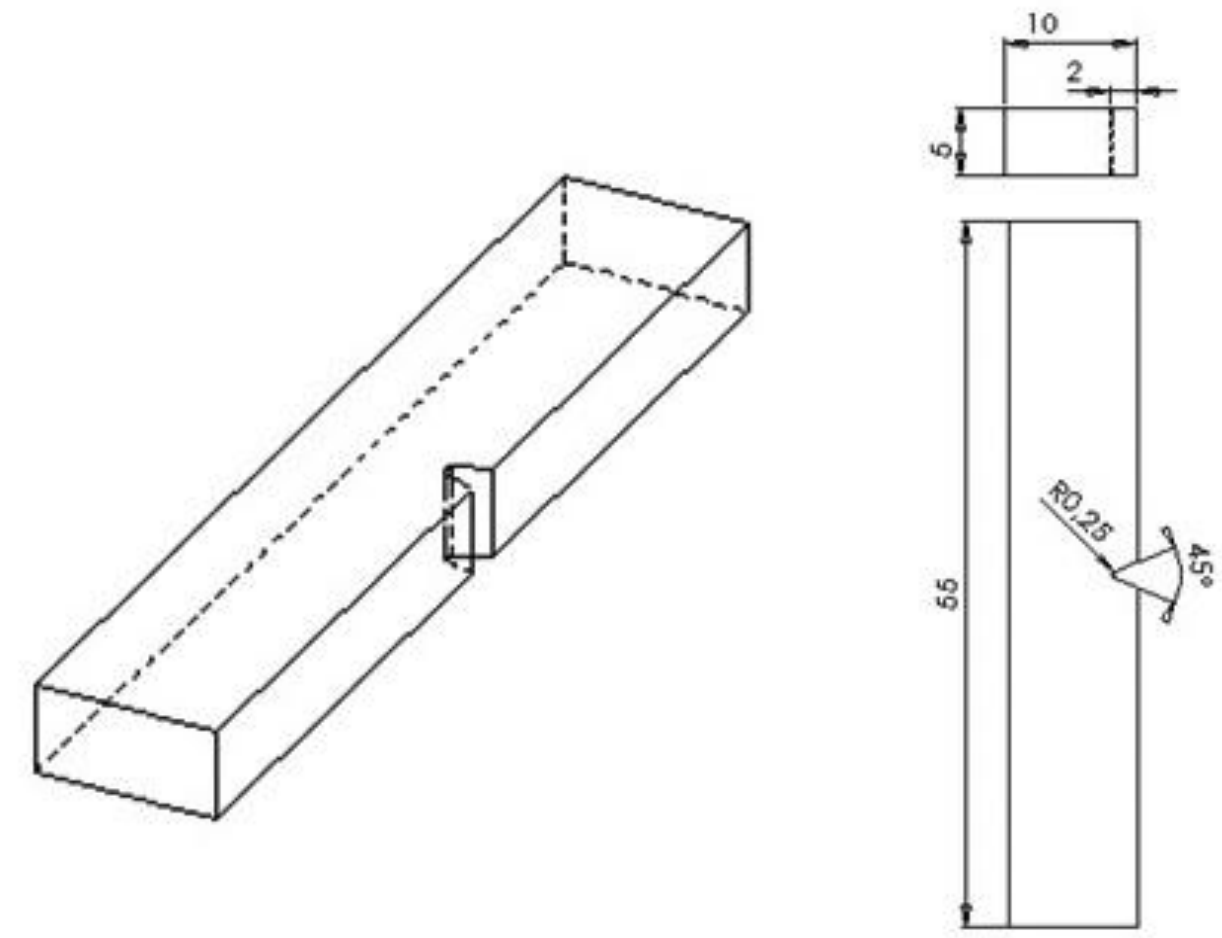

Figura 50. Dimensões dos corpos-de-prova de $1300{ }^{\circ} \mathrm{C}$, para o ensaio de impacto Charpy-V. Dimensões em (mm).

\subsubsection{Ensaio de Microdurezas Vickers}

Para determinar as durezas do material sem simulação e como simulado foi feito um perfil de microdurezas em amostras extraídas do tubo com as características do item 4.2. As durezas foram realizadas na altura de $12 \mathrm{~mm}$ do 
corpo-de-prova, desde a parte superior ate a parte inferior, na seção central do comprimento da amostra, como se vê na Fig. 51. Para os corpos-de-prova simulados se teve cuidado de medir as durezas no meio da seção que contem a ZAC. As indentações foram feitas, em um numero de 15 medições a uma distancia de 0,5 $\mathrm{mm}$ uma da outra e, com uma carga de 0,3 $\mathrm{Kg}$. $O$ equipamento utilizado foi um microdurômetro eletromecânico marca Buehler Micromet 2100 com indentador piramidal.

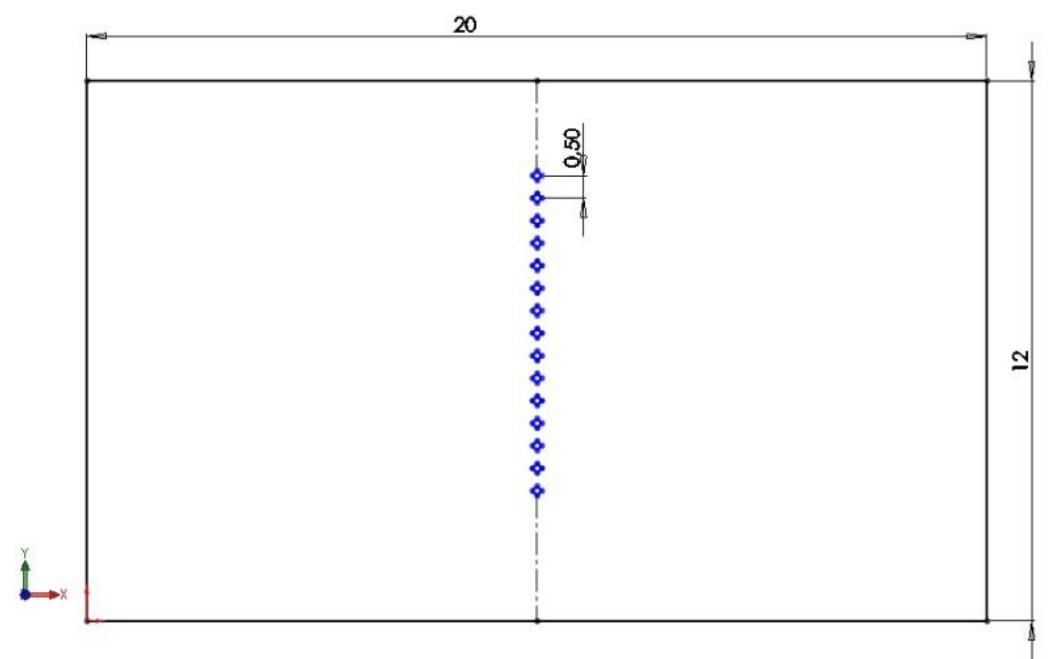

Figura 51. Distância das microindentações nos corpos-de-prova.

\subsection{Caracterização Metalográfica.}

A caracterização metalográfica foi feita nos corpos-de-prova, simulados e não simulados das mesmas regiões que para os ensaios mecânicos. As dimensões dos corpos-de-prova para a caracterização metalográfica foram de $10 \times 5 \times 20 \mathrm{~mm}$ e embutidos em resina. As amostras foram lixadas com lixas de 180, 320, 400, 600 e 1000 de granulometria. Depois de lixadas foram polidas com suspensão de diamante monocristalino em base aquosa Buehler com granulometrias de 6 , $3,1 \mu \mathrm{m}$ e sílica coloidal em suspensão com granulometria de 0,02 $\mu \mathrm{m}$ Buehler.

\subsubsection{Microscopia Óptica}

Os corpos-de-prova foram caracterizados em um microscópio óptico (MO) Olympus BX60M com câmera Altra 20 a fim de observar a microestrutura do material de base e do cordão de solda sem simulação e simulados nos 
diferentes ciclos térmicos. Para a microscopia óptica convencional se utilizou Nital ao 3\% e na microscopia óptica colorida se utilizou reagente Klemm1. O reagente Klemm tem como composição $1 \mathrm{~g}$ de metabissulfito de potássio dissolvido em $50 \mathrm{ml}$ de solução aquosa saturada de tiossulfato de sódio $[34,48]$. O reagente Klemm tem a propriedade de colorir os grãos de ferrita e perlita e não agir com a austenita e cementita. Pode dar uma cor azul ou vermelho à ferrita [34]. O Klemm identifica o microconstituinte MA ao não ser colorido deixando este na cor branca e os agregados eutetoídes são identificados da cor azul em diferentes tonalidades [23]. Usando reagente Picral é possível distinguir entre componentes escuros, que contem carbonetos, e componentes claros, que consistem de austenita retida ou martensita [39].

\subsubsection{Microscopia Eletrônica de Varredura}

As microestruturas dos corpos-de-prova simulados e não simulados foram caracterizados no microscópio eletrônico de barredura (MEV) Philip LX30. Lixadas e polidas como para o analise com microscopia óptica e atacadas com Nital a $3 \%$.

\subsection{Conteúdo de Perlita na Microestrutura}

A perlita foi medida em 10 áreas paralelas das micrografias obtidas por microscopia óptica. A porcentagem das áreas foi medida no programa Image J. 


\section{RESULTADOS E DISCUSSÃO}

\subsection{Caracterização Metalográfica}

\subsubsection{Microscopia Óptica}

Nesta seção será feita uma análise da microestrutura do aço API 5L grau X80 sem simulação e como-simulado para as 3 posições. É importante salientar que a posição 1 tem microestrutura, e composição química, diferente em comparação com a posição 2 e a posição 3 , devido ao cordão de solda longitudinal do tubo, que se encontra nesta posição. Para cada posição, a partir do metal base ou cordão de solda, e de uma ordem ascendente de temperaturas máximas dos ciclos térmicos será apresentada a evolução da microestrutura desta região da ZAC. A nomenclatura adotada para a descrição da microestrutura nesta seção é aquela da seção 3.4.6, proposta pelo IIW [21,32], a saber: (1) ferrita de contorno de grão (GF) que são os grãos de maior tamanho alongados; (2) ferrita acicular ( $\mathrm{AF}$ ) que é a ferrita fina e sem orientação definida; (3) ferrita poligonal intragranular (PF) que é a ferrita que nucleia dentro do grão austenítico anterior; (4) ferrita com segunda fase não alinhada $S F(N A)$ a qual tem uma forma de ferrita degenerada e equiaxial [49], (5) perlita (P) distribuída na microestrutura e (6) ferrita com segunda fase alinhada ( $A C)$, na qual as ripas de ferrita esta de forma alinhada com microconstituintes MAC (martensita-austenita-carboneto) [39].

\subsubsection{Posição 1 (zona fundida)}

Na Fig. 52(a) observa-se a presença de: (1) ferrita de contorno de grão (GF) (2) ferrita acicular (AF), na Fig. 52(b) (2) (AF), (3) ferrita poligonal intragranular (PF), (4) ferrita com segunda fase não alinhada SF(NA) e na Fig. 52(c) (2) (AF) e (5) perlita $(P)$. As avaliações metalúrgicas de Motohashi et al. [50], revelaram que os principais componentes microestruturais do metal de solda para um aço API $5 \mathrm{~L}$ grau $X 80$ foram, a ferrita acicular incluindo uma pequena quantidade de ferrita de contorno de grão, e o constituinte MA. 

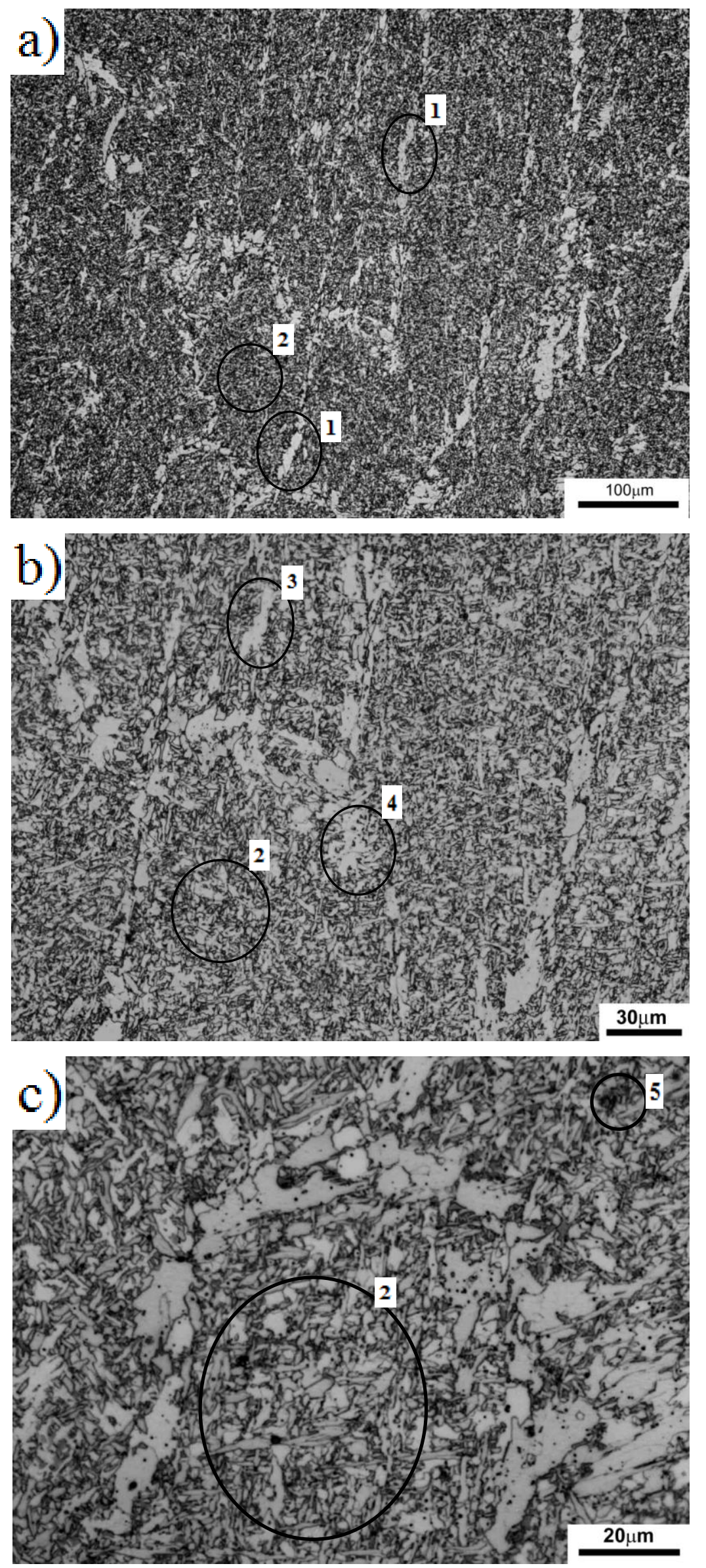

Figura 52. Microestrutura da posição 1 sem simulação; (1) ferrita de contorno de grão (GF), (2) ferrita acicular (AF), (3) ferrita poligonal intragranular ( $P F)$, (4) ferrita com segunda fase não alinhada SF(NA) e (5) perlita (P). a) 200X, b)500X c) 1000X. Ataque Nital 3\%. 


\subsubsection{Posição 1 simulação de um único passe}

Desde a Fig. 53 até a Fig. 56 a seguir, neste subitem, mostram-se as microestruturas obtidas nas simulações de ciclos térmicos de um único passe, em ordem crescente de temperatura máxima.

Na Fig. 53(a) observa-se a presença de: (1) ferrita de contorno de grão (GF), (2) ferrita acicular (AF), (3) ferrita poligonal intragranular (PF) e (6) ferrita com segunda fase alinhada ( $A C)$, e (5) perlita (P). Na Fig. 53(b) pode-se ver claramente a (1) ferrita de contorno de grão (GF) de cor branca alongada, assinalada pela elipse cor branca. Na Fig. 53(c) observa-se o encontro de três grãos de austenita anterior interceptando-se num ponto triplo, com a ferrita de contorno de grão assinalada por setas brancas, além de ferrita acicular no interior de cada grão, assinaladas com as circunferências de cor branca.

Na Fig. 54(a) observa-se a presença de: 1) ferrita de contorno de grão (GF) (2) ferrita acicular (AF), (3) ferrita poligonal intragranular (PF), (6) ferrita com segunda fase alinhada (AC). Na Fig. 54(b) pode-se ver claramente a ferrita de contorno de grão (GF) assinalada com a seta preta. Na Fig. 54(c) pode-se notar um aumento do tamanho do grão em comparação com o material de base da Fig. 52(c). Nota-se que nas Fig. 52, 53 e 54 que pertencem a material sem simulação e os ciclos térmicos de 650 e $800{ }^{\circ} \mathrm{C}$, respectivamente, sua microestrutura consiste principalmente de ferrita acicular (AF) e ferrita primária (PF), com alguns agregados eutetóides delineando o contorno de grão austenítico anterior [32].

$\mathrm{Na}$ Fig. 55(a) e 55(b) pode-se observar que não se tem a presença dos constituintes dos ciclos térmicos anteriores e do metal de base sem simulação. Pode-se notar ainda a presença da ferrita de contorno de grão (GF), assinalada com o número (1), de tamanho menor na microestrutura, rodeada de AF e perlita (P) distribuída na matriz ferrítica. Na Fig. 55(c) o grão apresentou uma diminuição em seu tamanho comparado com o grão da Fig. 54(c) do ciclo térmico de $800{ }^{\circ} \mathrm{C}$, isso pode ser explicado porque na temperatura de $950{ }^{\circ} \mathrm{C}$ se tem refino de grão [46]. 

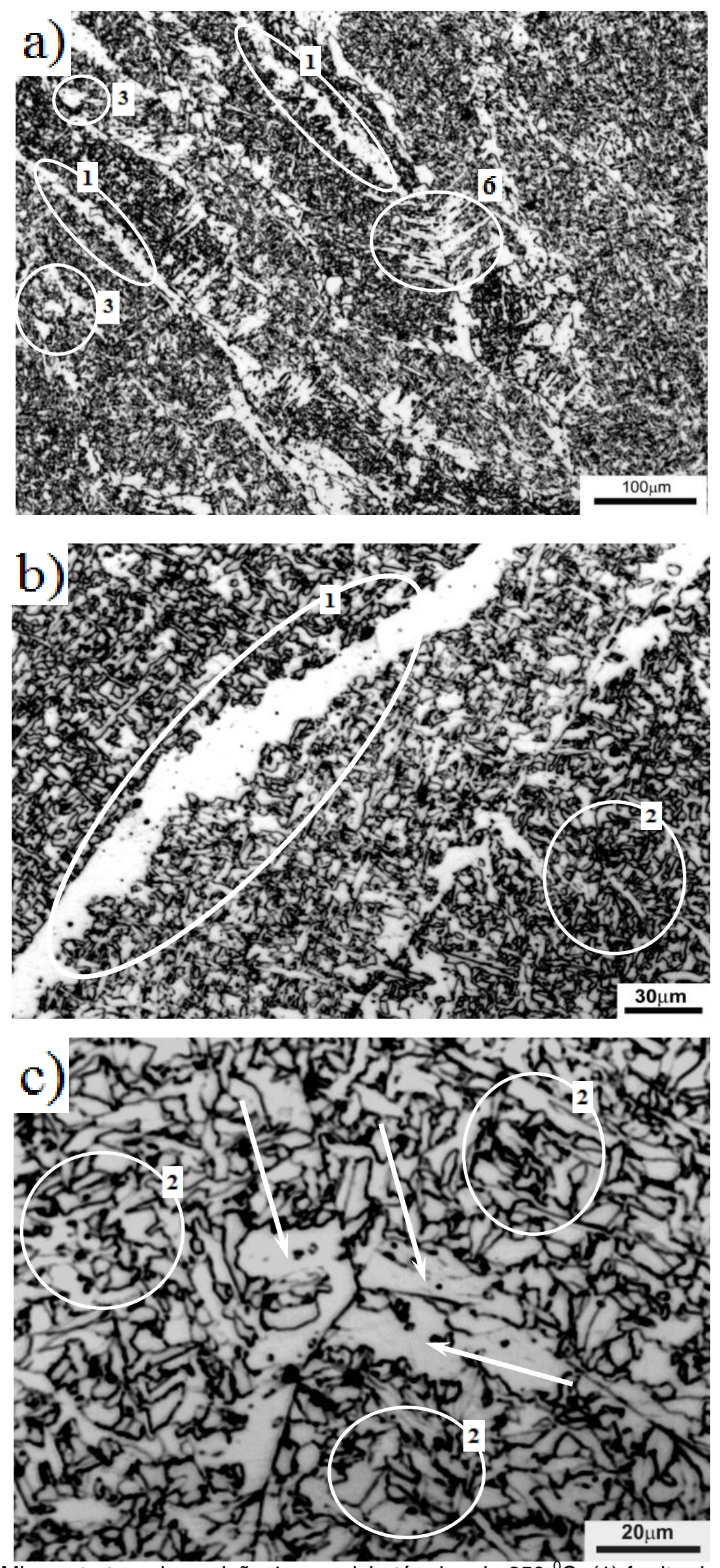

Figura 53. Microestrutura da posição $1 \mathrm{com}$ ciclo térmico de $650^{\circ} \mathrm{C}$; (1) ferrita de contorno de grão (GF), (2) ferrita acicular (AF), (3) ferrita poligonal intragranular (PF), (5) perlita (P) e (6) ferrita com segunda fase alinhada (AC). a) 200X, b) 500X e c) $1000 \mathrm{X}$. Ataque Nital $3 \%$. 

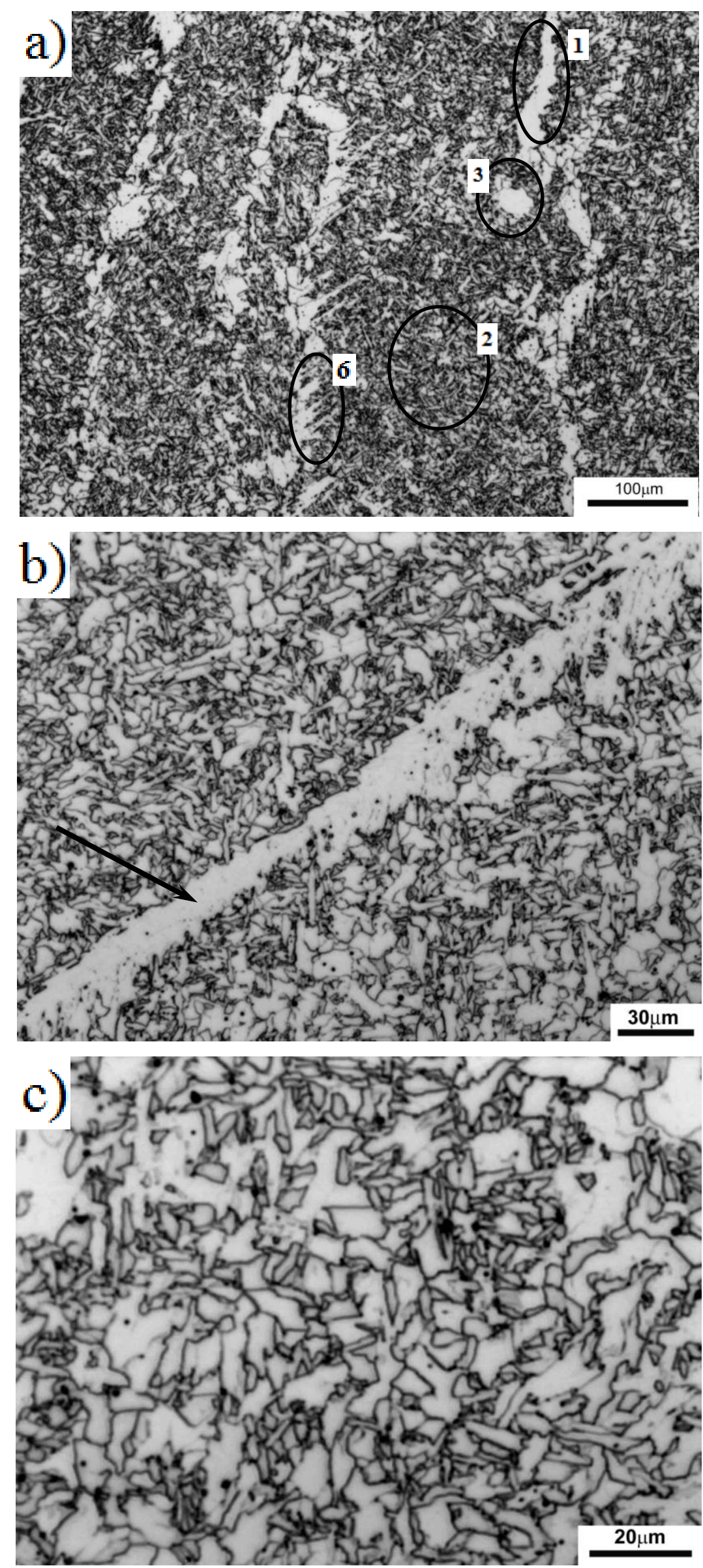

Figura 54. Microestrutura da posição $1 \mathrm{com}$ ciclo térmico de $800{ }^{\circ} \mathrm{C}$; (1) ferrita de contorno de grão (GF), (2) ferrita acicular (AF), (3) ferrita poligonal intragranular (PF), e (6) ferrita com segunda fase alinhada (AC). a) 200X, b) 500X e c) 1000X. Ataque Nital $3 \%$. 

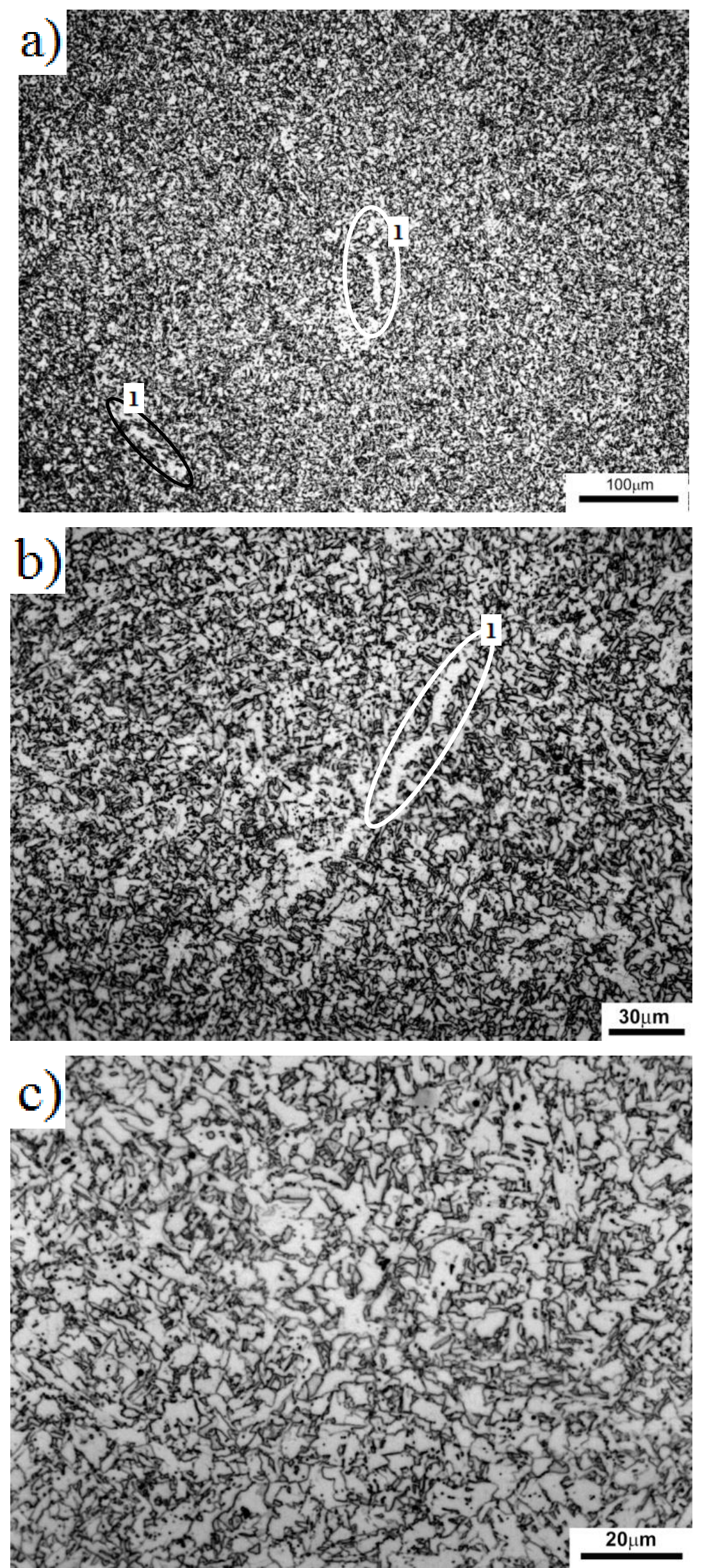

Figura 55. Microestrutura da posição 1 com ciclo térmico de $950{ }^{\circ} \mathrm{C}$; (1) ferrita de contorno de grão (GF). a) 200X, b) 500X e c) 1000X. Ataque Nital 3\%. 

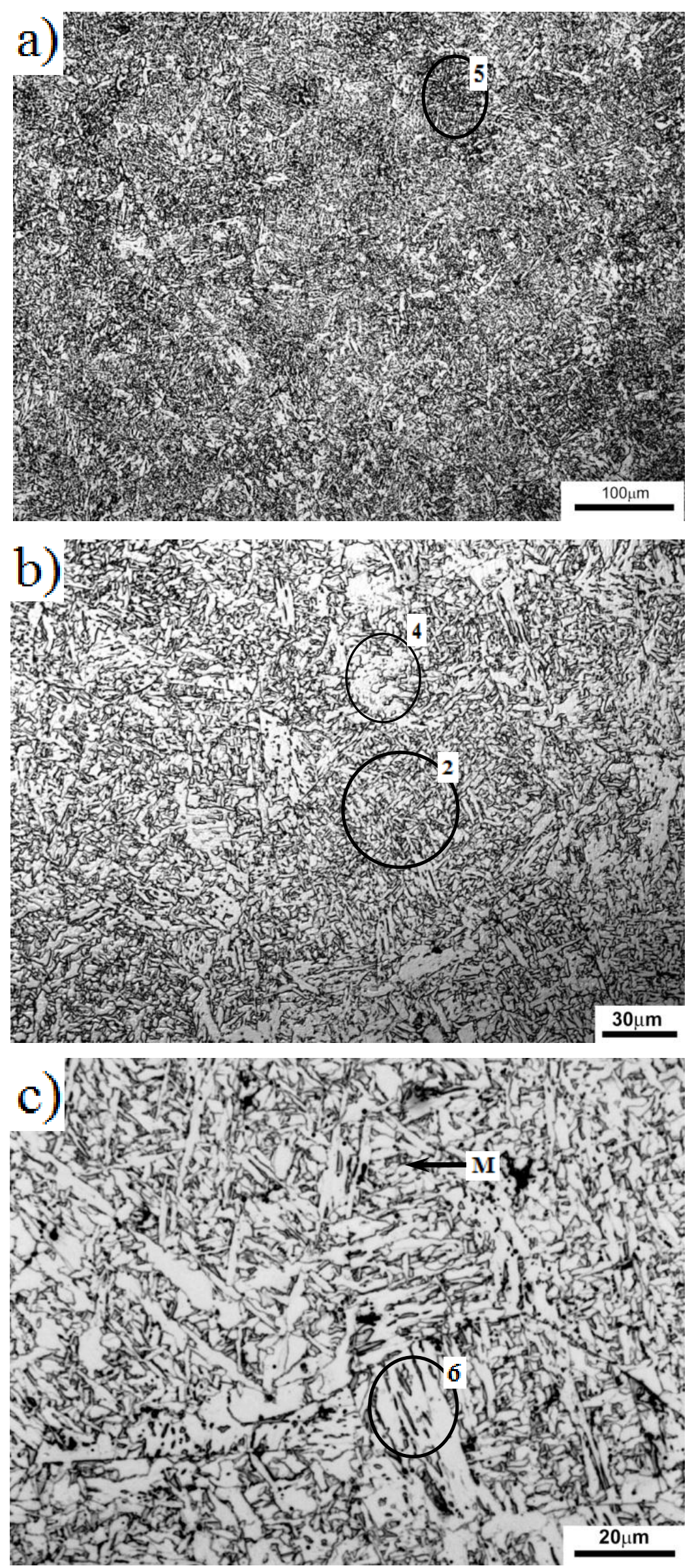

Figura 56. Microestrutura da posição $1 \mathrm{com}$ ciclo térmico de $1300{ }^{\circ} \mathrm{C}$; (2) ferrita acicular (AF), (4) ferrita com segunda fase não alinhada $S F(N A),(5)$ perlita $(P),(6)$ ferrita com segunda fase alinhada (AC). a)200X, b)500X e c)1000X. Ataque Nital 3\%. 
A Fig. 56(a) apresenta zonas escuras com maior presencia de (5) agregados eutetóides ou $\mathrm{P}$ e (2) AF distribuída em toda a matriz e ferrita primária (F) com grãos maiores. Na Fig. 56(b) se tem a presença de (4) FS(NA) e na Fig. 56(c) observa-se a (6) AC e martensita (M). O tipo de microestrutura que apresenta esta figura é típico de zonas afetadas pelo calor a elevadas temperaturas [32].

\subsubsection{Posição 2 (orientação L-T) no metal de base}

Na Fig. 57(a) pode-se observar os agregados eutetóides de cor preta em forma de bandas no sentido da laminação do processo termomecânico que sofreu a chapa com que se fez o tubo, assinalados por seta branca. Estes agregados eutetóides são formados a partir da austenita ainda não transformada e enriquecida em carbono, rejeitado pela ferrita, que se decompõe em ferrita, cementita e bainita, acompanhada de microconstituinte MA [24]. Na Fig. 57(b) observa-se a ferrita poligonal, ferrita quase poligonal e ferrita com forma alongada, uma vez que a austenita recristaliza de forma incompleta [24]. $\mathrm{Na}$ Fig. 57(c) observam-se possivelmente carbonetos de cor cinza escura assinalado pela circunferência de cor preta, além dos agregados euteóides de cor preta entre os grãos da ferrita. A microestrutura do tubo sem tratamento térmico é composta por uma matriz ferrítica com dispersão de martensitaaustenita retida (MA), cementita e heterogeneidade de tamanho de grão [51,52]. 

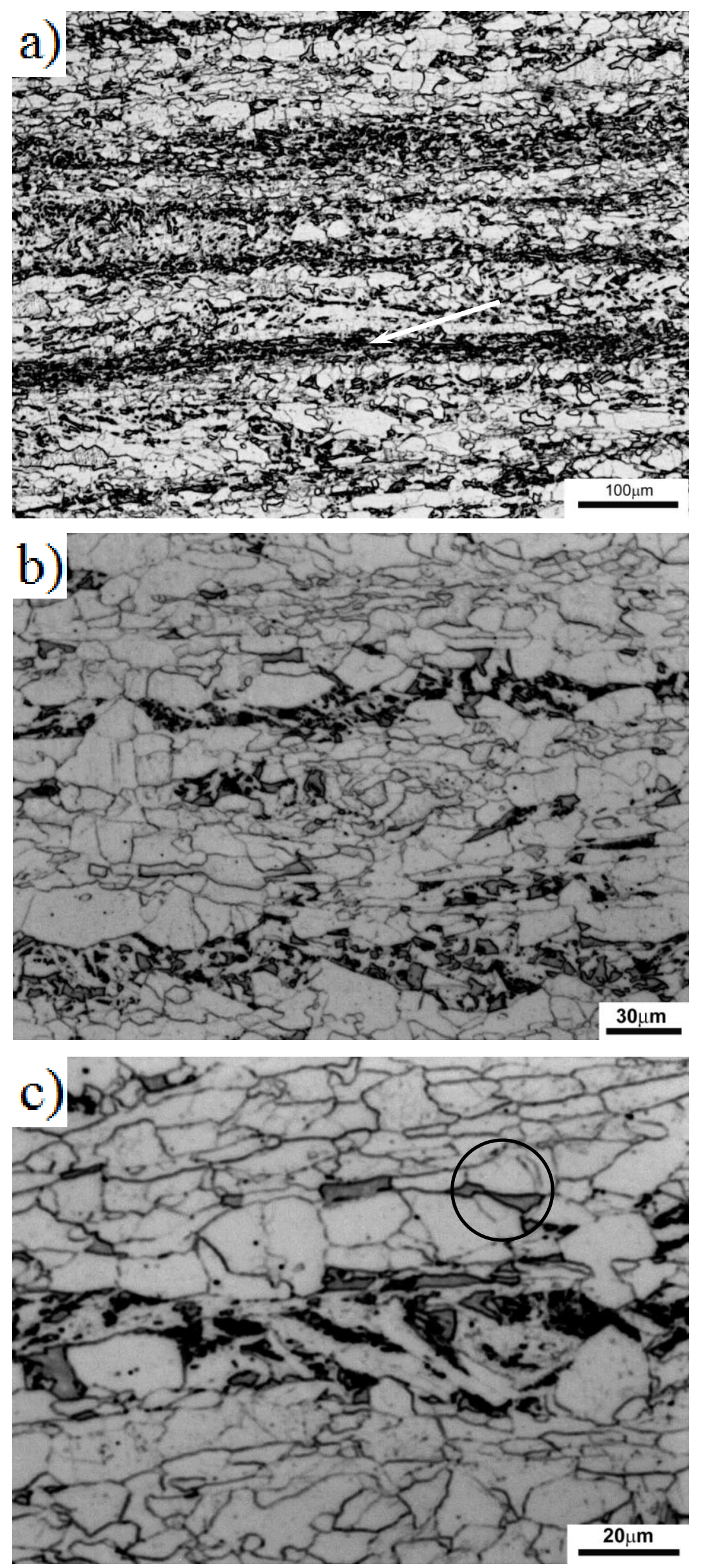

Figura 57. Microestrutura da posição 2 do material de base sem simulação; a)200X, b)500X e c) $1000 X$. Ataque Nital 3\%. 


\subsubsection{Posição 2 (orientação L-T) simulação de um único passe}

Na Fig. 58(a) observa-se diminuição do bandeamento em relação à Fig. 57(a) que pertence ao material de base. Na Fig. 58(b) pode-se ver a ferrita poligonal alongada e a perlita $(\mathrm{P})$, assinalada com a circunferência, de cor preta distribuída na matriz ferrítica.

$\mathrm{Na}$ Fig. 59(a) pode-se notar que o bandeamento desapareceu totalmente e os agregados eutetóides estão distribuídos mais uniformemente na matriz ferrítica em relação à Fig. 57(a) e a Fig. 58(a). Na Fig. 59(b) pode-se ver diminuição do tamanho de grão ferrítico e da perlita para este ciclo térmico em relação ao material de base sem simulação e o ciclo térmico de $650{ }^{\circ} \mathrm{C}$. Na Fig. 59(c) temse grão ferrítico poligonal mais uniforme, o que não apresentam a Fig. 57 (c) e a Fig. 58(c).

$\mathrm{Na}$ Fig. 60 observa-se a presença de granulação fina em comparação com o material de base sem simulação e os ciclos térmicos de 650 e $800{ }^{\circ} \mathrm{C}$ para esta posição. Temos a presença de ferrita poligonal e agregados eutetoídes distribuídos na matriz ferrítica.

Fonda [39,49] caracterizou a microestrutura de um aço de baixo carbono, simulando uma solda a uma temperatura de $1200{ }^{\circ} \mathrm{C}$ com tempos de resfriamento de 28 e 100 segundos, e em vez de usar o termo "Bainita" preferiu usar o termo "Ripas de Ferrita" para descrever a microestrutura que ele observou devido a que a bainita não pode ser identificada com certeza no microscópio óptico. Tomando em conta essa observação, a microestrutura encontrada na Fig. 61, tem-se a presença de ripas paralelas de ferrita na microestrutura. 

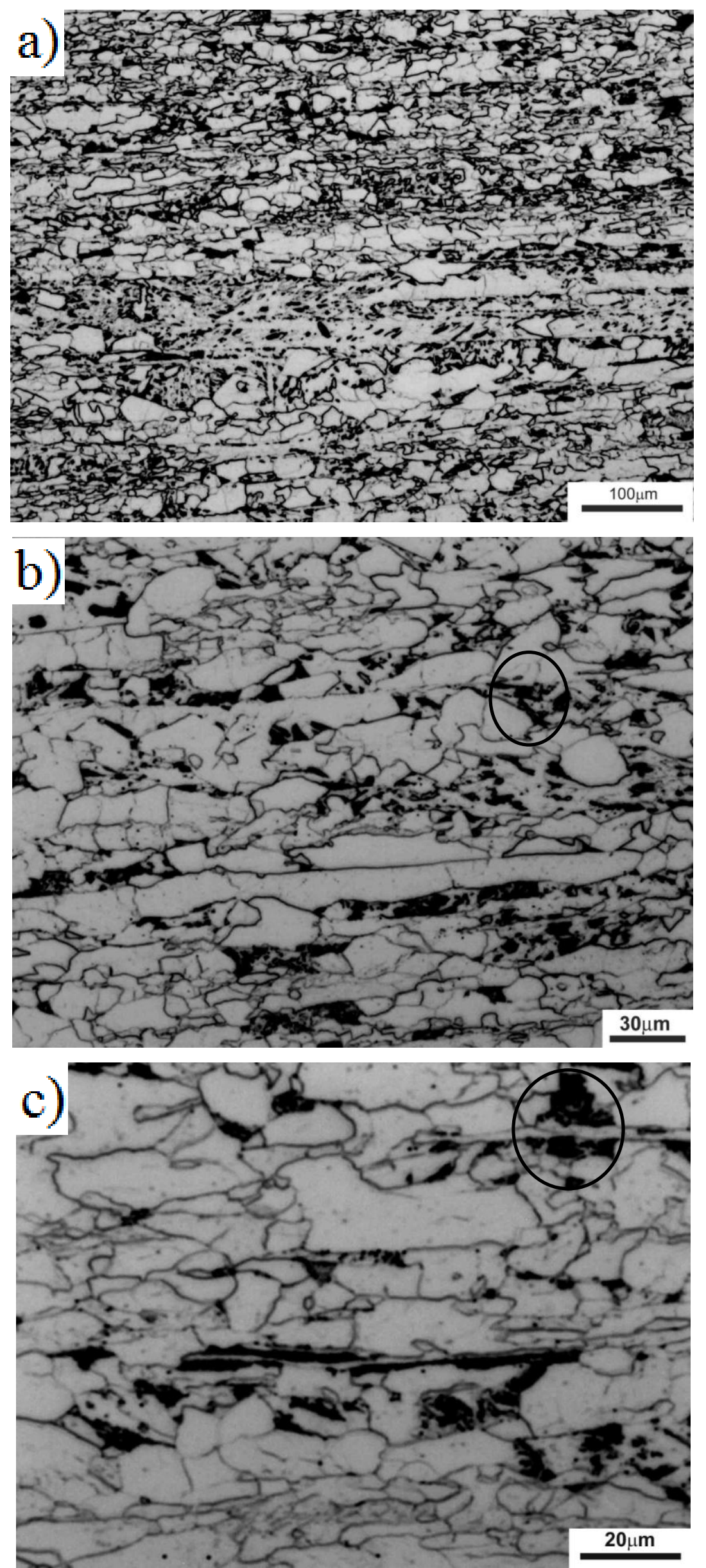

Figura 58. Microestrutura da posição 2 com ciclo térmico de $650{ }^{\circ} \mathrm{C}$; a) $200 \mathrm{X}$, b) $500 \mathrm{X}$ e c) $1000 X$. Ataque Nital 3\%. 

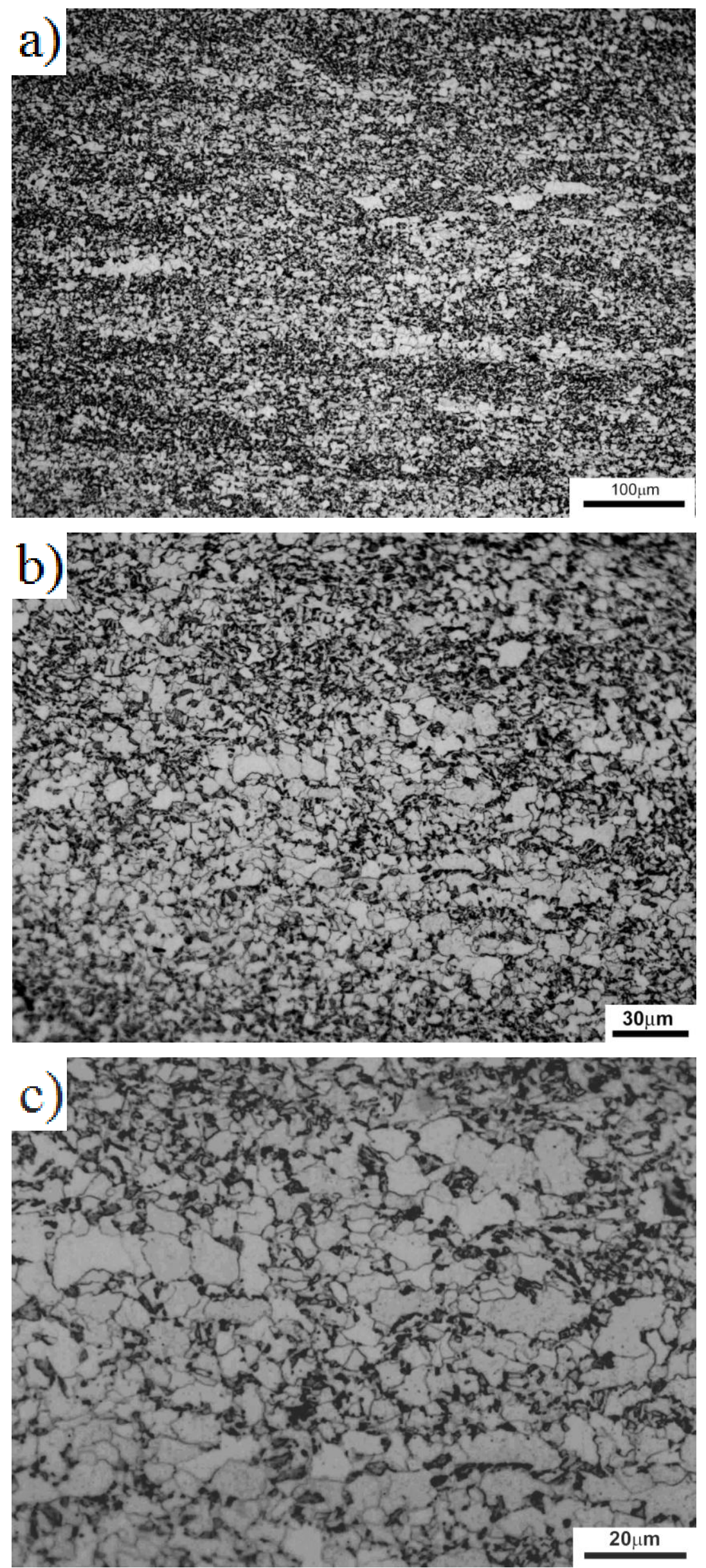

Figura 59. Microestrutura da posição 2 com ciclo térmico de $800{ }^{\circ} \mathrm{C}$; a) $200 \mathrm{X}$, b) $500 \mathrm{X}$ e c) $1000 X$. Ataque Nital $3 \%$. 


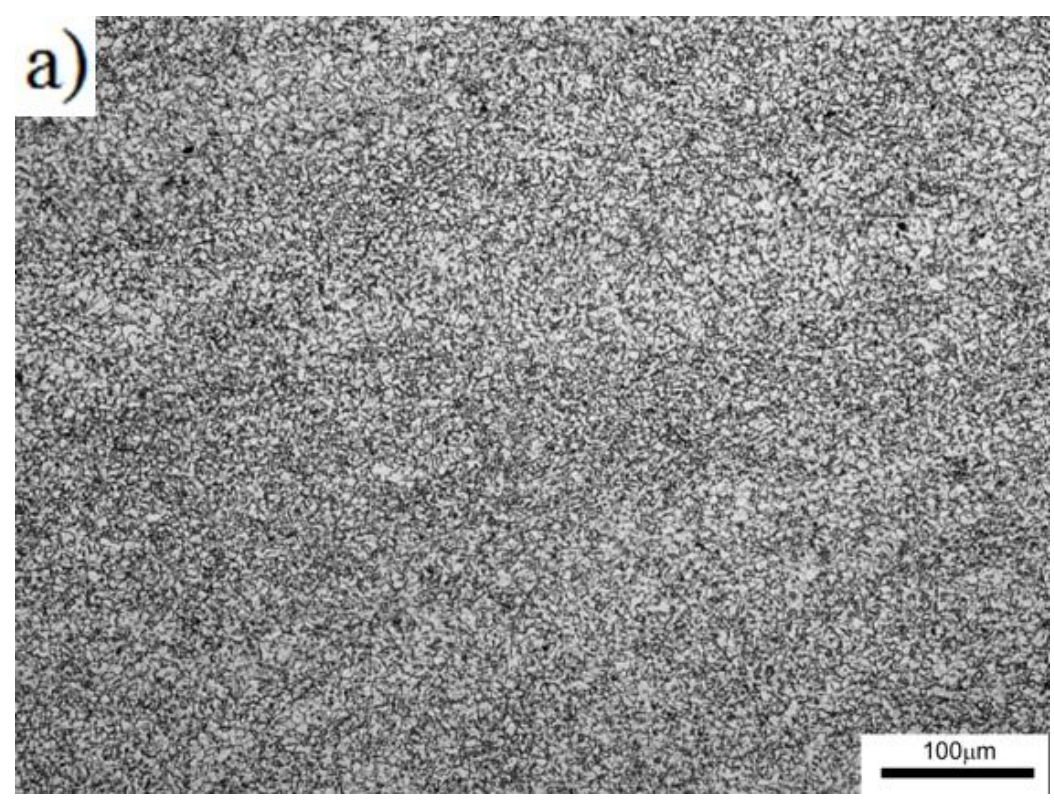

1) 235

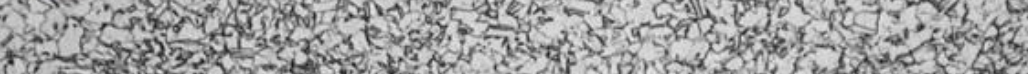
W. 30

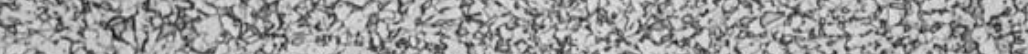

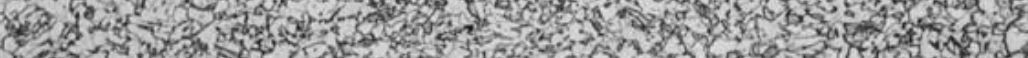

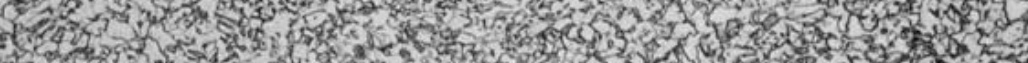

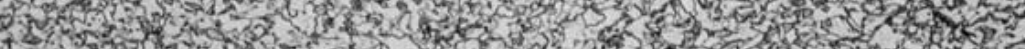

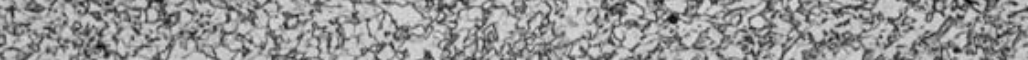

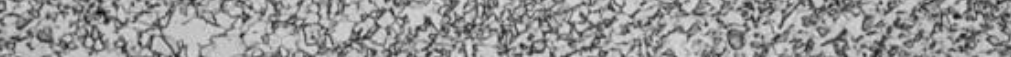

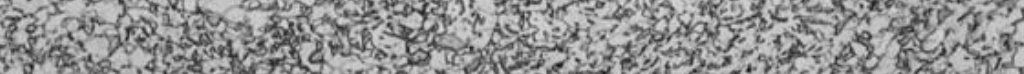

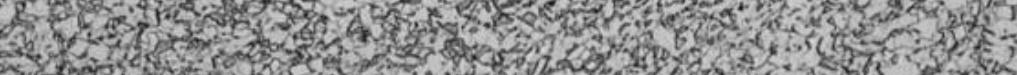

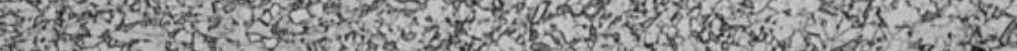
स3 300 .

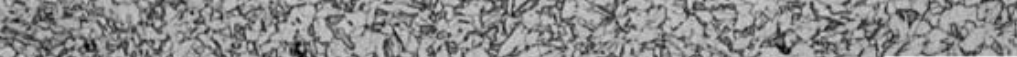

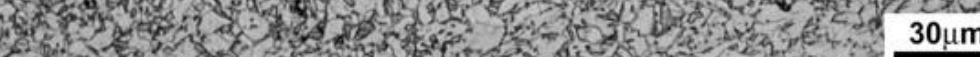

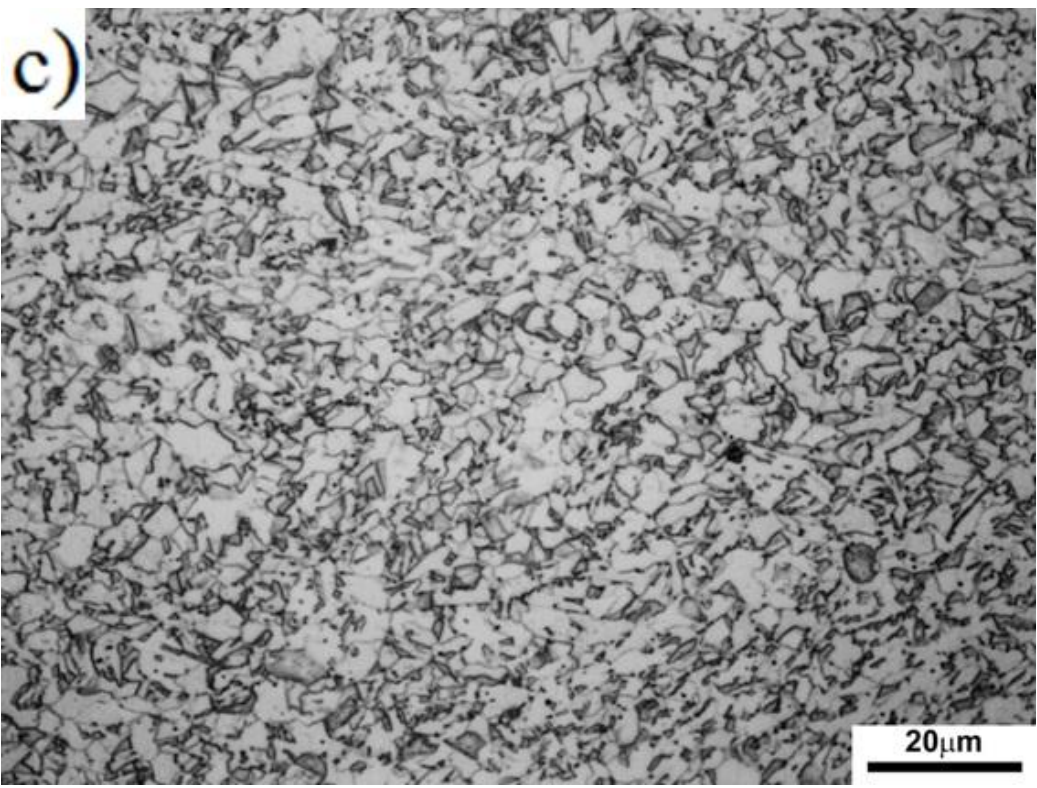

Figura 60. Microestrutura da posição 2 com ciclo térmico de $950{ }^{\circ} \mathrm{C}$; a) $200 \mathrm{X}$, b) $500 \mathrm{X}$ e c) $1000 X$. Ataque Nital 3\%. 

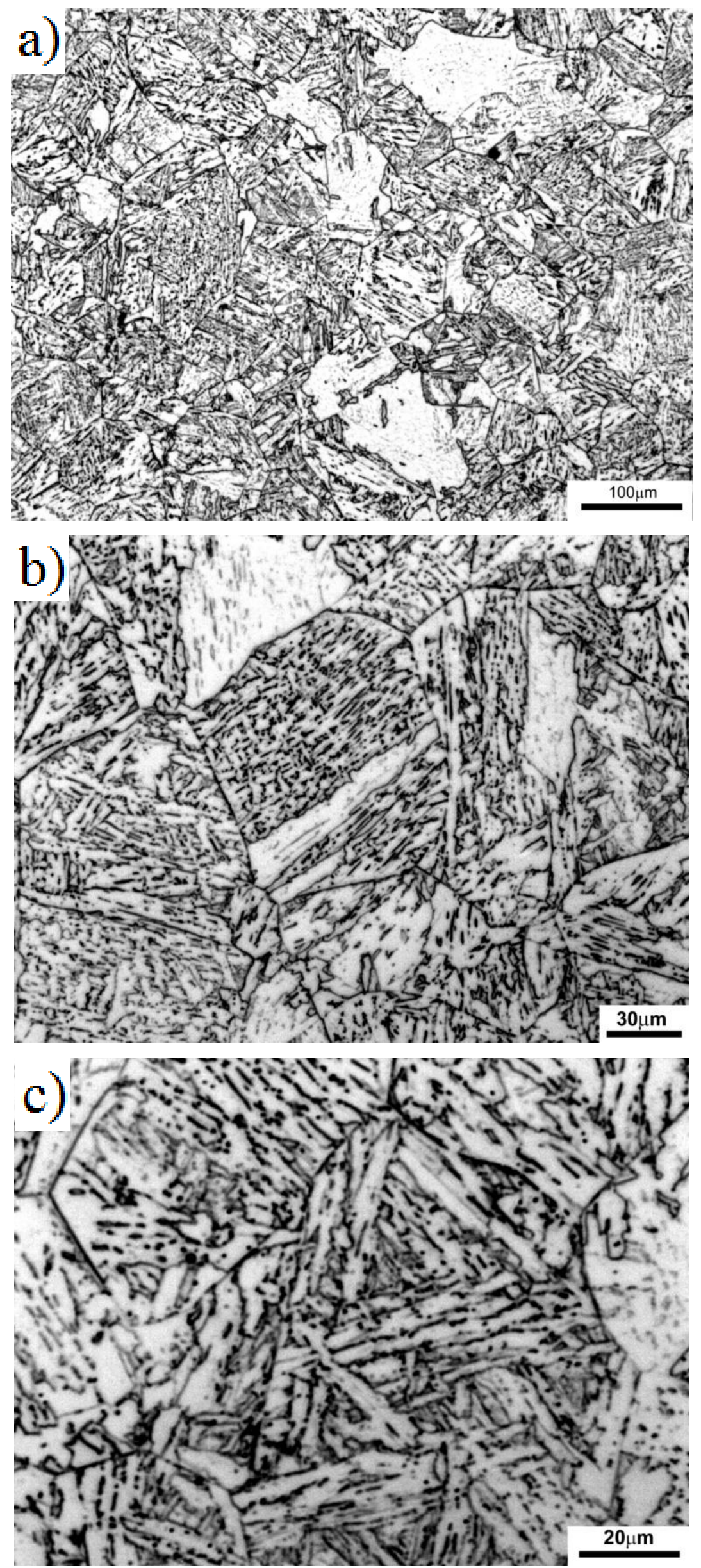

Figura 61. Microestrutura da posição 2 com ciclo térmico de $1300{ }^{\circ} \mathrm{C}$; a) $200 \mathrm{X}$, b) $500 \mathrm{X}$ e c) $1000 X$. Ataque Nital 3\%. 
$\mathrm{Na}$ Fig. 61 pode-se notar que o grão a esta temperatura tem um tamanho grosseiro (grão da austenita inicial), distinto dos outros ciclos térmicos a temperaturas inferiores e o metal de base sem simulação. Pode-se ver que a microestrutura é diferente em relação às outras figuras anteriores para esta posição. Esta microestrutura apresenta $\mathrm{AF}$, ferrita bainitica $(\mathrm{BF})$ e bainita granular (GB). Shin [52] simulou um ciclo térmico de solda a uma temperatura de $1400{ }^{\circ} \mathrm{C}$ para um aço API $5 \mathrm{~L}$ grau $\mathrm{X} 80$ obtendo uma microestrutura composta de AF, BF, e GB. A GB grosseira é formada em taxas de resfriamento baixas. Ela contém algumas fases secundárias em forma de ilhas, com contornos não claramente definidos. Áreas bastante densas, onde a bainita granular $(\mathrm{GB})$ e ferrita-bainita $(\mathrm{BF})$ se encontram ao redor da $\mathrm{AF}$ estão misturadas aleatoriamente, e encontram-se na ZAC do aço [52].

\subsubsection{Posição 3 (orientação T-L) no metal de base}

Na Fig. 62 pode-se notar a presença de grão ferrítico poligonal, quase poligonal e perlita de cor preta colocado em seções não uniformes da matriz ferrítica. Pode-se notar a diferencia entre a Fig. 57 que pertence à posição 2 e esta figura, que pertence a posição 3 , onde o grão ferrítico e os agregados eutetóides da posição 2 são afetados pelo processo de laminação da chapa do tubo, o que não ocorre nesta posição. 


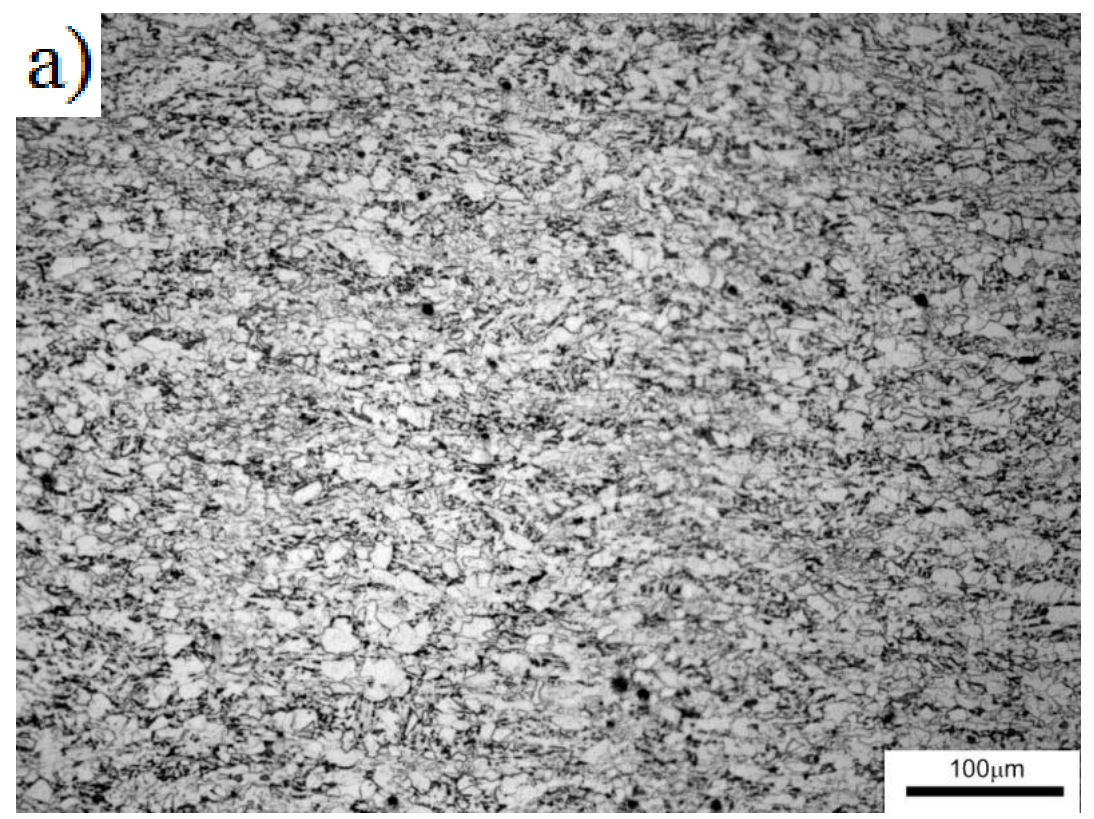

b)
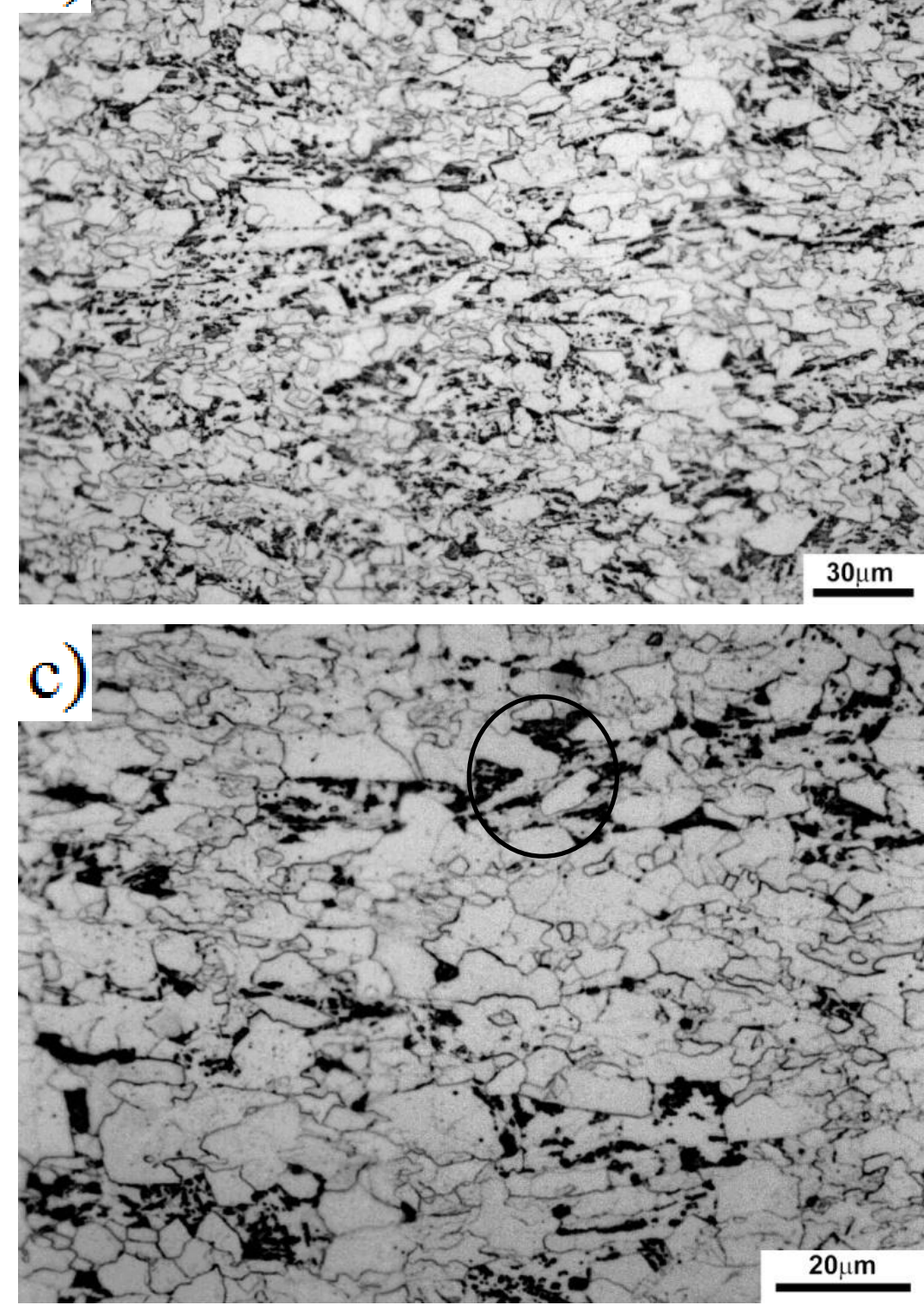

Figura 62. Microestrutura da posição 3 sem simulação; a)200X, b)500X e c)1000X. Ataque Nital 3\%. 


\subsubsection{Posição 3 (orientação T-L) simulação de um único passe}

Na Fig. 63 observa-se a presença de ferrita poligonal e ferrita quase poligonal. Nesta figura pode-se observar uma distribuição mais uniforme dos agregados eutetóides em relação à Fig. 62.

$\mathrm{Na}$ Fig. 64 observa-se a presença de ferrita poligonal, ferrita quase poligonal e uma distribuição mais uniforme dos agregados eutetóides em relação às Fig. 62 e 63.

$\mathrm{Na}$ Fig. 65 nota-se a presença de refino de grão em comparação com o material de base sem simulação e os ciclos térmicos de 650 e $800{ }^{\circ} \mathrm{C}$ para esta posição, como ocorreu para a Fig. 60. Tem-se a presença de ferrita poligonal e agregados eutetóides distribuídos na matriz ferrítica.

$\mathrm{Na}$ microestrutura encontrada na Fig. 66 tem-se a presença de ripas paralelas de ferrita e presume-se que se tem a presença de AF, GB e FB como no caso da Fig. 61. Pode-se ver na Fig. 66(c) o contorno de grão austenítico primário o qual é de um tamanho grosseiro em comparação dos ciclos térmicos de temperaturas inferiores e do material sem simulação. 

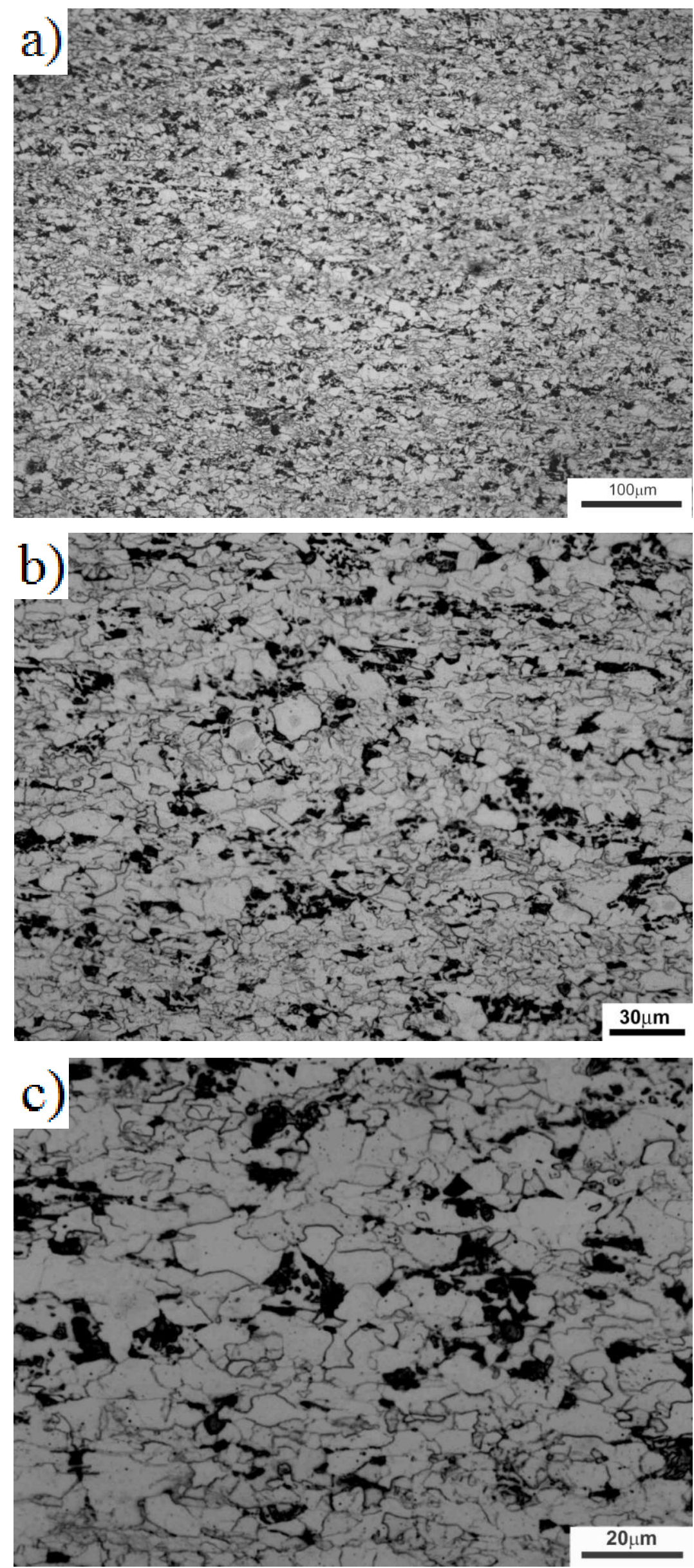

Figura 63. Microestrutura da posição $3 \mathrm{com}$ ciclo térmico de $650{ }^{\circ} \mathrm{C}$; a) $200 \mathrm{X}$, b) $500 \mathrm{X}$ e c) $1000 X$. Ataque Nital 3\%. 


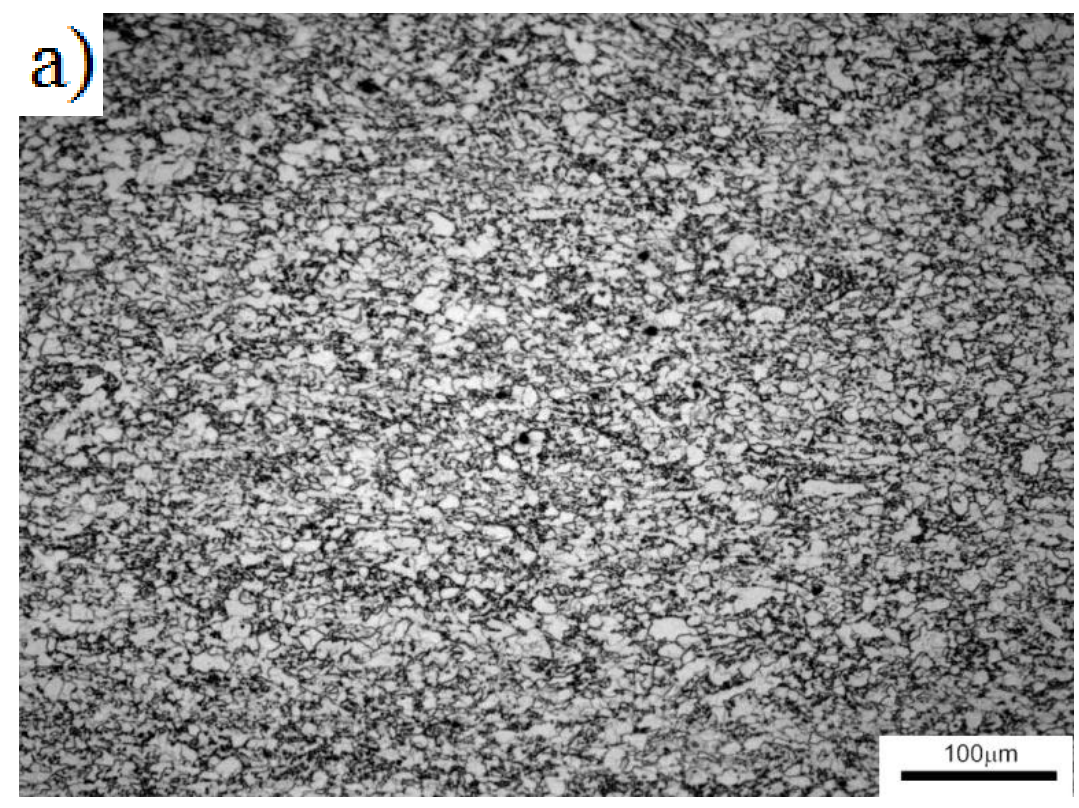

b)

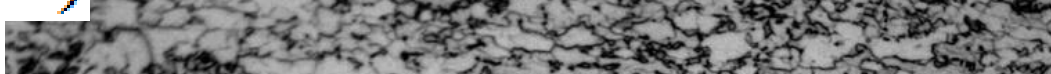

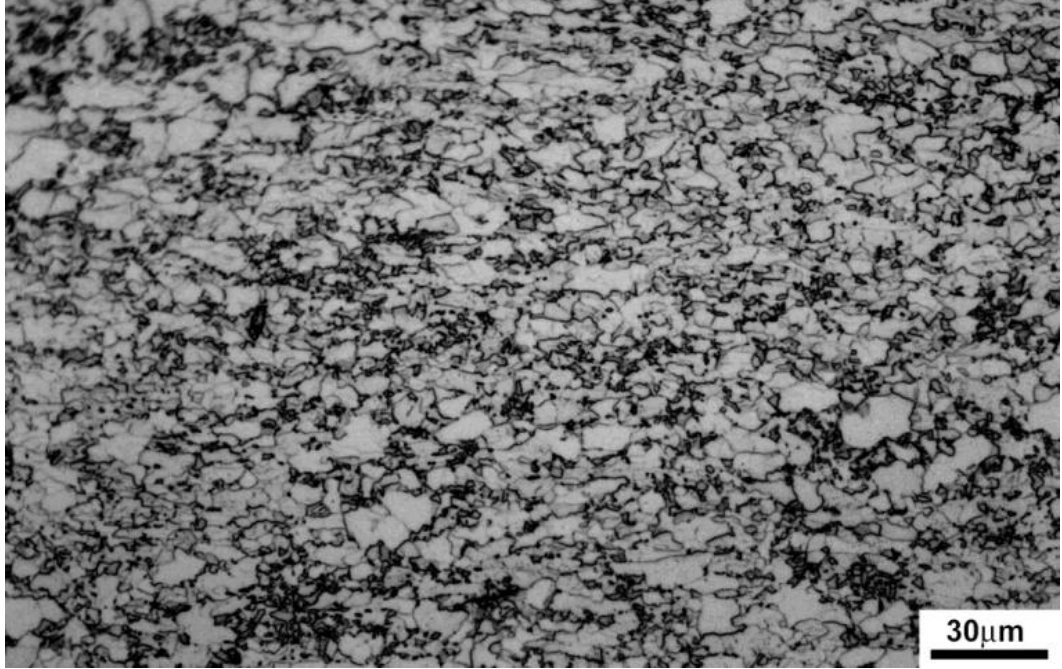

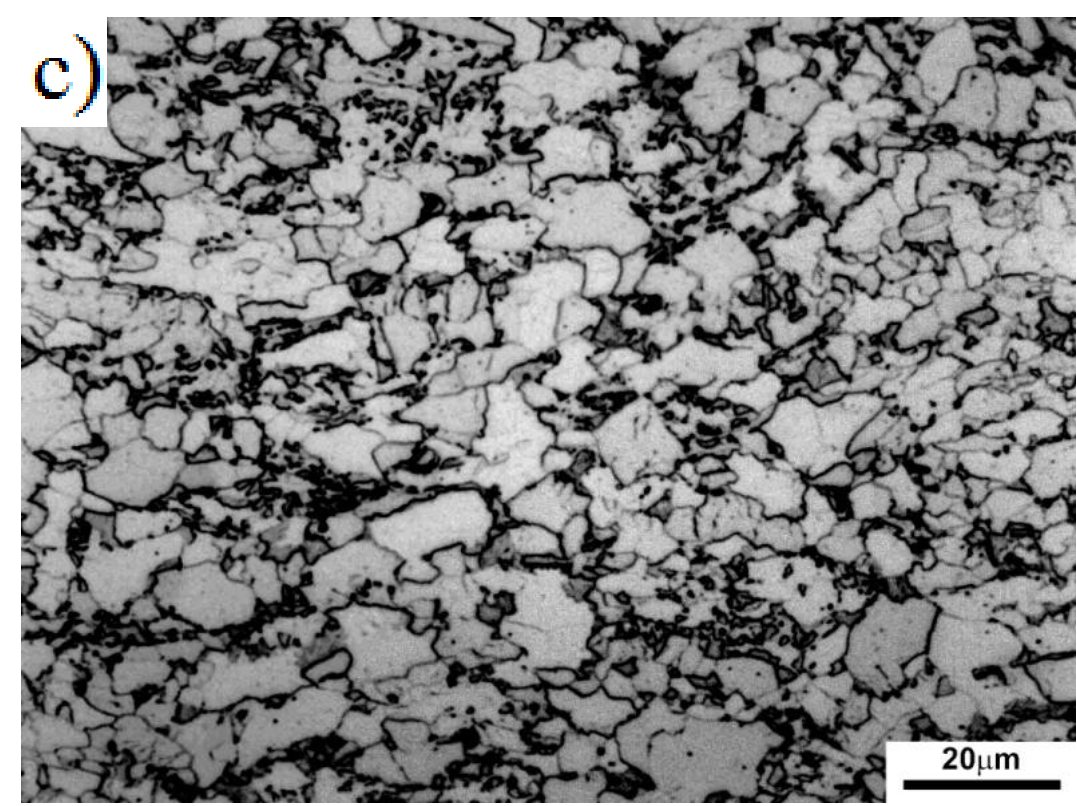

Figura 64. Microestrutura da posição $3 \mathrm{com}$ ciclo térmico de $800{ }^{\circ} \mathrm{C}$; a) $200 \mathrm{X}$, b) $500 \mathrm{X}$ e c) $1000 X$. Ataque Nital 3\%. 

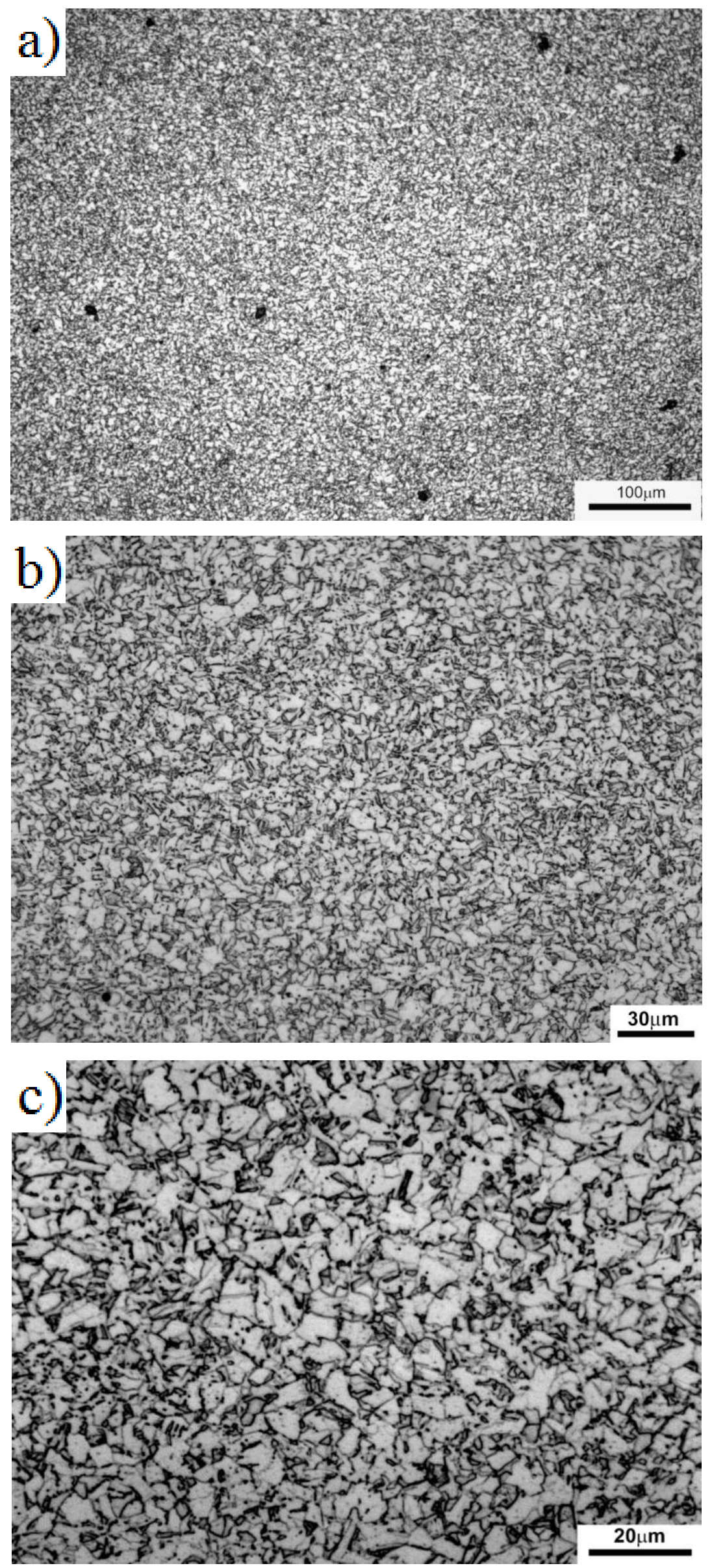

Figura 65. Microestrutura da posição $3 \mathrm{com}$ ciclo térmico de $950{ }^{\circ} \mathrm{C}$; a) $200 \mathrm{X}$, b) $500 \mathrm{X}$ e c) $1000 \mathrm{X}$. Ataque Nital $3 \%$. 

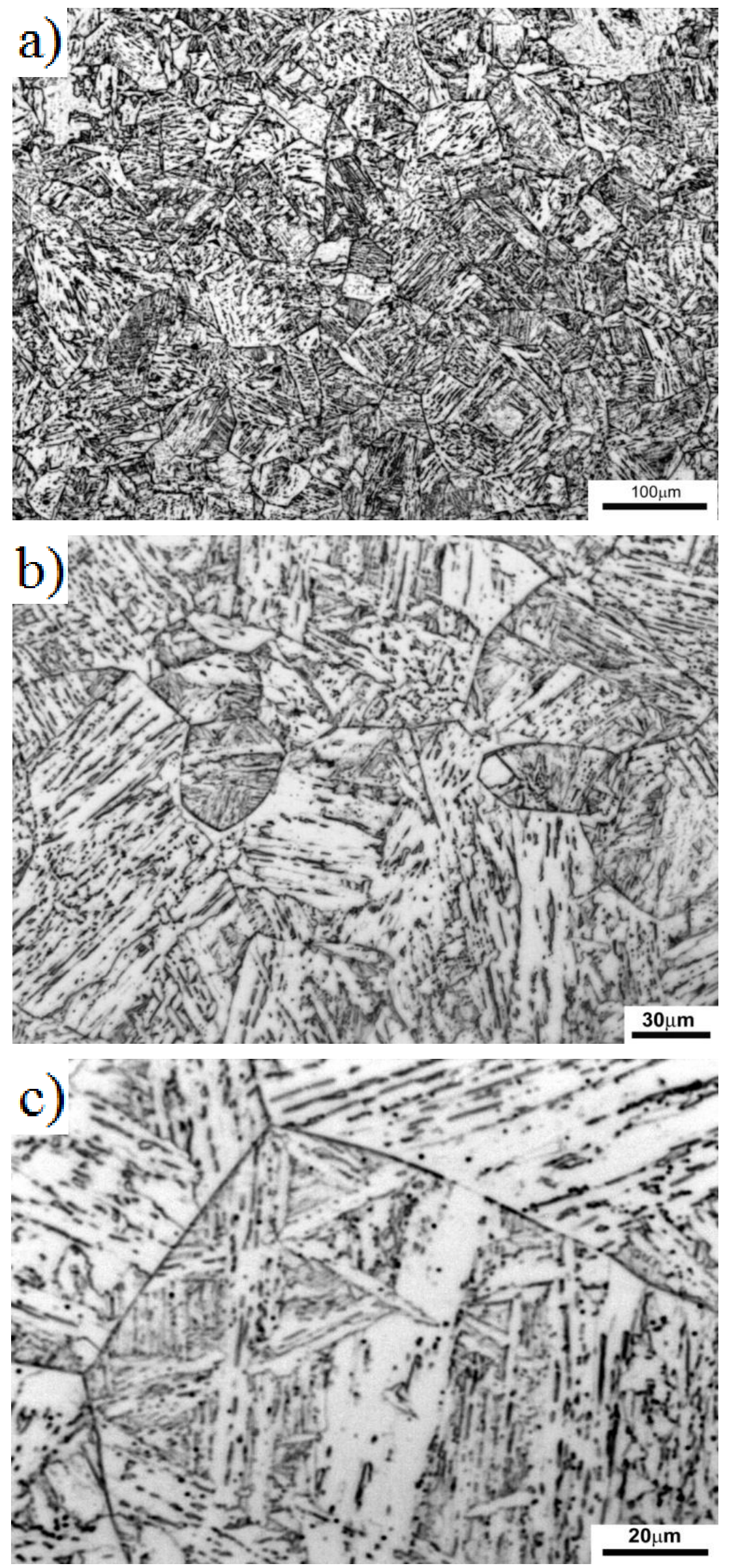

Figura 66. Microestrutura da posição $3 \mathrm{com}$ ciclo térmico de $1300{ }^{\circ} \mathrm{C}$; a) $200 \mathrm{X}$, b) $500 \mathrm{X}$ e c) $1000 X$. Ataque Nital 3\%. 


\subsubsection{Posição 1 (zona fundida) simulação multipasse}

Na Fig. 67(a) observa-se a presença de ferrita de contorno de grão de forma alongada e cor branca, na Fig. 67(b) a (1) ferrita de contorno de grão (GF), ferrita acicular (AF), (4) ferrita com segunda fase não alinhada $\operatorname{SF}(N A)$ e (6) ferrita com segunda fase alinhada (AC) e na Fig.67(c) a (2) ferrita acicular (AF). Na Fig. 68(a) observa-se a presença de (1) ferrita de contorno de grão (GF) e ferrita acicular (AF), na Fig. 68(b) ferrita de contorno de grão (GF), (2) ferrita acicular (AF) e na Fig. 68(c) ferrita de contorno de grão assinalado por uma seta preta, ferrita poligonal intragranular (PF), ferrita acicular (AF) e (5) perlita (P).

Estes constituintes formaram-se devido à soldagem que aconteceu devido ao processo submerged arc welding (SAW), os quais são distintos aos constituintes que apresenta o material de base sem solda.

Nestas micrografias (Fig. 67(a), (b), (c) e Fig. 68(a), (b), (c)) podemos ver que 0 tamanho de grão que se tem na maior parte da matriz ferrítica é pequeno, podendo isso ser explicado devido à temperatura de $950{ }^{\circ} \mathrm{C}$, que foi a primeira temperatura a ser simulada, como aconteceu para o ciclo térmico de um passe a $950{ }^{\circ} \mathrm{C}$ onde nesta temperatura o tamanho de grão é pequeno. Porem esta temperatura de $950{ }^{\circ} \mathrm{C}$ não afeto os constituintes como ferrita de contorno de grão ou a ferrita com segunda fase alinhada como pode-se observar nas Fig. $55(a)$ e $55(b)$. 

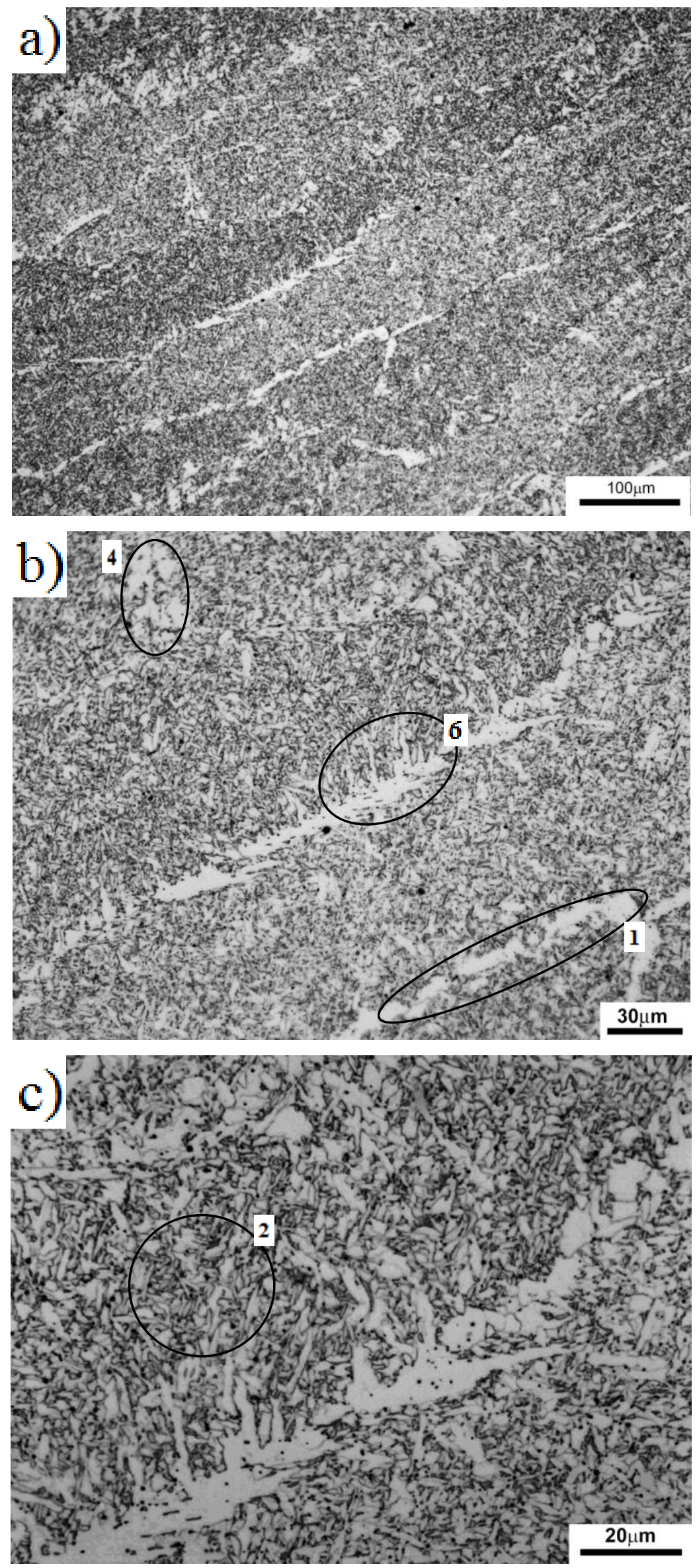

Figura 67. Microestrutura da posição $1 \mathrm{com}$ ciclo térmico multipasse de $950-800{ }^{\circ} \mathrm{C}$; (1) ferrita de contorno de grão (GF) (2) ferrita acicular (AF), (4) ferrita com segunda fase não alinhada $\mathrm{SF}(\mathrm{NA})$ e (6) ferrita com segunda fase alinhada (AC). a)200X, b) $500 \mathrm{X}$ e c) $1000 \mathrm{X}$. Ataque Nital $3 \%$. 

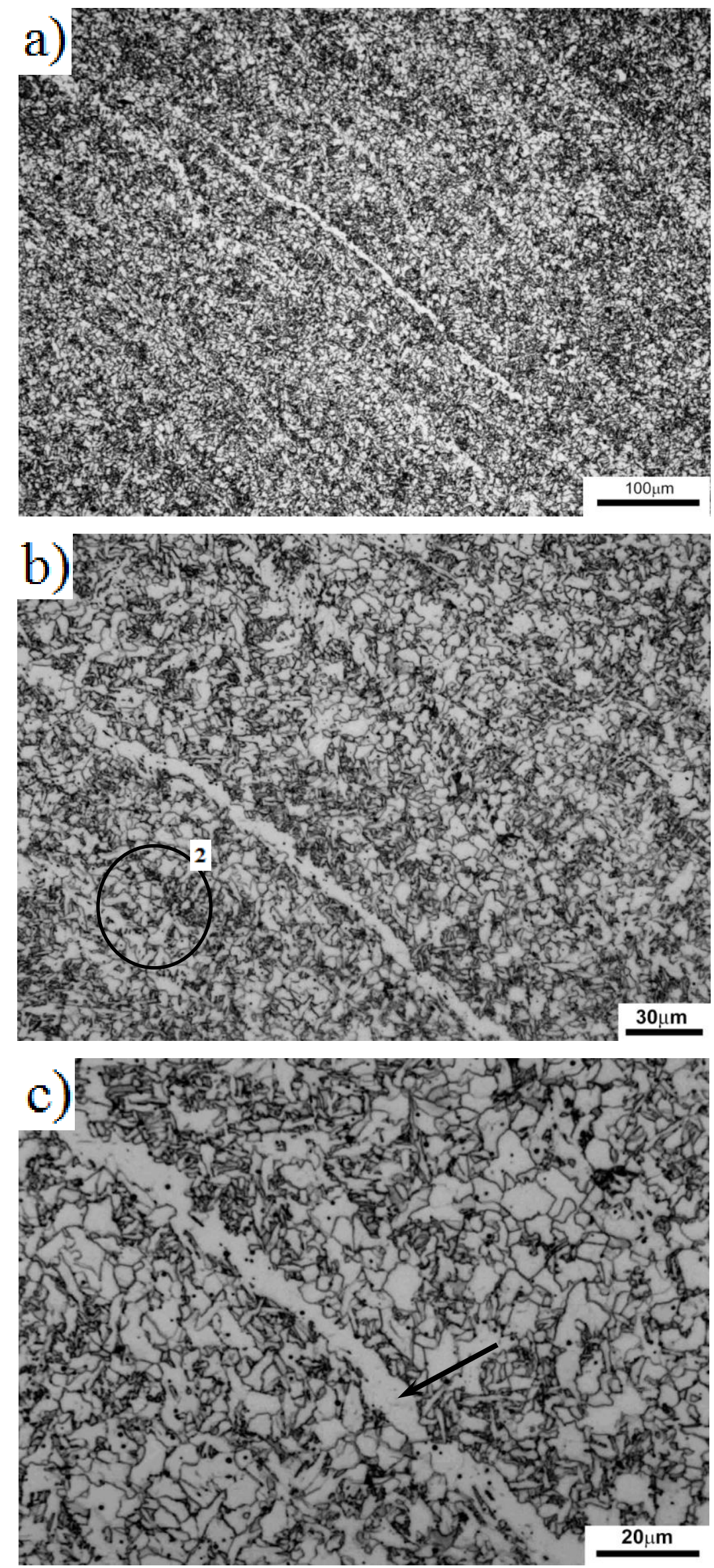

Figura 68. Microestrutura da posição 1 com ciclo térmico multipasse de 950-800-650 ${ }^{\circ} \mathrm{C}$; (1) ferrita de contorno de grão (GF), (2) ferrita acicular (AF), ferrita poligonal intragranular (PF) e perlita (P). a)200X, b)500X e c)1000X. Ataque Nital 3\%. 


\subsubsection{Posição 2 (orientação L-T) e Posição 3 (orientação T-L) simulação multipasse}

As Fig. 69(a), (b), (c) e Fig. 70(a), (b), (c) são as micrografias da posição 2, com ciclos térmicos de dois passes e três passes respectivamente, estas figuras apresentam ferrita poligonal de grão fino com perlita distribuída na matriz ferrítica.

Estas microestruturas são parecidas à microestrutura que apresento o ciclo térmico de um passe a $950{ }^{\circ} \mathrm{C}$ nas posições 2 e 3 como pode-se observar nas Fig. 65(a), (b), (c) e 60(a), (b), (c). As Fig. 71(a), (b), (c) e Fig. 72(a), (b), (c) que são as micrografias da posição 3 , de dois e três ciclos multipasse respectivamente, também apresentam as mesmas características e as mesmas fases das Fig. 69(a), (b), (c) e Fig. 70(a), (b), (c).

As características destas micrografias aparentemente são independentes da quantidade de simulações que se fez no material de base, por exemplo, a microestrutura do material de base na posição 2 com ciclos térmicos multipasse de 950-800 é quase idêntico que o material com ciclos térmicos multipasse de $950-800-650{ }^{\circ} \mathrm{C}$. 


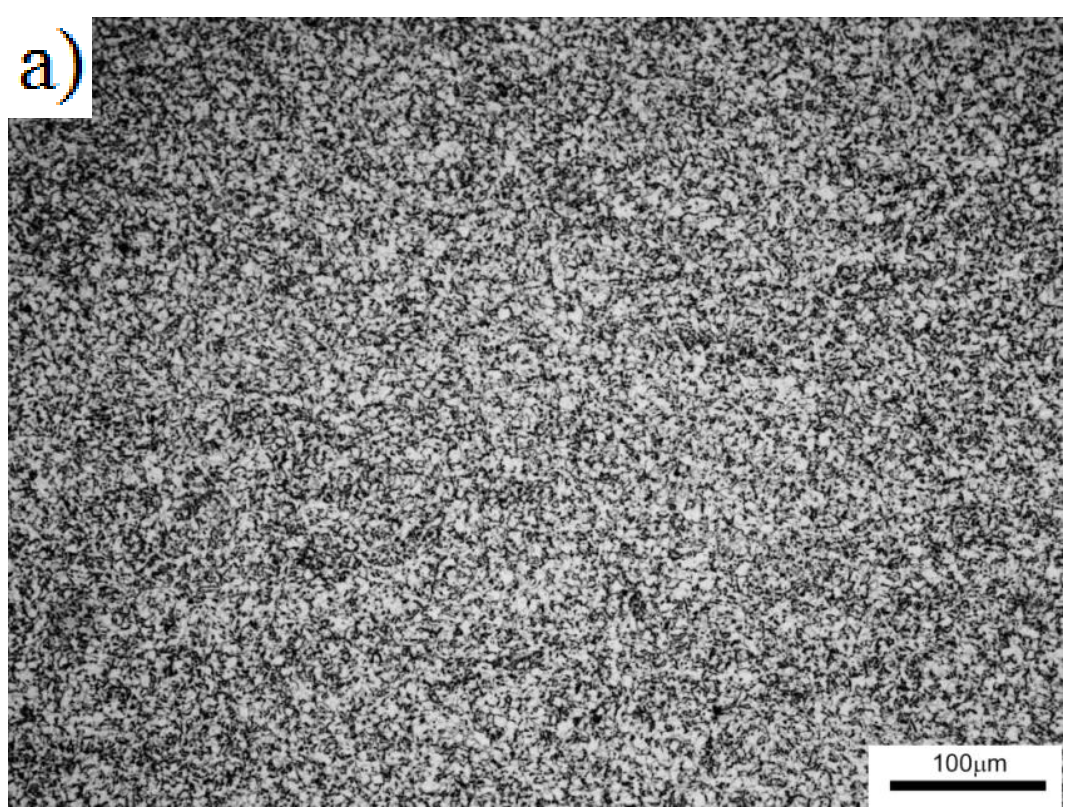

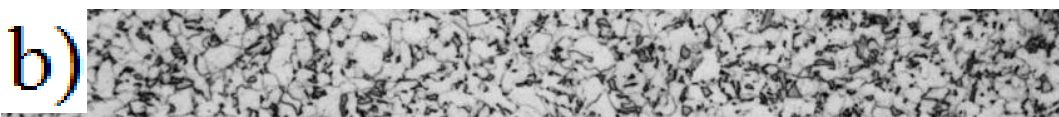
Whant

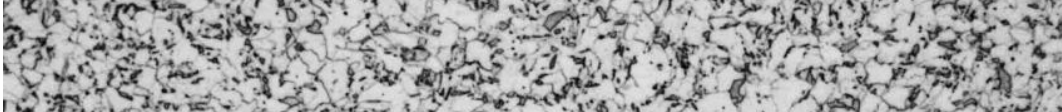
(5)

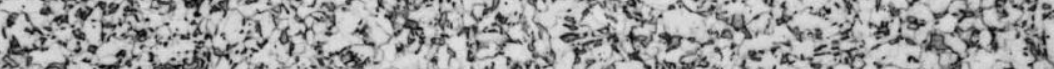

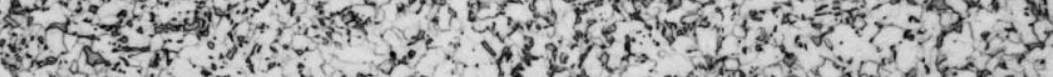
2. 0 a

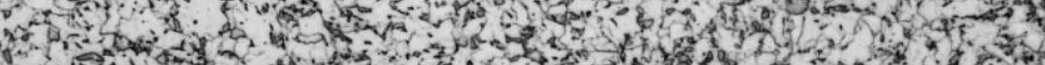

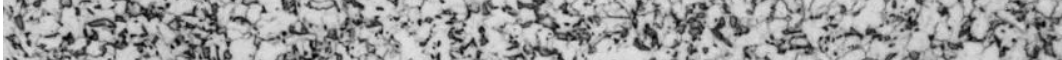

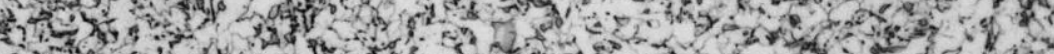

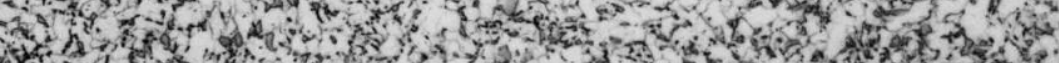

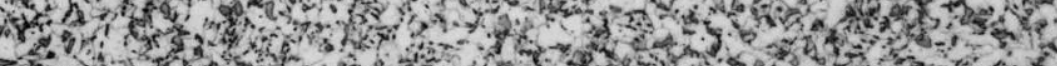

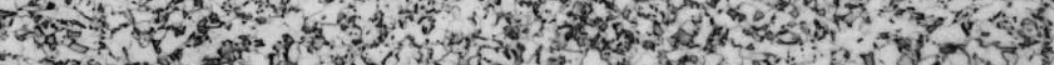

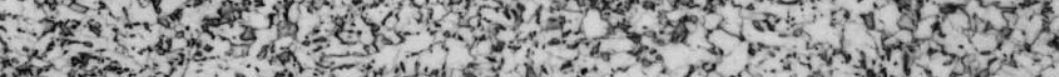
P.

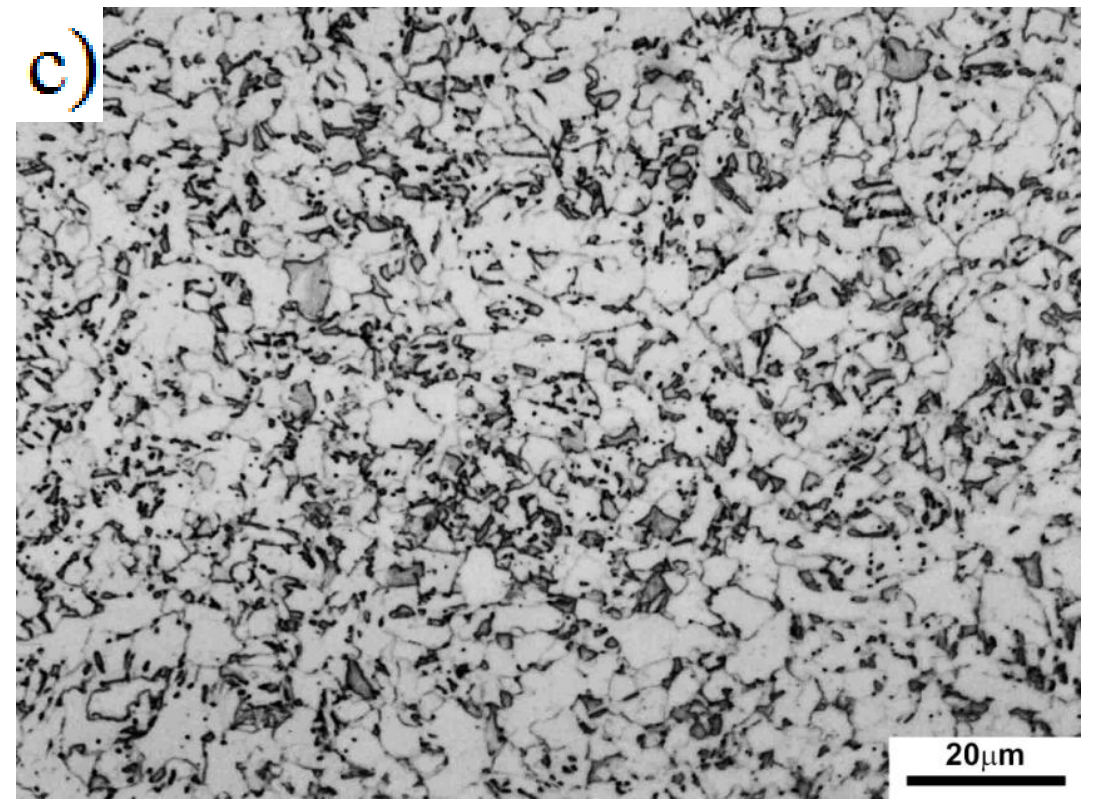

Figura 69. Microestrutura da posição 2 com ciclo térmico multipasse de $950-800{ }^{\circ} \mathrm{C}$; a)200X, b) $500 \mathrm{X}$ e c) $1000 \mathrm{X}$. Ataque Nital $3 \%$. 


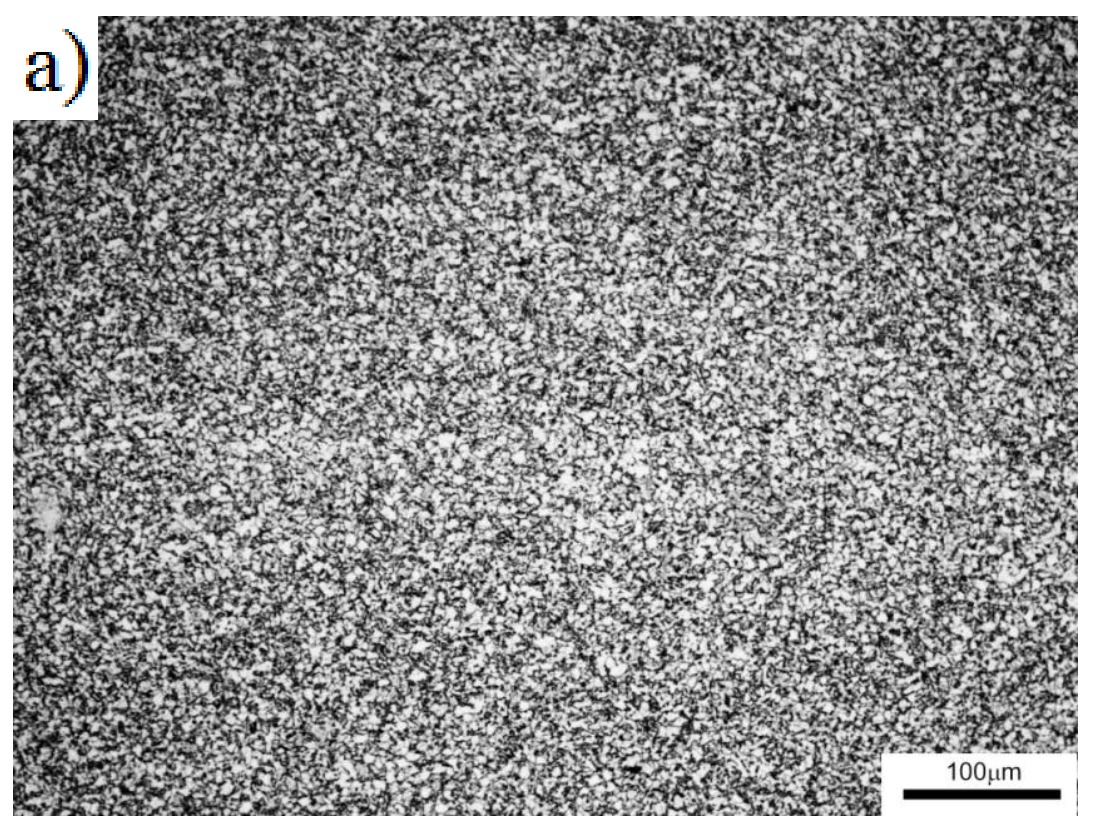

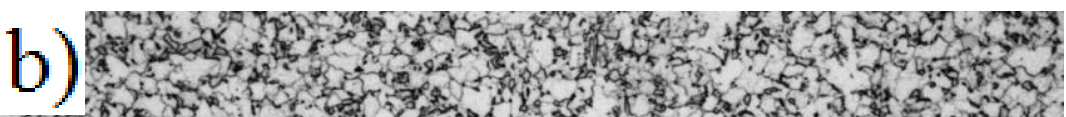

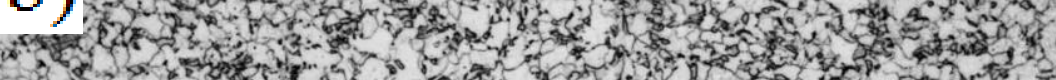

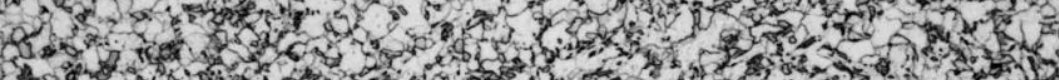

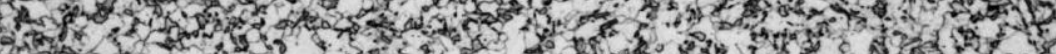

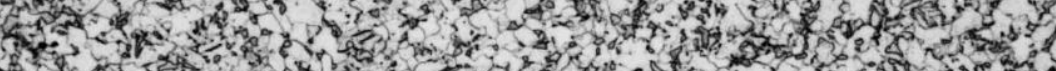

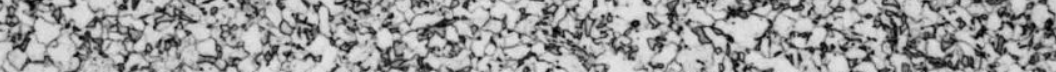

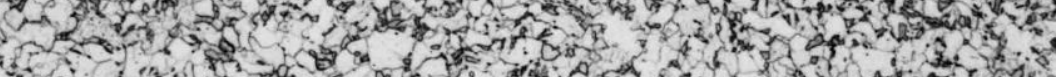

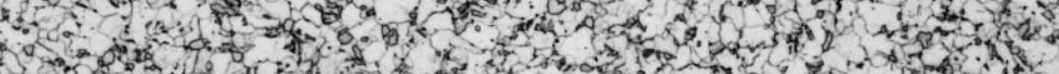

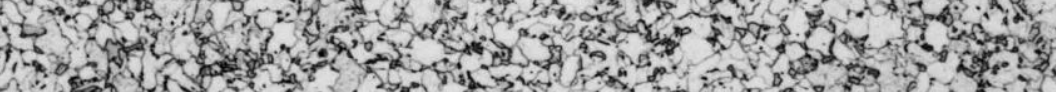

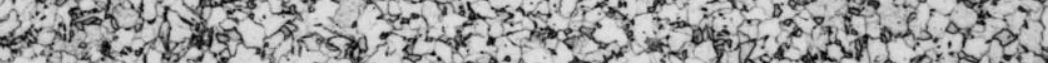

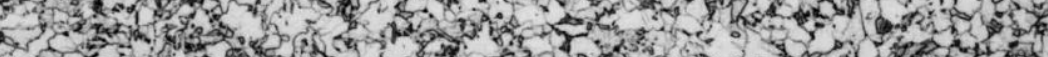

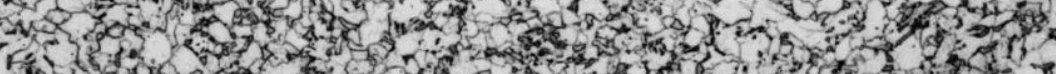

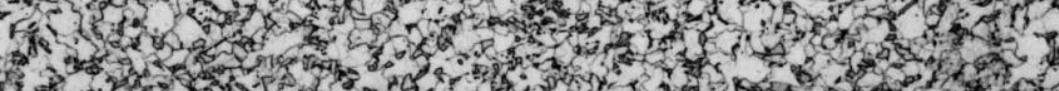

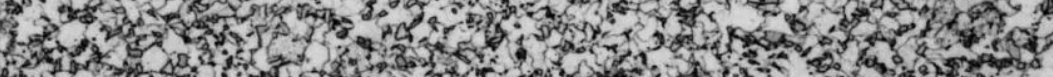

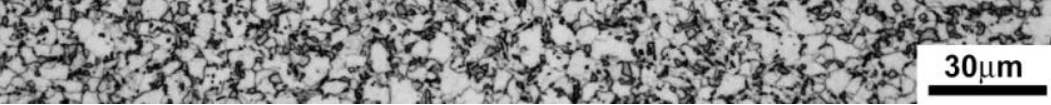

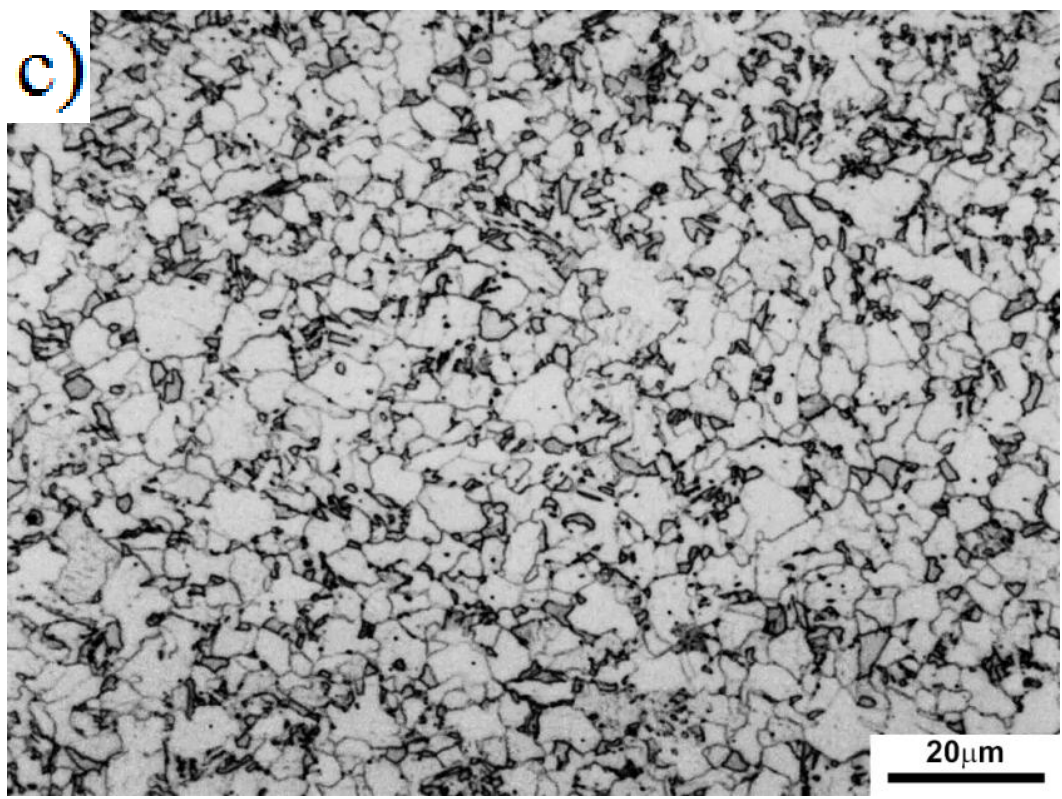

Figura 70. Microestrutura da posição 2 com ciclo térmico multipasse de $950-800-650{ }^{\circ} \mathrm{C}$; a)200X, b)500X e c)1000X. Ataque Nital 3\%. 

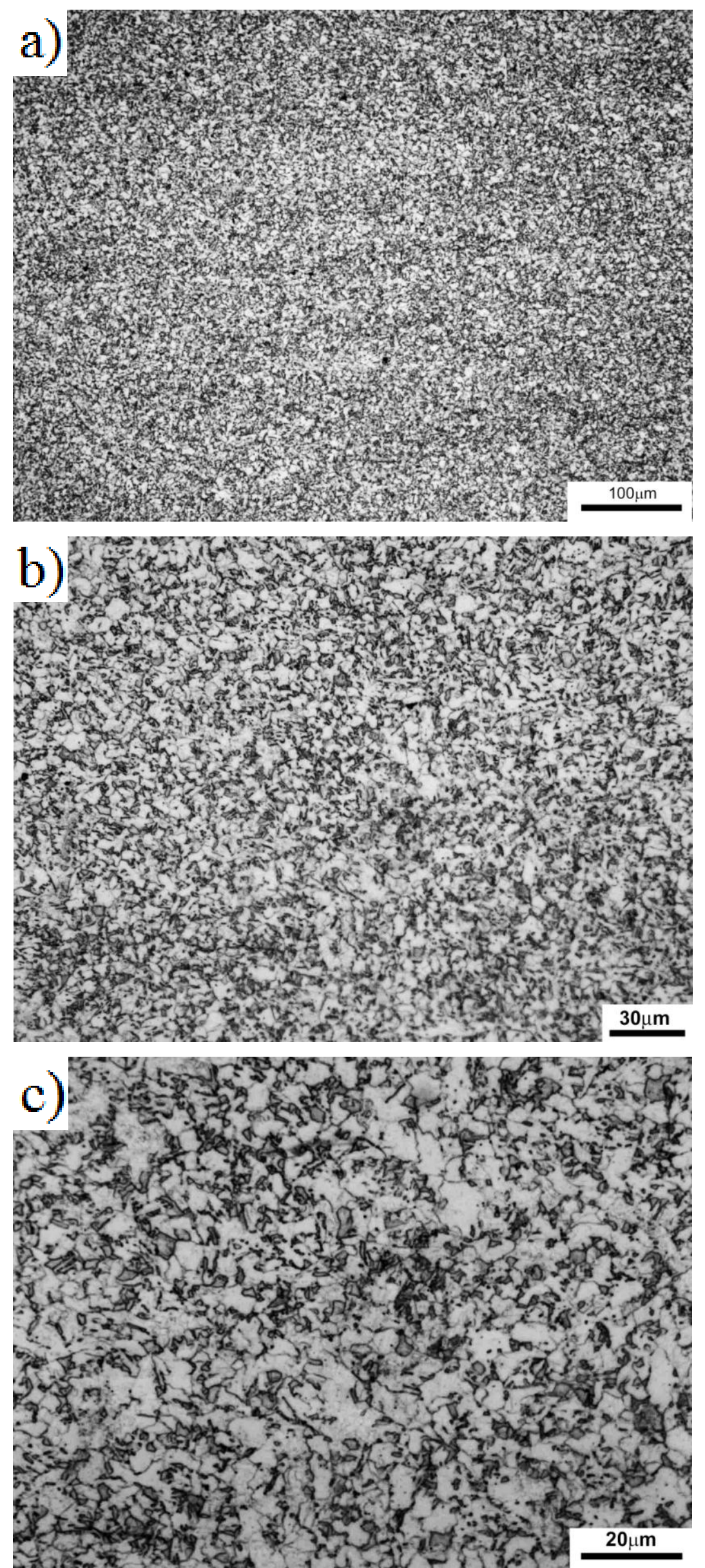

Figura 71. Microestrutura da posição 3 com ciclo térmico multipasse de 950-800 ${ }^{\circ} \mathrm{C}$; a)200X, b) $500 \mathrm{X}$ e c) $1000 \mathrm{X}$. Ataque Nital 3\%. 

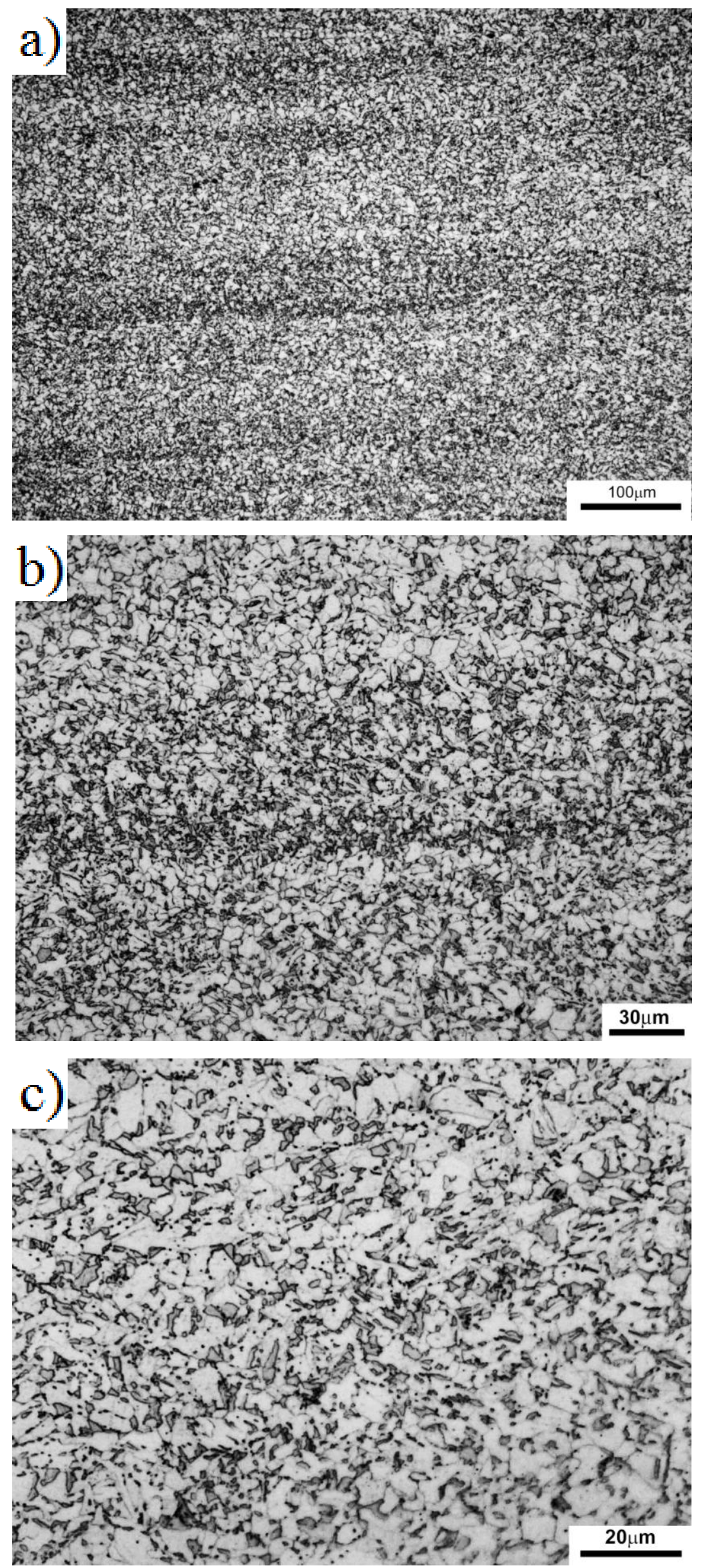

Figura 72. Microestrutura da posição 3 com ciclo térmico multipasse de 950-800-650 ${ }^{0} \mathrm{C}$; a)200X, b)500X e c)1000X. Ataque Nital 3\%. 


\subsubsection{Microscopia Eletrônica}

Nesta seção caracterizou-se a microestrutura do material no microscópio eletrônico de varredura para observar em detalhe os agregados eutetóides e 0 microconstituinte MA.

\subsubsection{Posição 1 (zona fundida)}

Na Fig. 73 pode-se notra a presença de uma matriz de ferrita acicular, ferrita de contorno de grão (GF) e constituintes MA finos distribuidos na matriz ferrítica.
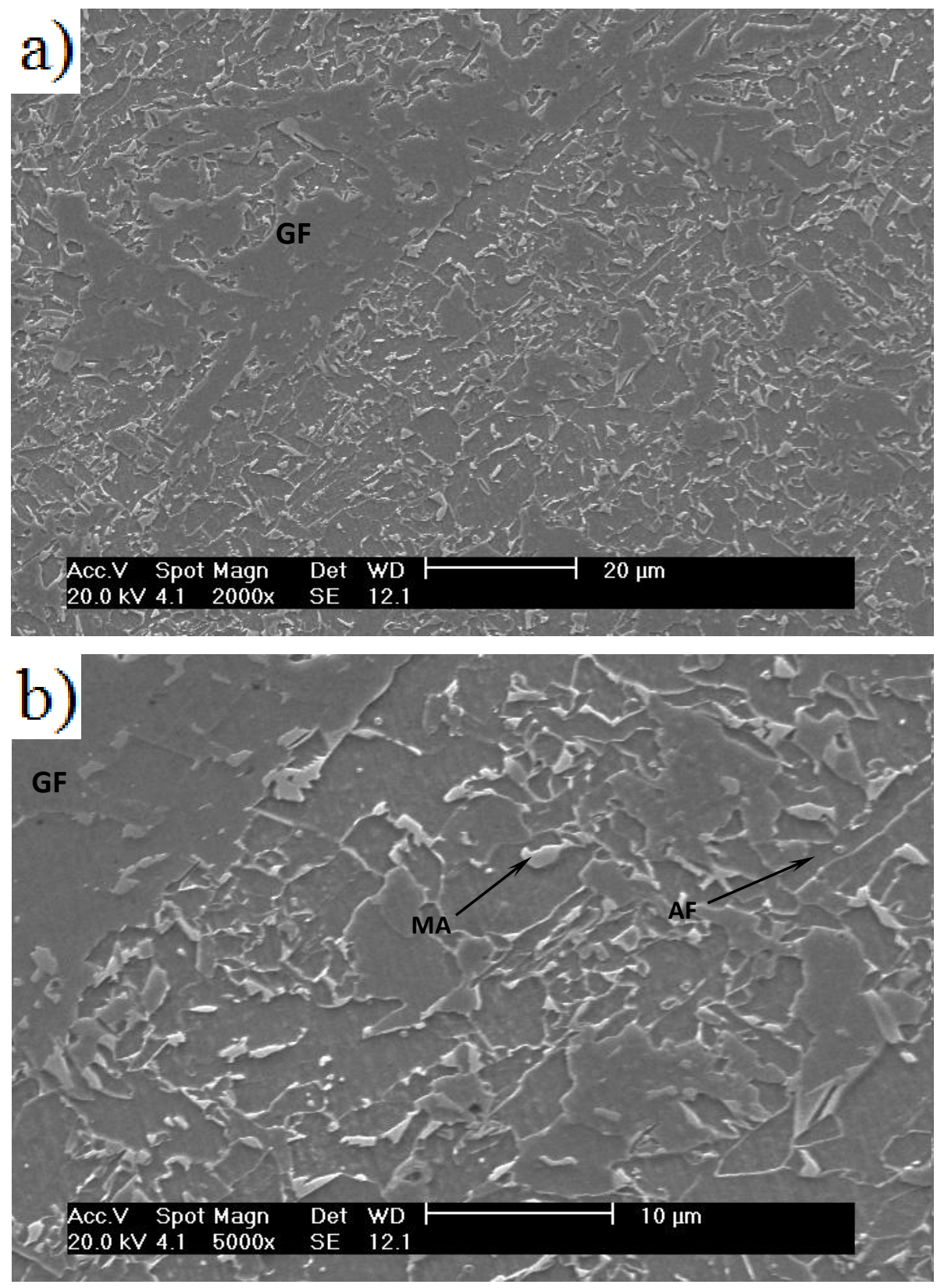

Figura 73. Microestrutura da posição 1 do material sem simulação em a)2000X e b) 5000X. Ataque Nital $3 \%$. 


\subsubsection{Posição 1 simulação de um único passe}

$\mathrm{Na}$ Fig. 74 pode-se notar a presença de uma matriz de ferrita acicular e microconstituintes MA finos distribuidos na matriz ferrítica. Pode-se observar na circunferência como a ferrita acicular cresce a partir possivelmente de uma inclusão não metalica na microestrutura, similar a Fig. 52(c) tambem assinalado por uma circunferencia preta na parte inferior.
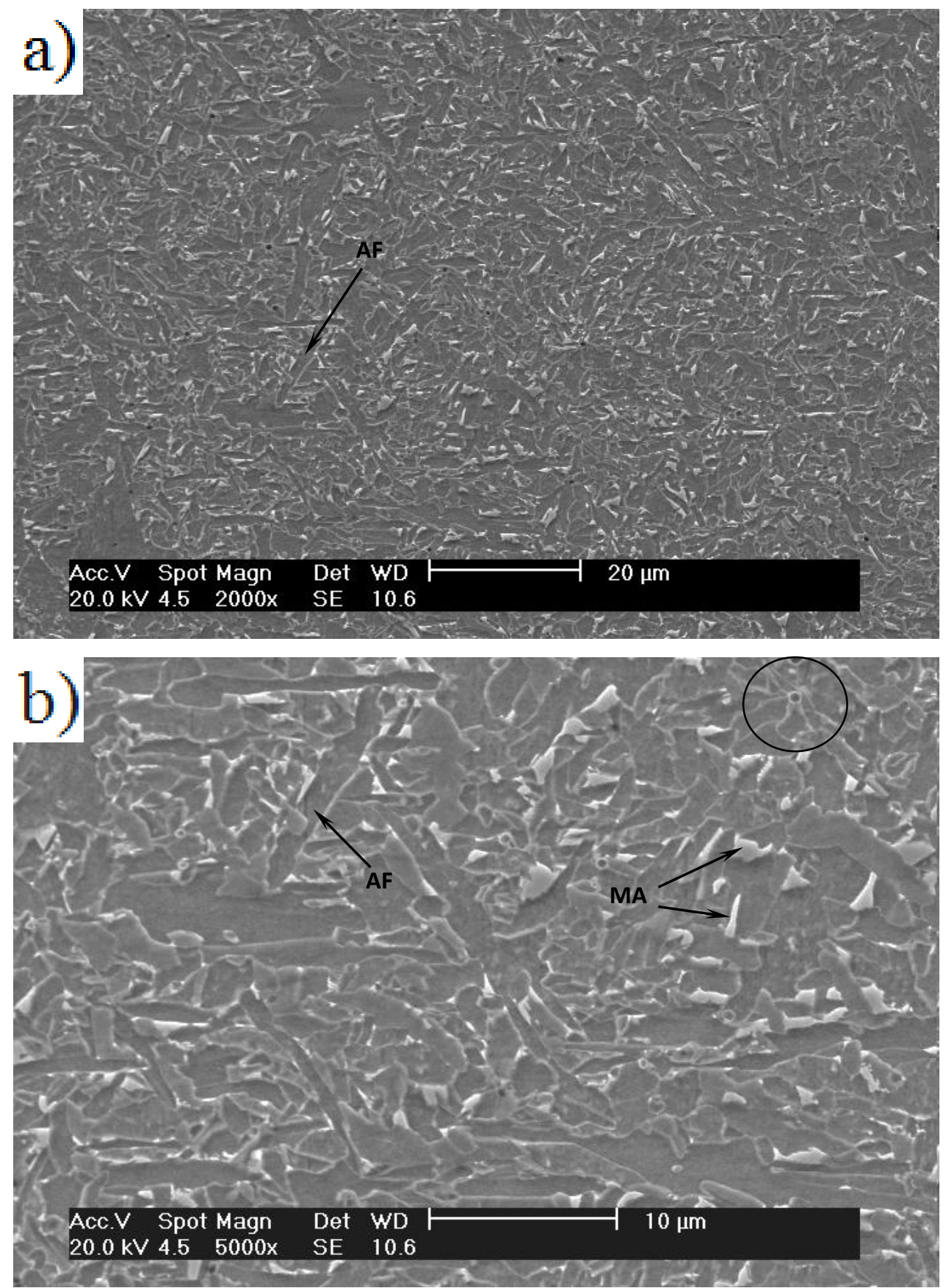

Figura 74. Microestrutura da posição 1 do material com ciclo térmico de $650^{\circ} \mathrm{C}$ em a) $2000 \mathrm{X}$ e b) $5000 X$. Ataque Nital $3 \%$. 

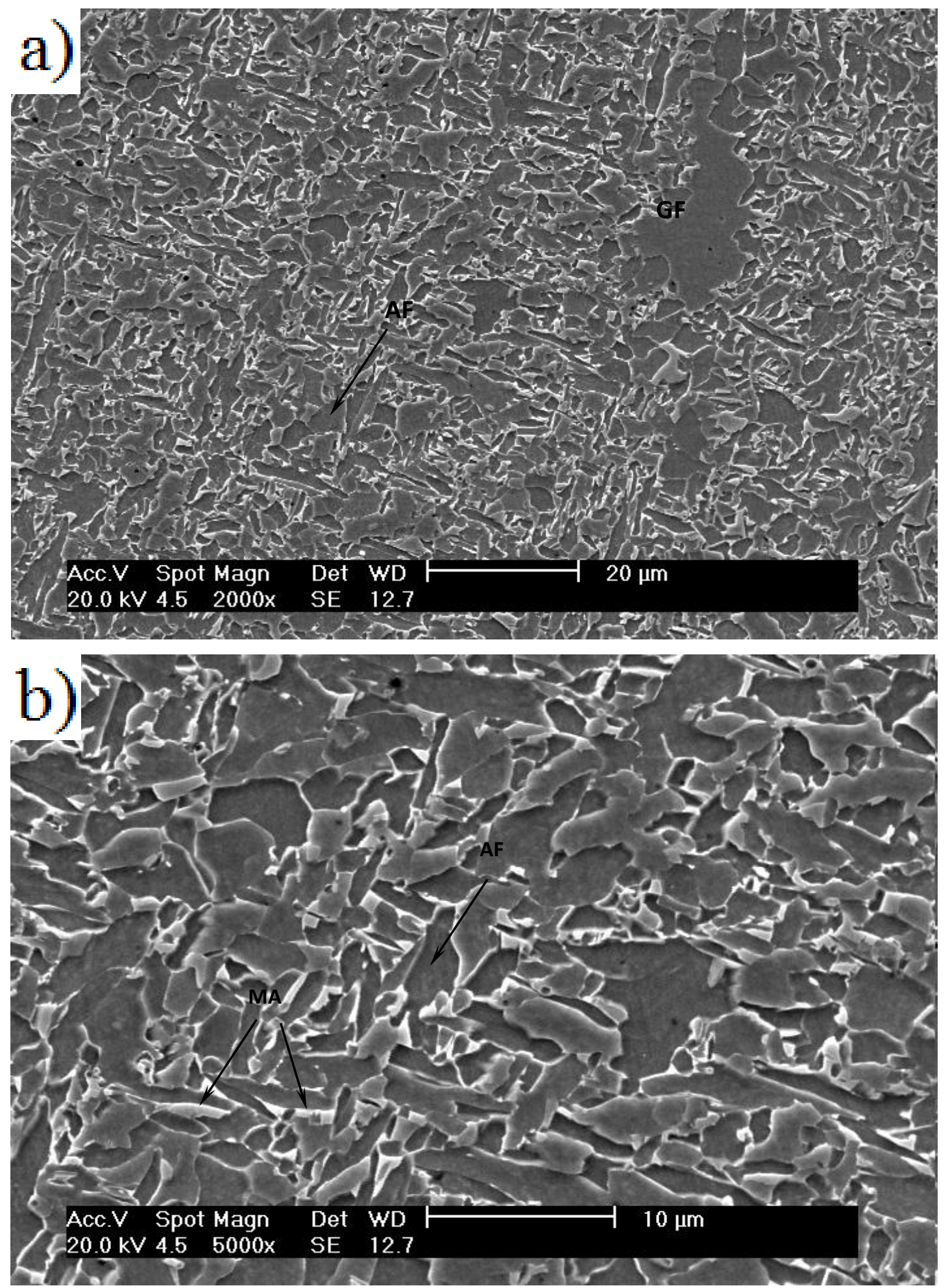

Figura 75. Microestrutura da posição 1 do material com ciclo térmico de $800^{\circ} \mathrm{C}$ em a) $2000 \mathrm{X}$ e b) $5000 X$. Ataque Nital $3 \%$.

$\mathrm{Na}$ Fig. 75 pode-se notar a presença de uma matriz de ferrita acicular (AF), ferrita de contorno de grão (GF) e microconstituintes MA finos, distribuídos na matriz ferrítica. 

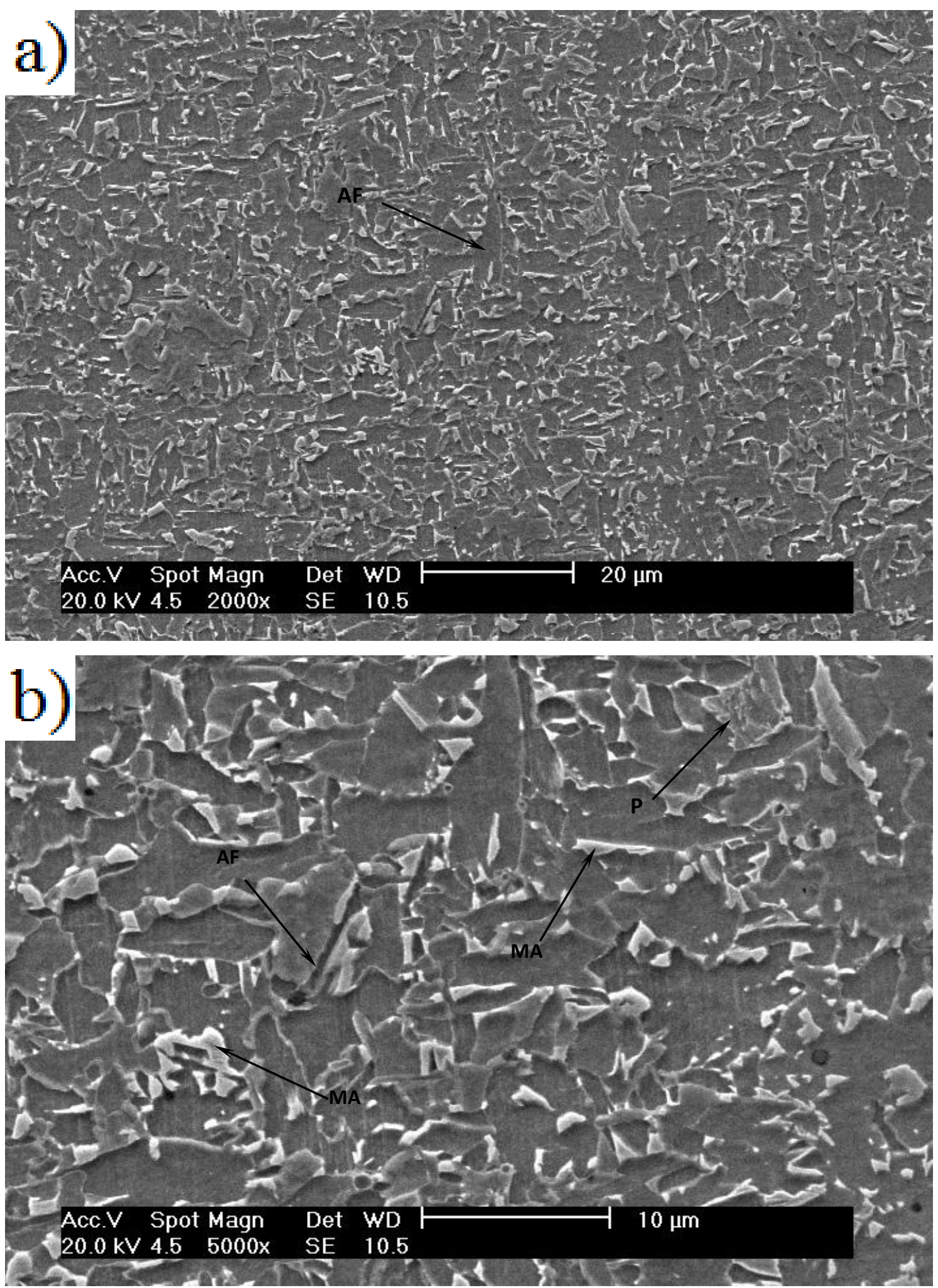

Figura 76. Microestrutura da posição 1 do material com ciclo térmico de $950^{\circ} \mathrm{C}$ em a) $2000 \mathrm{X} \mathrm{e}$ b) $5000 \mathrm{X}$. Ataque Nital $3 \%$.

Na Fig. 76 pode-se notar a presença de uma matriz de ferrita acicular, ferrita de contorno de grão (GF), perlita (P) e microconstituintes MA finos distribuidos na matriz ferrítica. 

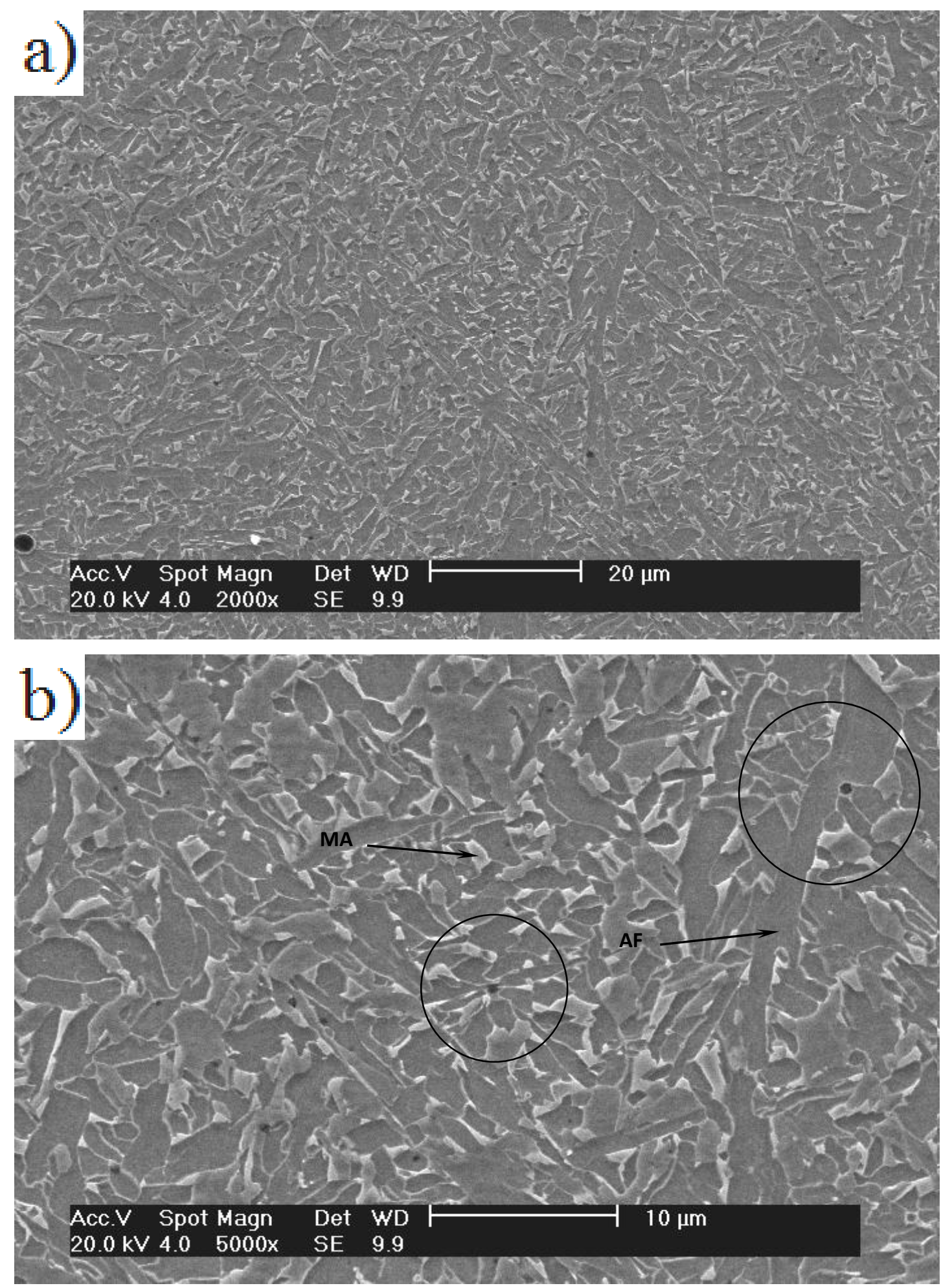

Figura 77. Microestrutura da posição 1 do material com ciclo térmico de $1300^{\circ} \mathrm{C}$ em a) $2000 \mathrm{X}$ e b) 5000X. Ataque Nital 3\%.

$\mathrm{Na}$ Fig. 77 pode-se notar a presença de uma matriz de ferrita acicular e microconstituintes MA finos distribuidos na matriz ferrítica. Pode-se observar nas circunferências pretas como a ferrita acicular cresce a partir de um defeito na microestrutura igual como na Fig. 52 e Fig 74. 


\subsubsection{Posição 2 (orientação L-T) no metal de base}
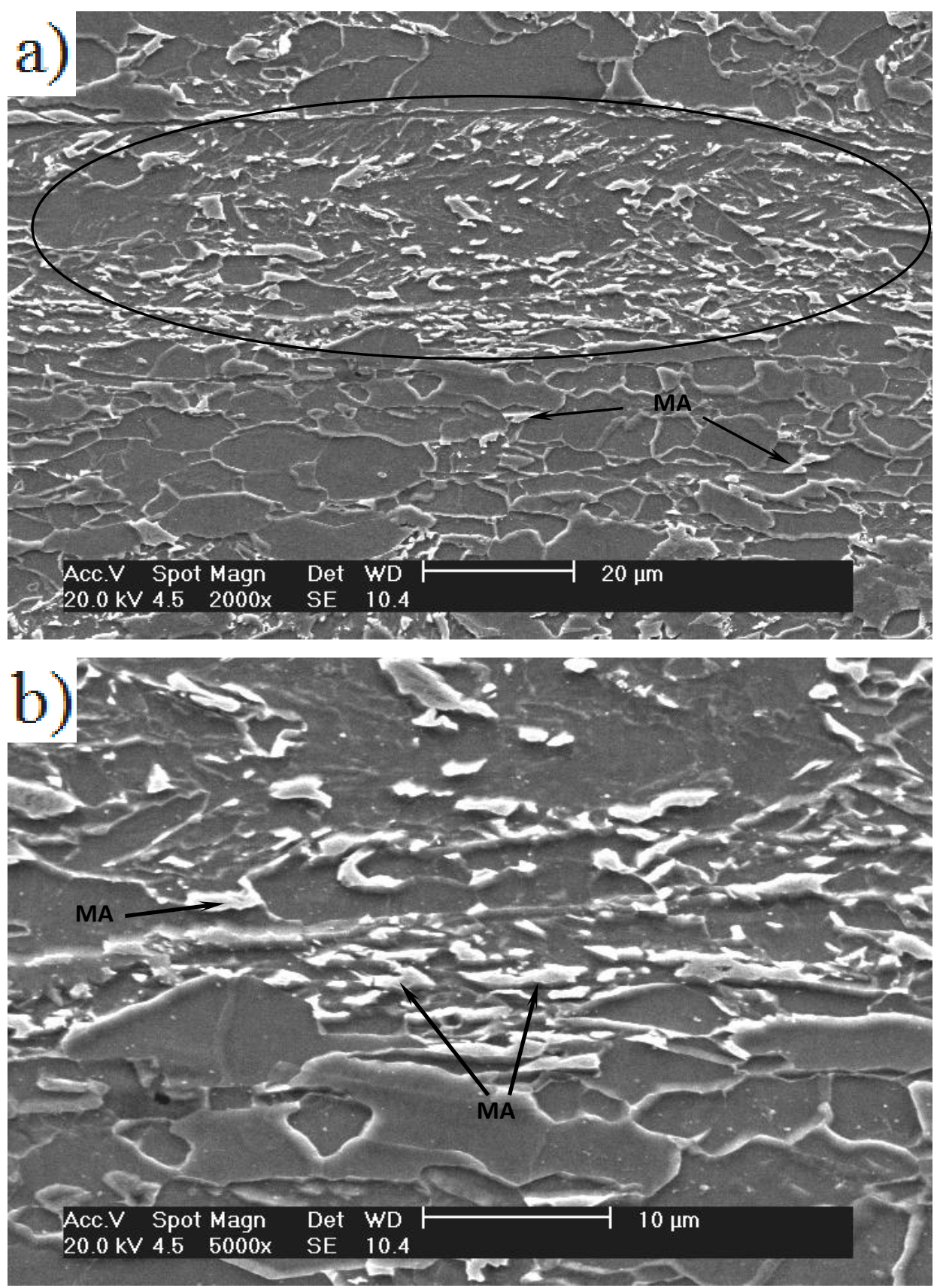

Figura 78. Microestrutura da posição 2 do material sem simulação em a) $2000 \mathrm{X}$ e b) 5000X. Ataque Nital 3\%.

Na Fig. 78(a) tem-se a presença de grãos de ferrita de grãos alongados, ferrita poligonal, ferrita quase poligonal e ferrita granular com tamanho herterogeneo de cor cinza escuro, também se tem a AF de menor tamanho. Na seção assinalda por uma elipse tem-se o bandeamento que ocorreu devido ao processo termomecânico na fabricação do aço. Este bandeamento contem agregados eutetoídes e o constituinte MA, originado de grãos de austenita 
deformada na direção de laminação [24], e perlita. Fora da zona de bandeamento pode-se notar que os microcostituintes estão em menor proporção. Segundo Ramirez o constituinte MA, fica nos contornos de grão e sempre associado à bainita, e precipita apartir de austenita enriquecida em carbono rejeitado pela ferrita formada inicialmente [24]. A microestrutura encontrada por Shin [53] num aço API $5 \mathrm{~L}$ grau X80 era composta de FP, AF, GB com a presença de pequenas quantidades de MA e cementita e $M$.

\subsubsection{Posição 2 (orientação L-T) simulação de um único passe}
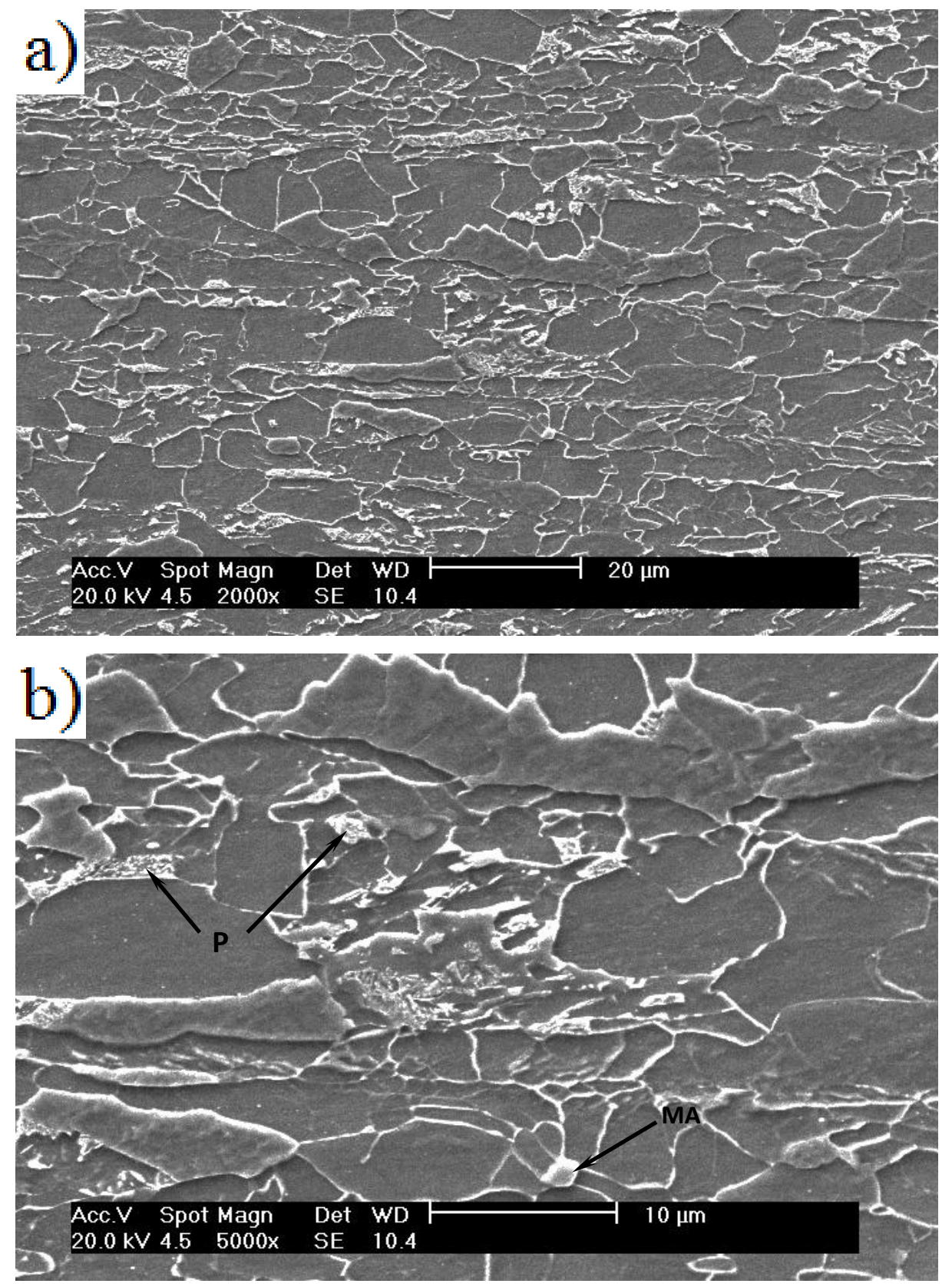

Figura 79. Microestrutura da posição 2 do material com ciclo térmico de $650{ }^{\circ} \mathrm{C}$ em a) $2000 \mathrm{X}$ e b) $5000 X$. Ataque Nital $3 \%$. 
$\mathrm{Na}$ Fig. 79(a) observa-se a ferrita poligonal e quase poligonal de cor cinza escuro, perlita e uma melhor distribuição dos agregados eutetoídes. Na Fig. 79(b) pode-se observar que, para este ciclo térmico, se tem pouca e quase nenhuma presença de microconstituintes MA, com grande presença de regiões contendo agregados de ferrita e carbonetos (bainita e perlita fina) [24]. Yu [46] em seu trabalho explica que a martensita é um produto da transformação austenítica acima da temperatura $\mathrm{A}_{1}$, e a temperatura pico de $650{ }^{\circ} \mathrm{C}$ abaixo da $A_{1}$ não apresenta quantidade significativa de MA.
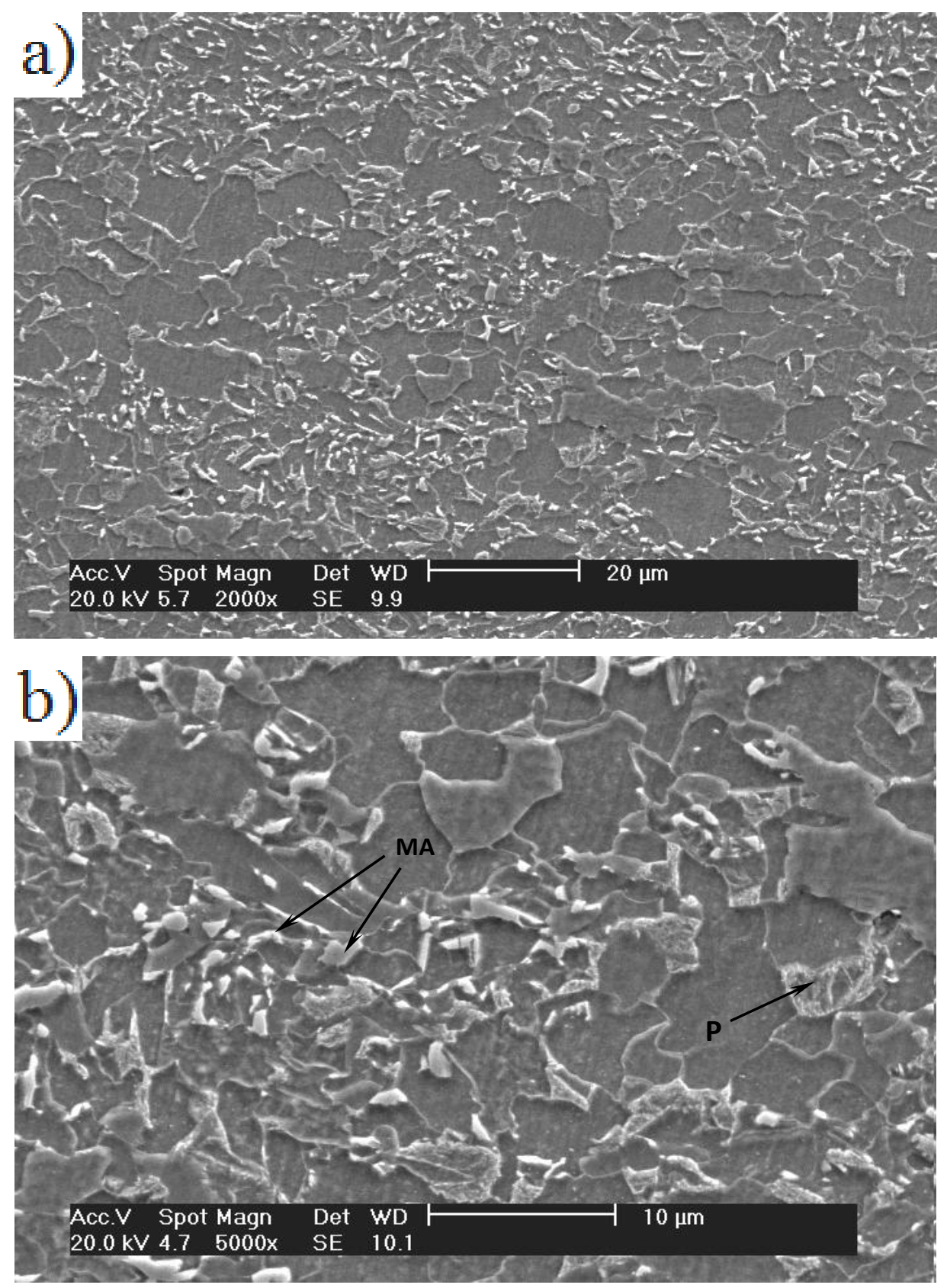

Figura 80. Microestrutura da posição 2 do material com ciclo térmico de $800{ }^{\circ} \mathrm{C}$ em a) $2000 \mathrm{X} \mathrm{e}$ b) $5000 X$. Ataque Nital $3 \%$. 
Na Fig. 80 observa-se a ferrita poligonal de cor cinza escuro, vê-se também a presença de constituintes MA de tamanho menor em comparaçao com os MA do material de base sem simulação. Pode-se supor que este comportamento é devido ao tamanho de grão menor austenitico que não teve tempo de crescer durante o aquecimento [46]. Também nota-se a presença de perlita $(P)$.
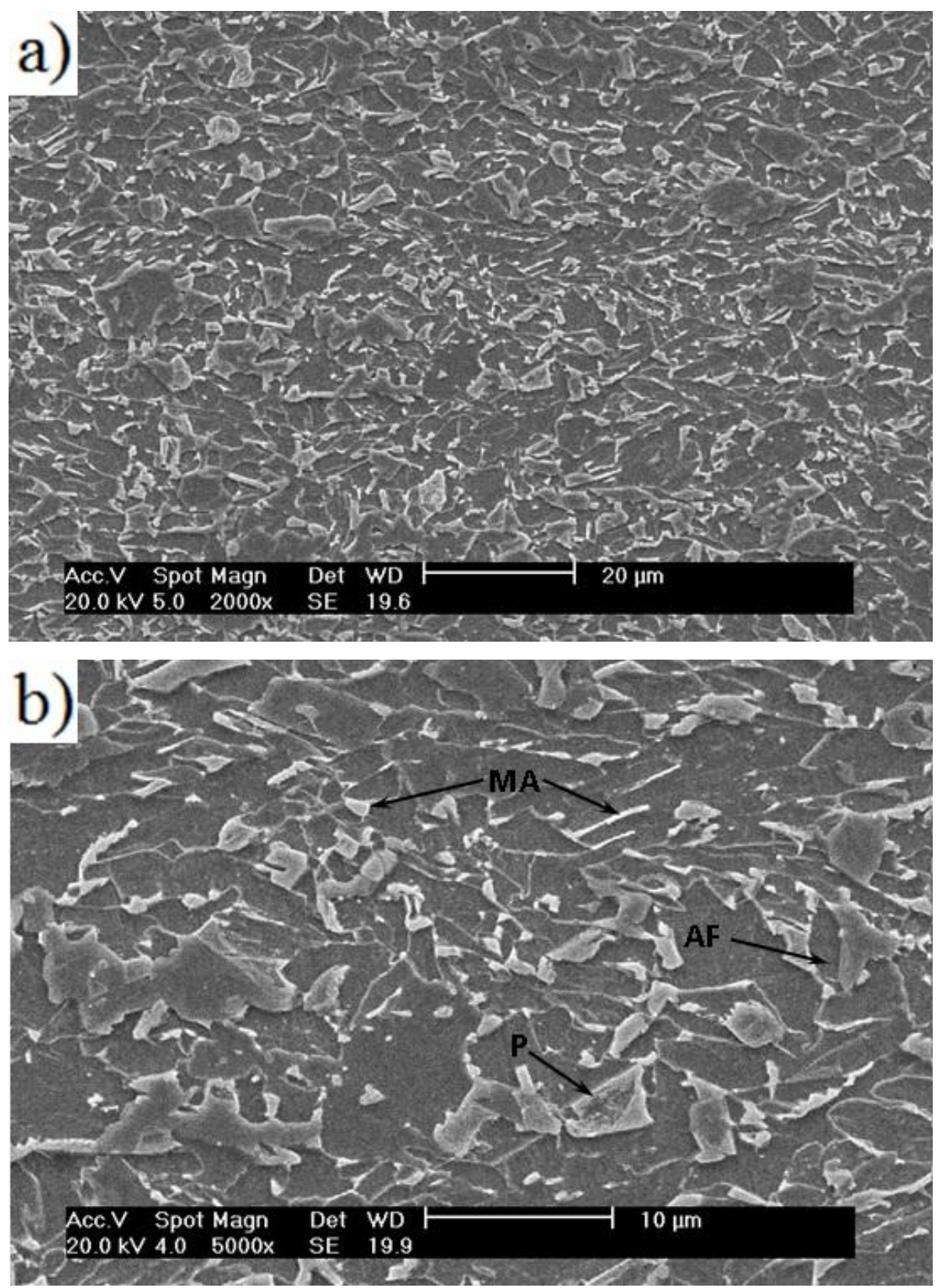

Figura 81. Microestrutura da posição 2 do material com ciclo térmico de $950{ }^{\circ} \mathrm{C}$ em a) $2000 \mathrm{X}$ e b) 5000X. Ataque Nital 3\%.

Na Fig. 81 nota-se a presença de ferrita poligonal de granulação fina cor cinza escuro, a perlita $(P)$ e o microconstituinte MA ficam distribuidos na matriz ferrítica. 

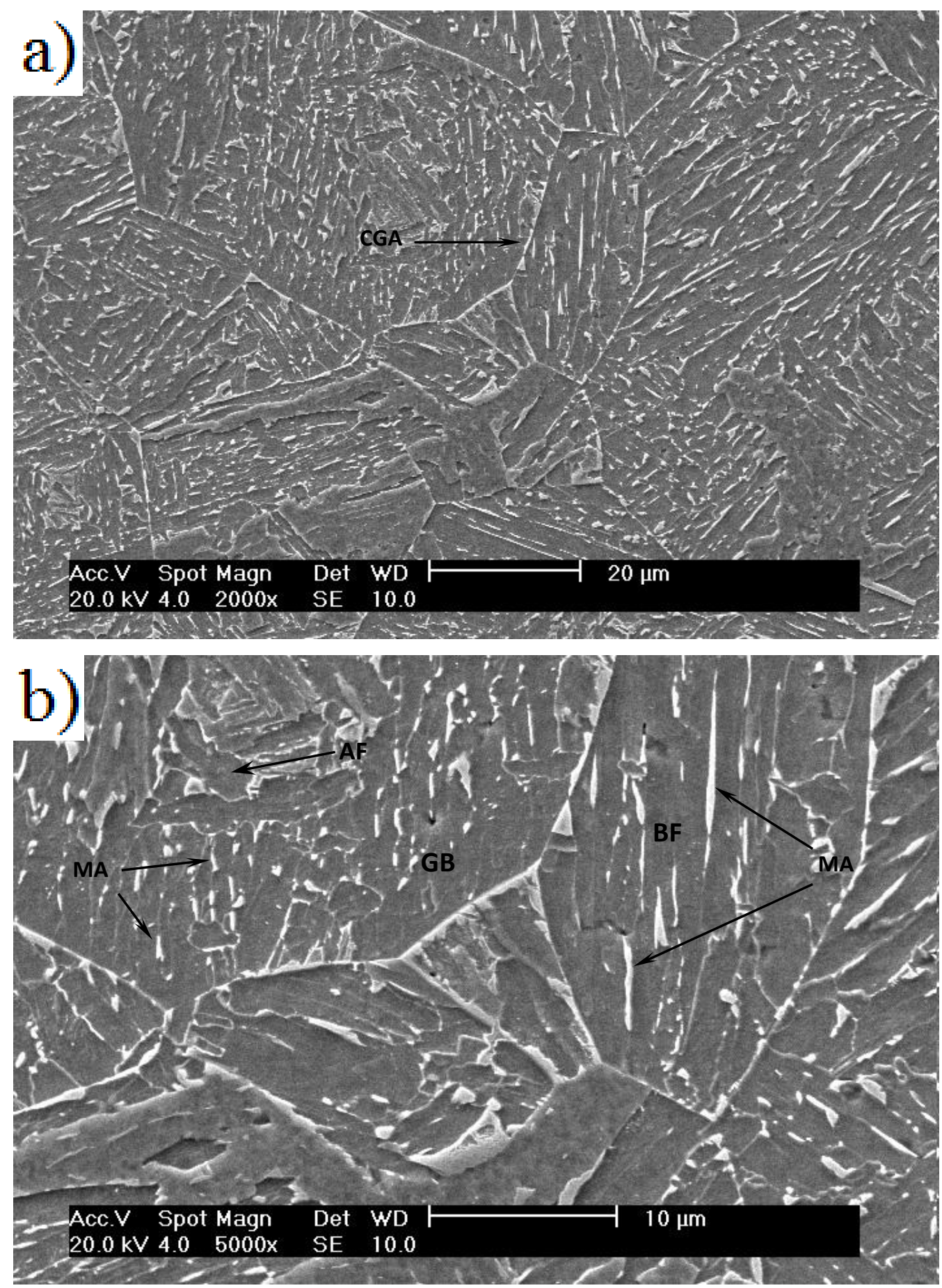

Figura 82. Microestrutura da posição 2 do material com ciclo térmico de $1300{ }^{\circ} \mathrm{C}$ em a) $2000 \mathrm{X}$ e b) 5000X. Ataque Nital 3\%.

Na Fig. 82 observa-se a presença de uma microestrutura ferritica-bainitica (BF) e bainita granular (GB) acompanhadas do microconstituinte MA e AF. Pode-se ainda observar o contorno de grâo austenitico anterior (CGA). Shin [52] descreve que os principais componentes da microestrutura da zona afetada pelo calor de um aço API $5 \mathrm{~L}$ grau X80 simulado a $1400{ }^{\circ} \mathrm{C}$ são a bainitaferritica (BF), a ferrita acicular (AF) e a bainita granular (GB) [52]. 


\subsubsection{Posição 3 (orientação T-L) no metal de base}
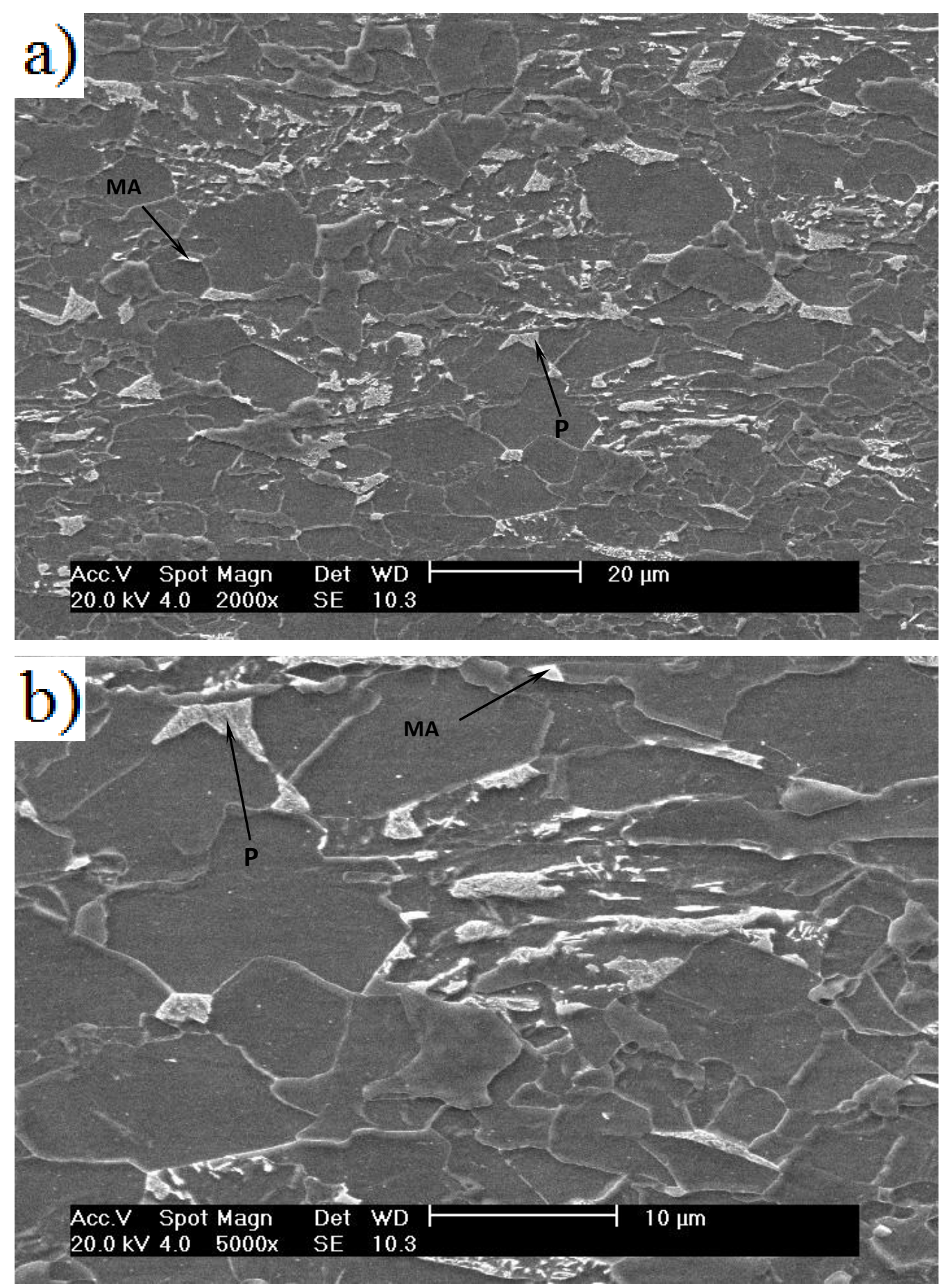

Figura 83. Microestrutura da posição 3 do material base sem ciclo térmico em a) 2000X e b) 5000X. Ataque Nital 3\%.

$\mathrm{Na}$ Fig. 83 tem-se presença de ferrita poligonal e quase poligonal de cor cinza escuro e a perlita $(P)$. Nesta figura pode-se notar a pouca presença de microconstituintes MA em comparaçao com a Fig. 78 pertencente a posição 2 devido à zona de bandeamento que esta apresenta. 


\subsubsection{Posição 3 (orientação T-L) simulação de um único passe}
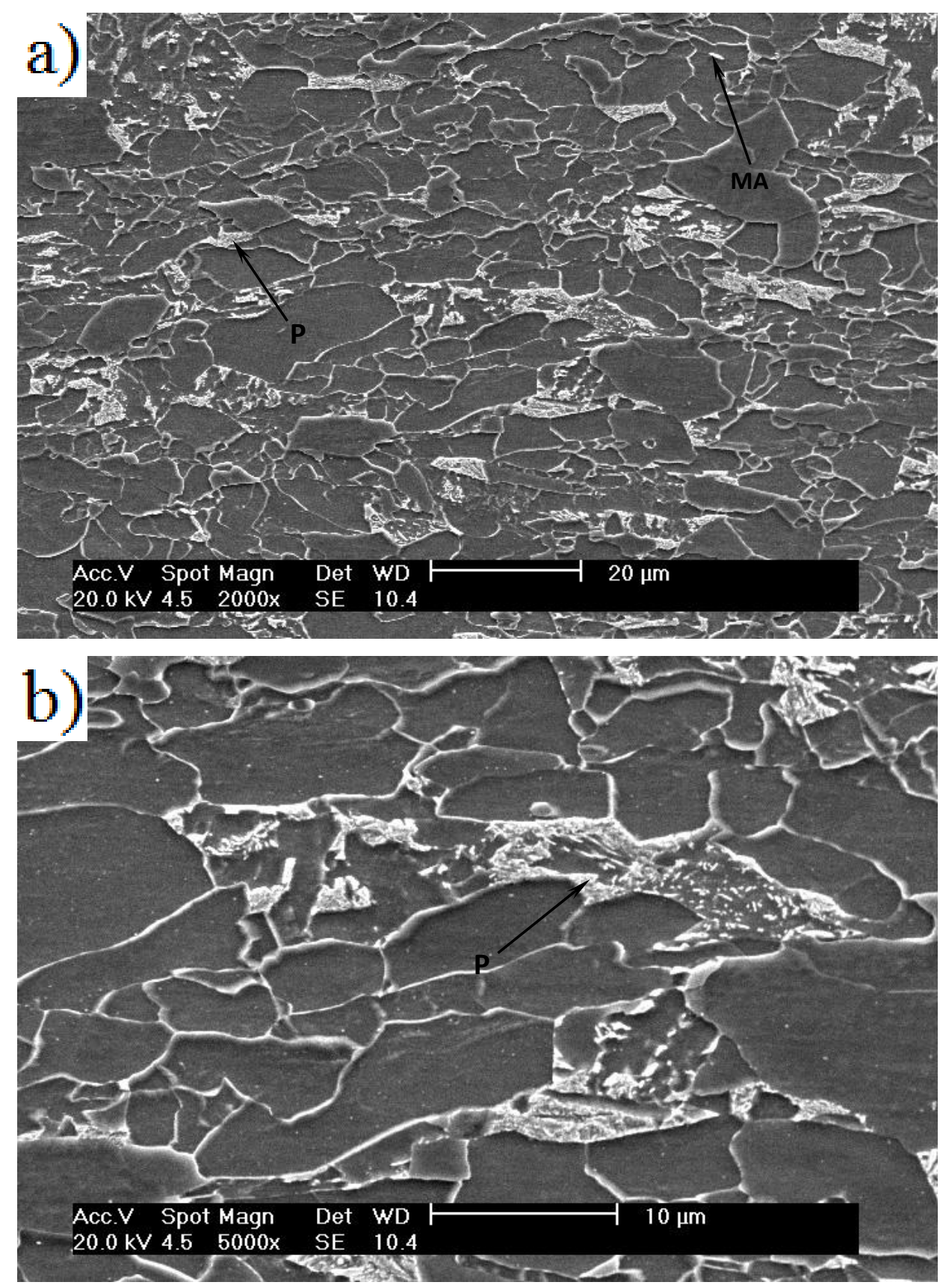

Figura 84. Microestrutura da posição 3 do material com ciclo térmico de $650{ }^{\circ} \mathrm{C}$ em a) $2000 \mathrm{X}$ e b) $5000 \mathrm{X}$. Ataque Nital $3 \%$.

Na Fig. 84(a) observa-se a ferrita poligonal e quase poligonal de cor cinza escuro, perlita e uma melhor distribuição dos agregados eutetoídes. Na Fig. 84(b) pode-se observar que para este ciclo térmico se tem pouca e quase nem huma presença de microconstituintes MA, com grande presença de regiões contendo agregados de ferrita e carbonetos (bainita e perlita fina) [24], similar ao obtido na Fig. 58. 

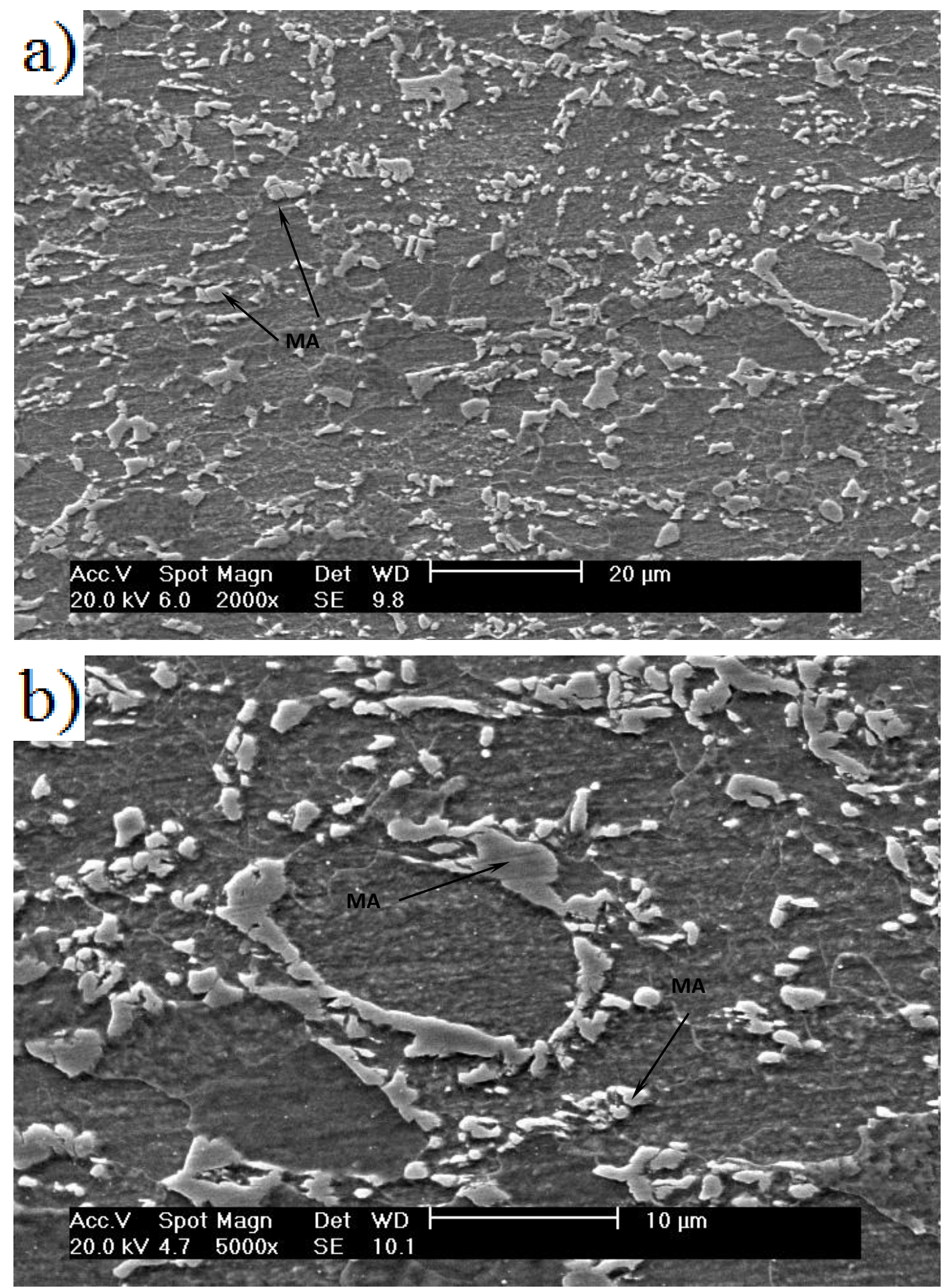

Figura 85. Microestrutura da posição 3 do material com ciclo térmico de $800{ }^{\circ} \mathrm{C} \mathrm{em} \mathrm{a)} 2000 \mathrm{X}$ e b) $5000 X$. Ataque Nital $3 \%$.

Observando a Fig.85 tem-se a presença de ferrita poligonal de cor cinza claro, nota-se maior quantidade de microconstituintes MA de tamanho menor distribuidos na matriz como aconteceu para a Fig. 59. Na Fig. 85(b) pode-se dizer que se tem microconstituintes MA que se ubicaram no contorno do grão. 

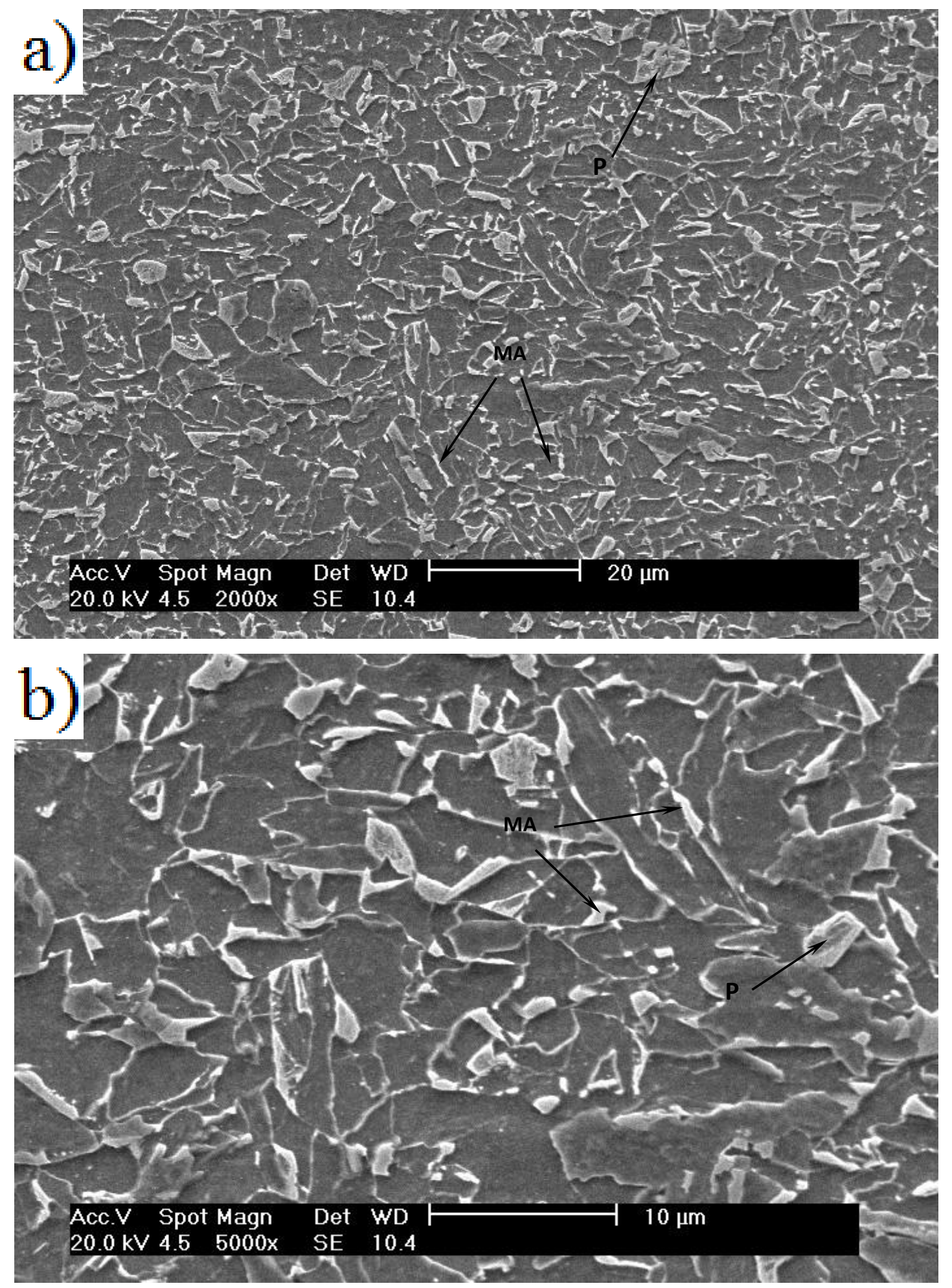

Figura 86. Microestrutura da posição 3 do material com ciclo térmico de $950{ }^{\circ} \mathrm{C}$ em a) $2000 \mathrm{X}$ e b) $5000 X$. Ataque Nital $3 \%$.

$\mathrm{Na}$ Fig. 86 observa-se a ferrita poligonal de granulação fina de cor cinza escuro, a perlita $(P)$ e o microconstituinte MA ficam distribuidos na matriz ferrítica. 

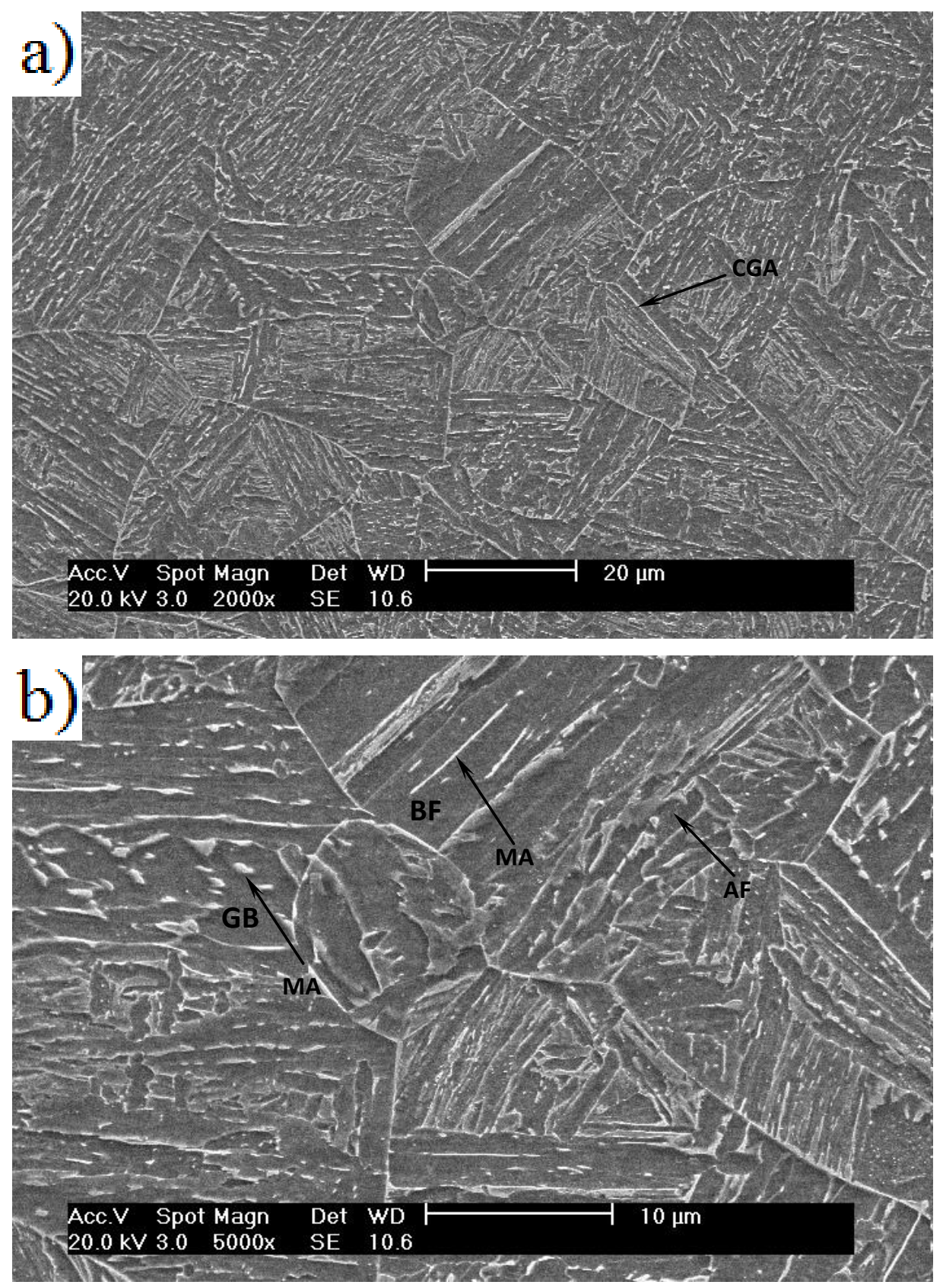

Figura 87. Microestrutura da posição 3 do material com ciclo térmico de $1300^{\circ} \mathrm{C}$ em a) $2000 \mathrm{X}$ e b) 5000X. Ataque Nital 3\%.

$\mathrm{Na}$ Fig. 87 notamos a presença de uma microestrutura ferritica bainitica (BF) e bainita granular (GB) acompanhadas do microconstituinte MA e AF, pode-se observar o contorno de grao austenitico inical (CGA). Esta microestrutura é também apresentada para Fig. 61. A BF e a GB se formam sobre a mesma temperatura de transformação, porem a taxa de resfriamento na qual se forma a GB é um tanto mais baixa que que da BF e a austenita retida se transforma em microconstituinte MA nos contornos de grao ou na forma de ripas [54] como se observa na Fig. 87(b). 


\subsubsection{Posição 1 (zona fundida) simulação multipasse}
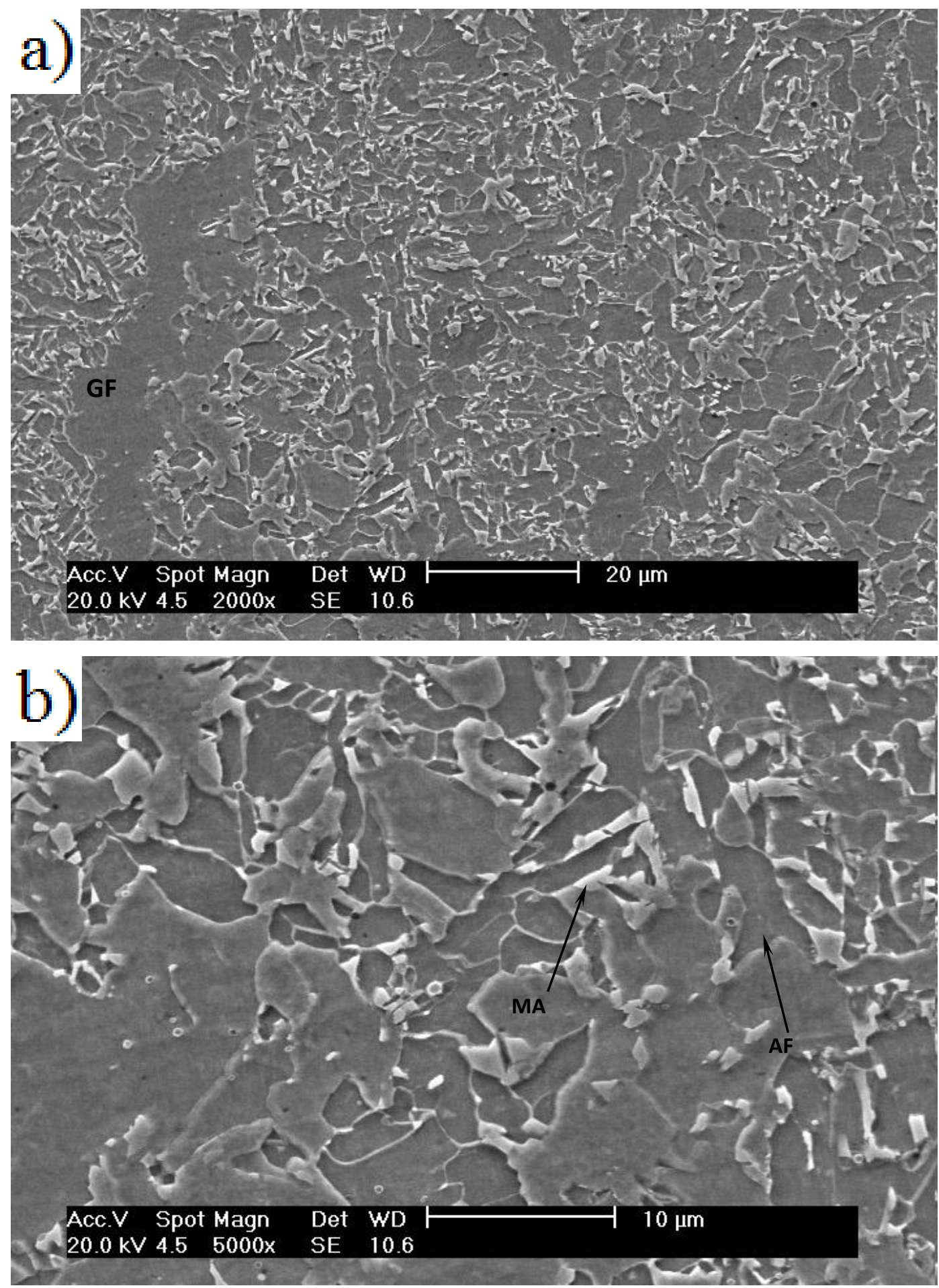

Figura 88. Microestrutura da posição 1 do material com ciclo térmico multipasse de 950-800 ${ }^{0} \mathrm{C}$ em a) 2000X e b) 5000X. Ataque Nital 3\%.

Na Fig. 88 notamos a presença da ferrita de contorno de grão e ferrita acicular que apresenta-se em maior quantidade, os constituintes MA estão distribuidos em toda a matriz e apresenta granulação fina. 

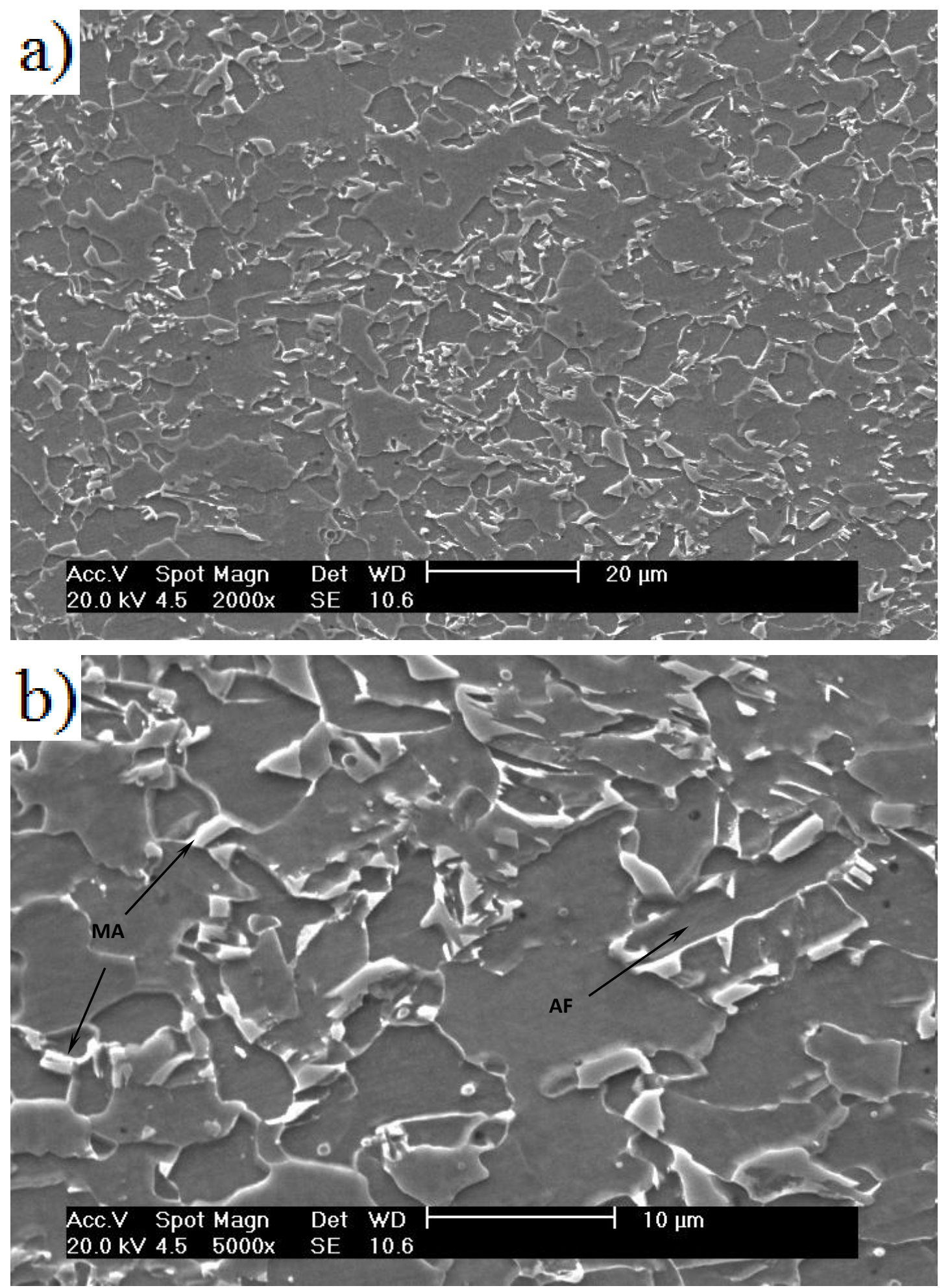

Figura 89. Microestrutura da posição 1 do material com ciclo térmico multipasse de 950-800$650^{\circ} \mathrm{C}$ em a) $2000 \mathrm{X}$ e b) $5000 \mathrm{X}$. Ataque Nital $3 \%$.

Na Fig. 89 notamos a presença da ferrita de contorno de grão e ferrita acicular, os microcosntituintes MA estao distribuidos em toda a matriz e apresenta tamanho fino. 


\subsubsection{Posição 2 (orientação L-T) simulação multipasse}
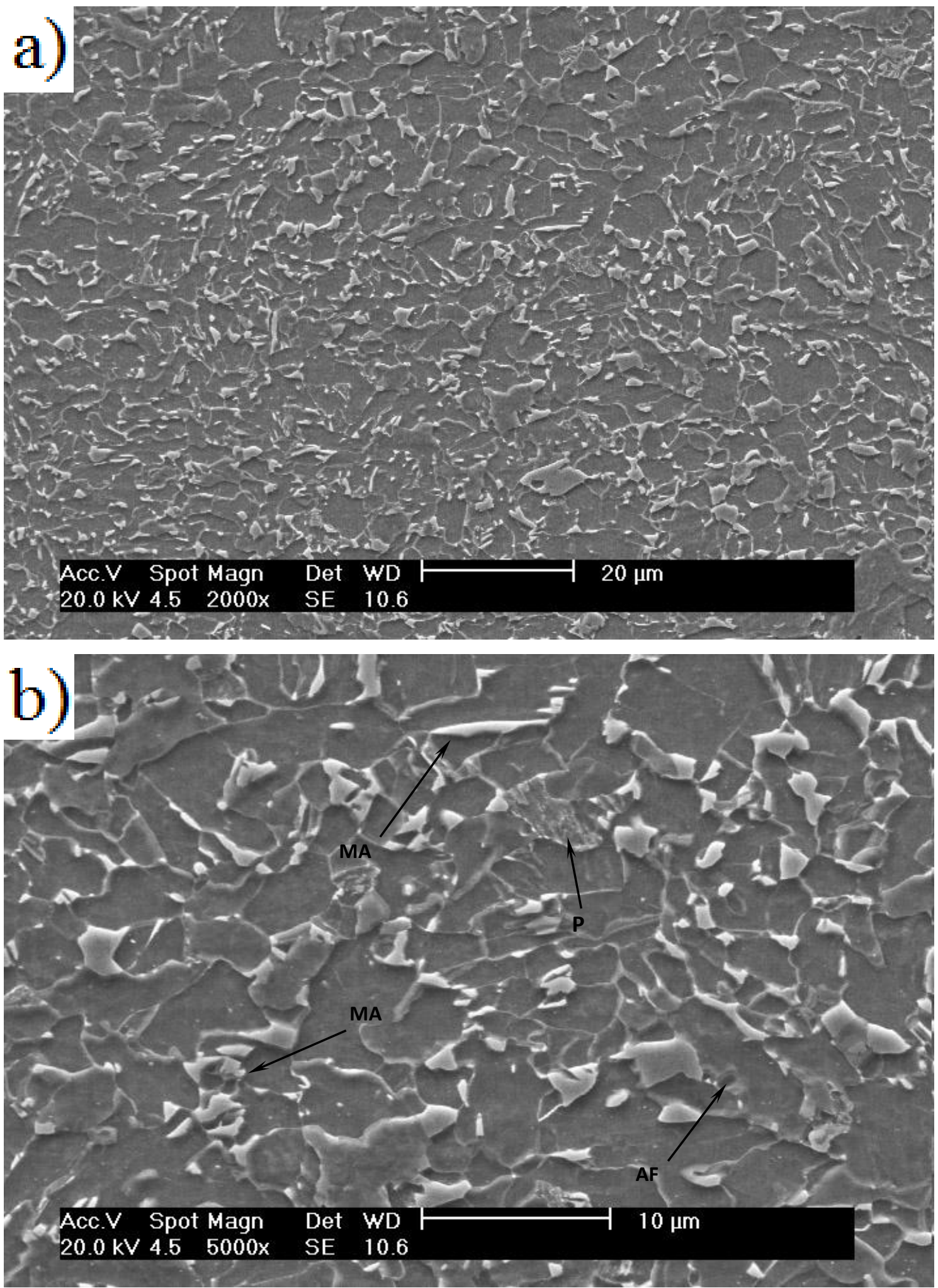

Figura 90. Microestrutura da posição 2 do material com ciclo térmico multipasse de 950-800 ${ }^{0} \mathrm{C}$ em a) 2000X e b) 5000X. Ataque Nital 3\%. 

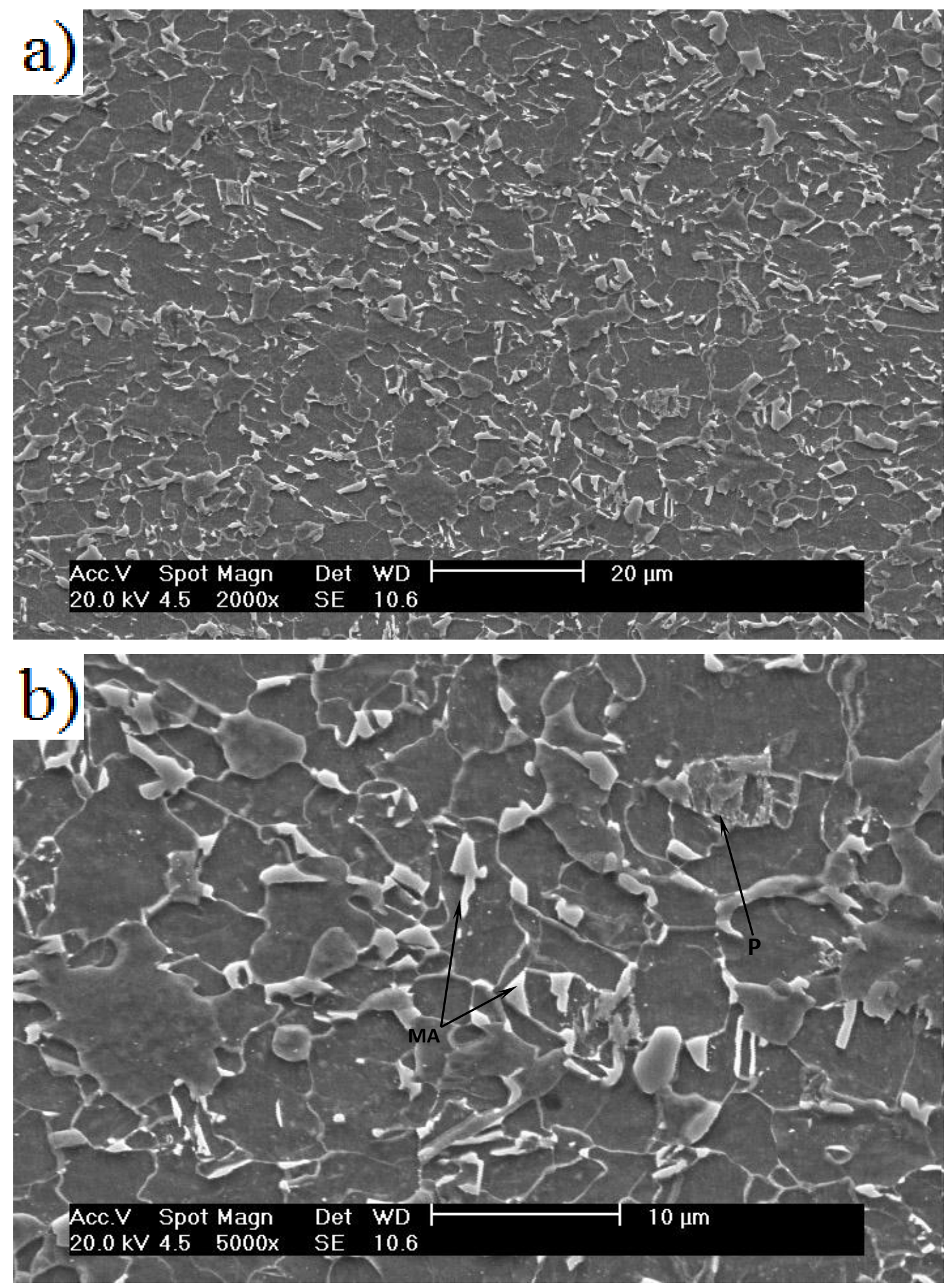

Figura 91. Microestrutura da posição 2 do material com ciclo térmico multipasse de 950-800$650{ }^{\circ} \mathrm{C}$ em a) $2000 \mathrm{X}$ e b) $5000 \mathrm{X}$. Ataque Nital $3 \%$. 


\subsubsection{Posição 3 (orientação T-L) simulação multipasse}
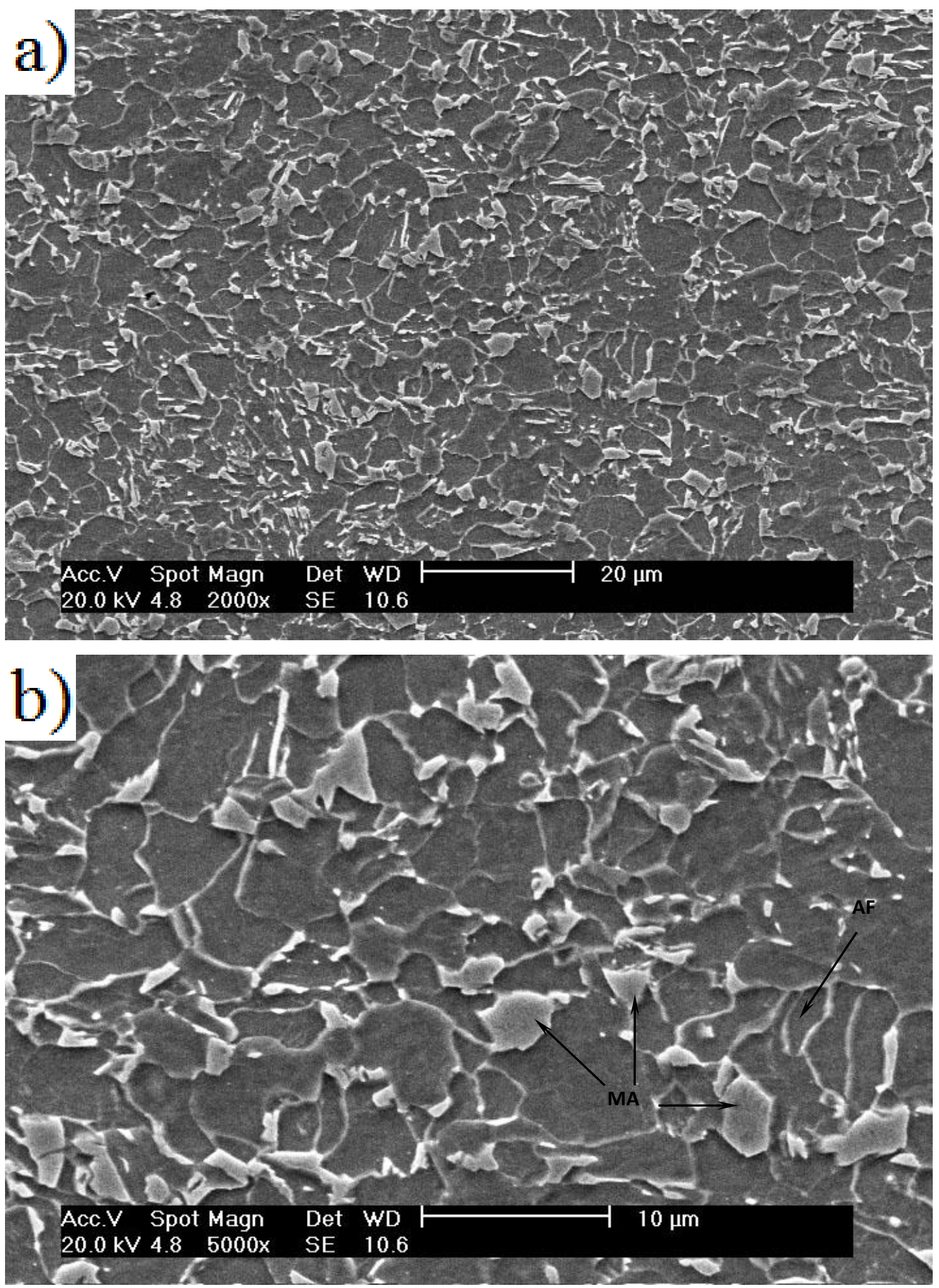

Figura 92. Microestrutura da posição 3 do material com ciclo térmico multipasse de 950-800 ${ }^{0} \mathrm{C}$ em a) 2000X e b) 5000X. Ataque Nital 3\%. 

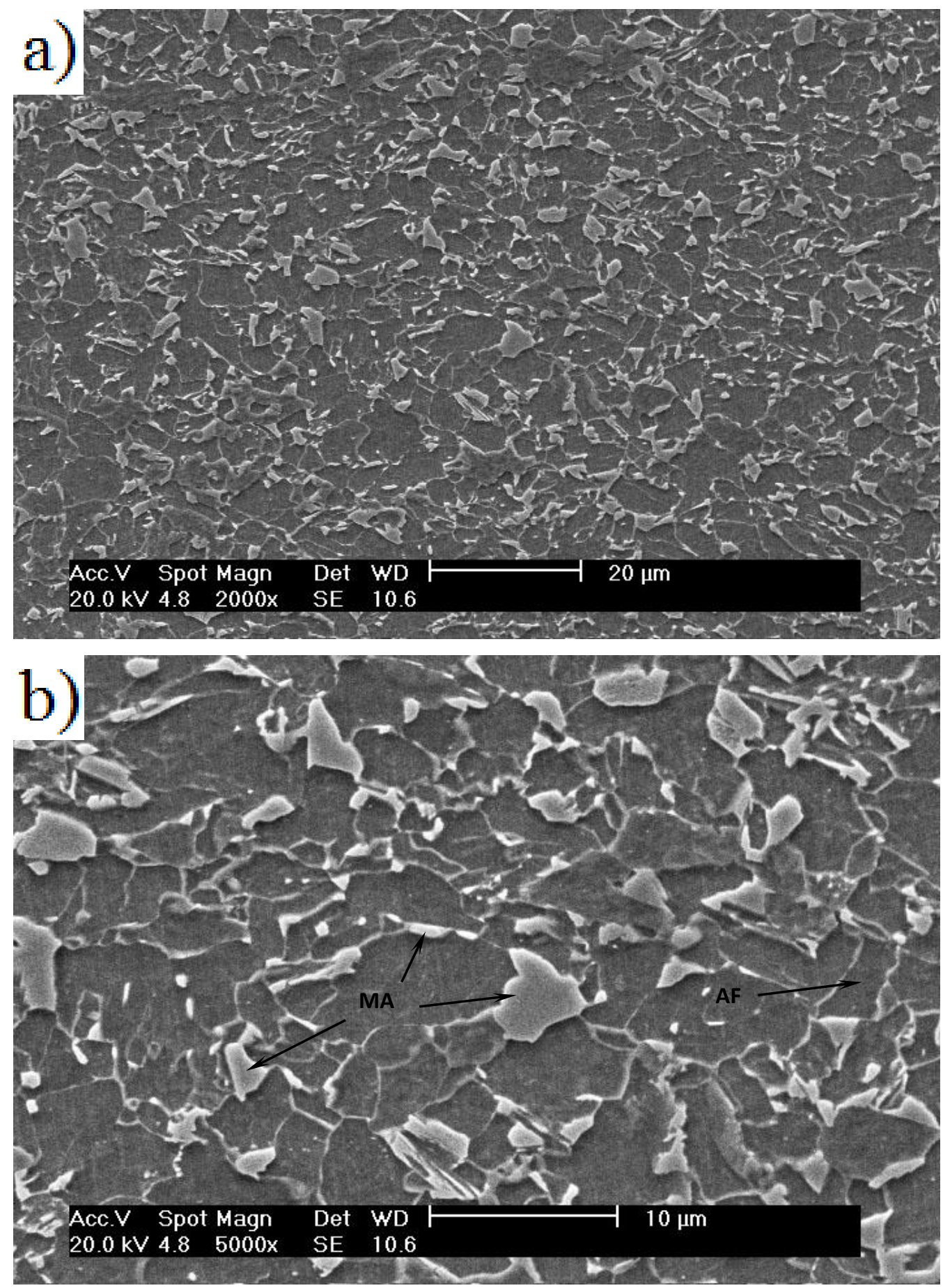

Figura 93. Microestrutura da posição 3 do material com ciclo térmico multipasse de 950-800$650^{\circ} \mathrm{C}$ em a) $2000 \mathrm{X}$ e b) $5000 \mathrm{X}$. Ataque Nital $3 \%$.

A Fig. 88 e Fig. 89 apresentam ferrita de contorno de grão (GF); ferrita acicular (AF) e microcontituintes MA. As Fig. 90 a Fig. 93 apresentam quase as mesmas características microestruturais da Fig. 81 e Fig. 86, diferindo somente na ferrita de granulação fina e microconstituintes MA de tamanho fino e com morfologia diferente. Aparentemente as Fig. 92 e 93 tem microconstituintes MA de maior tamanho que as apresentadas nas Fig. 88 a 91. 


\subsubsection{Microscopia Óptica com Reagente Klemm 1}

O reagente Klemm 1 é um dos reagentes que pode ser empregado para obter microestruturas coloridas de aços carbono e aços ARBL. Esta caracterização é feita para observar os constituintes MA na microestrutura. O constituinte MA não é atacado e aparece na cor branca nas micrografias dos aços ARBL [23].

\subsubsection{Posição 1 (zona fundida)}
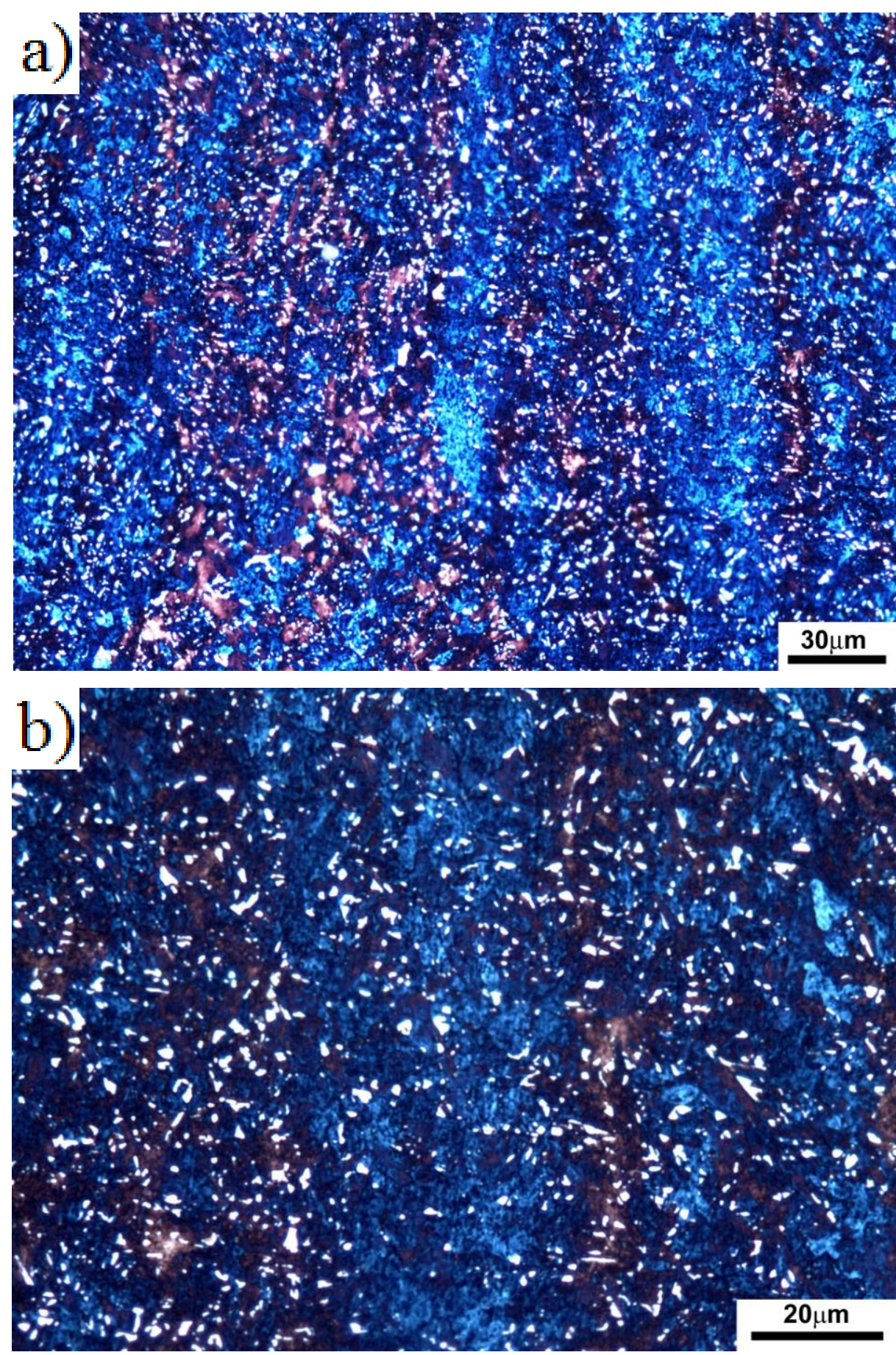

Figura 94. Microestrutura da posição 1 do material sem simulação, mostrando o agregado MA (branco) e os agregados eutetóides (azul escuro). Em a) 500X e b) 1000X. Ataque Klemm 1. 
A Fig. 94 apresenta os constituintes MA com cor branca e os agregados eutetóides com cor azul escura.

\subsubsection{Posição 1 simulação de um único passe}
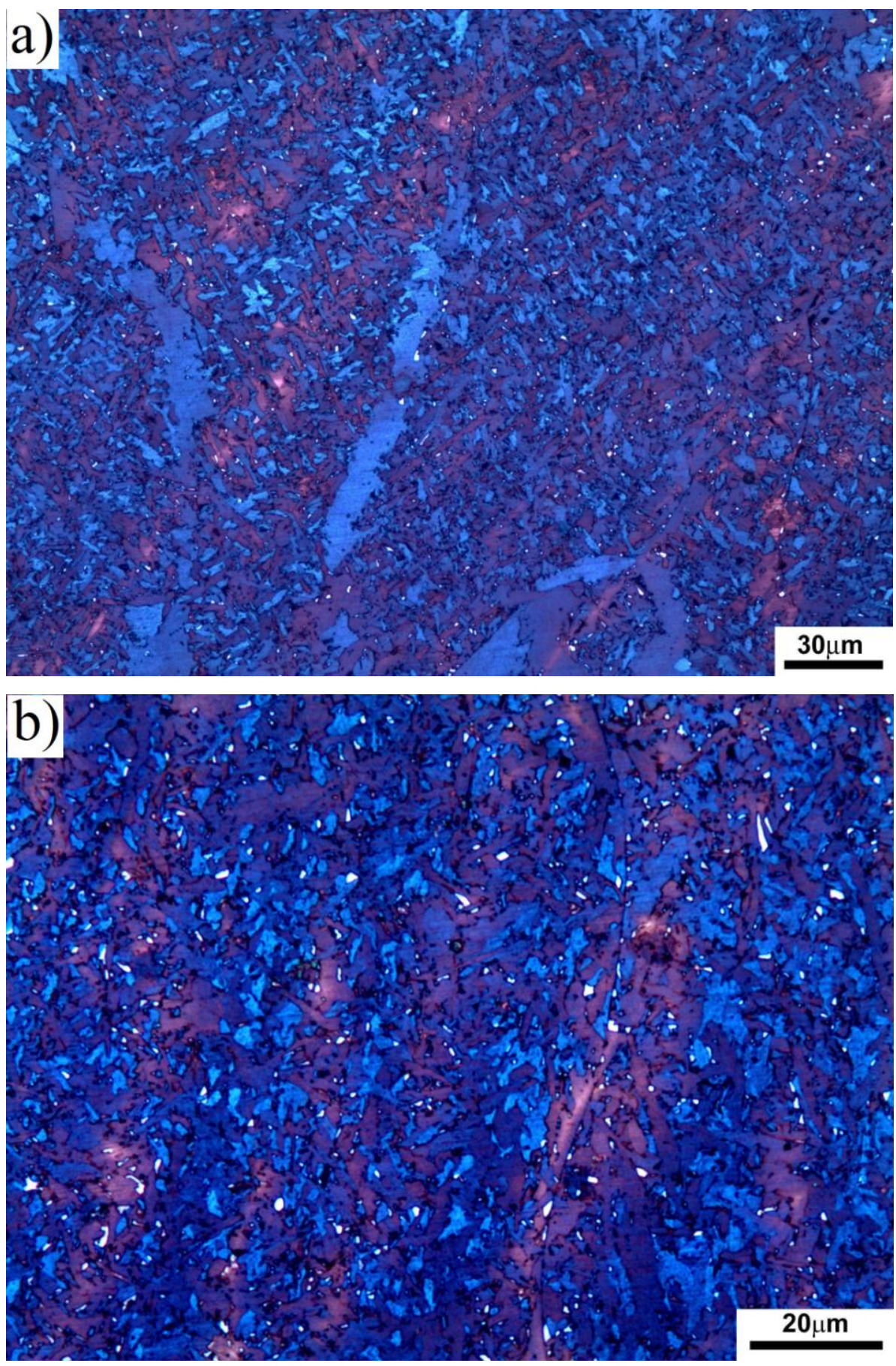

Figura 95. Microestrutura da posição 1 do material com ciclo térmico de $650^{\circ} \mathrm{C}$ em a) $500 \mathrm{X}$ e b) 1000X. Ataque Klemm 1. 


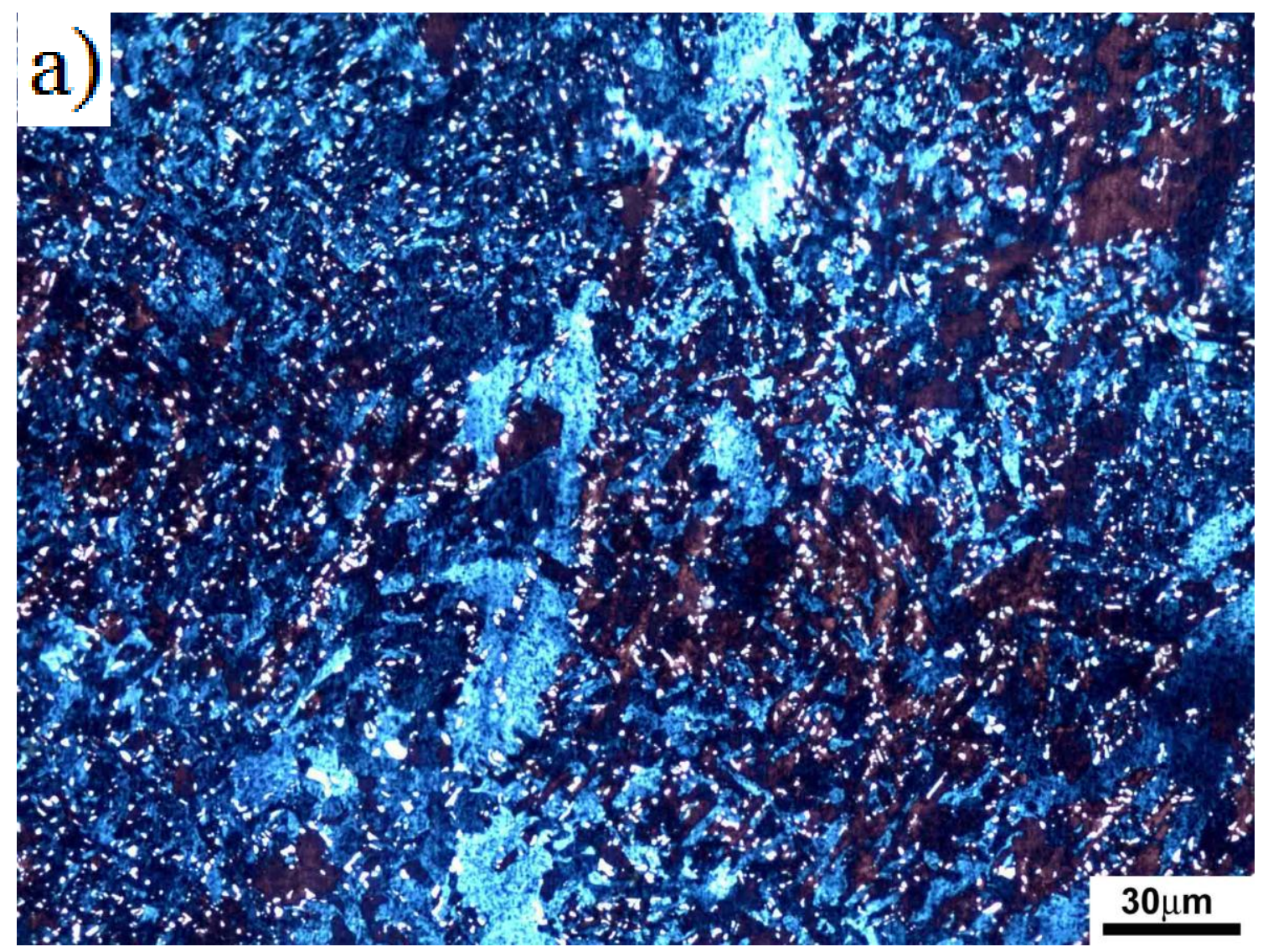

b)

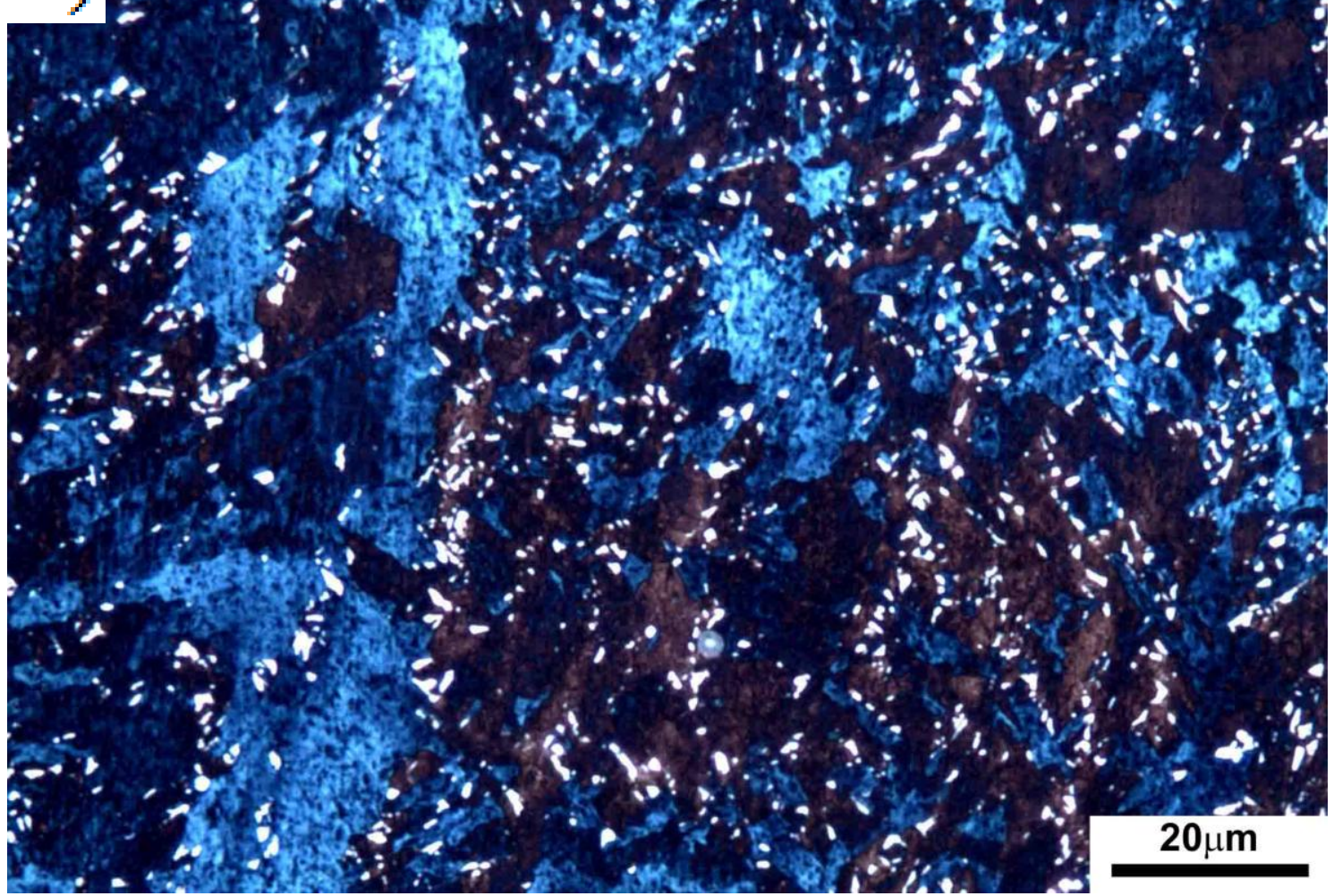

Figura 96. Microestrutura da posição 1 do material com ciclo térmico de $800^{\circ} \mathrm{C}$ em a) $500 \mathrm{X}$ e b) 1000X. Ataque Klemm 1. 

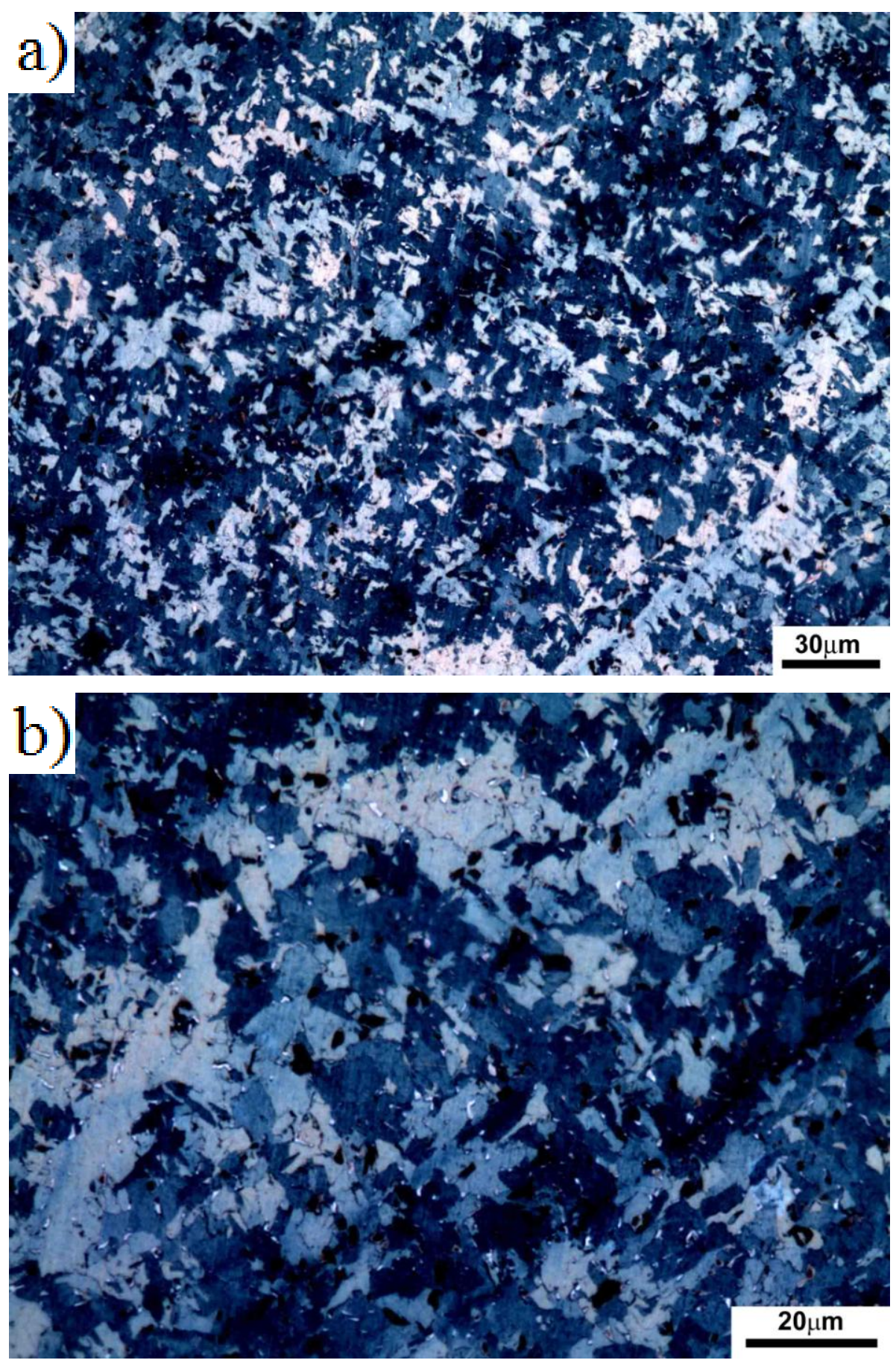

Figura 97. Microestrutura da posição 1 do material com ciclo térmico de $950^{\circ} \mathrm{C}$ em a) $500 \mathrm{X}$ e b) 1000X. Ataque Klemm 1.

Nas Fig. 95, 96 e 97 os constituintes MA são revelados de maneira similar à descrita na figura 94. Comparando-se as quantidades de MA, o ciclo térmico de $800{ }^{\circ} \mathrm{C}$ apresenta uma maior quantidade de MA quando comparado com 650 e $950{ }^{\circ} \mathrm{C}$. Uma provável explicação é o aquecimento dentro da região intercrítica, onde a austenita fica enriquecida em carbono, que estabiliza a austenita, e que aumenta a temperabilidade e pode produzir martensita e austenita retida no resfriamento. A $950{ }^{\circ} \mathrm{C}$ o material está dentro do campo austenítico, o teor de 
carbono na austenita é bem menor $e$, conseqüentemente, menor a possibilidade de estabilizar a austenita comparado com o ciclo de $800{ }^{\circ} \mathrm{C}$. A $650{ }^{0} \mathrm{C}$ pode ocorrer a precipitação de carbonetos, que desestabilizam a austenita e revenem a martensita.
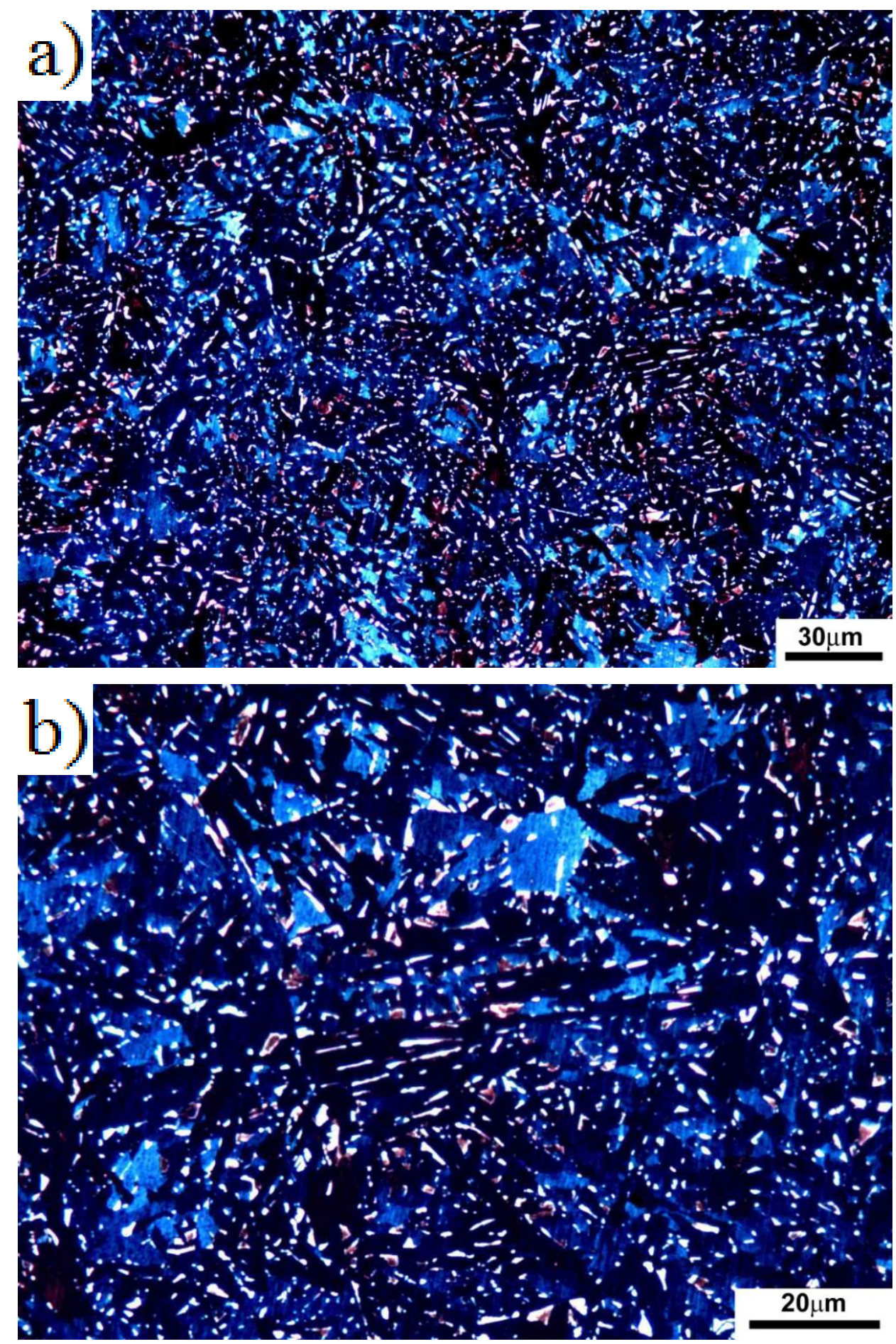

Figura 98. Microestrutura da posição 1 do material com ciclo térmico de $1300^{\circ} \mathrm{C}$ em a) $500 \mathrm{X}$ e b) 1000X. Ataque Klemm 1. 
Na Fig. 98 pode-se notar o constituinte MA de cor branca com diferentes morfologias, em forma de ripas e poligonais, iguais à forma que foi mostrada na Fig. 77. Neste caso, o aumento da quantidade de MA deve-se ao fato da dissolução total, ou parcial, de carbonetos e carbonitretos, que aumentam localmente a temperabilidade da região, estabilizando a austenita e favorecendo a transformação martensítica, produzindo o agregado MA.

\subsubsection{Posição 2 (orientação L-T) no metal de base}

Na Fig. 99 o constituinte MA e os agregados eutetóides apresentam colorações descritas anteriormente. A fração volumétrica de constituinte MA é maior na posição 1 que na posição 2 para todos os ciclos térmicos simulados. $A$ presença de constituintes MA em maior quantidade pode estar relacionada com a diferença de composição dos dois materiais, que está relacionada com os carbonos equivalentes e, indiretamente com a temperabilidade. A comparação entre as temperabilidades mostra que 0 metal de solda tem uma temperabilidade maior que o metal base, pelo cálculo do diâmetro ideal da barra (Eq. 3). Além disto, os fenômenos de microsegregação podem produzir aumentos locais de composição química, que também podem alterar localmente a temperabilidade da zona fundida.

Para o material base pode-se notar uma maior presença de MA em comparação com o ciclo térmico de $650{ }^{\circ} \mathrm{C}$ como observado na Fig. 99.

Além disso, podemos notar que os constiuintes MA estão principalmente localizados nos bordes de grão, isso pode ser notado também nas micrografias tiradas no MEV.

Na Fig. 100 com ciclo térmico de $650{ }^{\circ} \mathrm{C}$ se tem quase nemhuma presença de constituintes MA já que este ciclo térmico não atinge a transformação austenitica encontrandose por abaixo da linha A1.

$\mathrm{Na}$ Fig. $101 \mathrm{com}$ ciclo térmico de $800{ }^{\circ} \mathrm{C}$ a quantidade de constiuintes MA diminui mais um pouco comparado com o ciclo térmico de $950{ }^{\circ} \mathrm{C}$, porem não é muita a diferença já que esta temperatura também esta próxima a linha A3 e a disolução do carbono vem da fase alfa. 
Na Fig. 102 com ciclo térmico de $950{ }^{\circ} \mathrm{C}$ aparentemente a quantidade de MA diminui um pouco já que esta proximo a temperatura $A 3$ onde não existe muita dissolução de carbono e carbonitretos.

$\mathrm{Na}$ Fig. 108, que pertence ao ciclo térmico de $1300{ }^{\circ} \mathrm{C}$, podemos notar uma grande quantidade de constituinte MA provavelmente devido a que nesta temperatura se teve uma grande dissolução de carbono e carbonitretos.
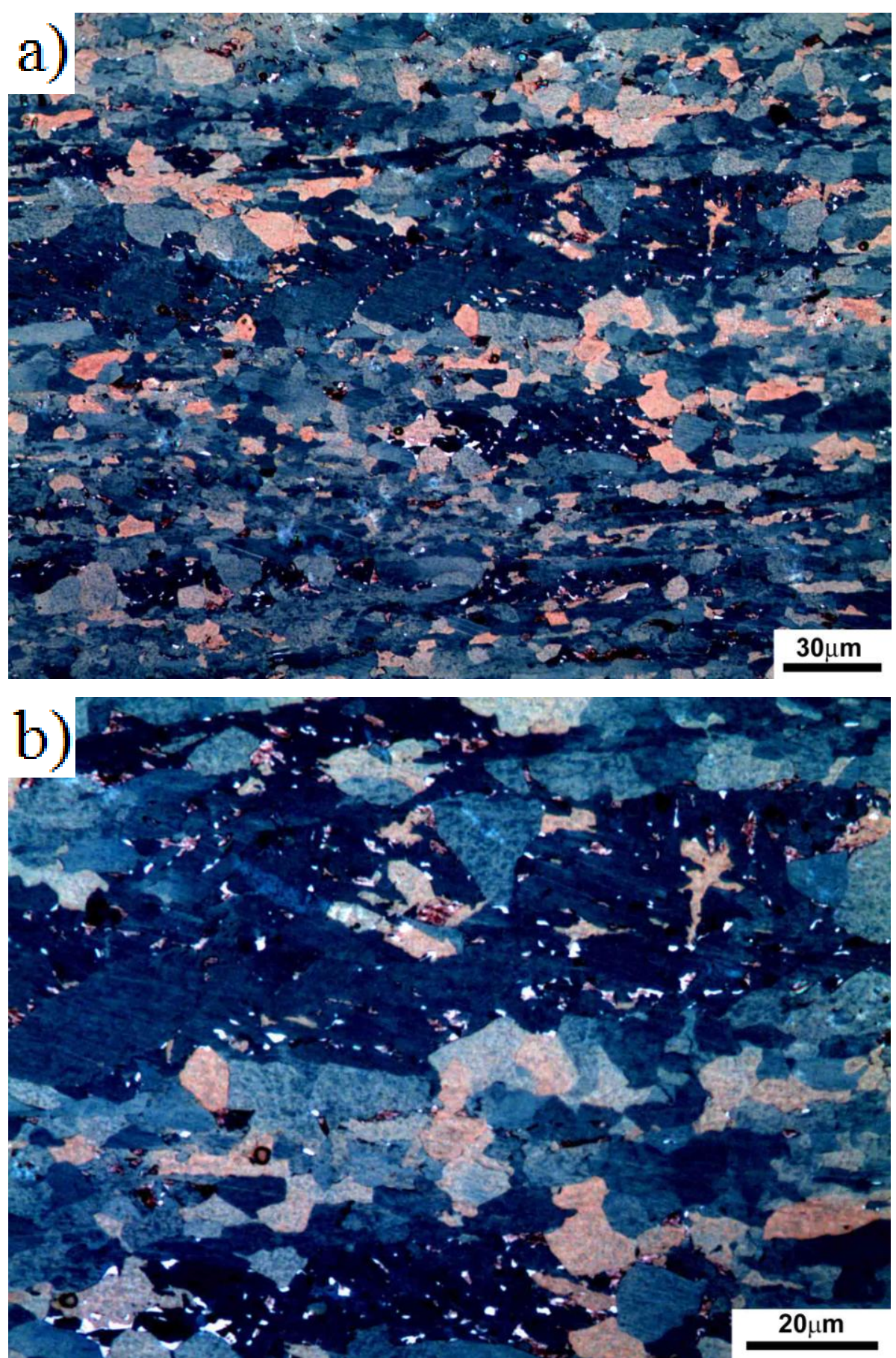

Figura 99. Microestrutura da posição 2 do material sem simulação em a) 500X e b) 1000X. Ataque Klemm 1. 


\subsubsection{Posição 2 (orientação L-T) simulação de um único passe}
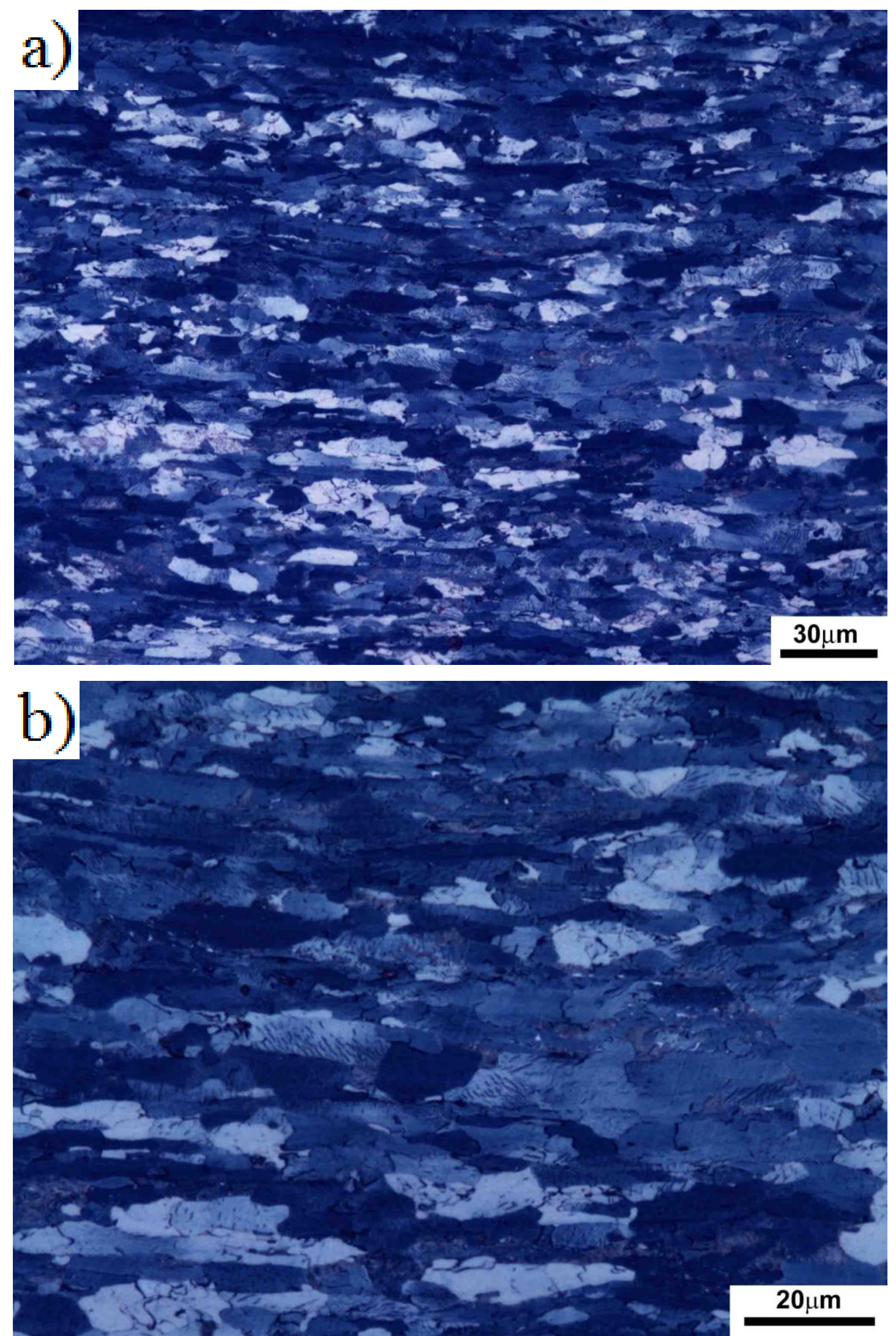

Figura 100. Microestrutura da posição 2 do material com ciclo térmico de $650^{\circ} \mathrm{C}$ em a) $500 \mathrm{X}$ e b) 1000X. Ataque Klemm 1. 

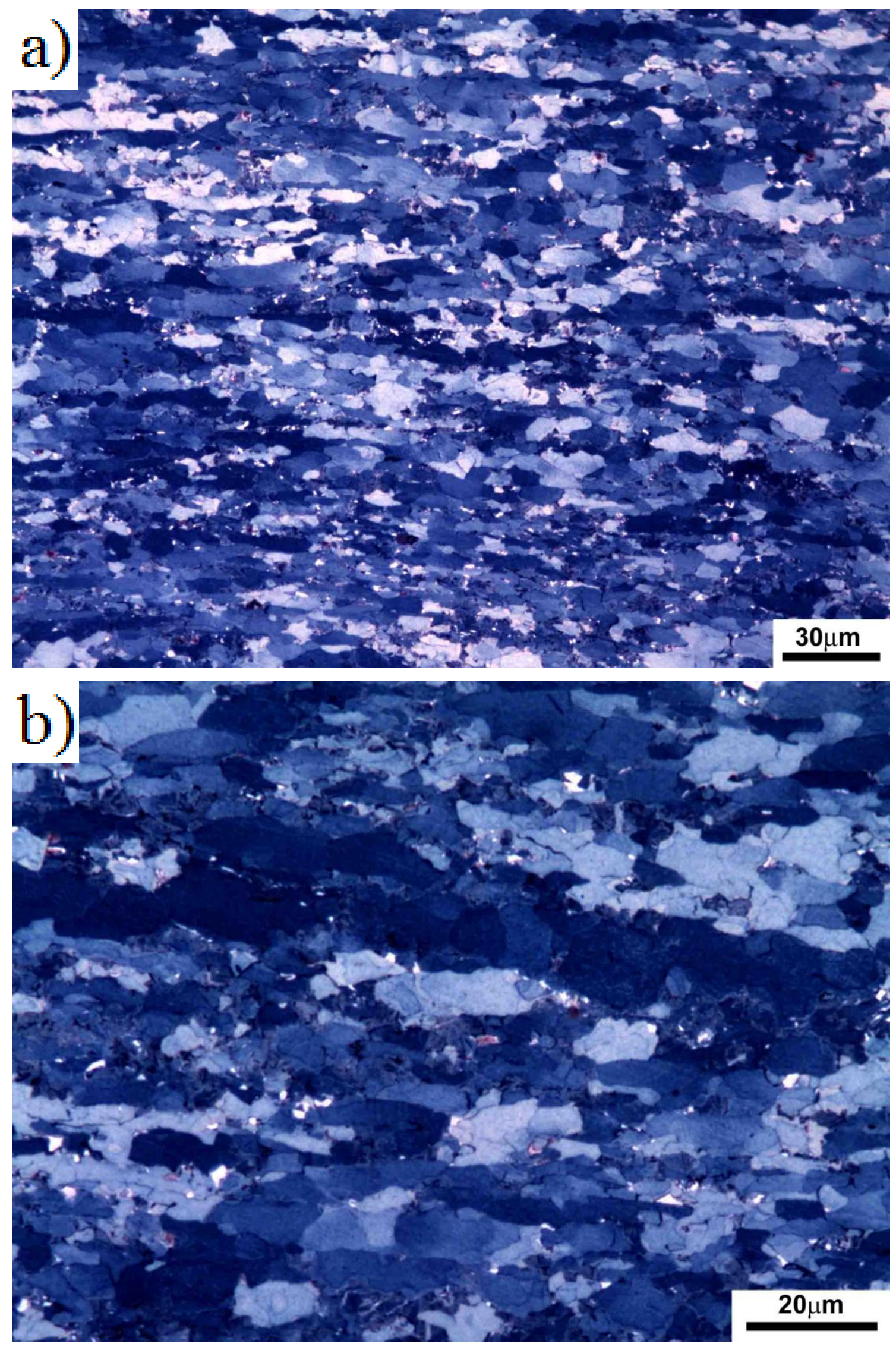

Figura 101. Microestrutura da posição 2 do material com ciclo térmico de $800^{\circ} \mathrm{C}$ em a) $500 \mathrm{X}$ e b) 1000X. Ataque Klemm 1. 

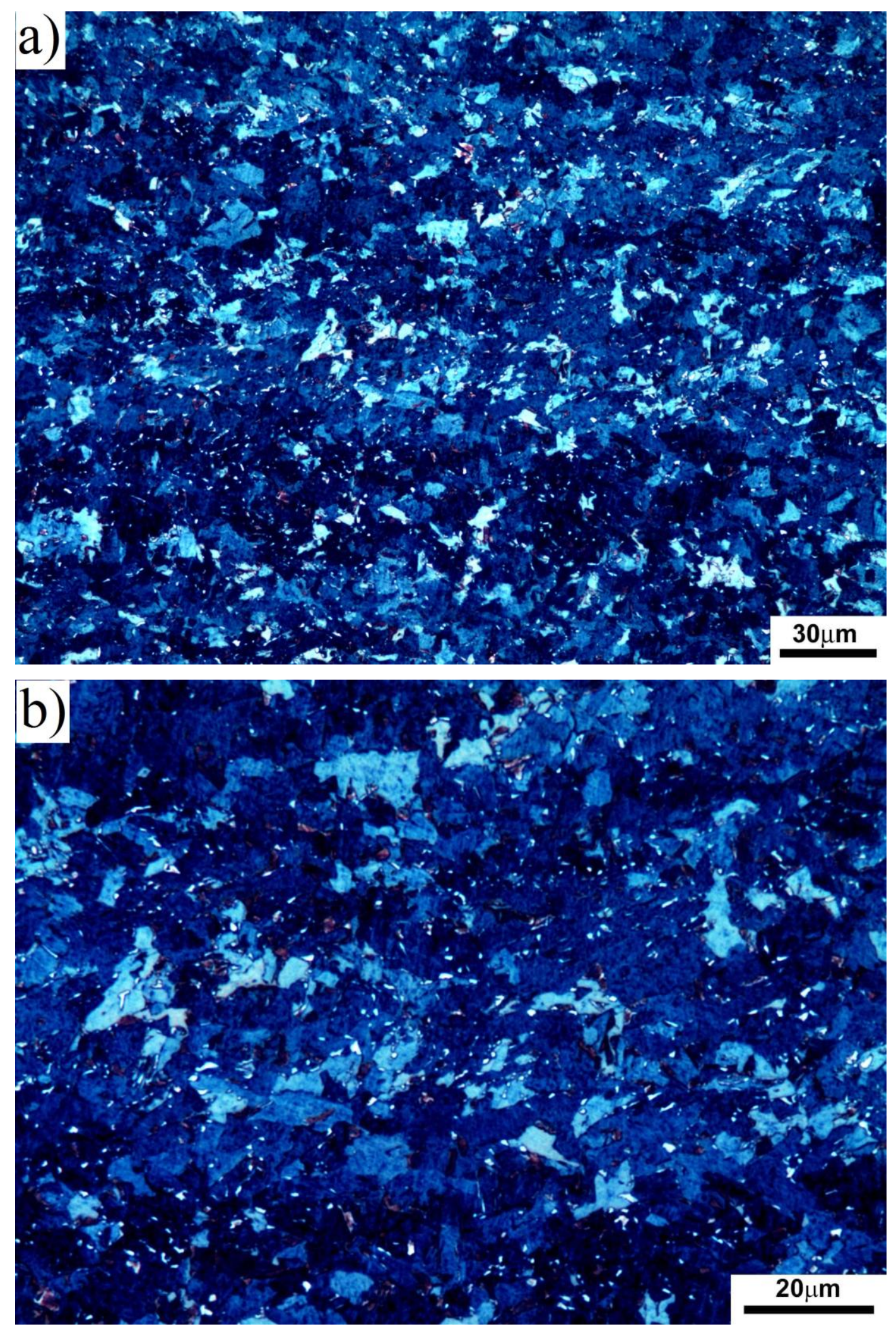

Figura 102. Microestrutura da posição 2 do material com ciclo térmico de $950^{\circ} \mathrm{C}$ em a) $500 \mathrm{X}$ e b) 1000X. Ataque Klemm 1. 

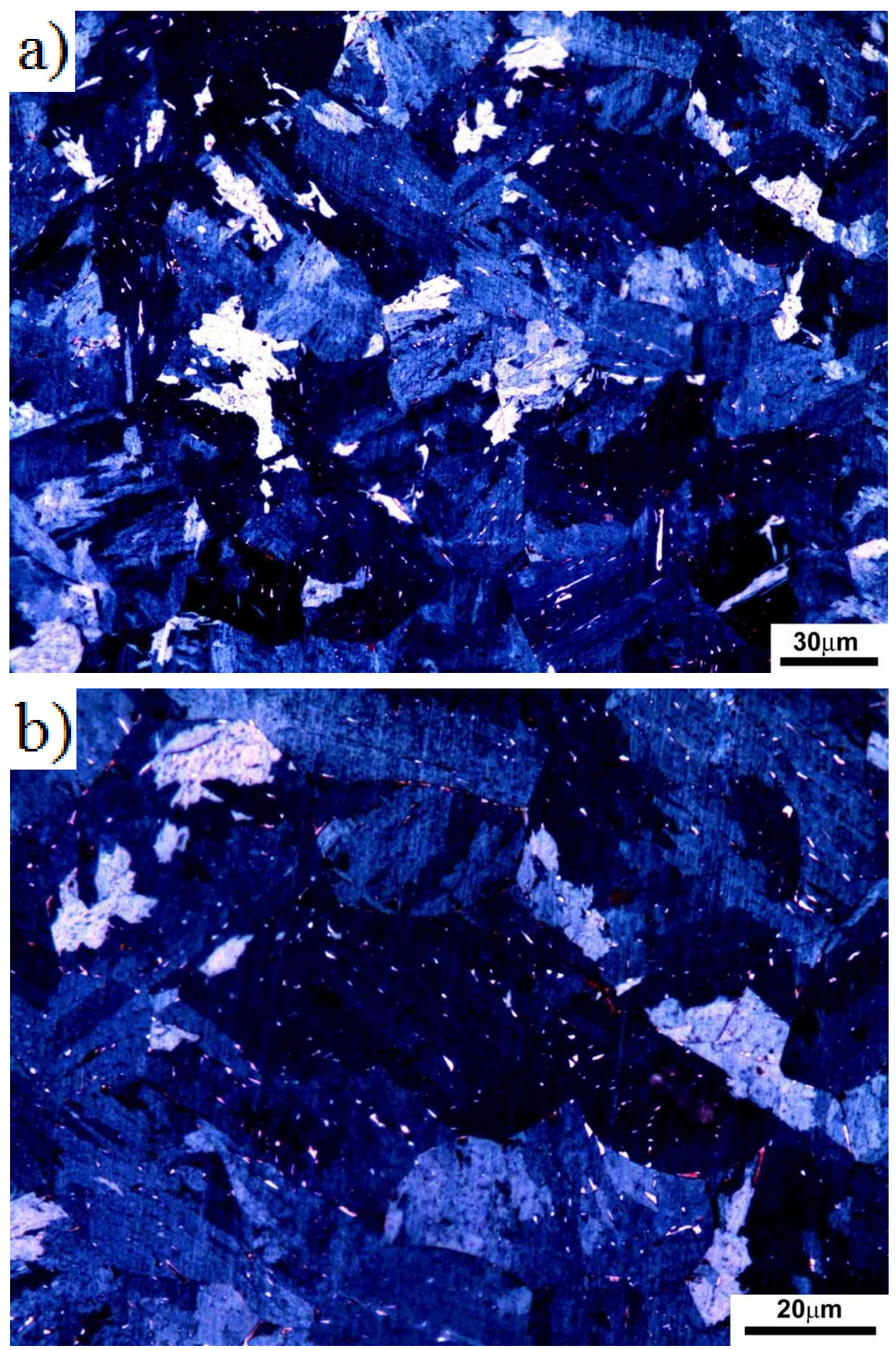

Figura 103. Microestrutura da posição 2 do material com ciclo térmico de $1300^{\circ} \mathrm{C}$ em a) $500 \mathrm{X}$ e b) 1000X. Ataque Klemm 1.

Na Fig. 100, pertencente ao ciclo térmico de $650^{\circ} \mathrm{C}$, o constituinte MA quase não existe, conforme foi explicado para a Fig. 79. Este ciclo térmico pode ter um efeito equivalente do tratamento térmico que se faz para reduzir a quantidade de MA, que é realizado a $400{ }^{\circ} \mathrm{C}$ por $1 \mathrm{~h}$. 


\subsubsection{Posição 3 (orientação T-L) no metal de base}
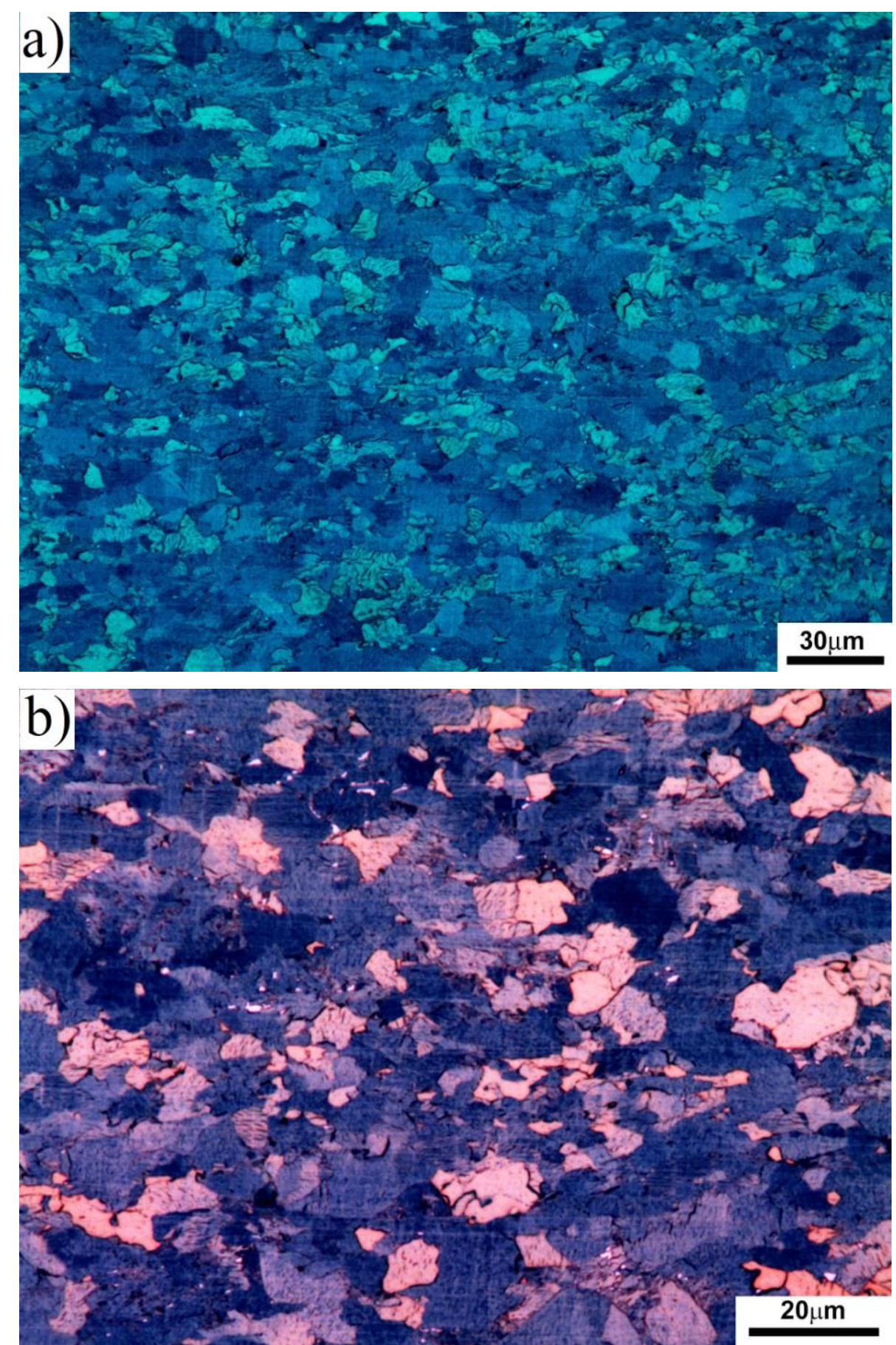

Figura 104. Microestrutura da posição 3 do material sem simulação em a) 500X e b) 1000X. Ataque Klemm 1.

Na Fig. 104 a fração volumétrica de MA é muito parecida com a Fig. 99. A eventual diferença pode estar na morfologia e na distribuição do MA, que parece ter um pouco mais de orientação com relação à direção de laminação na amostra 2. 


\subsubsection{Posição 3 (orientação T-L) simulação de um único passe}
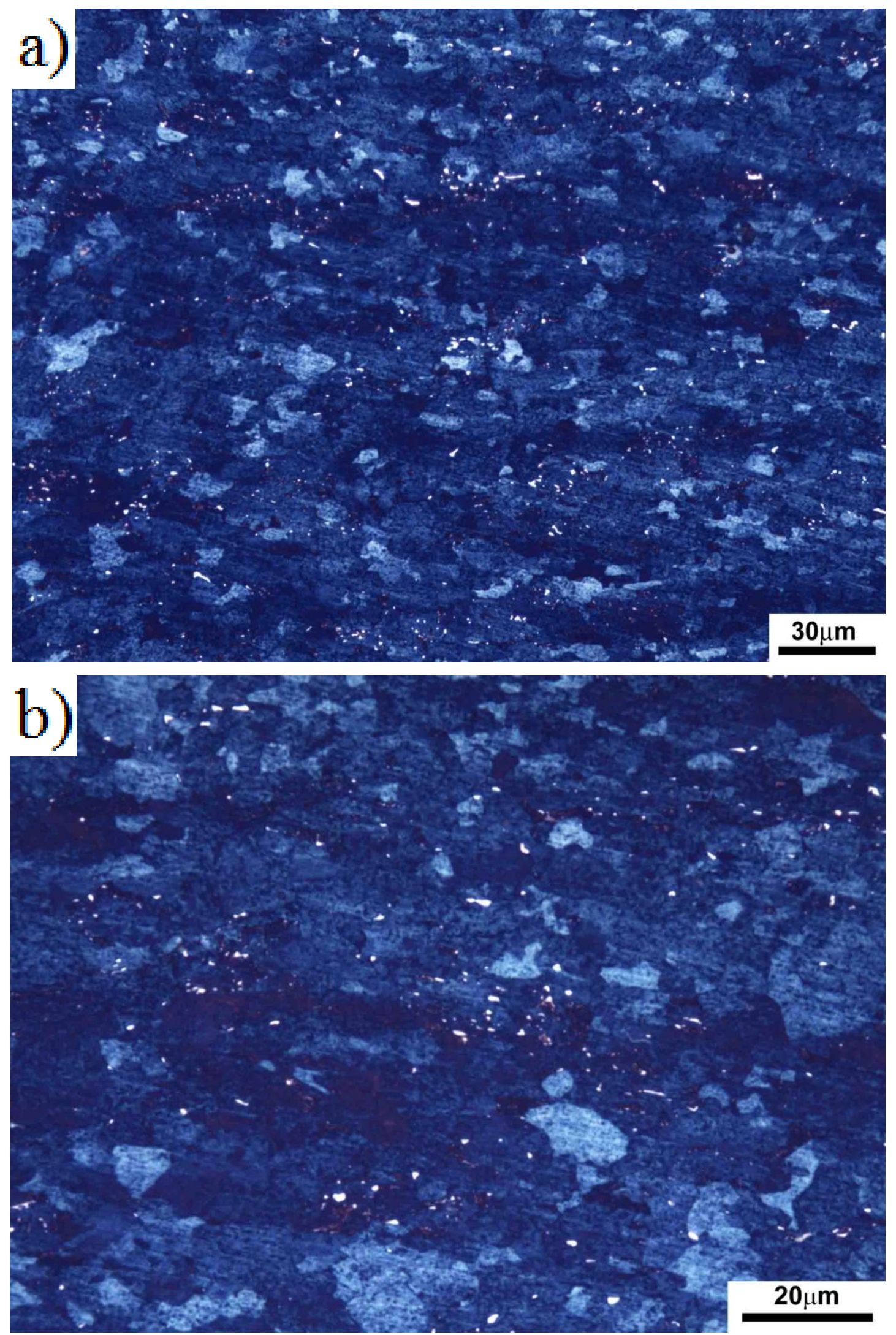

Figura 105. Microestrutura da posição 3 do material com ciclo térmico de $650^{\circ} \mathrm{C} \mathrm{em} \mathrm{a)} 500 \mathrm{X}$ e b) 1000X. Ataque Klemm 1. 

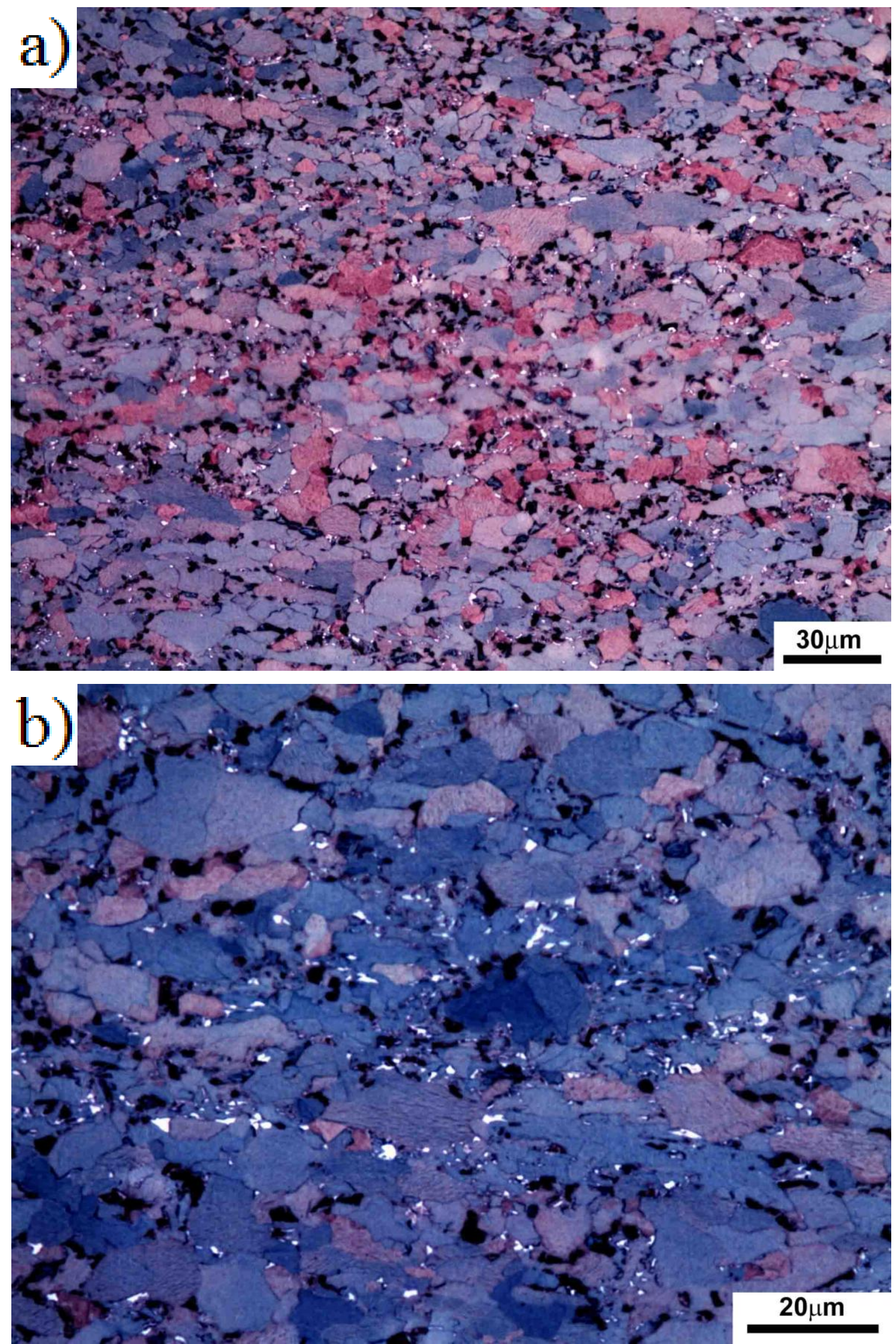

Figura 106. Microestrutura da posição 3 do material com ciclo térmico de $800^{\circ} \mathrm{C} \mathrm{em} \mathrm{a)} 500 \mathrm{X}$ e b) 1000X. Ataque Klemm 1. 

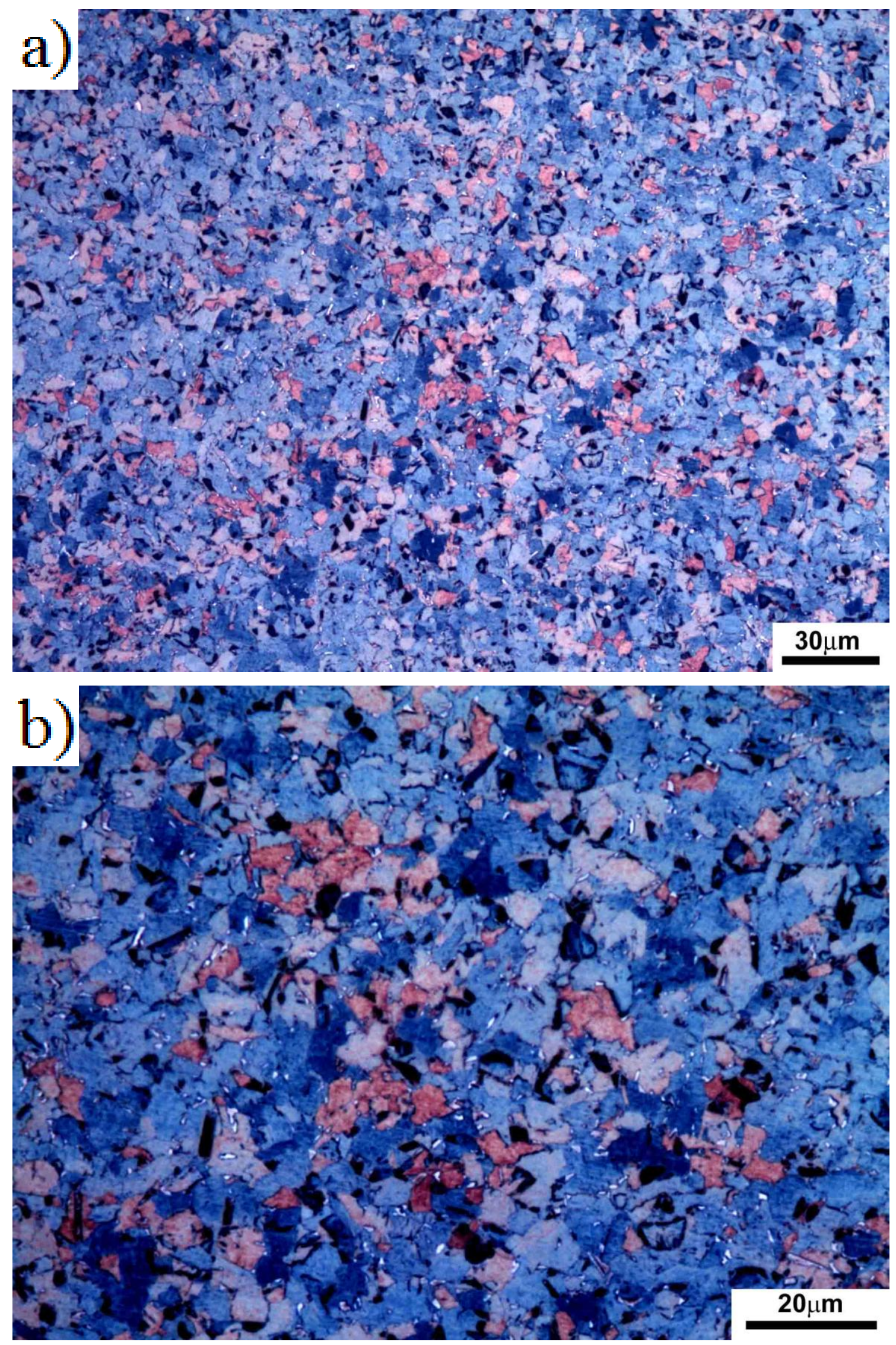

Figura 107. Microestrutura da posição 3 do material com ciclo térmico de $950^{\circ} \mathrm{C} \mathrm{em}$ a) $500 \mathrm{X}$ e b) 1000X. Ataque Klemm 1. 

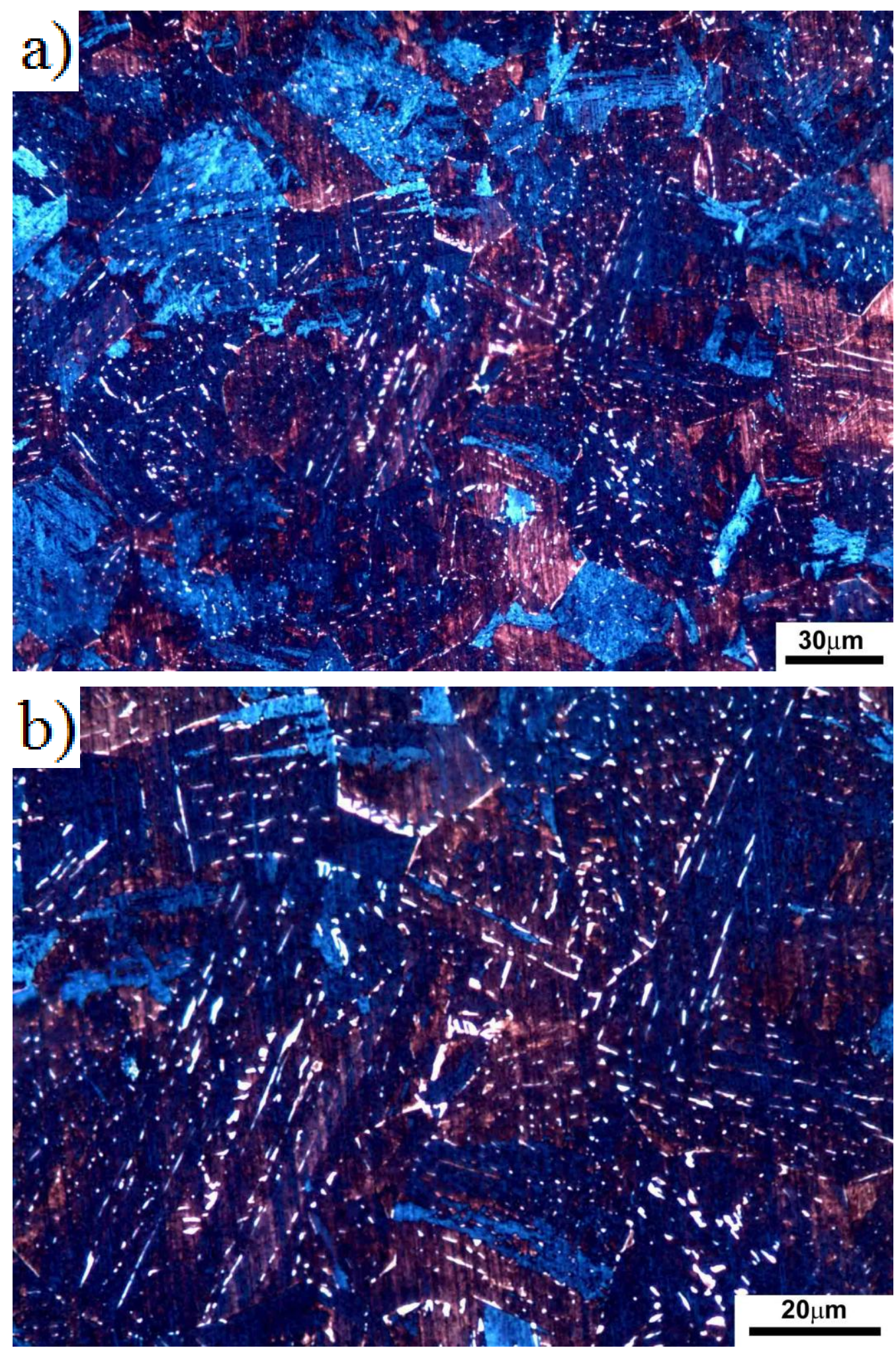

Figura 108. Microestrutura da posição 3 do material com ciclo térmico de $1300^{\circ} \mathrm{C}$ em a) $500 \mathrm{X}$ e b) 1000X. Ataque Klemm 1.

Na Fig. 105, pertencente ao ciclo térmico de $650^{\circ} \mathrm{C}$, o constituinte MA quase não existe como foi explicado para a Fig. 79. O ciclo da temperatura de $800{ }^{\circ} \mathrm{C}$ apresenta a maior quantidade de MA e também com tamanho médio maior. 


\subsubsection{Posição 1 (zona fundida) simulação multipasse}
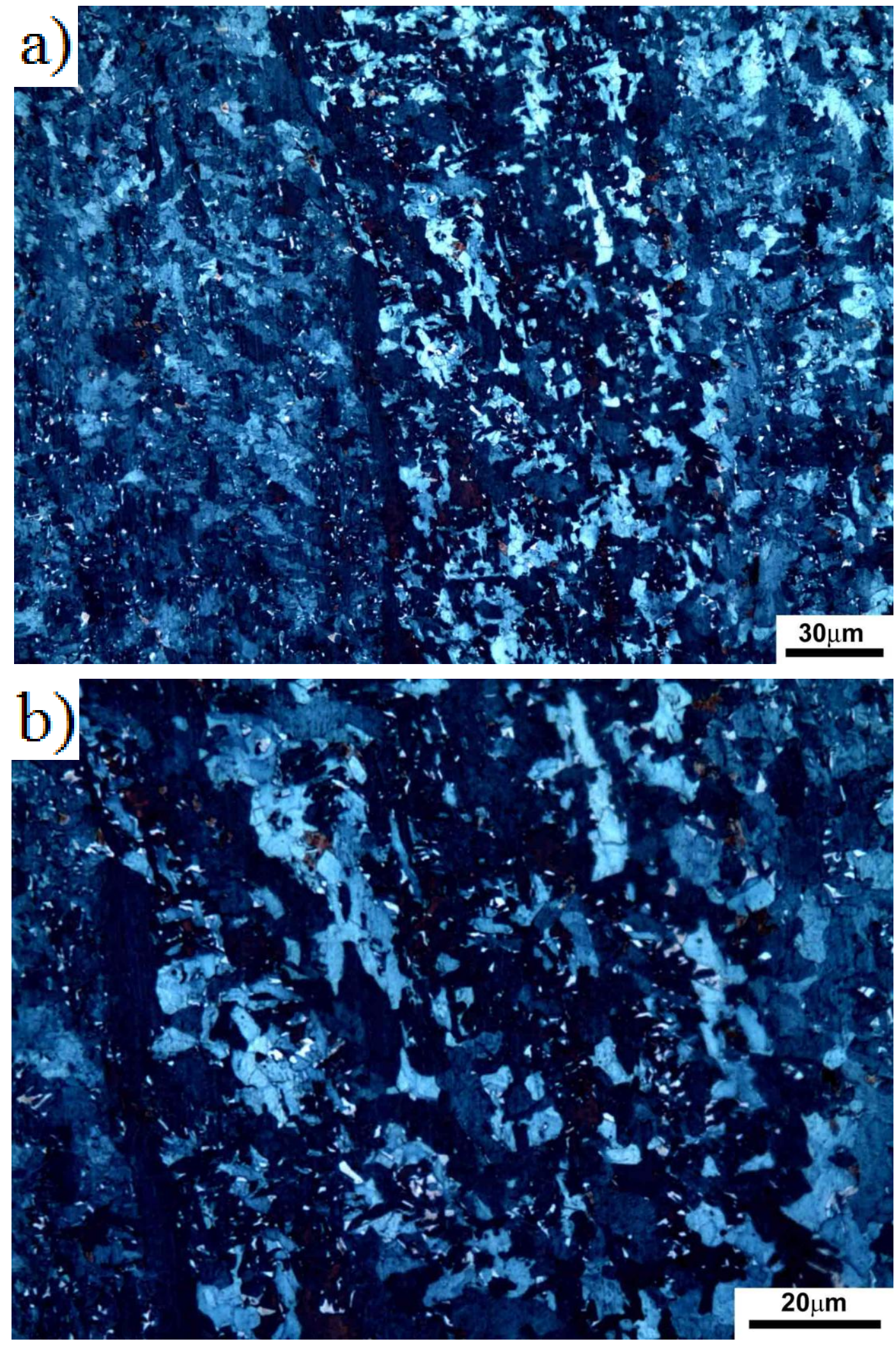

Figura 109. Microestrutura da posição 1 do material com ciclo térmico multipasse de 950-800 ${ }^{\circ} \mathrm{C}$ em a) $500 \mathrm{X}$ e b) $1000 \mathrm{X}$. Ataque Klemm 1. 

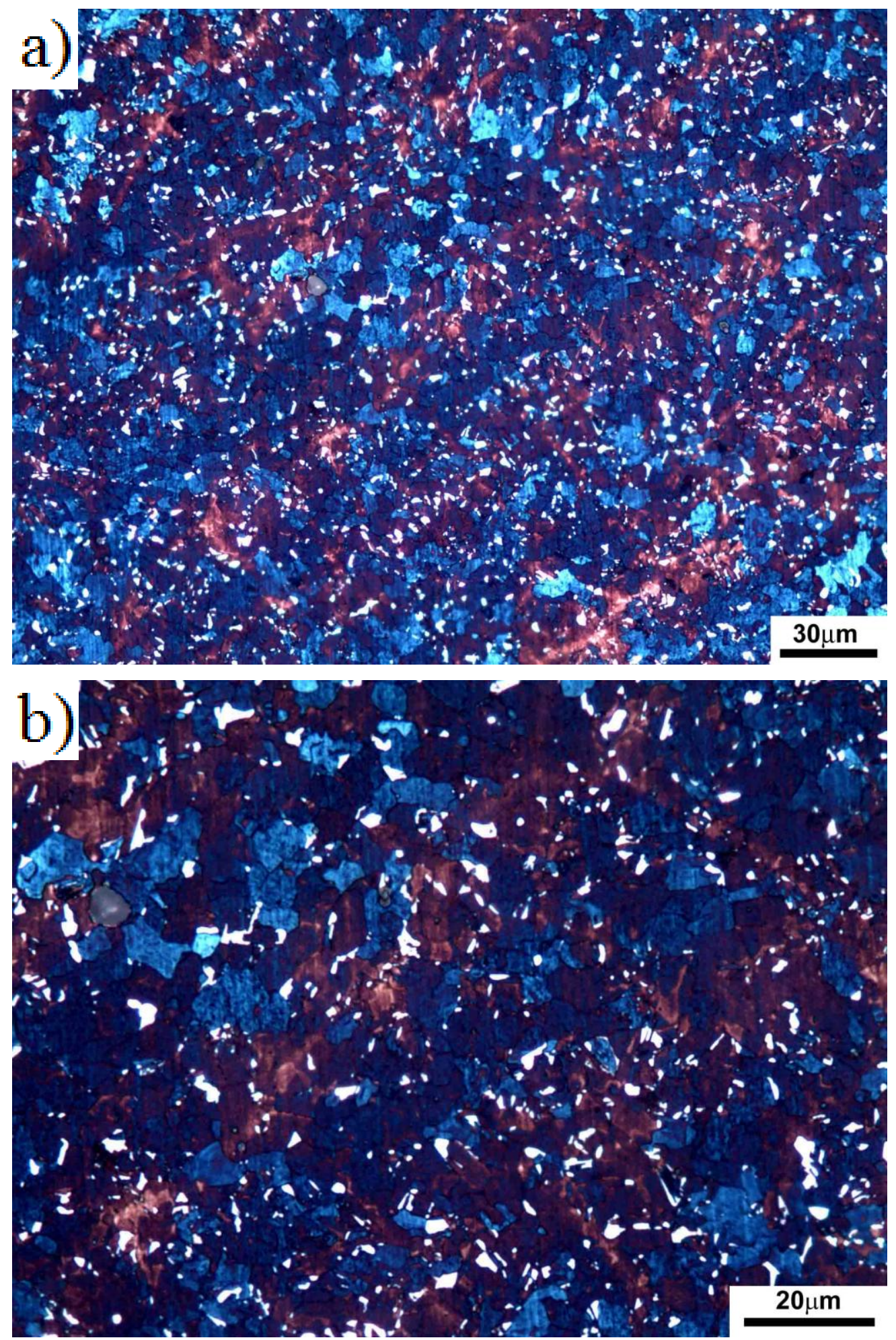

Figura 110. Microestrutura da posição 1 do material com ciclo térmico multipasse de 950-800$650{ }^{\circ} \mathrm{C}$ em a) $500 \mathrm{X}$ e b) $1000 \mathrm{X}$. Ataque Klemm 1.

As microestruturas das Fig. 109 e 110 mostram que a simulação de três passes apresenta uma maior quantidade de MA que de dois passes. Outro aspecto importante é que o constituinte MA ficou mais grosseiro no caso da simulação de três passes. 


\subsubsection{Posição 2 (orientação L-T) simulação multipasse}
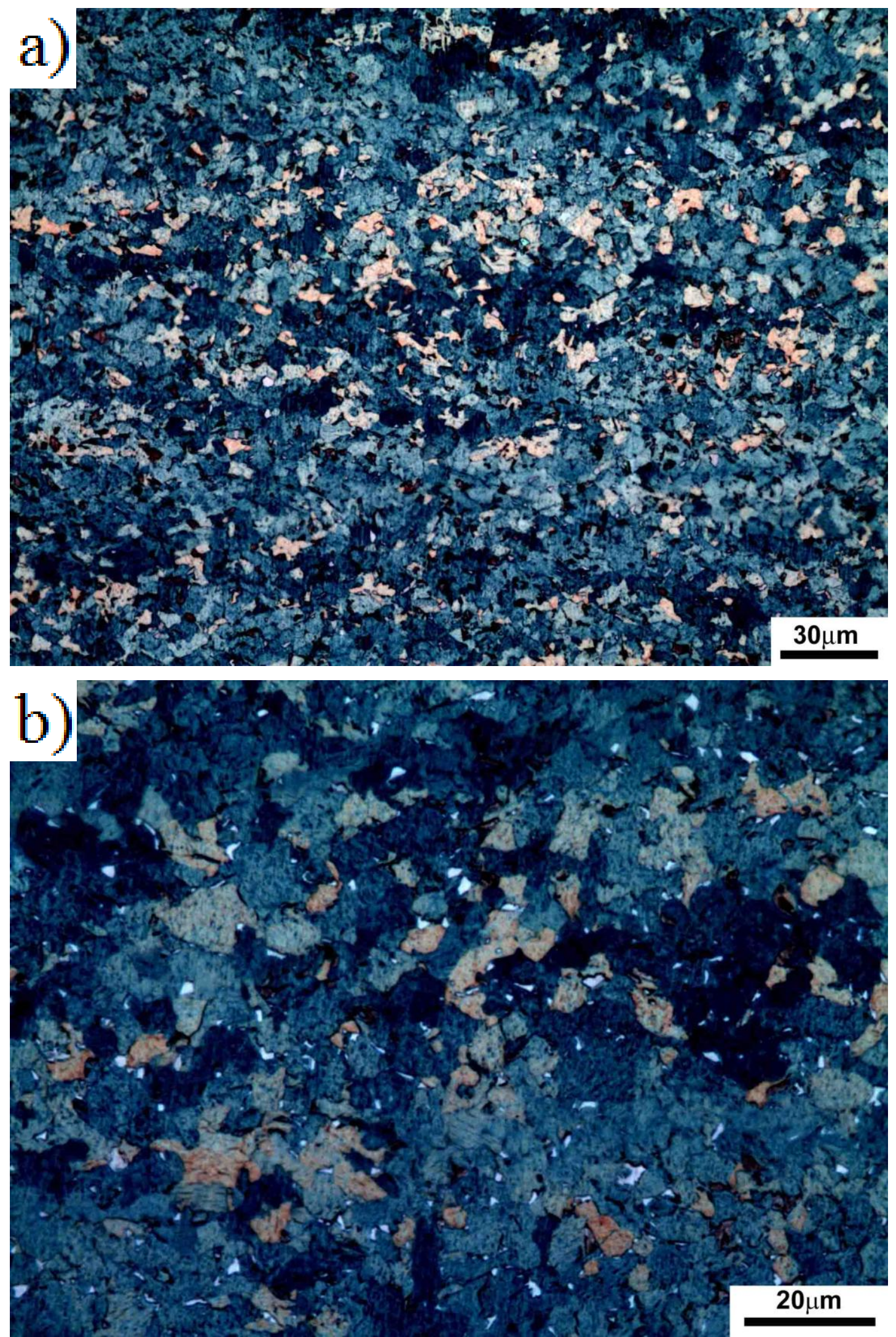

Figura 111. Microestrutura da posição 2 do material com ciclo térmico multipasse de 950-800 ${ }^{0} \mathrm{C}$ em a) $500 \mathrm{X}$ e b) $1000 \mathrm{X}$. Ataque Klemm 1. 

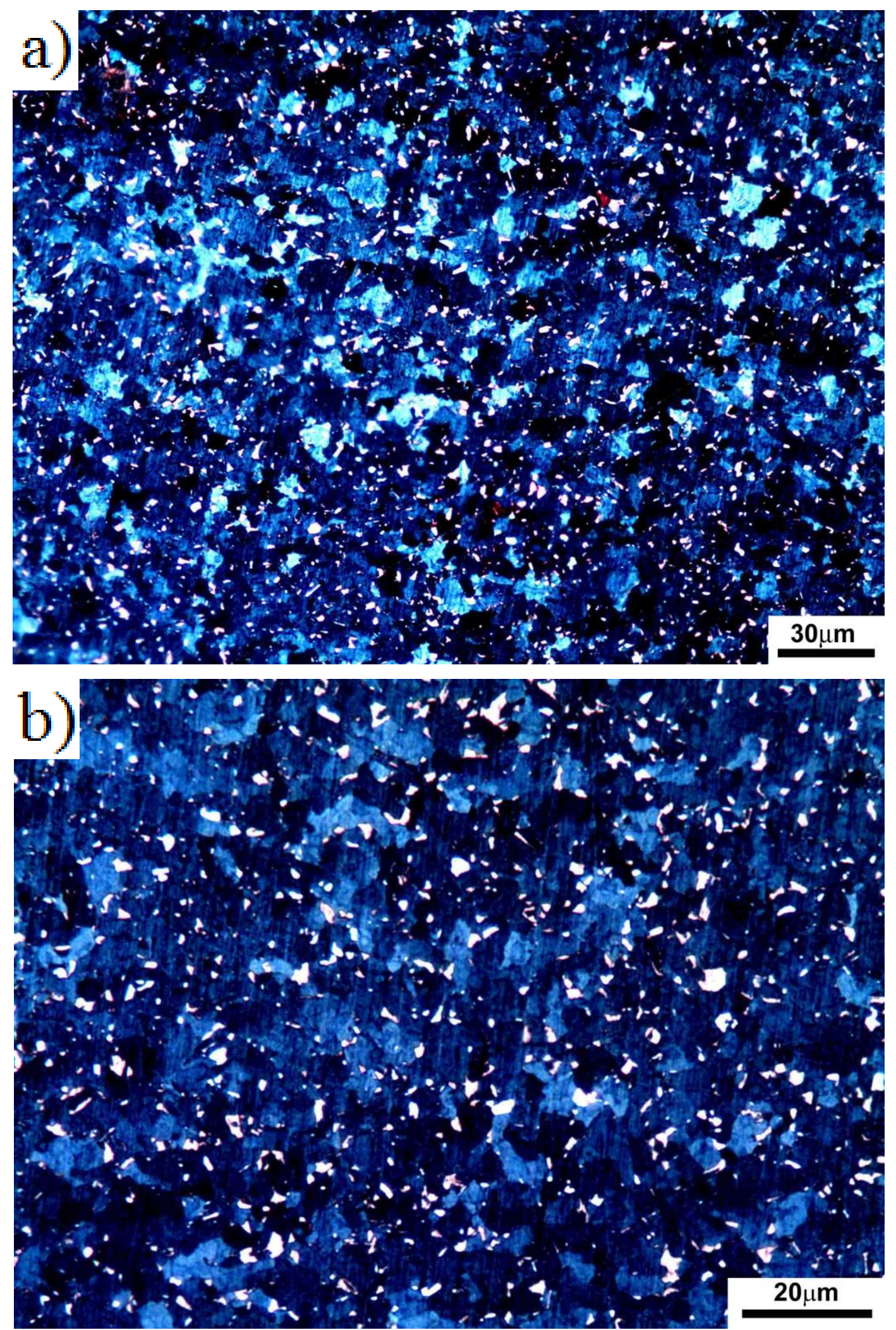

Figura 112. Microestrutura da posição 2 do material com ciclo térmico multipasse de 950-800$650{ }^{\circ} \mathrm{C} \mathrm{em} \mathrm{a)} 500 \mathrm{X}$ e b) $1000 \mathrm{X}$. Ataque Klemm 1.

A explicação é similar a das Fig. 109 e 110. A diferença está na composição química e na ausência de microsegregação no caso da posição 2. 


\subsubsection{Posição 3 (orientação T-L) simulação multipasse}
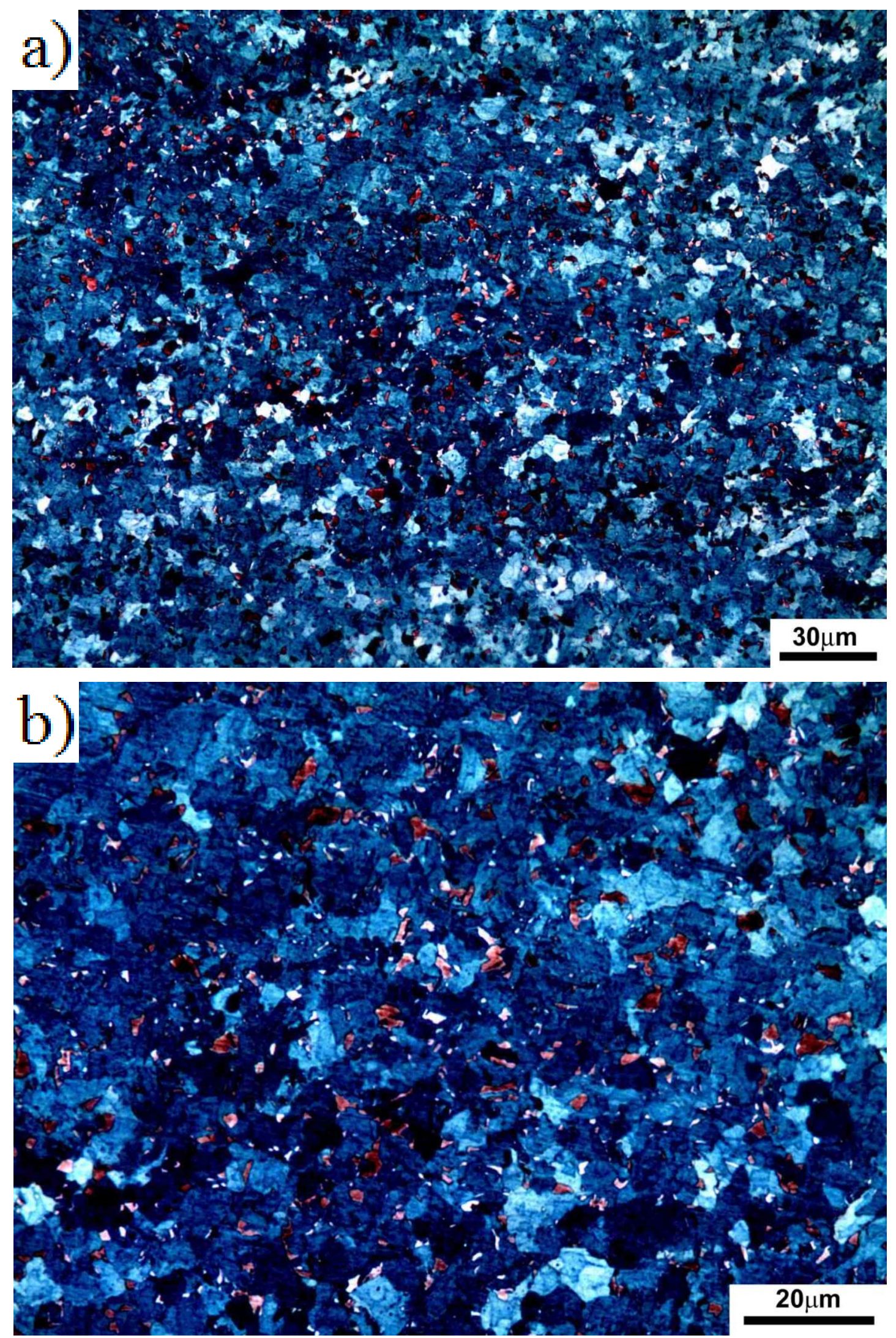

Figura 113. Microestrutura da posição 3 do material com ciclo térmico multipasse de 950-800 ${ }^{0} \mathrm{C}$ em a) 500X e b) 1000X. Ataque Klemm 1. 

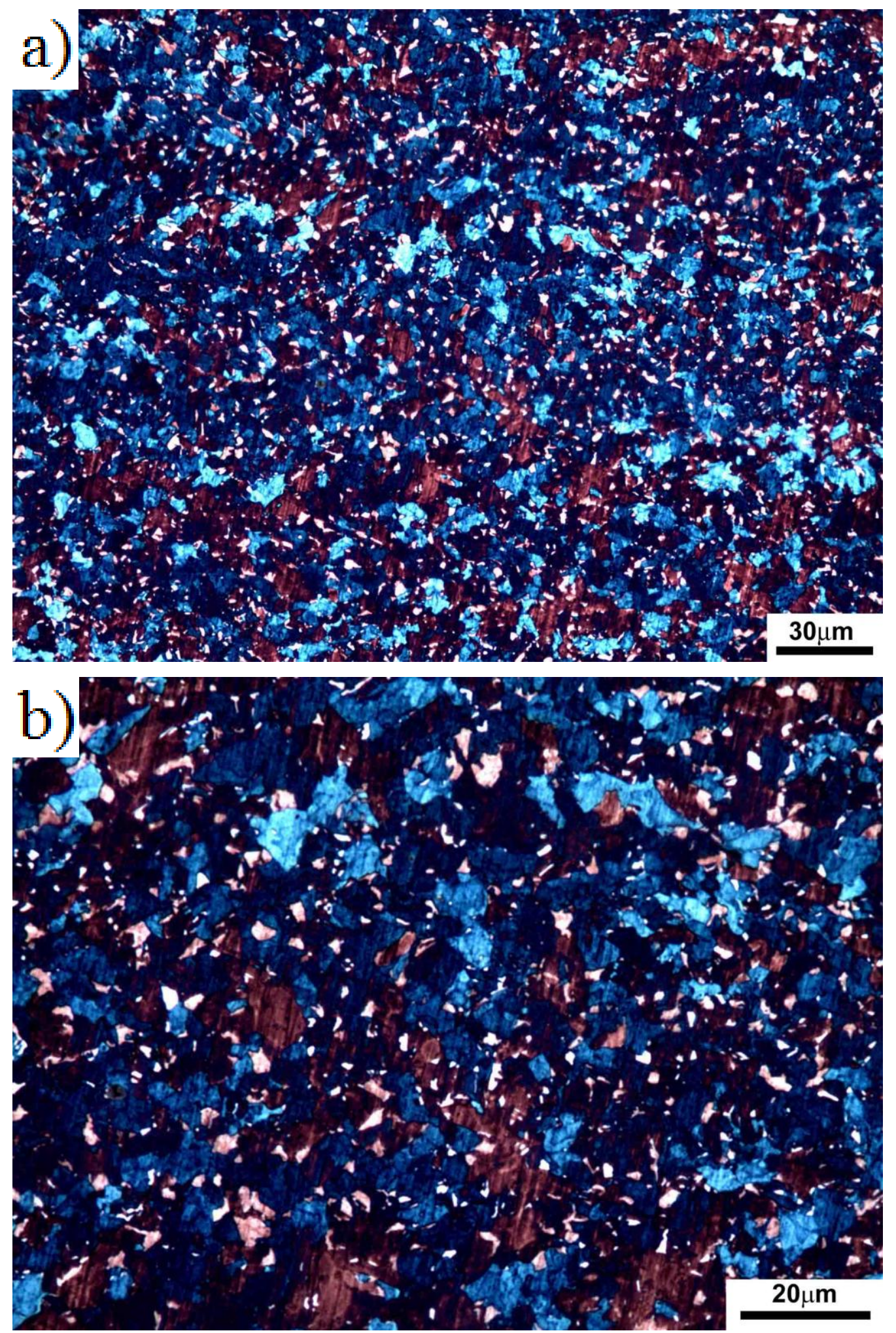

Figura 114. Microestrutura da posição 3 do material com ciclo térmico multipasse de 950-800$650{ }^{\circ} \mathrm{C}$ em a) $500 \mathrm{X}$ e b) $1000 \mathrm{X}$. Ataque Klemm 1.

As figuras com 3 ciclos térmicos multipasse apresentam aparentemente maior quantidade de MA e de maior tamanho. Provavelmente devido a que estes corpos de prova atingem a temperatura de $650{ }^{\circ} \mathrm{C}$ no terceiro passe. 


\subsubsection{Conteúdo de Agregados Eutetóides na Microestrutura do Aço nos Diferentes Ciclos Térmicos}

$\mathrm{Na}$ Tab. 11 e a Fig. 115 são apresentados os valores da fração volumétrica do conteúdo de agregados eutetóides na matriz ferrítica do aço como recebido e quando aplicados os ciclos térmicos simulados na ZF e na ZAC.

Tabela 11. Fração volumétrica dos agregados eutetóides na microestrutura do aço nos diferentes ciclos térmicos.

\begin{tabular}{|c|c|c|c|}
\hline \multirow{2}{*}{$\begin{array}{c}\text { Temperaturas Máximas dos } \\
\text { Ciclos Térmicos }\left({ }^{\circ} \mathbf{C}\right)\end{array}$} & \multicolumn{3}{|c|}{ Fração Volumétrica dos Agregados Eutetóides (\%) } \\
\cline { 2 - 4 } & Posição 1 (ZF) & Posição 2 (L-T) & Posição 3 (T-L) \\
\hline MB & $35,8 \pm 1,8$ & $20,5 \pm 1,3$ & $15,7 \pm 0,7$ \\
\hline 650 & $32,4 \pm 3,1$ & $18,2 \pm 0,9$ & $16,8 \pm 1,5$ \\
\hline 800 & $32,6 \pm 2,3$ & $25,1 \pm 1,8$ & $22,1 \pm 2,1$ \\
\hline 950 & $35,6 \pm 1,6$ & $28,6 \pm 2,3$ & $29,7 \pm 1,1$ \\
\hline 1300 & $32,7 \pm 1,7$ & $25,9 \pm 2,8$ & $28,9 \pm 2,1$ \\
\hline
\end{tabular}

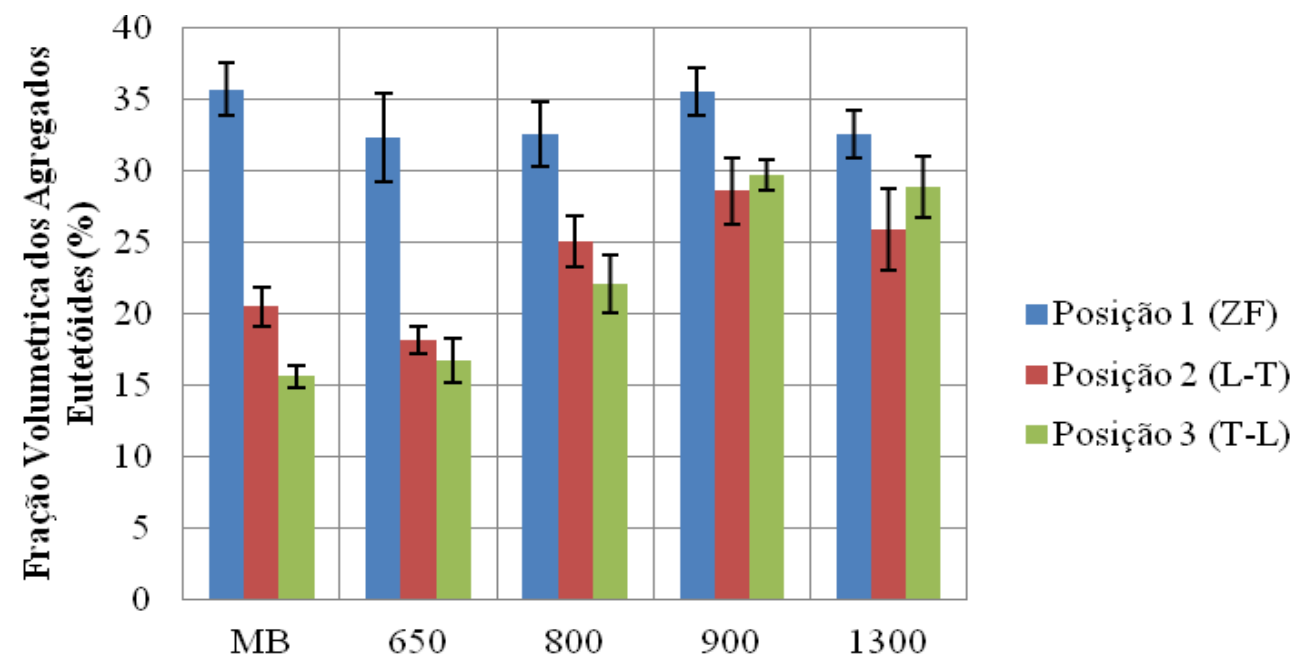

Temperaturas Máximas dos Ciclos Térmicos $\left({ }^{\circ} \mathrm{C}\right)$

Figura 115. Conteúdo de agregados eutetóides em função dos ciclos térmicos de uma passe.

Pode-se notar na Fig. 115 que a posição 1 é a que tem o maior conteúdo de agregados eutetóides em relação a posição 2 e 3 . Na posição 2 se tem conteúdo maior de agregados eutetóides que na posição 3 no material de base e nos ciclos térmicos de 650 e $800{ }^{\circ} \mathrm{C}$, e na posição 3 se tem maior conteúdo 
de agregados eutetóides que na posição 2 nos ciclos térmicos de 950 e $130{ }^{\circ} \mathrm{C}$. Observando-se os corpos-de-prova sem simulação (MB) se tem maior conteúdo de agregados eutetóides na posição 1 e o menor conteúdo de agregados eutetóides esta na posição 3 .

$\mathrm{Na}$ posição 1 o conteúdo volumétrico de agregados eutetóides diminui do material base sem simulação para o ciclo térmico de $650{ }^{\circ} \mathrm{C}$, e a partir de este ciclo térmico aumentou até o ciclo de $950{ }^{\circ} \mathrm{C}$ e voltou a diminuir em $1300{ }^{\circ} \mathrm{C}$. O mesmo comportamento apresentou-se na posição 2. Enquanto que, na posição 3 o conteúdo de agregados eutetóides aumento desde o material de base até 0 ciclo térmico de $950{ }^{\circ} \mathrm{C}$ com diminuição da agregados eutetóides no ciclo térmico de $1300{ }^{\circ} \mathrm{C}$. Na Tab. 12 temos a fração volumétrica dos agregados eutetóides para os ciclos térmicos multipasse.

Tabela 12. Fração volumétrica dos agregados eutetóides versus temperaturas máximas dos ciclos térmicos multipasse.

\begin{tabular}{|c|c|c|c|}
\hline \multirow{2}{*}{$\begin{array}{c}\text { Temperaturas Máximas dos } \\
\text { Ciclos Térmicos }\left({ }^{\circ} \mathbf{C}\right)\end{array}$} & \multicolumn{3}{|c|}{ Fração Volumétrica dos Agregados Eutetóides (\%) } \\
\cline { 2 - 4 } & Posição 1 (ZF) & Posição 2 (L-T) & Posição 3 (T-L) \\
\hline MB & $35,7 \pm 1,8$ & $20,5 \pm 1,3$ & $15,6 \pm 0,7$ \\
\hline $900-800$ & $30,2 \pm 2,3$ & $26,8 \pm 1,0$ & $30,1 \pm 1,3$ \\
\hline $900-800-650$ & $32,9 \pm 3,3$ & $26,1 \pm 1,1$ & $30,5 \pm 2,5$ \\
\hline
\end{tabular}

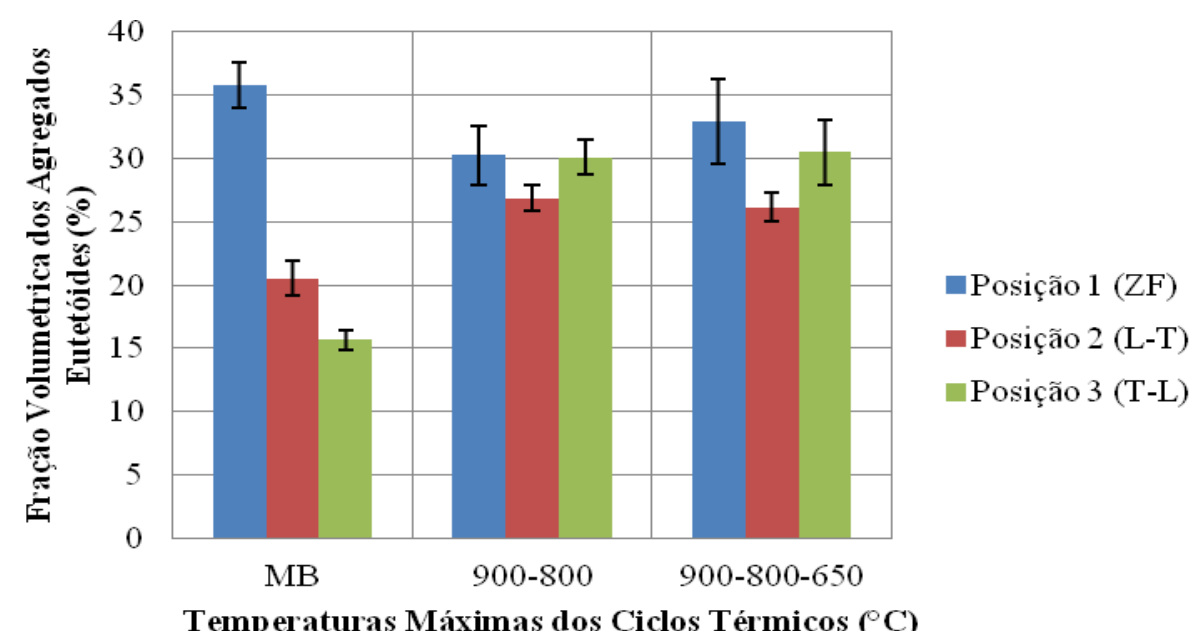

Figura 116. Fração volumétrica dos agregados eutetoides em relação as temperaturas máximas multipasse. 
Uma pequena quantidade maior de agregados eutetóides se obteve para a posição 1 em relaçao a posição 2 (L-T) e a posição 3 (T-L). Para a posiçao 2 e a posição 3 se tem quase o mesmo conteudo de agregados eutetóides para os distintos ciclos térmicos multipasse como se observa na Fig. 116.

\subsubsection{Resumo Comparativo dos Microconstituintes e Características da Microestrutura das Amostras Simuladas e na Condição Como-Recebida e Como-Soldada.}

A título comparativo foi montada a Tab. 13 , que mostra os microconstituintes presentes bem como as frações volumétricas do MA e dos agregados eutetóides além do tamanho de grão de todas as amostras estudadas. $\mathrm{Na}$ tabela, o menor número indica a menor medida ou fração volumétrica. A letra $\mathrm{G}$ indica que o microconstituinte apresente-se com tamanho maior que o normal. A letra $A$ indica que existe certa orientação e a letra $F$ indica que o tamanho é muito menor que o usual. Os sinais (+) e (-) indicam um tamanho pouco menor e maior que o tamanho normal. Foram comparados qualitativamente as porcentagens de microconstituintes $M A(\% M A)$ e tamanho de grão da ferrita (ou austenita anterior) (TG) além da porcentagem de agregados eutetóides e das fases e microconstituintes, que estão ordenadas da maior para a menor fração volumétrica. 
Tabela 13. Comparação das microestruturas dos corpos-de-prova estudados.

\begin{tabular}{|c|c|c|c|c|c|}
\hline \multirow[b]{2}{*}{ Condição } & \multirow[b]{2}{*}{ Localização } & \multicolumn{4}{|c|}{ Microestrutura } \\
\hline & & MA & TG & $\begin{array}{c}\text { \% agregados } \\
\text { eutetóides }\end{array}$ & $\begin{array}{c}\text { Fases e } \\
\text { microconstituintes }\end{array}$ \\
\hline \multirow[t]{3}{*}{ MB } & Posição 1 (ZF) & $4-5$ & $1-2$ & 36 & $A F>>F>M A$ \\
\hline & Posição 2 (L-T) & $2-3$ & 2 & 20 & $\mathrm{~F}>>\mathrm{MA}>\mathrm{AF}$ \\
\hline & Posição 3 (T-L) & $3-4$ & 1 & 16 & $\mathrm{~F}>>\mathrm{P}>\mathrm{AF}$ \\
\hline \multirow[t]{3}{*}{$650^{\circ} \mathrm{C}$} & Posição 1 (ZF) & $1-2$ & 1 & 32 & $\mathrm{AF}>>\mathrm{F}>>\mathrm{MA}$ \\
\hline & Posição 2 (L-T) & 1 & $2(A+)$ & 18 & $\mathrm{~F}>>\mathrm{P}>>\mathrm{MA}$ \\
\hline & Posição 3 (T-L) & 2 & 1 & 17 & $\mathrm{~F}>>\mathrm{P}>>M A$ \\
\hline \multirow[t]{3}{*}{$800^{\circ} \mathrm{C}$} & Posição 1 (ZF) & $4(\mathrm{G}-)$ & $0-1$ & 33 & $A F>>F>>M A$ \\
\hline & Posição 2 (L-T) & $2-3(\mathrm{G})$ & 1 & 25 & $\mathrm{~F}>>\mathrm{P}>\mathrm{MA}>\mathrm{AF}$ \\
\hline & Posição 3 (T-L) & $2-3(G+)$ & 2 & 22 & $\mathrm{~F}>>\mathrm{MA}$ \\
\hline \multirow[t]{3}{*}{$950{ }^{\circ} \mathrm{C}$} & Posição 1 (ZF) & $1-2$ & $0-1$ & 36 & $A F>>F>M A$ \\
\hline & Posição 2 (L-T) & 2 & 1 & 29 & $\mathrm{~F}>\mathrm{AF}>\mathrm{MA}>\mathrm{P}$ \\
\hline & Posição 3 (T-L) & 2 & 2 & 30 & $\mathrm{~F}>\mathrm{AF}>\mathrm{MA}>\mathrm{P}$ \\
\hline \multirow[t]{3}{*}{$1300{ }^{\circ} \mathrm{C}$} & Posição 1 (ZF) & $4-5(\mathrm{G}$ e $A)$ & 2 & 33 & $A F>>F>M A$ \\
\hline & Posição 2 (L-T) & $2-3(\mathrm{G}-\mathrm{e} A-)$ & $4-5$ & 26 & $\mathrm{~GB}, \mathrm{BF}>\mathrm{MA}>\mathrm{AF}$ \\
\hline & Posição 3 (T-L) & $5(G+e A+)$ & 4 & 29 & $\mathrm{~GB}, \mathrm{BF}>\mathrm{MA}>\mathrm{AF}$ \\
\hline \multirow[t]{3}{*}{$950-800{ }^{\circ} \mathrm{C}$} & Posição 1 (ZF) & $3(F)$ & 2 & 30 & $A F>>F>M A$ \\
\hline & Posição 2 (L-T) & $2(\mathrm{G})$ & 2 & 27 & $\mathrm{~F}>\mathrm{AF}>\mathrm{MA}>\mathrm{P}$ \\
\hline & Posição 3 (T-L) & $2-3(F)$ & $2-3$ & 30 & $\mathrm{~F}>\mathrm{AF}>\mathrm{MA}>\mathrm{P}$ \\
\hline \multirow{3}{*}{$\begin{array}{c}950-800-650 \\
{ }^{0} \mathrm{C}\end{array}$} & Posição 1 (ZF) & $3-4(\mathrm{G}+)$ & 3 & 33 & $A F>>F>M A$ \\
\hline & Posição 2 (L-T) & $4(\mathrm{G}+)$ & 2 & 26 & $\mathrm{~F}>\mathrm{AF}>\mathrm{MA}>\mathrm{P}$ \\
\hline & Posição 3 (T-L) & $4(\mathrm{G}+)$ & 2 & 30 & $\mathrm{~F}>\mathrm{AF}>\mathrm{MA}>\mathrm{P}$ \\
\hline
\end{tabular}




\subsection{Ensaio de Impacto Charpy-V}

\subsubsection{Energia Absorvida}

Este ensaio permite comparar entre si como os ciclos térmicos, que simulam a ZAC, afetam a tenacidade do material quando este é soldado. As Tab. $14 \mathrm{e}$ Tab. 15 apresentam os dados das médias dos resultados obtidos no ensaio de impacto Charpy- $\mathrm{V}$ das amostras ensaiadas a $0{ }^{\circ} \mathrm{C}$. Nestas tabelas tem-se as 3 posições estudadas do tubo, sem simulação e com as temperaturas máximas dos ciclos térmicos simulados, de um passe e multipasse, respectivamente, aplicados aos corpos-de-prova.

Tabela 14. Valores das energias absorvidas do ensaio de impacto Charpy- $V$ dos corpos-de-prova do metal base e com simulação do ciclo térmico de um passe.

\begin{tabular}{|c|c|c|c|}
\hline \multirow{2}{*}{$\begin{array}{c}\text { Temperatura Máxima dos } \\
\text { Ciclos Térmicos }\left({ }^{\circ} \mathbf{C}\right)\end{array}$} & \multicolumn{3}{|c|}{ Energia Absorvida (J) a 0 ${ }^{\circ} \mathbf{C}$} \\
\cline { 2 - 4 } & Posição 1 (ZF) & Posição 2 (L-T) & Posição 3 (T-L) \\
\hline MB & $120 \pm 4$ & $238 \pm 4$ & $169 \pm 14$ \\
\hline 650 & $102 \pm 25$ & $292^{(1)}$ & $185 \pm 4$ \\
\hline 800 & $105 \pm 1$ & $243 \pm 18$ & $179 \pm 15$ \\
\hline 950 & $120 \pm 6$ & $279 \pm 7$ & $207 \pm 14$ \\
\hline $1300^{(2)}$ & 74 & 94 & 75 \\
\hline \multicolumn{2}{|c|}{ Notas: (1) Três amostras com o mesmo valor de energia absorvida. }
\end{tabular}

(2) Amostra de ensaio com um lado menor (10x5x55 mm).

Segundo a norma API 5L [8] especifica que uma amostra é aprovada se sua energia absorvida, resultado do ensaio Charpy- $\mathrm{V}$, é maior ou igual que $80 \mathrm{~J}$. Como se pode observar na Tab. 14 as 3 posições ensaiadas e o material de base cumprem com o requisito da norma especificada, exceto nas posições $1 \mathrm{e}$ 3 submetidas ao ciclo térmico de $1300{ }^{\circ} \mathrm{C}$ por causa de que estas amostras tem dimensões distintas às outras amostras. Rocha [55] obteve para a ZAC de soldas circunferenciais valores médios reais de $234 \mathrm{~J}$ a $0{ }^{\circ} \mathrm{C}$. Este resultado está bem próximo dos valores médios obtidos para a posição 2 deste trabalho, como era de se esperar. 
A Fig. 117 apresenta os dados obtidos na Tab.14 para o material sem simulação e os ciclos térmicos de um único passe.

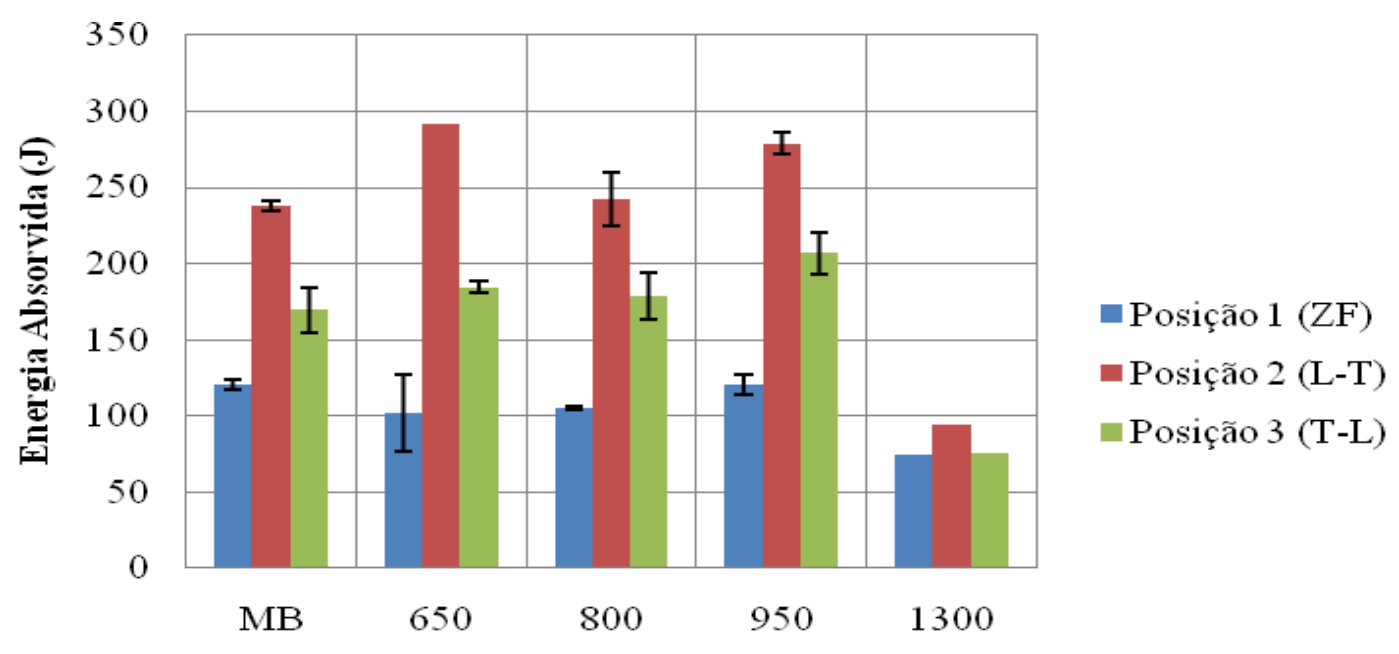

Temperatura Máxima dos Ciclos Térmicos $\left({ }^{\circ} \mathrm{C}\right)$

Figura 117. Energias absorvidas em relação a os ciclos térmicos.

Pode-se notar que a posição 1 na Fig. 117, que é região do cordão de solda, possui a mais baixa energia absorvida em relação às outras duas posições. Como era esperado na posição 1 , já que esta posição tem diferente composição química que as outras duas posições, e porque apresenta o cordão de solda longitudinal que se realizou no processo de fabricação UOE do tubo, que é afetado pela ZAC da solda circunferencial. Hashemi [45] obteve uma energia absorvida para região onde se encontra o cordão de solda numa faixa de 99 a $143 \mathrm{~J}$. Com relação à microestrutura, a posição 1 possui em média maior fração volumétrica de MA e agregados eutetóides.

Com base nos dados apresentados na Tab. 14, pode-se observar que, na Fig. 117, a posição 2 tem a maior energia absorvida em comparação a posição 3 e a posição 1 , para o material sem simulação e as distintas temperaturas máximas dos ciclos térmicos. Shin [52] obteve uma variação de tenacidade na ZAC de um aço API $5 \mathrm{~L}$ grau $X 80$ a $0{ }^{\circ} \mathrm{C}$ de 173 a $238 \mathrm{~J}$. Cabe salientar que 0 aço ensaiado nesta tese é feito sem resfriamento acelerado ao contrario do aço utilizado por Shin [52] que sim foi feito com resfriamento acelerado. Correlacionando estes resultados com a microestrutura, a posição 2 possui em média menor fração volumétrica de MA e agregados eutetóides em quantidade 
menor que a posição 1 e similar à posição 3 . 0 tamanho de grão da ferrita tende a ser menor que na posição 3 .

A seguir será analisada a tenacidade avaliada pelo ensaio Charpy em relação aos ciclos térmicos para cada posição, exceto para o ciclo de $1300{ }^{\circ} \mathrm{C}$, cujo corpo-de-prova tem medidas menores que os outros cps.

Analisando a tenacidade dos ciclos térmicos na posição 1, na Fig. 117, vê-se que a energia absorvida diminui do material sem simulação (120 J) para o ciclo térmico de $650{ }^{\circ} \mathrm{C}(102 \mathrm{~J})$, e a partir deste aumentou progressivamente até o ciclo térmico de $950{ }^{\circ} \mathrm{C}(120 \mathrm{~J})$, tendo este uma energia absorvida igual ao do material sem simulação. A menor energia absorvida média foi obtida no ciclo térmico de $650{ }^{\circ} \mathrm{C}$. Especificamente este ensaio apresentou uma dispersão de resultados, que acabou por superpor aos resultados da simulação a $800{ }^{\circ} \mathrm{C}$, que teve também uma média baixa.

O comportamento da energia absorvida nas posições 2 e 3 foram distintos da posição 1. A energia absorvida na posição 2 aumentou desde o material sem simulação (238 J) para o ciclo térmico de $650{ }^{\circ} \mathrm{C}(292 \mathrm{~J})$ e teve uma queda de energia no ciclo térmico de $800{ }^{\circ} \mathrm{C}(243 \mathrm{~J})$ e aumentou novamente no ciclo térmico de $950{ }^{\circ} \mathrm{C}(279 \mathrm{~J})$. Este comportamento foi o mesmo para os corposde-prova da posição 3. A diferença entre os resultados pode estar associada a quantidade de MA, que tende a ser maior para a posição 3 .

Na posição 2 a maior energia absorvida foi registrada no ciclo térmico de $650^{\circ} \mathrm{C}$ (região de acicularização do aço), e a menor energia absorvida para o material de base sem simulação. Esta energia absorvida menor pode ser devido à maior heterogeneidade do grão ferrítico [51] que apresenta o material de base sem simulação como se observa na Fig. 117.

Na posição 3, observou-se a maior energia absorvida no ciclo térmico de $950^{\circ} \mathrm{C}$ (região de refino de grão) e a menor energia absorvida no material de base sem ciclo térmico. Roza $E$. J. et al [13], estudou um aço API $5 \mathrm{~L}$ grau X80, produzido no Brasil, e seu valor médio de energia absorvida, a $0{ }^{\circ} \mathrm{C}$, em três corpos-de-prova foi de $207 \mathrm{~J}$, com $100 \%$ da área fraturada apresentando comportamento dúctil. 
Os valores das energias absorvidas para as simulações multipasse estão apresentados na Tab. 15.

Tabela 15. Valores das energias absorvidas do ensaio de impacto Charpy-V dos corpos-de-prova com ciclos térmicos multipasse.

\begin{tabular}{|c|c|c|c|}
\hline Temperatura Máxima dos & \multicolumn{3}{|c|}{ Energia Absorvida (J) } \\
\cline { 2 - 4 } Ciclos Térmicos $\left({ }^{\circ} \mathbf{C}\right)$ & Posição 1 (ZF) & Posição 2 (L-T) & Posição 3 (T-L) \\
\hline MB & $120 \pm 4$ & $238 \pm 4$ & $169 \pm 15$ \\
\hline $950-800$ & $126 \pm 16$ & $243 \pm 12$ & $199 \pm 8$ \\
\hline $950-800-650$ & $90 \pm 11$ & $230 \pm 4$ & $183 \pm 10$ \\
\hline
\end{tabular}

$\mathrm{Na}$ Fig. 118 representa as energias absorvidas dos ciclos térmicos multipasse em função das temperaturas máximas.

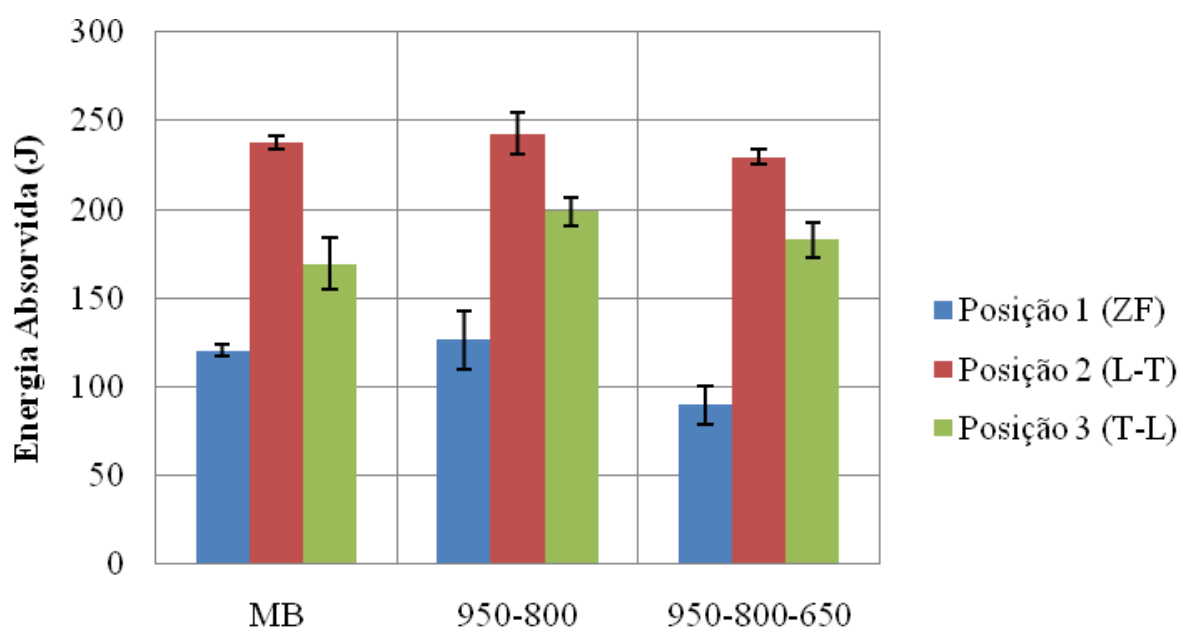

Temperatura Máxima dos Ciclos Térmicos $\left({ }^{\circ} \mathrm{C}\right)$

Figura 118. Energias absorvidas para os ciclos térmicos multipasse.

A posição 1 na Fig. 118 tem a menor energia absorvida com relação às posições 2 e 3. Este comportamento é devido ao tipo de microestrutura (bruta de fusão) e composição química do cordão de solda diferente do material do tubo. Este resultado das energias absorvidas pode ser explicado pela microestrutura, que apresenta \% de agregado MA um pouco maior além do tamanho de grão maior e da porcentagem de agregados eutetóides. Além disso, esta posição apresenta ferrita de contorno de grão (GF) e ferrita com 
segunda fase não alinhada SF(NA), as quais são prejudiciais para a tenacidade como pode ser observado nas Fig. 67, 68 e Fig. 88, 89. Além disso, a menor energia absorvida pode estar associada ao conteúdo de elementos de liga provenientes do eletrodo, os quais incrementam a fases duras que possuem baixa tenacidade [56].

Os corpos-de-prova da posição 2 apresentam maior energia absorvida que a posição 3, devido à diferença de orientação do entalhe, onde o entalhe da posição 2 foi feito perpendicular aos sentido da laminação da chapa do tubo $[42,43]$.

A seguir serão analisados os ciclos térmicos multipasse para cada posição, já que no parágrafo anterior analisamos as energias absorvidas em relação á posição dos corpos-de-prova.

As energias absorvidas dos corpos-de-prova com ciclos térmicos multipasse de 950-800-650 ${ }^{\circ} \mathrm{C}$, nas 3 posições, apresentam menor energia absorvida em relação aos ciclos multipasse de $950-800{ }^{\circ} \mathrm{C}$ isso pode ser devido à quantidade de passes de solda (3 ciclos térmicos), que se fez nesta simulação. Os ciclos térmicos com três temperaturas máximas, de 950-800-650 ${ }^{0} \mathrm{C}$, apresentam energias absorvidas menores que o material de base sem simulação para as posições 1 e 2 exceto para a posição 3. Este fato pode ser explicado devido a posição do entalhe esta paralelo ao sentido de laminação da chapa com que se fez o tubo, que é a posição critica e com menor tenacidade [42]. Além disso, esta posição não sofreu nenhuma modificação significativa na sua microestrutura, como se observa na Fig. 62, em comparação com a microestrutura que apresentou a posição 3, que foi afetada pelos ciclos térmicos, como se observa na Fig. 72.

Observando-se somente as energias absorvidas no material sem simulação $(\mathrm{MB})$, nota-se que as energias absorvidas das posições 2 e 3 são maiores que a posição 1. O material de base sempre tem maior energia absorvida que a zona fundida [45].

Fazendo uma comparação entre as energias absorvidas de todos os ciclos térmicos de um passe e multipasse pode-se observar que o ciclo térmico de 950-800-650 ${ }^{0} \mathrm{C}$ obteve as piores energias absorvidas devido à quantidade de ciclos térmicos feitos nestes corpos-de-prova. 
Apesar dos resultados serem diferentes entre si, alguns piores que outros, todos os valores das energias absorvidas dos corpos-de-prova do ensaio Charpy com dimensões de norma apresentaram resultados das energias absorvidas para estes ciclos térmicos dentro dos requisitos da norma API $5 \mathrm{~L}$ [8].

\subsubsection{Energia Absorvida/Área}

A seguir na Tab. 16 tem-se os dados das medias da energia absorvida entre a área transversal onde o corpo-de-prova foi fraturado. O objetivo desta análise é fazer a comparação do material sem simulação e dos ciclos térmicos de um passe único de 650,800 e $950{ }^{\circ} \mathrm{C}$ com o ciclo térmico de $1300{ }^{\circ} \mathrm{C}$, uma vez que este cp não pôde ser comparado anteriormente, porque possui medidas reduzidas, distinta a os outros corpos-de-prova. Os dados da Tab. 16 foram obtidos a partir da equação 4:

Energia absorvida

Eq. (4)

Area

A área para os corpos-de-prova simulados a 950,800 e $650{ }^{\circ} \mathrm{C}$ foi de $80 \mathrm{~mm}^{2} \mathrm{e}$ a área para $1300{ }^{\circ} \mathrm{C}$ foi de $40 \mathrm{~mm}^{2}$. A Fig. 119 apresenta os resultados da energia média absorvida por área, em relação às temperaturas máximas dos ciclos térmicos aplicados aos corpos-de-prova.

A posição 1 da Fig. 119 apresenta menor energia absorvida/área que a posição 2 e 3 uma vez que a ZAC foi produzida em uma microestrutura bruta de fundição (cordão de solda longitudinal), que possui microssegregação de impurezas e de elementos de liga, contrastando com a rota de produção das chapas produzidas por processos termomecânicos além de possuir composição química diferente. A energia absorvida na região onde esta o cordão de solda é menor em comparação com os valores para a ZAC $[45,56]$. 
Tabela 16. Energia absorvida/área em relação às temperaturas dos ciclos térmicos.

\begin{tabular}{|c|c|c|c|}
\hline \multirow{2}{*}{$\begin{array}{c}\text { Temperatura Máxima dos } \\
\text { Ciclos Térmicos }\left({ }^{\circ} \mathbf{C}\right)\end{array}$} & \multicolumn{3}{|c|}{ Energia Absorvida/Área (J/mm $\left.{ }^{2}\right)$} \\
\cline { 2 - 4 } & Posição 1 (ZF) & Posição 2 (L-T) & Posição 3 (T-L) \\
\hline MB & $1,50 \pm 0,04$ & $2,98 \pm 0,05$ & $2,11 \pm 0,18$ \\
\hline 650 & $1,28 \pm 0,32$ & $3,65^{(1)}$ & $2,31 \pm 0,05$ \\
\hline 800 & $1,31 \pm 0,01$ & $3,04 \pm 0,22$ & $2,24 \pm 0,19$ \\
\hline 950 & $1,50 \pm 0,08$ & $3,49 \pm 0,09$ & $2,59 \pm 0,17$ \\
\hline $1300^{(2)}$ & 1,39 & 1,76 & 1,31 \\
\hline
\end{tabular}

Notas: (1) Três amostras com o mesmo valor de energia absorvida.

(2) Amostra de ensaio com um lado menor (10×5×55 mm).

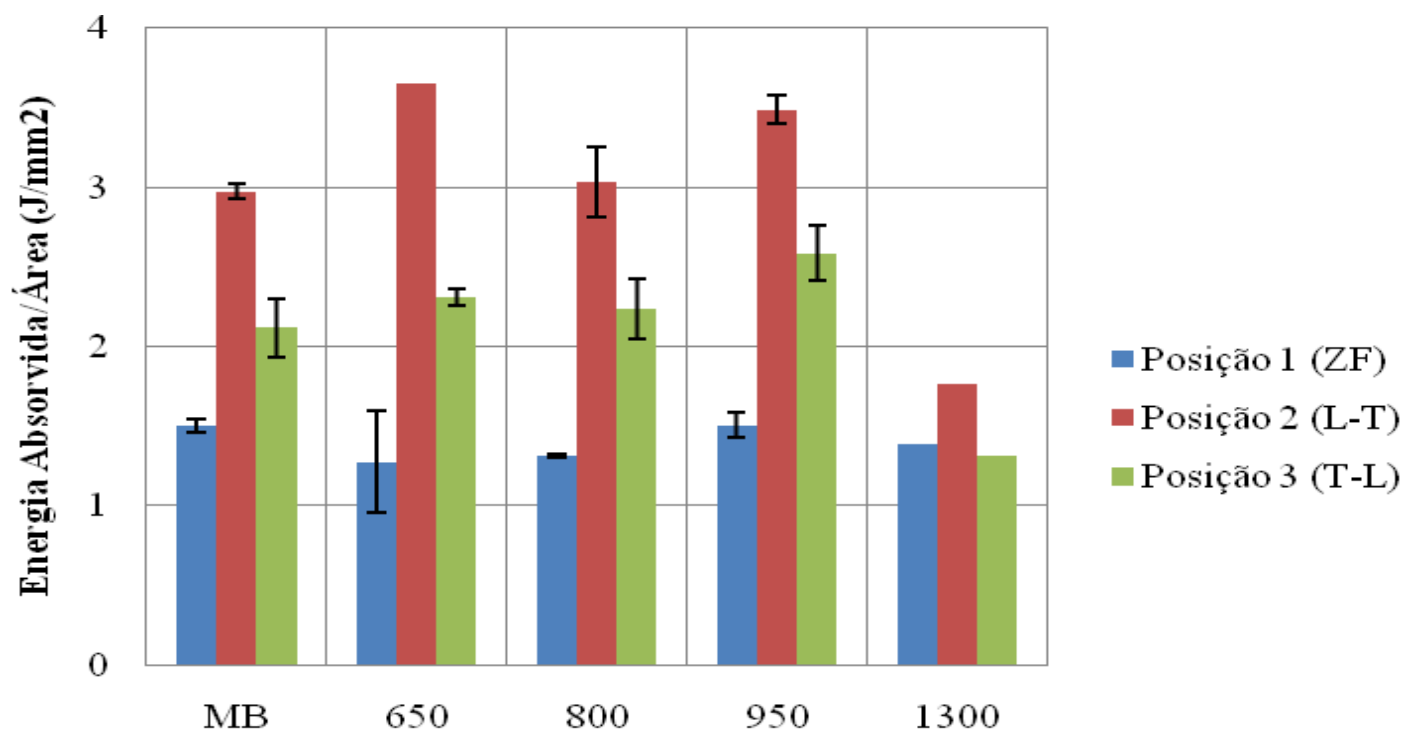

Temperatura Máxima dos Ciclos Térmicos ${ }^{\circ} \mathrm{C}$ )

Figura 119. Energia absorvida dos corpos-de-prova em relação às temperaturas máximas de um único passe.

Comparando-se somente as posições 2 e 3 do tubo nota-se que a posição 2, que esta paralela à direção do sentido de laminação do tubo (L-T) tem maior energia absorvida que a posição 3 , que esta na direção perpendicular ao sentido de laminação do tubo (T-L) para o material sem simulação e todos os ciclos térmicos simulados. A resistência à fratura aumenta quando a trajetória da trinca é normal ao sentido de laminação $[42,43]$. Portanto, de tudo que foi explicado anteriormente pode-se dizer que a posição 2 é a que tem maior 
tenacidade em comparação com as outras duas posições, já que é a que tem maior (energia absorvida)/área .

Nos parágrafos anteriores analisou-se as tenacidades segundo as posições dos corpos-de-prova. Em seguida, analisar-se-á a tenacidade em relação aos ciclos térmicos para cada posição.

Pode-se observar na Fig. 119 que a energia absorvida/área do material sem simulação da posição 1 tem uma queda inicial para o ciclo térmico de $650^{\circ} \mathrm{C}$ de $1,50 \mathrm{~J} / \mathrm{mm}^{2}$ para $1,28 \mathrm{~J} / \mathrm{mm}^{2}$ respectivamente, e a partir do ciclo térmico de 650 ${ }^{0} \mathrm{C}$ para adiante a energia absorvida/área aumento progressivamente ate alcançar o ciclo térmico de $1300{ }^{\circ} \mathrm{C}$ com energia absorvida de $1,39 \mathrm{~J} / \mathrm{mm}^{2}$. Esta tenacidade menor nos ciclos térmicos de $650{ }^{\circ} \mathrm{C}$ e $800{ }^{\circ} \mathrm{C}$ se deve a microestrutura de estes ciclos térmicos apresentam uma microestrutura contendo ferrita de contorno de grão (GF) e ferrita de segunda fase alinhada (AC), e a tenacidade aumentou para o ciclo térmico de $950{ }^{\circ} \mathrm{C}$ devido a que a ferrita de contorno de grão (GF) e ferrita de segunda fase alinhada (AC) diminuiu de tamanho como pode ser observado nas Fig. 53, 54 e 55. A maior tenacidade obtida no ciclo térmico de $1300{ }^{\circ} \mathrm{C}$ é devido a que apresenta uma microestrutura livre de ferrita de contorno de grão (GF) e ferrita com segunda fase alinhada $(A C)$ apresentando uma microestrutura com ferrita com segunda fase não alinhada SG(NA). A GF e a SG(NA) são microestruturas indesejáveis para o metal de solda, pois apresenta baixa resistência à propagação de trincas e, conseqüentemente, um baixo valor da energia absorvida [57].

Observa-se que os ciclos térmicos de 650 e $950{ }^{\circ} \mathrm{C}$ têm as maiores energias absorvidas/área em comparação aos ciclos térmicos de 800 e $1300{ }^{\circ} \mathrm{C}$. Podese dizer que o ciclo térmico de $650{ }^{\circ} \mathrm{C}$ apresenta uma alta energia absorvida/área devido a que, neste ciclo térmico se observa pouca ou quase nenhuma presença de microconstituinte MA como pode ser observado nas Fig. $79,84,100$ e 105. A alta energia absorvida/área do ciclo térmico de $950{ }^{\circ} \mathrm{C}$ pode ser associada com o refino de grão que se obtêm a estas temperaturas [51,54] como se observa nas Fig. 60, 65, 81 e 86. Enquanto que a baixa energia absorvida/área do ciclo térmico de $800{ }^{\circ} \mathrm{C}$ pode ser devido ao ligeiro aumento do grão e a grande quantidade de MA que apresenta na sua microestrutura como se observa nas Fig. 80 e 85 . A energia absorvida diminui 
quando a fração de segunda fase e o tamanho de grão aumenta [52]. Vega [56] atribui uma diminuição da tenacidade na ZAC ao crescimento do grão na microestrutura do material. Para o ciclo térmico de $1300{ }^{\circ} \mathrm{C}$ a baixa energia absorvida/área se deve à microestrutura de grão grande contendo ferritabainita (BF), bainita granular (GB) associados com o microconstituintes MA como se observa nas Fig. 82 e 87 . As propriedades de tenacidade na ZAC são geralmente deterioradas devido ao crescimento do grão austenítico, precipitação de partículas de segunda fase e formação de bainita-ferrita (BF) e bainita granular (GB) as quais apresentam baixa tenacidade [52, 54].

Comparando os ciclos térmicos de 650, 800 e $950{ }^{\circ} \mathrm{C}$ a maior energia absorvida foi obtida para estes ciclos térmicos e a menor energia para o ciclo térmico de $1300{ }^{\circ} \mathrm{C}$. Uma razão pela qual poderia ser explicado este fato é devido à morfologia dos microconstituintes MA. Onde o ciclo térmico de $1300^{\circ} \mathrm{C}$ tem microconstituinte MA alongados e com tamanhos maiores, que podem propiciar o inicio de trincas. Os ciclos térmicos de 800 e $950{ }^{\circ} \mathrm{C}$ têm microconstituintes de forma poligonal ou circunferencial como pode-se observar nas Fig. 80, 81, 85 e 86 . A tenacidade ao impacto não esta simplesmente associada com a fração de volume do microconstituinte MA, também esta associado com sua morfologia, tamanho e distribuição na matriz [58,59] e é prejudicial para a tenacidade.

\subsubsection{Expansão Lateral}

Por médio da expansão lateral veremos a ductilidade do material em relação aos ciclos térmicos. A expansão lateral foi obtida com a equação 5 :

$$
E L=\left(\frac{\Delta L_{0}-L_{f}}{\Delta L_{0}}\right) x 100
$$


$\mathrm{Na}$ Tab. 17 se apresentam os dados da expansão lateral em porcentagem de cada um dos corpos-de-prova não simulados e com ciclo térmico de um único passe.

Tabela 17. Expansão lateral dos corpos-de-prova submetidos ao ensaio de impacto Charpy-V para um único passe.

\begin{tabular}{|c|c|c|c|}
\hline Temperatura Máxima dos & \multicolumn{3}{|c|}{ Expansão Lateral (\%) } \\
\cline { 2 - 4 } Ciclos Térmicos $\left({ }^{0} \mathbf{C}\right)$ & Posição 1 (ZF) & Posição 2 (L-T) & Posição 3 (T-L) \\
\hline MB & $17,5 \pm 0,3$ & $23,1 \pm 0,5$ & $15,2 \pm 1,1$ \\
\hline 650 & $13,2 \pm 3,4$ & $21,9 \pm 0,1$ & $19,5 \pm 0,5$ \\
\hline 800 & $16,6 \pm 1,4$ & $16,3 \pm 2,2$ & $15,0 \pm 1,1$ \\
\hline 950 & $15,7 \pm 0,5$ & $19,8 \pm 3,6$ & $19,0 \pm 0,7$ \\
\hline
\end{tabular}

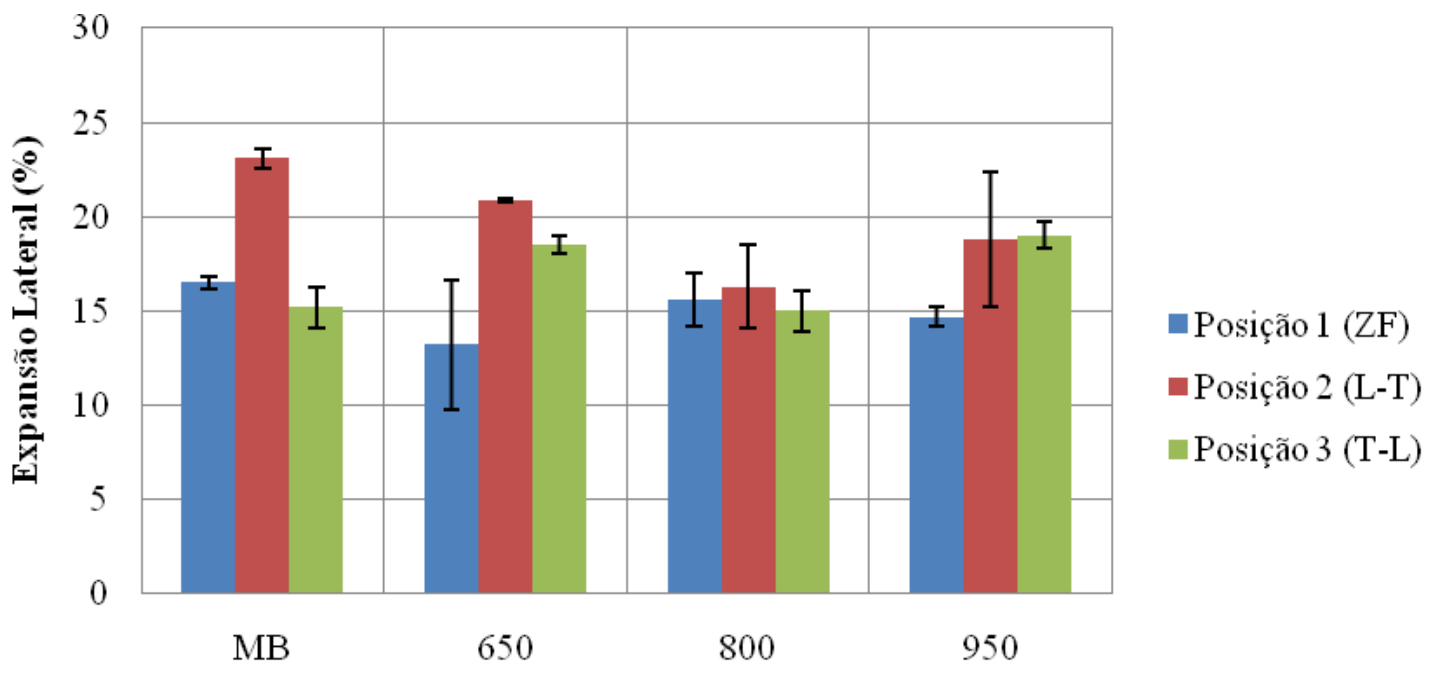

Temperatura Máxima dos Ciclos Térmicos $\left({ }^{\circ} \mathrm{C}\right)$

Figura 120. Expansão lateral dos corpos-de-prova em relação aos ciclos térmicos de um único passe.

Na Fig. 120 pode-se notar que a posição 1 apresentou uma tendência a uma menor ductilidade em relação às posições 2 e 3 . O resultado deste comportamento pode estar associado à diferente microestrutura (Fig. 52-66) e a composição química desta posição e a presença de micro inclusões de escória, que são inerentes ao processo de soldagem empregado (soldagem com arco submerso). Porem para os corpos-de-prova sem simulação e de 
$800^{\circ} \mathrm{C}$ a expansão lateral da posição 1 é relativamente maior que a posição 3. Esta inversão de comportamento entre a posição 1 e a posição 3 pode estar relacionado à posição do entalhe e a relação entre a ductilidade e o sentido da laminação da chapa. Pode-se observar que a posição 2, que é a posição paralela ao sentido de laminação do tubo, apresenta os maiores valores de expansão lateral em relação à posição 1 e à 3 , exceto para o ciclo térmico de $950^{\circ} \mathrm{C}$ na posição 2 , onde a ductilidade é $0,2 \%$ menor que a posição 3 . Esta expansão lateral maior nos demonstra que a posição 2 tem maior ductilidade que a posição 1 e 3 o que tem relação com as tenacidades obtidas para esta posição.

Segundo Rocha [55], as ductilidades dos corpos-de-prova estão relacionadas com a velocidade de resfriamento, a partir desta premissa se pode supor que as expansões laterais da posição 1 e 2 sem simulação tem as maiores expansões laterais em relação aos corpos-de-prova simulados.

$\mathrm{Na}$ Tab. 18 apresentam-se os resultados das expansões laterais dos corposde-prova simulados com ciclos térmicos multipasse.

Tabela 18. Expansões laterais dos corpos-de-prova em relação a os ciclos térmicos multipasse.

\begin{tabular}{|c|c|c|c|}
\hline Temperatura máxima dos & \multicolumn{3}{|c|}{ Expansão Lateral (\%) } \\
\cline { 2 - 4 } Ciclos Térmicos $\left({ }^{\circ} \mathbf{C}\right)$ & Posição 1 (ZF) & Posição 2 (L-T) & Posição 3 (T-L) \\
\hline MB & $16,5 \pm 0,3$ & $23,1 \pm 0,5$ & $15,2 \pm 1,1$ \\
\hline $950-800$ & $18,2 \pm 1,6$ & $23,7 \pm 0,2$ & $21,4 \pm 0,3$ \\
\hline $950-800-650$ & $14,0 \pm 2,2$ & $22,8 \pm 0,4$ & $20,5 \pm 1,3$ \\
\hline
\end{tabular}

Com os dados da Tab. 18 foi produzida a Fig. 121. 


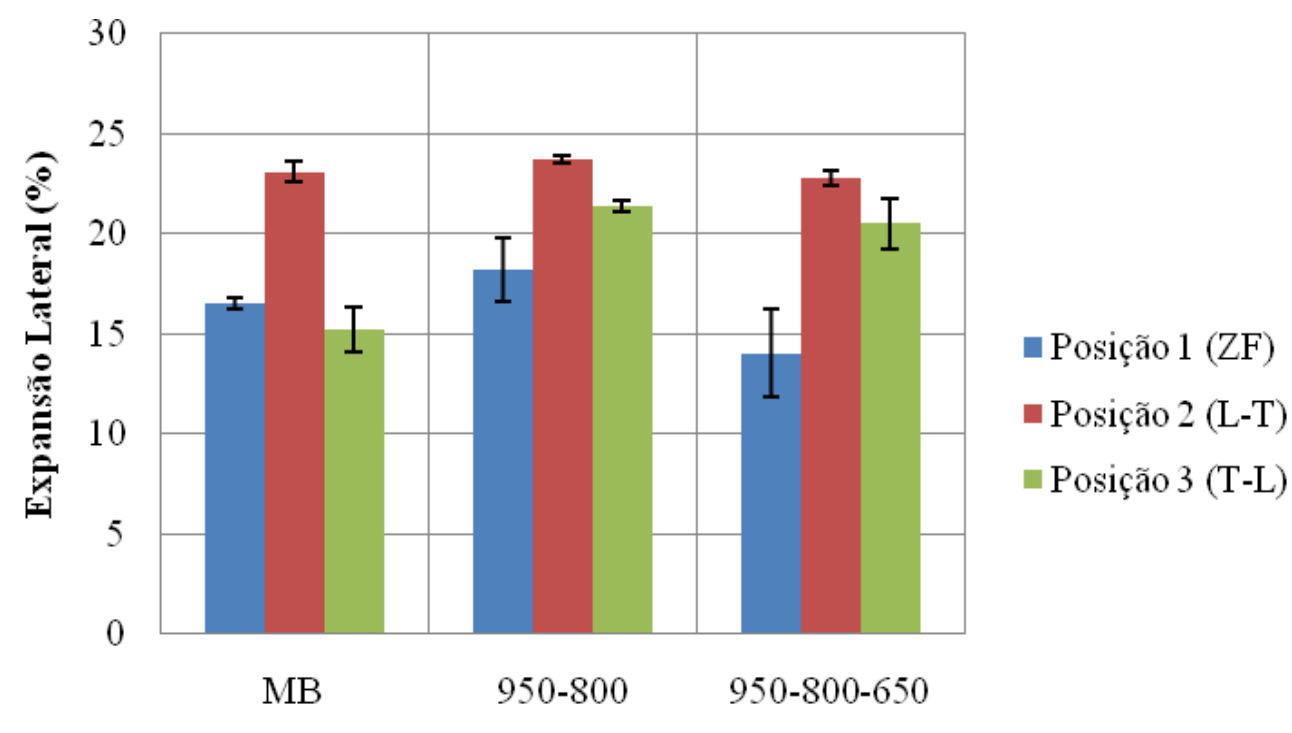

Temperatura Maxima dos Ciclos Térmicos $\left({ }^{\circ} \mathrm{C}\right)$

Figura 121. Expansão lateral em relação a os ciclos térmicos multipasse.

As expansões laterais da posição 2 na Fig. 121 para os distintos ciclos térmicos multipasse apresentam os maiores valores em relação às posições 1 e 3 devido à posição de onde foi extraído o corpo-de-prova. As expansões laterais, para a posição 1 nos ciclos térmicos de dois passes e três passes, apresentaram os menores valores em comparação com a posição 2 e 3 esse comportamento poderia ser devido à composição química que apresenta distinta às microestruturas da posição 2 e 3 como observados nas Fig. 67-72. Comparando os resultados do ciclo térmico com 2 passes e 3 passes observase que as menores expansões laterais foram obtidas para o ciclo térmico com 3 passes tendo relação com as energias absorvidas obtidas na Fig. 118.

\subsection{Microdureza Vickers}

As medias dos resultados dos ensaios de microdurezas dos diferentes ciclos térmicos de um único passe para as distintas posições de ensaio são mostradas na Tab. 19 e a Fig. 122.

Da Fig. 122 pode-se observar que, a dureza é maior para a posição $1 \mathrm{em}$ relação à posição 2 e 3 no material sem simulação térmica e nos ciclos 
térmicos de $650^{\circ} \mathrm{C}$. Este comportamento pode ser devido a que a posição 1 tem maior presença de microconstituinte MA em comparação com a posição 2 e 3 como se observa nas Fig. 73-74, 78-79. A posição 1 para o ciclo térmico de $800^{\circ} \mathrm{C}$ tem quase a mesma dureza que a posição 3 e ambas posições têm maiores durezas que a posição 2 , isso poderia ser atribuído a presença de maior quantidade de microconstituintes MA na posição 1 e 3 como pode-se observar nas Fig. 75, 80 e 85. Para o ciclo térmico de $950^{\circ} \mathrm{C}$ a dureza da posição 1 é menor que a posição 2 mas maior que a posição 3 , este resultado pode ser explicado observando as micrografias das Fig. 76, 81 e 86 onde a maior quantidade de microconstituintes MA está na posição 2. Por ultimo no ciclo térmico de $1300^{\circ} \mathrm{C}$ a dureza da posição 1 é menor em comparação com a posição 2 e 3 já que a maior quantidade de microconstituinte MA encontra-se na posição 2 e 3, como pode-ser observado nas Fig. 77, 82 e 87.

Tabela 19. Dureza Vickers em relação aos ciclos térmicos de um único passe.

\begin{tabular}{|c|c|c|c|}
\hline Temperatura Máxima dos & \multicolumn{3}{|c|}{ Dureza Vickers (HV) } \\
\cline { 2 - 4 } Ciclos Térmicos $\left({ }^{\circ} \mathrm{C}\right)$ & Posição 1 (ZF) & Posição 2 (L-T) & Posição 3 (T-L) \\
\hline $\mathrm{MB}$ & $249 \pm 11$ & $226 \pm 11$ & $233 \pm 6$ \\
\hline 650 & $236 \pm 14$ & $223 \pm 5$ & $221 \pm 9$ \\
\hline 800 & $217 \pm 7$ & $205 \pm 8$ & $216 \pm 8$ \\
\hline 950 & $226 \pm 4$ & $234 \pm 11$ & $219 \pm 5$ \\
\hline 1300 & $226 \pm 6$ & $241 \pm 13$ & $245 \pm 9$ \\
\hline
\end{tabular}

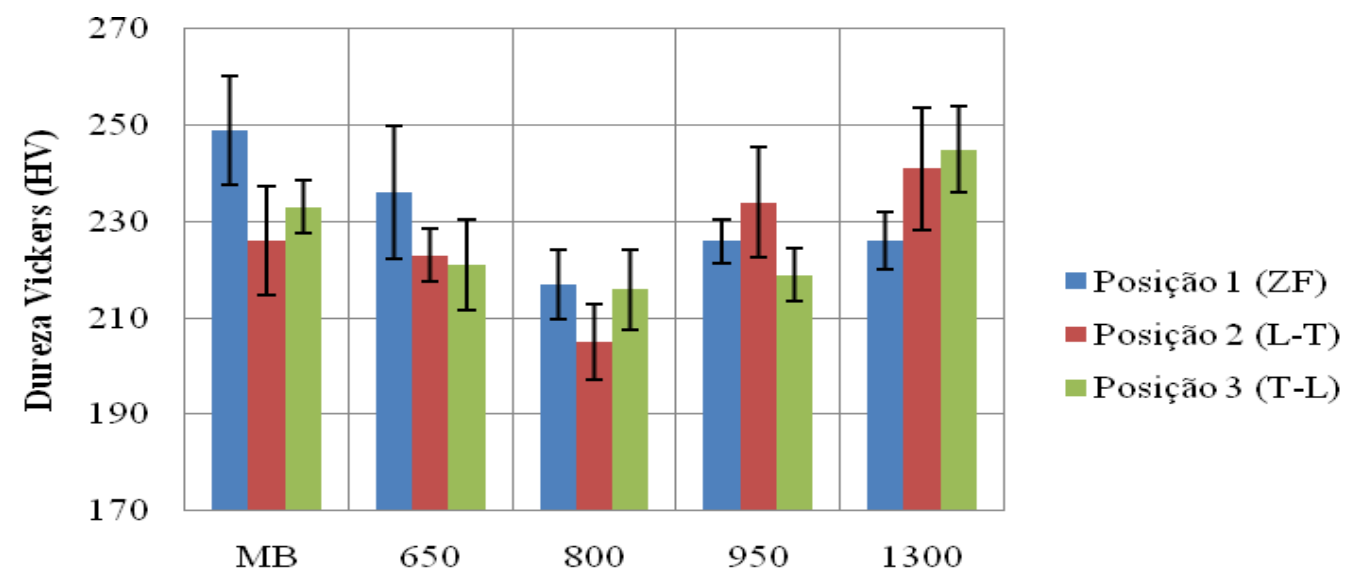

Temperatura Máxima dos Ciclos Térmicos $\left({ }^{\circ}\right.$ )

Figura 122. Dureza Vickers em relação aos ciclos térmicos de um único passe. 
Comparando-se as durezas da posição 2 e 3 não se pode determinar um padrão de diferencia entre elas porque seus valores variam entre 205 a $241 \mathrm{HV}$ para a posição 2 e de 216 a 245 HV para a posição 3, os quais são muito próximos entre si, o que se poderia entender que estas duas posições tem quase as mesmas durezas e a mesma microestrutura, sem tomar em conta 0 sentido de laminação. Ordoñes [60] comenta que através do ensaio de microdurezas não pode ser definida uma tendência do comportamento da dureza. O microconstituinte MA joga um fator principal nas microdurezas do material [54].

Observando-se as durezas só no MB sem simulação a maior dureza foi obtida para a posição 1 , que foi de $249 \mathrm{HV}$, em comparação das durezas obtidas para a posição 2 e a posição 3, 226 HV e 233 HV respectivamente. Este comportamento pode ser devido a que a posição 1 apresenta uma microestrutura distinta a essas posições como pode-se observar nas micrografias ópticas das Fig. 52-66. Em juntas soldadas de um aço API 5L a maior dureza encontra-se no metal fundido de uma junta soldada $[25,59,61]$. Motohashi obteve durezas para o metal de solda de um Aço API $5 \mathrm{~L}$ grau X80 numa faixa de 240 a $280 \mathrm{HV}$ e para a ZAC numa faixa de 218 a $265 \mathrm{HV}$ [50]. A dureza media de um aço API $5 \mathrm{~L}$ grau X80 produzido no Brasil obtida por Ramirez foi de 228 HV [23,24].

Fazendo um analise do material sem simulação (MB) em comparação com os ciclos térmicos pode-se dizer que: Para a posição 1 se observa que todos os ciclos térmicos apresentam menor dureza que o $\mathrm{MB}$ sem simulação. $\mathrm{Na}$ posição 2 os corpos-de-prova com ciclo térmico de 650 e $800^{\circ} \mathrm{C}$ tem menor dureza que o MB e os corpos-de-prova com ciclo térmico de 950 e $1300^{\circ} \mathrm{C}$ tem maior dureza que o MB. Na posição 3 os corpos-de-prova com ciclo térmico de 650,800 e $950^{\circ} \mathrm{C}$ têm uma diminuição da dureza em relação ao $\mathrm{MB}$ e um aumento da dureza se observou no ciclo térmico de $1300^{\circ} \mathrm{C}$ em relação ao MB.

Na Tab. 20 e na Fig. 123 apresentam-se as durezas médias dos ciclos térmicos multipasse. 
Tabela 20. Durezas Vickers em função dos ciclos térmicos multipasse.

\begin{tabular}{|c|c|c|c|}
\hline \multirow{2}{*}{$\begin{array}{c}\text { Temperatura Máxima dos } \\
\text { Ciclos Térmicos }\left({ }^{\circ} \mathbf{C}\right)\end{array}$} & \multicolumn{3}{|c|}{ Dureza Vickers (HV) } \\
\cline { 2 - 4 } & Posição 1 (ZF) & Posição 2 (L-T) & Posição 3 (T-L) \\
\hline MB & $249 \pm 11$ & $226 \pm 11$ & $233 \pm 5$ \\
\hline $950-800$ & $236 \pm 13$ & $223 \pm 5$ & $221 \pm 9$ \\
\hline $950-800-650$ & $217 \pm 7$ & $205 \pm 7$ & $216 \pm 8$ \\
\hline
\end{tabular}

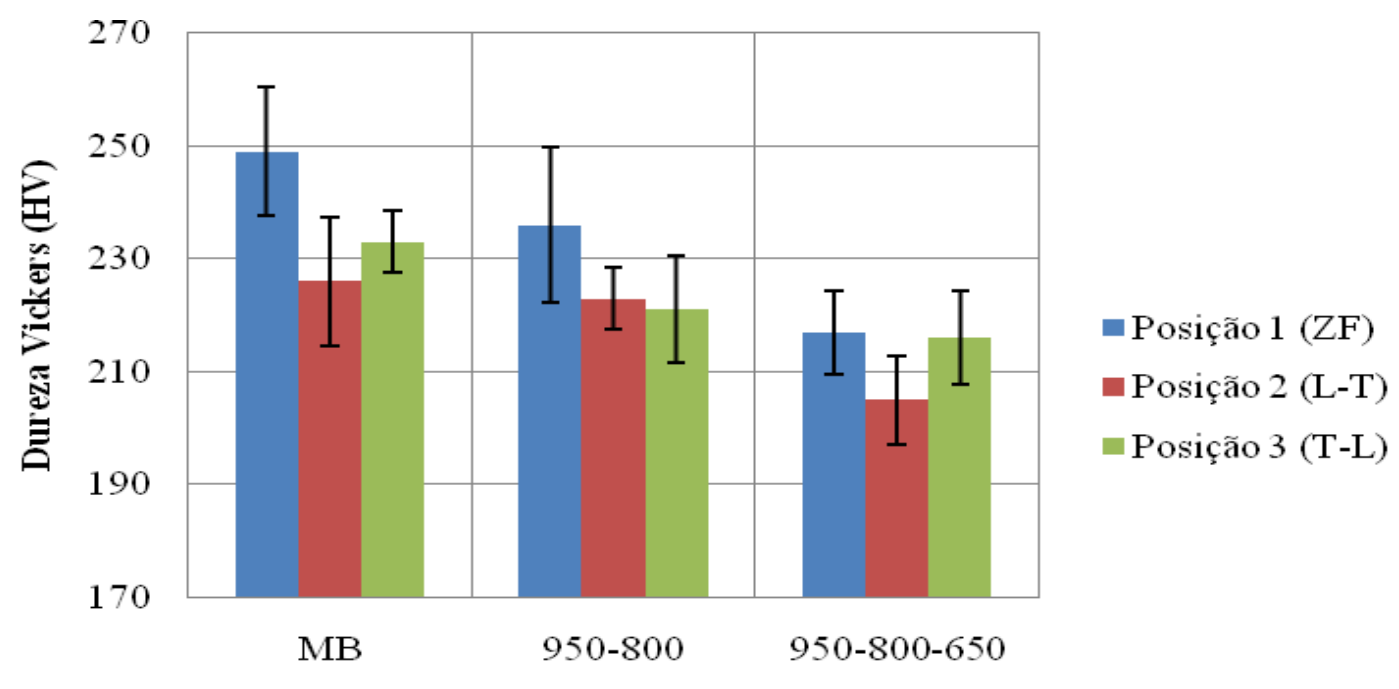

Temperatura Máxima dos Ciclos Térmicos $\left({ }^{\circ} \mathrm{C}\right)$

Figura 123. Durezas Vickers em função dos ciclos térmicos multipasse.

$\mathrm{Na}$ Fig. 123 pode-se notar que a posição 1 apresenta os valores das durezas mais elevados para o material sem simulação e os ciclos térmicos de 950$800^{\circ} \mathrm{C}$ e $950-800-650^{\circ} \mathrm{C}$, igual como ocorreu nos ciclos térmicos de um único passe. Enquanto que para a posição 2 e 3 não se tem um padrão como para diferenciar qual das posições apresenta maior dureza, isso pode ser explicado devido a microestrutura que apresentam estas duas posições as quais são similares.

Analisando só os corpos-de-prova sem simulação (MB) pode-se observar que a posição 1 que contem o cordão de solda tem maior dureza que a posição 2 e 3. Bae [25] em seus resultados obteve que a dureza do material de solda não é mais alta que a dureza do material base num aço API $5 \mathrm{~L}$ grau X80 soldado com arco submerso e as durezas que obteve estão numa faixa de 225 a 275 HV. Analisando o ciclo térmico de $950-800-650^{\circ} \mathrm{C}$ (3 passes) em comparação com o ciclo térmico de $950-800^{\circ} \mathrm{C}$ (2 passes) e o material de base, observa-se 
que o ciclo térmico de 3 passes apresenta as menores durezas nas 3 posições. Pode-se supor que isso é devido à quantidade de ciclos térmicos que se fez nestes corpos-de-prova. Enquanto que, observando os corpos-de-prova sem simulação estes apresentam maiores durezas em relação aos ciclos térmicos multipasse que experimentaram uma queda das suas durezas.

\subsection{Analise das Fraturas dos Corpos-de-prova}

\subsubsection{Caracterização das Superfícies de Fratura no Microscópio Eletrônico de Varredura}

As superfícies fraturadas dos corpos-de-prova submetidos ao ensaio de impacto Charpy-V foram caracterizados no MEV para ver se os corpos-deprova apresentam comportamento dúctil, frágil ou dúctil-frágil. Nas figuras a seguir apresentam-se as micrografias com ampliações de 50X e 1000X. As ampliações de 1000X foram tiradas da parte inferior e superior da fratura em sentido perpendicular ao entalhe.

Nas imagens centrais da Fig. 124 até 128 pode-se notar que esta posição apresenta características típicas de uma região fundida devido ao cordão de solda. As microcavidades que apresenta aspecto dúctil são menores que nas outras posições 2 e 3 como se observará na Fig. 129 até a Fig. 138. Esta observação é devido à presença de microinclusões que produzem um número grande de microcavidades com tamanho médio menor. Nas Fig. 124 até a Fig. 127 nota-se um comportamento dúctil-fragil o qual está relacionado com sua energia absorvida e expansão lateral correspondente, como se observa nas Tab. 14 e Tab. 16 e as Fig. 117 e Fig. 119 respectivamente. O comportamento dúctil-frágil é um comportamento típico dos aços API 5L X80. Além disso, a Fig. 128 tem um comportamento puramente dúctil, esta micrografia pertence à posição $1 \mathrm{com}$ ciclo térmico de $1300{ }^{\circ} \mathrm{C}$ a qual obteve maior energia absorvida em relação a os outros corpos-de-prova da mesma posição como se pode observar na Fig. 119. Observa-se também nas Fig. 124 ate a Fig. 127 que as zonas frágeis apresentam nucleação de vazios. A ferrita acicular é responsável da nucleação de vazios durante a fratura frágil, ou a nucleação de trincas por clivagem durante a fratura frágil [33]. 


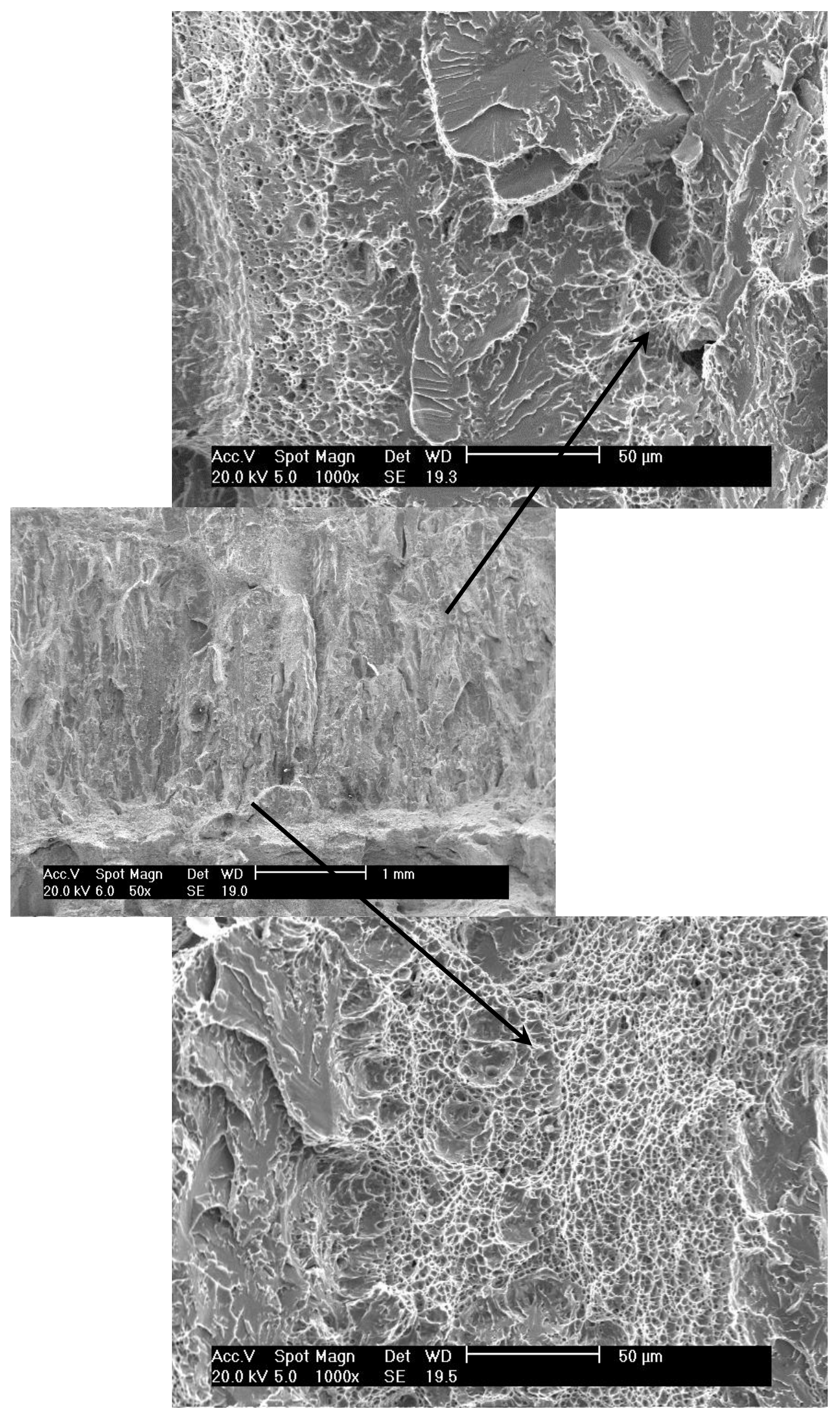

Figura 124. Fraturas superficiais observadas no MEV para a posição 1 sem simulação. 


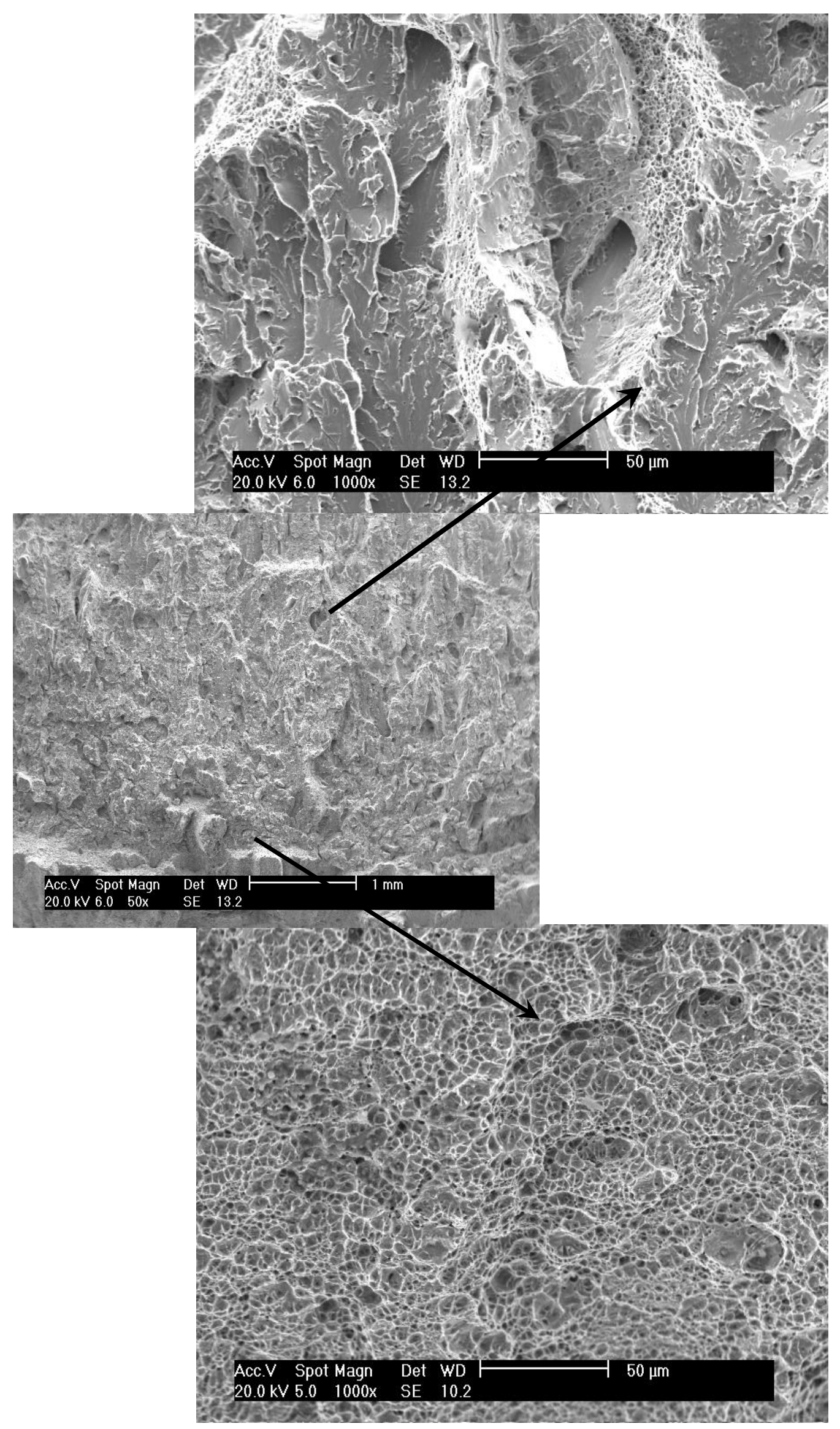

Figura 125. Fraturas superficiais observadas no MEV para a posição 1 com ciclo térmico de $650^{\circ} \mathrm{C}$. Foto inferior comportamento dúctil, foto superior comportamento dúctil-frágil. 


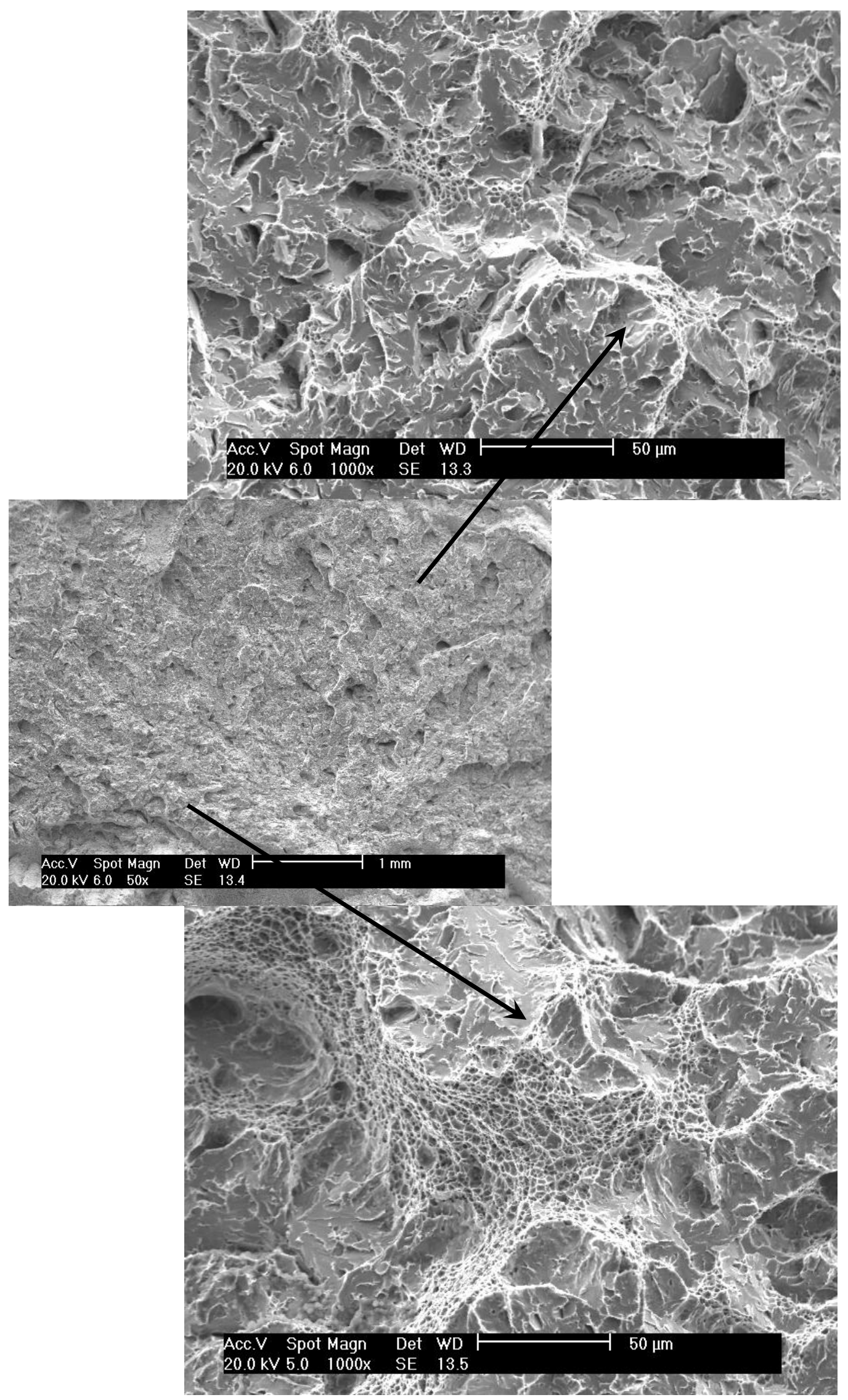

Figura 126. Fraturas superficiais observadas no MEV para a posição $1 \mathrm{com}$ ciclo térmico de $800{ }^{\circ} \mathrm{C}$. Foto inferior comportamento dúctil-frágil, foto superior comportamento principalmente frágil. 


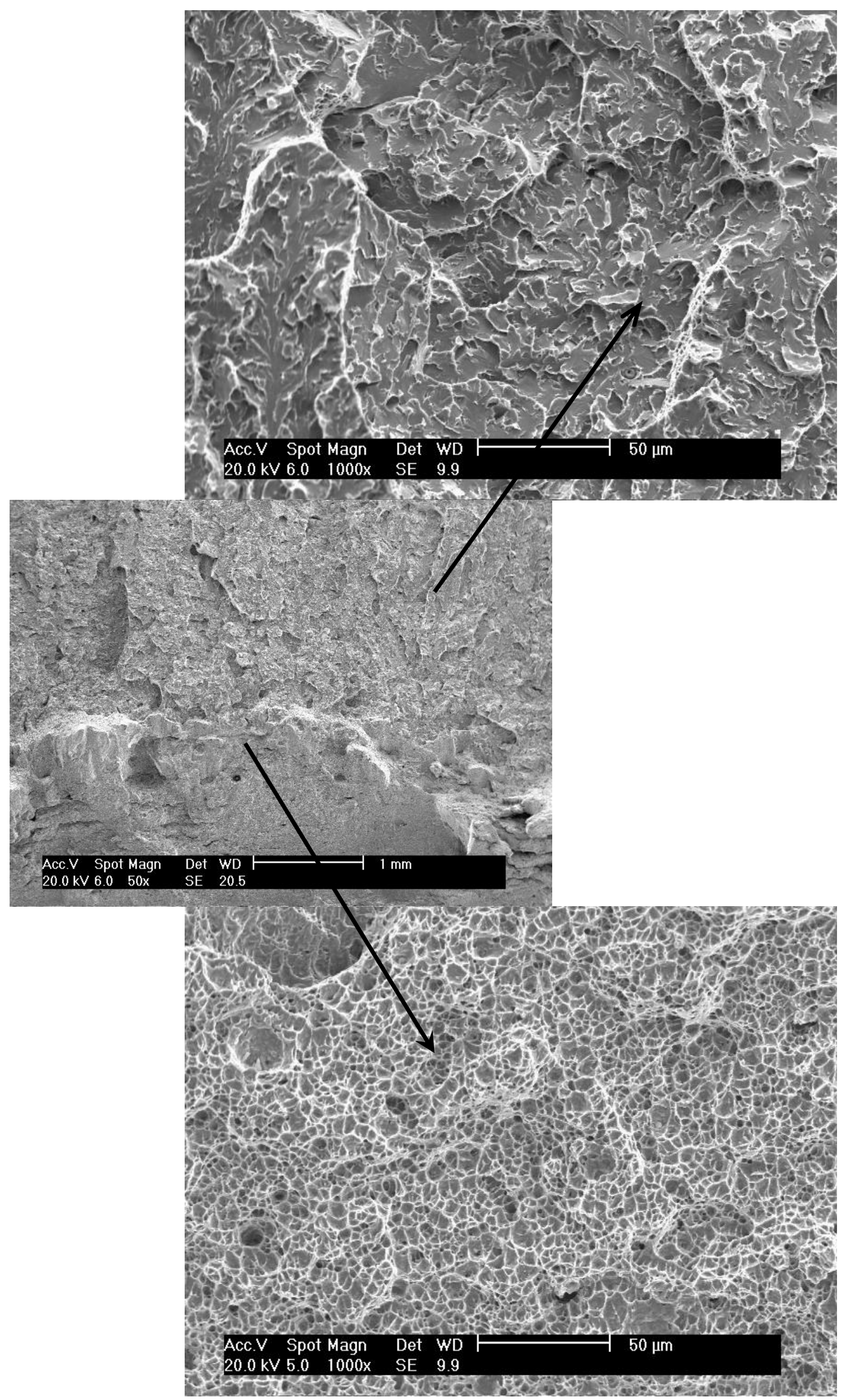

Figura 127. Fraturas superficiais observadas no MEV para a posição $1 \mathrm{com}$ ciclo térmico de $950{ }^{\circ} \mathrm{C}$. Foto inferior comportamento dúctil, foto superior comportamento frágil. 


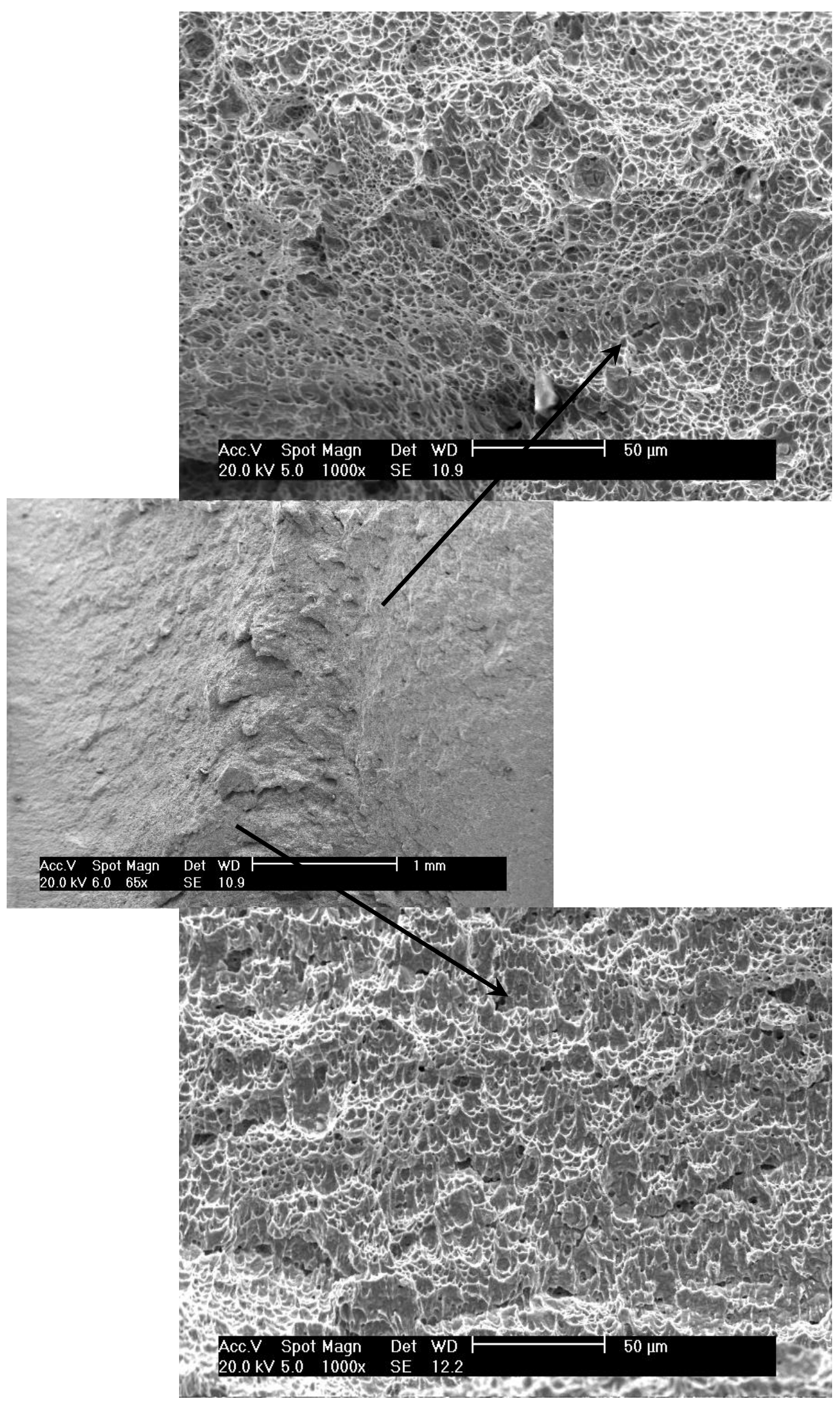

Figura 128. Fraturas superficiais observadas no MEV para a posição $1 \mathrm{com}$ ciclo térmico de $1300{ }^{\circ} \mathrm{C}$. Comportamento puramente dúctil na foto inferior e superior. 


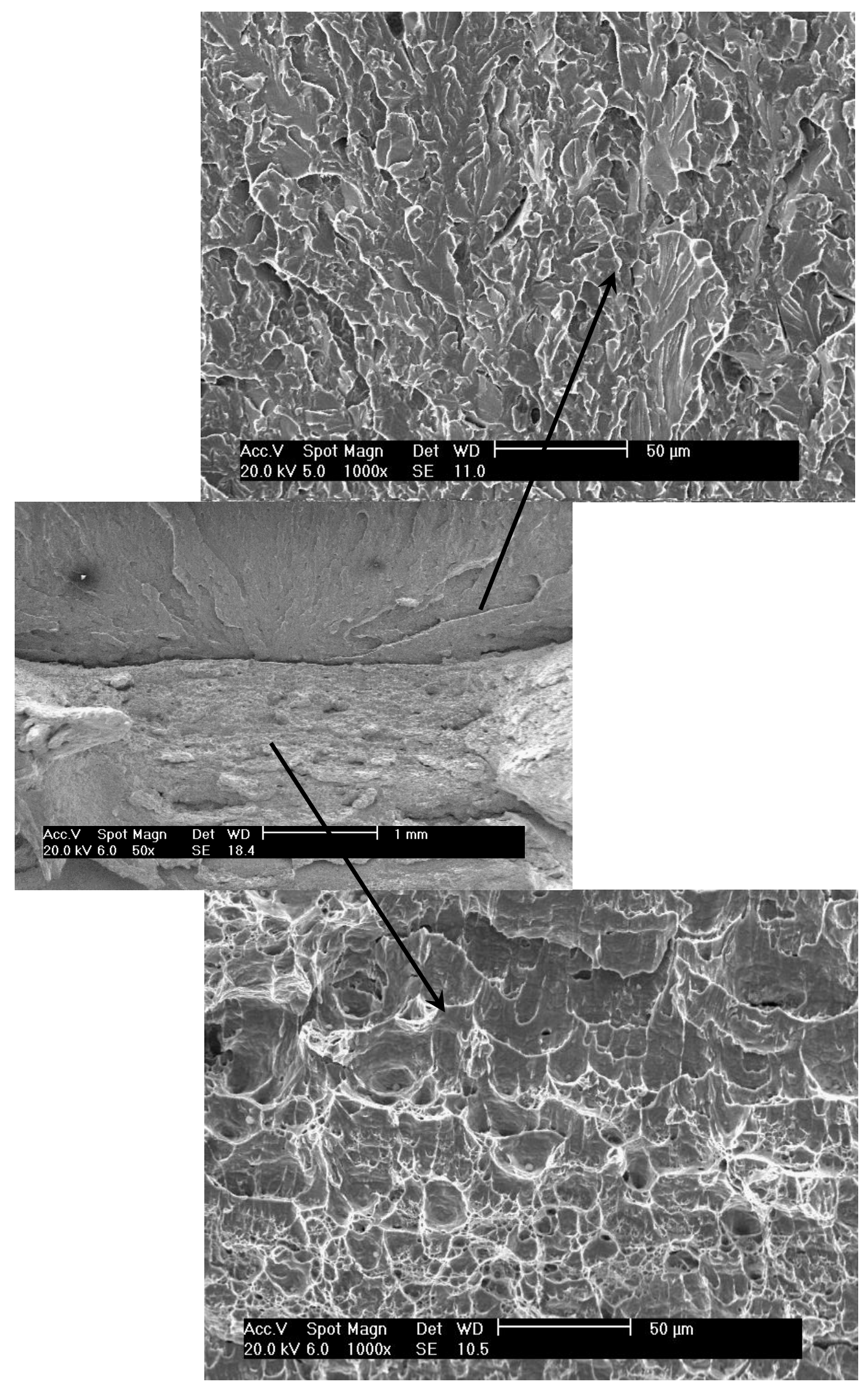

Figura 129. Fraturas superficiais observadas no MEV para a posição 2 sem simulação. Foto inferior comportamento dúctil formado por dimples originados pelas inclusões, foto superior comportamento frágil. 


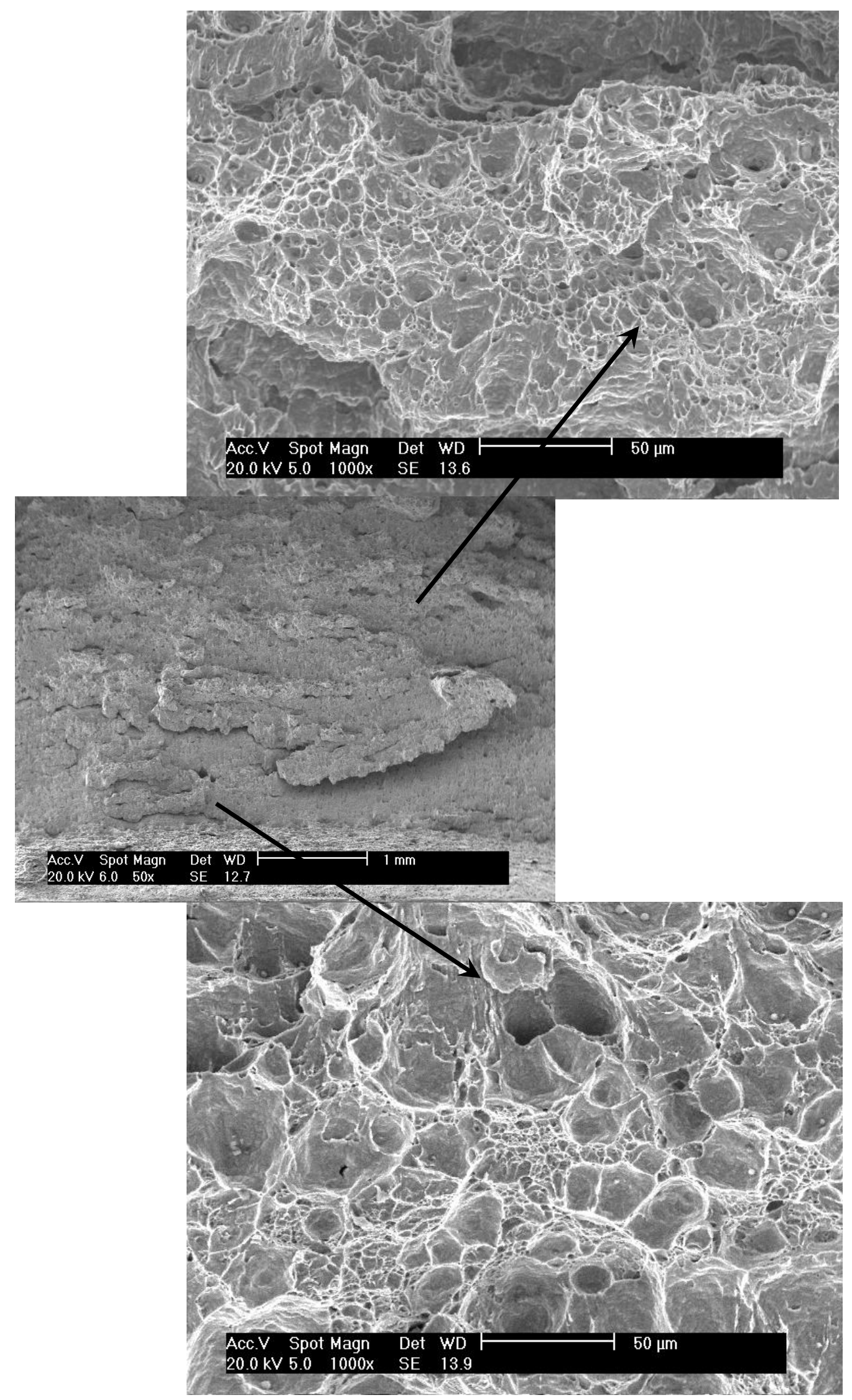

Figura 130. Fraturas superficiais observadas no MEV para a posição 2 com ciclo térmico de $650{ }^{\circ} \mathrm{C}$. Comportamento puramente dúctil na foto inferior e superior com inclusões no interior dos dimples. 


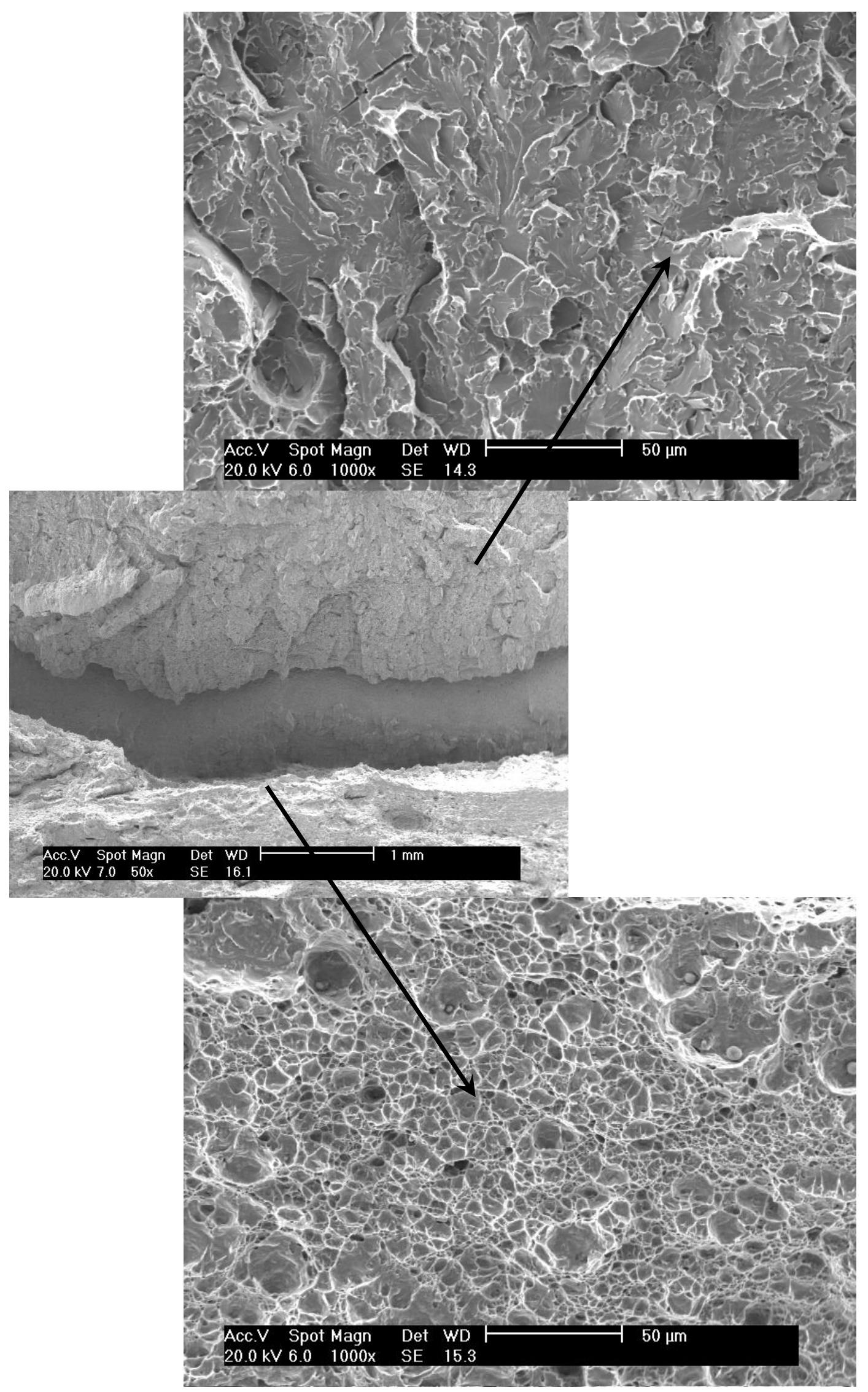

Figura 131. Fraturas superficiais observadas no MEV para a posição 2 com ciclo térmico de $800{ }^{\circ} \mathrm{C}$. Comportamento dúctil na foto inferior, comportamento dúctil na foto superior. 


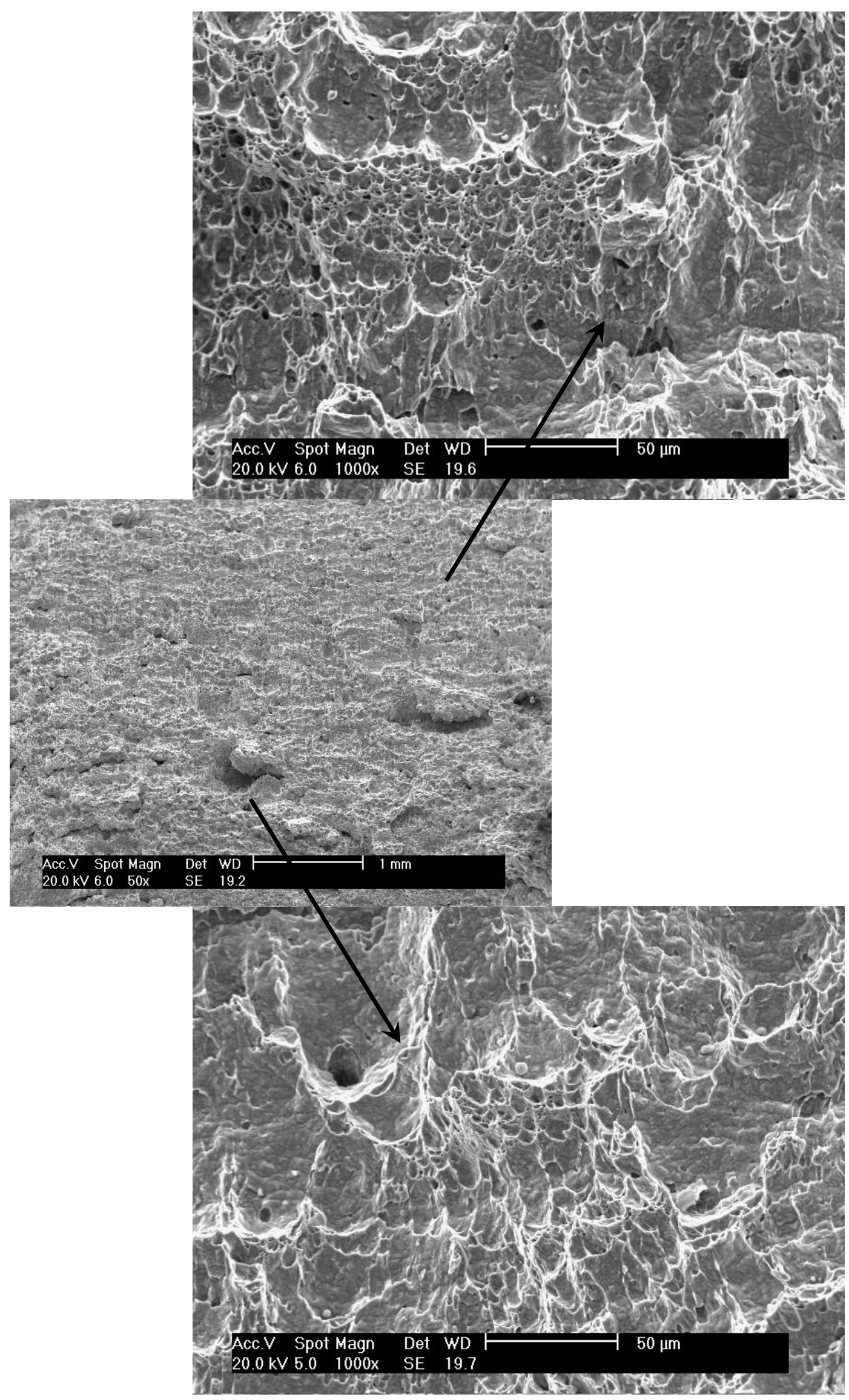

Figura 132. Fraturas superficiais observadas no MEV para a posição 2 com ciclo térmico de $950^{\circ} \mathrm{C}$. Comportamento puramente dúctil na foto inferior e superior. 


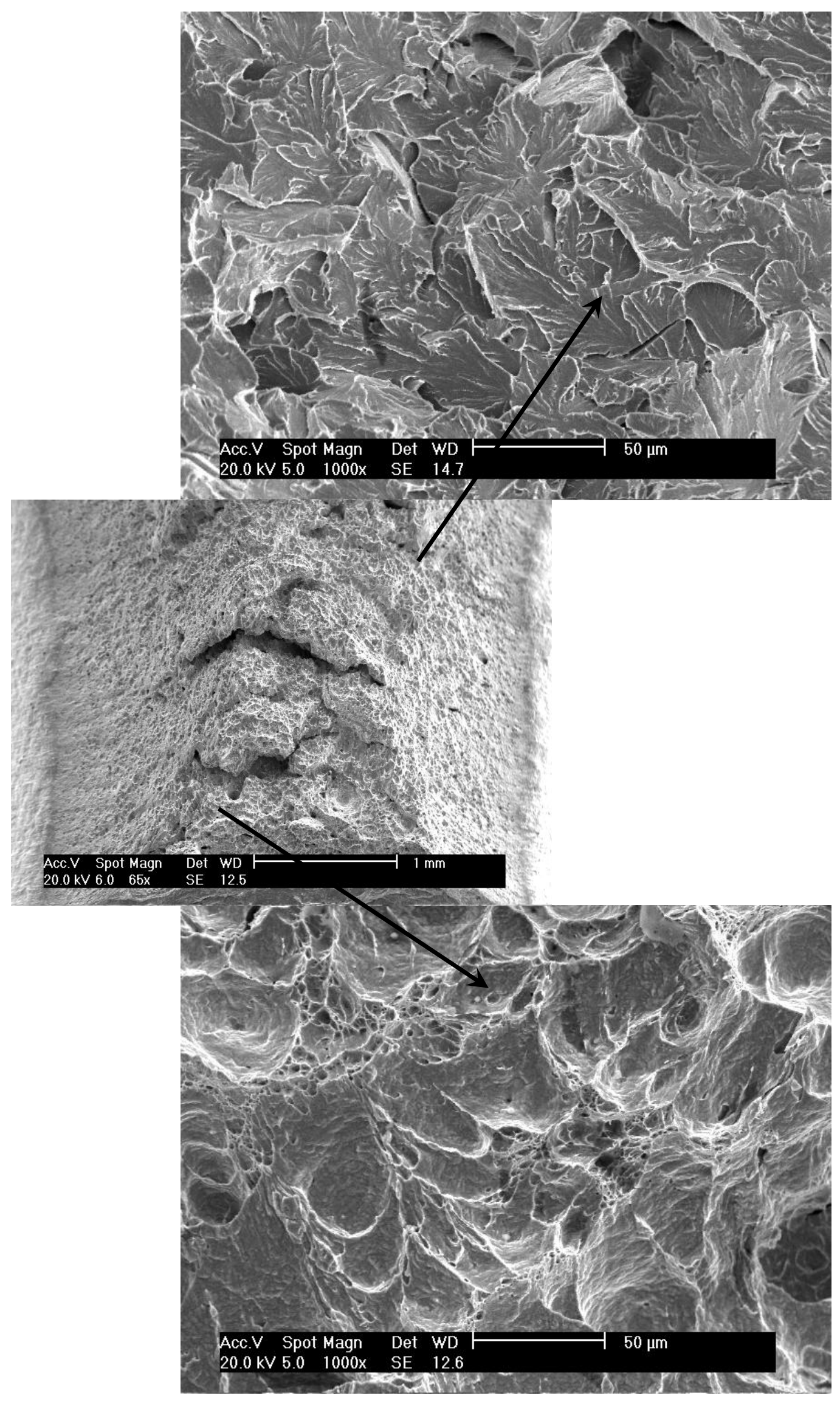

Figura 133. Fraturas superficiais observadas no MEV para a posição 2 com ciclo térmico de $1300{ }^{\circ} \mathrm{C}$. Comportamento dúctil na foto inferior, comportamento frágil na foto superior. 
$\mathrm{Na}$ análise das fraturas superficiais da Fig. 129 até a Fig. 133 pode-se ver na zona dúctil a formação de dimples ou microcavidades de tamanho maior que a posição 1. O comportamento da superfície de fratura da Fig. 129 até a Fig. 133 para cada ciclo térmico esta relacionado com as energias absorvidas da Fig. 119 em cada ciclo térmico. O material de base sem simulação (MB) e os ciclos térmicos de 950 e $1300{ }^{\circ} \mathrm{C}$, Fig. 129, Fig. 131 e Fig. 133 respectivamente, apresentam um comportamento dúctil-frágil. Dúctil perto do entalhe e frágil mais longo do entalhe, estes comportamentos estão relacionados com as menores energias absorvidas da Fig. 119 nesta posição. Para um aço API X52 um tipo de fratura dúctil por coalescencia de microvazios foram observados no começo da fratura, e um comportamento frágil por clivagem para o centro e 0 final da superfície da fratura [56]. O aço API X65 apresenta um mecanismo de fratura dúctil-frágil, iniciando de uma forma frágil e terminando numa forma dúctil [62]. Enquanto que os ciclos térmicos de 650 e $950{ }^{\circ} \mathrm{C}$, Fig. 130 e Fig. 132 respectivamente, apresentaram um comportamento totalmente dúctil e estes obtiveram as maiores energias absorvidas na Fig. 119 em relação a esta posição. Também, na Fig. 120 pode-se notar que para os ciclos térmicos de 650, 800 e $950{ }^{\circ} \mathrm{C}$, as expansões laterais estão relacionadas com os comportamentos apresentados na Fig. 129 até a Fig. 132. Quando a bainita granular (GB) é de tamanho maior, grandes facetas de clivagem são formadas as quais facilitam o deslocamento da trinca [63] como se pode apreciar na Fig. 133 superior, esta figura representa o ciclo térmico de $1300^{\circ} \mathrm{C}$ onde se obteve a menor energia absorvida e apresenta microestrutura bainítica de grão maior como se observara na Fig. 82. 


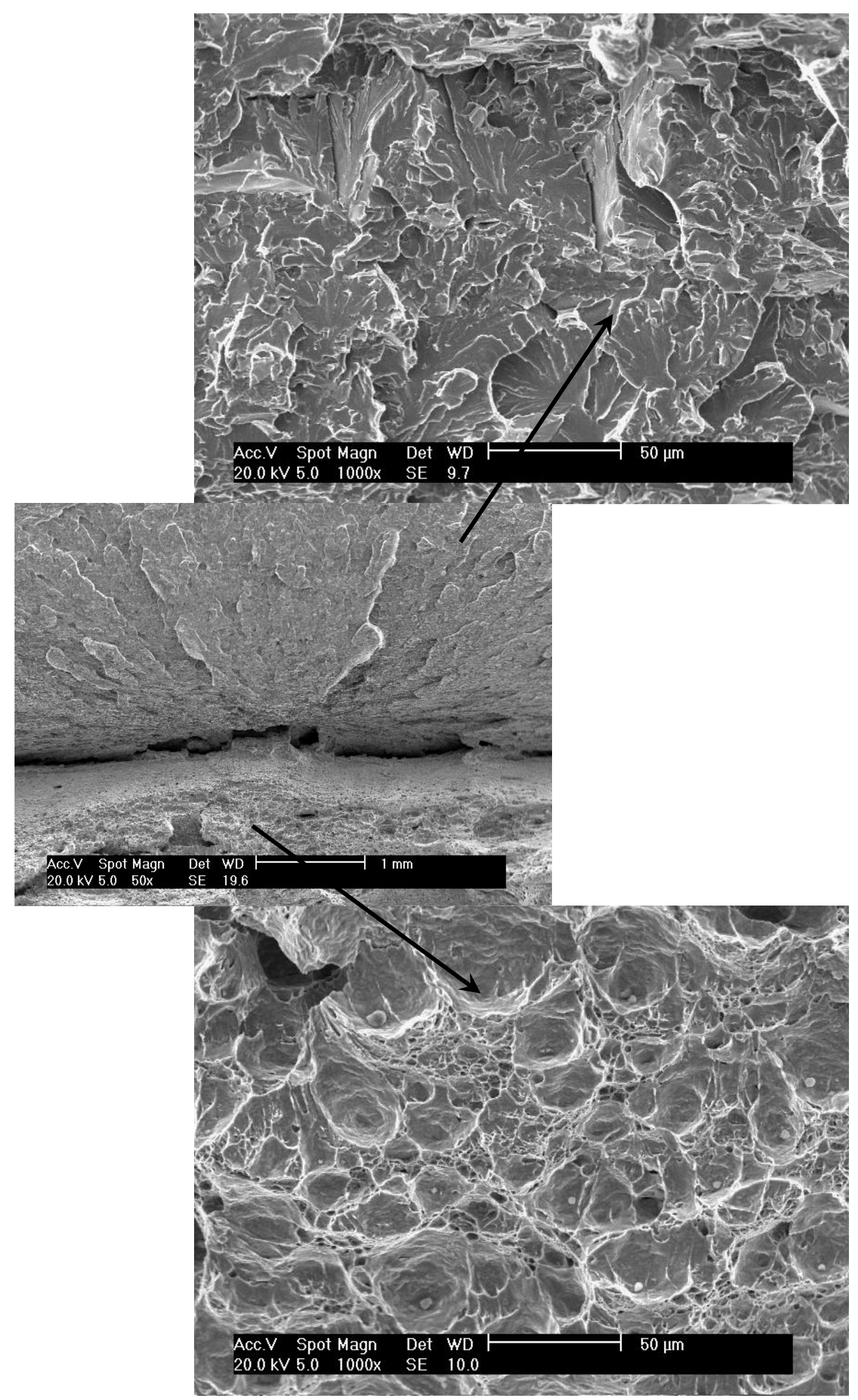

Figura 134. Fraturas superficiais observadas no MEV para a posição 3 sem simulação. Comportamento dúctil na foto inferior, comportamento frágil na foto superior. 
$\mathrm{Na}$ análise das fraturas superficiais da Fig. 134 até a Fig. 138 pode-se ver na zona dúctil a formação de dimples ou microcavidades com tamanho maior que a posição 1 , dentro dos dimples se pode observar inclusões que propiciam a formação destas microcavidades. O comportamento da superfície de fratura da Fig. 135 até a Fig. 138 esta relacionado com a energia absorvida da Fig. 119 em cada ciclo térmico. O material de base sem simulação (MB) e os ciclos térmicos de 950 e $1300{ }^{\circ} \mathrm{C}$, Fig. 134, Fig. 136 e Fig. 138 respectivamente, apresentam um comportamento de dúctil para frágil e estão relacionados com as menores energias absorvidas da Fig. 119 nesta posição. Enquanto que os ciclos térmicos de 650 e $950{ }^{\circ} \mathrm{C}$, Fig. 135 e Fig. 137 respectivamente, apresentam um comportamento totalmente dúctil e estes obtiveram as maiores energias absorvidas na Fig. 119 em relação a esta posição. Também, na Fig. 120 pode-se notar que para os ciclos térmicos de 650,800 e $950{ }^{\circ} \mathrm{C}$, as expansões laterais estão relacionadas com este comportamento. A Fig. 138 superior representa o ciclo térmico de $1300{ }^{\circ} \mathrm{C}$ onde se obteve a menor energia absorvida, esta figura apresenta microestrutura e comportamento como a Fig. 133 superior.

Das Fig. 128, Fig. 133 e Fig. 138 poderíamos dizer que o comportamento dúctil da Fig. 128 faz com que a tenacidade de este material, que pertence à posição 1, não tenha muita diferença em comparação com as tenacidades da posição 2 e 3 que pertencem as Fig. 133 e Fig. 138, como ocorre para os outros ciclos térmicos de menor temperatura onde a tenacidade da posição 1 é muito menor em comparação a posição 2 e 3 . 


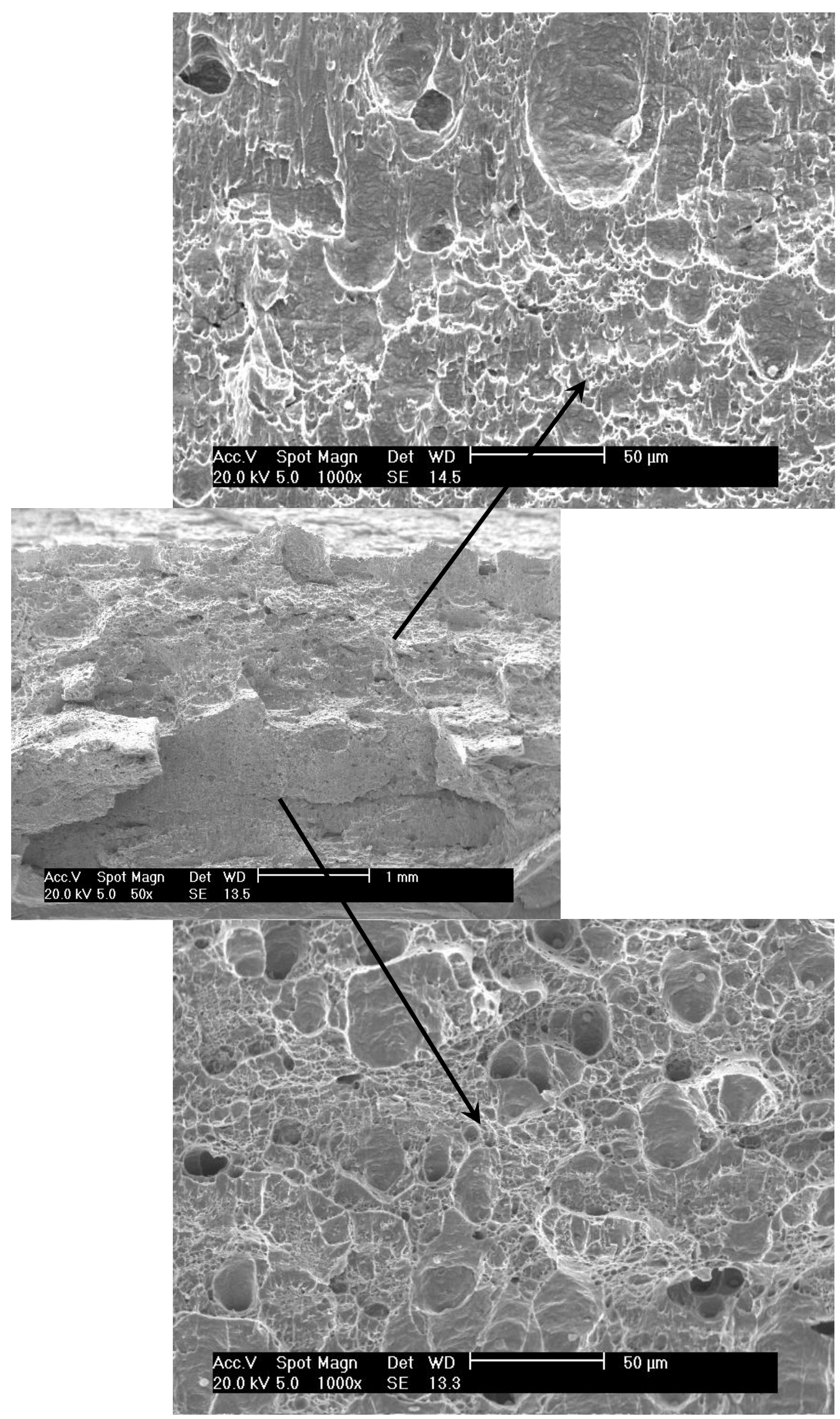

Figura 135. Fraturas superficiais observadas no MEV para a posição 3 com ciclo térmico de $650^{\circ} \mathrm{C}$. Comportamento puramente dúctil na foto inferior e superior. 


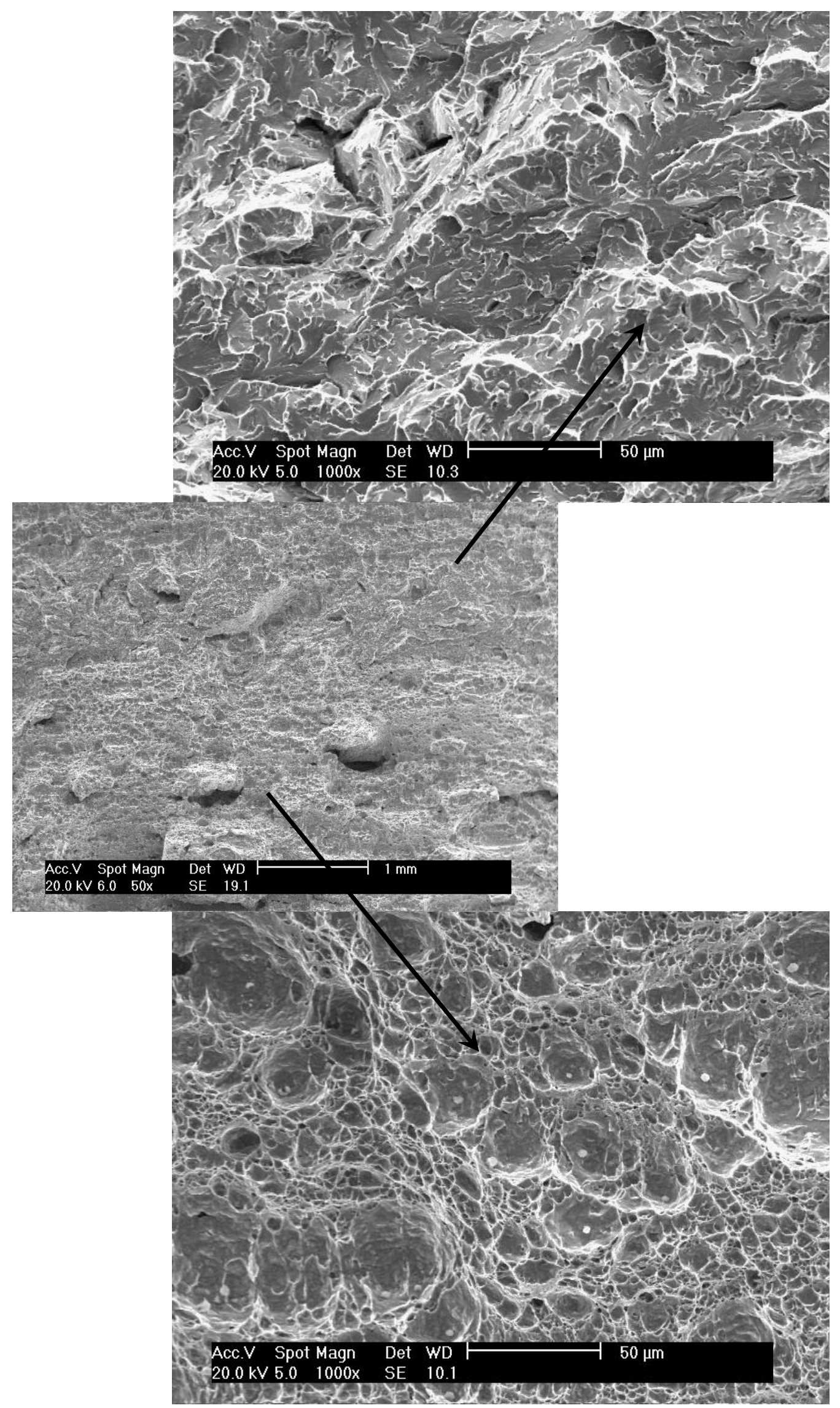

Figura 136. Fraturas superficiais observadas no MEV para a posição $3 \mathrm{com}$ ciclo térmico de $800^{\circ} \mathrm{C}$. Comportamento dúctil na foto inferior e comportamento frágil na foto superior. 


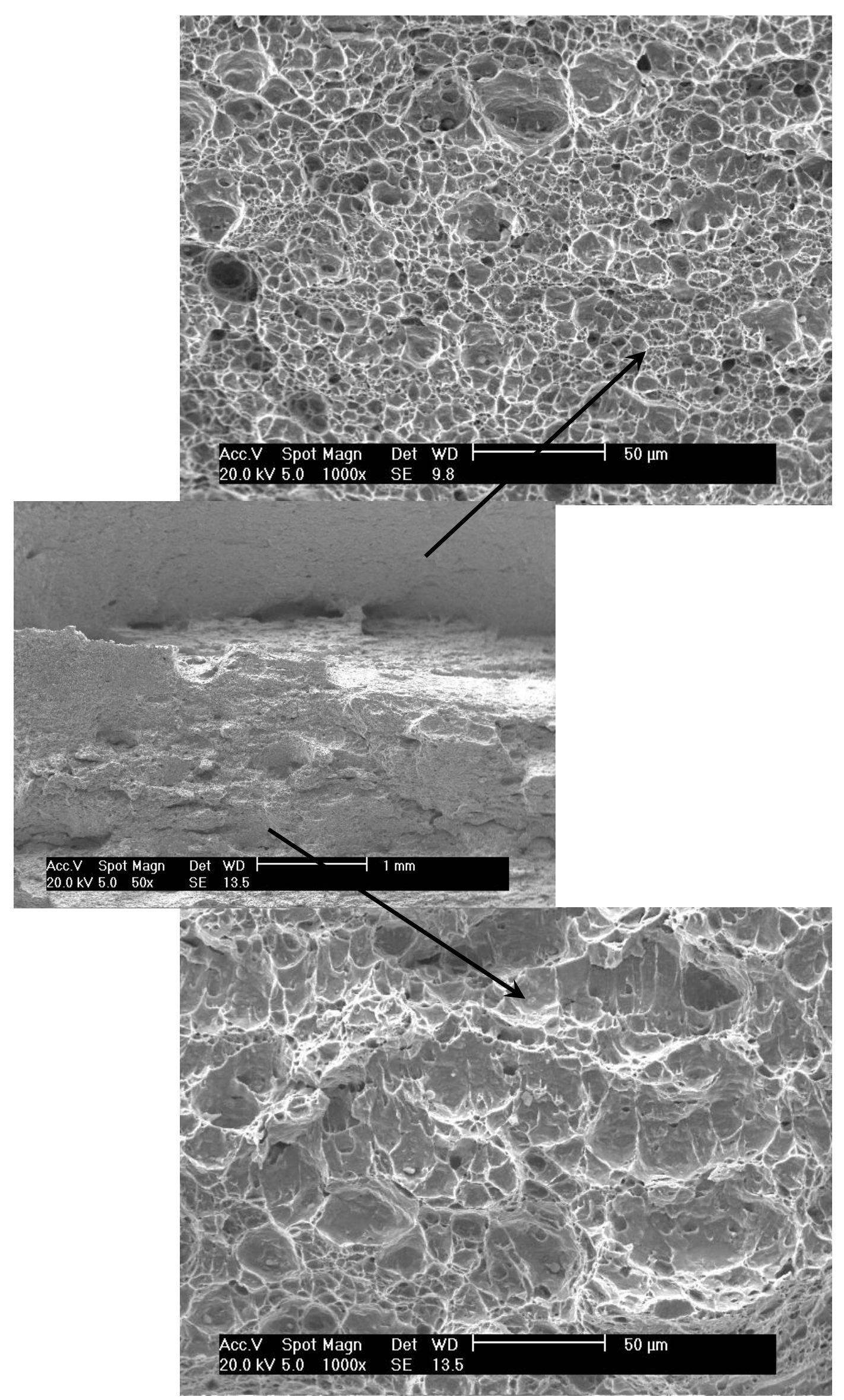

Figura 137. Fraturas superficiais observadas no MEV para a posição $3 \mathrm{com}$ ciclo térmico de $950^{\circ} \mathrm{C}$. Comportamento puramente dúctil na foto inferior e superior. 


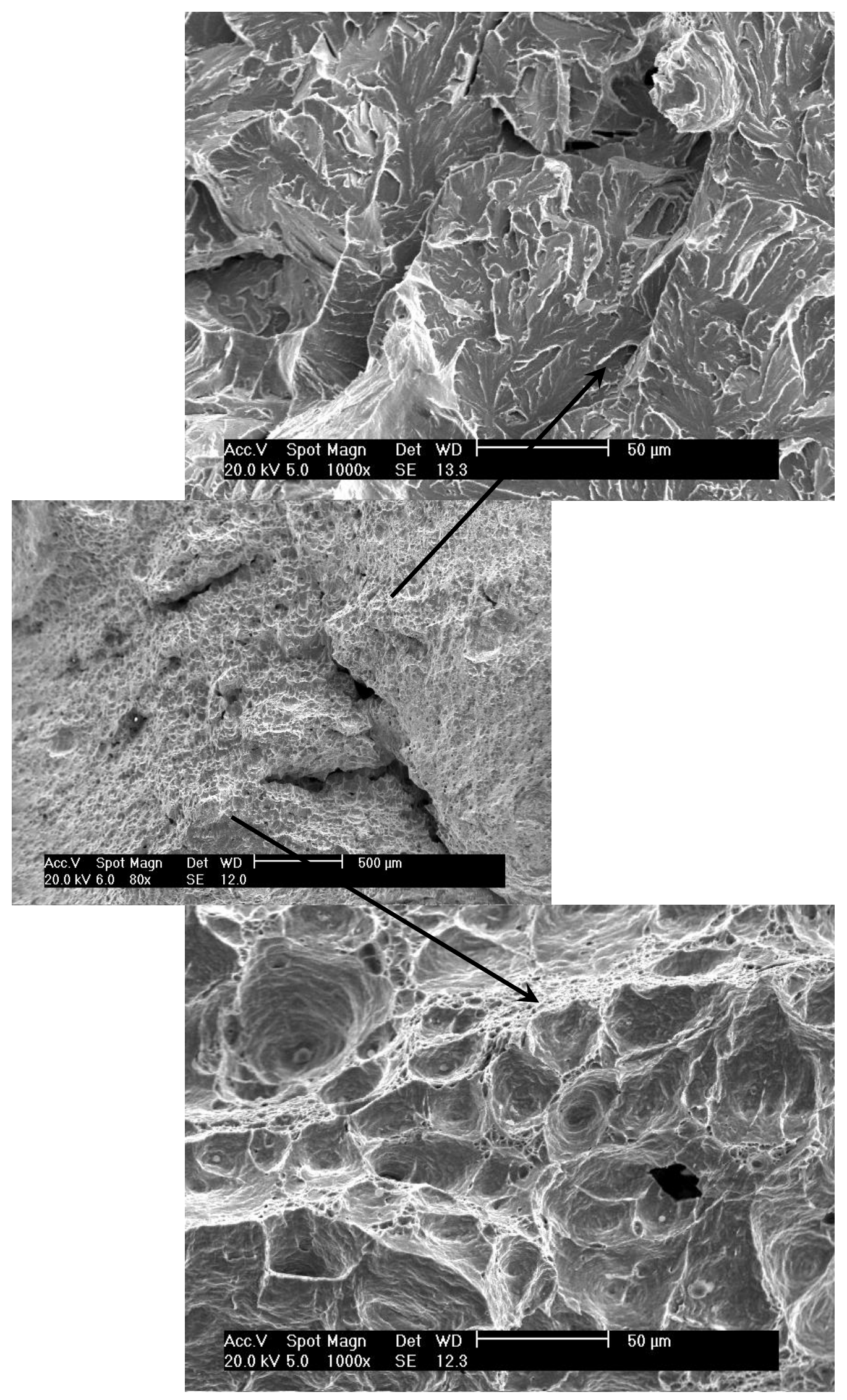

Figura 138. Fraturas superficiais observadas no MEV para a posição 3 com ciclo térmico de $1300{ }^{\circ} \mathrm{C}$. Comportamento dúctil na foto inferior e comportamento frágil na foto superior. 
Além da análise das micrografias dos ciclos térmicos de um único passe, analisaremos o comportamento da superfície da fratura das micrografias dos ciclos térmicos multipasse.

Nas micrografias centrais da Fig. 139 e Fig. 140 observa-se as características de uma zona fundida devido ao cordão de solda nesta posição.

Observando as Fig. 139 e Fig. 140 pode-se notar que as micrografias dos dois corpos-de-prova apresentam um comportamento dúctil-frágil. A Fig. 140 apresenta menos regiões dúcteis, o que explicaria o resultado obtido na Fig. 118 onde a menor energia absorvida foi obtida para a condição experimental representada por esta figura.

Na Fig. 141 e Fig. 142 apresentam comportamento puramente dúctil, os quais pertencem ao material com os ciclos térmicos multipasse. Nos resultados obtidos na Fig. 121 pode-se ver que os ciclos térmicos multipasse não apresentam uma diferença significativa, o que pode explicar o comportamento obtido nas Fig. 141 e Fig. 142. 


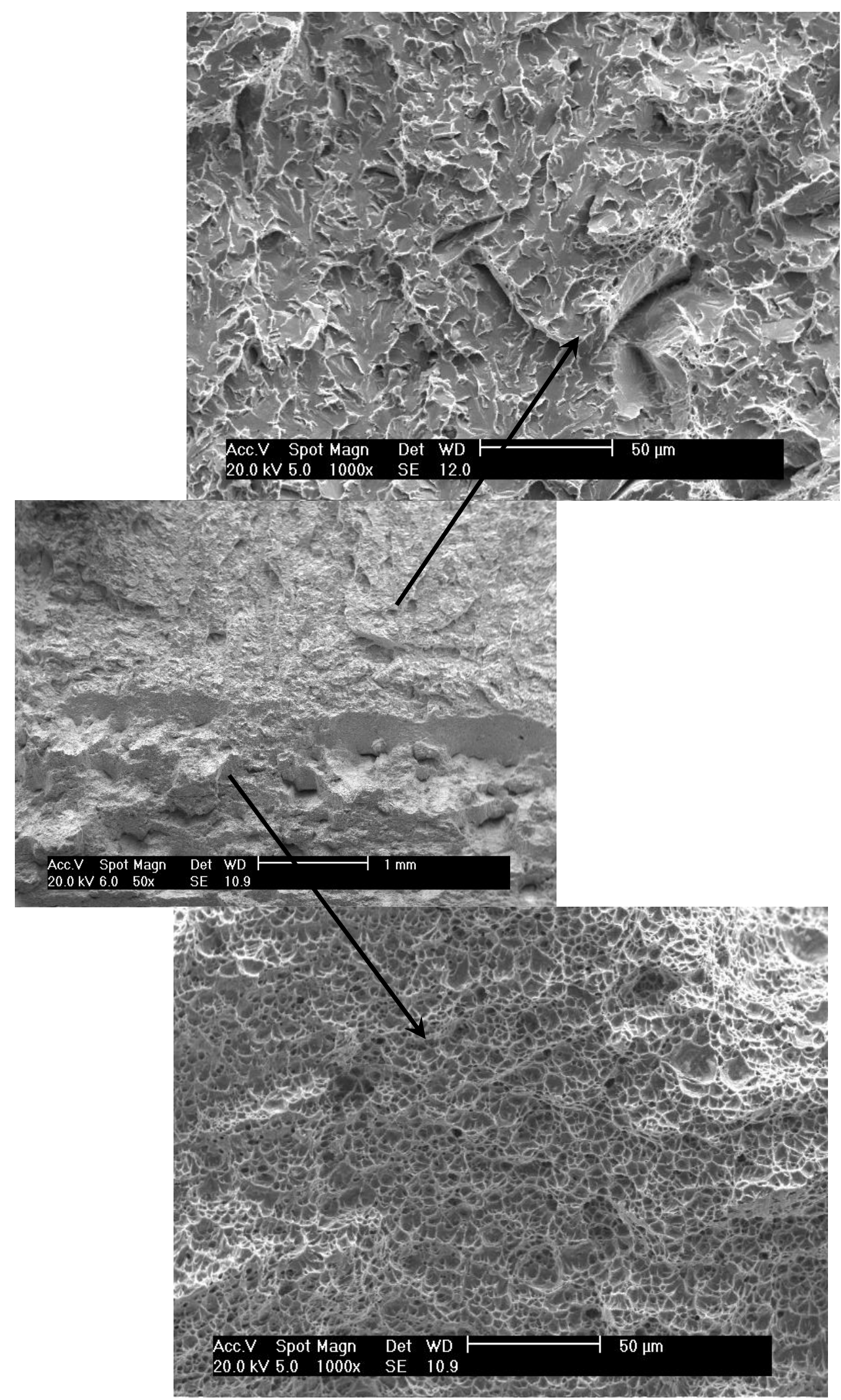

Figura 139. Fraturas superficiais observadas no MEV para a posição 1 com ciclo térmico multipasse de $950-800{ }^{\circ} \mathrm{C}$. Comportamento ductil na foto inferior e comportamento frágil na foto superior. 


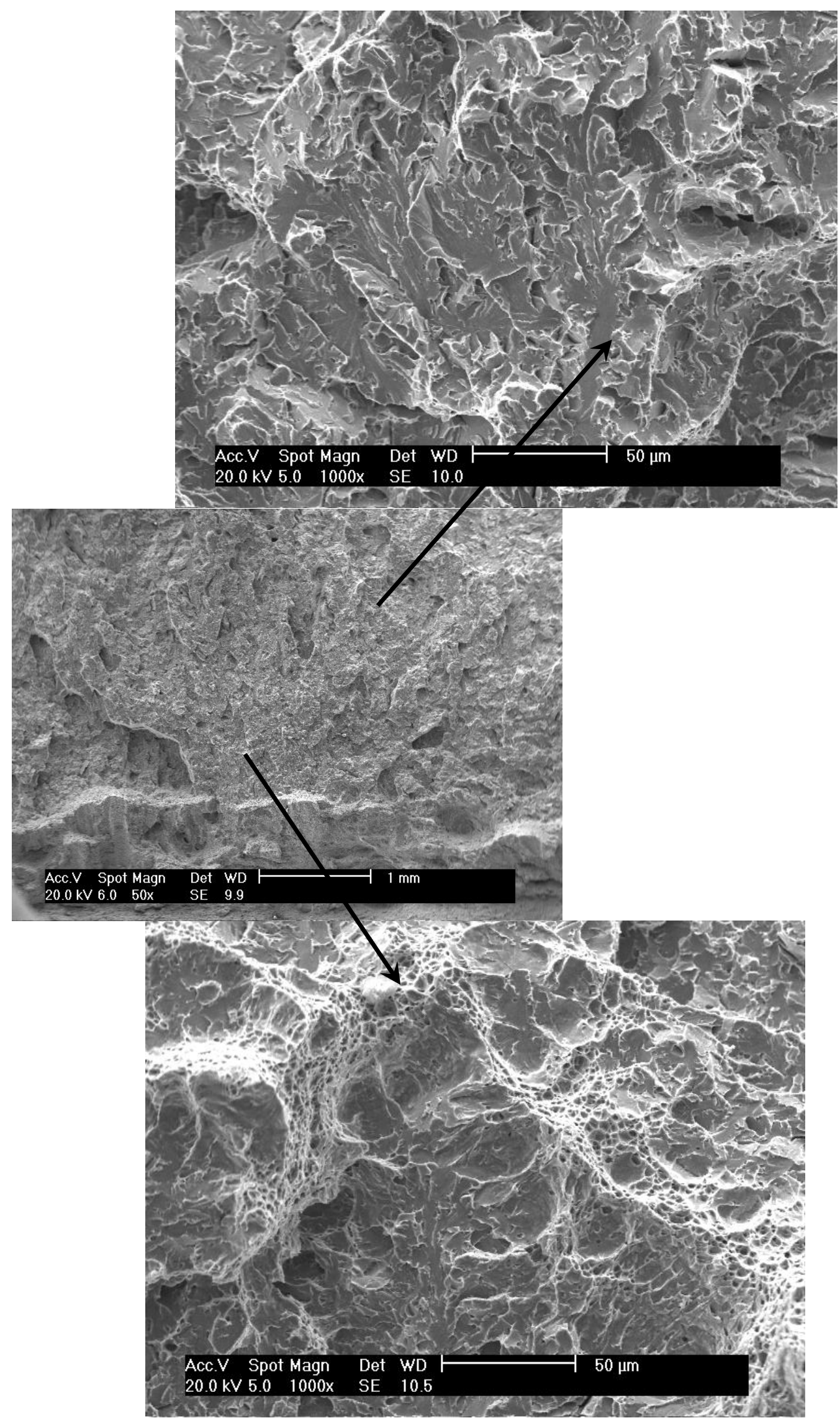

Figura 140. Fraturas superficiais observadas no MEV para a posição 1 com ciclo térmico multipasse de $950-800-650{ }^{\circ} \mathrm{C}$. Comportamento dúctil-frágil na foto inferior e comportamento frágil na foto superior. 


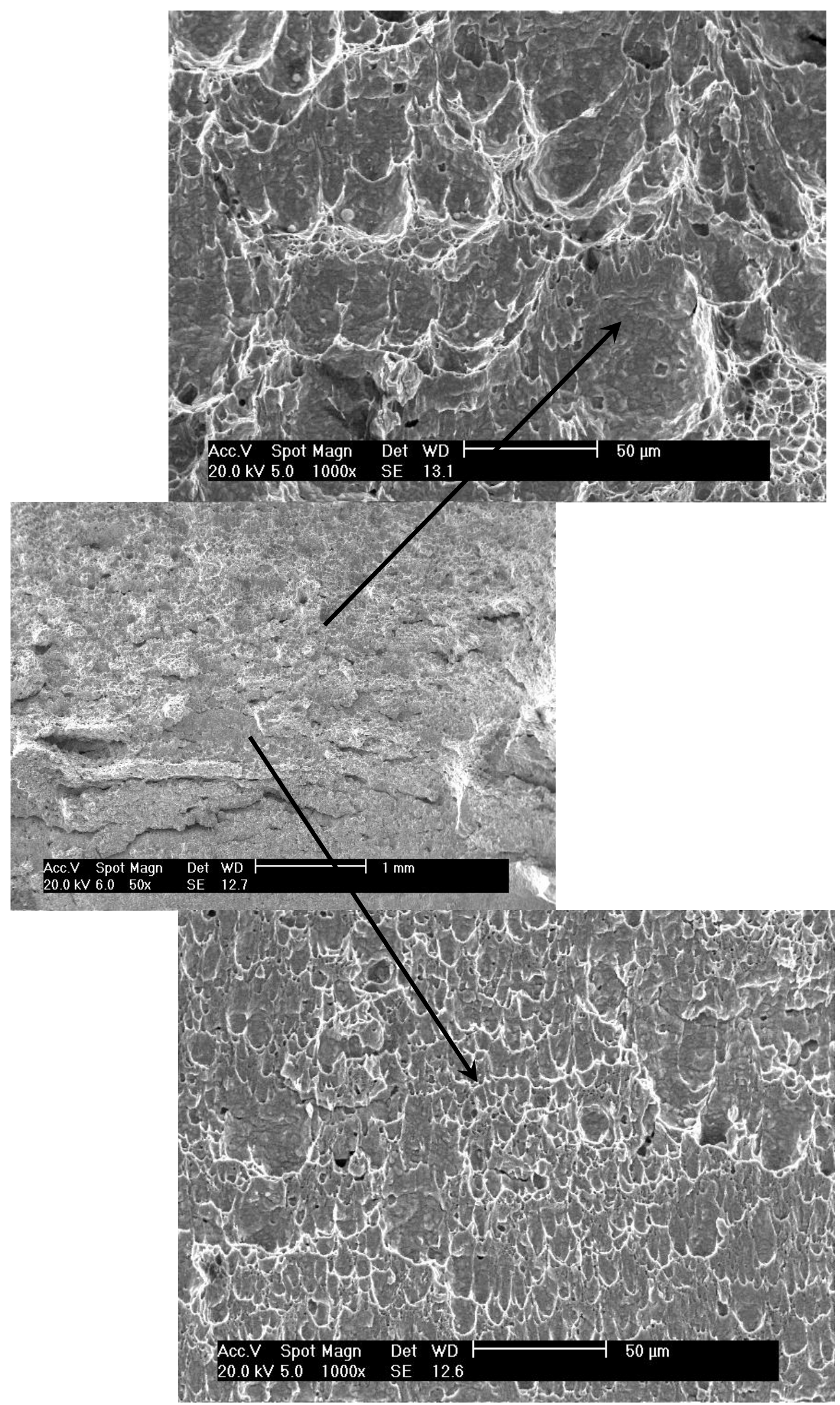

Figura 141. Fraturas superficiais observadas no MEV para a posição 2 com ciclo térmico multipasse de $950-800{ }^{\circ} \mathrm{C}$. Comportamento puramente dúctil na foto inferior e superior. 


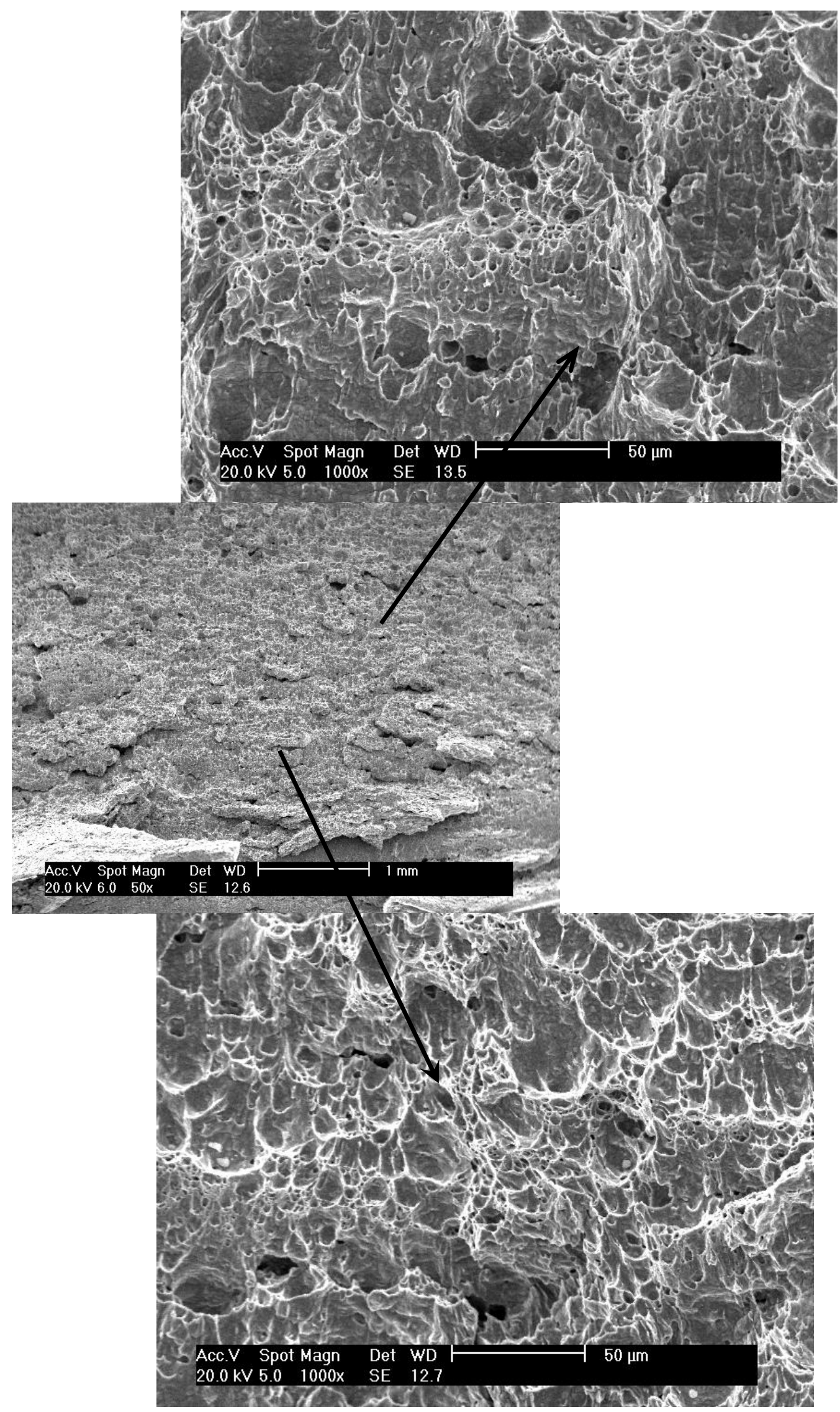

Figura 142. Fraturas superficiais observadas no MEV para a posição 2 com ciclo térmico multipasse de $950-800-650^{\circ} \mathrm{C}$. Comportamento puramente dúctil na foto inferior e superior. 


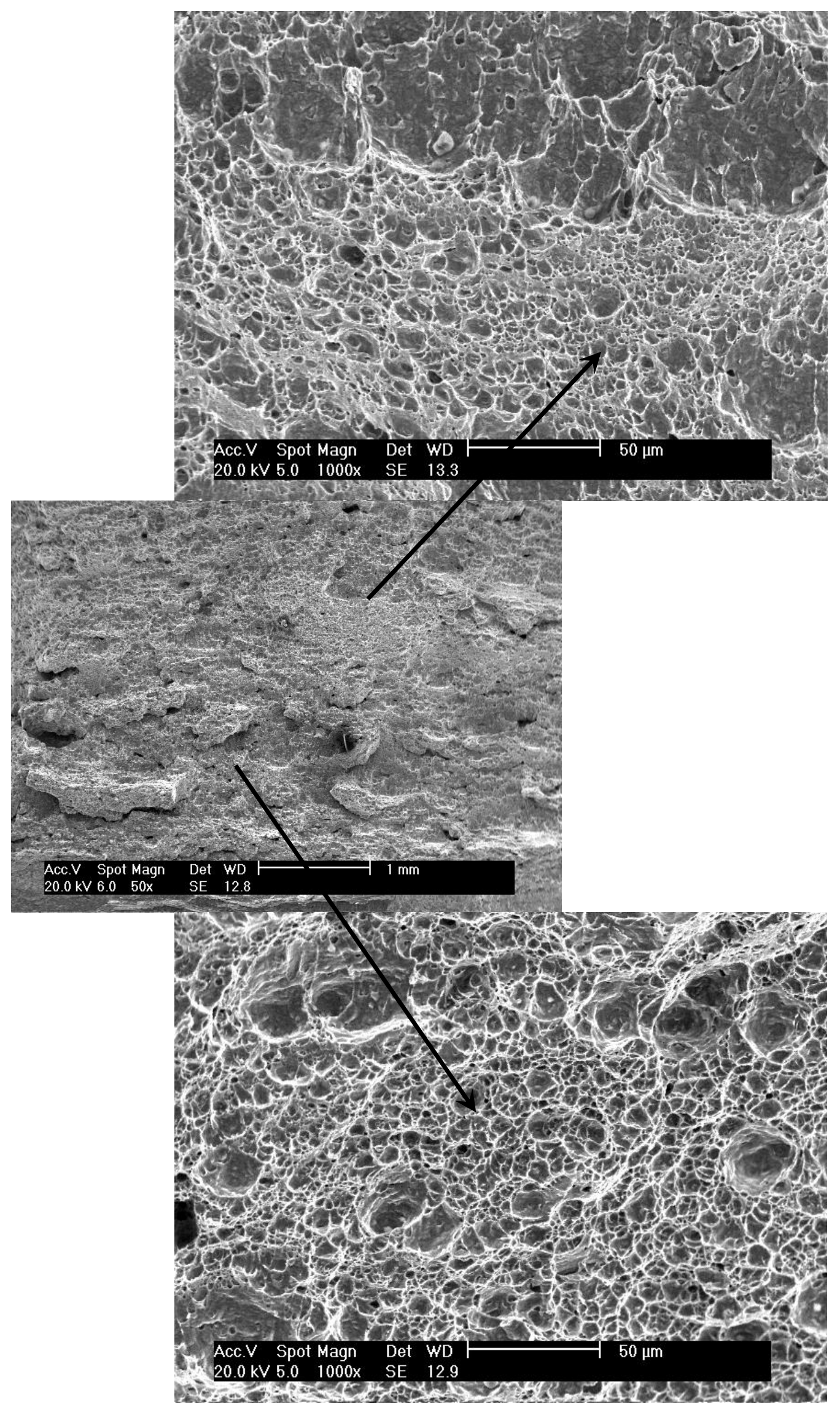

Figura 143. Fraturas superficiais observadas no MEV para a posição $3 \mathrm{com}$ ciclo térmico multipasse de $950-800{ }^{\circ} \mathrm{C}$. Comportamento puramente dúctil na foto inferior e superior. 


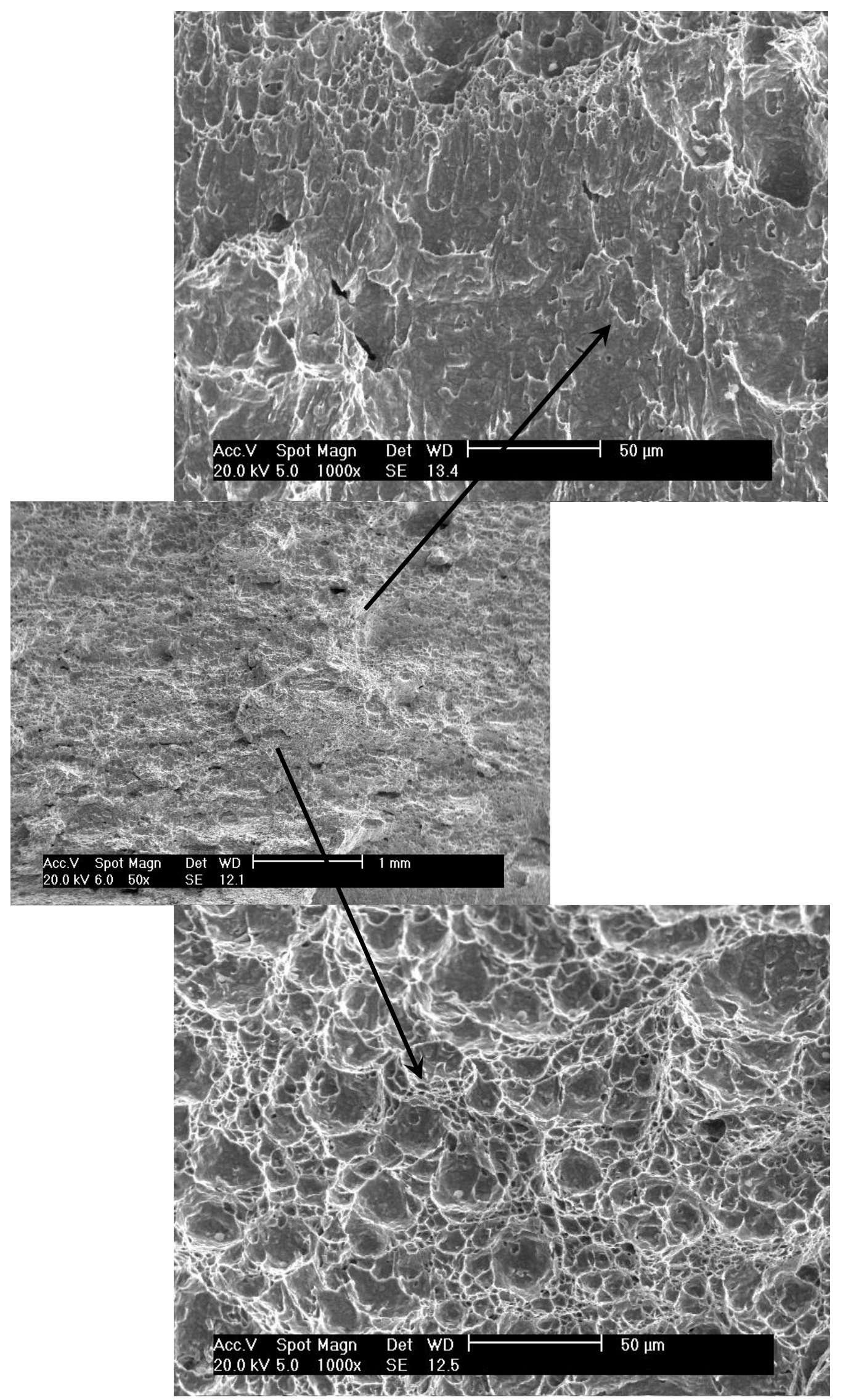

Figura 144. Fraturas superficiais observadas no MEV para a posição $3 \mathrm{com}$ ciclo térmico multipasse de $950-800-650^{\circ} \mathrm{C}$. Comportamento puramente dúctil na foto inferior e superior. 
As micrografias Fig. 143 e Fig. 144 apresentam comportamento puramente dúctil as quais pertencem ao material com os ciclos térmicos multipasse. Este comportamento pode ser explicado observando as Fig. 118 e Fig. 121 onde as energias absorvidas ciclos térmicos multipasse são maiores que a energia absorvida do material de base sem simulação (MB).

Cabe salientar que as Fig. 141 até a Fig. 144 que pertencem a posição 2 e 3 respectivamente, são as micrografias dos corpos-de-prova que apresentaram maior energia absorvida em relação à posição 1 (Fig. 139 e 140).

\subsubsection{Caracterização dos caminhos de propagação das trincas por microscopia óptica e eletrônica de varredura}

Além da observação das características da topografia e aspecto das superfícies das fraturas é importante verificar também como a trinca se propagou durante o ensaio. Para isso as amostras rompidas no ensaio Charpy foram cortadas na metade da sua espessura e foram feitas macrografias para mostrar a propagação da trinca e micrografias no microscópio óptico e

eletrônico de varredura, que serão mostradas a seguir. É importante observar a presença de trincas secundárias, geralmente perpendiculares à trinca principal iniciada no entalhe. A presença destas trincas produz um aumento na energia absorvida, mascarando eventuais fragilizações devido à microestrutura simulada.

\subsubsection{Caminhos de trinca dos corpos-de-prova sem simulação}

A seguir são apresentados, nas Fig. 145 a 147 os caminhos de trincas dos corpos-de-prova sem simulação. 


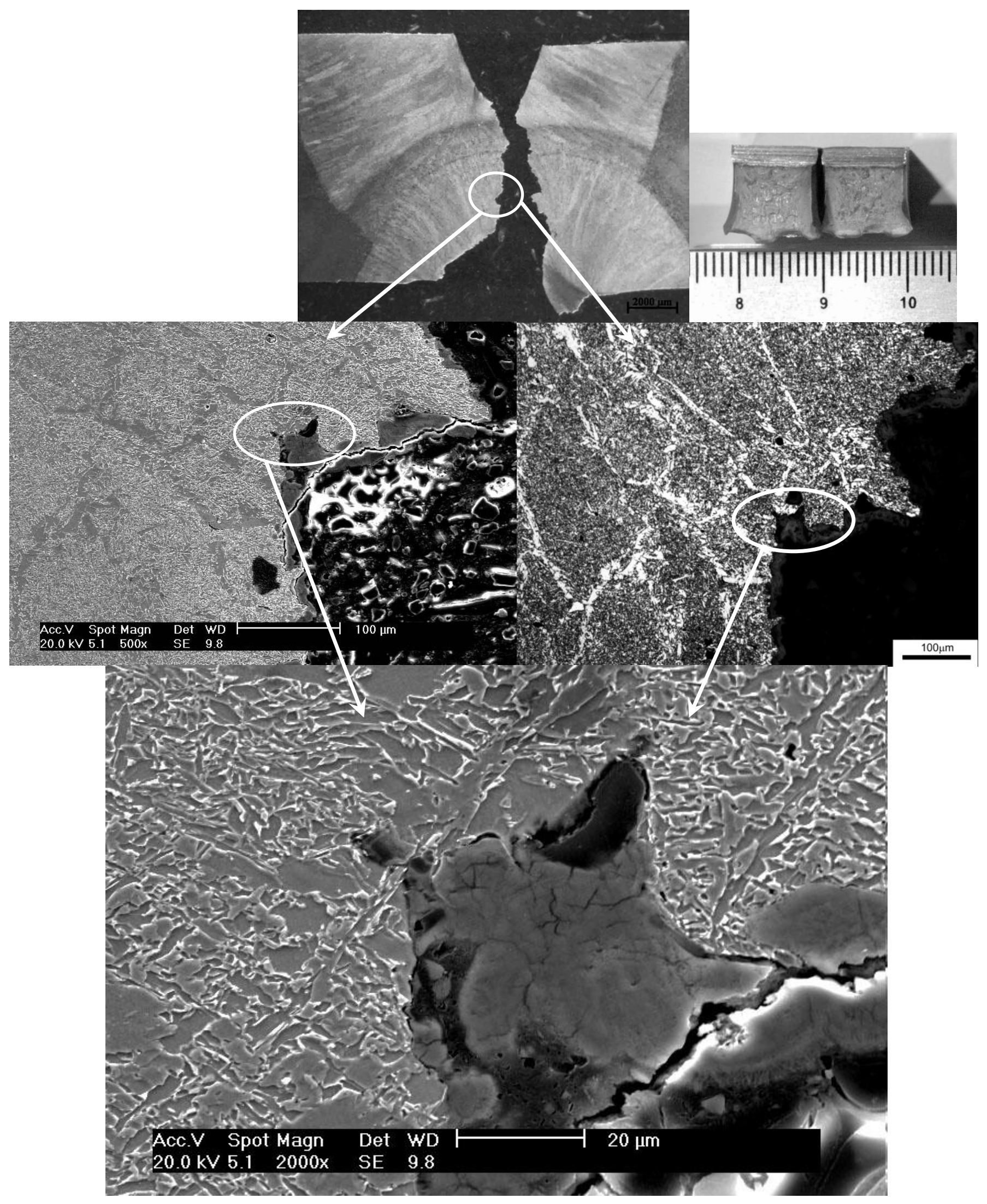

Figura 145. Detalhes do caminho da trinca empregando microscopia óptica e eletrônica de varredura da posição 1 , sem simulação. 


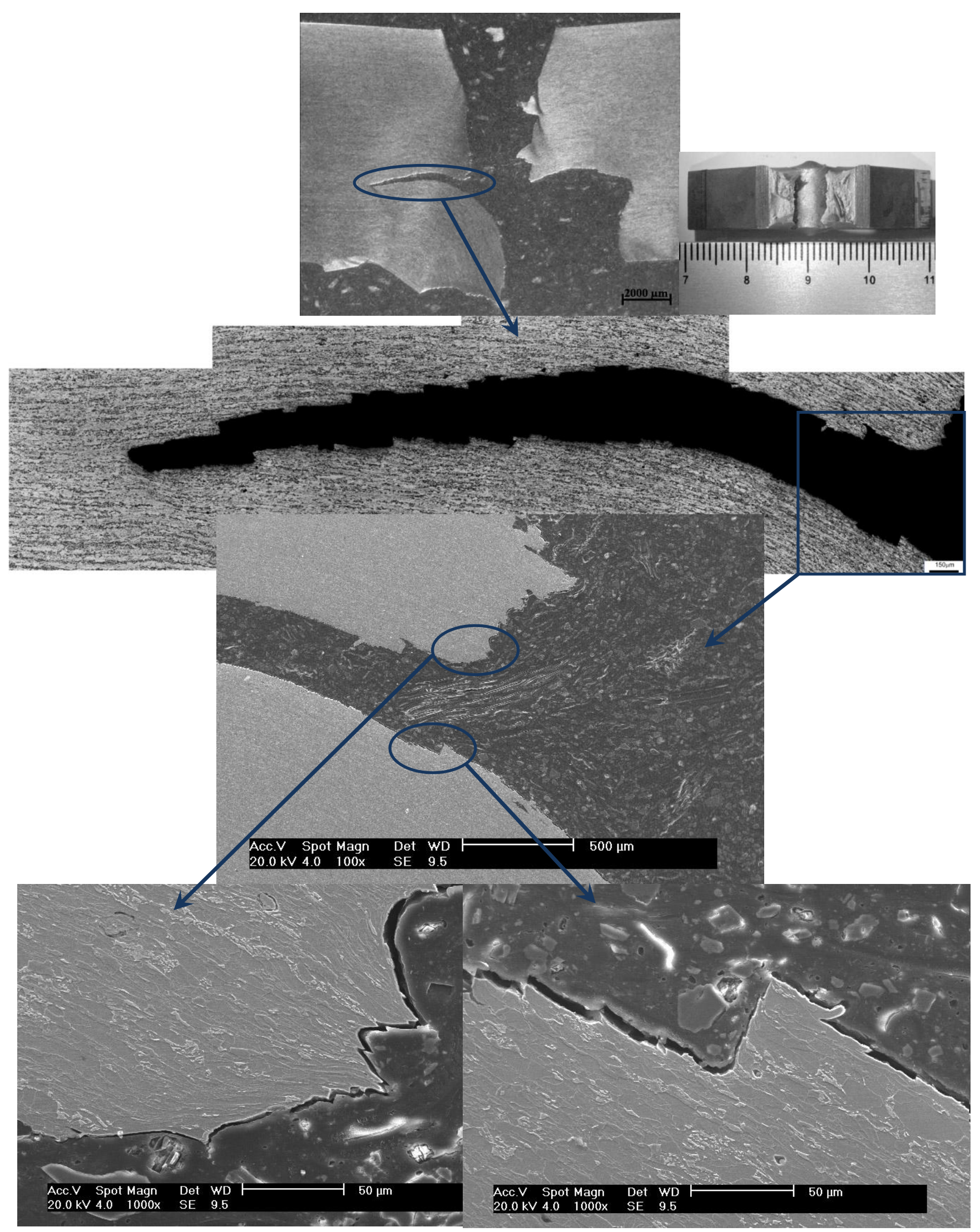

Figura 146. Detalhes do caminho da trinca empregando microscopia óptica e eletrônica de varredura da posição 2 , sem simulação. 


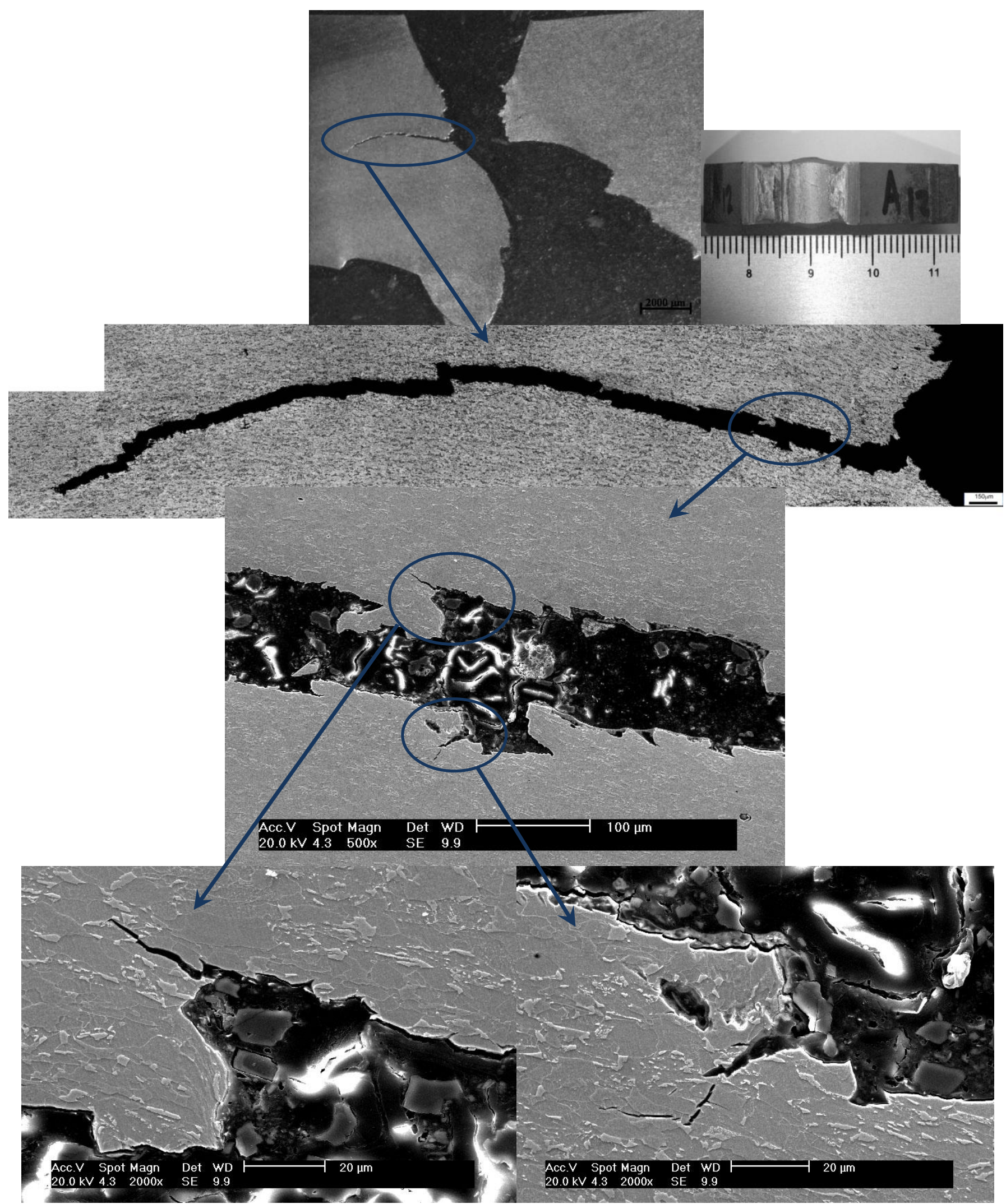

Figura 147. Detalhes do caminho da trinca empregando microscopia óptica e eletrônica de varredura da posição 3 , sem simulação. 


\subsubsection{Caminhos de trinca dos corpos-de-prova com simulação a $1300{ }^{\circ} \mathrm{C}$}

A seguir são apresentados, nas fig. 148 até a 150 os caminhos de trincas dos corpos-de-prova com simulação, para o ciclo térmico de $1300{ }^{\circ} \mathrm{C}$.

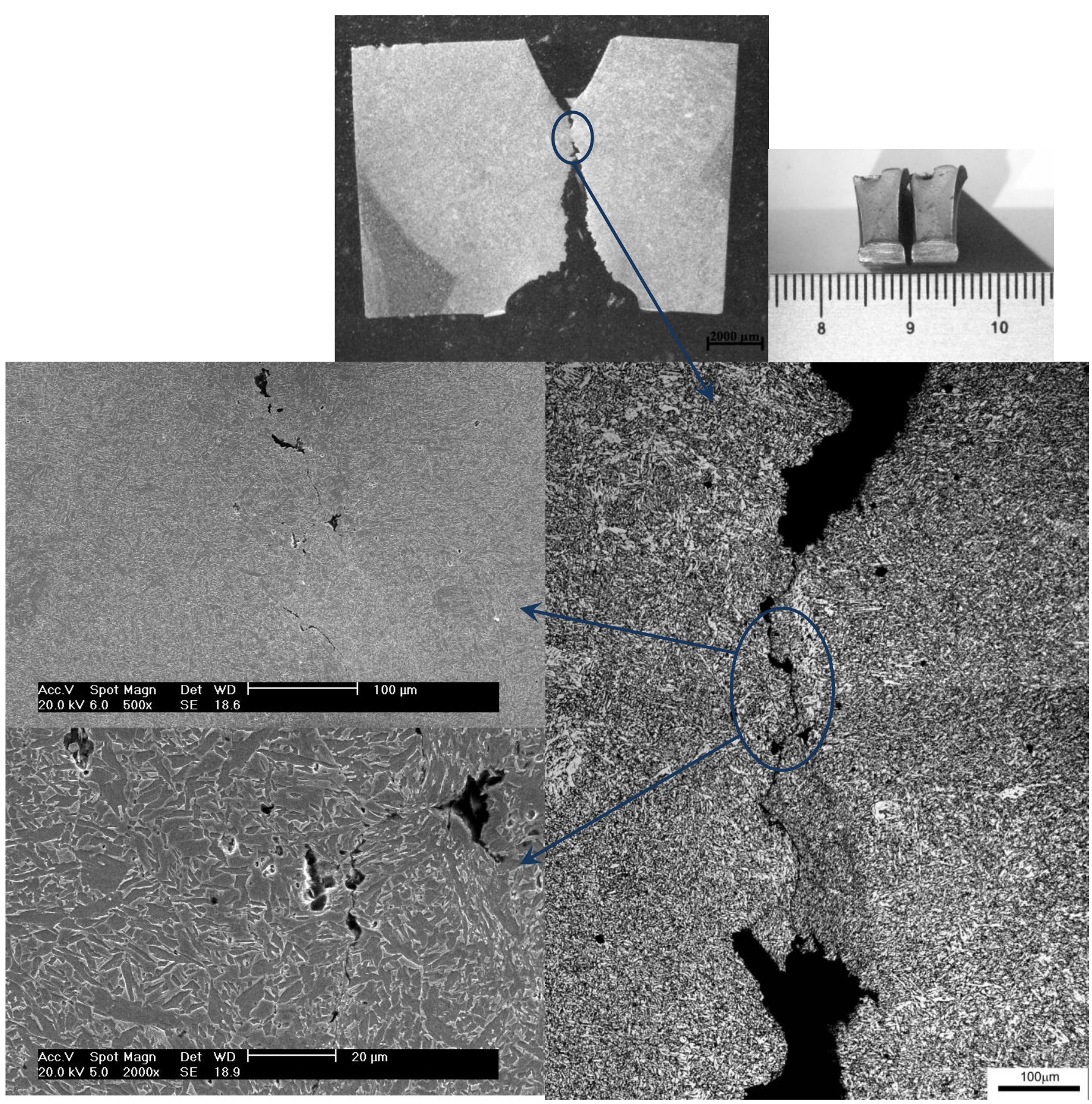

Figura 148. Detalhes do caminho da trinca empregando microscopia óptica e eletrônica de varredura da posição 1 , simulado a $1300{ }^{\circ} \mathrm{C}$. 


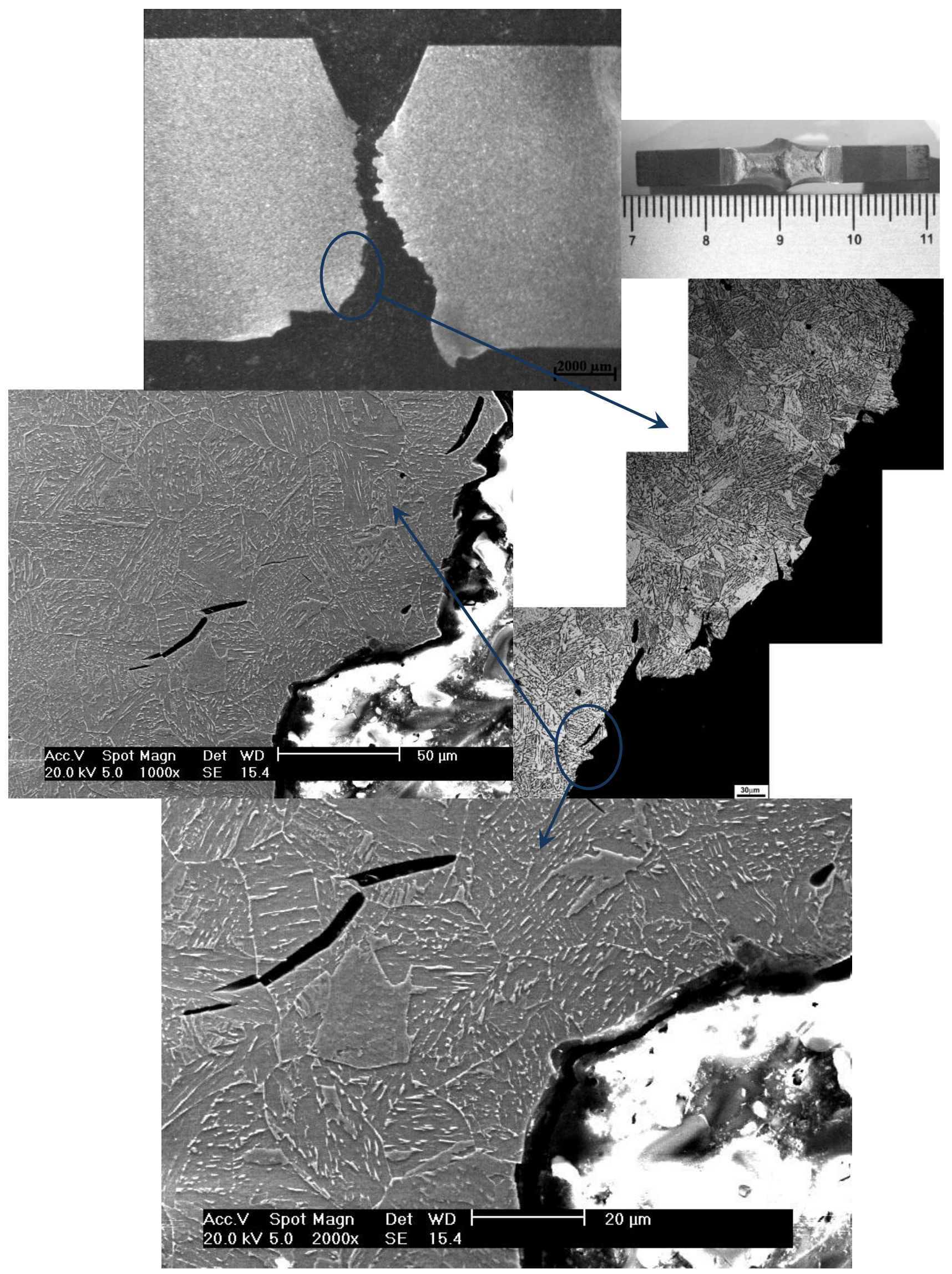

Figura 149. Detalhes do caminho da trinca empregando microscopia óptica e eletrônica de varredura da posição 2 , simulado a $1300{ }^{\circ} \mathrm{C}$. 


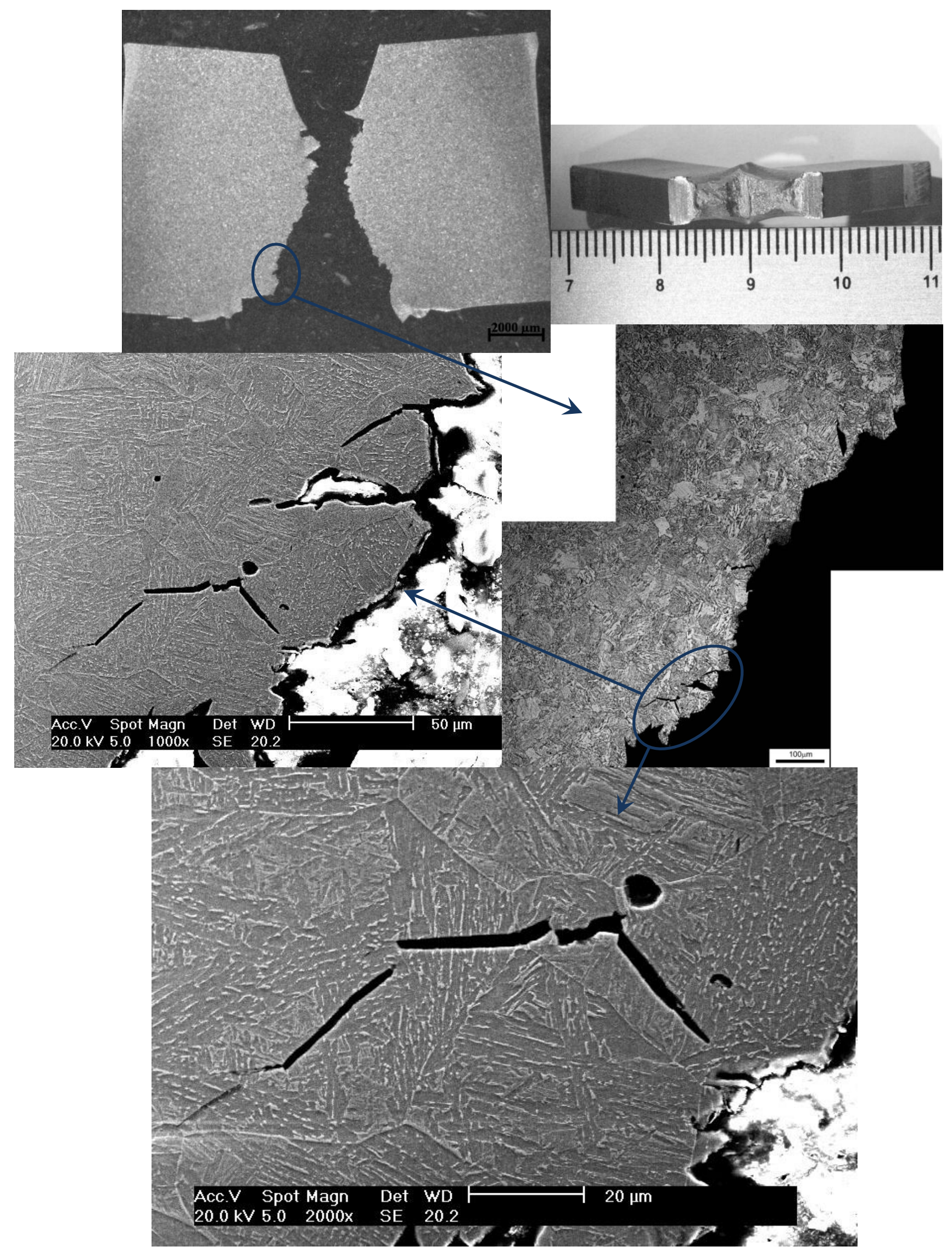

Figura 150. Detalhes do caminho da trinca empregando microscopia óptica e eletrônica de varredura da posição 3 , simulado a $1300^{\circ} \mathrm{C}$. 


\subsubsection{Caminhos de trinca dos corpos-de-prova com simulação a $800{ }^{\circ} \mathrm{C}$}

A seguir são apresentados, nas fig. 151 ate a 153 os caminhos de trincas dos corpos-de-prova com simulação, para o ciclo térmico de $800^{\circ} \mathrm{C}$.

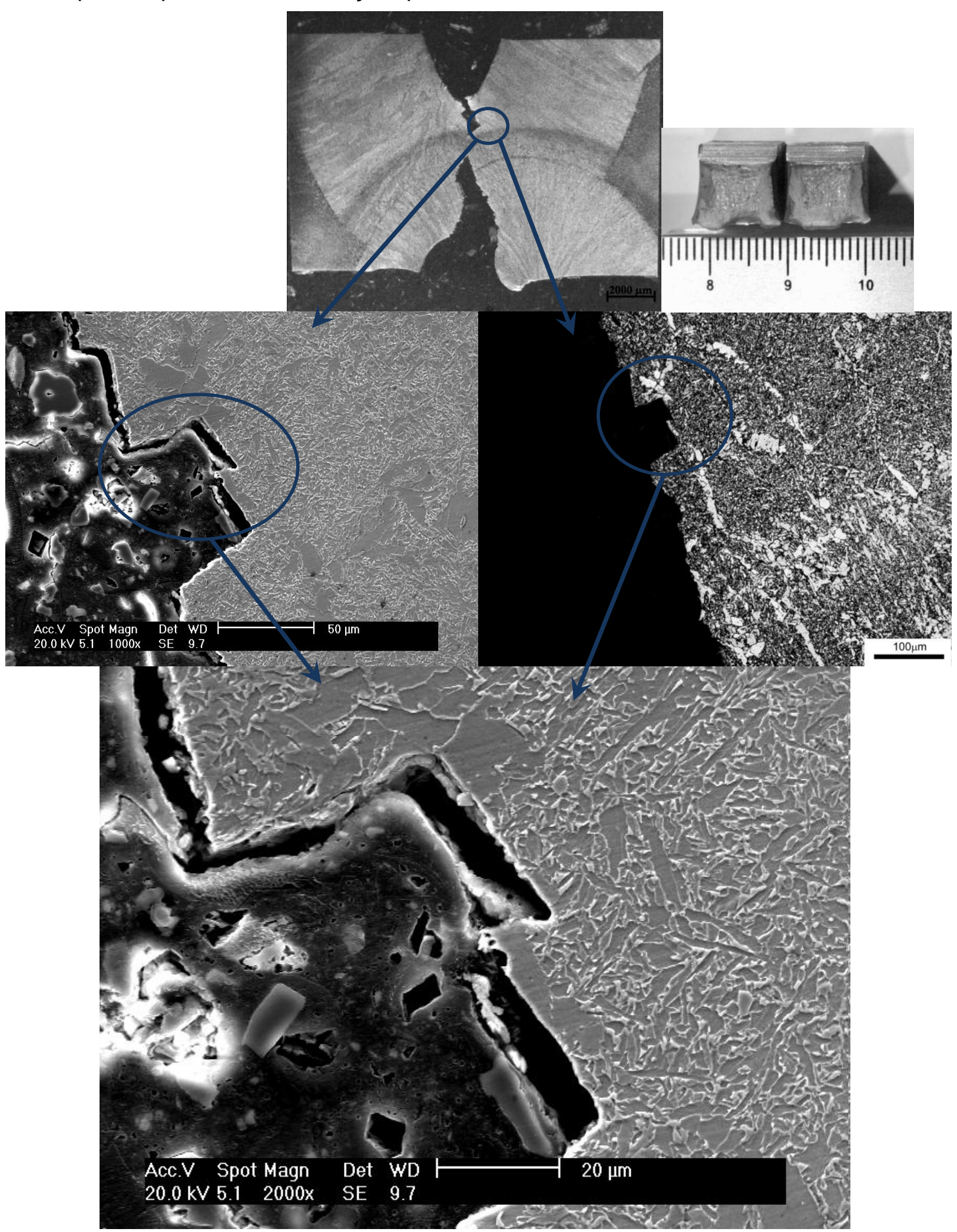

Figura 151. Detalhes do caminho da trinca empregando microscopia óptica e eletrônica de varredura da posição 1 , simulado a $800{ }^{\circ} \mathrm{C}$. 


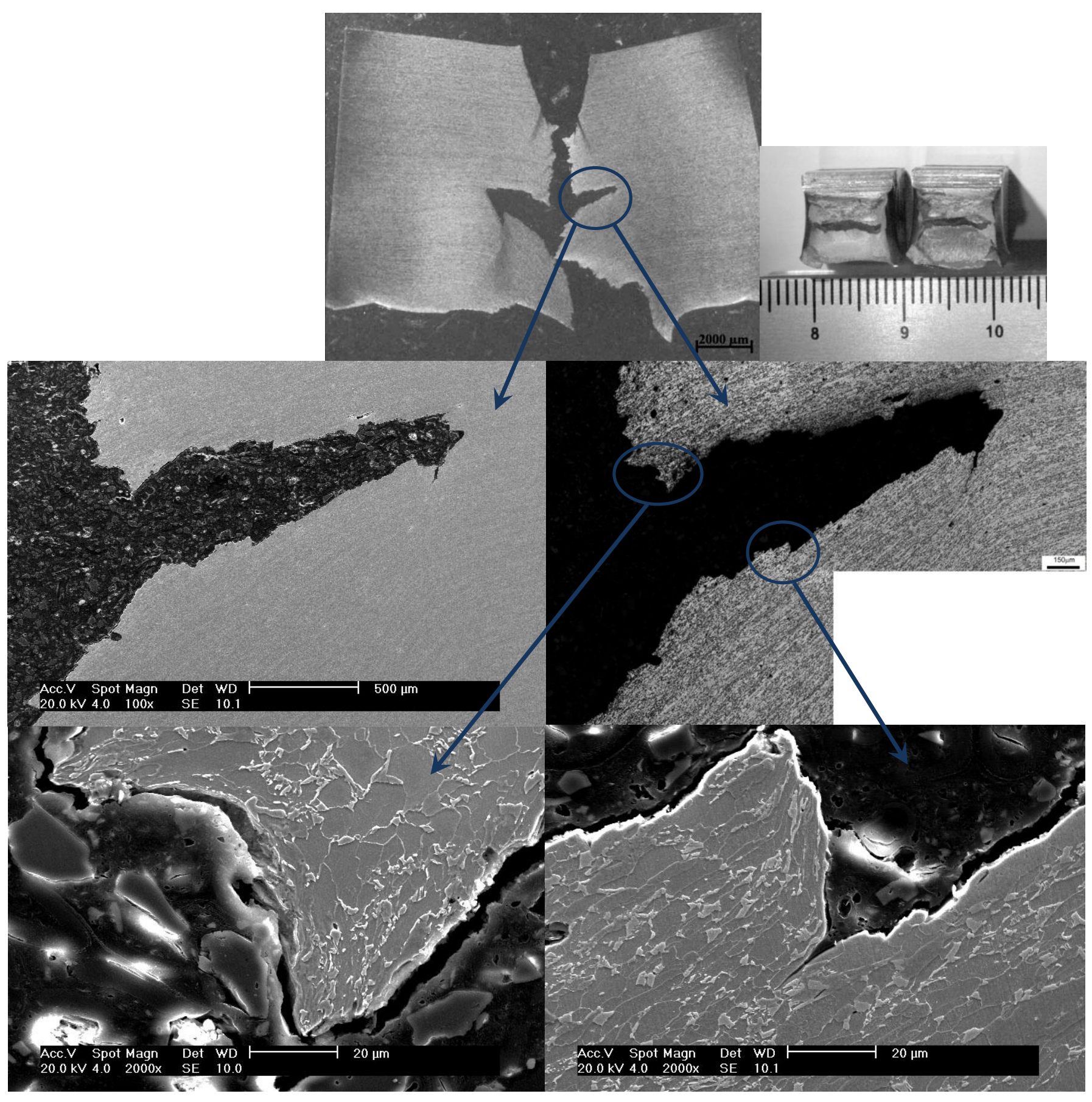

Figura 152. Detalhes do caminho da trinca empregando microscopia óptica e eletrônica de varredura da posição 2 , simulado a $800{ }^{0} \mathrm{C}$. 


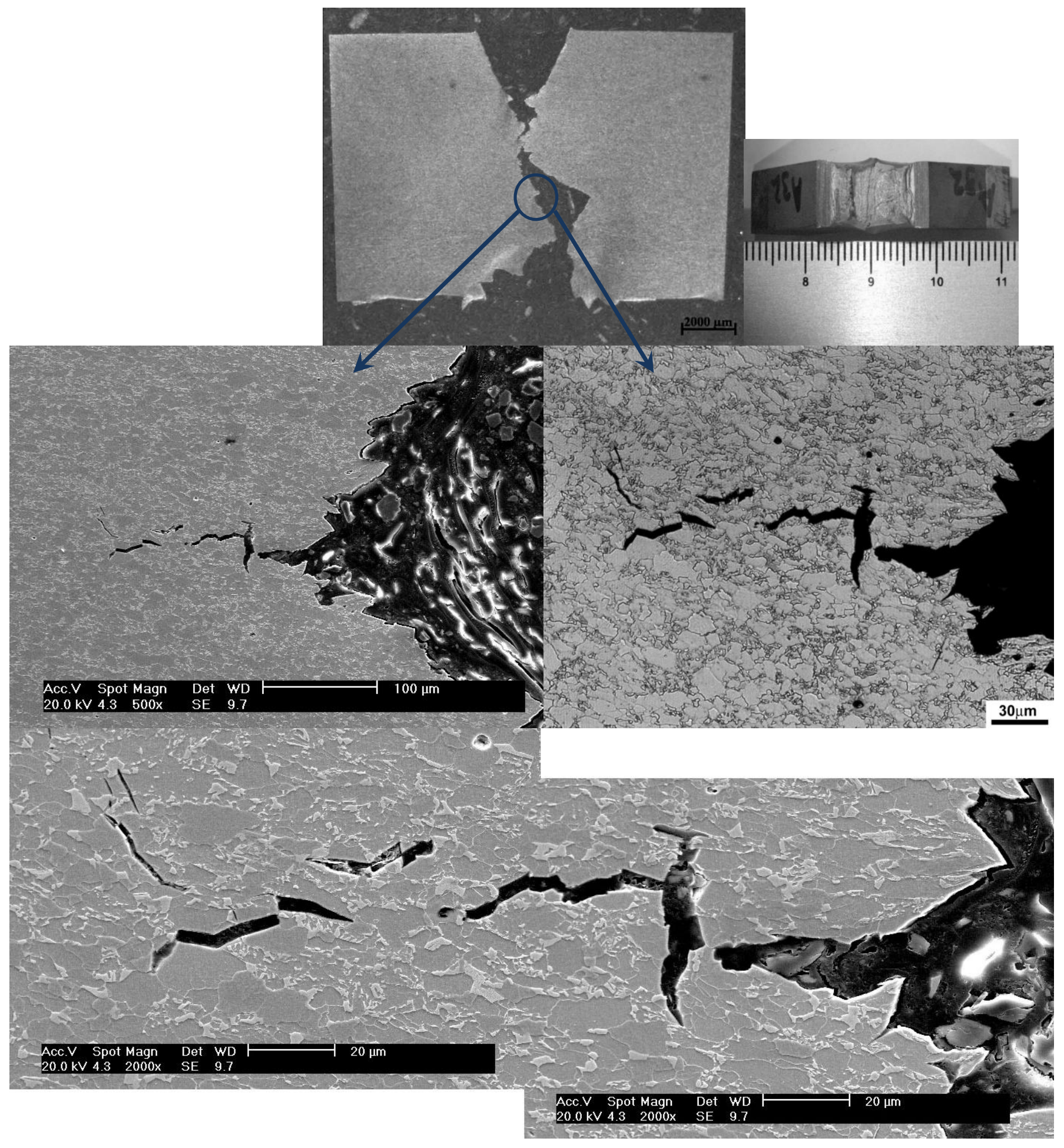

Figura 153. Detalhes do caminho da trinca empregando microscopia óptica e eletrônica de varredura da posição 3 , simulado a $800{ }^{\circ} \mathrm{C}$. 


\subsubsection{Caminhos de trinca dos corpos-de-prova com simulação a $950{ }^{\circ} \mathrm{C}$}

A seguir são apresentados, nas fig. 154 até a 156 os caminhos de trincas dos corpos-de-prova com simulação, para o ciclo térmico de $950{ }^{\circ} \mathrm{C}$.

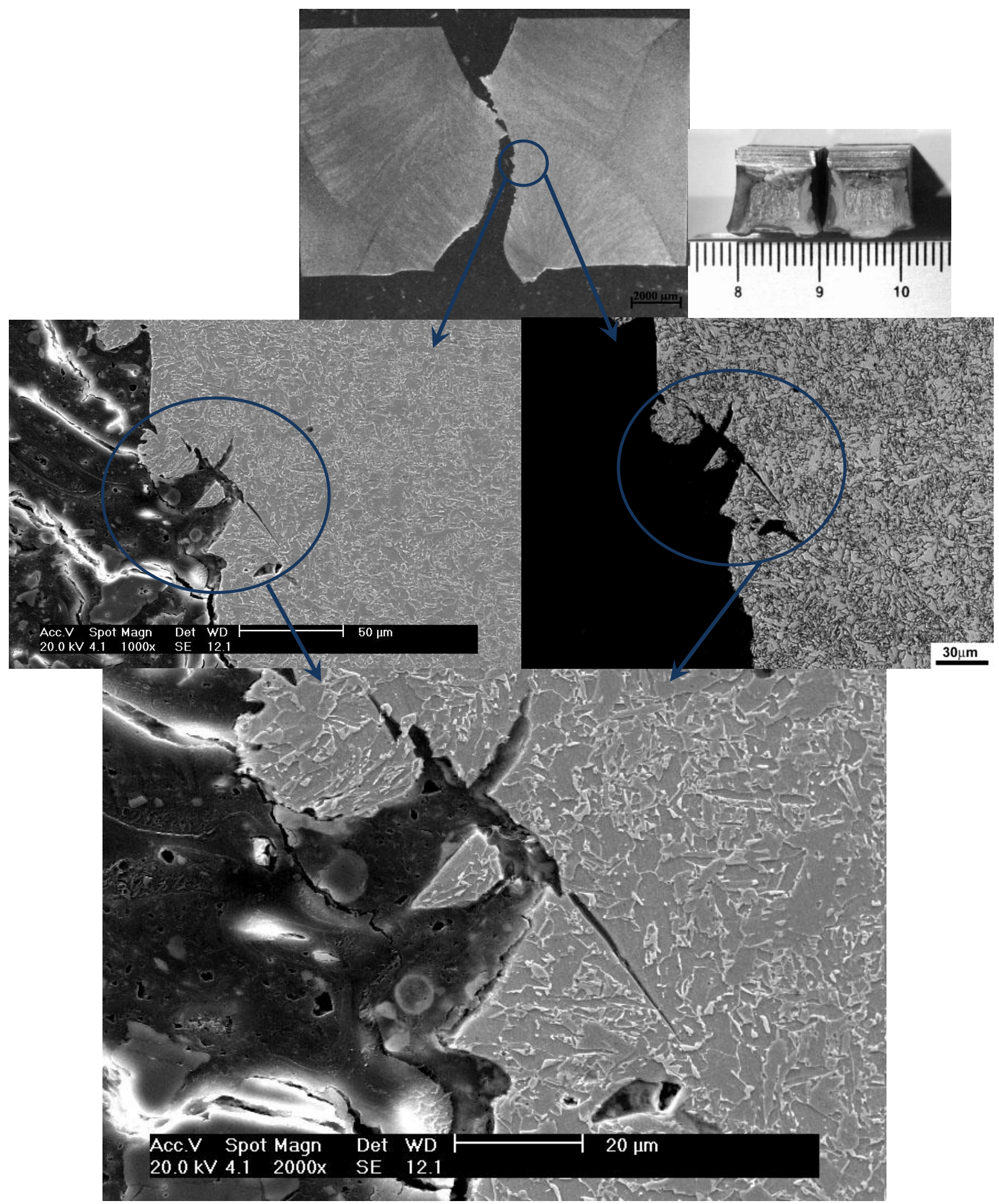

Figura 154. Detalhes do caminho da trinca empregando microscopia óptica e eletrônica de varredura da posição 1 , simulado a $950{ }^{\circ} \mathrm{C}$. 


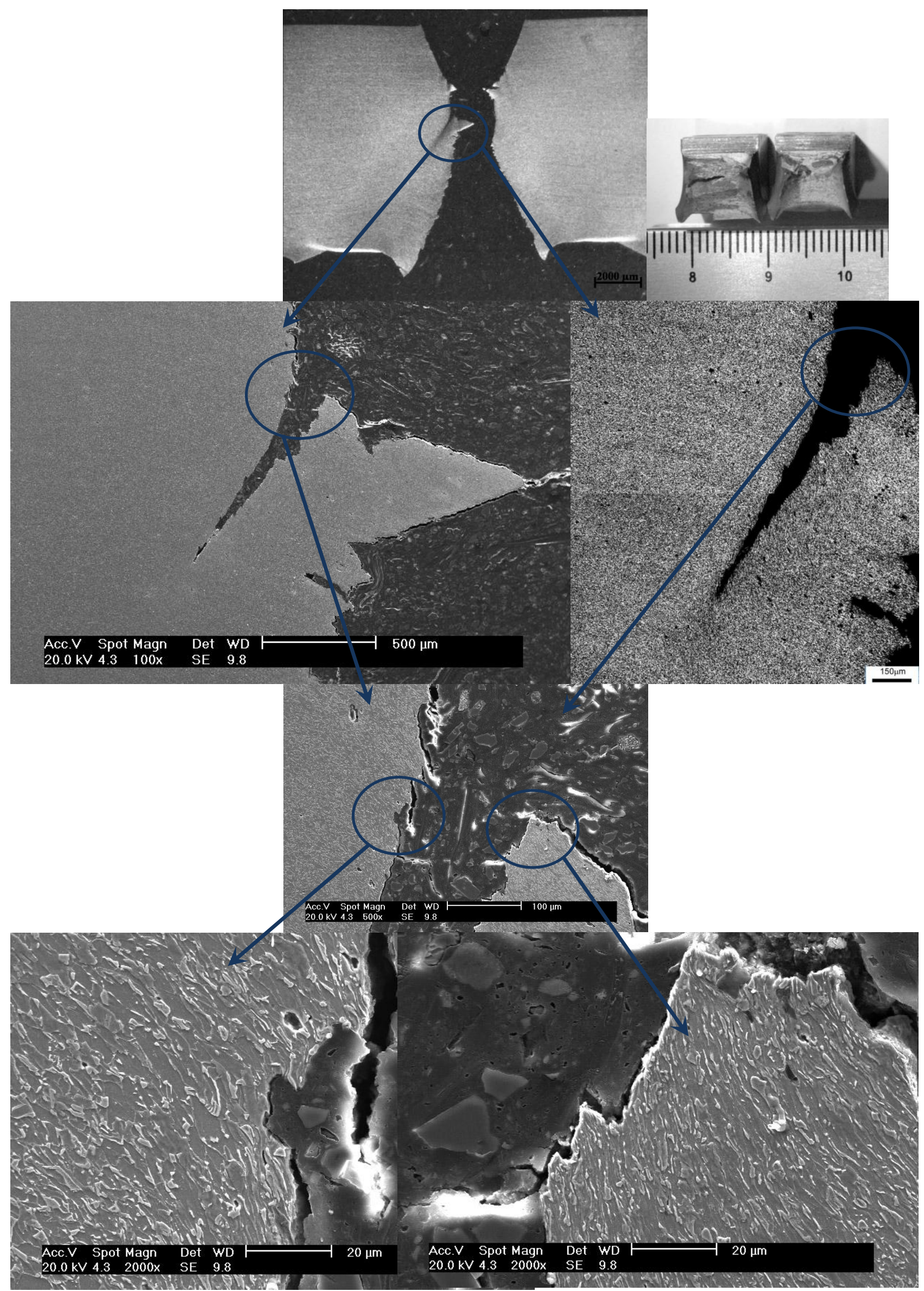

Figura 155. Detalhes do caminho da trinca empregando microscopia óptica e eletrônica de varredura da posição 2 , simulado a $950{ }^{\circ} \mathrm{C}$. 


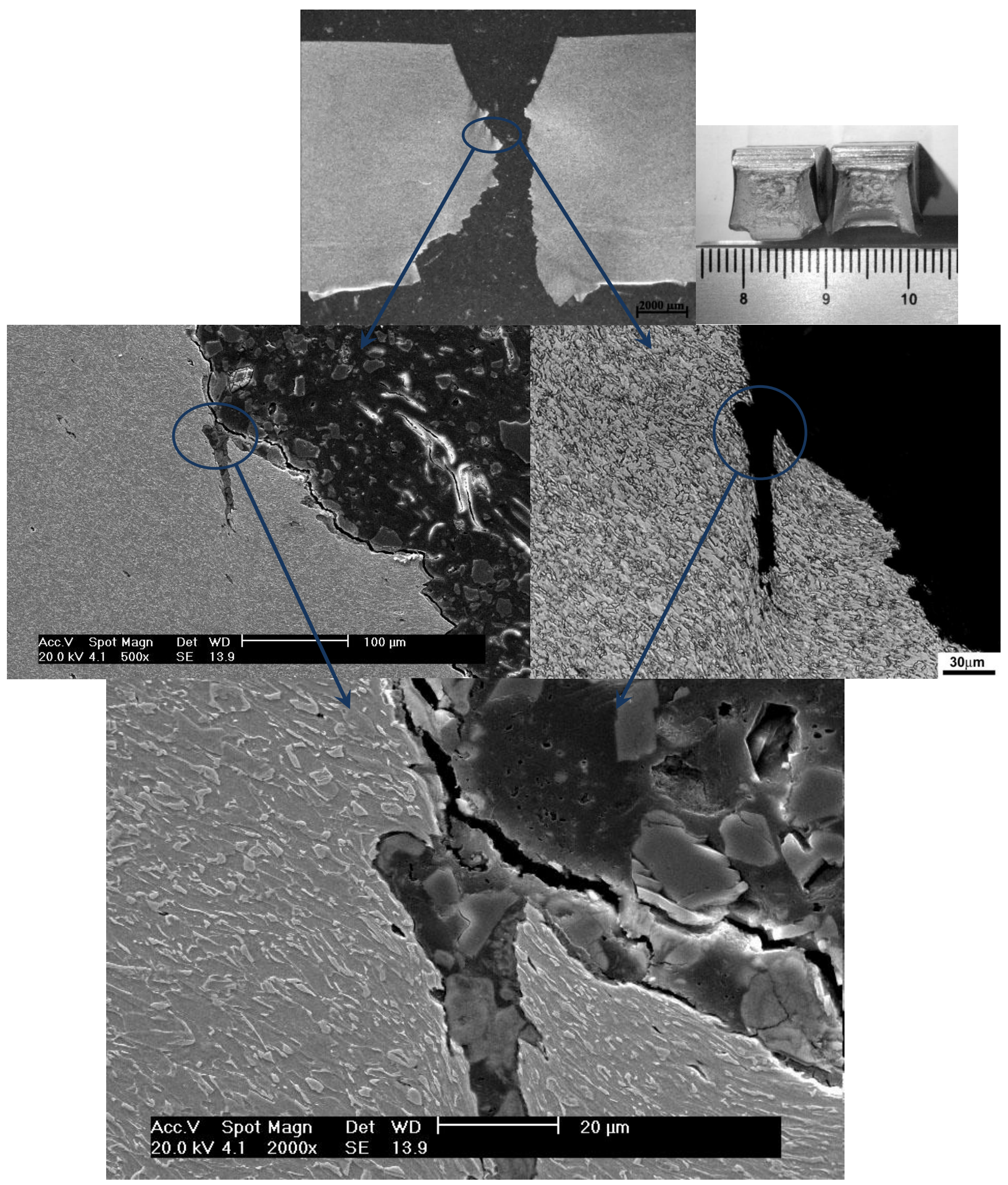

Figura 156. Detalhes do caminho da trinca empregando microscopia óptica e eletrônica de varredura da posição 3 , simulado a $950{ }^{\circ} \mathrm{C}$. 


\subsubsection{Caminhos de trinca dos corpos-de-prova com simulação multipasse $950-800{ }^{\circ} \mathrm{C}$}

A seguir são apresentados, nas fig. 157 a 159 os caminhos de trincas dos corpos-de-prova com simulação, para o ciclo térmico de $950-800{ }^{\circ} \mathrm{C}$.

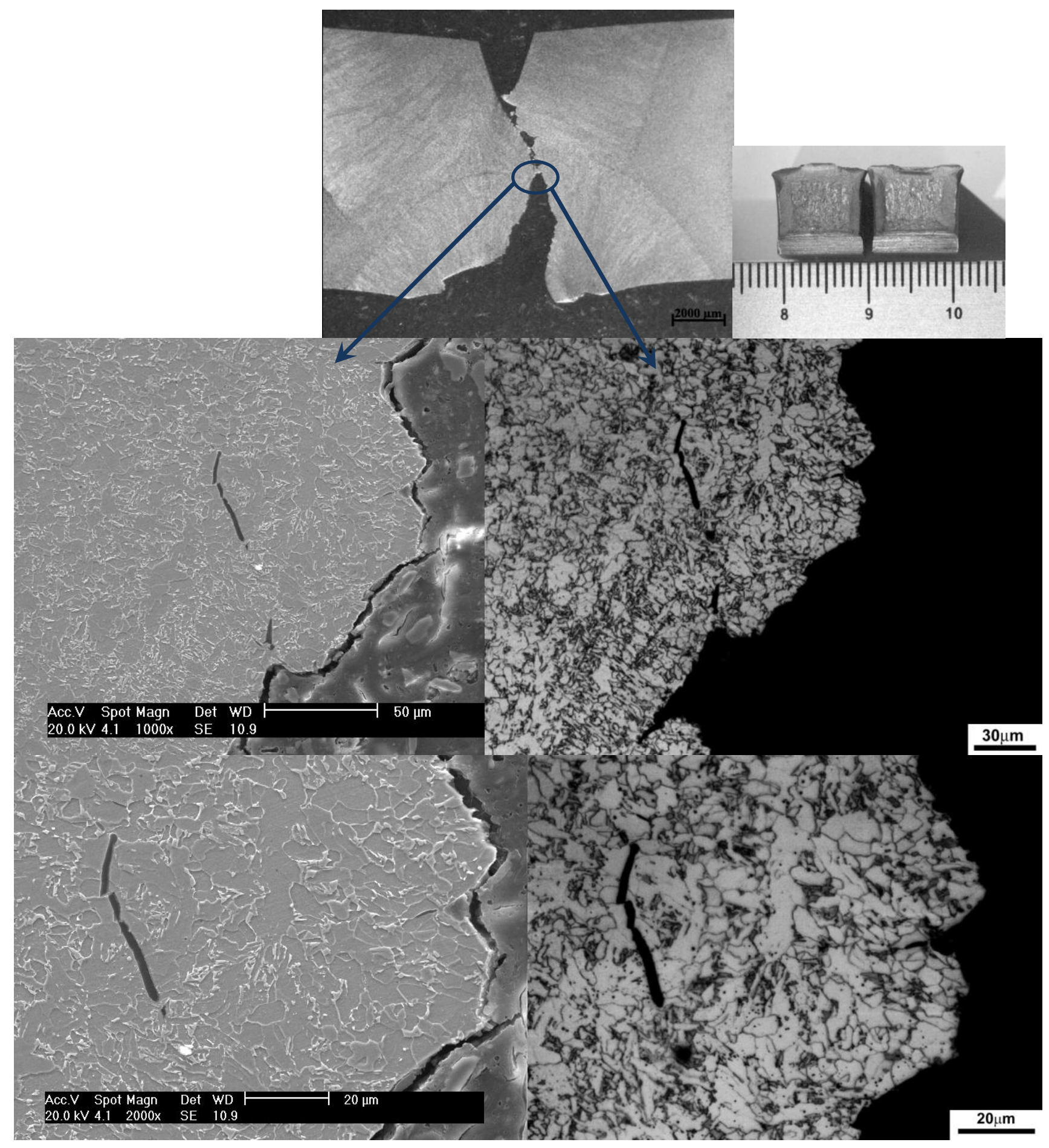

Figura 157. Detalhes do caminho da trinca empregando microscopia óptica e eletrônica de varredura da posição 1 , simulado a $950-800{ }^{\circ} \mathrm{C}$. 


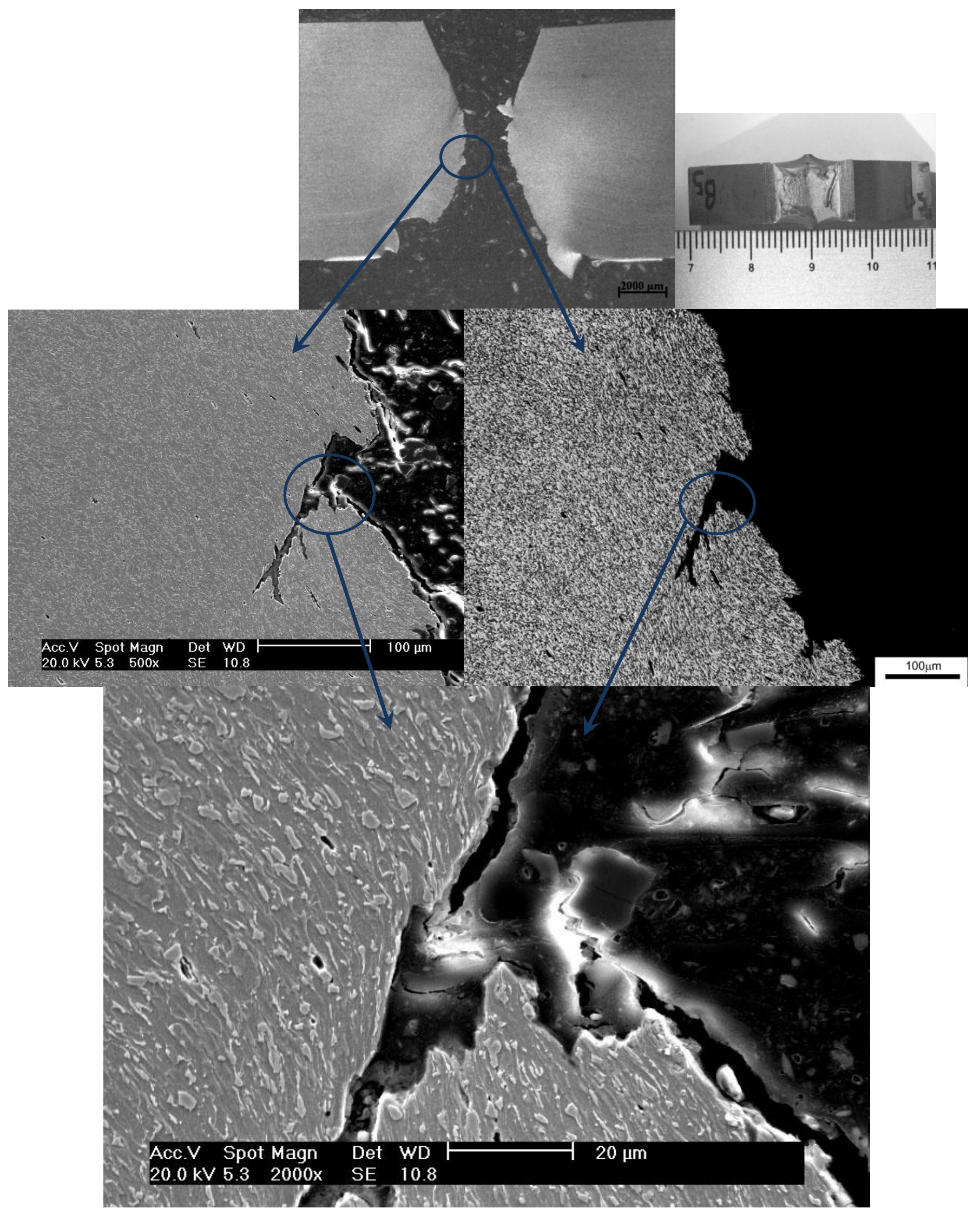

Figura 158. Detalhes do caminho da trinca empregando microscopia óptica e eletrônica de varredura da posição 2 , simulado a $950-800{ }^{\circ} \mathrm{C}$. 


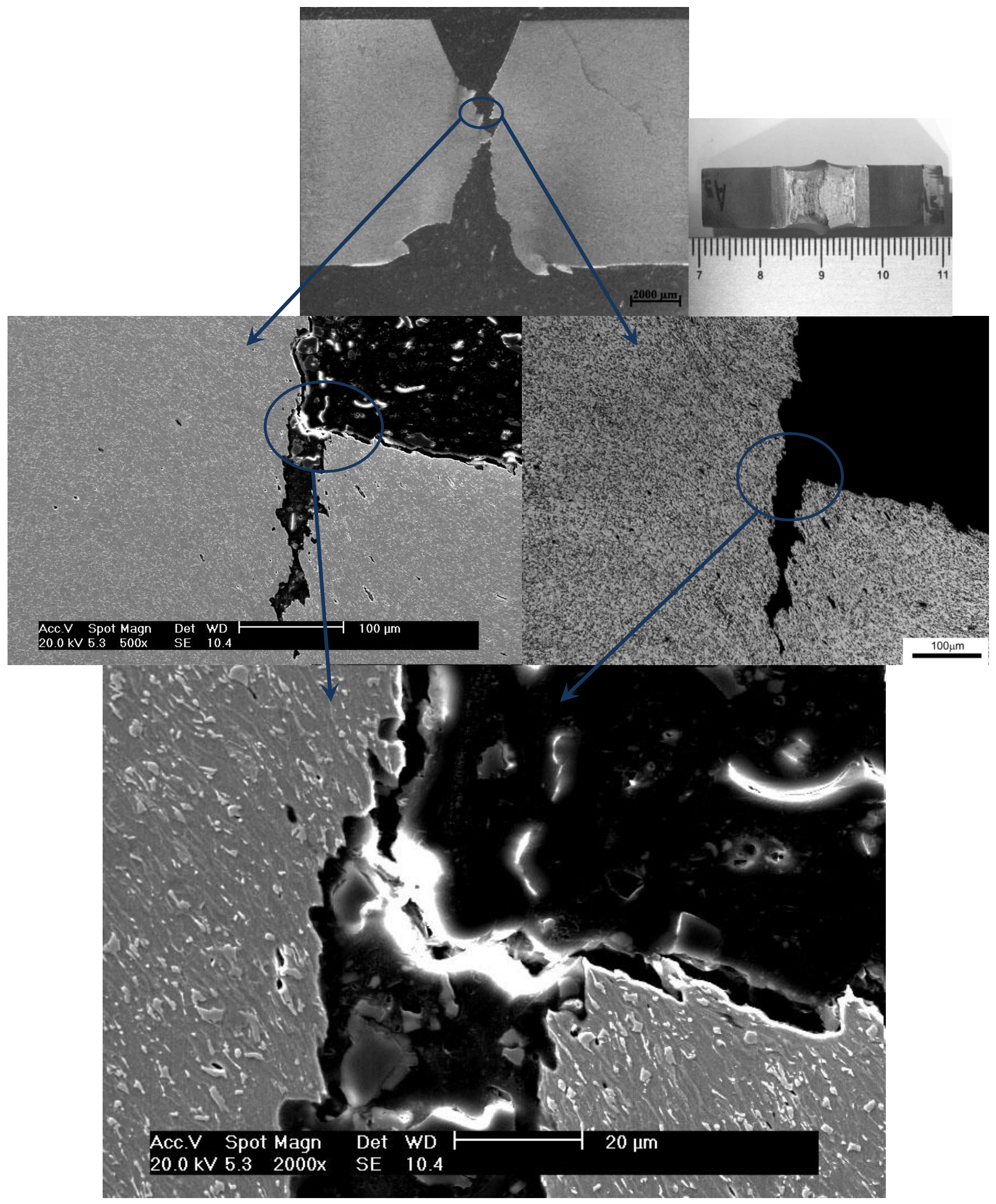

Figura 159. Detalhes do caminho da trinca empregando microscopia óptica e eletrônica de varredura da posição 3 , simulado a $950-800{ }^{\circ} \mathrm{C}$. 


\subsubsection{Caminhos de trinca dos corpos-de-prova com simulação multipasse $950-800-650{ }^{\circ} \mathrm{C}$}

A seguir são apresentados, nas Fig. 160 a 162 os caminhos de trincas dos corpos-de-prova com simulação, para o ciclo térmico de $950-800-650{ }^{\circ} \mathrm{C}$.

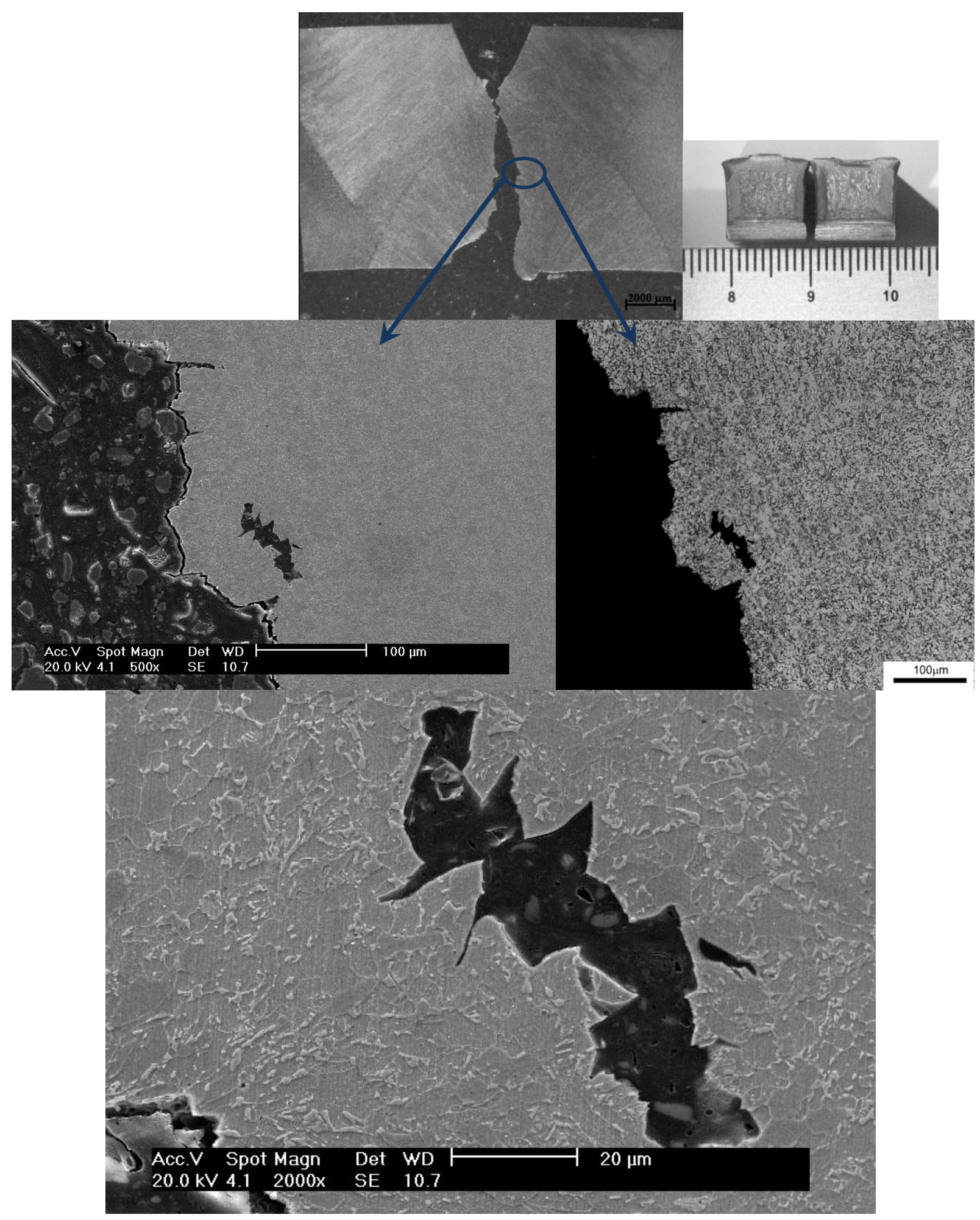

Figura 160. Detalhes do caminho da trinca empregando microscopia óptica e eletrônica de varredura da posição 1 , simulado a $950-800-650{ }^{\circ} \mathrm{C}$. 


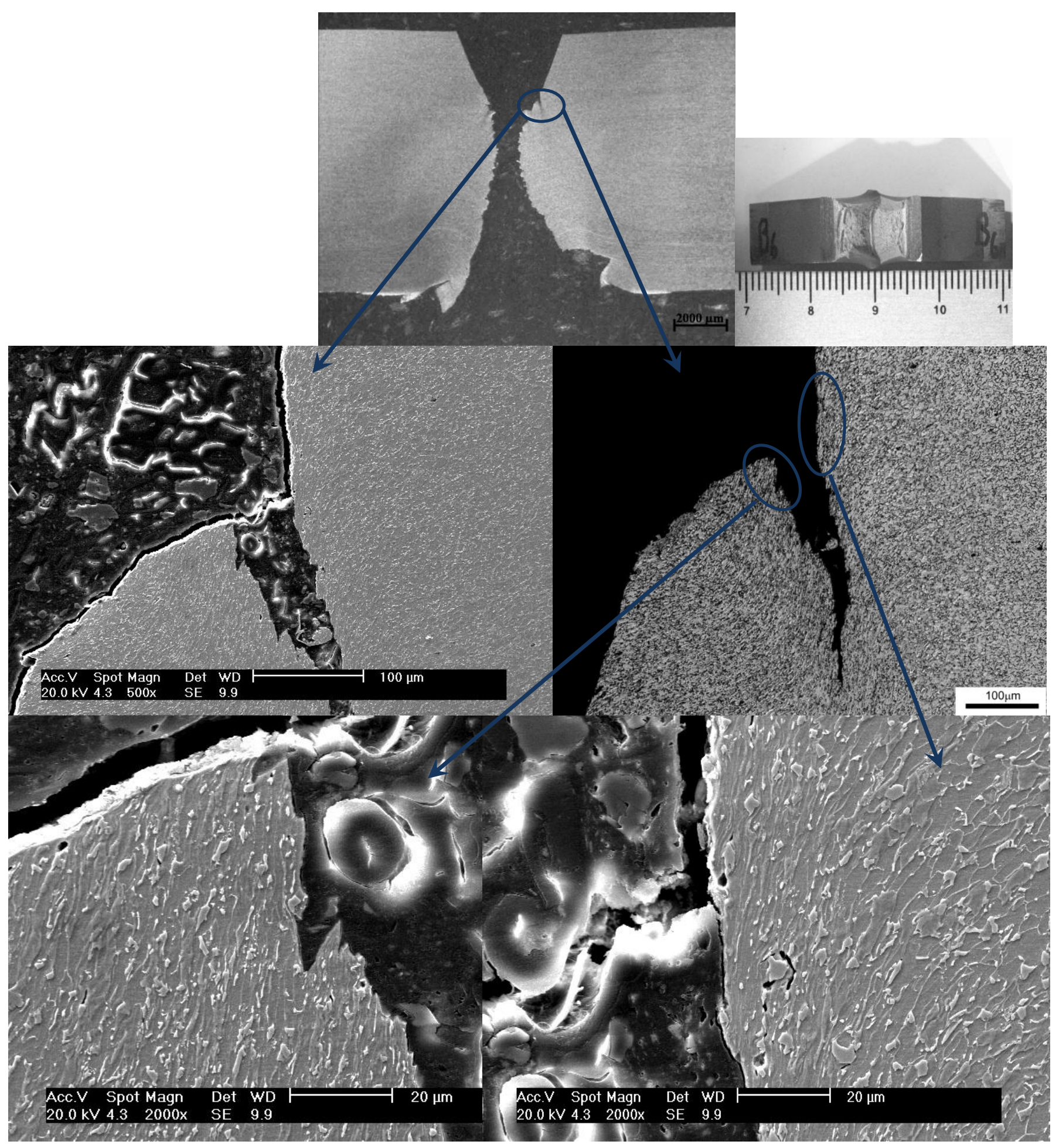

Figura 161. Detalhes do caminho da trinca empregando microscopia óptica e eletrônica de varredura da posição 2 , simulado a $950-800-650{ }^{\circ} \mathrm{C}$. 


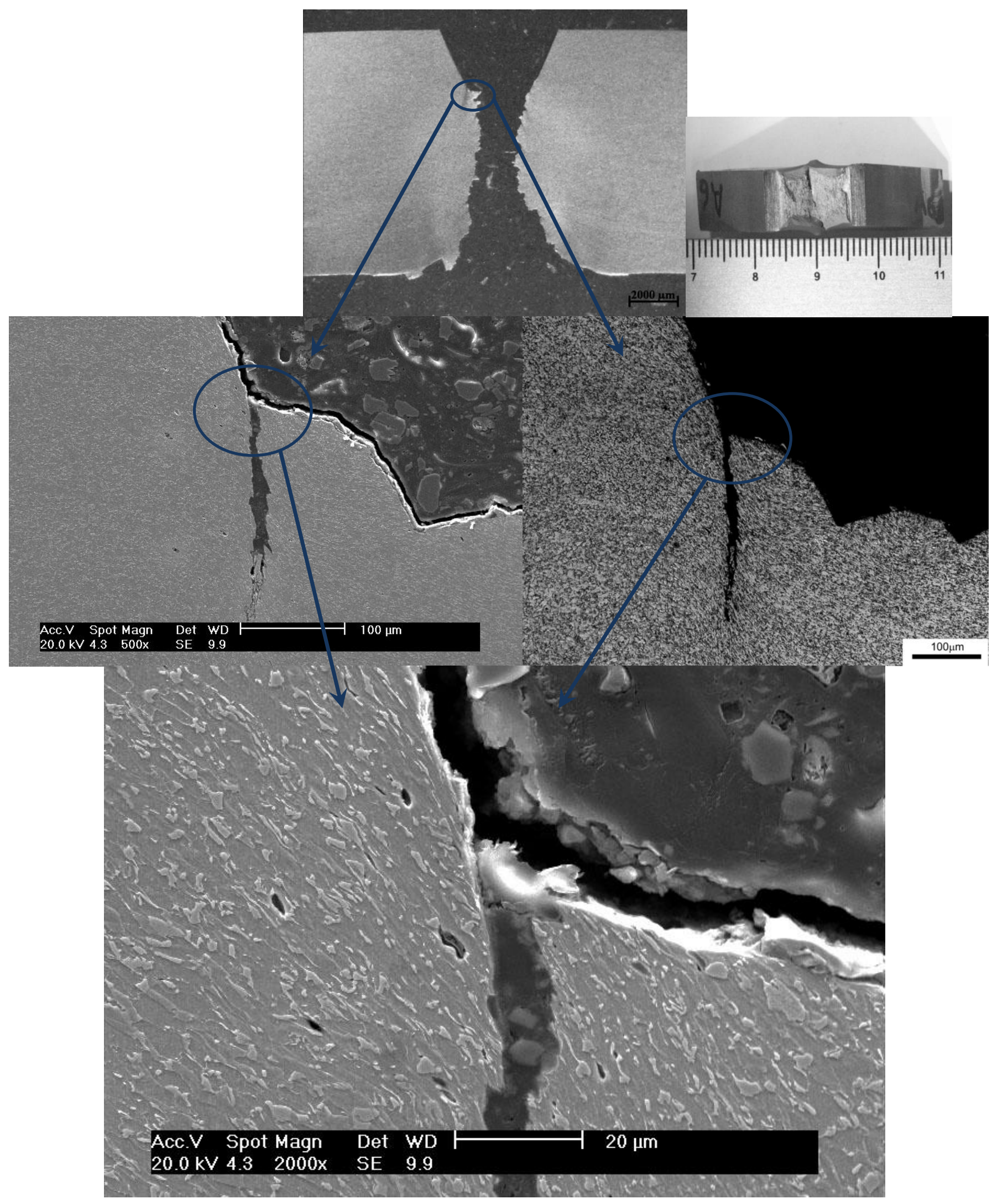

Figura 162. Detalhes do caminho da trinca empregando microscopia óptica e eletrônica de varredura da posição 3 , simulado a 950-800-650 ${ }^{\circ} \mathrm{C}$. 


\section{CONCLUSÕES}

Com base nos resultados obtidos pode-se concluir que:

1. Na posição 1 (ZF do cordão de solda longitudinal), para o ciclo térmico com temperatura máxima de $1300{ }^{\circ} \mathrm{C}$, a microestrutura apresentou-se principalmente como ferrita acicular, ferrita com segunda fase não alinhada e microconstituinte MA. Para o ciclo térmico com temperatura máxima de $950{ }^{\circ} \mathrm{C}$, os microconstituintes, como a ferrita acicular, ferrita com segunda fase não alinhada, foram diminuindo de tamanho, gerando um refino de grão. Os ciclos térmicos de 800 e $650{ }^{\circ} \mathrm{C}$ apresentaram ferrita acicular, ferrita de contorno de grão e microconstituinte MA. Os microconstituintes MA apresentam-se em maior quantidade no ciclo térmico de $1300{ }^{\circ} \mathrm{C}$, seguindo-se o ciclo térmico de $800{ }^{\circ} \mathrm{C}$ e pelos ciclos térmicos de $950{ }^{\circ} \mathrm{C}$ e $650{ }^{\circ} \mathrm{C}$, que apresentaram quantidades de MA próximas e menores que os outros ciclos simulados.

2. Para as posições 2 (L-T) e $3(T-L)$ o bandeamento e os agregados eutetóides foram-se distribuindo na matriz com o aumento da temperatura máxima de cada ciclo térmico, tendo-se como referência o material base sem simulação. $\mathrm{O}$ ciclo térmico de $1300{ }^{\circ} \mathrm{C}$ apresentou o maior tamanho de grão, entre os ciclos simulados, e com bainita granular, ferrita acicular e microconstituinte $M A$, independente da posição de onde foram extraídos os corpos-de-prova (L-T ou T-L). O tamanho do grão ferrítico para o ciclo térmico de $950{ }^{\circ} \mathrm{C}$ foi o de menor tamanho em comparação com os ciclos térmicos de 800 e $650{ }^{\circ} \mathrm{C}$. Os microconstituintes observados foram ferrita, ferrita acicular, agregados eutetóides e microconstituinte MA, dependendo da temperatura máxima e da orientação dos corpos-de-prova. A quantidade de constituintes MA do ciclo térmico de $1300{ }^{\circ} \mathrm{C}$ é a maior, seguindo-se do ciclo térmico de $800{ }^{\circ} \mathrm{C}$, que é maior que as quantidades dos ciclos térmicos de $950 \mathrm{e}$ $650{ }^{\circ} \mathrm{C}$. Estas quantidades de MA são similares para as três posições estudadas, mostrando que o efeito está basicamente nas temperaturas 
máximas dos ciclos térmicos simulados e não nas temperaturas, orientações ou composições diferentes dos materiais.

3. A microestrutura apresentada pelos ciclos térmicos de dois passes e três passes é muito similar à microestrutura apresentada pelo ciclo térmico com um único passe com temperatura máxima de $950{ }^{\circ} \mathrm{C}$, com exceção do microconstituinte MA. Os constituintes MA para o ciclo térmico de 950-800 ${ }^{\circ} \mathrm{C}$ nas 3 posições apresentam-se de menor tamanho e em menor quantidade que os constituintes MA para o ciclo térmico de 950$800-650{ }^{\circ} \mathrm{C}$, mostrando que o ciclo térmico de $650^{\circ} \mathrm{C}$ após os ciclos de 950 e $800^{\circ} \mathrm{C}$ influenciam na quantidade e morfologia do MA.

4. Para os corpos-de-prova sem simulação (MB), a posição 1 (ZF) apresenta menor energia absorvida que as posições 2 (L-T) e 3 (T-L), pois a microestrutura da posição 1 (ZF) apresenta ferrita de contorno de grão, que é um local preferencial para propagação da trinca. Para os corpos-de-prova sem simulação (MB), a posição 2 (L-T) apresenta maior energia absorvida que a posição 3 (T-L) já que a posição 2 (L-T) tem o entalhe no sentido perpendicular ao sentido de laminação da chapa com que foi feito o tubo, e nesta direção a quantidade de agregados eutetóides é maior que na outra direção.

5. A maior energia absorvida que a posição 1 (ZF) apresentou foi no ciclo térmico de $950{ }^{\circ} \mathrm{C}$, já que a microestrutura deste ciclo térmico foi mais refinada e apresentou uma quantidade mínima de ferrita de contorno de grão e ferrita com segunda fase alinhada. A menor energia absorvida foi obtida no ciclo térmico de 650 e $800{ }^{\circ} \mathrm{C}$. Estes valores estão relacionados com a microestrutura presente nestes corpos-de-prova. $\mathrm{Da}$ mesma maneira, a maior energia absorvida para as posições 2 (L-T) e 3 (T-L) foi obtida no ciclo térmico de $950{ }^{\circ} \mathrm{C}$, pelos mesmos motivos descritos anteriormente e pela baixa quantidade de constituintes MA. A menor energia absorvida para as posições 1 (ZF), 2 (L-T) e 3 (T-L) foi obtida no ciclo térmico de $1300{ }^{\circ} \mathrm{C}$ devido ao maior tamanho de grão e a microestrutura presente nestes corpos-de-prova.

6. Com relação aos ciclos térmicos multipasse de 950-800 ${ }^{\circ} \mathrm{C}$ e 950-800$650{ }^{\circ} \mathrm{C}$, se obteve a maior energia absorvida no ciclo térmico de 950$800^{\circ} \mathrm{C}$. Este resultado pode ser explicado pela microestrutura dos 
corpos-de-prova simulados. Estes resultados confirmam que caso haja um terceiro cordão, que reaqueça a região dentro de $650{ }^{\circ} \mathrm{C}$, após aquecimentos a 950 e $800{ }^{\circ} \mathrm{C}$, ocorrerá uma redução na tenacidade, devido a transformação de fase que ocorre nesta faixa de temperatura.

7. A melhor expansão lateral foi apresentada pela posição 2 (L-T) nos ciclos térmicos de um passe único e multipasse. As expansões laterais das posições 1 (ZF) e 3 (T-L) são menores e estão associadas as microestruturas, composições químicas e condição da região simulada (como-fundida e direção T-L).

8. Durezas elevadas foram apresentadas no ciclo térmico de $1300{ }^{\circ} \mathrm{C}$ para as três posições, pois estes corpos de prova apresentam uma grande quantidade de microconstituintes MA e agregados eutetóides.

9. Os corpos de prova com ciclo térmico de $950-800{ }^{\circ} \mathrm{C}$ apresenta maior dureza que o ciclo térmico de $950-800-650{ }^{\circ} \mathrm{C}$, contrastando com os resultados da conclusão 6 , onde a maior tenacidade foi obtida para 0 ciclo térmico de $950-800{ }^{\circ} \mathrm{C}$. É importante ressaltar que no ciclo de 950 $800^{\circ} \mathrm{C}$ a quantidade de MA é menor e mais fina.

10. Na análise das superfícies das fraturas da posição 1 (ZF) encontrou-se um comportamento dúctil-frágil para os corpos-de-prova sem simulação e de ciclos térmicos de 650, 800 e 950. Para os corpos-de-prova das posições 2 (L-T) e 3 (T-L), os ciclos térmicos de 650 e $950{ }^{\circ} \mathrm{C}$, apresentaram um comportamento totalmente dúctil e um comportamento dúctil-frágil para o material de base e os ciclos térmicos de $800 \mathrm{e}$ $1300^{\circ} \mathrm{C}$. Todos estes resultados estão relacionados com as energias absorvidas e com as microestruturas descritas anteriormente.

11. Comparando todos os resultados das energias absorvidas de todos os corpos de prova, sejam de um único passe ou multipasse, pode-se concluir que a pior tenacidade obtida encontra-se no ciclo térmico multipasse de $950-800-650{ }^{\circ} \mathrm{C}$ nas 3 posições, provavelmente isso se deva à morfologia e quantidade dos constituintes MA. Contudo, as tenacidades de todos os ciclos térmicos simulados nas posições 1 (ZF), 2 (L-T) e 3 (T-L) cumprem com os requisitos exigidos pela norma API 5L. 


\section{SUGESTÕES DE TRABALHOS FUTUROS}

1. Estudar como influencia nas propriedades mecânicas a porcentagem volumétrica, morfologia e tamanho de microconstituintes MA em diferentes ciclos térmicos.

2. Estudar a influência das taxas de resfriamento sobre a formação do microconstituinte MA em zonas afetadas pelo calor.

3. Estudar a tenacidade e resistência da zona afetada pelo calor a temperatura máxima de $1300{ }^{\circ} \mathrm{C}$ do aço API $5 \mathrm{~L}$ X80 comparado com outros ciclos térmicos.

4. Estudar as propriedades mecânicas de ciclos térmicos multipasse com temperaturas máximas de $1300-950$ e $1300-950-800{ }^{\circ} \mathrm{C}$.

5. Estudar a influencia dos ciclos térmicos na porcentagem volumétrica de ferrita acicular e como isso afeta as propriedades mecânicas do aço API $5 \mathrm{~L} X 80$. 


\section{REFERÊNCIAS BIBLIOGRÁFICAS}

1. ASM International Handbook: Metals Handbook. Properties and Selection: Irons, Steels and High Performance Alloys. $10^{\text {th }}$ ed. United State of America. 1990. Vol. 1. 328-423p.

2. SILVA, M. C. Caracterização das Propriedades Mecânicas e Metalúrgicas do Aço API5L-X80 e Determinação experimental de Curvas J-R para a Avaliação da Tenacidade a Fratura. 2004. 96p. Dissertação (Mestrado) Escola Politécnica, Universidade de São Paulo, São Paulo, 2004.

3. HILLENBRAND, H. G.; KALWA, C. High Strength Line Pipe for Project Cost Reduction. World Pipelines. 2002. V. 2, $\mathrm{N}^{0} 1$.

4. KAUP, K. High Strength Low Alloy Steels. Belgium: International Iron Steels Institute. 1987. 3_9-3_12p.

5. ASM International Handbook: ASM Specialty Handbook. Carbon and Alloy Steels. United State of America: Davis J. R. 1996. 644-653p.

6. HILLENBRAND, H. G. et al. Procedures, considerations for welding $X 80$ line pipe established. Oil \& Gas Journal, 15 de setembro de 1997. 2p.

7. VALIM, M. T. Tenacidade a Fratura da Junta Soldada Obtida a Arco Submerso de Aço API 5L Grau X80. 2005. 86p. Dissertação (Mestrado) Pontifícia Universidade Católica do Rio de Janeiro, Rio de Janeiro, 2005.

8. AMERICAN PETROLEON INSTITUTE. Specification for Line Pipe. API Specification 5 L. $43^{\circ}$ Ed. Washington, D. C. 2004. 155p.

9. STALHEIM, D.; G. BRANES, K. R.; MCKUTCHEON, D. B. Alloy Designs for High Strength Oil and Gas Transmission Linepipe Steels. International Symposium on Microalloyed Steels for the Oil and Gas Industry. Ed. TMS, Pensilvania, U. S. 2007. 73-108p.

10. BOTT, A. J. et al. Brazilian High Temperature Processed Steels for Pipelines. International Symposium on Microalloyed Steels for the Oil and Gas Industry. Ed. TMS, Pensilvania, U. S. 2007. 197-219p.

11. KONG, J. et al. The Development and Application of X80 Line Pipe Steels and Pipe in China. International Symposium on Microalloyed Steels for the Oil and Gas Industry. Ed. TMS, Pensilvania, U. S. 2007. 239-256p. 
12. KANG, K. B. An Overview of New Development on Linepipe Steels and Offshore Structural Steels at POSCO. International Symposium on Microalloyed Steels for the Oil and Gas Industry. Ed. TMS, Pensilvania, U. S. 2007. 257-270p.

13. ROZA, E. J. et al. API $5 L$ X80 ERW Pipelines. TenarisConfab \& Usiminas Development. $6^{\text {th }}$ International Pipeline Conference, 2006. Proceedings. Alberta, Canada, American Society of Mechanical Engineers. 2006. 7p.

14. GRAY, J. M.; PONTREMOLI, M. Metallurgical Options for API Grade X70 and X80 Linepipe. In International Conference Pipe Technology, 1987. Rome Italy.

15. FEDELE, R. Soldagem de Tubulações: Metalurgia, Procedimentos e Desafios. Revista Metalurgia e Materiais. 2002. Vol. 58, $N^{0} 521,2-4 \mathrm{p}$.

16. HILLENBRAND, H. G.; HECKMANN, C. J.; NIEDERHOFF, K. A. X80 Line Pipe for Large-Diameter High Strength Pipelines. APIA 2002 Annual Conference. 2002. Hobart, Australia.

17. COSTA E SILVA, A. L. V.; MEI, P. R. Aços e Ligas Especiais. $2^{\underline{a}}$ ed. São Paulo: Edgar Blücher. 2006.

18. VALENTE, F. TenarisConfab: TenarisConfab Produz Tubos API X80 para o Mercado de Linepipe. São Paulo, Brasil, 2008. 8p. Disponivel em:< http://www.tenaris.com/shared/documents/files/NL544.pdf >. Acceso em: 26 nov. 2010.

19. PINTO, P. S. Soldagem Circunferencial de Tubo API 5 L X80 Empregando Processos Manual/Semi-Automático. 2006. 130p. Dissertação (Mestrado) Pontifícia Universidade Católica do Rio de Janeiro, Rio de Janeiro, 2006.

20. GLADMAN, T. The physical Metallurgy of Microalloyed Steels. 1a ed. UK: Cambridge. 1997.

21. COLPAERT, H. Metalografia dos Produtos Siderúrgicos Comuns. Revisão técnica André Luiz V. Da Costa Silva. $4^{\mathrm{a}}$ ed. São Paulo: Edgard Blucher, 2008.

22. HAMAD, F.; COLLINS, L. High-strength, Large-diameter Steel Pipes for Pipeline Application. Canadian Welding Association Journal, 2005.

23. RAMIREZ, M. G. Estudo da Transformação Durante o Resfriamento Continuo e da Microestrutura do Aço Microligado X80 Utilizado na Construção de Tubos para Transporte de Gás Natural e Petróleo. 2008. 
159p. Dissertação (Mestrado) - Escola Politécnica, Universidade de São Paulo, São Paulo, 2008.

24. RAMIREZ, M. G.; GORNI, A. A.; LANDGRAF, F.; OGATA, P. H.; GOLDENSTEIN, H. Caracterização Microestrutural de um Aço API 5L-X80 Através de Microdureza e Microscopia Ótica e Eletrônica. In: CONGRESSO ANUAL DA ABM - ITERNACIONAL, 62․ 2007 Vitória - ES, Brasil. 36333642p.

25. BAE, H. J. et. al. Development of High Strength Linepipe Steels with Excellent Weldability. Posco Technical Report. 2006. Vol. 10. 12-20p.

26. TenarisConfab: Tubos Para Condução (Line Pipe). São Paulo, Brasil, 2004. 12p. Disponível em:

<http://www.tenaris.com/TenarisConfab/pt/files/CF Tubos Cond.pdf>. Acesso em: 21 dez. 2010.

27. FOSCA, C. Metalurgia de la Soldadura. $7^{\underline{a}}$ ed. Lima: PUCP, 2007. 123$182 p$.

28. MARQUES, P. V.; MODENESI, P. J.; BRACARENSE, A. Q. Soldagem Fundamentos e Tecnologia. Belo Horizonte: UFMG, 2005.

29. WAINER, E.; BRANDI, S. D.; HOMEM DE MELLO, F. D. Soldagem Processo e Metalurgia. São Paulo: Edgard Blucher, 1995.

30. GRANJON, H. Fundamentals of Welding Metallurgy. Cambridge: Abington Publishing, 1991.

31. VentRelLA, V. A.; ALVÂNTRA, N. G.; EVANS, G. M.; Microestrutura de Metais de Solda Ferríticos de Aços ARBL; In: Encontro Nacional de Tecnologia da Soldagem (ENTS), SENAI e CETEC, XXII, 1997, São Paulo. Associação Brasileira de Soldagem - ABS. 47-52p.

32. IIW The International Institute of Welding. Compendium of Weld Metal Microstructures and Properties: Submerged-arc weld in ferritic steel. The Welding institute Abington Hall, Cambridge UK. 1985.

33. BADESHIA, H. K. D. H. Bainite in Steels. $2^{\mathrm{a}}$ ed. UK: Cambridge. 2001.

34. ASM International Handbook. Metallography and Microestrutures. Vol. 9. United State of America. 2004.

35. HARRISON, P. L.; FARRA, L. A. Application of continuous cooling transformation diagrams for welding of steels. International Materials Reviews. 1989. Vol. 34. $N^{0} 1$. 35-51p. 
36. BOSE FILHO, W. W.; STRANGWOOD, M. Efeito da Temperabilidade na Microestrutura de Aços Alta Resistência Baixa Liga (ARBL) Soldados. In: Encontro Nacional de Tecnologia e Soldagem (ENTS), XXII., 1996, Blumenau - Santa Catarina. Associação Brasileira de Soldagem - ABS. 471-480p.

37. Ventrella, V. A.; AlCÂNTARA, N. G.; EVANS, G. M. Efeito dos Elementos de Liga nas Microestruturas e Propriedades de Metais de Solda de Aços ARBL, In: Encontro Nacional de Tecnologia e Soldagem (ENTS), XXII., 1996, Blumenau - Santa Catarina. Associação Brasileira de Soldagem - ABS. 447-457p.

38. EVANS, G. M.; BAILEY, N. Metallurgy of Basic Weld Metal. England: Abington Publishing. 1997.

39. CRAWFORD, D. G. Microstructure and Toughness of Low Carbon Steel Weld Metal. Materials Science and Engineering. 1991. Vol. A131. 255263p.

40. KOU, S. Welding Metallurgy. $2^{\mathrm{a}}$ ed. United States of America: WileyInterscience. 2003.

41. FORTES, C. Arco Submerso. [S.L.: s.n.], 2004. 144p.

42. ASM Handbook. Mechanical Testing and Evaluation. Vol. 8. ASM International. United State of America. 2002.

43. HERTZBERG, R. W. Deformation and Fracture Mechanics of Engineering Materials. 4 ed. United States of America. John Wiley \& Sons. 1996. 786p.

44. CETLIN, P. R.; PEREIRA DA SILVA, P. S. Associação Brasileira de Metais (ABM). Análise de Fraturas. EDILE - São Paulo. 229p.

45. HASHEMI, S. H. Absorption of Charpy Energy in API 5L Grade X70 Pipeline Steel. International Journal of Pressure Vessels and Piping. 2008. Vol. 85. 879-884p.

46. YU, X. et al. Characterization of Microstructural Strengthening in the HeatAffected Zone of a Blast-Resistant Naval Steel. Acta Materialia. 2010. Vol. 58. 5596-5609p.

47. ASTM International. Standard Practice for Microetching Metals and Alloys: E 407-07. Ed. United States. 2007. 23p.

48. ASTM International. Standard Test Methods and Definitions for Mechanical Testing of Steel Products: A370-10. Ed. Pensilvânia. 2010. 47p. 
49. FONDA, R. W.; SPANOS, G. Microestrutural Evolution in Ultra-Low-Carbon Steel Weldments. Part 1: Controlled Thermal Cycling and Continuous Cooling Transformation Diagram of the Weld Metal. Metallurgical and Materials Transactions A. 2000. Vol. 31A. 2145-2149p.

50. MOTOHASHI, H.; HAGIWARA, N.; MASUDA, T. Tensile Properties and Microstructure of Weld Metal of X80 Linepipe Steels. IIW Doc XI-822-04. $13 p$.

51. BATISTA, G. Z. et al. Avaliação da Microestrutura e Propriedades Mecânicas de Tubo API 5L X80 Submetido a Curvamento por Indução. Tecnologia em Metalurgia e Materiais. São Paulo. 2007. Vol. 3. N ${ }^{0} .4,16-$ 22p.

52. SHIN, S. Y.; OH, K.; KANG, K. B.; LEE, S. Improvement of Charpy Impact Properties in Heat Affected Zones of API X80 Pipelines Steels Containing Complex Oxides. Materials and Science Technology. 2010. Vol. 26. $\mathrm{N}^{0} 9$. 1049-1058p.

53. SHIN, S. Y.; et al. Correlation of Microestruture and Charpy Impact Properties in API X70 and X80 Line-pipe Steels. Materials Science and Engineering A. 2007. Vol. 458. 281-289p.

54. MOEINFAR, S. Role of Tandem Submerged Arc Welding Thermal Cycles on Properties of the Heat Affected Zone in X80 Microalloyed Pipe Line Steel. Journal of Materials Processing Technology. 2011. Vol. 211. 368$375 p$.

55. ROCHA, D. B. Estudo da Soldabilidade do Tubo API 5L X80 Utilizando os Processos de Soldagem: MAG com Transferência Controlada e Eletrodo Tubular. 2010. 219p. Dissertação (mestrado)-Escola Politécnica, Universidade de São Paulo, São Paulo 2010.

56. VEGA, O. E. et. al. Effect of Multiple Repairs in Girth Welds of Pipelines on the Mechanical Properties. Materials Characterization. 2008. Vol. 59. 1498$1507 p$.

57. BUBNOFF, D. V.; VENTRELLA, V. A. Relação Entre Microestrutura/Tenacidade ao Impacto do Metal de Solda do Aço API X70 Soldado por Eletrodo Revestido AWS E8010-G. [s.n]. 6p. 
58. DAVIS, C. L, KING, J. E. Cleavage Initiation In the Intercritically Reheated Coarse Grained Heat Affected Zone: part II. Metallurgical and Materials Transactions A. 1996. Vol. 27. 3019-3029p.

59. BOTT, IVANI de S. et al. High-Strength Steel Development for Pipelines: A Brazilian Perspective. Metallurgical and Materilas transactions A. 2005. Vol. 36A. 443-456p.

60. ORDOÑEZ, R. E. C. et. al. Estudo do Comportamento das Micro e Macrodurezas de Juntas de Aço API 5L X80 Soldadas com Arame Tubular. [s.n.]. 10p.

61. TREVISAN, R. E. et. al. Effect of Interpass Temperature on Morphology, Microstructure and Microhardness of Welded API 5L X65 Steel. In: International Pipeline Conference. Calgary, Canada. 2002.

62. GOMES, R. V B.; AIDAR, C. H.; KOJIMA, S. S. Study of the Mechanics Fracture in API 5L X65 and X70 Steel Pipes. TenarisConfab. 7p.

63. Han, S. Y. et. al. Effects of Cooling Conditions on Tensile and Charpy Impact Properties of API X80 Linepipe Steels. Metallurgical and Materials Transactions A. 2010. Vol. 41A. 329-340p. 